ARCHITEKTURA

PSYCHOLOGICZNEJ

PRZESTRZENI

ŻYCIA

Behawioralne

Podstawy Projektowania

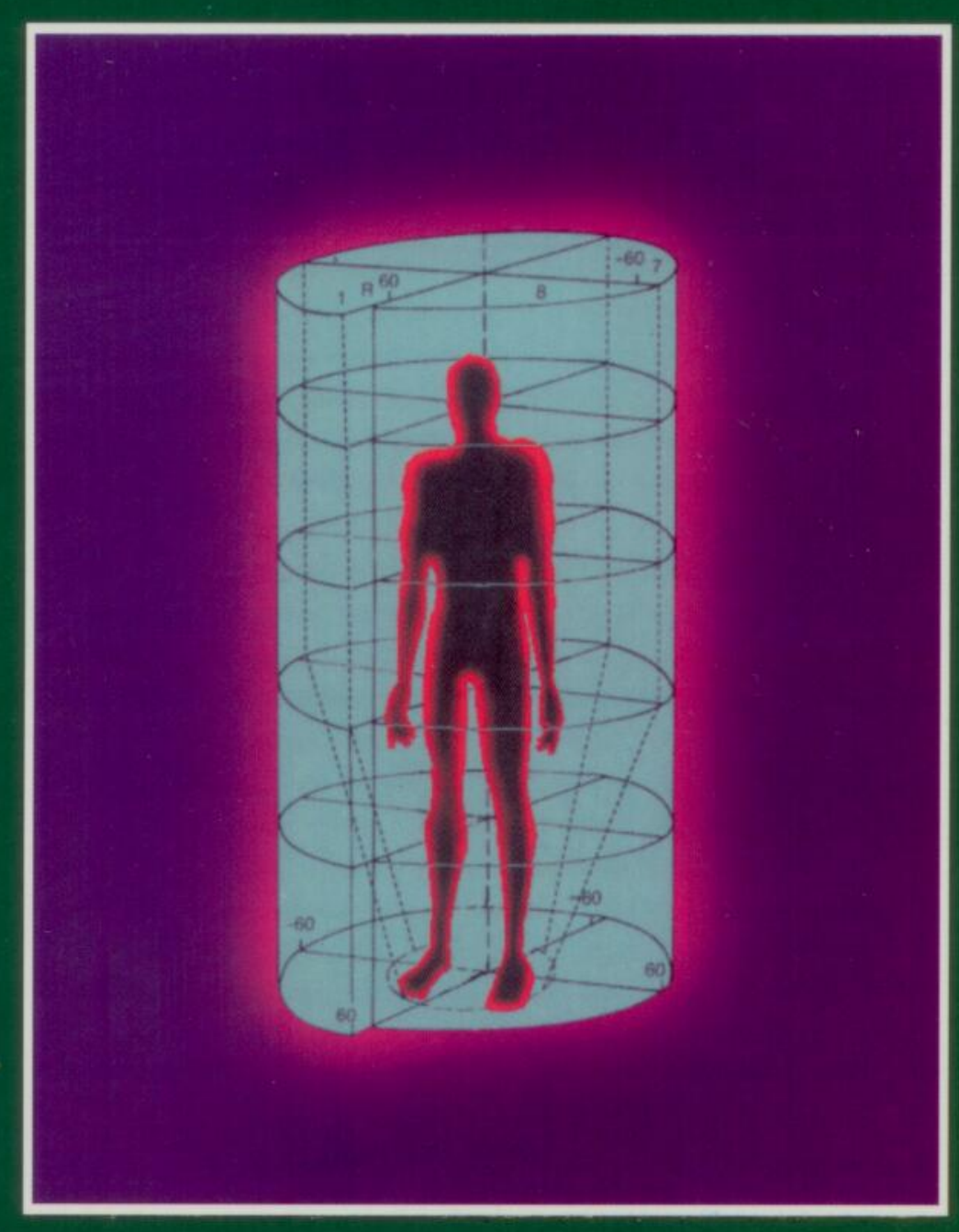

Augustyn Bańka 


\section{ARCHITEKTURA PSYCHOLOGICZNEJ PRZESTRZENI ŻYCIA}

\section{Behawioralne Podstawy Projektowania}

Augustyn Bańka

Poznań 2016 
Augustyn Bańka

Architektura psychologicznej przestrzeni życia. Behawioralne podstawy projektowania (2016)

Copyright (C) by Augustyn Bańka \& SPiA

Wydanie drugie, 2016

ISBN 978-83-62051-76-2

DOI 10.14691/APPZ.2016

Wydawca: Stowarzyszenie Psychologia i Architektura, Poznań 


\section{SPIS TREŚCI}

\section{Część I}

\section{PSYCHOLOGICZNA PRZESTRZEŃ ŻYCIA}

\section{A PROJEKTOWANIE}

NAUKOWY I MENTALNY STATUS PROJEKTOWANIA ARCHITEKTONICZNEGO

Psychologia i architektura

Pojęcie projektowania oraz jego relacje z nauka 12

Projektowanie a technika $\mathbf{1 5}$

Rozwój „,wzorów myślenia” w technice a zmiana rozumienia pojęcia projektowanie 17

KONTEKST PSYCHOLOGICZNY ROZWOJU POJĘCIA PROJEKTOWANIE

Behawioralne wyznaczniki projektowania architektonicznego 20

Stereotyp projektowania i psychogeneza pojęcia projektowania sensu largo 23

Teoria projektowania architektonicznego $\quad \mathbf{2 6}$

BEHAWIORALNE TEORIE PROJEKTOWANIA ARCHITEKTONICZNEGO

Zachowanie sie jako substrat projektowania architektonicznego 28

„, Nielogiczność" i argumentacyjnych charakter problemów projektowania 31

Projektowanie jako proces uczenia sie

Synteza formy oraz wzory Alexandra

Wnioski

\section{Część II}

\section{ARCHITEKTURA BEHAWIORALNEJ PRZESTRZENI ŻYCIA}

WYMIAR LUDZKI W ARCHITEKTURZE

Teoria behawioralna $w$ projektowaniu środowiska dużej skali

Teoria behawioralna w projektowaniu środowiska matej skali $\quad \mathbf{4 1}$

Podstawowe kierunki badań w psychologii środowiskowej $\mathbf{4 3}$

Problem poziomu analizy zjawisk w psychologii środowiskowej $\quad \mathbf{4 5}$

Praktyczne cele psychologii środowiskowej i architektury $\mathbf{4 6}$

\section{ANTROPOLOGIA I AKSJONOMIA PRZESTRZENI}

Biologiczny wymiar zachowań przestrzennych 449

Przestrzeń o statych cechach $\quad \mathbf{5 9}$

$\begin{array}{ll}\text { Przestrzeń o zmiennych cechach } & \mathbf{6 3}\end{array}$

$\begin{array}{lr}\text { Przestrzeń nieformalna } & \mathbf{6 5}\end{array}$

PRZESTRZEŃ, TERYTORIALNOŚĆ A ZMIENNOŚĆ ZACHOWAŃ

$\begin{array}{ll}\text { Obszar i jego granice } & \mathbf{7 0}\end{array}$

Model organizacyjny zachowań terytorialnych $\quad \mathbf{7 5}$

Zmiany przestrzenne a zmiany zachowań

Różnorodność psychologiczna a architektoniczna $\mathbf{8 2}$ 


\section{Część III}

\section{ARCHITEKTURA EMOCJONALNEJ PRZESTRZENI ŻYCIA}

PSYCHOLOGICZNE POJĘCIE ŚRODOWISKA ARCHITEKTONICZNEGO

Forma, środowisko i sytuacja architektoniczna $\quad \mathbf{8 5}$

$\begin{array}{lr}\text { Stymulacyjny i zadaniowy aspekt środowiska } & \mathbf{8 7}\end{array}$

Specyficzne i niespecyficzne oddzialywanie architektury $\quad \mathbf{8 8}$

Architektura a struktura sytuacji zadaniowej $\quad \mathbf{8 9}$

WEWNĘTRZNE REAKCJE EMOCJONALNE NA CZYNNIKI

ŚRODOWISKA ARCHITEKTONICZNEGO

Psychologiczny model zależności między człowiekiem a środowiskiem

Emocjonalne reakcje przyjemności a zachowania typu ,,unikanie-zblizenie” 93

Emocjonalne reakcje pobudzenia a zachowania typu ,, unikanie-zbliżenie” 9

Emocjonalne reakcje dominacji 99

OSOBOWOŚCIOWE A SYTUACYJNE KORELATY REAKCJI EMOCJONALNYCH NA CZYNNIKI ŚRODOWISKA ARCHITEKTONICZNEGO

Reaktywność

Introwersja i neurotyzm a preferencje estetyczne dotyczace architektury $\quad \mathbf{1 0 8}$

Zawartość informacyjna środowiska architektonicznego

\section{Część IV}

\section{ARCHITEKTURA POZNAWCZEJ PRZESTRZENI ŻYCIA}

ROZWÓJ PERCEPCJI PRZESTRZENI U CZŁOWIEKA

$\begin{array}{ll}\text { Rola aktywności w rozwoju percepcji przestrzeni } & \mathbf{1 1 7}\end{array}$

Percepcja własnego ciała jako poczatek rozwoju percepcji przestrzeni $\quad \mathbf{1 1 8}$

Percepcja przestrzeni bliskiej

WZROKOWE SPOSTRZEGANIE PRZESTRZENI

Rozwój reprezentacji przestrzennych jako przejaw spostrzegania

środowiska dużej skali

Rola zmystu wzroku w spostrzeganiu przestrzeni $\quad \mathbf{1 2 4}$

$\begin{array}{ll}\text { Statość spostrzegania } & \mathbf{1 2 4}\end{array}$

$\begin{array}{ll}\text { Organizacja w spostrzeganiu } & \mathbf{1 2 7}\end{array}$

Zludzenie wzrokowe $\quad \mathbf{1 3 0}$

Czynniki wptywające na spostrzeganie $\quad 132$

Kulturowe aspekty spostrzegania przestrzeni $\quad 133$

SPOSTRZEGANIE PRZESTRZENI ARCHITEKTONICZNEJ I URBANISTYCZNEJ

Mapy poznawcze a percepcja środowiska $\quad \mathbf{1 3 5}$

Mapy poznawcze miasta i przestrzeni zurbanizowanej $\mathbf{1 3 6}$

LITERATURA $\quad \mathbf{1 4 0}$ 


\title{
CZĘŚĆ I
}

\section{PSYCHOLOGICZNA PRZESTRZEŃ ŻYCIA A PROJEKTOWANIE}

\author{
NAUKOWY I MENTALNY STATUS PROJEKTOWANIA \\ ARCHITEKTONICZNEGO
}

\section{Psychologia i architektura}

Rozważania na temat psychologicznych (behawioralnych) podstaw projektowania architektonicznego, ze względu na nowość tej tematyki, muszą być z konieczności poprzedzone refleksjami nad istota związku między psychiką i architekturą oraz samym projektowaniem.

Analogia między psychologią a architekturą opiera się na małym, ale za to magicznym słowie „psyche”. Pojęcie to stanowi synonim tego, co ożywia, nadaje sens, tchnienie, rozum, plan, logikę, intencję, program, harmonię i uczucie. A zatem, wszystko to, na oznaczenie czego używane jest słowo „psyche” jest niezbywalnym wymiarem człowieczeństwa, wymiarem nadającym ludzkim zachowaniom charakter hierarchiczny, wolny i rozumny. Dzięki „psyche” człowiek jest nie tylko reagującym na bodźce otoczenia organizmem, ale również lub przede wszystkim podmiotem, czyli tym, który sam od siebie jest źródłem i sprawcą idei, rzeczy i działań.

Wszystkie działania i ich efekty jak architektura zawierają się między biologicznym zaprogramowaniem człowieka, tj. instynktem, a wolnym wyborem, wolną wola, tj. tym na oznaczenie czego chętniej używamy dzisiaj takich określeń jak „,plan” czy „motyw”. Działania instynktowne opiera się na odruchowym sprzężeniu zwrotnym między bodźcem a pewną użytecznościa (utilitas), stanowiąca wartość z punktu widzenia przetrwania organizmu w otoczeniu. Zachowania instynktowne $\mathrm{w}$ odniesieniu do architektury nie są cechą wyłącznie ludzką gdyż opierają się na pierwotnym wyobrażeniu bezpieczeństwa nie obcym również zwierzętom. Wraz z Umberto Eco można nawet bawić się w spekulację, czy tzw. „wyobrażenie jaskini” powstało u człowieka wskutek naśladownictwa innych zwierząt, czy też pod wpływem wewnętrznego impulsu oraz co było pierwsze - wyobrażenie czy naśladownictwo.

Do dzisiaj nie rozstrzygniętą kwestią pozostaje to, czy tzw. „wyobrażenie jaskini” powstało u człowieka wskutek naśladownictwa innych zwierząt, czy też pod wpływem wewnętrznego impulsu oraz co było pierwsze - wyobrażenie czy naśladownictwo.

Tak czy inaczej cechą wyłącznie ludzką jest zdolność do celowego, rozumnego zachowania się, które, nie umniejszając utylitarnej wartości reakcjom odruchowym, przenosi punkt ciężkości na ogniwo

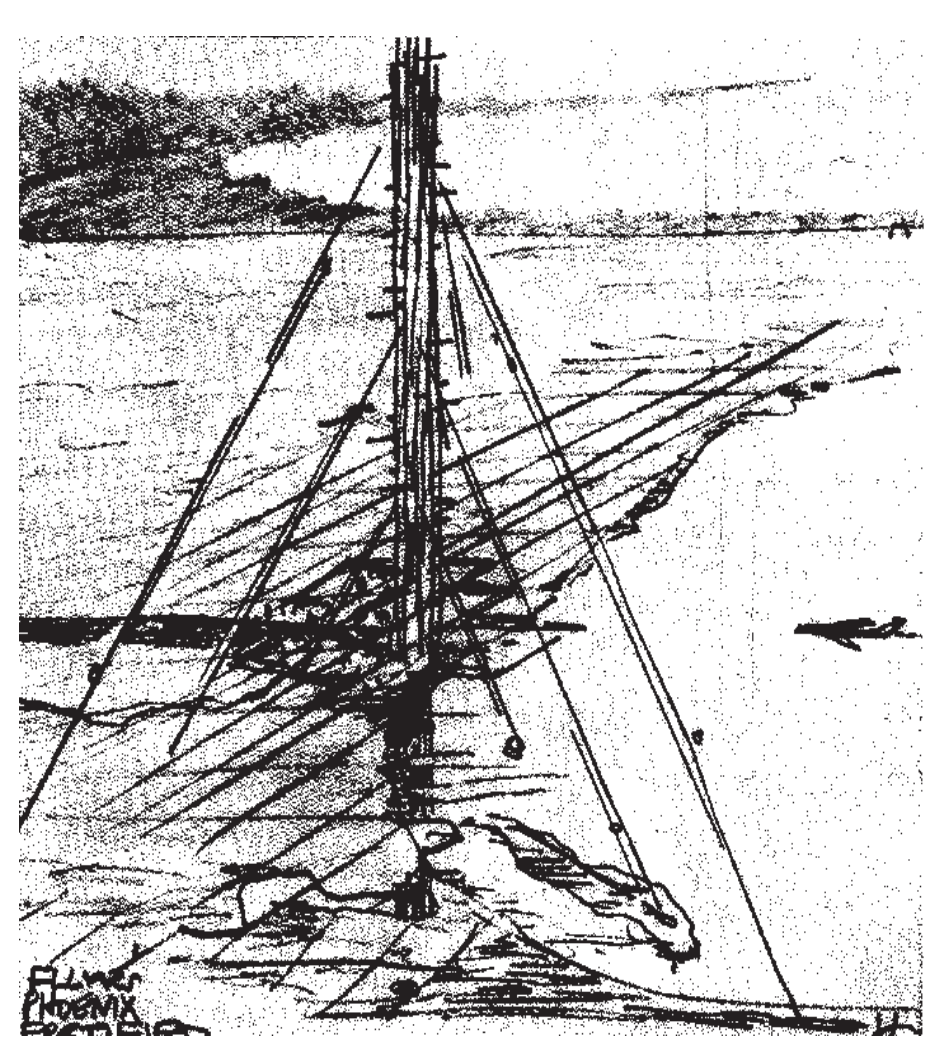

F.L. Wright'a „One mile building” jest świadectwem tego, że idea nie musi mieć żadnego zakotwiczenia w rzeczywistości. 
pośredniczące między bodźcem i reakcja - tj. na umysł człowieka. Najbardziej ludzkie zachowania nie sa więc instynktownym odruchem na bodźce płynące z otoczenia, ale rozumnym, świadomym i planowym działaniem. Działanie świadome może mieć też związek z określonym bodźcem zewnętrznym - czyli tak zwana „potrzeba obiektywna”, ale jej wystapienie nie jest warunkiem koniecznym dla podjęcia działalności. Innymi słowy zachowanie planowe (celowe) może być samoistne, bez związku z bodźcami środowiska jako motywacji działania. Architektura może być więc efektem motywacji wynikajacej z działania obiektywnych potrzeb, ale może też być gry przebiegającej jedynie w psychicznej przestrzeni życia człowieka. Osoba ludzka jako podmiot życia umysłowego jest zdolna do działania sama z siebie, bez impulsów płynących ze środowiska. Umysł człowieka jako psychologiczna przestrzeń życia, może być wystarczającym źródłem natchnienia, motywacji i wizji działania. Zdolność tę jedni nazywają bytem samym w sobie (Kant), a inni specyficzną zdolnością mózgu ludzkiego do wytwarzania autonomicznych planów i struktur zachowania (Miller).

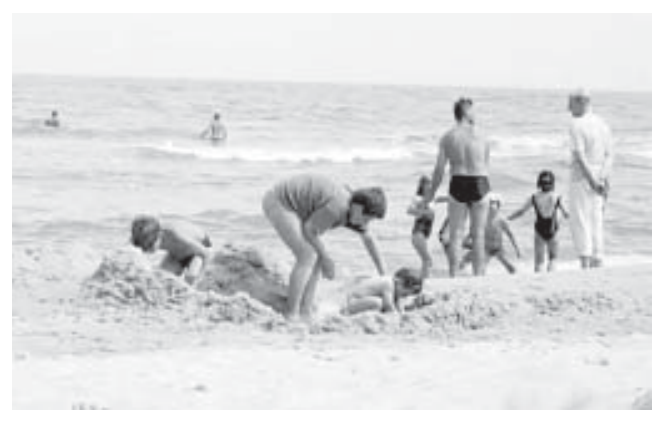

A zatem psychika i umysł człowieka to pewna hierarchiczna całość, która ma własną przestrzeń obejmującą nieświadome instynkty oraz świadome tj. kierowane wolną wolą działania. Oczywiście architektura może wyrastać zarówno z pierwotnego instynktu bezpieczeństwa, którego synonimem jest „archetyp jaskini”, jak i rozumu, który jest niczym innym jak tylko „obrazem świata", w którym stapiają się czas z przestrzenia, emocja z poznaniem, a wolność z determinacją czyli z góry określonym losem. W pierwszym przypadku architektura jest wszystko to, co ma charakter użyteczny z punktu widzenia przetrwania jako wartości samej w sobie i zaprogramowanej biologicznie.

Instynkt budowlany, jaki występuje u dzieci od najmłodszych lat świadczy o tym, że wystarczająca racja powstawania formy architektonicznej jest wyobrażenie mentalne i wolna wola.

W drugim przypadku architektura jest to, co stanowi odbicie ładu psychicznego. W ten sposób architektura może być albo odruchem, który znajduje wyraz w archetypie „bezpiecznej jaskini”, albo świadomie ukształtowanym ładem umysłu. O architekturze można mówić jako o „sztuce budowania” wtedy i tylko wtedy, gdy forma przestrzeni jest świadomą struktura, z wbudowanym sensem (celem), planem i rozpoznawalną intencja.

Ład psychiczny jako uporządkowany zbiór zdarzeń, będących punktem przecięcia niezliczonych procesów dokonujących się w umyśle człowieka w całym przekroju jego życia (tj. długości i szerokości - ang. life span), tworzy strukturę będącą jedynie w stanie równowagi dynamicznej. Oznacza to, że ład umysłowy i jego emanacja w architekturze, nie jest nigdy danym raz na zawsze stanem równowagi, ale takim, który powstaje, trwa, zanika i na nowo odradza się. Architektura jako emanacja psychologicznej przestrzeni życia na przestrzeń fizyczna jest „żywa” dopóty, dopóki trwa ład umysłowy. Jego rozpad wskutek wojen, gwałtownych zmian kulturowych, choroby psychicznej, działalności dyktatorskiej czy działalności nieludzkich systemów politycznych oznacza utratę psychicznej integralności człowieka. Oznacza to, że w ramach tego samego organizmu, tego samego umysłu do głosu dochodzą odrębne systemy celów i wartości w relacji do środowiska, społeczeństwa i kultury. W każdym przypadku skutek jest taki sam - utrata zdolności do celowego, rozumnego i sensownego działania.

W architekturze utrata ładu psychicznego ma dwojaki wymiar. Pierwszy dotyczy kryzysu w sztuce budowania, ujawniającego się brakiem jednolitego wzorca rozwiązywania przestrzennych problemów życia.
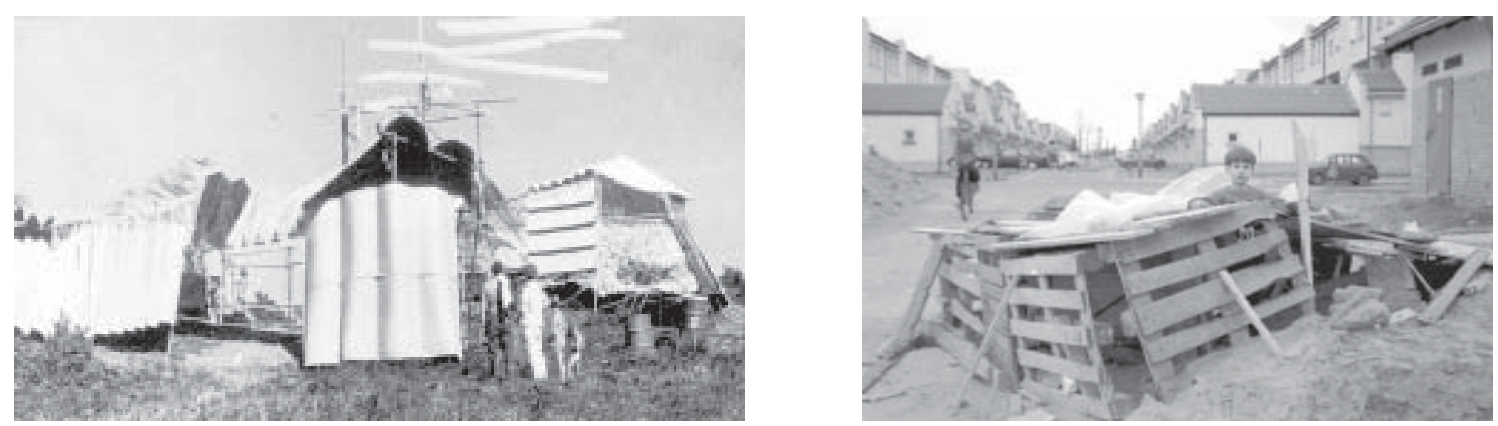

Architektura „samoistna”, jaką tworzą dzieci i dorośli nie jest jeszcze „sztuką budowania”?. Jest to głównie działanie instynktowne, bowiem w wytwarzanej formie nie ma wyraźnie określonego planu i jego dopełnienia, tj. rozpoznawalnej intencji, która pozwalałaby np. na praktyczne użytkowanie formy. 
Konkretnie zaś chodzi tu o brak konsensusu w zakresie podstawowych pojęć (rozbicie słownika na rzecz tzw. „nowomowy”), metod planowania i projektowania. Prowadzi to do przypadkowości oraz powiększania

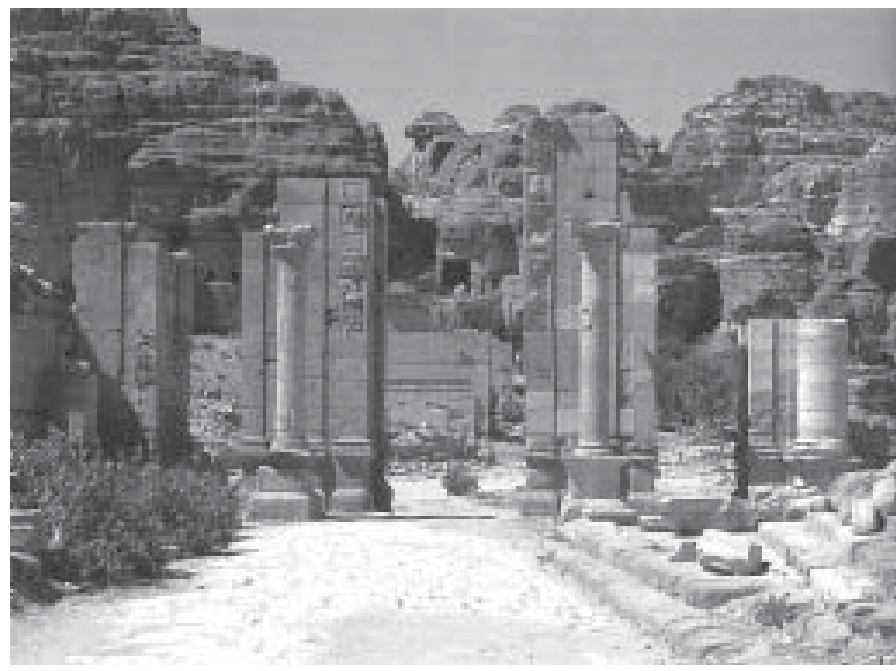
się chaosu.

Drugi wymiar utraty w architekturze ladu psychicznego uwidacznia się w kryzysie użytkowania architektury, czyli w zaniku lub nie rozpoznawalności „intencji” przyświecające autorom poszczególnych realizacji, czego wymownym przykładem może być architektura Petry.

W tym przypadku chodzi o to, że wszelkie realizacje architektoniczne sa, $\mathrm{z}$ jednej strony, wprowadzeniem w życie określonego „planu" jako psychicznej reprezentacji struktury myślowej określonego architekta, żyjącego w określonej kulturze, której jest reprezentantem i wzbogacajacym podmiotem. Z drugiej strony, realizacje architektoniczne sa rozpoczęciem i inscenizacją ,nowego życia” w postaci „,intencji”. „Żywa intencja” jest dla architekta „życiem po życiu". Dzięki niemu rola architekta nie kończy

Architektura jest żywa dopóty, dopóki trwa ład czyli plan mentalny, harmonizujący działania indywidualne i społeczne ludzi. Petra jest przykładem zerwania ciągłości z niewiadomych powodów.

się wraz z realizacja formy czy też z fizyczną śmiercią architekta jako osoby, ponieważ intencja „żyje” jako niematerialna idea.

Intencja jako idea jest dopełnieniem zrealizowanego w psychologicznej przestrzeni życia „planu”. Jest ona kontynuacją planu w fizycznym czasie i w przestrzeni. Intencja jako niematerialna kontynuacja planu jest przedłużeniem myśli architekta na potencjalne możliwości stawania się formy. Transformacje formy sa tym bardziej ukierunkowane im bardziej rozpoznawalna jest intencja. Intencja jest medium komunikowania się twórcy z innymi ludźmi, z innymi kulturami. A więc to, że jakaś forma architektoniczna została zrealizowana według określonego planu nie oznacza jeszcze tego, że jest to forma żywa. Wręcz przeciwnie, zrealizowanie fizycznej formy architek-
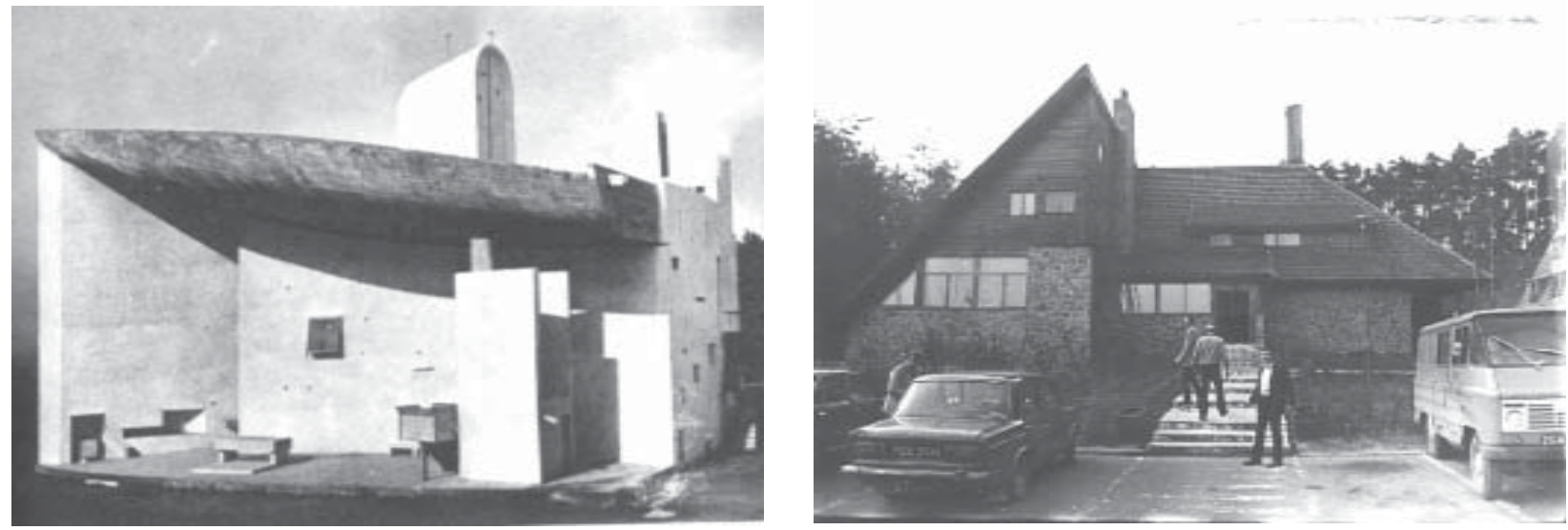

Jak kryzys w architekturze można mierzyć „upadkiem stylu”, tak postęp (jakość dorobku) architekta można mierzyć zdolnościa projektu do wymuszania zmian układających się w nowy styl. W skali międzynarodowej przykładem wielkości architektury jako prototypu dla tworzenia się nowego stylu jest kaplica Romp Champ Le Corbusiera. W Polsce przykładem stylotwórczej działalności projektowej są Buszkiewicza i Kopydłowskiego „Zajazdy Wielkopolskie”. Zajazdy na terenie całej Wielkopolski zapoczątkowały modę na strome dachy ceramiczne.

tonicznej jest zaledwie preludium do istnienia żywej, intencjonalnie użytkowanej architektury. Niemal wszędzie można zaobserwować występowanie form, których sensu istnienia nikt nie zna, nie jest w stanie odgadnać i których jedyną racją istnienia jest czyste trwanie. Ale czyste trwanie nie jest jeszcze życiem.

To czy architektura jako forma fizyczna będzie „żyła” zależy od tego, na ile zostanie w nią wbudowana wewnętrzna moc stawania się, ukryta ale rozpoznawalna intencja możliwych zdarzeń i to nie jakichkolwiek, lecz ustrukuralizowanych zachowań celowych. 

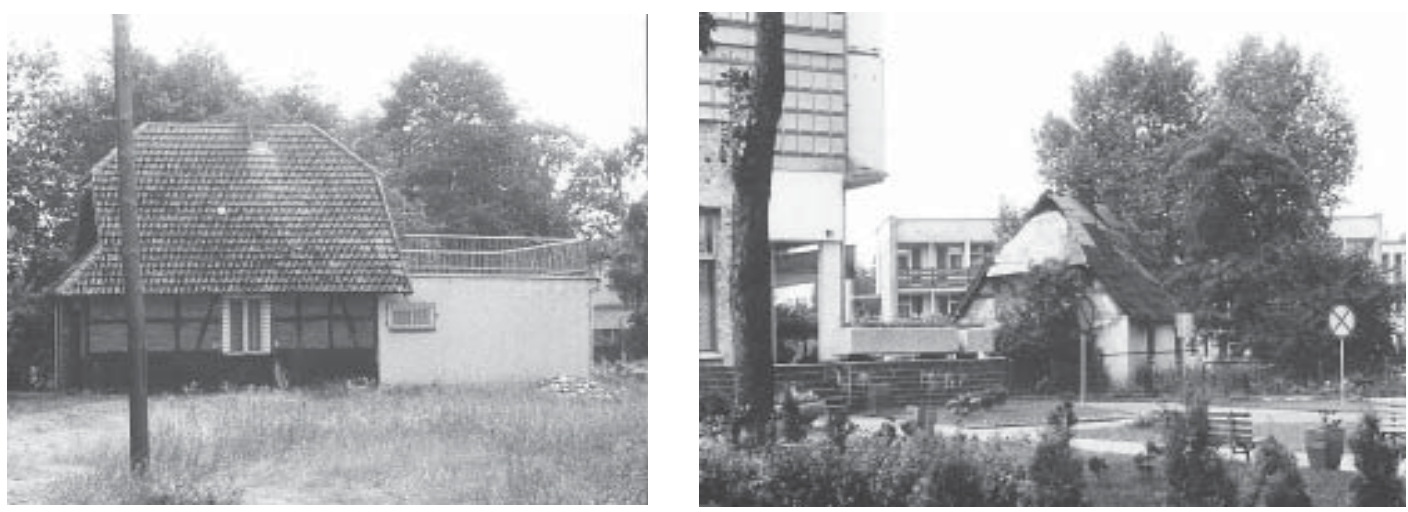

Dębno. Dom wybudowany w ramach, wydawać by się mogło, łatwo rozpoznawalnego stereotypu i stylu, jest przez użytkowników, być może pochodzących z innej kultury, traktowany w formie i w estetyce nie mającej żadnego związku z intencjami pierwotnych twórców. W jednym domu i w jednym środowisku współegzystują dwa światy: jeden ślepy i nieczuły na drugi, z tym, że pierwszy jest już na trwałe „uśmiercony” przez drugi - pyrrusowo zwycięski.

Architektura posiada naturę dwoista - prymarną i sekundarną. Pierwsza prymarną wyznacza przeistoczony z ładu psychicznego ład fizyczno-przestrzenny. Druga, sekundarną wyznacza emanujący ze zrealizowanej fizycznej formy architektonicznej ład psychiczny, którego rzeczywistość nie należy do materialnego świata formy - jak w pierwszym przypadku, ale niematerialnego świata zachowań ludzkich. Krótko mówiąc, architektura istnieje zarówno w formie fizycznej przestrzeni, jak i w niematerialnej formie zachowań ludzkich w psychologicznej przestrzeni życia. Obydwa przejawy istnienia architektury wzajemnie się warunkują i potrzebuja, z tym, że dla funkcji prymarnej architektury właściwym czynnikiem

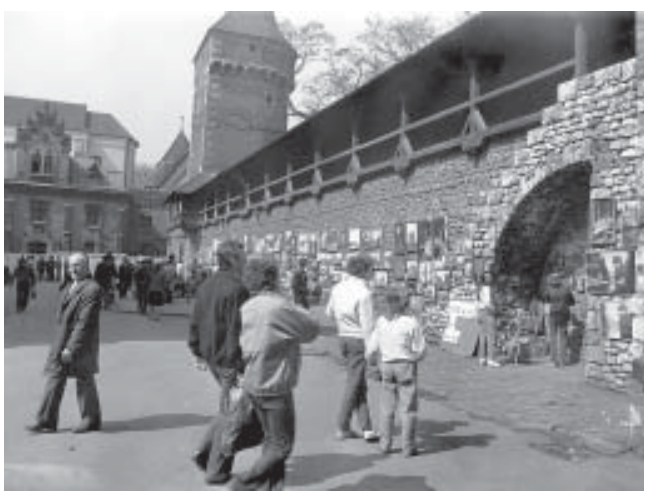

Jednym z kryterium „dobrej” architektury jest zdolność do stawania się i życia od nowa.

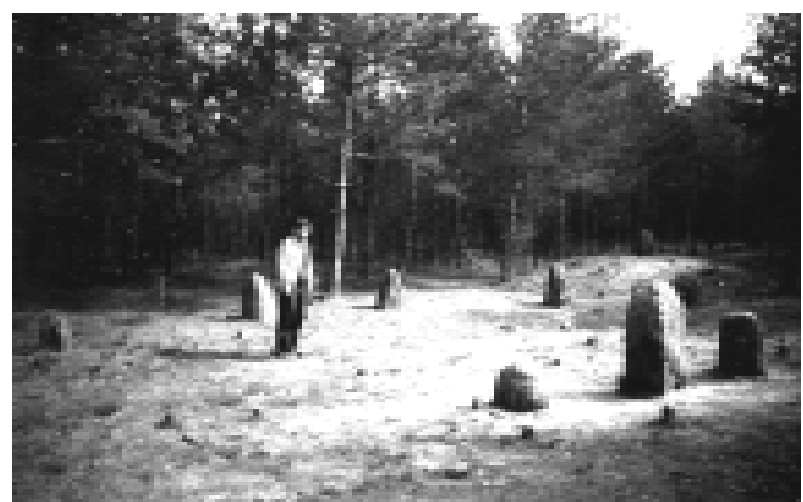

„Święty krag”.

animującym jest spójny plan, a dla funkcji sekundarnej - rozpoznawalna intencja.

Kryzys architektury przejawiający się w jej użytkowaniu wywołany jest jej niespójnościa, fragmentarycznością lub niespójnością ze zrealizowanymi planami działania. I tak z kryzysem będziemy mieli do czynienia wtedy, gdy np. średniowieczne miasto nie jest w stanie spełniać wymogów współczesnego życia, a więc nowych potrzeb w zakresie komunikacji, stylu życia itd. Nowa formuła życia, „nowe” potrzeby wymagaja zmian, ponieważ stara forma przestrzenna została zrealizowana według planu mentalnego, którego dopełnieniem sa intencje całkowicie rozbieżne ze współczesnym „stylem życia” (Allport). Jest to sytuacja konfliktowa między planami porządkującymi zdarzenia życiowe Dawniej, a planami aktualnymi Tu i Teraz. Rozwiązanie konfliktu następuje poprzez: a) przekształcenie formy przestrzennej, b) całkowite wyprowadzenie się ludzi do przestrzeni fizycznej dopasowanej do standardów i oczekiwań współczesności, c) zdefiniowanie na nowo podstawowych zasad funkcjonowania przestrzeni, d) petryfikację (umuzealnienie) istniejącej formy przestrzennej bez identyfikowania się z pierwotną intencją twórców.

Z kryzysem architektury na podłożu psychologicznym można spotkać się nie tylko w kontekście form historycznych, lecz także form współczesnych. Sa to sytuacje najczęściej spowodowane nieznajomością przez architekta podstawowych faktów odnoszących się do natury człowieka i/lub oparcia się na fałszywej teorii. Ten rodzaj kryzysów jest powszechniejszy niż się na pozór zdaje, bowiem ich podstawowym podłożem jest postawa ignorancji i arogancji. Obydwie postawy są dopełniającymi się stanami patologii umysłu. 
Przykładem tragicznej, bo skutkującej bezdomnościa, patologizacji umysłu jest tzw. „prawo spółdzielcze”. Jest to wytwór wulgarnego intelektalizmu, naiwnych założeń i zwykłych niedorzeczności, takich jak ta, że własność prywatna jest własnością publiczną. Każdy zdrowy psychicznie człowiek, który rozumie prawdy pospolite i obowiązujące niezmiennie od początku ludzkości, nie jest w stanie pojąc tej ostatniej prawdy żadną miara.
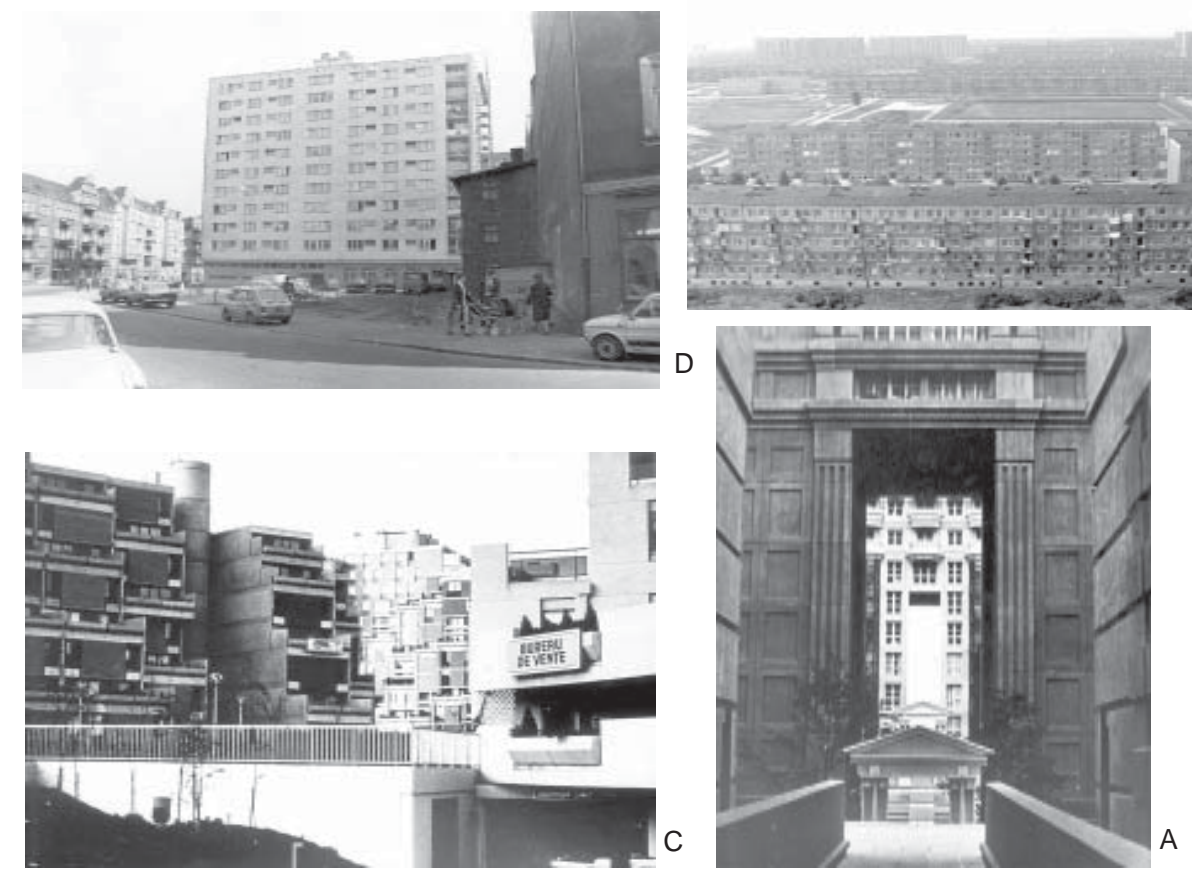

Cztery przykłady kryzysów w architekturze współczesnej. A) Awangardowe osiedla Noisy la Grand w regionie Marne la Vallee projektu Ricardo Boffila oraz Nuneza Jankowskiego ulegaja degradacji mimo wysokiej jakości. Mieszkaja w nich dziś głównie imigranci, dla których są one obco kulturowo. B) Osiedle Winogrady w Poznaniu. Zachwianie proporcji między przestrzenią prywatną a przestrzenia publiczna, będace skutkiemwdrażania błędnych teorii społeczno-architektonicznych, stanowi jeden z istotnych powodów społecznej degradacji. Brak środków na utrzymanie powoduje rozdzielenie tych dwóch rodzajów przestrzeni. C) Osiedle Evry pod Paryżem z trudem broni się przed degradacją i to tylko dzięki temu, że większość domów jest własności prywatną a nie komunalną. D. Zniszczenie struktury dziewiętnastowiecznej struktury urbanistycznej przez brak poszanowania praw psychologicznych ciagłości i prawa własności. Wyburzenie niemal połowy kwartału domów zastapione zostało jednym blokiem, który nie ma ani przodu, ani tyłu.

Wszelkie zamierzone działania w świecie architektury są rozpoczęciem realizacji określonego planu czyli psychicznej reprezentacji pełnego przebiegu zdarzeń. Kiedy jednak psychiczna reprezentacja planu jest niepełna, rozbita, fragmentaryczna (np. w skutek oparcia rozumowania na fałszywej teorii, teorii czasstkowej), wtedy łańcuch działań rozpoczyna się, ale poszczególne jego elementy nie sa zamierzone, co oznacza, że wymykają się one spod kontroli świadomości jednostki. Brak kontroli powoduje to, że działanie staje się zdeterminowane przypadkiem. Stan taki nie umożliwia jeszcze realizacji dzieła, jak to ma miejsce w przypadku utraty zdolności wyobrażeniowej u kompozytora, którego dotknął wylew krwi do mózgu, jak np. M.Ravela. Nawet w niespójnym planie można rozpoczać proces budowania i dążyć w efekcie do jakiejś „,całości”, jakiejś architektury, tyle tylko, że pozbawionej głębszego sensu, a w konsekwencji bezdusznej. Architektura, której istotne fragmenty w trakcie powstawania nie są poddane kontroli świadomości może mieć sensowny tylko początek - a więc zamiar, natomiast rezultat końcowy jest pozbawiony głębszego sensu, bo nie zawiera intencji.

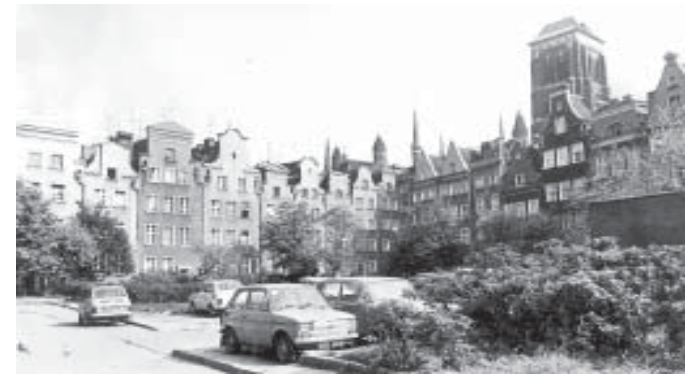

Jedną z możliwości rozwiązania kryzysu w architekturze jest przekształcenie formy. Gdańsk odbudowano po zniszczeniach wojennych wg współczesnych standardów w zakresie doświetlenia, wentylacji i programu użytkowego wewnątrz budynku. Efekt tego zabiegu w skali urbanistycznej jest zaskakujący - w wyniku skrócenia budynków w planie zabudowy działki powstały wewnętrzne dziedzińce, których pierwotnie nie było. 
Tak np. dom, którego realizacja zapoczatkowana została według mało precyzyjnego wyobrażenia najważniejszych choćby tylko przyczyn i skutków działania, może być w efekcie całością zrozumiałą jedynie od przypadku do przypadku. Architektura, którą tworzą ludzie nie wiedzący, jaki realizują ład psychiczny ma taką samą mała szansę spotkania się ze zrozumieniem (konotacją intencji) przez innych ludzi, jak twórczość człowieka cierpiącego na autyzm. Jedna i druga jest produktem rozbicia świata wewnętrznego, co w najlepszym razie prowadzi w obydwu przypadkach do interesujących, frapujących artefaktów idiosynkretycznych, ale w równej mierze niezdolnych do animowania poprzez ukrytą intencję planów działania innych ludzi. W najgorszym przypadku jeden i drugi rodzaj twórczości tworzy chaos, uniemożliwiający innym ludziom realizację ich własnych celów bez wchodzenia w konflikt z potrzebami innych użytkowników.

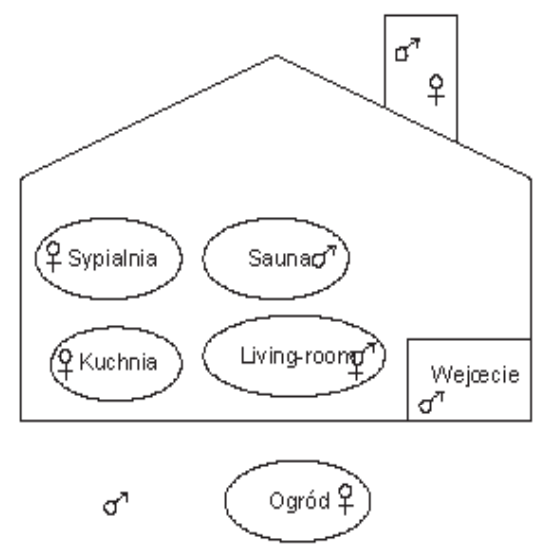

Lissa Horelli: w domach rodzinnych istnieją przynajmniej dwie sfery: żeńska i męska; obydwie maja równe prawa i winny być uwzględniane przed faktem projektowym, a nie po.

Na przykład, niektóre realizacje osiedlowych ulic tworza struktury przestrzenne, które nie będąc kreacjami ani z nazwy schizofrenicznymi, ani z zamierzenia idiosynkretycznymi - bo są usankcjonowane prawem - w istocie rzeczy sa jednym i drugim. Jeśli ktoś postawiony zostanie przed zadaniem odszukania konkretnego adresu według wskazanej ulicy, której w rzeczywistości nie ma, bo istnieje tylko na papierze i w „wyobraźni” urzędnika arbitralnie narzucającego strukturę myślową na coś, co tej struktury nie chłonie, wtedy wbrew pozorom sprawa staje się bardzo poważna, gdyż odbiera człowiekowi wolę i plan działania. Zdrowa i jak najbardziej normalna jednostka nie może nagle podjać żadnego sensownego działania według przymiotów osoby dorosłej. Staje się ona ubezwłasnowolniona, gdyż zdać się musi bądź na strategię chaotycznego programu prób i błędów (jak szczur w skrzynce Skinnera w eksperymentach nad uczeniem się), bądź zdać się na pomoc innych jak dziecko. Efekt jest w każdym przypadku taki sam: osoba dorosła nie może działać jak osoba psychicznie dojrzała.

Osobną kwestię stanowi problem zachowywania przez architekturę jej własnej tożsamości, czyli tego, co jest w niej równoważnikiem planu, sensu, ładu, rozumu i zdrowego życia. Jak już powiedziano większa część architektury wyrasta z rozumu ludzkiego, i że to on stanowi jej główne źródło życia oraz rozwoju. Teza ta prowadzi w konsekwencji do konieczności rozważenia innej tezy, a mianowicie tej, że kryzys w architekturze jest spowodowany kryzysem myślenia i od jego zmiany należy rozpoczynać wszelkie jej „uzdrawianie”. Budowanie ładu psychicznego to budowanie pozytywnej zdolności umysłu ludzkiego, dzięki której człowiek wie jak mądrze żyć, pracować i odpoczywać.

$\mathrm{Z}$ założeniem powyższym jest prawdopodobnie skłonna zgodzić się większość myślących ludzi. Różnica zdań pojawia się dopiero wtedy, gdy idzie o wskazanie konkretnych sposobów formułowania wizji dochodzenia do „dobrej” architektury. Z pewnościa dobrze by było, gdyby większość zaakceptowała założenie, iż do tego celu nie ma i być nie może jednej i najlepszej drogi. Zadaniem tej książki jest pokazanie jednej z możliwych „dróg” prowadzących do dobrej architektury. Przydatność psychologii jako nauki w projektowaniu architektonicznym polega na tym, że jest ona w stanie udzielić w miarę zadowalającej odpowiedzi na pytanie, jak osiagnąć pozytywny stan umysłu, dzięki któremu człowiek wie jak żyć i kształtować świat mądrze. Stan ów, osiaga się poprzez budowanie ładu duchowego, syntetyzującego w jedną całość odmienne lecz dopełniające się aspekty osobowości ludzkiej, a więc biologiczny, indywidualno-psychiczny i społeczno-kulturowy. Ład psychiczny ma również swoją architekturę, którą za każdym razem trzeba budować przyjmując określony punkt wyjścia i określony substrat. Zasada mówiąca o tym, że nic z niczego nie powstaje dotyczy w dużym stopniu również świata myśli, idei. większe niż duże średniowieczne miasta, a sposoby ich percepcji niespójne ze wzorami przestrzeni ukształtowanymi w kulturze Zachodu. Widoczny na zdjęciu dystans człowiek łatwiej pokonuje wzrokiem niż pieszo. W kulturze zachodniej obowiązywała zgodność wrażeń zmysłowych. 
To że psychologia może być możliwym punktem wyjścia w dochodzeniu do dobrej architektury nie oznacza przyznania tej dziedzinie wiedzy nieograniczonych możliwości i wyłączności w ferowani tzw. „słusznych rozwiązań". Przede wszystkim psychologia to tylko nauka, i jak każda inna ma głównie wyjaśniać istniejący stan rzeczy, a nie być najlepszą „nauczycielką” życia. Ograniczenia psychologii w zastosowaniu do architektury polegają na tym, że jak każda nauka empiryczna z istoty swej opiera się na poznaniu fragmentarycznym.

Pojęcie logos w słowie „psychologia” obejmuje nie całą mądrość o człowieku, lecz jedynie waskie i wyspecjalizowane spojrzenie, ograniczone do metody pomiaru i obserwacji. W tej pracy użyteczność psychologii $\mathrm{w}$ tej zastosowaniach architektonicznych widziana jest przede wszystkim przez pryzmat dostarczyciel użytecznego „substratu”. Otóż myśl, idea, obraz, program czy plan, będące synonimami ładu psychicznego muszą być z czegoś zbudowane, tak jak dom zbudowany jest z cegieł, z wielkiej płyty bądź jeszcze z czegoś innego. Substratem ładu psychicznego są między innymi pojęcia, koncepcje czy teorie. W ramach przestrzeni pojęciowej umysł człowieka porzą dkuje i strukturalizuje myśli, idee, obrazy, projekt, wizje czy plany.

Podstawowym zadaniem tej pracy jest przedstawienie sposobu, w jaki ludzie moga spostrzegać przestrzeń za pomocą różnych zmysłów i umysłu. Przestrzeń jest podstawowa kategoria psychologiczna i architektoniczna. Cokolwiek istnieje w zasięgu zmysłów człowieka albo wyobrażeń musi istnieć w przestrzeni czy to rzeczywistej (fizykalnej) czy też wyobrażonej (mentalnej). Nie ma sposobu odrzucenia jej wszechobecnego uczestnictwa w otaczającym nas świecie, nawet jeśli uznamy ją za fikcję, czy jak Leibnitz, za idealna koncepcję
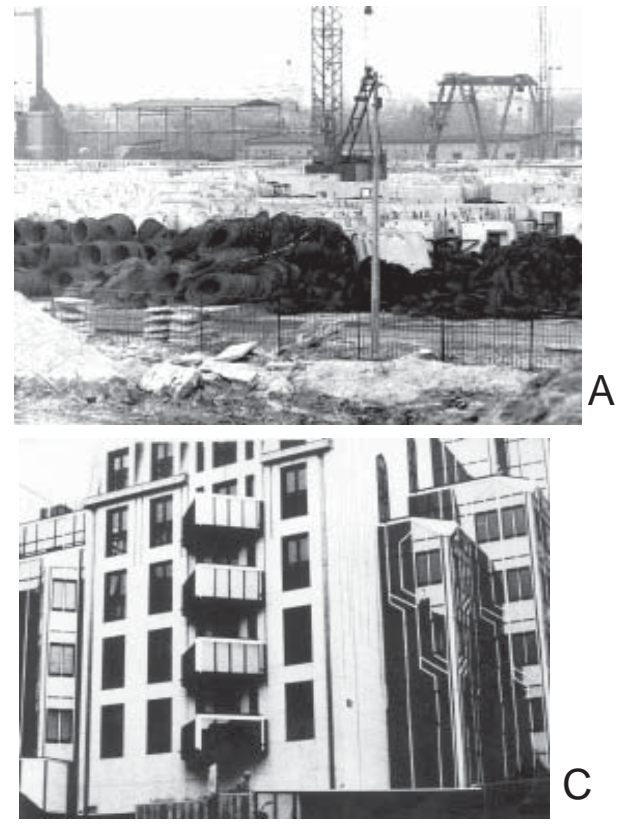

Kilka przykładów substratu w architekturze. A) Fabryka domów, do niedawna symbol nowoczesności i nowoczesnego substratu architektury. B) Architektura będąca równoważnikiem substratu: zbyt nudna, uproszczona i nieszczera. C) Architektura, w której substrat został utożsamiony fasadą. D) Les Hales: subtrat utożsamiany z formą to zbyt „słaby” wkład do dobrej, a nie mówiąc już ponadczasowej architektury. D) Architektura ze wzornika gotowych schematów. umysłu. Przestrzeń jest fenomenem niezbywalnym. Ogarnia sobą wszystko, co jest przedmiotem naszych spostrzeżeń i co potrafimy sobie pomyśleć.

Podstawowym zamierzeniem tej książki jest pokazać przestrzeń od strony psychologicznej, tak jak jawi się ona w umyśle architekta i w doświadczeniu codzienności zwykłego człowieka. Celem przeprowadzanych analiz nie jest pouczanie architektów jak tworzyć dobrą architekturę, ale pokazanie jak korzystać z pojęć i struktur psychologicznych w zwiększaniu prawdopodobieństwa stworzenia bardziej komfortowych warunków życia. Tworzenie architektury z myślą o człowieku zaczyna się od myślowego budowania obrazu zdarzeń, które są dostępne w wyobraźni architekta, ale niewidoczne dla innych. Psychologia jest jedną z wielu dyscyplin zwiększającą możliwości twórczego doświadczania i wizualizowania rzeczywistości ludzkiej w momencie przystępowania do projektowania. Twórczość architektoniczna jest myślowym konstruowaniem zdarzeń w przestrzeni mentalnej projektanta, na podstawie różnych doświadczeń, jakie zgromadzili psycholodzy, użytkownicy różnych form przestrzeni architektonicznej i sami architekci w trakcie procesu twórczego i świadomej refleksji post factum. Niniejsza praca ma celu zintegrować owe trzy różne płaszczyzny doświadczenia Tak widziana funkcja architektury jest jeszcze w Polsce na tyle egzotyczna, że wymaga dalszego uszczegółowienia, co jest właśnie celem następnego rozdziału. 


\section{Pojęcie projektowania oraz jego relacje z nauka}

Pytanie o istotę projektowania jest w zasadzie pytaniem o status epistemologiczny procesu, opierającego się w głównej mierze na ideach tkwiących w umyśle człowieka, a których ostateczną konsekwencją jest powoływanie do istnienia nowej, wcześniej nieistniejącej rzeczywistości. Zasadniczym pytaniem, na które odpowiada niniejszy rozdział tej książi jest to, na ile projektowanie jest tylko mnemotechnicznym kreowaniem rzeczywistości, a na ile jest ono aktem poznawczym rzeczywistości?

Podstawową tezą wyznaczająca treść zawartych

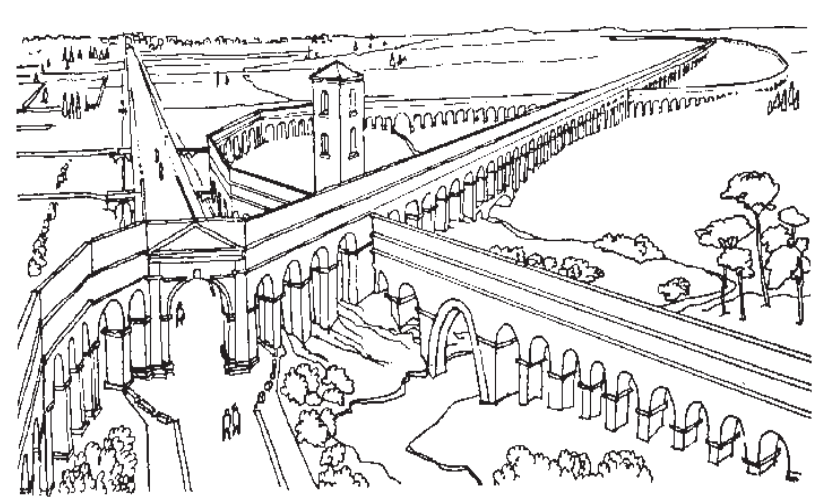

A. Antyczna wizja przestrzeni życia jako ludzkiego projektu „drugiej natury” i dominacji nad środowiskiem naturalnym. Od najdawniejszych lat człowiek niezależnie od postawy afirmacji i adaptacji wobec natury i genius locci, projektował przestrzeń na swój własny psychiczny wizerunek nie mający odpowiednika w jakiejkolwiek rzeczywistości materialnej.

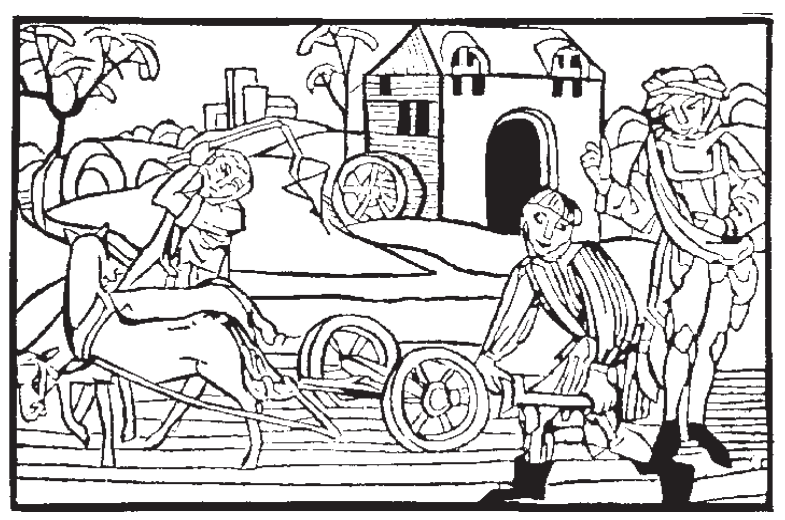

B. Średniowieczna wizja życia przedstawia bardziej totalna dominację człowieka vis-á-vis środowiska naturalnego: na pierwszym planie zespół rolników wykonuje orkę za pomoca ciężkiego pługa; na drugim planie młyn wodny wykonuje pracę na potrzeby człowieka; na trzecim planie architektura zamku. Przejście od antyczności do średniowiecza jest przejściem do początku profesjonalizmu jako zawodowej specjalizacji. poniżej rozważań jest to, iż projektowanie jest czymś więcej niż zwykłą mnemotechnika. Projektowanie jest zarówno procesem tworzenia czegoś praktycznego na podstawie wyuczalnych reguł i odtwarzania doświadczenia praktycznego, jak też skomplikowanym procesem poznawczym, w efekcie którego wytwarzany jest specyficzny rodzaj wiedzy, refleksji i teorii. Nowoczesne spojrzenie na projektowanie jest takie, że chociaż nie jest to ono jeszcze jednym rodzajem nauki, to jest jednak procesem poznawania rzeczywistości równie wartościowym jakim jest proces poznania naukowego.

Literatura drążąca strukturę projektowania jako procesu kształtowania świata w niematerialnej przestrzeni myśli, pojęć, idei oraz wartości zaczęła pojawiać się w latach pięćdziesiątych naszego wieku w rezultacie zmian dokonujaccych się w świadomości zawodowych projektantów. Zmiany te przejawiały się w wysuwaniu na plan pierwszy nowych kryteriów profesjonalizmu i w rozwoju nowych racjonalnych, naukowych metod projektowania. Profesjonaliści, jak zauważa Sanoff (1992), nie sa szanowani za to co robia, ale za sposób wykonywania zadań, różny od możliwości zwykłych ludzi. To narzuca na nich szczególną odpowiedzialność za zrozumienie tego, tym kim są oraz dzięki jakim zdolnościom?

$\mathrm{W}$ architekturze, jak w wielu innych dziedzinach związanych z zaspokajaniem ludzkich potrzeb, przez tysiace lat obywano się bez profesjonalistów, i być może byłoby to możliwe w dalszym ciagu. Jednak rozwój cywilizacji zwiększający stopień współzależności zjawisk natury i inteligencji człowieka jako rodzaju odbiera jednostce ludzkiej wolność w decydowaniu o sposobach zaspokajania własnych potrzeb, powierzając tę funkcję profesjonalistom. Zwykli ludzie poddani są wręcz tyranii profesjonalizmu, która przejawia się

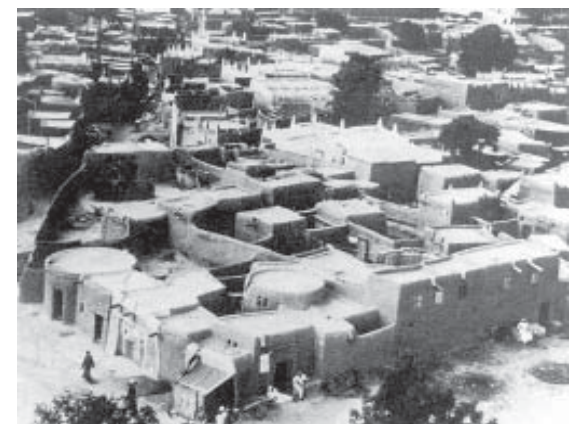

Architektura self made jest nie tylko wyrazem konieczności zaspokajania potrzeb przy ograniczonych możliwościach ekonomicznych, ale również wyrazem dążenia do autoekspresji indywidualnych oczekiwań i wizji szczęścia, dobrobytu, osobowej oraz kulturowej tożsamości.

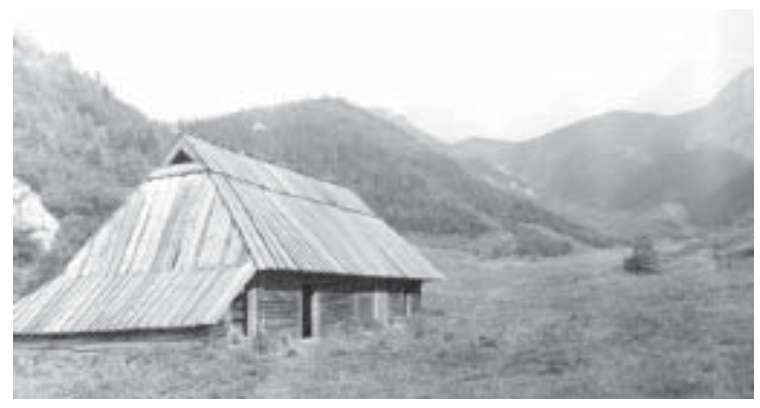


tym, że coraz więcej funkcji, które byliby w stanie wykonać we własnym zakresie, mogą wykonywać wyłącznie za pośrednictwem specjalistów, a więc ludzi obdarzonymi szczególnymi zezwoleniami, licencjami, akredytacjami i przywilejami. Do tych szczególnych ludzi chronionych rozlicznymi „,wyłącznościami” należy również zawodowy (licencjonowany) architekt.

Kiedy zadajemy sobie pytanie, co zrobić aby dane miejsce stało się „żywe” natychmiast, a nie po kilkudziesięciu latach mało przydatne jest studiowanie historii miejsc. Adekwatną odpowiedź może dać jedynie odwołanie się do pamięci, a więc historii zdarzeń w miejscach, w których tętniło to życie. Zwykli ludzie też posiadają wiedzę praktycznie użyteczna, mogą też być utalentowanymi artystami, tyle że nie są profesjonalistami. Co to oznacza? Ano tyle, że ich wiedza jest wiedza indywidualna, prywatna, nie uniwersalna i idiosynkretyczna. Profesjonalizm wymaga wielowymiarowości kompetencji, obejmującej zarówno wiedzę prawna, psychologiczna, historyczna, metodologiczna, jak i wiedzę dotyczącą sposobów praktycznego rozwiązywania problemów w różnych warunkach: programowania, badania, eksperymentowania, symulowania. Często myli się profesjonalizm i teorię idiosynkretyczna. Przykładem na to jest m.in. twórczość Steinera, którego teorie z poetyckiego punktu widzenia są twórczym artefaktem, ale z naukowego punktu widzenia nieweryfikowalnym nomotetyzmem.

Wciąż postępującej złożoności świata nie są w stanie stawić czoła zwykli ludzie, bez specjalistycznego przygotowania, dlatego w większości przypadków sa zdani na profesjonalistów. Mimo to, albo wskutek tego, na aktualności zyskuja pytania w stylu: Czy projektowanie profesjonalne w każdej sytuacji jest skuteczniejsze i bardziej racjonalne od projektowania spontanicznego, tj. na własny użytek?

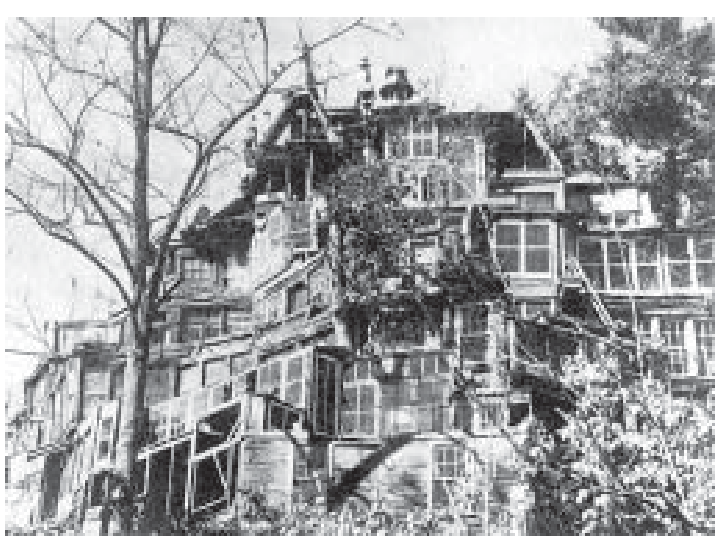

Prawo budowlane w coraz większym zakresie odbiera zwykłym ludziom prawo decydowania o ich własnym domu, jego wartości. Profesjonalizm ogranicza wolność jednostce, która mimo to dąży do realizacji swoich marzeń. Jak oceniać wartość przestrzeni architektonicznej, gdy jest ona subiektywnie inna w psychologicznej przestrzeni życia właściciela, a inna w „zobiektywizowanej” wiedzy profesjonalisty? Czy i w jaki sposób profesjonalista powinien wykorzystywać wiedzę użytkowników, klientów i innych nieprofesjonalistów? Czyja wiedza i w jakich okolicznościach jest „lepsza” oraz według jakich kryteriów należałoby ową lepszość oceniać? Na jakich zasadach należałoby opierać współpracę i partycypację różnych podmiotów projektowych? Czy istnieje wiedza pewna i pewna metoda projektowania?

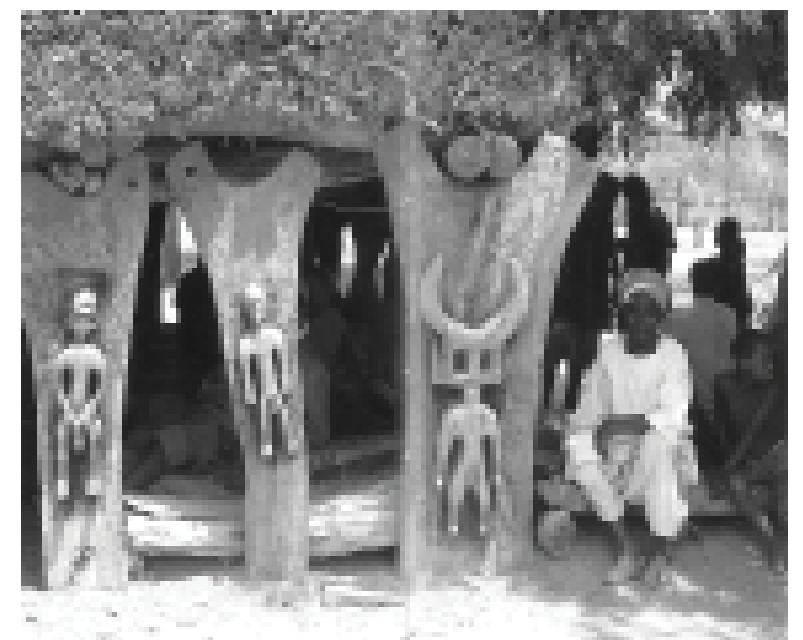

Toguna jako ośrodek kultowy i kulturalny w plemieniu Dogonów (Mali). Architektura kultur ekologicznych opiera się na wiedzy tajemnej, której nosicielem jest każdy członek danej kultury. Weryfikowalność wiedzy jako gwarancja antywtajemniczenia w cywilizacji współczesnej ma charakter przedstawicielski, tj. realizowany za pośrednictwem profesjonalistów (ekspertów).
Na pytanie o rolę ,ignorantów” w architekturze profesjonalnej w sposób metafizyczny odpowiedział Venturi w książce pod znamiennym tytułem Learning from Las Vegas. Wnioski, jakie wyciaga Venturi dotyczą między innymi możliwości akceptowania przez profesjonalistów zasad myślenia niby „prymitywnego".

Odpowiedzi na postawione pytania prowadza do różnych teorii projektowania. W miarę wyczerpującego przeglądu metod projektowania profesjonalnego, wykraczajaccego poza tradycyjne ramy intuicjonizmu, można znaleźć m.in. w pracy J.C. Jonesa. Rozwój refleksji teoretycznej dotyczacej projektowania był w ostatnich kilkudziesięciu latach tak żywiołowy, że dokonując przeglądu powstałych ostatnio definicji i opisów projektowania, jak chociażby Asimowa czy Halla trudno oprzeć się wrażeniu, że istnieje tyle modeli projektowania, ilu jest piszących. Różnorodność ta jest z jednej strony efektem różnicowania się kryteriów profesjonalizmu, z jakimi w różnych sytuacjach muszą radzić sobie projektanci, a z drugiej - efektem wspomnianej wcześniej specyficznej refleksji poznawczej towarzyszącej świadomemu projektantowi. 


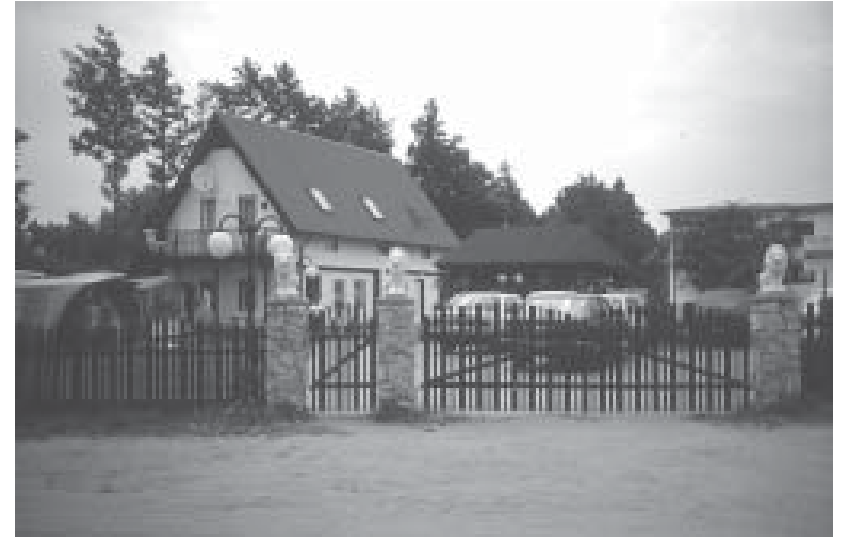

Elementy totemiczne w postaci lwów, ozdabiające prywatną rezydencję świadczą o tym, że człowiek tak naprawdę w środku się nie zmienia.

Różnorodność teorii projektowania, które będa m.in. przedmiotem rozważań dalej, jest w dużym stopniu pozorna, bowiem wszystkie łączy wspólna cecha, polegająca na dążeniu do uchwycenia samej struktury esencjalnej procesu jako standardu mogącego odnosić się do wszystkich form designu: architektury, urbanistyki, wnętrzarstwa, wzornictwa przemysłowego, budowy maszyn. Wspólną cechą nowoczesnych koncepcji projektowania jest to, że nie ograniczaja się one do analizowania produktu końcowego projektowania, ale do jego składników proceduralnych: analizy, syntezy i oceny. Wspólną cecha projektowania w każdym przypadku, tj. bez względu na rodzaj projektowanej rzeczy, jest zapoczatkowanie $\mathrm{w}$ przestrzeni mentalnej zmian $\mathrm{w}$ rzeczach wytwarzanych przez ludzi. Taka „rzeczą” może być zarówno obiekt budowlany, jak również środowisko naturalne przekształcane w architekturę krajobrazu lub plan zagospodarowania przestrzennego. Projektowanie jest u źródeł zawsze procesem myślowym zapoczątkowującym zmiany innego typu, takie jak: materialne, instytucjonalne, proceduralne. Jest tak niezależnie od tego czy rzeczywiste rezultaty spełniają określone oczekiwania, czy też nie.

Nowa kwestia, jaka pojawiła się w teorii projektowania związana jest dość paradoksalnie ze starym pytaniem filozoficznym o związek niematerialnej idei tkwiącej w przestrzeni umysłowej projektanta z rzeczywistością materialną. Upraszczając sprawę, problem polega na tym, jak z niematerialnej idei ma powstawać materialny świat. Gdzie są granice, a gdzie płaszczyzny styku? Chęć i potrzeba zrozumienia wspólnej płaszczyzny dla niematerialnej wiedzy oraz materialnego bytu (projektu) stanowi impuls do poszukiwania odpowiedzi na pytanie: Czym jest projektowanie z punktu widzenia różnych dziedzin wiedzy, takich jak sztuki piękne, nauki ścisłe, matematyka, psychologia czy inne nauki o człowieku? Odpowiedzi słyszy się różne w zależności od preferencji odpowiadającego. W klasycznej architekturze najwięcej jest zwolenników sztuki. Niemal równie dużo zwolenników wśród

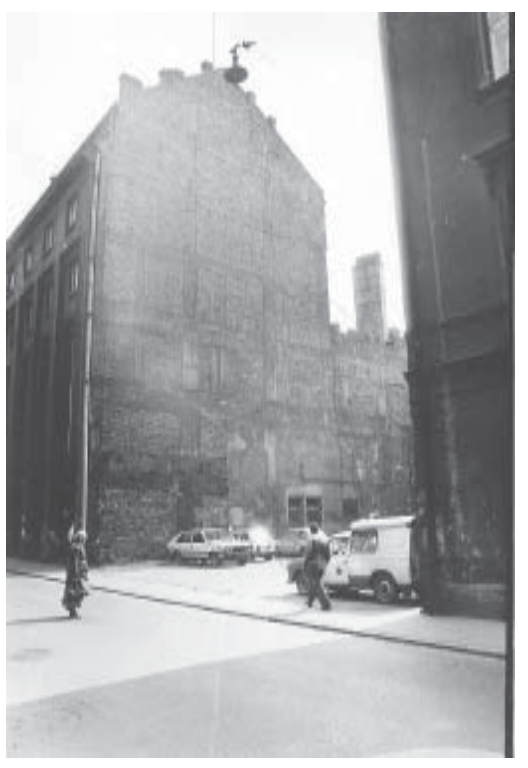
zaprojektowanie wymaga wiedzy wielowymiarowej, a liczba możliwych rozwiąań nie jest ograniczona niczym oprócz wyobraźni projektanta. architektów ma tech-

nika. Ostatnio coraz więcej zwolenników zyskują sobie nauki behawioralne, w szczególności psychologia.

Jedno, co nie podlega wątpliwości to to, że projektowanie nie jest żadna z tych dziedzin z osobna, lecz wielowymiarowym połączeniem różnych schematów działania, myślenia i metod należących do każdej z tych dziedzin z osobna. Projektowanie nie jest jednak też zwykłym zsumowaniem poszczególnych dziedzin, ale produktem myślenia interakcyjnego, realizującym się w czasoprzestrzeni mentalnej projektanta. Dzięki temu ten sam projektant, jako ta sama osoba w różnych problemach może odwoływać się do różnych systemów wartości i odniesień.

Różnice między projektowaniem a sztuka, nauką i techniką są wielokryterialne, niemniej jednak zasadnicza jest kwestia czasu. W przypadku działalności projektowej uwidacznia się konieczność uznawa- 
nia za realne coś, co istnieje „Tu” i „Teraz” w psychologicznej przestrzeni życia projektanta, natomiast z punktu widzenia przestrzeni i rzeczywistości materialnej jest zawsze zapowiedzią, a więc nieistniejąca jeszcze przyszłością. Każda działalność inna od projektowej, jak na przykład naukowa, zawiera się w realnym czasie historycznym, lub - jak w przypadku matematyki - jest poza nim.

Bardzo często projektowanie ujmowane jest $\mathrm{w}$ powiązaniu z naukami praktycznymi. Zgodnie z tą koncepcja „projektowanie jest czynnościa poznawcza, której celem jest znalezienie takiej teorii optymalizacyjnej określonego systemu (np. urządzenia technicznego, struktury organizacyjnej), z której będzie wynikało, iż system ów spełnia przyjęte kryteria efektywności”. Wydaje się jednak, że ujęcie takie nie jest precyzyjne, gdyż zbytnio akcentuje składnik poznawczy projektowania, nie uwzględniając jednocześnie innych składników, jak chociażby czynności implementacyjnych, wdrożeniowych wyprowadzanych z twierdzeń teorii optymalizacyjnej kryteriów efektywności.

Reasumując można powiedzieć, że współ-

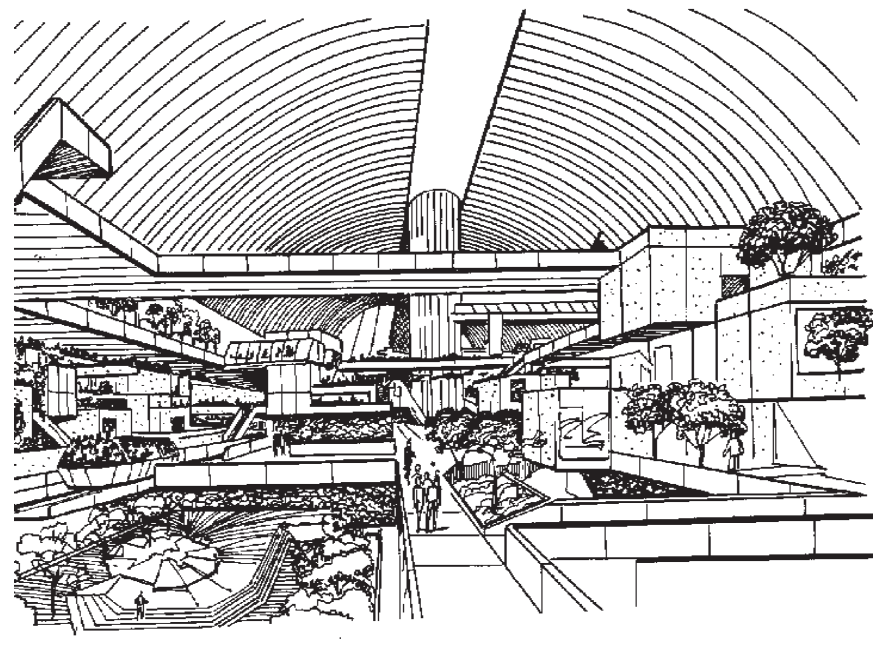

Bez względu na to jak ściśle wizje architektury opierają się na naukowych podstawach i osiągnięciach techniki, zawsze są one wytworem sztuki. cześnie projektowanie stanowi splot czynności zwiazanych z formułowaniem problemów, podejmowaniem decyzji i implementacją (wdrożeniem) wyprowadzonych kryteriów efektywności do praktyki na podstawie wypracowanych w różnych naukach szczegółowych procedur i metod działania.
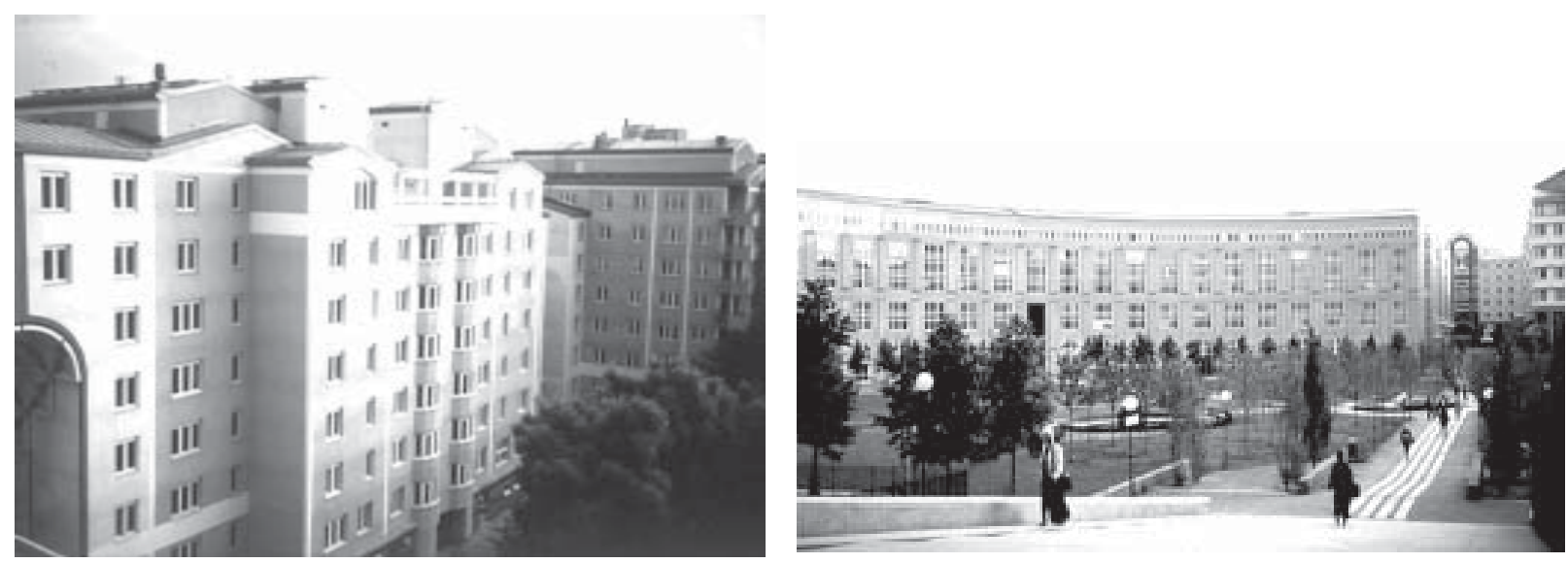

Bardzo często jako panaceum na niedostatki współczesnej architektury proponuje się powtarzanie historii. Nie jest to ani najlepsza droga, o czym świadczą doświadczenia postmodernizmu, ani skuteczna, bowiem współcześnie nie można odtworzyć piazza czy forum w sensie dosłownym, a tylko esencjalnym (C. Plac w Sztokholmie).

\section{Projektowanie a technika}

Z punktu widzenia teorii projektowania, kryterium efektywności czy kryterium postępu coraz bardziej istotnym staje się pytanie o to, jaka jest relacja między projektowaniem a techniką. Czy projektowanie jest częścią myślenia technicznego, czy też jest czymś więcej? Odpowiedź na to z pozoru oczywiste pytanie nie jest bynajmniej prosta uwzględniwszy fakt, że poglądy na istotę projektowania jako części składowej działalności technicznej zmieniały się równolegle z ewolucją specyficznych wzorów myślenia technicznego, jako wykładnika postępu.

Po pierwsze, technika jako forma ludzkiej wiedzy ustawicznie zmienia swoje powiązania z innymi formami wiedzy. Po drugie, postęp techniki coraz częściej pociaga za sobą implikacje moralne, gdyż rozwój 
techniki ma charakter semiautonomiczny, tzn. w dużej części sterowany jest przez cele i wartości spoza sfery technicznej . Zadaniem m.in. filozofii techniki jest badanie celów leżących u podłoża rozwoju techniki oraz określanie ich implikacji dla człowieka. Szczególnie ważny wydaje się problem stosunku techniki do nauki. Dwiema podstawowymi tezami, wyznaczajacymi m.in. treść niniejszego rozdziału, są: 1) technika nie jest nauką stosowana, 2) różnice między nauką a techniką są najlepiej widoczne poprzez wykazanie różnic w istocie postępu technicznego i naukowego.
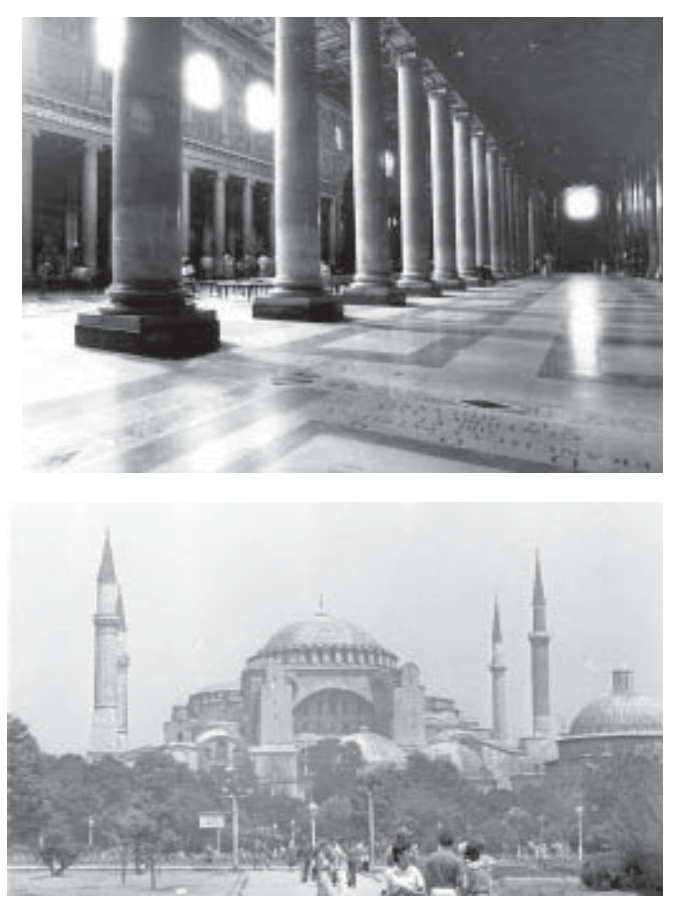

Wielu metodologów i filozofów nauki uważa, że technika jest w zasadzie kompozycją różnych sztuk lub rzemiost. Ten pogląd pociaga za sobą koncepcję wywodzenia metodologicznego aspektu techniki z nauk przyrodniczych, tj. nie przyznawanie technice niezależnego metodologicznego statusu. Sprowadzenie techniki do nauki stosowanej jest jednak zabiegiem z gruntu błędnym, gdyż nie uwzględnia koncepcji postępu technicznego. By nauka mogła egzystować, musi podlegać rozwojowi. Rozwój nauki jest rezultatem ciagłego rozwoju teorii naukowych i ciagłego wzbogacania wiedzy naukowej. Innymi słowy, rozwój nauki polega na ciagłej zmianie gorszych teorii na lepsze (prostsze, bardziej logiczne, bardziej uniwersalne, bardziej szczegółowe lub o większej mocy wyjaśniającej). Drugą istotna cechą nauki jest to, że idea postępu naukowego nieodłącznie związana jest ze wzrostem możliwości badania rzeczywistości, co powoduje podział teorii naukowych według kryterium funkcji wyjaśniających.

Co w tym kontekście można powiedzieć o technice? Czy jest ona innym sposobem poznawania rzeczywistości? Czy jej celem jest wzbogacanie wiedzy? Odpowiedzi na obydwa pytania są negatywne. O ile celem nauki jest poznawanie rzeczywistości, o tyle celem techniki jest kreacja rzeczywistości. Oczywiście te dwa rodzaje rzeczywistości nie należą do tego samego porzqdku. Nauka bowiem koncentruje się na badaniu rzeczywistości $\mathrm{w}$ jej podstawowym znaczeniu, tzn. celem jej celem badań jest odpowiedź na pytanie „co jest?". Natomiast w technice chodzi o tworzenie artefaktów, czyli rzeczywistości sztucznej, będącej wytworem umysłu człowieka. Dlatego też rozwój techniki manifestuje się w jej zdolności do tworzenia coraz to nowych wyrobów, posiadających coraz to nowe cechy, w coraz bardziej efektywny sposób.

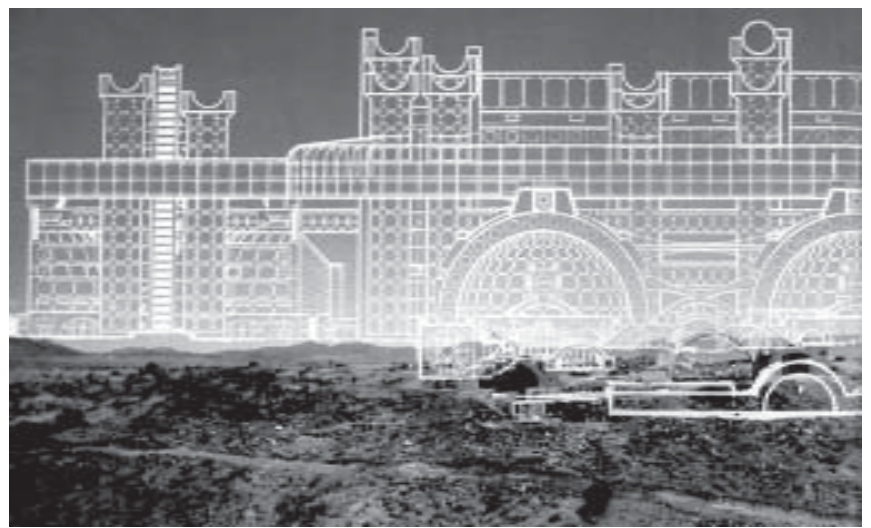

Paolo Sorelli: Przykład poszukiwania rozwiązań architektonicznych we wzorach myślenia technicznego prowadzi czasami do ekscytujących wizji, których przełożenie na środowisko życia człowieka nie ma bynajmniej krótkiej drogi..
Cechą szczególną postępu techniki jest dostarczanie przez nia, prócz nowych wyrobów, również środków tworzenia coraz to lepszych wyrobów tego samego rodzaju. Kryteriami „lepszości” w tym przypadku sa: a) większa niezawodność, b) większa uniwersalność, c) większa czułość, d) większa szybkość w wykonywaniu funkcji e) mniejsze koszty produkcji, f) kombinacja czynników a, b, c i d.

Kryteria postępu technicznego nie moga być zastapione kryteriami postępu naukowego oraz odwrotnie, kryteria postępu naukowego nie mogą być wyrażone kryteriami postępu techniki. Oznacza to, że w danym czasie możliwy jest do pewnego stopnia postęp techniki bez równoczesnych postępów w nauce, co szczególnie widoczne jest na przykładzie architektury. 

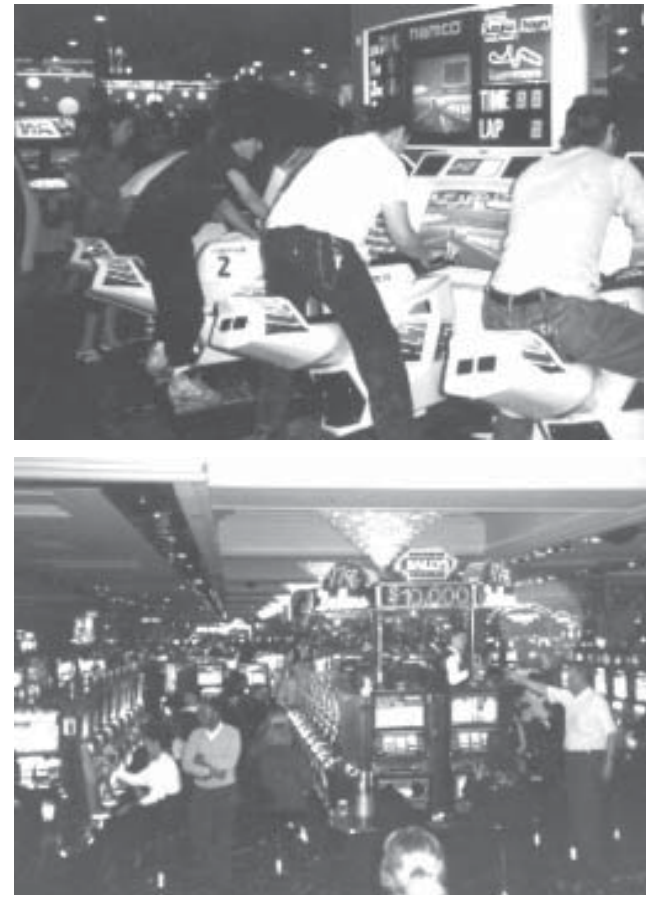

W architekturze coraz częściej pojawia się dylemat: czy projektowanie ma podążać za postępem technicznym czy rozwojem naukowym. Pierwszy wybór grozi kreowaniem sztucznych potrzeb, czyli tzw. osobowości marketingowej podporządkowanej maszynowemu tempu życia (formacja Las Vegas). Drugi zaś grozi gloryfikowaniem jednostronnych, wąskich teorii naukowych jak np. ekologicznych.

Generalnie jednak, postęp w technice ułatwia postęp nauki i odwrotnie. Obserwacje te doprowadzaja do konkluzji, że postęp nauki, jak i techniki, nie może być osiagnięty w czystej formie, zaawansowanie techniki pociaga za sobą postęp w nauce i zaawansowanie nauki stymu-

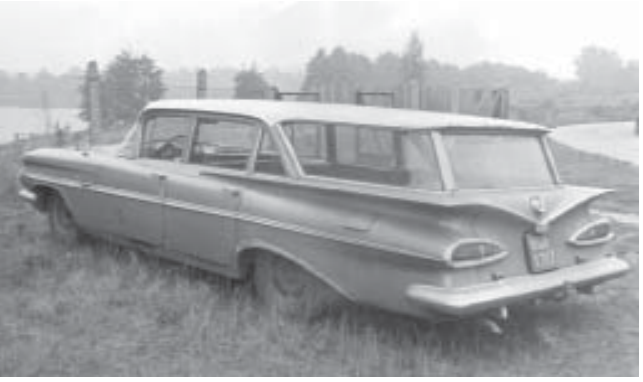

Postęp techniki rodzi nerwową gonitwę za nowościa pierwszeństwem, oryginalnościa i jakością. Projektowanie wspomagane komputerowe wychodząc z tych wartości doprowadziło do paradoksu, że wszystkie produkty sa takie same. Stare samochody przynajmniej mają „duszę”. luje rozwój techniki.

Istotę postępu naukowego można prosto określić jako pogoń za wiedza. Takie samo jednoznaczne stwierdzenie w odniesieniu do istoty postępu technicznego jest zadaniem o wiele trudniejszym, ze względu na różnorodność kryteriów jego oceny. Wydaje się jednak możliwe znalezienie jakiegoś wspólnego mianownika dla tych różnorodnych kryteriów zaawansowania techniki. Tym wspólnym kryterium jest efektywność. Postęp techniczny można zatem zdefiniować jako wzrost efektywności tworzenia wyrobów danego rodzaju.

Analiza postępu technicznego w kategoriach efektywności prowadzi jednak do dwóch pytań. Po pierwsze, czy istnieje możliwość wyrażenia efektywności technicznej w pewnych kategoriach ogólnych? Pozytywna odpowiedź na to pytanie doprowadza do rozważań z zakresu prakseologii. Po drugie, czy możliwe jest określenie specyficznych wzorów myślenia prowadzących do wzrostu efektywności w różnych dziedzinach techniki?
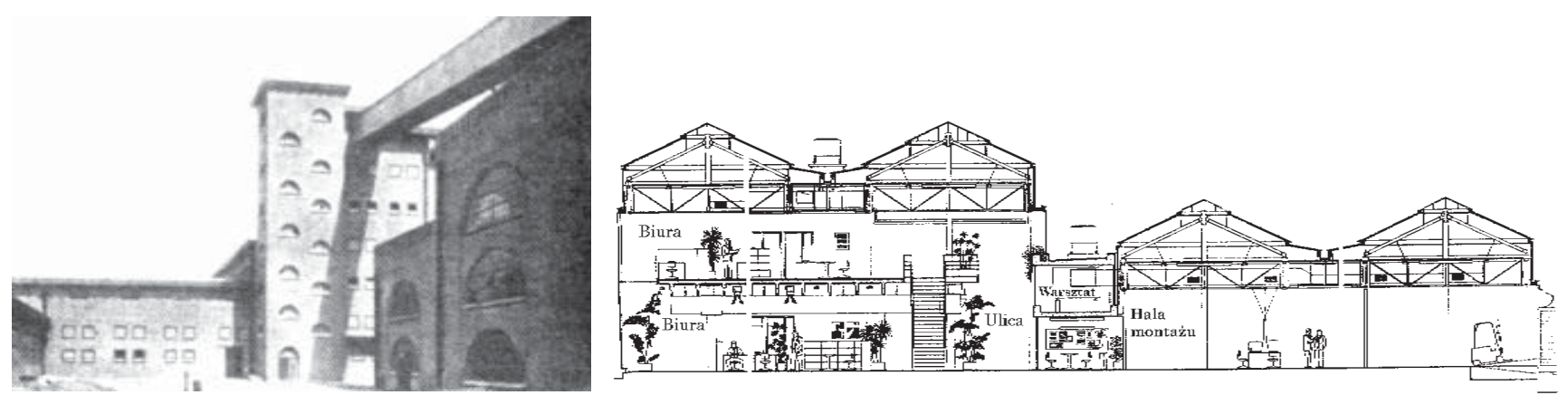

Architektura jako sztuka zaspokajania potrzeb człowieka może rozwijać się zgodnie z postępem techniki i rozwojem nauki, jak też bez żadnego związku każdej z tych dziedzin z osobna. Koncepcja „nowej architektury” jest grą formalną w przestrzeń. Postęp techniki bez postępu naukowego jest jedynie udoskonalaniem danego pomysłu, natomiast postęp techniki poparty postępem naukowym jest rewolucjonizowaniem produktu i jego funkcji. A. Dwie wizje fabryki - z początku epoki kapitalistycznej i obecnie.

\section{Rozwój „wzorów myślenia” w technice a zmiana rozumienia pojęcia projektowanie}

Celem tego i następnych rozdziałów jest: 1) wykazanie możliwości wyróżnienia specyficznych „wzorów myślenia” technicznego oraz 2) wskazanie implikacji niektórych z tych „wzorów myślenia” dla psychologicznej teorii projektowania. Do zilustrowania tezy o możliwości wyróżnienia specyficznych „wzorów myślenia” 


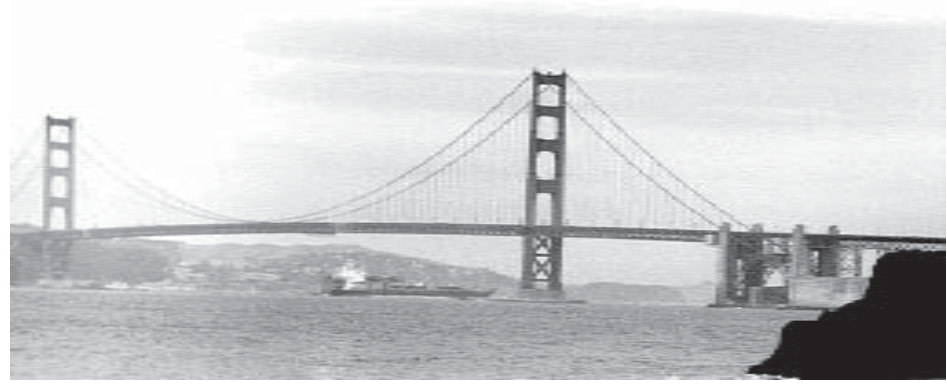

W geodezji naczelnym kryterium postępu jest dokładność pomiaru. W architekturze kryterium dokładności może, ale nie musi być wyznacznikiem postępu. Dla architektury, która jest przede wszystkim konstrukcja budowlaną wartością naczelną była i jest wytrzymałość. technicznego posłużą przykłady zaczerpnięte z takich dyscyplin technicznych, jak geodezja, budownictwo lądowe i wodne, budowa maszyn, architektura. Tak np. ostatecznym celem pracy geodety jest sporządzenie map czy profilów. Co jest szczególne w postępowaniu geodety, co wyznacza postęp w tej dziedzinie? Dokładność pomiarów jest tym czynnikiem, który wyznacza postęp w geodezji Innymi słowy, myślenie geodezyjne, to myślenie w kategoriach dokładności. Cały wysiłek badawczy od początku istnienia tej dyscypliny zmierzał do opracowania jak najdokładniejszych metod pomiaru.

W budownictwie natomiast, niezależnie od tego, czy chodzi o konstrukcję mostu, budynku lub innego obiektu, naczelnym kryterium, które ma zawsze na względzie każdy projektant, jest wytrzymałość konstrukcji. Tak więc $\mathrm{w}$ tej dyscyplinie specyficznym wzorem myślenia technicznego jest rozstrzyganie dobroci przedsięwzięć w kategoriach wytrzymałości. Wytrzymałość jest punktem wyjścia jakiejkolwiek analizy. Również dobór materiałów i metod konstruowania jest zawsze zdeterminowany kryterium wytrzymałości konstrukcji. Teoretyczne badania, podejmowane w dziedzinie budownictwa lądowego, ukierunkowane są na odkrycie kombinacji materiałów zwiększającej wytrzymałość lub zmniejszającej koszt konstrukcji tej samej wytrzymałości.

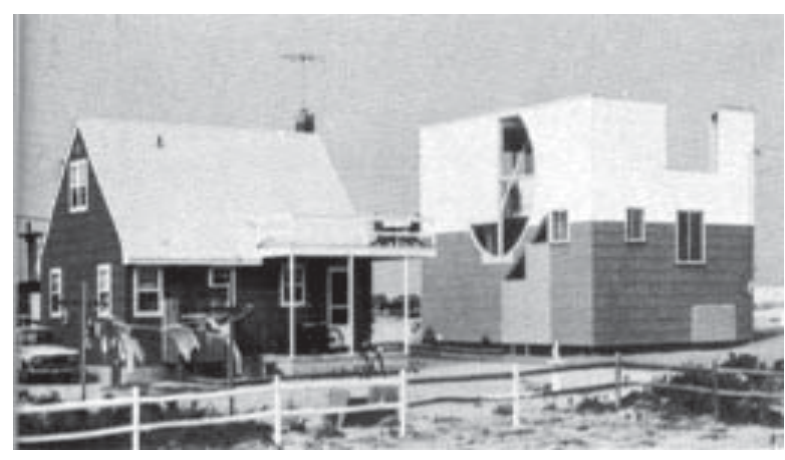

W technologii budowy maszyn specyficzny „wzór myślenia” polega na preferowaniu kategorii efektywności. Efektywność w tym przypadku oznacza dobroć urządzenia w tym sensie, że jest mniej energochłonne, bezpieczniejsze, bardziej odporne, o dłuższym cyklu użytkowania, bardziej niezawodne. Oczywiście w budowie maszyn kryterium wytrzymałości jest również ważne, niemniej jednak w tym przypadku ma ono charakter pochodny od kryterium efektywności.

Myślenie architektoniczne, jako inne w stosunku do myślenia technicznego czy naukowego, polega z kolei na równoczesnym myśleniu kategoriami wytrzymałości, estetyki i użytkowości, przy czym dwa ostatnie kryteria wydaja się nawet ważniejsze od pierwszego. Opracowując budynek inżynier konstruktor musi rozważyć przede wszystkim możliwości zestawienia różnych materiałów oraz ewentualne rozwiąania konstrukcyjne. Projektując ten sam budynek architekt musi rozważyć kwestie komfortu, sanitarne, estetyczne, czyli wszystkie te aspekty dzieła, które decydują o jakości życia zgodnego z duchem epoki, z jej predylekcjami i awersjami. To, co różni inżyniera budownictwa od architekta polega na tym, że pierwszy musi rozstrzygać problemy przede wszystkim w kategoriach wytrzymałości, a drugi przede wszystkim w kategoriach użyteczności i artystycznych upodobań.

Reasumujac, charakter współczesnej architektury w dużym stopniu determinowany jest przez szereg nietechnicznych czynników, takich jak: kontekst społeczny, system ekonomiczny, upodobania estetyczne, uwarunkowania psychologiczne. Należy mieć jednak na uwadze to, że nie wszystkie dziedziny projektowania architektonicznego sa w jednakowym stopniu podatne na wpływy techniki i czynników pozatechnicznych, a co za tym idzie, w różny sposób na ich gruncie formułowane są poglądy na istotę projektowania. Architektura uprawiana w modelu działalności technicznej i tak pozostanie na zawsze najbardziej podatna ze wszystkich dyscyplin technicznych na wpływy pozatechnicznych celów, kryteriów i wartości. Dominacja kryterium postępu technicznego nad czynnikami ludzkimi rzadko kiedy prowadzi do trwałych dobrych rozwiązań. Przykładem na to ostatnimi czasy jest modne kryterium efektywności ekologicznej. Jako kryterium jakości życia $\mathrm{w}$ środowisku nie jest ono podważalne w jakikolwiek sposób. Jednak potraktowane w kategoriach myślowych postępu technicznego w niewielkim stopniu przyczynia się do zapewniania rzeczywistej jakości życia jako stylu wykazującego się wyższą efektywnością (harmonijnościa). 
W architekturze postep ma charakter wielokryterialny. Często wartościa jest to, co stworzyli poprzednicy. Przykładem tego jest „polska wieża Eiffla”, czyli: a) Wieża Gornośląska Pelziga, b) „Iglica Szmidta”, pawilon recepcyjny Buszkiewicza i Skrzypczaka, którego projekt wydobywa na światło dzienne idee pierwszego autora, warsztat epoki oraz istotę materiału, z którego dzieło zostało pierwotnie wykonane.
A

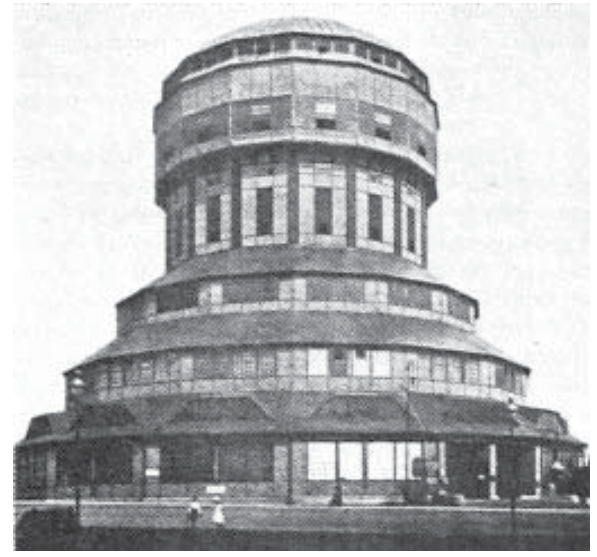

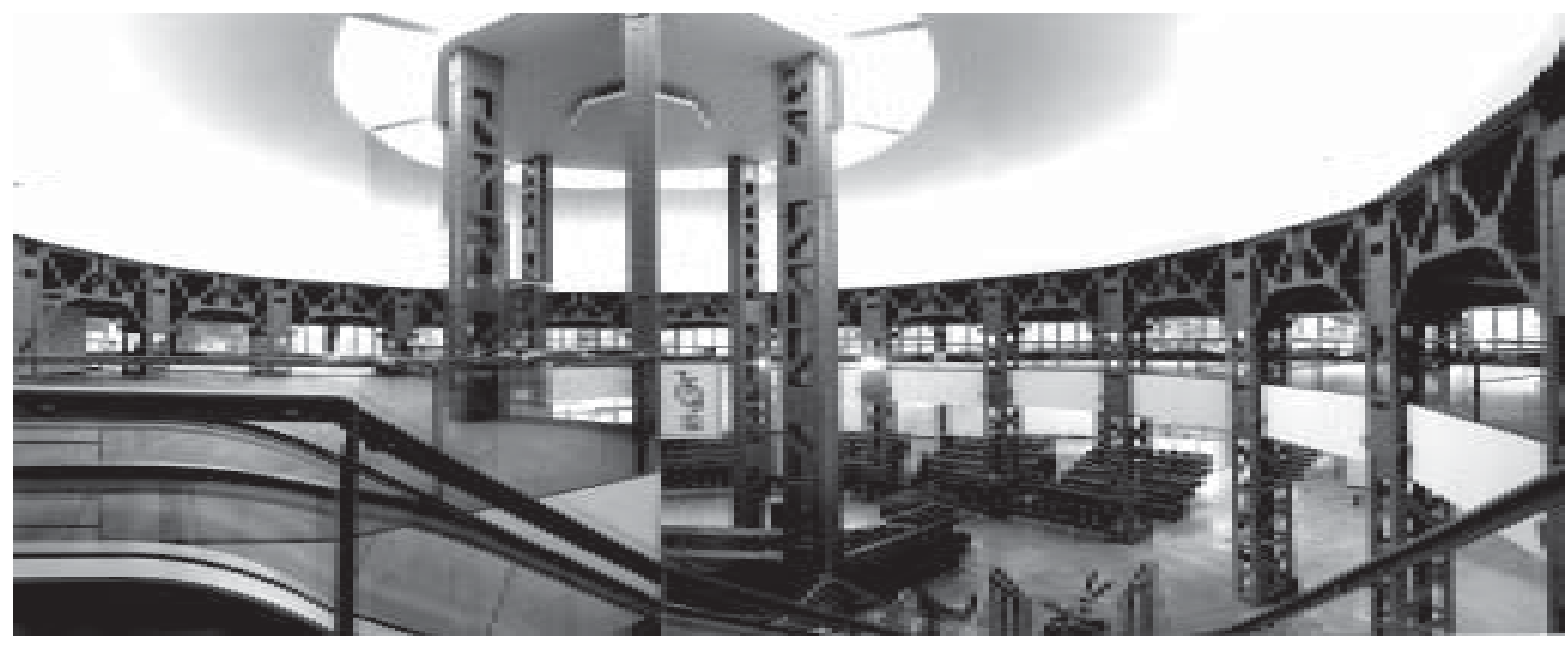

Wiele z tzw. kultur ekologicznych afrykańskich, jak np. Dogonów w zachodniej Afryce przeżywa dramat z powodu podporządkowania architektury zachodnim standardom postępu i zanegowaniu tradycyjnego, holistycznego (całościowego) związu człowieka z przestrzenią. Zachodni blok mieszkaniowy w kulturze Islamu odebrał kobiecie godność i prywatność. Tradycyjne domostwo wbrew rozpowszechnionym stereotypom zapewnia kobiecie w wielożeństwie istotna przewagę nad mężczyzna, dzięki potraktowaniu czynnika architektonicznego jako protektora bezpieczeństwa fizycznego, kontrolowanej komunikacji międzyludzkiej, regulatora prywatności i harmonijności życia psychicznego.

W następnym rozdziale, omówione zostaną niektóre z nich z punktu widzenia rozwoju pojęcia projektowania architektonicznego.

Efektywność ekologiczna w architekturze może być kryterium postępu technicznego, jak też tradycyjnej sfery jakości życia. Te dwa
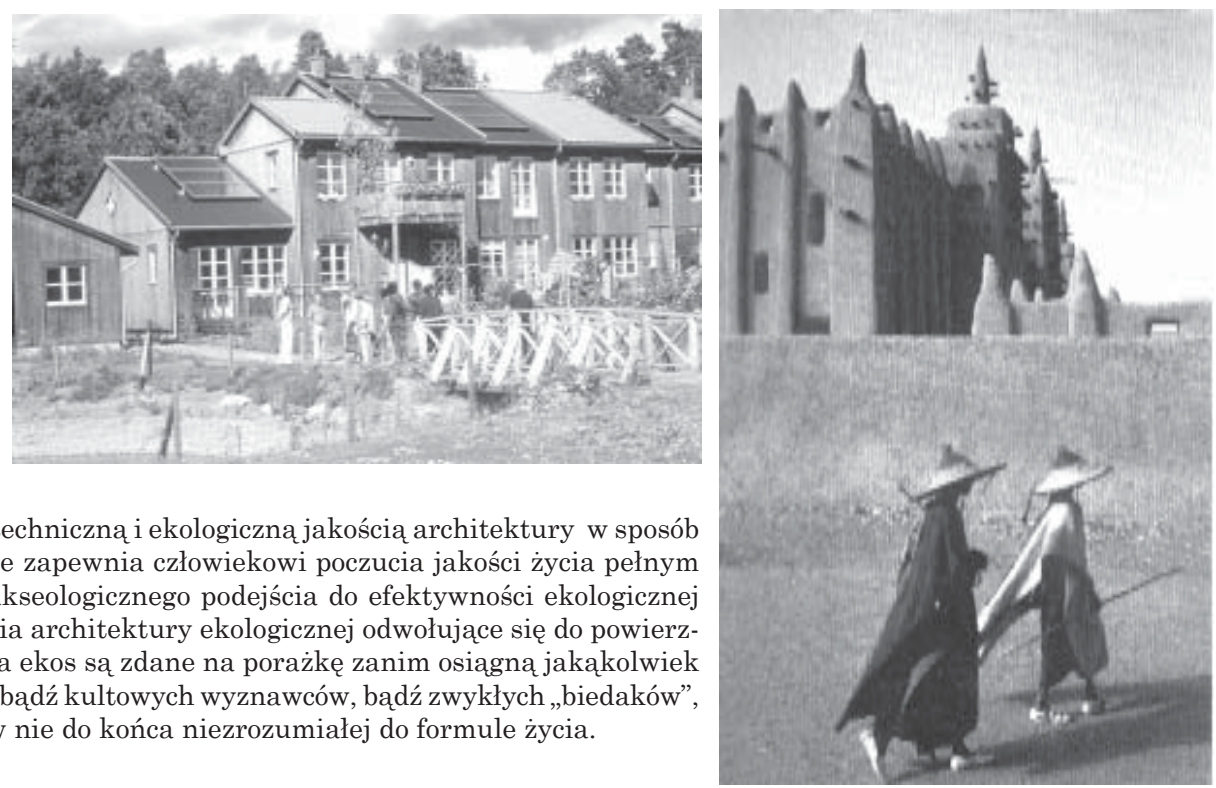

pokrywać Jakość życia połączone z techniczna i ekologiczna jakościa architektury w sposób prakseologiczny (sprawnościowy) nie zapewnia człowiekowi poczucia jakości życia pełnym tego słowa znaczeniu. Przykład prakseologicznego podejścia do efektywności ekologicznej w Sztokholmie, Szwecja. Rozwiązania architektury ekologicznej odwołujące się do powierzchownej, kulturowej warstwy pojęcia ekos są zdane na porażkę zanim osiagną jakąkolwiek dojrzałość. Osiedla takie przyciagają bądź kultowych wyznawców, bądź zwykłych „biedaków”, którym „przydzielono” mieszkanie w nie do końca niezrozumiałej do formule życia. 


\title{
KONTEKST PSYCHOLOGICZNY ROZWOJU POJĘCIA PROJEKTOWANIE
}

\author{
Behawioralne wyznaczniki projektowania architektonicznego
}

$\mathrm{Na}$ podstawie dotychczas przeprowadzonych rozważań nad istotą projektowania z teoriopoznawczego punktu widzenia można wyciagnąć następujące wnioski, które dalej traktowane będą jako podstawowe założenia koncepcji zastosowania danych behawioralnych, tj. danych dotyczących zasad funkcjonowania psychiki i zachowania się ludzi, w projektowaniu architektonicznym:

1) Rozwój projektowania, tzn. rozwój zadań, jakie stawiane są przed wszystkimi dziedzinami projektowania, związany jest z rozwojem profesjonalizmu, który opiera się na specyficznych wzorach myślenia naukowego i technicznego.

2) Wzory myślenia profesjonalnego, w tym myślenia architektonicznego, uwarunkowane są postępem naukowym i technicznym.

3) Teorie projektowania architektonicznego, jako „pochodne” wzorów myślenia profesjonalnego, stanowia ogniwo łączące naukę, technikę i refleksję wywodzącą się z doświadczenia praktycznego.

4) Teorie projektowania architektonicznego, pełniąc funkcję ogniwa wiążącego naukę, technikę i praktykę, umożliwiają skuteczne zaspokajanie różnorodnych potrzeb człowieka.

Powyższe założenia mają dwa aspekty - poznawczy i praktyczny. Pierwszy oznacza to, że projektowanie jako integrowanie w przestrzeni mentalnej (psychologicznej) różnych form doświadczenia jest procesem nie tylko generowania nowej rzeczywistości, dotychczas jeszcze nieistniejącej, ale także procesem poznawania tej rzeczywistości, która już jest, jak i tej, która ma dopiero być wykreowana. Inaczej mówiąc projektowa-

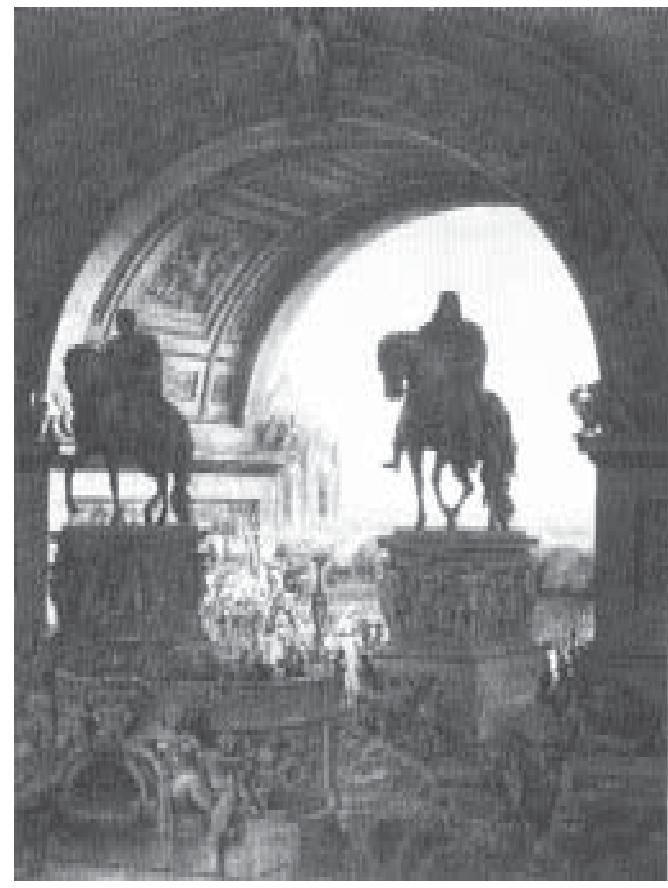

Dla F.K. Schinkla projektowanie było uprawianiem historii. Malując „Łuk triumfalny” w 1817 r był nie tylko architektem ale także historykiem. Schinkel poszukujący plastycznego wyrazu dla wielkości ducha narodu, prawdę historyczną traktował jak konstrukcję mentalna, historiozoficzną oraz punkt wyjścia dla wyobraźni poszukującej prawdy esencjalnego skrótu w przestrzeni konstruowanej (malarskiej). nie jako kreowanie rzeczywistości jest jednocześnie poznawaniem w znaczeniu odkrywania rzeczywistości, jak i poznawaniem w znaczeniu wytwarzania rzeczywistości.

Drugi aspekt, praktyczny, dotyczący założeń projektowania oznacza, że aby projektowanie było skuteczne musi być interakcją co najmniej trzech rodzajów wiedzy: naukowej, technicznej i refleksyjnej. Rozwój wiedzy z zakresu nauk o człowieku, takiej jak psychologia, stymuluje postęp współczesnej architektury podobnie, jak w dawnych wiekach robiła to sztuka, mieszcząca się w kanonie myślenia refleksyjnego, a później technika. Zrozumienie wiedzy naukowej i jej asymilacja we wzorach myślenia architektonicznego, jest jednym z podstawowych warunków skuteczności współczesnej architektury w zaspokajaniu potrzeb ludzkich. Nawet największa fascynacja techniką nie może przesłonić architektowi ostatecznych celów, którym służy. Są one bowiem zawsze związane z człowiekiem.

Tradycja włączania w sferę myślenia architektonicznego danych dotyczących czynnika ludzkiego jest tak stara, jak sama architektura. Niemniej jednak proces ten polegał głównie na intuicyjnym operowaniu danymi dotyczacymi natury ludzkiej. Obecnie zaś zachodzi potrzeba oparcia projektowania architektonicznego na teoriach zgodnych $\mathrm{z}$ postępem technicznym oraz naukowym w różnych dziedzinach, w tym również w naukach o człowieku.

Między wiedzą intuicyjną (refleksyjna) a naukową istnieje ścisły związek, ale i zasadnicza różnica. Granica podziału przebiega podobnie, jak różnica między kanonem uniwersalistycznym, opartym na klasycznej definicji prawdy, a kanonem postmodernistycznym relatywizującym prawdę do wybranych fragmentów rzeczywistości. W przypadku intuicyjnej wiedzy o człowieku zakres teoretyzowania (wyjaśniania) ma charakter lokalny, bowiem odnosi się do realne- 
go doświadczenia i realnej rzeczywistości. Ten typ teorii nazywa się też folk theories. Wąskość, zrozumiałość, swojskość teorii typu folk jest ulubionym myślowym środkiem rozwiązywania problemów w sytuacjach podobnych do tych, w których powstały. Prawda zawarta w wyjaśnianiu potocznym jest postrzegana przez większość ludzi jako naturalna i nie wymagająca specjalnego wysiłku do wmontowania jej w utarte struktury myślowe. Proces włączania myślenia refleksyjnego w sferę rozwiązywania problemów architektonicznych przebiega bezproblemowo i nie nakłada na projektanta specjalnych wymagań w zakresie samoświadomości. Intuicja, refleksja czy metafora żywią się terminami i pojęciami naturalnymi. Intuicja traktuje rzeczywistość ateoretycznie, a więc tak, jaka ona jest i w takich samych pojęciach, jakich używa się w życiu codziennym. Działanie oparte na intuicji całkowicie pokrywa się z myśleniem intuicyjnym, a więc stanowi z nim nierozłączną całość.

O wiele trudniej przebiega proces włączania do projektowania architektonicznego naukowej wiedzy o człowieku. W tym przypadku występuje konflikt pomiędzy wiedzą intuicyjną o naturze i środowisku człowieka, a wiedzą naukową wyrażaną najczęściej w abstrakcyjnych terminach i pojęciach. W konflikcie z intuicją wiedza naukowa z reguły „przegrywa”, jako mniej naturalna, tzn. nie mieszcząca się w systemie utartych i wygodnych pojęć charakterystycznych dla „potocznego” wzorca myślenia architektonicznego. Wiedza naukowa wypierana jest też przez wiedzę intuicyjną w efekcie procesu zwanego zakapsutkowaniem. Polega to na tendencji do autonomizowania w umyśle człowieka systemu wiedzy teoretycznej i separowania jej od systemu wiedzy operacyjnej architekta. Prościej mówiąc, najczęściej jest tak, że teoria to jedno, a praktyka - to drugie. Jeżeli nawet jakaś teoria przebija się do świadomości projektanta, to i tak nic nie musi z tego wynikać, gdy ryzyko psychologiczne związane $\mathrm{z}$ zastosowaniem teorii jest zbyt duże. Teorie wyznaczaja praktyczne działania architekta tylko w trzech przypadkach: a) gdy jest inteligentny i świadomy swojej misji, b) gdy jest emocjonalnie związany z danym systemem poglądów lub wartości, c) gdy takie, a nie inne poglądy sa na nim wymuszane $\mathrm{np}$. w miejscu pracy.

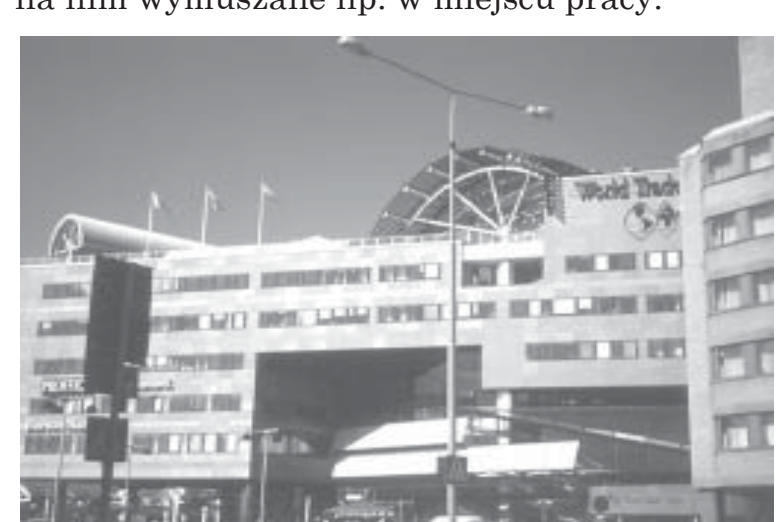

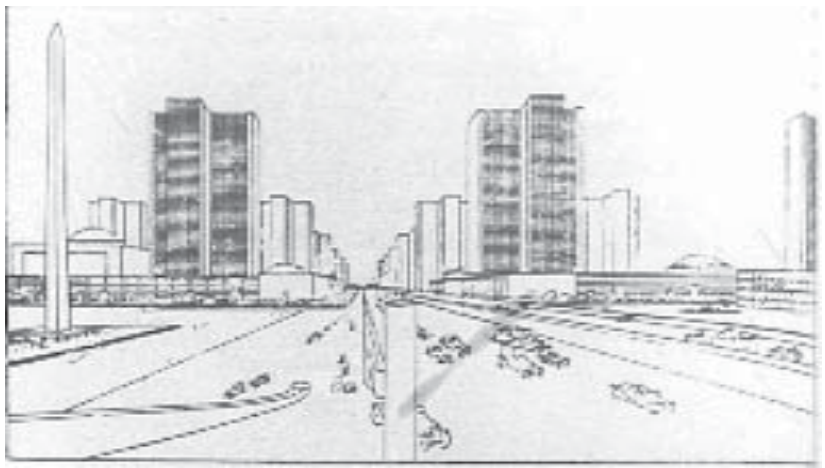

Przeludnienie, postępująca urbanizacja, rozwój przemysłu jako wciąż niezastapiony środek osiagania dobrobytu wymagaja rozwiązywania problemów na niespotykaną skalę w bardzo krótkim czasie. W obliczu skali, wielości wyzwań, różnorodności podmiotów uczestniczacych w projektowaniu niemożliwe jest skuteczne radzenie sobie z problemami projektowymi na bazie wyłącznie artystycznej, intuicyjnej i refleksyjnej. Nie uwzględnienie tego faktu w konsekwencji musi prowadzić do porażki. Dotyczy to nawet największych geniuszy jak LeCorbusier, ponieważ lokalna prawda nie jest w stanie zastapić prawidłowości psychologicznych.

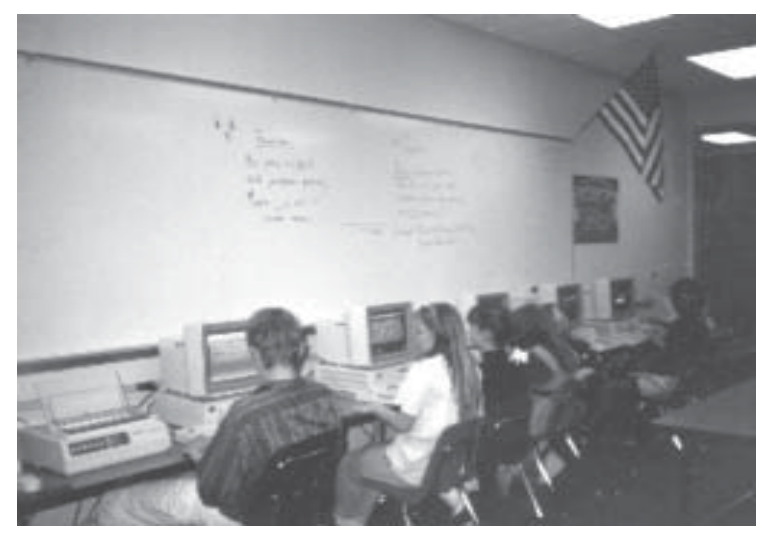

Intuicja jako działający umysł i jako umysł poznający w działaniu. Ta zasada jest szczególnie widoczna u dziecka, którego rozwój umysłowy uzależniony od działalności praktycznej przebiega od pojęć konkretnych do pojęć abstrakcyjnych. Jak dotychczas nikomu na bazie intuicji nie udało się rozwiązać problemu nowoczesnej szkoły, w której uczeń nabywając wiedzy w działaniu, nie odwracałby się plecami do nauczyciela.

Skrajnym przypadkiem wolności wyboru jako racji projektowej jest architektura postmodernistyczna. Jest ona relatywizowaniem i lokalizowaniem prawdy w formie zideologizowanej. Ideologia postmodernistyczna nakazuje łączenie i repetytorium różnych fragmentów porządku historycznego, dekompozycję tęczy według uznania autora. Jest to też refleksja nad tym, że istnieje możliwość zaprzeczenia postępu. 
Podstawowy problem współczesności nie dotyczy pytania, czy należy rozwijać teorie projektowania i korzystać z teorii naukowych, ale tego, jak zmniejszyć opór przed rzeczywistymi a nie pseudo teoriami naukowymi? Czynnikiem umożliwiajaccym proces usystematyzowanego włączania wiedzy naukowej, w tym wiedzy naukowej o człowieku, w sferę projektowania architektonicznego jest świadomość metodologiczna projektanta, na którą składa się teoria projektowania, a więc:

- zbiór zasad i pojęć podstawowych,

- metoda operacyjna projektowania,

- metoda krytyczna czyli zespół refleksji nad przedmiotem, podmiotem i celem projektowania.
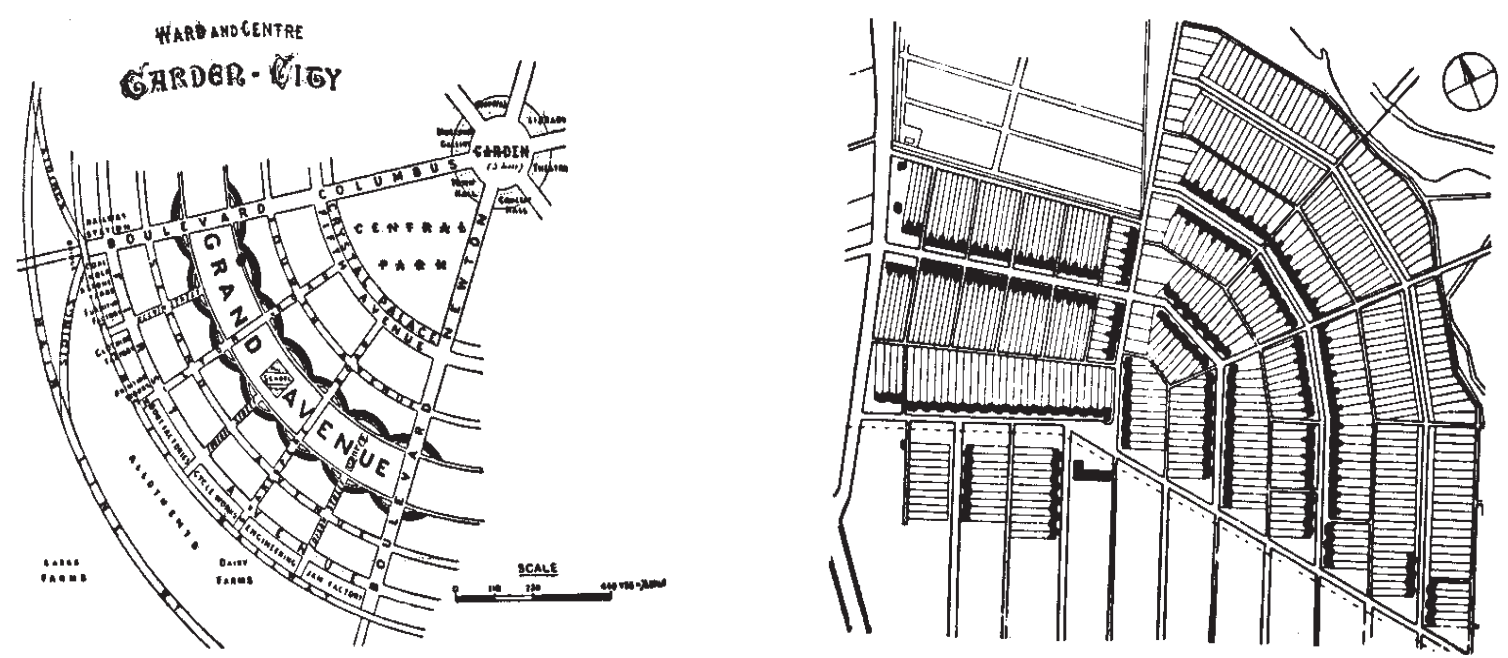

Efekt zakapsułkowania wiedzy przejawia się w skrajnym niehonorowaniu standardów edukacyjnych. W systemie edukacyjnym ludzie są nagradzani za inny rodzaj wiedzy i umiejętności niż w działaniu zawodowym. Osiedla społeczne miały rozwiązać problemy mieszkaniowe nie tylko w sensie arytmetycznym, ale również w kategoriach jakości życia. Tymczasem jednowymiarowość teorii osiedla społecznego sprawiła, że bliżej im do teorii chodnikowych (folk) niż właściwych nauce.

Świadomość metodologiczna jest zbudowaną w przestrzeni umysłowej projektanta strukturą umożliwiającą porządkowanie pojęć, metod i standardów oceny realizacji oczekiwań. Na poziomie intuicyjnym jest możliwe rozwiązywanie problemów nawet na podstawie pojęć zaczerpniętych z języka potocznego. Jednak im bardziej komplikuje się problem decyzyjny, tym bardziej niezbędne staje się oparcie myślenia projektowego na pojęciach abstrakcyjnych - teoretycznych. Pojęcia abstrakcyjne nie mają bezpośrednich desygnatów w rzeczywistości dostępnej obserwacji zmysłowej. Ale fakt ten dla innowacyjnego projektanta nie jest tylko wada, zbędnym utrudnieniem, lecz także zaleta. Pojęcia abstrakcyjne pozwalają wyobraźni na przełamanie konkretu, stereotypu, banału i mało twórczego naśladownictwa.

Z punktu widzenia praktyki projektowej zasadnicze znaczenie ma metoda operacyjna, rozumiana jako sposób rozwiązywania problemów i sytuacji decyzyjnych związanych z przygotowaniem projektu, w oparciu o ustalone zasady i pojęcia podstawowe. Podstawowymi jej składnikami sa: - struktura pozioma projektowania oraz - struktura pionowa projektowania.

Pozioma struktura projektowania, umożliwiająca realizację struktury pionowej projektowania, określona jest m.in. zasadą powtarzajacego się cyklu, polegającego na następstwie czasowym „syntezy-analizy-oceny” lub „analizy-syntezy-oceny”. Z psychologicznego punktu widzenia struktura pozioma projektowania to plan rozwiązania problemu w umyśle projektanta. Ma on zawsze do wyboru dwie drogi postępowania: od szczegółów do ogółu lub odwrotnie - od ogółu do szczegółów.

Struktura pionowa projektowania określa przebieg procesu projektowania w sensie sekwencji powstawania projektu, wyodrębniając etapy składające się na tę strukturę. Etapy te powiązane są ze sobą następstwem chronologicznym i zależnościami logicznymi i ustalone są bądź a priori, bądź empirycznie.

Trzecim ważnym elementem świadomości metodologicznej projektanta jest metoda krytyczna. Każde działanie poznawcze i praktyczne powinno podlegać krytycznej refleksji, jeżeli chce się uniknąć wypaczeń, płycizn i innych pułapek wynikających z rutyny. Pojęcia teoretyczne jako abstrakty mają tę zaletę, że można z nich budować różne idee rzeczywistości. Ale z kolei wadą ich jest nie trzymanie kontaktu z rzeczywistościa.

Projektant poddając refleksji krytycznej swój system pojęciowy i projekt rzeczywistości broni się w ten sposób przed utratą kontaktu z realną rzeczywistościa, przed schizofrenią. Struktura pozioma projektowania jako myślowy plan działania prowadzi do projektu, który jest realizowany w strukturze pionowej 
projektowania. Ale każdy plan dzieli się na dwie części: część zrealizowaną i część niezrealizowaną zwaną też intencja. Intencja jako niezrealizowana część planu pozwala użytkownikowi rozpoznawać ideę zamierzenia i zrealizowana w projekcie. Refleksja krytyczna zapobiega rozwiązaniom, które sa oczywiste dla projektanta, ale nieczytelne dla użytkownika. Stąd też we współczesnej teorii i praktyce architektonicznej tak duży nacisk kładzie się na tzw. badania weryfikacyjne „W użytkowaniu” (postoccupancy research).

Refleksja krytyczna nad procedura projektowania pozwala projektantowi na unikanie błędów wynikajacych z rutyny. Powtarzanie tego samego wzorca osłabia czujność, stwarza pokusę do samozadowolenia i osłabia kreatywność. Podobnie jak w poszukiwaniu prawdy lepsza gwarancję stanowi postawa sceptycyzmu, tak w działalności praktycznej lepsza gwarancją skuteczności jest poddanie ocenie krytycznej poszczególnych przypadków, ponieważ każdy ma swoją specyfikę, lokalne uwarunkowania.

Struktury pozioma i pionowa projektowania tworzą razem ogólny schemat postępowania projektotwórczego $\mathrm{w}$ architekturze. Schemat ten, uzupełniony zbiorem pojęć podstawowych i zasad oceny krytycznej, tworzy

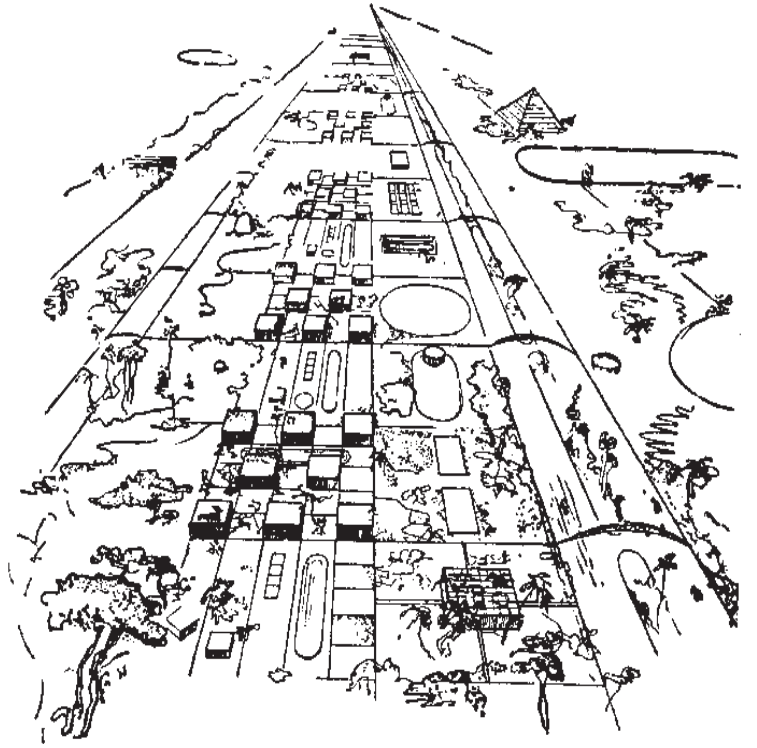

Świadomość metodologiczna projektanta nie jest gwarantem skuteczności, ale pozwala przynajmniej ograniczyć błędy w odpowiedzi na pytania zaczynajace się od: po co? dla kogo? dlaczego? kto? w jaki sposób? Świadomość metodologiczna chroni przed ignorancja, arogancją i jałowym zasklepieniem się w wąskiej ideologii, tak jak się to przydarzyło projektantom Magnitogorska! teorię projektowania architektonicznego.

$\mathrm{Z}$ punktu widzenia prezentowanego tutaj zagadnienia behawioralnych podstaw projektowania architektonicznego istotnym jest pytanie, w jaki sposób i w jakim stopniu wiedza o zachowaniu się ludzi potrzebna jest w praktyce projektowania architektonicznego? Odpowiadając na postawione pytanie można powiedzieć, że wiedza ta może być wykorzystana na tyle sposobów, na ile wiąże się ona z teoriami projektowania architektonicznego.

Po pierwsze, wiedza psychologiczna wchodzi w sposób naturalny, niezależnie od tego, czy się to komuś podoba, czy nie, w skład zbioru zasad i pojęć podstawowych teorii projektowania. Są i mogą to być zarówno pojęcia zdroworozsądkowe, jak i naukowe.

Po drugie, wiedza psychologiczna determinuje metodę operacyjna projektowania architektonicznego, zarówno w obrębie struktury poziomej, jak i pionowej, stanowiąc podstawę decyzji projektowych. Tak np. w obrębie struktury poziomej projektowania w ramach cyklu „synteza-analiza-ocena” w dużym stopniu wykorzystywane sa pojęcia, metody i koncepcje psychologiczne. Poza tym, każdy z tych etapów dotyczy innego aspektu zachowania się ludzi.

Po trzecie, teorie projektowania architektonicznego wyznaczają problemy badawcze w naukach behawioralnych (psychologii, socjologii), których rozwiązanie na zasadzie sprzężenia zwrotnego staje się kryterium poprawności zarówno dla metod operacyjnych jak i teorii projektowania architektonicznego.

Po czwarte, sam proces projektowania, jako akt twórczy, jest przedmiotem badawczym w naukach behawioralnych, a w szczególności w psychologii. W dalszej części pracy omówiony zostanie każdy z czterech wymienionych wątków, przy czym główny nacisk położony zostanie na kompleks wiedzy behawioralnej, która w stopniu największym wyznacza pojęcia i zasady projektowania architektonicznego. Dla lepszego zrozumienia zasadności stosowania wiedzy behawioralnej w projektowaniu architektonicznym w następnym rozdziale zawarto analizę rozwoju teorii, projektowania z punktu widzenia założeń dotyczących czynnika ludzkiego.

\section{Stereotyp projektowania i psychogeneza pojęcia projektowania sensu largo}

Zmiany zachodzace $\mathrm{w}$ technice i rozwoju społeczeństw stawiają przed wszystkimi dziedzinami projektowania nowe zadania. Biorąc pod uwagę przedstawione uwarunkowania można postawić tezę, że zmiany, jakie dokonały się w podejściu do projektowania, polegają między innymi na odchodzeniu $\mathrm{w}$ teorii i $\mathrm{w}$ 
praktyce od tradycyjnego stereotypu. Stereotyp ten najogólniej polega na tym, że projektowanie kojarzy się z deską rysunkową i pochyloną nad nią osobą oraz ze zdolnością przewidywania przyszłych zdarzeń w postaci wizualnej. Natomiast nowoczesną definicję projektowania, tak jak została ona tutaj przedstawiona, stosuje się już nie tylko do pracy inżynierów, architektów i innych zawodowych projektantów, ale również do działalności psychologów, ekonomistów, badaczy, ustawodawców, menedżerów, polityków oraz tych wszystkich, których zadaniem jest nadawanie wytworom czy decyzjom zmian w ich formach i treści. Projektowanie takie można nazwać projektowaniem sensu largo, lub programowaniem.

Następujące pod naciskiem współczesności, odchodzenie od stereotypu projektowania, oprócz tego, że przyczyniło się do sformułowania postulatywnych koncepcji projektowania sensu largo, spowodowało także istotne zmiany zadań projektantów w tradycyjnym tego słowa znaczeniu, to znaczy inżynierów projektantów. W tej nowej sytuacji zadania projektanta nie ograniczają się już wyłącznie do opracowania rysunkowej dokumentacji projektowej z całym przynależnym mu sztafażem opisów, lecz implikują konieczność podjęcia różnych działań, zanim rysowanie zostanie rozpoczęte. Oznacza to, że zadania projektowania zaczynaja coraz mniej dotyczyć samego projektu jako takiego, a coraz bardziej koncentrują się na zmianach, które wykonać muszą dostawcy, dystrybutorzy, wykonawcy (np. w sensie inwestycyjnym), użytkownicy i społeczeństwo. Ten obraz projektowania, jako tworzenia długiego łańcucha współzależnych przewidywań i dokumentacji, pokazuje rysunek.

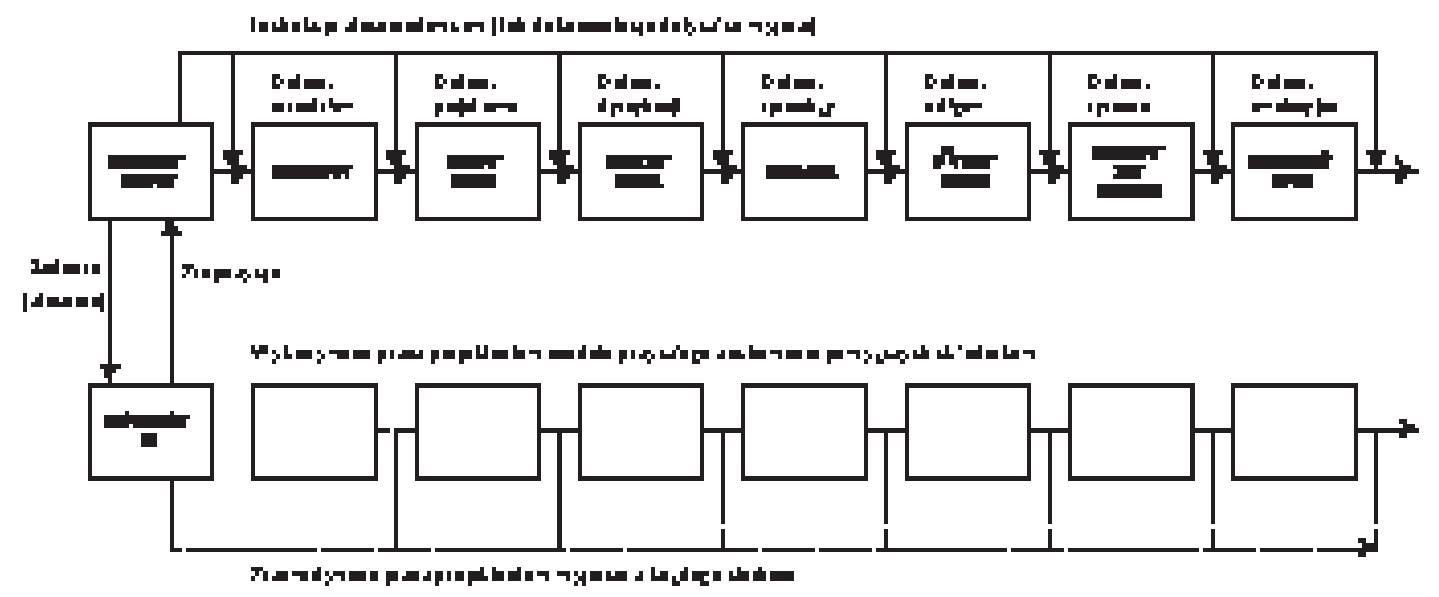

Proces ewolucyjny wprowadzania zmian w rzeczach wytwarzanych przez ludzi. Łańcuch współzależnych przewidywań.

W kontekście przedstawionego procesu ewolucyjnego wprowadzania zmian w rzeczach wytworzonych przez człowieka uwidacznia się wielorakość działań które muszą być spełnione, aby projektowanie można było uznać za skuteczne. Niewykonanie przez projektantów modeli przyszłego zachowania się poszczególnych

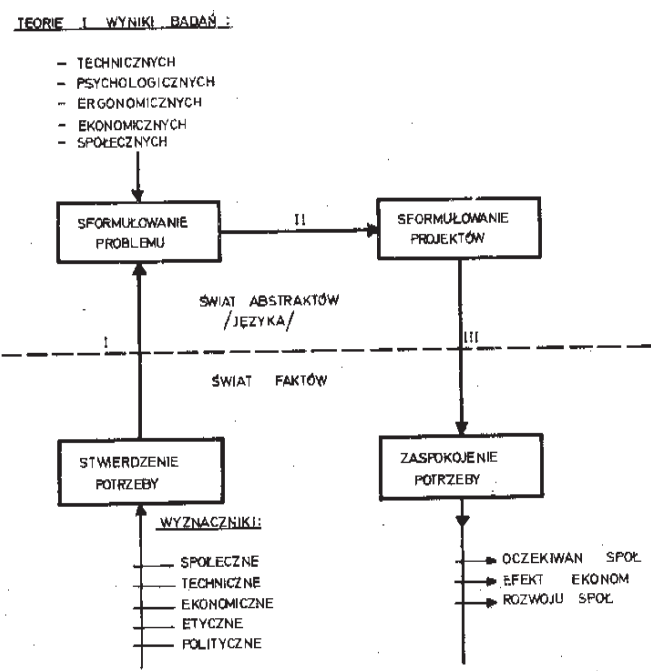

I - SYTUACJA PROBLEMOWA - przejście od świata realnego do świata abstrakcji, w którym fakty świata realnego odwzorowywane są za pomocą wyrażeń należących do klasy języków projektowania.

II - SYTUACJA ROZWIAZZYWANIA PROBLEMU - jest to przyporządkowanie jednemu wyrażeniu, należącemu do języka projektowania jakim jest problem projektowy, języka projektowania, jakim jest rozwiązanie problemu, czyli projekt.

III - SYTUACJA IMPLEMENTACYJNA - jest to przejście od języka projektowania do faktów świata realnego będących realizatorami projektu. 
składników przedstawionych na rysunku prowadzi do genetycznych błędów projektowych przekreślających skuteczność całego procesu projektowania, co na przykładzie hałasu obrazuje kolejny rysunek.

Spowodowana wymogami współczesności zmiana zadań projektanta doprowadziła do ukształtowania się nowych wzorów myślenia technicznego oraz związanego z nimi, używając terminologii Kuhna, nowego „paradygmatu" postępowania projektotwórczego w technice, a w ślad za nim w architekturze. Nowe wzory myślenia w technice polegaja, jak już wspomniano, na włączeniu w obręb tradycyjnych kryteriów i wartości technicznych kryteriów i wartości pozatechnicznych, jak psychologicznych, społecznych, etycznych innych.

Powody uwzględniania kryteriów pozatechnicznych we wzorach myślenia technicznego można podzielić na wewnętrzne i zewnętrzne. Działanie przyczyn pierwszego rodzaju można zobrazować na przykładzie kryteriów psychologicznych związanych z projektowaniem urządzeń technicznych. Szybki postęp techniczny już w okresie II wojny światowej doprowadził do sytuacji, w której dalszy postęp uzależniony został od wiedzy o zmianach zadań stawianych człowiekowi przez postęp techniczny oraz od wiedzy o właściwościach i możliwościach człowieka z punktu widzenia tych zadań. W związku z tym konstruktorzy zainteresowali się szeregiem problemów psychologicznych, jak chociażby wpływem człowieka na niezawodność systemu.

Przyczyny zewnętrzne zainteresowania się techników w swojej działalności poza technicznymi celami i wartościami związane sa z kontekstem społecznym, w jakim funkcjonuja twórcy techniki oraz pewnymi ubocznymi skutkami postępu technicznego, których społeczeństwo nie chce tolerować. Stąd też nawet wtedy, gdy formy techniczne lub architektoniczne służą celom społecznym, potrzebna jest umiejętność przewidywania kierunków ich rozwoju, a nadto skutków indywidualno-psychicznych i społecznych tego rozwoju.

Z tych to zewnętrznych przyczyn zrodziła się idea adaptacji techniki do człowieka, zwana też humanizacją techniki. Idea adaptacji techniki do człowieka nie jest jako taka wymysłem ostatnich lat. Już bowiem w czasie pierwszej rewolucji przemysłowej powszechne wprowadzenie do procesów produkcji nowych maszyn wywoływało ostre reakcje ludzi, a portrety tych niestrudzonych przeciwników maszyn nakreślił L. Mumford.

Obawy „burzycieli maszyn” nie znalazły jednak potwierdzenia w późniejszym okresie rozwoju techniki, a dominujacym efektem jej rozwoju było wyeliminowanie większej części
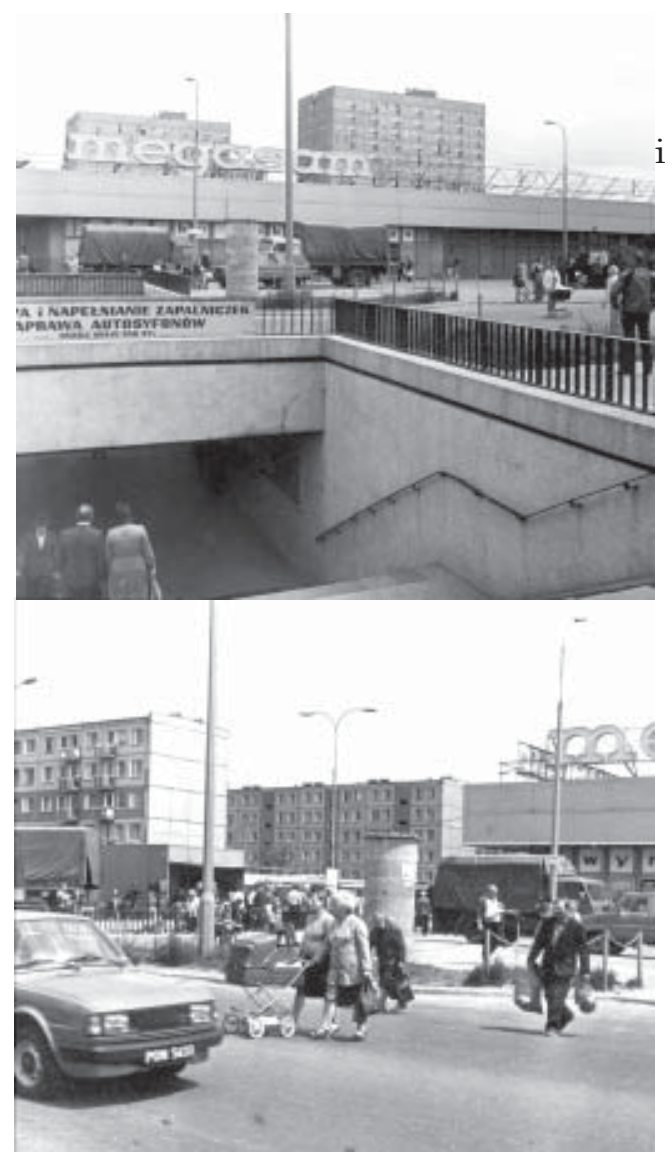

Człowiek jako element systemu jest ważnym wyznacznikiem niezawodności. Ze względu na swoja zawodność większe wymagania niezawodności stawiane muszą być urządzeniom technicznym. To technika musi służyć człowiekowi a nie odwrotnie. Spychanie człowieka pod ziemię jest połowicznym rozwiązaniem bezpieczeństwa ruchu. $\mathrm{Z}$ tego niby ułatwienia nie korzystaja akurat najsłabsi uczestnicy ruchu. wysiłku, zwłaszcza fizycznego, oraz podwyższenie poziomu higieny życia. Okazało się jednak, że owe „dobroczynne” mechanizmy dają nieprzewidziane następstwa, niejednokrotnie bardzo kosztowne. Ponieważ następstwa te najczęściej dotyczą człowieka, rozwiązanie problemu nastapić może jedynie poprzez odpowiednie kształtowanie transferu techniki na człowieka, np. ostrożne i przemyślane stosowanie w budownictwie mieszkaniowym nowych technologii i rozwiązań. W związku z tym nowoczesne projektowanie polegałoby na integrowaniu człowieka z technika, tj. na takim procesie rozwoju techniki (w tym i architektury), w którym wszystkie zamierzone działania uwzględniałyby jego skutki w sferze psychicznej, społecznej i morfologicznej ludzi.

Ukształtowanie się nowych wzorów myślenia w technice spowodowało powstanie nowego paradygmatu postępowania projektotwórczego w technice. Najistotniejszą cechą charakterystyczną tego paradygmatu jest rozszerzenie projektowania z sytuacji rozwiązywania problemu na sytuację problemową i sytuację implementacyjna. Nowy paradygmat postępowania projektotwórczego zaczął intensywnie torować sobie drogę od przełomu lat pięćdziesiątych, a jego głównym rzecznikiem była „inżynieria systemów” (systems engineering) na czele z Macholem, Asimowem i Hallem. Zasługą inżynierii systemów było zaprezentowanie całościowego punktu widzenia na projektowanie, to znaczy „równouprawnienie” sytuacji problemowych, decyzyjnych i implementacyjnych. Równouprawnienie to stało się niejako koniecznością umożliwiająca 
projektantowi uporanie się ze złożonością świata kształtowanego przez człowieka - z jednej strony, a z drugiej strony zadecydowało o potrzebie nowych metod projektowania. Znaczną część nowych metod projektowania w inżynierii systemów oparto na teoriach psychologicznych, wykorzystując w bardzo dużym stopniu metodologię badań psychologicznych (np. kwestionariusze, skale pomiarowe). Reasumując, można zaryzykować stwierdzenie, że jedną z cech charakterystycznych współczesnych metod projektowania jest ich „psychologizm”.

\section{Teoria projektowania architektonicznego}

Można przyjąć, że uwagi, wywodzące się z rozważań dotyczących projektowania w technice, odnieść można do projektowania architektonicznego. Co prawda porównanie zakresu znaczeniowego pojęć technika i architektura - zarówno w ich tradycyjnym, jak i nowoczesnym rozumieniu - nakazuje pewną ostrożność w wysuwaniu zbyt daleko posuniętych analogii. Do najważniejszych specyficznych cech projektowania architektonicznego A. Wojda zalicza:

- zakres znaczeniowy pojęcia architektura, obejmujący - poza technicznymi - także i inne zagadnienia związane z jej kulturotwórczymi funkcjami,

- grupę zagadnień artystycznych, związanych z projektowaniem architektonicznym,

- występującą w architekturze nadrzędność aspektu humanistycznego i kulturowego w stosunku do techniki,

- występujące w projektowaniu i realizacji architektury dążenia wywodzące się z roli wiedzy o człowieku $\mathrm{w}$ tym projektowaniu,

- specyfikę formowania koncepcji architektonicznej,

- potrzebę (psychologiczna - przypis własny) stosowania kryterium oryginalności rozwiązań, wynikłą z artystycznych cech twórczości architektonicznej,

- wyodrębnienie czynników mierzalnych i niemierzalnych, oddziałujących na projektowanie architektoniczne.

Pomimo takich czy innych odmienności, prawidłowości rządzące rozwojem techniki i architektury zawierają w sobie perspektywę interesujących ujęć syntetyzujacych.

Projektowanie w technice i technika systemów, będąc najbardziej rozwiniętymi dziedzinami projektowania, dysponują szeregiem zweryfikowanych w praktyce metod operacyjnych. Wiele elementów i cech charakterystycznych tych metod wywarło i wywiera w dalszym ciagu wpływ na teorię projektowania architektonicznego. W tym też należy upatrywać „rodowodu” ciagle żywej tendencji w architekturze do przechodzenia, na wzór projektowania w technice, do projektowania usystematyzowanego, częściowo zautomatyzowanego. Niemniej trudno przypuszczać, aby pełna automatyzacja projektowania architektonicznego mogła być możliwa i celowa ze względu na bardzo istotny w architekturze czynnik tworzenia wartości indywidualno-psychicznych, estetycznych, kulturowych, społecznych.

Jednak pewne elementy i cechy zostały już przez architektów zapożyczone z techniki systemów i ich obecność w projektowaniu architektonicznym trudno dziś ignorować. Cechy, które zaadaptowano, przynajmniej częściowo, w praktyce i teorii projektowania architektonicznego polegają na:

1) włączeniu w jednolity cykl projektowania całości zagadnień, związanych z projektowaniem, czyli tzw. bloku programowo-projektujacego, projektowania realizacyjnego i zagadnień eksploatacji,

2) usystematyzowaniu przebiegu projektowania,

3) wprowadzeniu zasady sprzężenia zwrotnego między poszczególnymi fazami i krokami projektowania, a także między określeniem potrzeby, programowaniem, projektowaniem, realizacją i eksploatacja,

4) włączeniu zagadnień związanych z problematyką projektowania modelowego i budowy prototypu,

5) wprowadzeniu kompleksowych badań wykonalności i możliwości realizacji we wczesnych etapach projektowania,

6) przyjęciu zasady prowadzenia prac rozwojowych równolegle z projektowaniem, tam gdzie jest to celowe i możliwe,

7) określeniu we wczesnych etapach projektowania celów i kryteriów projektowania,

8) przyjęciu zasady optymalizowania rozwiązań wyrażających się m.in. w ustaleniu kroków, w których optymalizacja ma być dokonywana,

9) stosowaniu mierzalnych kryteriów oceny projektowania. 
Z dotychczas przeprowadzonych rozważań wyprowadzić można paradoksalną do pewnego stopnia prawidłowość. O ile bowiem ewolucja projektowania w technice w ogólności przebiegała od projektowania rzeczy do projektowania zmian (przy czym to ostatnie zjawisko obejmuje również różnorodne aspekty ludzkie), o tyle rozwój architektury przebiegał niejako na odwrót, tzn. od dominacji w myśleniu architektonicznym elementów intuicyjnych, symbolicznych i humanistycznych do dominacji we wzorach myślenia architektonicznego elementów racjonalnych i techniczno-technologicznych. Konsekwencją tego stanu rzeczy jest to, że współcześnie stan sztuki budowania mieści się między krytyką techniki i technologii budownictwa, a krytyką budownictwa jako indywidualnych kulturowych artefaktów, czyli obiektów wytworzonych przez człowieka. Luka między tymi dwoma ekstremami wypełniana jest zdrowym rozsądkiem. W związku z powyższymi uwagami należy mieć na uwadze dwie rzeczy. Po pierwsze, brak jest współcześnie jednolitego paradygmatu teorii projektowania architektonicznego. Po drugie, koncepcja wprowadzania zasad zachowania się ludzi do projektowania architektonicznego uzależniona jest od przyjmowanej przez projektanta teorii projektowania (oczywiście, jeżeli uwzględni się fakt, że programowy brak teorii jest również teoria).

Tak więc, choć słuszne wydaje się stwierdzenie Goslinge’a, iż ,... nie wydaje się nieuzasadnioną nadzieja, że cała dyscyplina zwana inżynieria systemów może służyć jako paradygmat racjonalnej teorii projektowania", to jednak nie jest ona jedynym nurtem intelektualnym w rozwoju współczesnych koncepcji projektowania architektonicznego. Szczególnie nieuzasadnioną wydaje się być wyrażana przez wielu teoretyków opinia, że „... występująca w projektowaniu architektonicznym konieczność podejmowania decyzji projektowych w sytuacji wiążącej się z wprowadzaniem na coraz szersza skale kompleksowego uprzemysłowienia budownictwa, narastającego ryzyka techniczno-ekonomicznego, konieczności gromadzenia, selekcji i oceny znacznej ilości informacji - spowoduje w konsekwencji przejście do projektowania usystematyzowanego - częściowo zautomatyzowanego". W braku ogólnej teorii projektowania architektonicznego wielu teoretyków architektury upatruje - jeżeli nie wszystkich, to przynajmniej znacznej części przyczyn niedostatków współczesnej architektury.

V. Bazjanc dzieli tych, którzy są szczególnie niezadowoleni z braku ogólnej teorii projektowania architektonicznego, na dwie kategorie: architektów-teoretyków oraz architektów próbujących wprowadzać innowacje w architekturze wywodzące się z innych dyscyplin. Na przykład, reprezentantem tej drugiej kategorii „niezadowolonych” jest Teague, który za brak postępów w wykorzystaniu współczesnych metod techniki komputerowej obwinia „... brak teoretycznych i analitycznych podstaw architektury oraz brak dokładnie zdefiniowanych procedur". Brak paradygmatu ogólnej teorii projektowania architektonicznego nie oznacza, że brak jest w ogóle jakichkolwiek teorii projektowania. Architektura i teoria projektowania architektonicznego sa tak stare, jak cywilizacja. Przykładów teorii projektowania z przeszłości dostarczają prace Witruwiusza, Albertiego (1404-1472), Palladia (1508-1580),

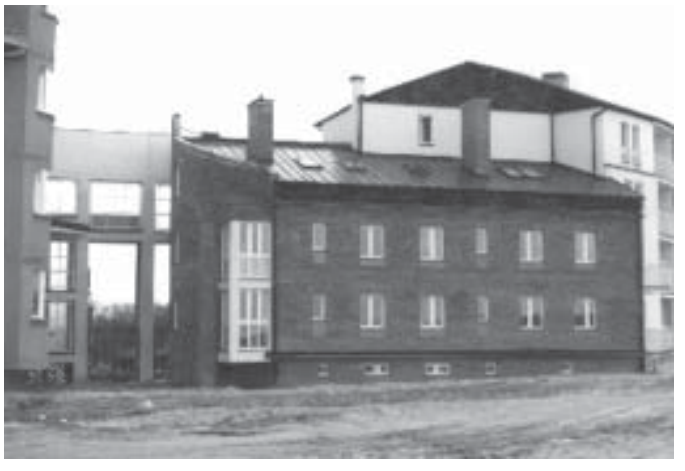
Ewolucja projektowania w technice i w architekturze przebiega w przeciwnych kierunkach. Architektura staje się, co prawda, coraz bardziej racjonalna, ale walory estetyczne i ludzkie pojawiają się często jako efekt uboczny przystosowywania formy do wymagań formalnych. W projekcie E. Skrzypczaka w Murowanej Goślinie, forma jest tylko w części efektem zamierzeń autora, a w części funkcją dopasowania do wymagań technicznych i formalnych, jakie pojawiły się w zaawansowanych już etapach procesu projektowego.

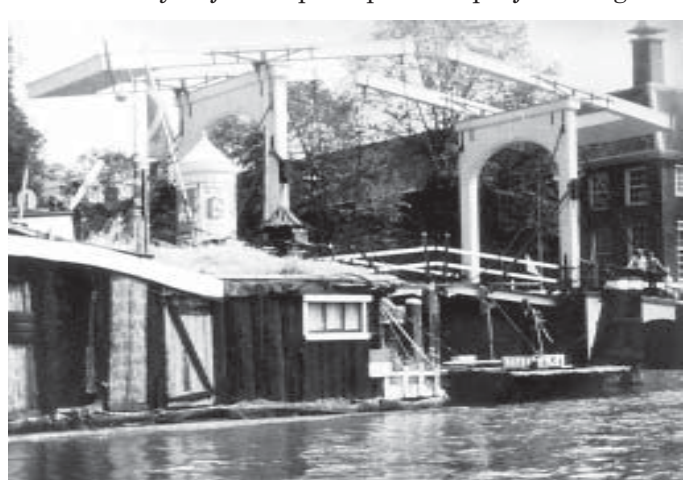

Brak teorii jest również teoria. Głód mieszkaniowy po II wojnie światowej zmuszał ludzi w wielu krajach do adaptowania istniejaccych zasobów na potrzeby mieszkaniowe. Dla wielu ludzi „zastępcze” środki zaspokojenia potrzeb stały się celem samym w sobie. Lodoliego (1690-1751), Laugiera (1711-1769) i innych teoretyków architektury w ścisłym tego słowa znaczeniu. Być może, że nie warto by było o nich wszystkich tutaj wspominać, gdyby nie fakt, że wiele ze współczesnych koncepcji projektowych bazuje na wypracowanych przez nich poglądach.

Współczesne koncepcje projektowania architektonicznego, znane bardziej jako modele projektowania, stanowią niezależne teorie architektury. Zasadniczą ich cechą jest procesualne ujmowanie projektowania. Każda z tych teorii w sposób odmienny określa zasady stosowania czynnika ludzkiego w projektowaniu. W związku z tym zastosowanie zasad zachowania się ludzi w projektowaniu architektonicznym w różny sposób i w różnym stopniu realizuje się na gruncie różnych teorii projektowania. Innymi słowy, mówiąc o behawioralnych aspektach projektowania architektonicznego, zawsze należy mieć na uwadze określoną teorię projektowania, a nie ogólna, gdyż tej ostatniej po prostu brak. 


\section{BEHAWIORALNE TEORIE PROJEKTOWANIA ARCHITEKTONICZNEGO}

\section{Zachowanie sie jako substrat projektowania architektonicznego}

Powstanie behawioralnych modeli projektowania związane jest z zainteresowaniem się projektantów w połowie lat pięćdziesiątych niektórymi dziedzinami psychologii, matematyki stosowanej (w szczególności badaniami operacyjnymi) i techniką systemów. Wczesne modele procesu projektowania, takie, jak Kaufmana, Archera, Luckmana, Asimova, wykorzystują ideę dekompozycji problemu i na jej podstawie tworzy się matematyczne algorytmy rozwiązywania problemu. Inne teorie, jak C. Alexandra idą o krok dalej, łącząc zainteresowanie procedurami matematycznymi z psychologia. Wszystkie owe modele projektowania maja jedna, wspólną cechę: ujmują proces projektowania jako sekwencję dobrze dajacych się zdefiniować czynności i opierają się na możliwościach zastosowania w procesie rozwiązywania problemu idei i zasad naukowych.

Spośród różnych psychologicznych koncepcji największy wpływ na rozwój teorii projektowania architektonicznego wywarły teorie behawioralne (zachowaniowe). Ich popularność w kręgach architektów (głównie amerykańskich i brytyjskich) wiąże się z z następującymi kwestiami? W jaki sposób najlepiej dogadać się z klientem i na podstawie czego? W jaki sposób formułować problem projektowy, aby ominąć pułapkę zamknięcia się $\mathrm{w}$ stereotypie? W jaki sposób wyprowadzić formę z pojęciowego opisu problemu projektowego? Jakimi kryteriami należy oceniać jakość projektowania? Kiedy i na podstawie czego można powiedzieć, że projektowanie było satysfakcjonujące i pełne? Pytania te zadawali sobie projektanci którzy, w przeciwieństwie do polskich projektantów byli: a) wystawieni na ryzyko ostrej konkurencji; b) świadomi swojej misji; c) zdominowani dążeniem do przełożenia swoich osobistych doświadczeń (poznania) na uniwersalne reguły, występujące w standardowych sytuacja, lub w sytuacjach podobnych oraz d) musieli liczyć się z opinią klienta,.

$\mathrm{W}$ teoriach behawioralnych projektowania architektonicznego za jednostkę analizy problemów projektowych i substrat budowania formy przyjęto zachowanie się człowieka. Opiera się ten wybór na generalnym założeniu, iż zachowanie się jest obiektywnie rejestrowalnym, obserwowalnym faktem, zarówno w realnej przestrzeni życia, jak w psychologicznej przestrzeni życia projektanta. O ile np. pojęcie potrzeby jest niewyobrażalne, o tyle zachowanie się jest zjawiskiem poddającym się wizualizacji. Wiąże się to z odkryciem

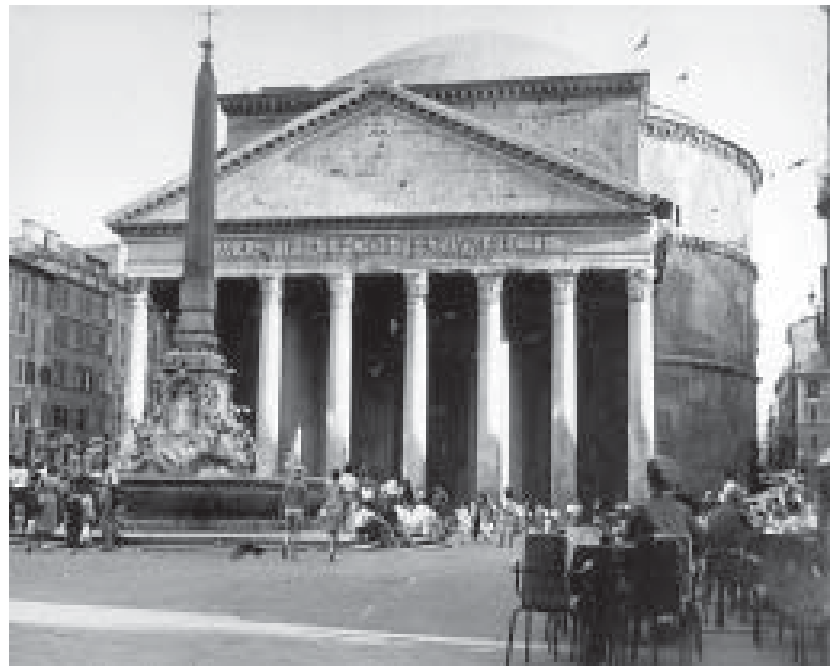

Zapamiętywanie formy architektonicznej nie jest spowodowane „jakością" obrazu na siatkówce oka, ale skojarzonymi z forma zachowaniami. Wartość miejsc w kawiarniach jest uzależniona nie tylko od tego, na jaki obiekt ma się widok, ale również od tego, jak szerokie spektrum zachowań innych ludzi realizuje się $\mathrm{w}$ danym miejscu. prostego faktu, że architekt nie tylko jest w stanie odtworzyć sobie z pamięci widziane wcześniej obiekty, ale jest również w stanie przypomnieć sobie w formie obrazowej wydarzenia i zachowania ludzi, jakie wiążą się z poszczególnymi obiektami. Co więcej niektóre obiekty (formy) są zapamiętywane nie dzięki temu, że rysują obrazy na siatkówce oka obserwatora, ale dzięki temu, że w świadomości i podświadomości kojarzą się z określonymi zdarzeniami, których podmiotem jest sam obserwator lub inni ludzie.

Przykładem behawioralnej procedury analizy i wyprowadzania fizycznej formy architektonicznej, z punktu widzenia zachowań ludzkich, reprezentuje m.in. model R.G. Studera. Poszczególne. kroki zaproponowanego przez niego algorytmu przedstawione sa na rysunku.

Podstawowym założeniem, na którym oparty jest model Studera, jest stwierdzenie, że w każdym przypadku projektowania środowiska architektonicznego należy brać pod uwagę uczestnictwo ludzi w projektowanym środowisku a podstawowa jednostką analizy jest „zachowanie się”. 
W związku z tym, że z projektowania architektonicznego nie da się wykluczyć uczestnictwa ludzi, należy ustalić jednostkę analizy systemu „ludzie-środowisko”. „Zachowanie się” jest najlepsza jednostką analizy i stanowi klasę zmiennych obejmujaca zestaw biologicznych i niebiologicznych potrzeb. Rozwiazanie projektowe i jego poprawność polegają na dopasowaniu systemu fizycznego środowiska do systemu zachowań ludzi, wynikających z psychologicznych i fizjologicznych ich właściwości. W związku z tym projektowanie architektoniczne obejmuje dwa elementy:

- projektowanie systemu zachowania się ludzi,

- projektowanie fizycznego systemu środowiska spełniającego wymagania systemu zachowania się.

Jego przebieg charakteryzują powtarzające się procesy analizy i syntezy w obydwu elementach. Zakończeniem procesu projektowania jest taka realizacja systemu fizycznego środowiska, która spełnia wszystkie podstawowe wymagania systemu zachowania się. Pozycję wejściową cyklu projektowania zajmuje projektowanie modelu systemu zachowania się ludzi, a dopiero po nim następuje projektowanie fizycznego systemu środowiska, np. miasta, budynku, szkoły, szpitala.

Ten sposób postępowania, uznający za punkt wyjścia procesu projektowania modelowanie uwarunkowań zachowaniowych, a nie „stereotypowa” listę fizycznych wymagań przestrzeni, oznacza, że detekcja, wyodrębnienie oraz struktura problemu projektowego wyrasta $\mathrm{z}$ analizy systemu zachowania się ludzi. Tak więc jedynie poprzez analizę zmiennych zachowaniowych możliwe jest odpowiednie określenie wielkości, jakości i zależności między elementami projektowanego środowiska architektonicznego.

Zaprojektowane środowisko jest systemem elementów materialno-energetycznych rozmieszczonych pomiędzy poszczególnymi ludźmi (jako partycypantów systemu) oraz między przeciwstawnymi siłami oddziałujacego otoczenia. Jeżeli owe elementy w procesie projektowania przybiorą odpowiednia konfigurację, to moga

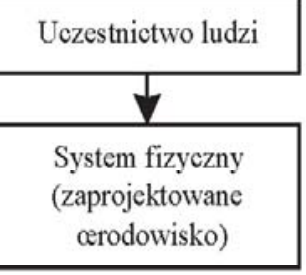

W każdym przypadku projektowanie środowiska architektonicznego uwzględnia uczestnictwo ludzi.

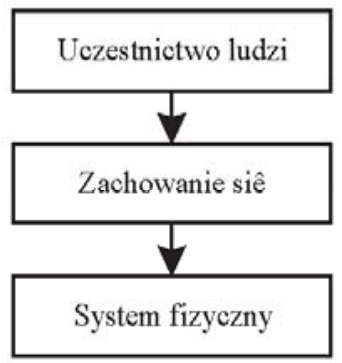

Zachowanie się jako podstawowa jednostka analizy. one generować różnorodna a aktywność, za pośrednictwem której uczestnicy systemu realizuja swoje biologiczne, psychologiczne, społeczne i kulturowe cele. Innymi słowy, zaprojektowane środowisko architektoniczne w tym układzie może być analizowane z punktu widzenia funkcji protetycznej. Funkcja protetyczna zaprojektowanego środowiska dotyczy dwóch sfer: protetyki fizjologicznej i protetyki behawioralnej. Protetyka fizjologiczna zaprojektowanego środowiska polegałaby na podtrzymywaniu celów zachowania się poprzez podtrzymywanie wymaganych (behawioralnie skorelowanych) stanów fizjologicznych. Z kolei protetyka behawioralna polega na kształtowaniu specyficznej behawioralnej topografii.

Aby system „ludzie-środowisko architektoniczne” mógł być należycie zaprojektowany, należy:

- określić wymagania systemu zachowania się ludzi,

- zdefiniować wymagania systemu fizycznego,

- zrealizować wymagania systemu fizycznego,

- zweryfikować wynikowy system „środowisko-zachowanie się".

Proces określania wymaganych zachowań przystosowanych do określonej sytuacji problemowej nie jest tym aspektem metod projektowania, o którym można by było powiedzieć, że ma długa tradycję. Najbardziej powszechnym podejściem do tego zagadnienia jest podejście empiryczne. Drugim sposobem uzyskiwania danych umożliwiajacych określenie systemu pożądanych zachowań jest naturalistyczna obserwacja. Oczywiście, zarówno pierwsza, jak i druga metoda są niewystarczające dla sformułowania zestawu pożądanych zachowań, gdyż badania empiryczne i obserwacje dotyczą tego, co jest (w danej sytuacji fizycznej, a nie pozwalają w pełni skutecznie określić, co ma być w sytuacji przyszłej. Dlatego też proces określania pożądanych zachowań z punktu widzenia projektowania form fizycznych ma charakter normatywny, a nie empiryczny. Podobnie jak $\mathrm{w}$ ekonomii proces ten nie ma charakteru normatywnego $\mathrm{w}$ tym sensie, że nie próbuje się opisywać tego, „czego ludzie powinni pragnąć?”, lecz to ,jaki przebieg będą miały zachowania się ludzi, gdy spełnione zostaną ich pragnienia?".

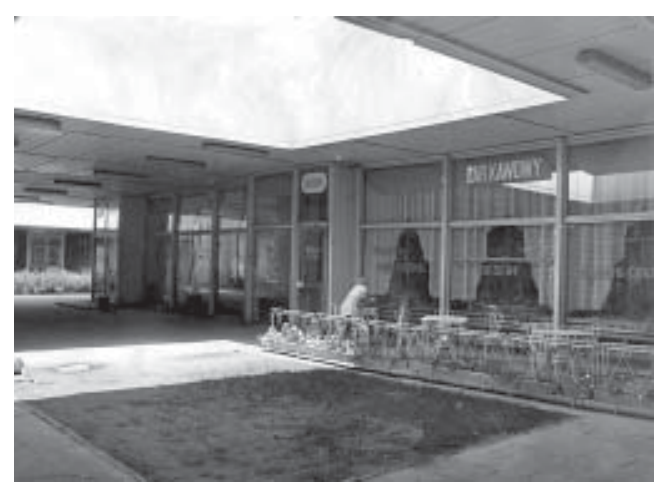

Kawiarnia w typowym „blaszaku osiedlowym”. Kiedy usiłuje się odpowiedzieć na pytanie, co tu brakuje, nieuchronnie nasuwa się wniosek - „brak życia”. Jest to typowy przykład projektowania architektonicznego ograniczającego się wyłącznie do wyprowadzenia formy i pominięcia sfery zachowań ludzi. 
Identyfikacja wartości i celów poszczególnych subkultur jest w tym kontekście warunkiem koniecznym sformułowania problemu. Innymi słowy, nie znając tego, jakie cele i wartości są charakterystyczne dla danej zbiorowości, nie można w żaden sposób zdefiniować problemu projektowego, w ramach którego dążenia poszczególnych członków zbiorowości mają się realizować. W rzeczywistości jednak każda zbiorowość ludzka - niezależnie od tego, czy mała, duża, formalna albo nieformalna - jest generatorem i nośnikiem celów oraz wartości wyrażanych explicite bądź implicite.

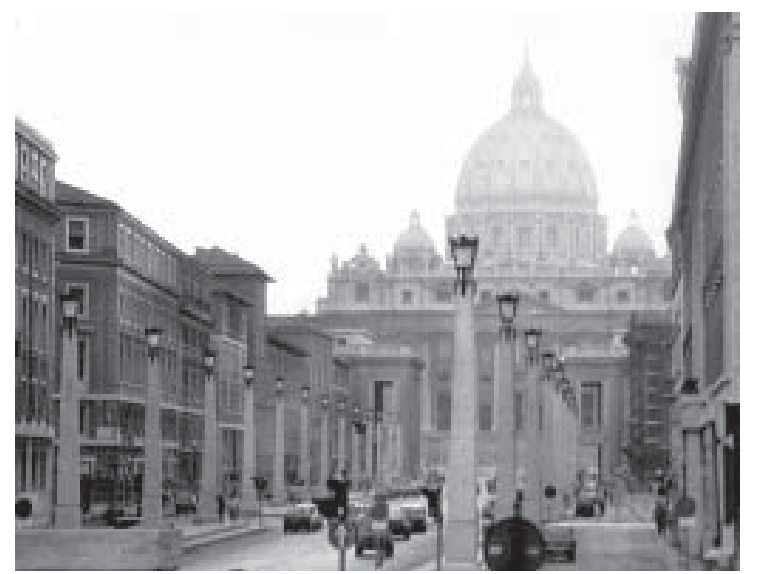

Dotychczas architekt skłonny był podróżując po świecie obserwować i zapamiętywać głównie formę. Jednak czysta forma bez powiązania $\mathrm{z}$ fascynujacymi zachowaniami się ludzi jest formą pusta, czczą i jałową. To zbiorowości ludzkie poprzez ich zachowania określają wartość poszczególnych form i miejsc. Ulica przebita w Rzymie w okresie międzywojennym z czasem przestała budzić kontrowersje.

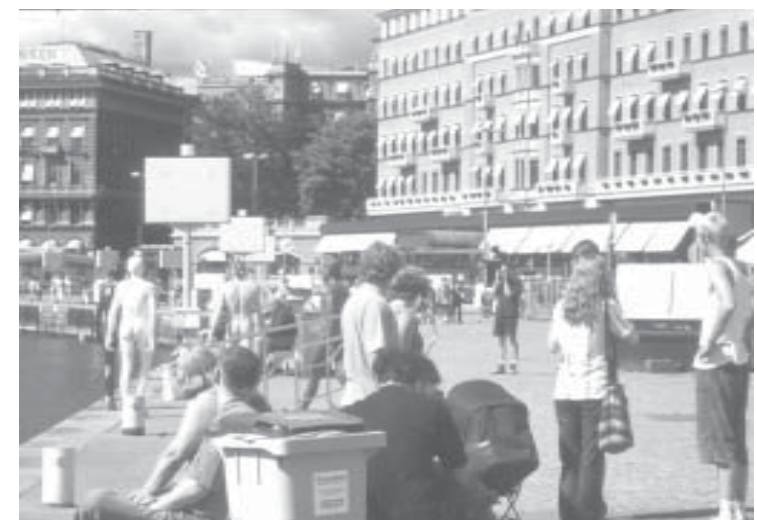

Percepcja miasta jest nie tylko kwestią oceny formy, ale również zdarzeń, jakie w danym miejscu i czasie zachodza.

Cele i wartości organizacji i zespołów ludzkich wyznaczają podstawowe rodzaje zachowań, które są warunkiem niezbędnym dostosowania poszczególnych członków zespołu do celów i wartości organizacji. Niezależnie więc od trudności związanych z identyfikacją celów i wartości poszczególnych zbiorowości ludzkich, występują trudności z ich operacyjnym zdefiniowaniem w kategoriach sprzężeń zachowaniowych. Ponieważ, jak to już stwierdzono, żadne indukcyjne metody nie maja większego zastosowania $\mathrm{w}$ procesie określania pożądanego systemu zachowań dla danej sytuacji problemowej, w związku z tym proces ten należałoby uznać w istocie rzeczy za problem projektowy. Określanie pożądanego systemu zachowań jest zagadnieniem z zakresu projektowania behawioralnego $\mathrm{w}$ tym sensie, że brak jest jakichkolwiek deterministycznych procedur opisu systemu zachowań dla danego zbioru celów.

Projektowanie systemu zachowań uwarunkowane jest fizjologicznymi, psychologicznymi i kulturowymi właściwościami analizowanej populacji. Rezultatem procesu projektowania behawioralnego jest model systemu zachowania się.

Problem projektowy fizycznej formy może być określony wtedy i tylko wtedy, gdy wcześniej zostanie skonceptualizowany system zachowań. Poza tym według Studera problem projektowy pojawia się dopiero wtedy, gdy zachodzi rozbieżność (dysonans) między pożądanym systemem zachowań, a zaprojektowanym środowiskiem (systemem fizycznym). W celu określenia dysonansu fizycznego należy przeprowadzić testowanie, które obejmuje: systematyczne porównania skonceptualizowanego systemu zachowań $\left(\mathrm{R}_{2}\right)$ z egzystujacym systemem $\left(\mathrm{R}_{1}\right)$ w celu wykrycia rozbieżności (z odpowiednio ustalonym marginesem tolerancji). oraz następnie sprawdzenie tego, czy rozbieżności te nie sa powodowane przez elementy fizycznego systemu $\left(\mathrm{S}^{\mathrm{de}}\right)$. Dysfunkcja ta w rzeczywistości bowiem może być związana z innymi aspektami środowiska $\left(\mathrm{S}^{\mathrm{de}}\right)$, na przykład społecznymi, ekonomicznymi, edukacyjnymi. W przypadku zaistnienia fizycznej dysfunkcji pojawia się potrzeba konceptualizacji alternatywnego środowiska. Innymi słowy, pojawia się problem projektowy systemu fizycznego.

Określenie pożądanego systemu fizycznego obejmuje systematycznie korelowanie elementów systemu środowiskowego z elementami systemu zachowań $\left(\mathrm{R}^{2}\right)$. To, co podlega w tym przypadku opisowi, jest zaprojektowanym interfejsem (płaszczyzną kontaktu) systemu ,środowisko-zachowanie się”.

Określenie fizycznych wymagań środowiska przestrzennego w istocie rzeczy jest budowaniem modelu fizycznych ewentualności mogących powodować pożądane stany zachowań.

Tak zaprojektowane środowisko w procedurze, projektowania poddane zostaje takiej dalszej konceptualizacji i realizacji, aż otrzyma walor dynamicznego systemu zdolnego do przekształceń w kierunku uzyskania pożądanych stanów. W schemacie tym dynamika zachowań uwzględniona jest na tej zasadzie, że ostateczny system zachowań dzięki interakcyjnym czynnościom, czyli zestawowi wszystkich procedur testowych i przekształceń wyprowadzania fizycznego systemu środowiska, staje się realnym systemem 
zachowań $\left(\mathrm{R}_{1}\right)$. Jak więc $\mathrm{z}$ tego wynika, jednostki zachowania się są podstawowym elementem weryfikacji fizycznej formy systemu.

Najbardziej słaba stroną zaprezentowanego tu pokrótce modelu Studera jest to, że przyjęty przez niego system pojęć (szczególnie chodzi tu o koncepcję Skinnera przyjmowany jest ze zbyt dużym stopniem pewności i oczywistości, co praktycznie jest nie do osiagnięcia. Conatance Perin, komentując model Studera, zalicza go do tych poszukiwań twórczych, które cechuje „pogoń za pseudoproblemami, będąca źródłem niepokoju zarówno dla projektantów, jak i samych reprezentantów nauk o człowieku, gdyż pytania stawiane w nich naginane sa w sposób najbardziej odpowiadajaccy założeniom modelu".

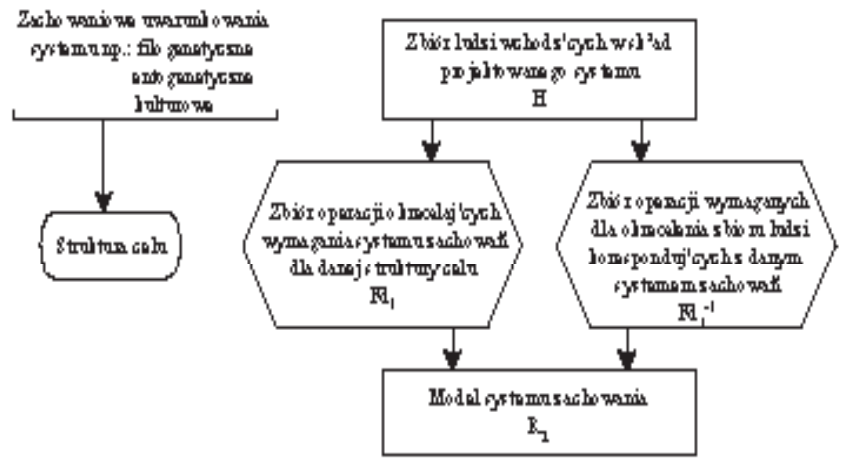

Sposób określania wymaganych zachowań przystosowawczych do sytuacji problemowej oraz procedura określania fizycznej formy architektonicznej

\section{„Nielogiczność” i argumentacyjny charakter problemów projektowania}

Inna teorię projektowania architektonicznego jest teoria Rittela. Oparta ona została na krytyce m.in. wcześniej omówionego modelu Studera, a jej kwintesencję podsumować można w następujący sposób: a) projektowanie nie jest czysto sekwencjonalnym procesem, oraz b) problemy projektowe sa „nielogiczne” (wicked problems) i w zwiąku z tym stosowanie w ich przypadku procedury step-by-step (krokowej) nie może prowadzić do żadnego rozwiązania. Pojęcie nielogiczności pochodzi od Rittela i oznacza „klasę problemów z zakresu systemów społecznych, które są trudno formułowalne, gdzie procesy informacyjne sa chaotyczne, gdzie wielu jest decydentów uczestników z konfliktowymi systemami wartości, gdzie odgałęzienia problemu sa bardzo liczne i gdzie ramifikacja całości jest chaotyczna”.

Nielogiczne problemy posiadają określone cechy, które ujęto w następujących stwierdzeniach:

1. Nielogiczny problem nie ma ostatecznego sformułowania.

2. Każde sformułowanie nielogicznego problemu jest równoznaczne ze sformułowaniem jego rozwiązania (i vice versa).

3. Nielogiczne problemy moga być formułowane i rozwiązywane bez końca.

4. Rozwiąania nielogicznych problemów nie mogą być ani prawdziwe, ani fałszywe.

5. W rozwiązywaniu nielogicznych problemów nie moż- na tworzyć listy czynności skutecznych lub nieskutecz- nych, prowadzących do rozwiązania.

6. Każdy nielogiczny problem zawsze ma więcej niż jed- no wyjaśnienie.

7. Każdy nielogiczny problem jest symptomem innego „wyższego rzędu" problemu.

8. Każdy nielogiczny problem jest problemem unikalnym. Nie ma dwóch problemów podobnych do siebie. Również rozwiązania lub strategie doprowadzające do tych rozwiązań nie mogą być przenoszone z jednego problemu na inny.

9. Człowiek rozwiąujacy nielogiczne problemy nie ma prawa do błędów, jest w pełni odpowiedzialny za swoje działanie.

Rozważając wymienione cechy problemów nielogicznych narzuca się wniosek, że wszystkie problemy, które rozwiązuje projektowanie architektoniczne, sa problemami nielogicznymi. Zawsze bowiem można stawiać nowe pytania, zawsze można coś dodać do już sformułowanego rozwiązania oraz żadne roz-

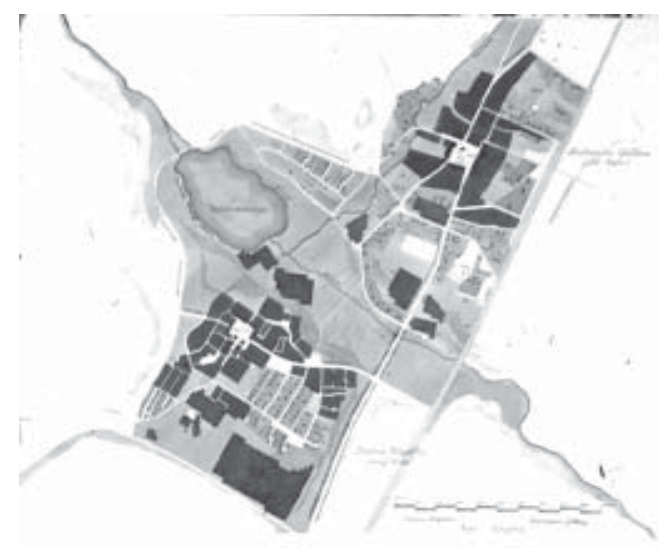

Plan plamkowy jako program funkcjonalny to użyteczna „ścieżka” projektowania. Jednak ta ulubiona podstawa rozwiazywania problemów projektowych w okresie tzw. „realnego socjalizmu” stwarza złudzenie, które dla niektórych było czymś bardziej realnym niż namacalna rzeczywistość; stwarza pokusę wiary w istnienie logiczności w problemach projektowych i w możliwość uporządkowania funkcji w sposób zalgorytmizowany. 
wiązanie architektoniczne nie może być określone jako całkowicie „poprawne” lub całkowicie „fałszywe”. Wynikałoby więc, że procedury czysto sekwencyjne są nieużyteczne w konfrontacji z problemami nielogicznymi. Prowadzą one wcześniej czy później do frustracji u projektantów. Nie da się bowiem rozdzielić analizy i syntezy, w związku z czym modele zalgorytmizowane nie opisują dokładnie w terminach jednostek zachowania, tego, co dzieje się w czasie projektowania.

Odpowiedzią Rittla na jego krytykę modeli projektowania „pierwszej generacji” jest koncepcja „myślowych środków projektowania przed działaniem" (designing means thinking before acting). Zakłada ona, że projektant nie potrzebuje ani też nie dąży do wyjaśnienia części universum, lecz poszukuje zmiany jego części. W poszukiwaniu rozwiązania problemu projektowego podejmuje on przede wszystkim próbę rozwinięcia szeregu alternatywnych kierunków działania, a następnie stara się przewidzieć ich rezultaty oraz prawdopodobieństwo wystapienia. Wreszcie projektant dokonuje ich oceny, wybierając to działanie, które uważa za rozwiązanie. Rozwiązanie projektowe jest planem dochodzenia do rozwiązania, a nie samym rozwiązaniem.

Pierwsze istotne założenie modelu Rittla związane jest z pojęciem rozpoznania. Polega ono na rozpoznaniu tego, czy w danym kontekście dana konfiguracja projektowa prowadzi do konkretnego funkcjonowania. Proces projektowania obejmuje cztery bloki: predyktor kontekstu, model celu, wskaźniki funkcjonowania oraz funkcjonowanie jako takie. Rola projektanta sprowadza się do budowniczego i operatora modelu - celu, poprzez manipulowanie parametrami oraz - zwrotnie - poprzez ocenę i pomiar funkcjonowania.

Drugie istotne założenie związane jest $\mathrm{z}$ definicją kolejnych faz procesu projektowania. Projektant w

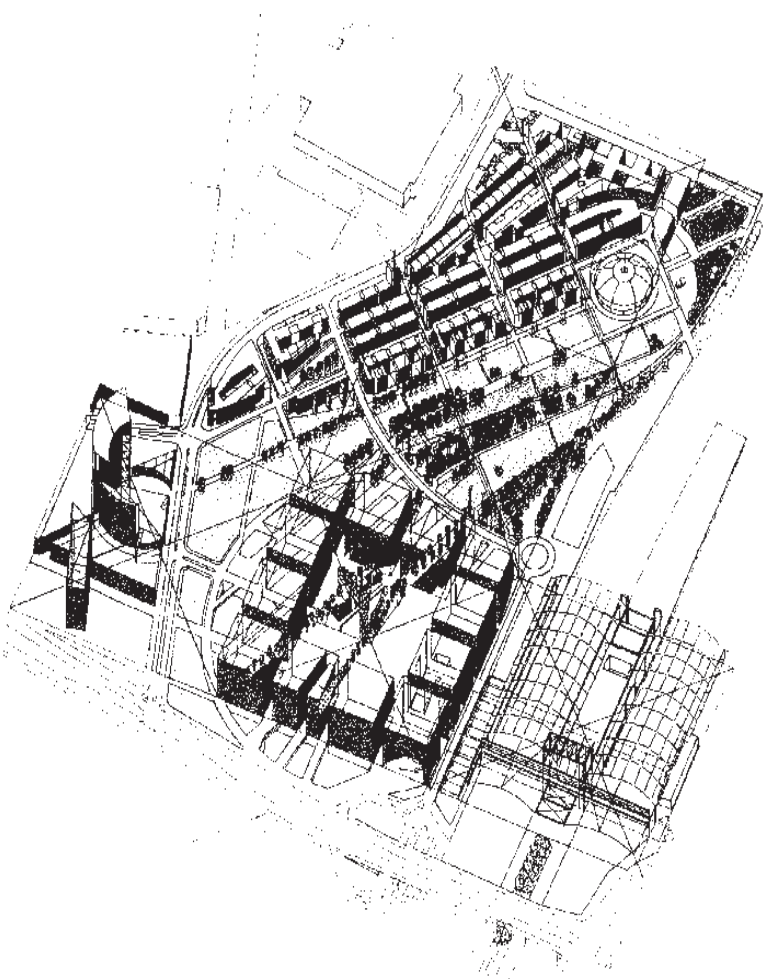

„Pięta achillesową" w projektowaniu architektonicznym jest proces „argumentacji”, obejmujący między innymi proces komunikowania alternatywnych rozwiąań sobie i innym. Udział (partycypacja) laików w procesie argumentacyjnym, czyli w procesie oceniania projektu jest utrudniony, a czasami uniemożliwiony przez sposób prezentacji. Zwykli ludzie nie są w stanie wyobrazić sobie niektórych rzutów czy perspektyw, bowiem nie mają one żadnej relacji do rzeczywistości. Dawniej problem ten rozwiązywał model, a obecnie komputerowa technologia wirtualna. procesie projektowania ustawicznie przechodzi przez następującą sekwencję: generowanie różnorodności i redukcję różnorodności. Podczas generowania projektant poszukuje relewantnych (majacych istotne znaczenie) ewentualności. Natomiast podczas redukcji różnorodności projektant dokonuje oceny tych ewentualności oraz przeprowadza selekcję możliwych do przeprowadzenia.

Trzecim istotnym założeniem omawianego modelu procesu, projektowania jest plan usprawniania procesu podejmowania decyzji. Proces podejmowania decyzji projektowych opisuje Rittel w następujacy sposób: „... projektant dyskutuje o rozwiązaniu z samym sobą i z innymi uczestnikami projektu. Buduje on koncepcję prowadzacca do lepszego zrozumienia tego, do czego osiągnięcia całe przedsięwzięcie zmierza. W trakcie tego procesu samorzutnie określają się podstawy rozwiązania, które następnie poddane są ocenie z punktu widzenia ich skutków oraz podjęte zostają w związku z tym określone decyzje. Poszczególni uczestnicy deklarują się za określonym kierunkiem, biorąc równocześnie na siebie całe ryzyko zawarte w nim. W ten sposób następuje lepsze sformułowanie problemu oraz jaśniejsze wyobrażenia rozwiązania”.

Najistotniejszym elementem projektowania według Rittla jest argumentacja (deliberacja). Proces argumentacji dotyczy zarówno grupy osób, jak i jednostki. Najogólniej rzecz biorac, jest to proces myślowy polegajaccy na rozważaniu alternatyw, ustosunkowywaniu się do nich, wnioskowaniu o zaletach każdej z nich i podjęciu decyzji. Proces argumentacji, który ma na celu podjęcie lepszych decyzji, nie jest tożsamy z procesem optymalizacji w takim sensie, w jakim rozumie się go w badaniach operacyjnych. Jest to raczej proces negocjacji i kompromisu między reprezentantami realnego rodzaju architektonicznych wyobrażeń (Weltanschaungen). 


\section{Projektowanie jako proces uczenia sie}

Autorem teorii projektowania architektonicznego w oryginalny sposób odwołującej się do psychologicznych procesów uczenia się jest V. Bazjanc. Według jego poglądów, proces projektowania polega na formułowaniu przez projektanta problemu i poszukiwaniu dlań rozwiązania. Sformułowanie problemu nigdy nie jest ostateczne, lecz odzwierciedla jedynie sposób rozumienia go na podstawie posiadanej w danym momencie wiedzy projektanta. Sposób sformułowania problemu determinuje sposób jego rozwiązania. Tak więc poszukiwanie rozwiązania jest poszukiwaniem definicji takiego rozwiązania, które w stopniu możliwie największym stanowi zadośćuczynienie wiedzy projektanta w danym czasie. Sformułowane rozwiązanie podlega dokumentowaniu, które rozpoczyna się w fazie formułowania problemu i jest kontynuowane $\mathrm{w}$ fazie określania rozwiąania. Wszystkie trzy fazy procesu projektowania mogą przebiegać równocześnie. Ostatecznym celem dokumentacji jest komunikowanie sformułowania i rozwiązania problemu. Natomiast pośrednia rola dokumentacji polega na ułatwianiu projektantowi definiowania problemu i jego rozwiązania. Dzięki dokumentacji projektant łatwiej może wykryć zarówno nowe aspekty problemu i jego rozwiązania, jak i niespójność swoich poglądów.

W czasie poszukiwania definicji problemu i rozwiązania oraz ich dokumentacji projektant uczy się. Efektem tego procesu uczenia się jest zdobycie nowego wglądu w problem, a w ostateczności ukształtowanie nowych poglądów przeformułowujących problem i jego rozwiązanie. W świetle psychologii „uczenie się" jest ubocznym skutkiem wykonywania wszelkich czynności przez ludzi, przejawiającym się w zmianach zachodzących przy wykonywaniu tych samych lub podobnych czynności w przyszłości, innymi słowy, nabywanie doświadczenia, wprawy, umiejętności w zakresie określonych czynności pod wpływem ich wykonywania. „Uboczny skutek” w tym kontekście nie znaczy bynajmniej „mniej ważny", a jedynie to, że uczenie się nie jest bezpośrednim skutkiem danej czynności. Zawsze jednak w uczeniu się chodzi o zdobywanie doświadczenia pod wpływem wykonywania określonych czynności. Ponieważ sama natura uczenia się jest czymś nieuchwytnym, nie dającym się zaobserwować, bada się czynniki warunkujące określony wynik uczenia się. Określonym wynikiem uczenia się jest zmienione zachowanie człowieka lub gotowość do takiej zmiany w odpowiednich ku temu warunkach. Mechanizmy kierujace uczeniem się są różne. W najprostszej postaci może to być mechanizm odruchu warunkowego, dalej, uczeniem się może kierować intuicja, może się ono odbywać w procesie wykonywania kolejnych prób i eliminacji błędów. Odpowiednio do tych sposobów uczenia się mówimy o uczeniu się warunkowym, intuicyjnym, poprzez naśladownictwo lub metodą prób i błędów (Hilgard, 1967).

A więc uczenie się według Bazjanca stanowi najbardziej istotny element procesu projektowania. Redefinicja problemu i rozwiazania możliwa jest tylko wtedy, gdy zgromadzona zostanie dostateczna wiedza na dany temat. Procesy te wielokrotnie powtarzają się aż do momentu, gdy: a) niecelowe jest dalsze poszerzanie wiedzy dotyczącej danego problemu (np. w przypadku, gdy projektant odczuwa osiagnięcie granicy lepszego zrozumienia problemu), b) dalsze gromadzenie wiedzy staje się zbyt kosztowne, c) występują naturalne przeszkody (np. brak czasu).

Opisany model procesu projektowania wskazuje na możliwość ostatecznego sformułowania problemu i związanego z nim rozwiązania. Założenie to kontrastuje z wcześniej omówionym założeniem Rittla,

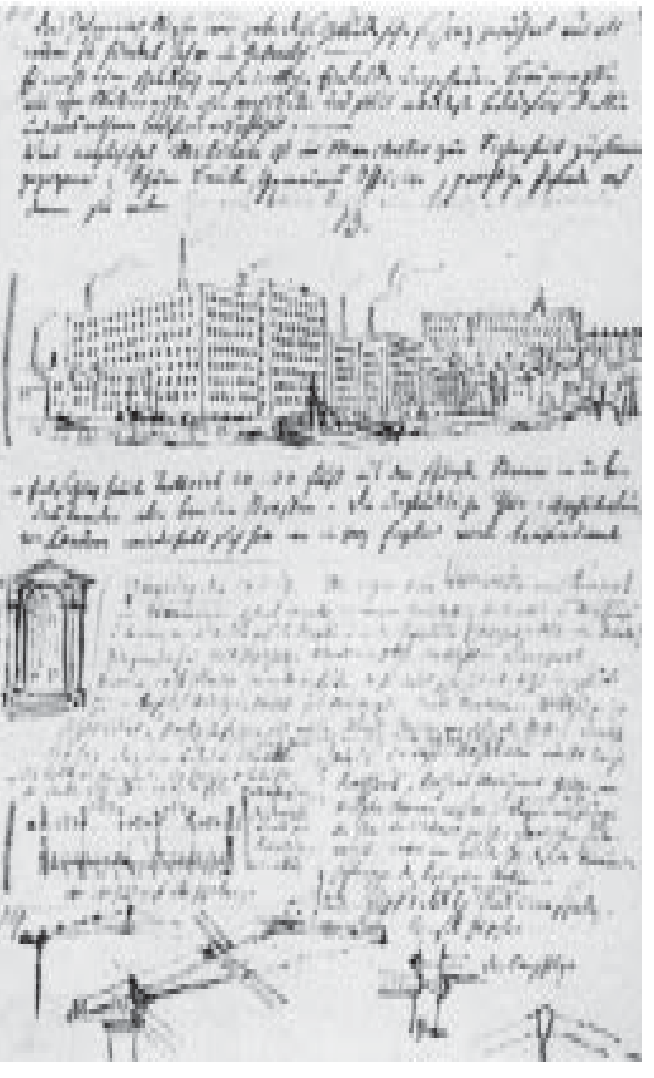

Podwójna rola dokumentacji polega z jednej strony na komunikowaniu rozwiązań, a z drugiej strony na weryfikowaniu własnych poglądów, które należy lub warto poddawać korekcie. Zapiski Schinkla z Manchesteru. że „problemy nielogiczne” nie mogą mieć ostatecznych sformułowań rozwiązań, a co za tym idzie, nie maja „,reguł zatrzymania” w ich wyprowadzaniu. Sprzeczność ta wynika z różnicy założeń psychologicznych dotyczących roli osobowości projektanta w modelu projektowania. W aktualnie opisywanym przypadku nawet wtedy, gdy problem nie ma ostatecznego rozwiazania (jak w koncepcji Rittla), projektant może ze względu na swoje ograniczone możliwości dalszego redefiniowania problemu przyjąć jakieś rozwiązanie za ostateczne. To naturalne psychologiczne ograniczenie stanowi praktyczna „,regułę zatrzymania” procesu projektowania. 


\section{Synteza formy oraz wzory C. Alexandra}

Najbardziej znanym w świecie, a jednocześnie najbardziej dojrzałym modelem teoretycznym projektowania architektonicznego, opartym na psychologicznych założeniach zachowania się ludzi jest koncepcja syntezy formy Alexandra. Opisana jest ona w pracy pt. The Notes on the Synthesis of Form - Rozważania nad synteza formy. Stwierdził on istotna zależność między wzorem problemu, a procesem projektowania fizycznej formy. Fizyczna forma jest zawsze odpowiedzią na dany problem projektowy. Idea Alexandra opiera się na założeniu, że tak samo ważna jest droga prowadzaca do rozwiazania problemu, co jego rozwiazanie.

Według definicji Alexandra proces projektowania składa się z dwóch faz: pierwsza faza to analiza, druga - synteza. Analityczna faza procesu projektowania polega na dekompozycji problemu, tzn. na rozbiciu problemu na elementy składowe i pohierarchizowaniu ich w określonym porządku. Punktem wyjścia fazy analitycznej jest analiza wymagań, rezultatem natomiast jest program, realizowany w fazie następnej. Faza druga - faza syntezy - polega na wyprowadzaniu formy z programu. Punktem startu tej fazy jest „diagram”, a rezultatem - „dendryt diagramów”, który stanowi realizację programu. Rozwiązanie problemu polega na zbudowaniu zsyntetyzowanego diagramu obejmującego wszystkie diagramy.

Istotą procesu projektowania jest proces organizowania kryteriów projektowych, ich podział na podsystemy, a te z kolei na pod-podsystemy. W przypadku rynku jako placu targowego pełen zestaw kryteriów projektowych obejmuje czynniki społeczno-psychologiczne oraz takie elementy jak: funkcje w zakresie transportowania, eksponowania i magazynowania towarów, problemy związane z utrzymaniem i konserwacja, problemy przebudowy zgodnie ze standardami nowoczesności i wymaganiami konserwatorskimi, problemy zarządzania terenem, problemy identyfikacji ze społecznością i miejscem, współzarządzanie, problemy własnościowe. Elementy te ulegają rozbiciu na elementy składowe. Pierwszy subsystem elementów składowych związany jest z perspektywą biurokratyczną: założeń i ograniczeń nieprzekraczalnych przez nikogo. Drugi zbiór elementów wiąże się z perspektywą użytkowania przestrzeni rynku przez kupców. Trzeci susbsystem kryteriów projektowych wiąże się z perspektywą użytkowników, takich jak mieszkańcy, stali klienci, przypadkowi przechodnie.

Alexander w dalszych swoich pracach uzupełnił swój dekompozycyjny model projektowania, dostosowany do projektowania wspomaganego komputerowo, o tzw. „wzory zachowania”. Idea, którą nazwał wzorami (patterns) ma w zamierzeniu autora wzbogacić zawodowych architektów o trwały środek projektowania, który zastosowany w zbliżonych warunkach da zawsze podobny efekt. Innymi słowy, Alxandrowi chodziło o to, aby doświadczenie, jakie zdobywa projektant w analizowaniu problemu projektowego przez pryzmat zachowań użytkownika nie umykały bezpowrotnie wraz z odłożeniem dokumentacji projektowej na półki, lecz były wykorzystywane w następnych projektach. Zdaniem Alexandra nie zawsze trzeba zaczynać analizę kryteriów projektowych od początku, bowiem pozwalają na to zdobyte wcześniej doświadczenia i zsumowane obserwacje w formie tzw „wzorów” zachowań charakterystycznych dla określonych sytuacji. W myśl tej idei Alexander zaczął budować katalog wzorów, które pozwalają w obliczu tego samego problemu na takie samo rozwiązanie. Forma w jego zmodyfikowanym modelu jest determinowana przez diagramy. Diagramy te nie sa już jednak rezultatem rygorystycznej analizy, jak również proces projektowania nie jest podzielony na oddzielne fazy analizy i syntezy.

Model Alexandra opisuje projektowanie jako w istocie rzeczy proces dochodzenia do wiedzy i podejmowania decyzji, która odpowiada danej wiedzy. Decydującą kwestią jest osiagalność wiedzy, ponieważ rozwiązanie projektowe odzwierciedla tylko wiedzę zakumulowaną przez projektanta. Najważniejsza czynnościa projektanta jest zdobywanie „odpowiedniej” wiedzy potrzebnej do rozwiazania problemu. Alexander w wykonaniu tego zadania upatruje pomocy w swojej koncepcji „wzoru”. Polega ona na tym, że specjalista (projektant) projektuje wzór, będący diagramem opisującym jego wiedzę, po czym rozważa jego najważniejsze aspekty. Następnie przedstawia wzór odbiorcom lub zleceniodawcom projektu. W procesie tym specjalista prezentuje im wszystkie uwarunkowania wzoru. Odbiorca (zleceniodawca lub użytkownik) akceptuje go albo nie. Jeżeli wzór jest zaakceptowany, to automatycznie staje się częścia „własnej” wiedzy projektanta (proces internalizacji). Jeżeli wzór nie jest akceptowany przez odbiorcę, wtedy projektant rozwija dalej proces projektowania na podstawie dotychczasowej wiedzy.

Model Alexandra zbudowany jest na założeniu, że każdy człowiek jest w istocie rzeczy projektantem i że każdy ma określone, własne wzory. Każdy podejmuje decyzje projektowe, niezależnie od tego, w jakim stopniu wzory te są informacyjnie poprawnie zorientowane. Celem wzorów projektowanych przez „specjalistów" (zawodowych projektantów) jest poprawianie istniejących wzorów, które mogłyby prowadzić do błęd- 


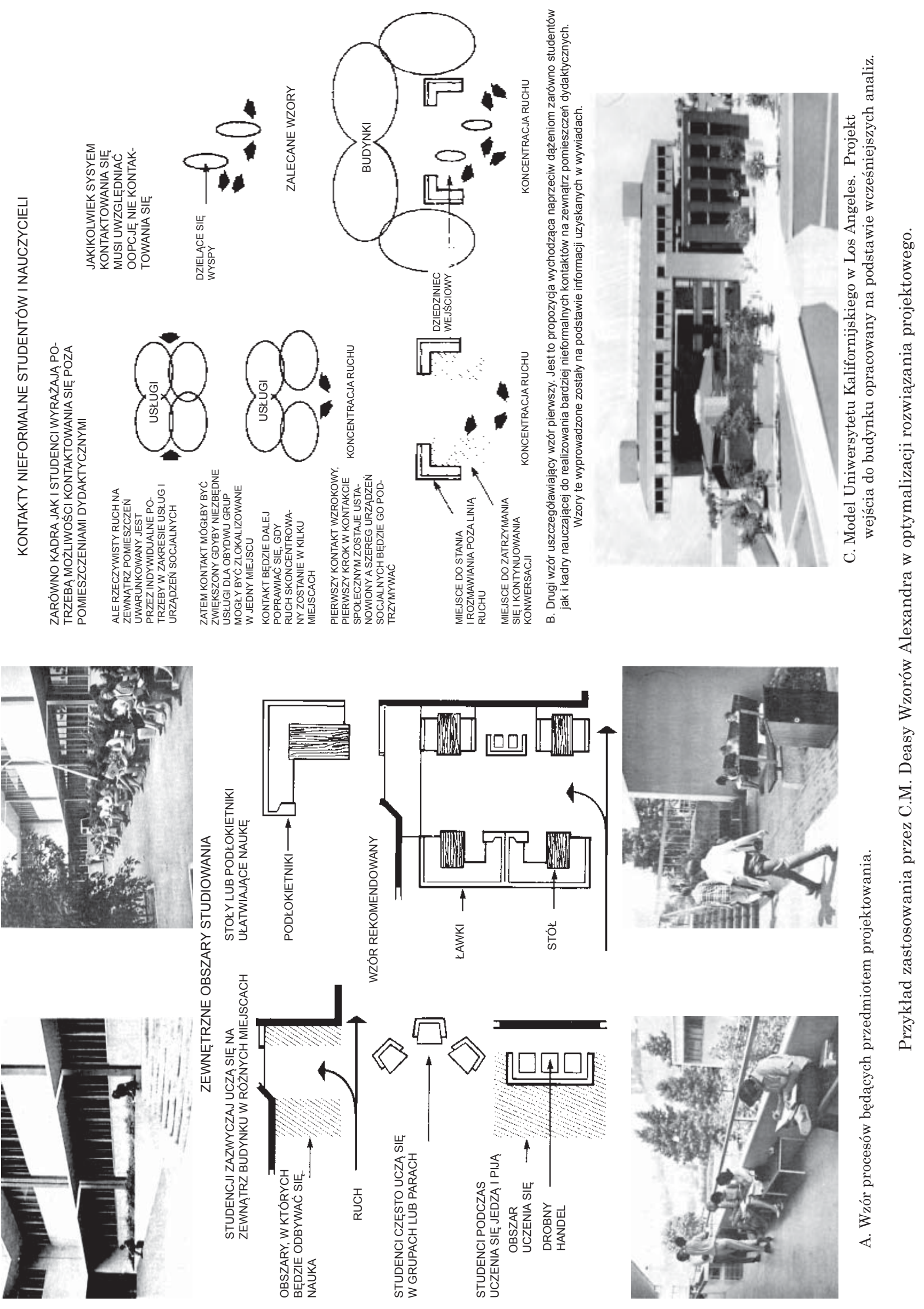


nych rozwiazań, ulepszanie lub konceptualizacja nowych wzorów. Każdy z subsystemów kryteriów odpowiada innym wzorom. Architekt uwzględnia je i koordynuje we wspólną całość we własnym wzorze, który finalnie przybiera postać „projektu technicznego”.

Projektant podczas komunikowania własnego wzoru kontrpartnerowi (zleceniodawcy, urzędnikowi, właściwemu użytkownikowi, mieszkańcom i wszystkim innym zainteresowanym) oferuje swoje przekonania, przedstawia swoje „uważam, że najlepiej...” oraz upewnia się, w jakim stopniu jego przekonania moga być zaakceptowane. Jeżeli np. przedmiotem projektowania jest dom mieszkalny dla rodziny, to zgodnie z powyższą koncepcją projektantami tego domu powinni być poszczególni członkowie rodziny, czyli laicy w dziedzinie architektury.

Alexander uważa, że każdy, kto powierza projektantowi do rozwiązania określone zadanie, zawsze ma jakiś pomysł, ideę, wizję tego, jak to coś ma wyglądać, przy czym pomysły te zwykle opierają się na uprzednim doświadczeniu, stylu życia, możliwościach ekonomicznych. Specjalista, czyli zawodowy architekt, ma jedynie za zadanie zaoferować klientowi swoje osobiste przekonania odnoszące się do wzorów prezentowanych przez klienta-projektanta. Wszystko to, co wie na dany temat, co uważa za istotne w projektowaniu danej formy architektonicznej, projektant-specjalista przedstawia za pomoca rysunkowych diagramów, które wyrażają jego ideę jako specjalisty. Wzór projektanta-specjalisty ma zatem za zadanie zorientowanie klienta-projektanta $\mathrm{w}$ problemie i zaoferowanie mu optymalnego jego rozwiązania. Ostateczne jednak rozwiązanie projektowe odzwierciedla wiedzę, przekonania i preferencje będące własnością projektanta-klienta. Jak więc z tego wynika, Alexander przyznaje główną rolę w procesie projektowania architektonicznego użytkownikowi i jego wiedzy, która jedynie podlega wpływom (modyfkacji, rozszerzaniu, zmianom) wiedzy i wartości projektanta-specjalisty, czyli architekta.

Zarówno Rittel, jak i Alexander podkreślają wagę rozumienia i uwzględniania innych wyobrażeń architektonicznych przy podejmowaniu decyzji projektowych. Jedno z najważniejszych założeń w ich modelach procesu projektowania dotyczy konieczności uczenia się zawodowych architektów innych wyobrażeń. Na przykład u Rittla celem ustrukturalizowanej argumentacji jest informowanie poszczególnych uczestników procesu projektowania o formułowanych przez nich sugestiach rozwiązań. Niemniej jednak zarówno Rittel jak i Alexander nie formułuja procesu projektowania w terminach procesu uczenia się.

\section{Wnioski}

Behawioralne teorie projektowania architektonicznego należą do odwiecznej tradycji architektonicznego funkcjonalizmu. Na rozpowszechnienie się myślenia racjonalnego w projektowaniu architektonicznym niewątpliwy wpływ wywarły nowe prądy intelektualne przeformułowujące istotę projektowania technicznego w ogólności. Oprócz tego jednak myślenie racjonalne w architekturze prawdopodobnie wywodzi się z poglądów Lodoliego i prac teoretycznych Laugiera. Lodoli kwestionował wartość architektury swoich czasów i przeszłości stojąc na gruncie funkcjonalizmu i „rzetelnego wykorzystania materiałów”. Laugier z kolei stoi na stanowisku, że nie jest najważniejsze, czy architektura się podoba, lecz to, co jest w niej niezbędne.

Reasumując, współczesne racjonalne koncepcje projektowania posiadaja swoich prekursorów wśród ojców funkcjonalizmu i reprezentują żywą wciąż w architekturze filozofię funkcjonalizmu, której okres świetności przypada na lata międzywojenne. Istotą funkcjonalizmu architektonicznego jest oszczędność

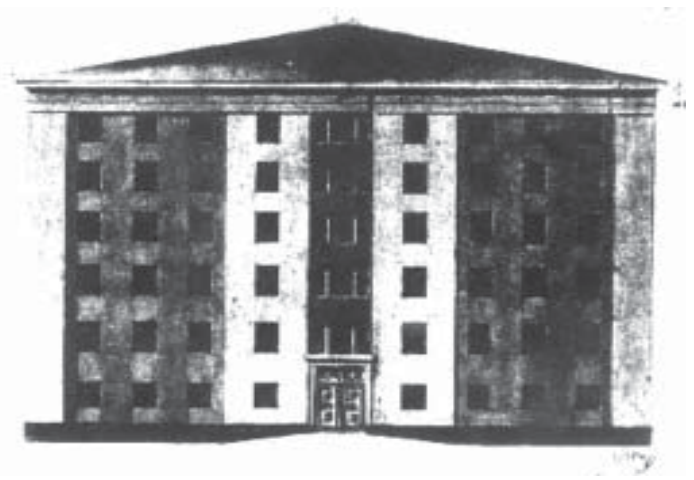

Przykład funkcjonalizmu z okresu neoklasycyzmu. i drugoplanowy charakter kulturowych symboli formy, jak też arbitralne rozstrzyganie, co $\mathrm{w}$ formie architektonicznej jest słuszne, tzn. co jest funkcjonalne dla człowieka, a co jest zbędne.

Funkcjonaliści hołdujący doktrynie, według której forma determinuje funkcję jako antidotum na zbędną ornamentację, $\mathrm{w}$ istocie rzeczy (co jest do pewnego stopnia paradoksem) większy nacisk kładą na formę aniżeli funkcję. Według tej doktryny funkcja jako taka, np. harmonia miejsca, integralność materiałów, spójność poszczególnych części, jest już spełnieniem funkcji. Nic natomiast lub bardzo niewiele uwagi poświęca się aktywności człowieka, czyli jego funkcji w ramach tej struktury. Jest to charakterystyczne dla architektów, którzy nauczeni są patrzeć na budynki jako formy bez ludzi . Architektura taka podobna 
jest do kolorowych fotografii w ilustrowanych magazynach pokazujacych i reklamujących funkcjonalne wnętrza, z zastawionymi stołami, otwartymi książkami, w których jest wszystko, czego „dusza” pragnie, prócz „cienia” człowieka.

Zasady funkcjonalizmu, tak jak je rozumiano w pierwszej połowie dwudziestego wieku, oczywiście wciąż zdają egzamin do dzisiaj przy realizacji nieznanych uprzednio funkcji, jak np. dworców lotniczych, fabryk o nowym programie produkcji. Eksponowanie nowoczesnej technologii materiału, tworzenie wyłącznie z własną epoką symboli kulturowych jest w tym przypadku oczywiste. Zrozumiała jest tu dążność do kreowania nie związanych z tradycją ultrawspółczesnych „typów uniwersalnych”. Problem nowych i starych funkcji, współczesnych i dawnych symboli kulturowych komplikuje się w obiektach takich, jak muzea, domy mieszkalne, ratusze, uczelnie wyższe, miasta, gdzie zasada zalecajacca kształtowanie zewnętrznej formy w analogii do sporządzania, opierając się na nowoczesnej technologii, „opakowania” dla użytkowej funkcji, przestaje już wystarczać, natomiast tam, gdzie chodzi o przestrzeń życiową człowieka - jest absolutnie błędny.

Arbitralizm, mający swoje źródło w racjonalizmie, jest chyba najważniejszą cechą funkcjonalizmu i współczesnych jego odpowiedników, to jest racjonalnych teorii projektowania. Razi on nawet zagorzałych niegdyś jego zwolenników. Tak np. Filip Johnson w swej pracy Styl międzynarodowy - śmierć czy metamorfoza (The International Style. Death of Metamorphosis) tak uzasadnia częste używanie przez siebie łuków: „Koncepcja łuku pozostaje oczywiście w sprzeczności z nowoczesnymi zasadami projektowania, bowiem ... łuki nie sa w rzeczywistości elementami konstrukcji nośnych,... w moim odczuciu wyglądają one jednak dobrze i lubię je”.

Wszystkie współczesne behawioralne modele projektowania, mają tę niewątpliwą zasługę, że podniosły wśród projektantów poziom świadomości na temat procesów projektowania do niespotykanego, bezprecedensowego poziomu. Ich autorzy pozwalaja zrozumieć procesy projektowania poprzez definiowanie logicznych i myślowych struktur. W ten sposób uszlachetniaja myślenie funkcjonalne chroniąc twórców i użytkowników architektury przed nadużyciami postawy arbitralnej.

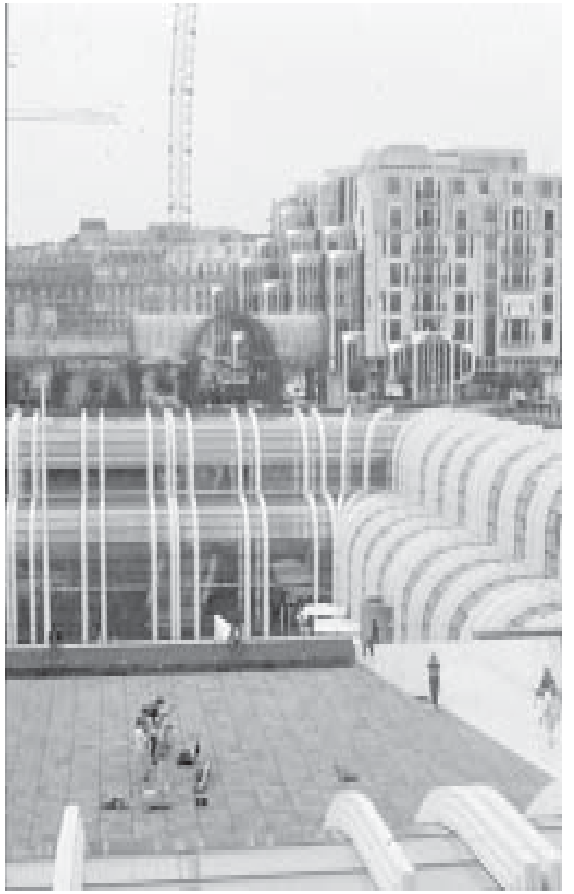

Skrajny funkcjonalizm w paradoksalny sposób prowadzi do zaprzeczenia funkcjonalności formy.
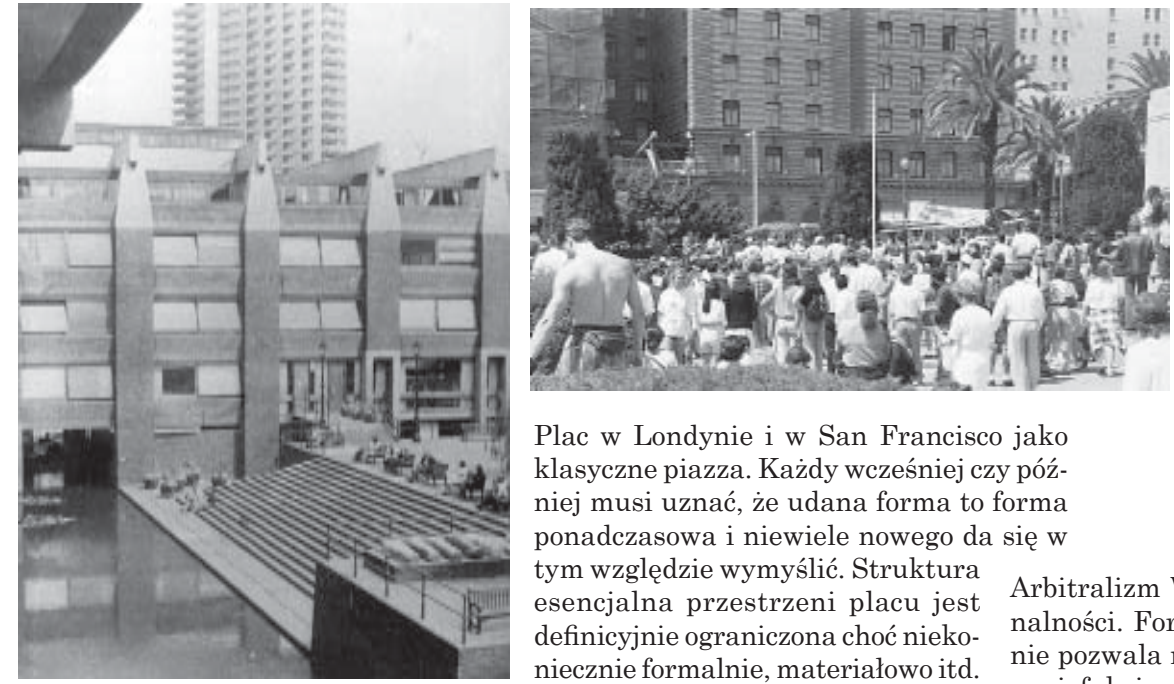

Plac w Londynie i w San Francisco jako klasyczne piazza. Każdy wcześniej czy później musi uznać, że udana forma to forma ponadczasowa i niewiele nowego da się w tym względzie wymyślić. Struktura esencjalna przestrzeni placu jest definicyjnie ograniczona choć niekoniecznie formalnie, materiałowo itd.
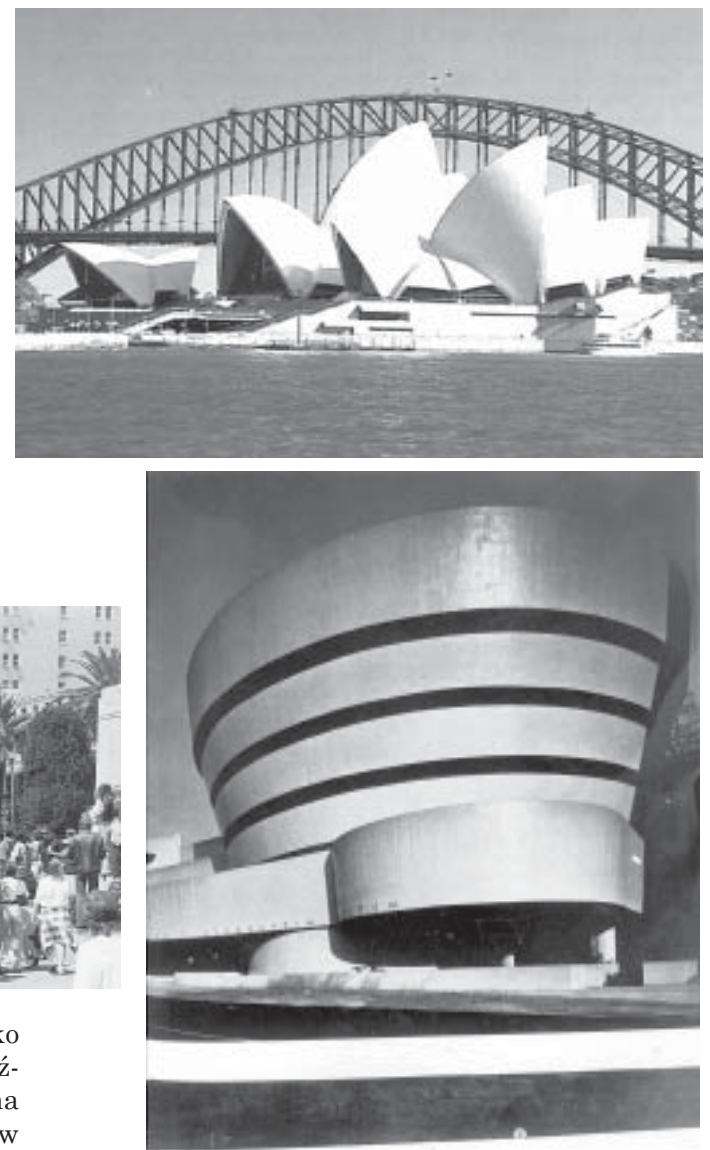

Arbitralizm Wrighta, to żart funkcjonalisty z niefunkcjonalności. Forma garażu zastosowana do funkcji muzeum nie pozwala na wygodna ekspozycję obrazu. Podobnie gre w niefukcjonalność zastosował Jôrn Utzon. Opera w Sydney wybudowana wielkim nakładem kosztów posiada sto miejsc, z których nie widać sceny. 


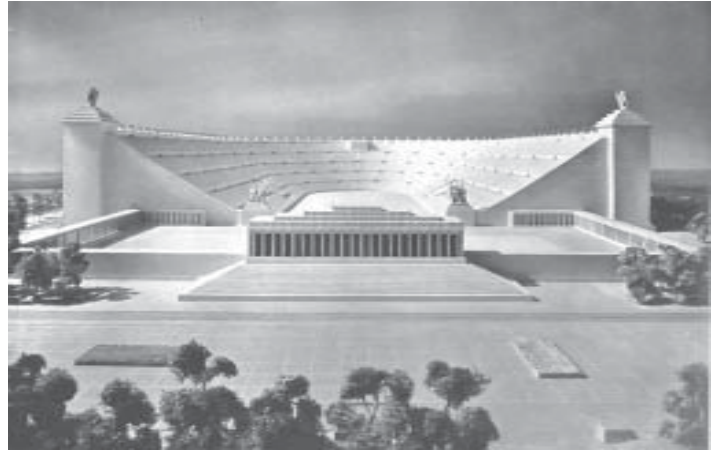

Arbitralizm jako nieodłączna część totalitaryzmów zawsze prowadził do pułapki historyzmu. Historyzm jest oglądaniem się wstecz, ale po powierzchni formy, a nie zapuszczaniem się w głębię duszy. Speer: Projekt stadionu. Pułapki tej nie stwarza „powrót do źródeł”, czyli zwykłe odtwarzanie tego, co zniszczyła np. wojna - w odbudowywanej starówce w Antwerpii nie razi beton, a w Gdańsku „tymczasowo” wybudowana kotłownia.
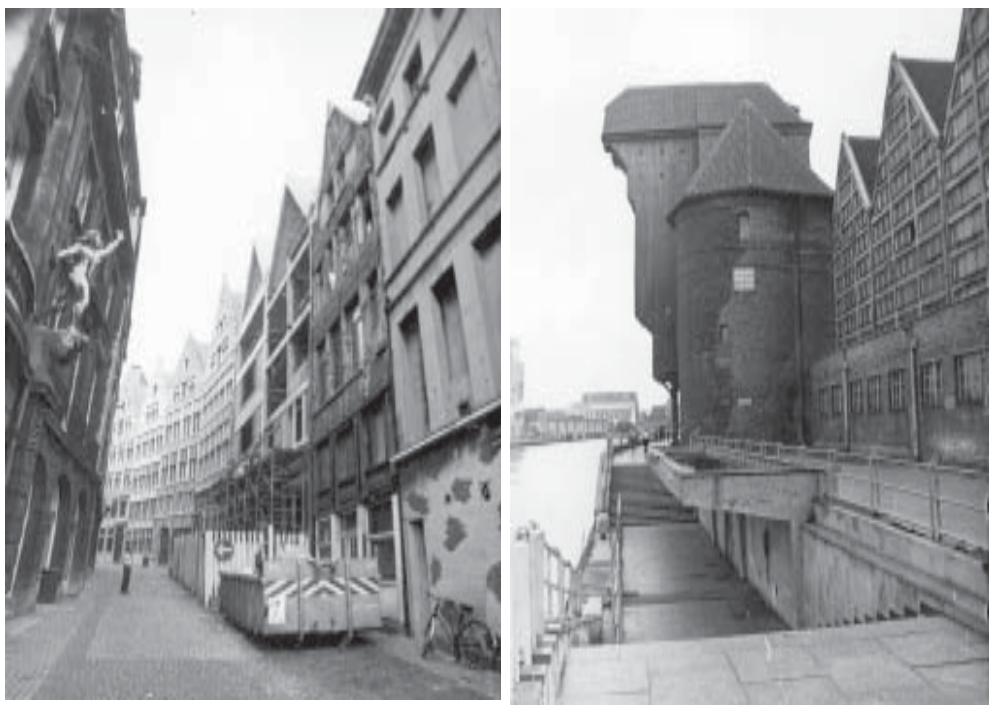

Najistotniejszym wkładem współczesnych behawioralnych teorii projektowania jest zwrócenie uwagi na konieczność honorowania w projektowaniu architektonicznym poglądów i przekonań innych jego uczestników, a w szczególności użytkowników. Jest to przejście niejako od postawy arbitralnej w rozwiązywaniu problemów projektowych do tolerancji wobec innych architektonicznych „weltanschaungen”. Generalnie stanowi to zmianę postaw, wobec celów projektowania, przejawiającą się w coraz to większym zainteresowaniu kontrola wpływu oddziaływań środowiska fizycznego na wzory zachowań ludzi.

Powstaje jednak pytanie, co warunkuje realizowanie się tego rodzaju postawy w praktyce? Wydaje się, że podobnie jak przedstawiciele nauki myślą w swej pracy kategoriami przyszłości, tak projektanci częściej
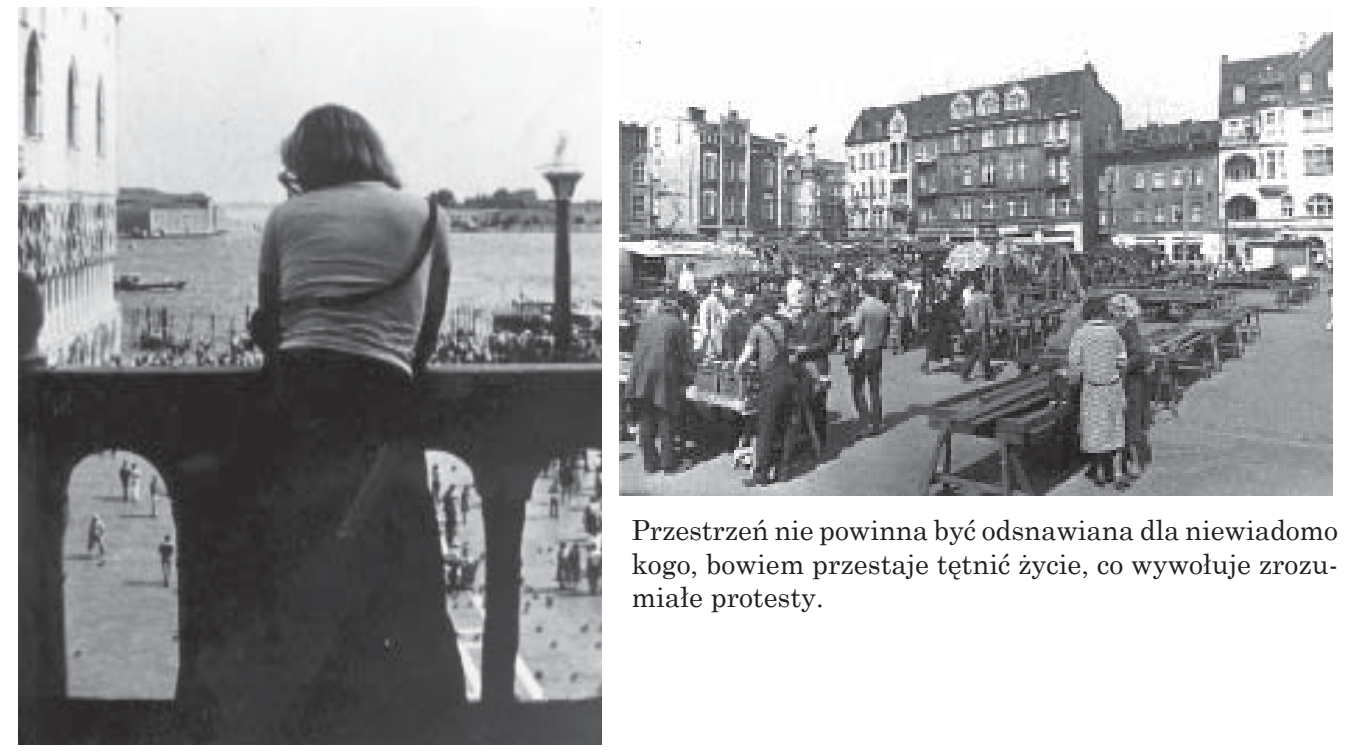

Przestrzeń nie powinna być odsnawiana dla niewiadomo kogo, bowiem przestaje tętnić życie, co wywołuje zrozumiałe protesty. powinni odwoływać się do przeszłości nie tracąc z pola widzenia konieczności tworzenia przyszłości (utopii) oraz nie uciekając od badań nad sposobami wykorzystania istniejacych form architektonicznych z punktu widzenia użytkownika. Innymi słowy, architekci powinni odrzucić hasło, będące nazbyt często wyznacznikiem postępowania, a mianowicie „nie oglądać się nigdy

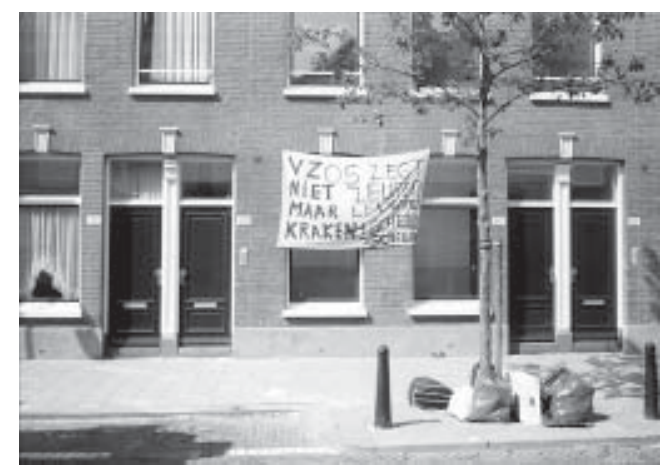

wstecz". Nie oznacza to jednak prostego historyzmu w stylu A. Speera czy zwolenników socrealizmu (Goldzamt).

$\mathrm{Z}$ punktu widzenia pojedynczego człowieka historia to niekoniecznie historyzm, ale psychiczna zdolność sięgania wstecz i lokowania przeszłości w nastawieniach i oczekiwaniach.

Kiedy zadajemy sobie pytanie, co zrobić aby dane miejsce stało się „żywe” natychmiast, a nie po kilkudziesięciu latach, mało przydatne jest studiowanie historii miejsc. Adekwatną odpowiedź może dać jedynie odwołanie się do pamięci, a więc historii zdarzeń w miejscach, w których tętniło życie. 


\title{
CZĘŚĆ II
}

\section{ARCHITEKTURA BEHAWIORALNEJ PRZESTRZENI ŻYCIA}

\author{
WYMIAR LUDZKI W ARCHITEKTURZE
}

Podstawowa przesłanką zastosowań i badań w zakresie obszaru „środowisko-system zachowań” jest założenie, w myśl którego występują wyraźne zależności między architekturą a wzorami ludzkich zachowań. Izumi zaproponował diagram, który jest użyteczny w zrozumieniu „zawartości” czynnika ludzkiego w architektonicznej strukturze środowiska. Z lewej strony diagramu znajdują się formy, które obejmują obiekty „nieożywione”. Z prawej strony znajdują się obiekty „zanimizowane”, tzn. takie, które bezpośrednio służą człowiekowi. Między dwoma ekstremami, występują obiekty w różnym stopniu wykorzystywane przez człowieka. W miarę przesuwania się na diagramie z lewej strony ku prawej, ocena form architektonicznych staje się coraz, bardziej istotna z punktu widzenia funkcji indywidualnych, społecznych czy estetycznych.

Akceptacja jednak założenia, zgodnie z którym projektowanie architektoniczne środowiska powinno opierać się na zrozumieniu zachowań ludzi - z jednej strony, a $\mathrm{z}$ drugiej - na kontroli konsekwencji projektowych, nasuwa nieuchronnie pytanie, czy behawioralna wiedza naukowa (psychologiczna, socjologiczna, antropologiczna) jest w stanie zadośćuczynić praktycznej realizacji tych celów. Inaczej formułujac pytanie: Czy nauki o człowieku sa przygotowane do wspomagania działalności architektów, urbanistów (projektantów środowiska) w realizacji idei kształtowania środowiska $z$ myślq o człowieku?

Odpowiedź na postawione pytanie nie jest prosta i jednoznaczna. $Z$ jednej bowiem strony faktycznie niemożliwe jest kształtowanie, a nawet zrozumienie

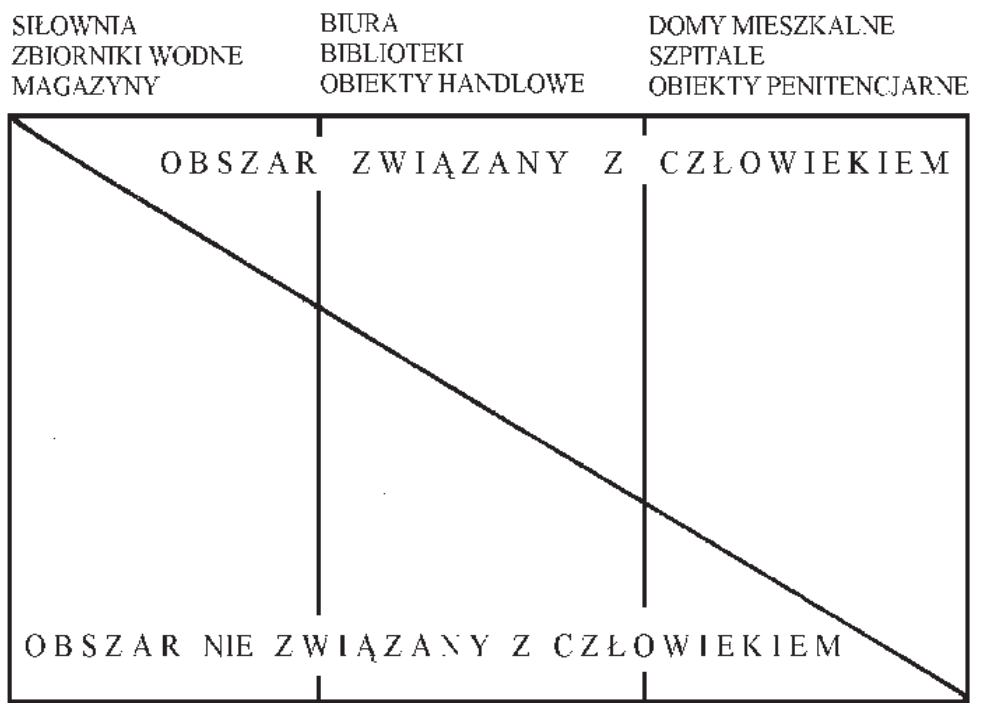

Wymiar ludzki w architekturze. projektów architektonicznych lub urbanistycznych z punktu widzenia aksjologii behawioralnej, odwołującej się do takich teorii, jak teorie S. Freuda, R. Benedict, B.F. Skinnera czy K. Horney. Z drugiej strony nasuwa się kolejne pytanie, co w takim razie ze współczesnych teorii psychologicznych, socjologicznych czy antropologicznych może być wykorzystane w myśleniu architektonicznym, w dziele tworzenia nowego środowiska, nowej przestrzeni życiowej człowieka. Jakie sa osiagnięcia, lub niedociagnięcia tych teorii z punktu widzenia potrzeby kształtowania środowiska człowieka?

W tej części pracy przeprowadzona zostanie udzielona, przynajmniej częściowo, odpowiedź na postawione pytania. Należy mieć na uwadze fakt, że odpowiedź na pytania typu „co trzeba wiedzieć, by móc projektować z myślą o człowieku?", aczkolwiek nie jest sprawą łatwa, stanowi równocześnie podstawowy zrąb epistemologii projektowania architektonicznego. Mówiąc prościej odpowiedź na powyższe pytania ukazuje rolę architektury w poznawaniu i definiowaniu istoty człowieczeństwa. 


\section{Teoria behawioralna w projektowaniu środowiska dużej skali}

Projektowanie architektoniczne środowiska w rzeczywistości nie jest czymś jednolitym zarówno w sensie profesjonalnym, edukacyjnym, jak i epistemologicznym. Mamy tutaj do czynienia z projektowaniem środowiska w dużej i małej skali. Projektowanie środowiska w dużej skali częściej zastępuje się pojęciem planowania i obejmuje swoim zasięgiem region lub co najmniej miasto. Z kolei projektowanie środowiska w małej skali lub też jak to niektórzy nazywaja, w skali mikro, obejmuje swoją skalą budynki, osiedle i najwyżej miasto. Drugi rodzaj projektowania to właściwe projektowanie architektoniczne i choć obejmuje również szeroki zakres zagadnień (od pojedynczego budynku do miasta), to jednak zasadniczo różni się od planowania przestrzennego, regionalnego.

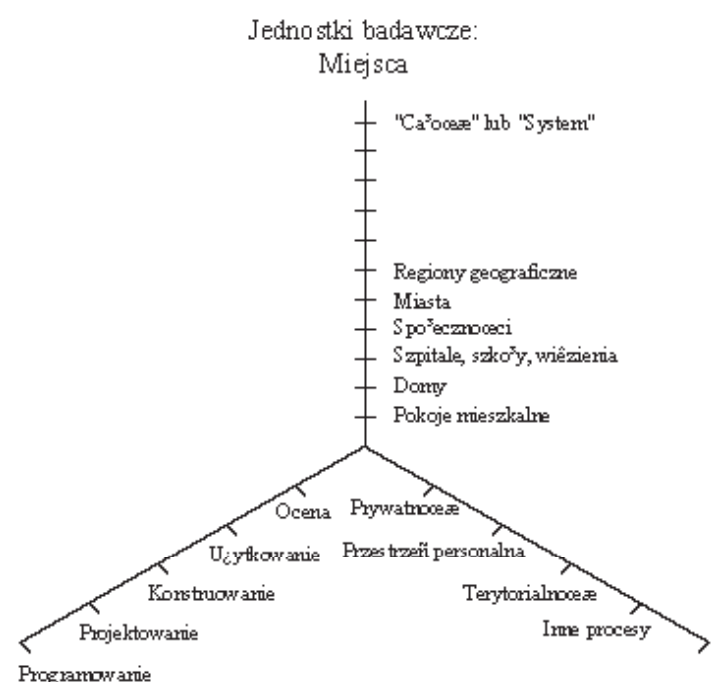

Trójdymesjonalny model zależności między człowiekiem i środowiskiem wg Altmana.
$\mathrm{Na}$ poziomie planowania regionalnego wykorzystywane sa głównie teorie, które zgodnie z dużą skalą projektowanego środowiska mają równie duży stopień uogólnienia. Są to najczęściej teorie z zakresu ekonomii oraz nauk politycznych. Wykorzystuje się je w wyjaśnianiu takich czynników, jak: odpowiednie rozmieszczenie działalności gospodarczej w przestrzeni, rozwiązywanie systemów transportowych i komunikacyjnych, rozwiązywanie zależności między walorami środowiska naturalnego a kosztami jego transformacji. Skala koncepcji teoretycznych i podejść na poziomie regionalnego planowania przestrzennego jest skala makro, w związku z czym teorie behawioralne maja stosunkowo niewielki udział w ich kształtowaniu. Mimo to sytuacja nie jest $\mathrm{w}$ tym aspekcie zupełnie jasna i zadowalajaca. Ostatnie osiagnięcia w zakresie urbanistycznej teorii zachowań komunikacyjnych sugeruja, że „deterministyczne modele ekonomiczne które wyrastają $z$ założeń ekonomicznej racjonalności, są osobliwe z punktu widzenia braku sukcesów w wyjaśnianiu przestrzennych zachowań ludzi, z wyjątkiem bardzo ogólnego poziomu. Wysiłki w kierunku wykorzystania zmiennych ekonomicznych wykazujących statystyczna zależność z zachowaniami komunikacyjnymi na bardzo ogólnym poziomie, prawie zawsze okazywały się nieskuteczne w wyjaśnianiu zachowań na poziomie pojedynczego mieszkańca. Czynniki, które są istotnymi determinantami zachowań dużych społeczności pozbawione są behawioralnej mocy wyjaśniającej na mniej ogólnym poziomie".

Generalnie rzecz biorąc, uwidaczniają się coraz częściej niedostatki współczesnej ekologii człowieka w aspekcie jej funkcji wyjaśniania zależności między człowiekiem i środowiskiem. Kunkel zauważył, że natura i charakter powiązań człowieka ze środowiskiem nie są takie proste, jak zakładają to teorie ekonomiczne. Stwierdza on, że „społeczna organizacja nieadekwatnie skonceptualizowana stwarza trudności w dokładnym wskazaniu, jakie aspekty życia społecznego i jakie rodzaje zjawisk społecznych odnoszą się do środowiska". W jego przekonaniu przyczyna tego leży w niedostatku danych analitycznych, co w konsekwencji prowadzi do dalszej analizy skomplikowanych zjawisk bez rozpoznania ich zmienności i złożoności. Michelson z kolei zauważa, że nawet humanistycznie ortodoksyjne teorie z zakresu ekologii człowieka opierają się w zbyt dużym stopniu na badaniach, które apologetyzują zmienne ekonomiczne jako główne czynniki wyjaśniające. Nadmierną uwagę przyciagają szczególnie cztery zmienne niezależne), a mianowicie populacja, organizacja, środowisko i technika. [Zmienna niezależna jest to zmienna, której zmiany nie zależa od zmian innych zmiennych w ramach rozpatrywanego zespołu zmiennych, wodróżnieniu od zmiennej zależnej, której zmiany zależa od innych zmiennych (sa przez nie wywotywane)]. Kunkel i Michelson zgodni sa co do tego, że metoda ekologiczna oparta na zagregowanych danych dotyczących populacji stanowi mało użyteczne narzędzie w wyjaśnianiu środowiskowych zależności w mikroskali, to znaczy z punktu widzenia jednostki lub małych grup. [Grupa jest to zbiór kontaktujacych się ze sobq ludzi, tworzacych mniej lub bardziej zamknięty krag, oddzielajacych się od zbiorów innych. Najważniejszym czynnikiem zewnętrznym tworzqcym grupejest obszar przestrzenny: doktadne rodzaje grup podano w pracy: Baley, S. (1964)] Jest rzeczą naturalna, że kryteria ekologiczne uzasadniające np. budowę autostrady na podstawie takich elementów, jak koszty społeczne, 
czas przeznaczony na dojazdy itp., są zasadne z punktu widzenia większej zbiorowości. Nie oznacza to jednak, że automatycznie muszą być one tak samo zasadne z punktu widzenia interesów, celów i wartości jednostek, dla których komfort środowiska mieszkalnego, nieskażenie środowiska naturalnego czy brak hałasu mogą być o wiele ważniejsze.

Podsumowujacc, teorie ekonomiczne wykorzystywane w procesach planowania przestrzennego opierają się na koncepcji człowieka racjonalnego - homo economicus. W związku z tym zawarte w tych koncepcjach wartości i cele dążeń ludzkich oraz istota procesów społecznych stanowią nieadekwatna podstawę planowania regionalnego i urbanistycznego. Uproszczenia w koncepcji człowieka prowadzą do uproszczeń w koncepcjach rozwiązań projektowych. Zaakceptowanie natomiast różnorodności celów działania człowieka oraz różnorodności procesów społecznych implikuje naturalnym biegiem rzeczy konieczność przyjęcia zasady tworzenia większej, odpowiadającej człowiekowi różnorodności środowiskowej. Innymi słowy, tylko różnorodne środowisko jest w stanie zadośćuczynić całej różnorodności człowieka w społeczeństwie. Niezbędne jest jednak ścisłe zdefiniowanie zależności między różnorodnością środowiska a różnorodnością człowieka.

Teorie behawioralne, zawierając opis różnorodności zachowań ludzkich w kontekście różnorodności środowiskowej, stają się w ten sposób

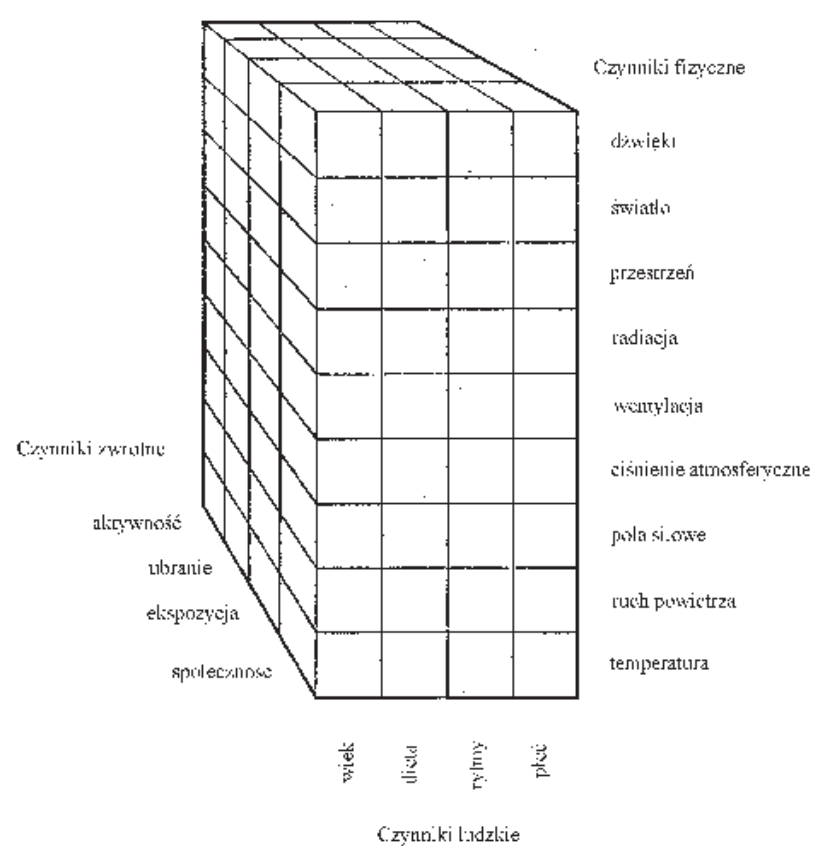

Zmienne badane w psychologii środowiskowej wg Rohle'sa użytecznym kryterium rozwiązań urbanistycznych i architektonicznych w dużej skali środowiska. Podstawowy cel odwoływania się projektantów, rozwiąujących problemy projektowe w dużej skali środowiska, do danych behawioralnych związany jest z dążeniem do opanowania trudnej sztuki redukcji różnorodności zachowań ludzkich do takiej liczby konstruktów (typów), które są wystarczające dla trafnej konceptualizacji rozwiązań projektowych - z jednej strony, a z drugiej - nie są zbytnim uproszczeniem wizji człowieka (jego natury) w środowisku. Poszczególne typy zachowań winny być scharakteryzowane różnicami w zakresie takich cech, jak np. różnice w nawykach podróżowania, różnice w sposobach dokonywaniá wyborów między czasem a kosztami, różnice w sposobach zachowania się w związku ze sposobami dokonywania zakupów.

Dane takie umożliwiaja projektantowi środowiska w makroskali wyrobić sobie większą pewność siebie w zakresie tego, „kim niektórzy ludzie sa”, i w odrzuceniu niezbyt precyzyjnego poglądu (na jaki pozwalają dane ekologiczne), że „każdy człowiek jest...”.

\section{Teoria behawioralna w projektowaniu środowiska matej skali}

Tak jak uwidacznia się potrzeba zbudowania teorii behawioralnej na poziomie projektowania środowiska $\mathrm{w}$ dużej skali, tak w jeszcze większym stopniu istnieje zapotrzebowanie na teorię behawioralną mająca zastosowanie w projektowaniu środowiska w mikroskali. Od kilkudziesięciu lat znane jest powiedzenie, którego autorstwo Holahan przypisuje Winstonowi Churchillowi, że „najpierw kształtujemy budynki, a później budynki kształtują nas”. Dzisiaj wiemy już, że stwierdzenie to, choć w zasadzie słuszne, niezupełnie oddaje zależność między człowiekiem a środowiskiem fizycznym Przede wszystkim człowiek wobec oddziaływujących nań czynników fizycznego środowiska nie pozostaje bierny. W ukształtowanym przez architektów środowisku człowiek podejmuje szereg działań przystosowawczych, które obejmują zarówno jego samego jak i środowisko.

Uświadomienie sobie tego faktu nastąpiło w połowie lat sześćdziesiątych najpierw u architektów, a później u reprezentantów świata nauki. Efektem tego była wzrastająca liczba badań z zakresu takich dziedzin, jak psychologia, socjologia, geografa i architektura. W USA powstało „Badawcze Stowarzyszenie Projektowania Środowiska” (Environmental Design Research Association), które do tej pory wydaje cza- 

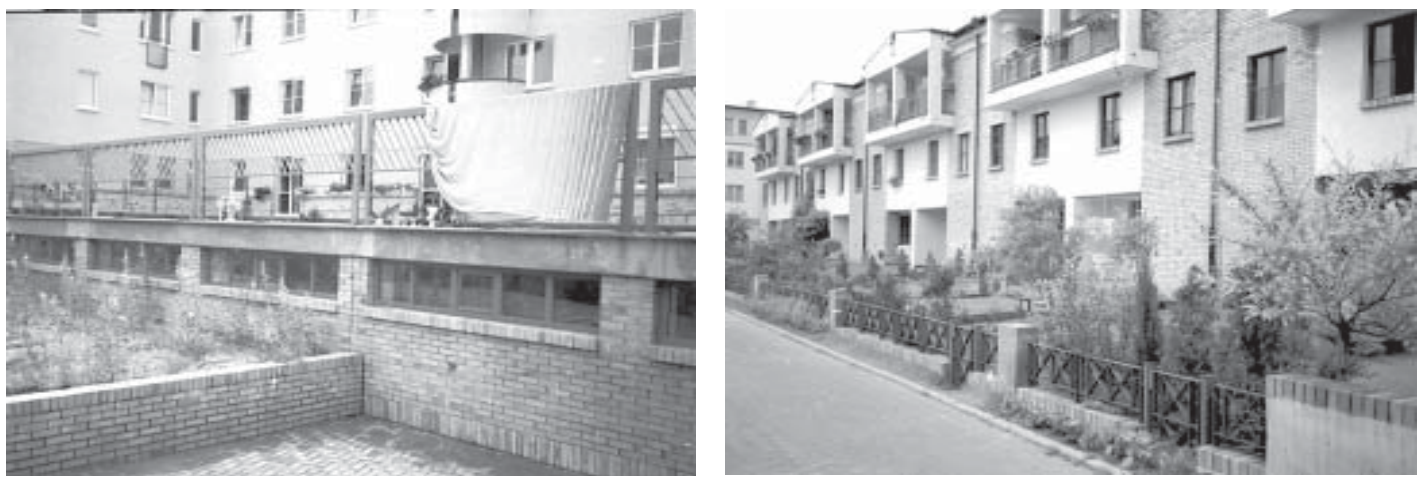

Jednym z działań przystosowawczych podejmowanych przez ludzi w środowisku jest zawłaszczanie przestrzeni prowadzące do personalnej kontroli nad środowiskiem. Użytkownik zmieniając czasowo lub na stałe elementy otoczenia wkomponowuje w środowisko niejako swoje własne „projekty”.

sopismo pod nazwą Environment and Behavior. W 1969 roku wyszło trzecie wydanie pracy pt. Directory of Behavior and Environmental Design (Research and Design Institute, P.O. Box 307, Providence, Rhode Island), która zawiera listę „praktykujących osób w dziedzinie zależności między ludzkim zachowaniem a projektowaniem środowiska w trzydziestu czterech obszarach”. Wyniki tych badań i poszukiwań tworzyły i tworzą nadal interdyscyplinarny obszar wiedzy lub, jak niektórzy twierdza, interdyscyplinarną naukę pod nazwą „psychologia środowiskowa” (environmental psychology). Stała się ona w ten sposób ucieleśnieniem, co prawda do pewnego tylko stopnia, dążeń architektów i urba-
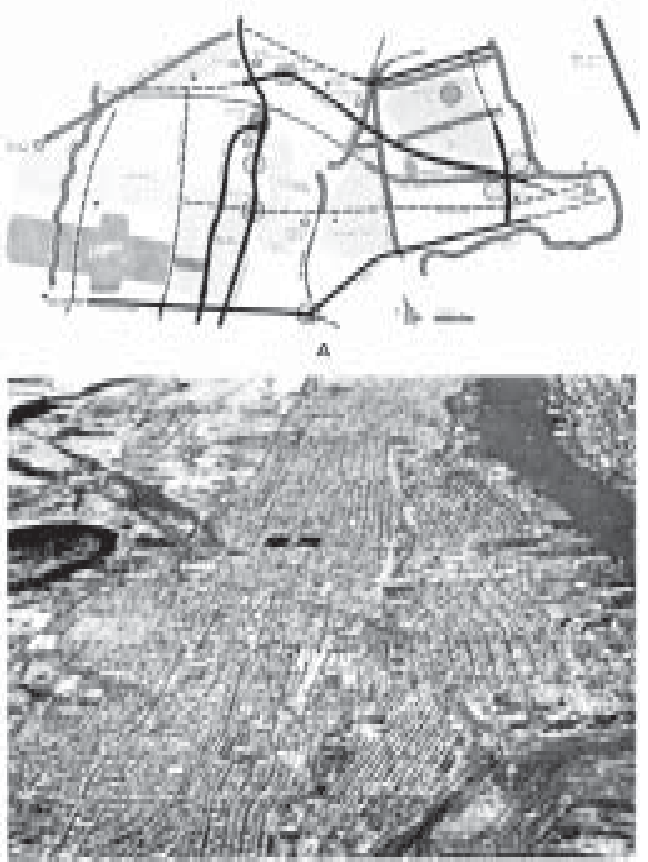

Mapa poznawcza Jersey City wykonana przez K. Lyncha (1960) nistów do wypracowania nowego systemu wiedzy użytecznej w architektonicznym i urbanistycznym projektowaniu środowiska.

W obrębie samej psychologii zrodzenie się takiego obszaru badawczego zwróciło uwagę psychologów na paradoks, że o wiele więcej wiadomo jest na temat funkcjonowania człowieka $\mathrm{w}$ różnorodnych ekstremalnych sytuacjach fizycznego środowiska (np. w środowisku podwodnym), niż o funkcjonowaniu człowieka w środowisku, w którym przebywa na co dzień, tj. w środowisku mieszkalnym. Paradoks po części wynikł stąd, że psychologowie przez długi okres czasu wzbraniali się przed przeprowadzaniem badań w tzw. sytuacjach niekontrolowanych (feld studies). To z kolei spowodowane było kompleksem niższości psychologów w stosunku do przedstawicieli takich nauk, jak fizyka czy biologia. Psychologowie za wszelką cenę dążyli do uściślenia eksperymentalnych planów badawczych, w efekcie czego osiagnęli cel, pogubiwszy po drodze istotne problemy, a nawet istotę problemu. Okazuje się bowiem, że dzięki tym „super” kontrolowanym eksperymentom mamy mnóstwo fragmentarycznych informacji dotyczących fragmentów zachowania się człowieka, z których jednak nie układa się całościowy obraz zachowań człowieka w normalnych życiowych sytuacjach. I tak wiemy, jak oddziaływują izolowane bodźce na psychikę człowieka, natomiast prawie nic nie wiemy, jak na niego wpływają całościowe sytuacje, tzn. kompleksy bodźców. Bodziec, inaczej podnieta, jest to wszelka zmiana w otoczeniu organizmu lub w samym organizmie, która może wywołać lub zmienić stan czynny, tj. stan pobudzenia, w którymkolwiek z posiadanych przez organizm receptorów (wzrok, słuch, etc.), a więc fale świetlne są dla normalnie widzącego bodźcem, ale nie sa nim dla niewidomego. W tej sytuacji jedynym rozsądnym rozwiązaniem jest budowanie obrazu człowieka w całościowych sytuacjach, wykorzystując fragmentaryczne, empiryczne informacje oraz w charakterze spoiwa różne psychologiczne i socjologiczne teorie. Tego rodzaju zabieg zastosowany zostanie m.in. w trzeciej części pracy. 


\section{Podstawowe kierunki badań w psychologii środowiskowej}

Centralnym obszarem badawczym w psychologii środowiskowej jest analiza funkcjonalna (tzn. z punktu widzenia funkcji zachowania się) różnych przestrzeni i form architektonicznych. Dzięki badaniom przeprowadzonym w ramach tej orientacji teoretycznej zdewaluowało się wiele funkcjonujących mitów na temat zależności między architektura a aktywnością człowieka. Na przykład badania empiryczne środowiska szpitalnego wykazały, że sale chorych zaspokajają o wiele szerszy wachlarz potrzeb człowieka, niż tylko te, które związane są ze snem, odpoczynkiem czy spożywaniem posiłków. Sale chorych powinny więc być projektowane w taki sposób, aby umożliwiały zaspokajanie również potrzeb zabawowych i rekreacyjnych w sensie gry społecznej.

Badania środowiskowe, określające zależności miedzy ludzkimi potrzebami a różnymi rodzajami przestrzeni architektonicznej, przeprowadzano w różnych układach środowiska architektonicznego, przy czym głównie koncentrowały się one na zachowaniach związanych z miejscami instytucjonalnymi oraz ze środowiskiem urbanistycznym. Szczególnie dużo badań poświęcono problematyce mikrointerpersonalnych zachowań oraz stłoczeniu w odniesieniu do takich środowisk instytucjonalnych, jak szpitale (w tym szczególnie psychiatryczne) i uniwersytety. Szczególnie liczne badania tego rodzaju przestrzeni architektonicznych spowodowało względne odosobnienie użytkowników, tych przestrzeni, umożliwiające stosunkowo łatwe przeprowadzenie badań na wymaganym poziomie metodologicznej poprawności. Natomiast stosunkowo trudno jest analizować zachowania ludzi np. w ich prywatnych łazienkach przy zastosowaniu metody eksperymentalnej.
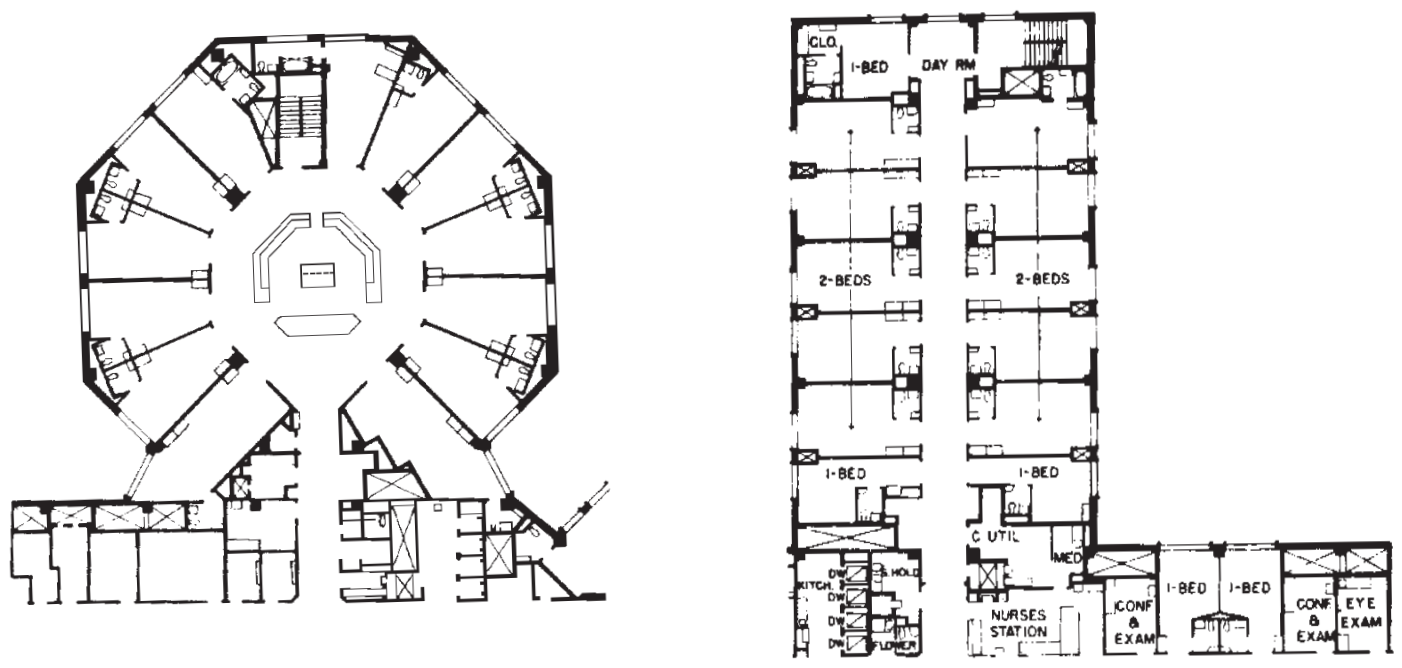

Ulubionym tematem pierwszych badań z psychologii środowiskowej były analizy porównawcze zachowań przestrzennych w zależności od architektury szpitala.

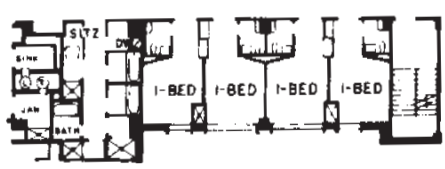

Badania przeprowadzone w szpitalach Nowego Jorku dały interesujące wyniki w zakresie różnic we wzorach reagowania pacjentów w zależności od wielkości pomieszczeń i liczby znajdujących się w nich łóżek. W miarę jak rozpowszechniała się moda na wznoszenie wysokich domów studenckich, przeprowadzono liczne badania nad ich wpływem na zachowania mieszkańców. Wykazały one wpływ wysokich budynków na takie aspekty zachowań, jak kooperacja, postawa odpowiedzialności społecznej czy też trwałość więzi przyjacielskich. Szereg autorów charakteryzując istotę mody, przeciwstawiają zwyczajom i obyczajom. Zarówno zwyczaj, jak moda polegają na pewnych przepisach i wskazaniach. Podczas gdy jednak zwyczaje sa czymś przez dłuższy okres czasu niezmiennym, przepisy mody mają charakter raczej przejściowej „wariacji” w ramach zwyczajów. Dla mody istotna jest jej okresowość, która zaznacza się specjalnie w pewnych jej ukształtowaniach, takich jak mody odzieżowe, które dają znać o sobie stale w pewnych okresach roku, tzw. sezonach, i mijaja, gdy minie sezon. W pewnych zakresach swego ujawniania się moda ulega zmianie na zasadzie kontrastu. Dalsza charakterystyczna właściwość przepisów mody polega na tym, że nie sięgaja one głębszych warstw osobowości człowieka, są zjawiskiem powierzchownym. Powyższe zasady mody w całości rozciagają się na zagadnienia związane $\mathrm{z}$ architekturą. Tak np. tradycją architektoniczną uniwersyteckich 


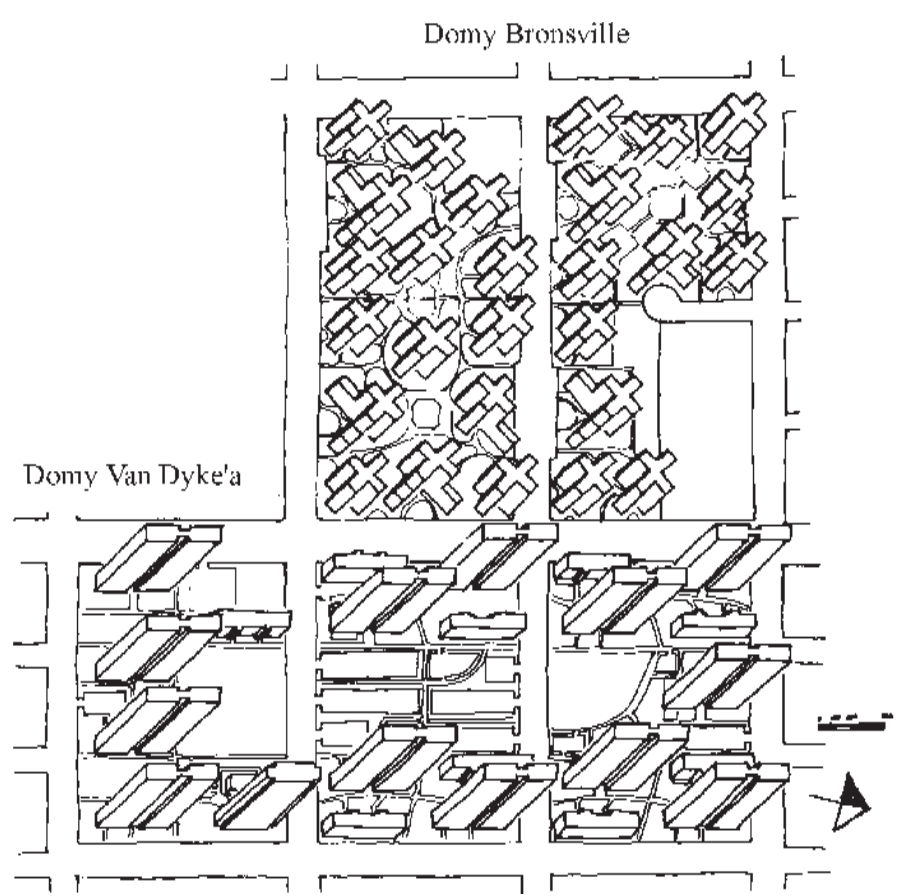

Porównanie dwóch osiedli: 14 piętrowego osiedla VanDyk z przestrzenią pustą między budynkami z niższą zabudową Brownville i zagospodarowanymi ciagami pieszymi pokazuje wyraźnie istotne różnice statystyczne wskaźników przestępczości

campów w USA była niska zabudowa nie przekraczająca dwóch lub trzech kondygnacji. Zasadę tę złamano w latach sześćdziesiątych i można domniemywać, że jedyną przyczyna tego była moda. Najbardziej obszerne w tym zakresie badania przeprowadzili Van der Ryn i Silverstein w University of California w Berkeley. Między innymi zaobserwowali oni interesująca prawidłowość polegająca na tym, że poczucie apatii i zobojętnienia jest mniej więcej wprost proporcjonalne do liczby kondygnacji domu studenckiego.

Inny nurt badawczy koncentruje się na ocenie zurbanizowanych obszarów w granicach ich przestrzennej czytelności odzwierciedlającej coś w rodzaju map poznawczych mieszkańców miast. Pojęcie „mapy poznawczej” (cognitive maps) wprowadził do nauki amerykański psycholog E.T. Tolman. Oznacza ono percepcyjna reprezentację przestrzeni która człowiek wyrabia sobie w oparciu o wskaźniki środowiska i własne oczekiwania będące podstawą uczenia się - dróg osiagania celów w przestrzeni. W przekonaniu Tolmana (Tolman, 1948) uczenie się w znacznej części jest uczeniem się znaków. Człowiek poruszajacy się w jakiejś przestrzeni (np. w mieście) uczy się czegoś w rodzaju mapy tej przestrzeni, opierając się na zrozumieniu. stosunków przestrzennych. Tak więc mapa poznawcza jest to percepcyjna reprezentacja przestrzeni oparta na uczeniu się znaków środowiska i oczekiwań. Uczenie się znaków środowiska można zdefiniować jako nabywanie oczekiwania, że po danym bodźcu nastapi inny, jeśli trzymać się znanego trybu postępowania. Należy zwrócić uwagę, że nabywane jest tu oczekiwanie (tj. poznanie, wiedza, przewidywanie), a nie reakcja ruchowa. Dzięki temu procesowi jadąc np. samochodem do określonego punktu w mieście i stojąc w obliczu sytuacji, w której jazda obraną drogą jest niemożliwa, możemy obrać inną trasę, opierając się na zrozumieniu stosunków przestrzennych. Tak więc, mapy poznawcze umożliwiają człowiekowi swobodne poruszanie się w przestrzeni miejskiej. Tym też należy tłumaczyć trudności poruszania się, zwłaszcza samochodem, w nieznanych miastach. Pionierskie prace w tym zakresie wykonał K. Lynch, który jako pierwszy sporządził mapy poznawcze dla takich metropolii, jak Boston, Jersey City, Los Angeles Podobnych badań nie przeprowadzono w żadnym z miast polskich, aczkolwiek wydaje się, że

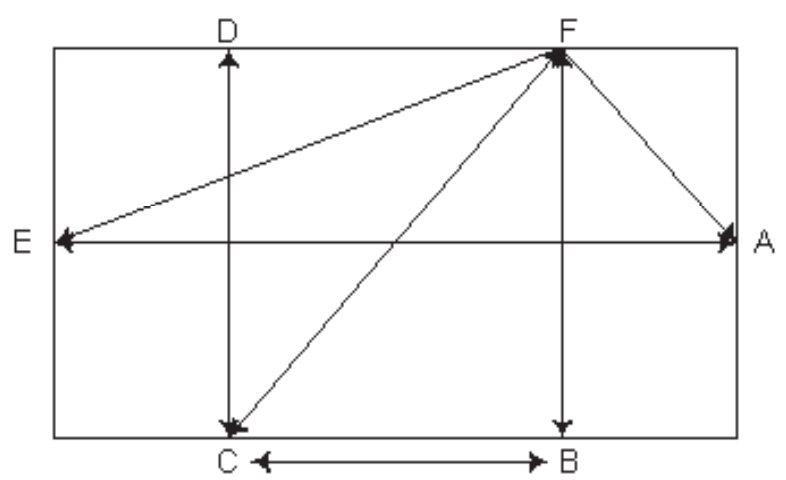

Warunki komfortu konwersacji przy stole dla sześciu osób: F-A - przez róg stołu, C-B - bokiem do siebie, C-D - w poprzek stołu, E-A - od jednego końca do drugiego, E-F - ukośnie wzdłuż stołu, C-F - ukośnie w poprzek stołu. ich wyniki mogłyby mieć duże znaczenie poznawcze i praktyczne, zwłaszcza w odniesieniu do nowych rozwiązań architektoniczno-urbanistycznych.

Oto co na ten temat pisze w swoim eseju M. Czerwiński: „Może nie wszystkim było dane uprzytomnić sobie z cała siła, jak dalece posunięte jest upodobnienie elementów składających się na całe obszary miejskie, na całe nawet miasta". Chcąc objaśnić drogę komuś, kto nie był w jednym z nowych osiedli, grzęźniemy często w jakiejś bezwyrazowej magmie opisowej. „Zobaczysz witryny w dużym bloku między takimi samymi dużymi blokami głównej arterii dzielnicy, gdzieś wpół drogi, między jakimiś dwiema identycznymi przecznicami”. Na próżno chcemy przypomnieć sobie jakikolwiek detal: jakaś barwę, jakiś występ, załamek, jakieś drzewa czy kwietniki, jakieś ławki, kiosk różniący się czymś osobliwym" (Czerwiński, 1972; Lynch 1960. Po Lynchu nasta- 
piła cała seria badań, które pokryły mapami poznawczymi szereg miast w całym świecie, jak Amsterdam, Rotterdam, Haga (De Jong), Chicago (Saarinen), Mediolan i Rzym (Francescato i Mebone).

Kolejny nurt psychologii środowiskowej skupiony jest wokół zagadnień zachowań interpersonalnych oraz stłoczenia. Altman zaproponował termin mikrointerpersonalny do określenia analizy na poziomie małych grup społecznych poddanych oddziaływaniom fizycznego środowiska w interakcjach o charakterze twarzq w twarz (face-to-face). Wykrył on nie tylko wpływ środowiska fizycznego na procesy interakcji, lecz również sposoby, jakimi ludzie aktywnie wykorzystują środowisko do kształtowania społecznych interakcji. Osmond w rozważaniach nad społeczna jakością przestrzeni określił takie środowiska, jak szpitale, dworce kolejowe, hotele, więzienia, jako społecznie ucieczkowe (sociofugal), które przeszkadzają lub zniechęcaja do rozwijania interpersonalnych związków. Szczególnie wielu badaczy zajmowało się analizą sposobów wykorzystywania przez ludzi fizycznej przestrzeni dla celów konwersacji. Badania te znane sa pod nazwa ograniczenia komfortu konwersacji. Tak np. Somer wykrył, że nie każde miejsce przy stole jest równie dobre. Gdy przy stole zasiada sześć osób, najlepsza jest pozycja twarzą w twarz oraz z rogu do rogu (FA). Mehrabian i Diamond uściślili warunki, w jakich pozycje obok siebie nie sprzyjają konwersacji. Ma to istotne znaczenie w projektowaniu np. barów, gdzie stołki sa stałym elementem przestrzeni. Somer określił minimalny dystans między uczestnikami procesu konwersacji twarzą w twarz na 5,5 stopy (1,67 $\mathrm{m})$, podczas gdy Hall dystans ten ocenił na 7 stóp $(2,13 \mathrm{~m})$. Wyniki te trzeba traktować w odniesieniu do polskiej populacji z pewną ostrożnościa, gdyż mogą tu zachodzić istotne różnice międzykulturowe.

Szczególnie dużo badań w ostatnich latach poświęcono zjawisku stłoczenia Podczas gdy badania nad stłoczeniem przeprowadzane $\mathrm{w}$ eksperymentach ze zwierzętami rzadko wykazują wpływ stłoczenia na wzrost nienormalności zachowań, o tyle analogiczne eksperymenty z ludźmi daja jednoznaczny obraz. Między innymi Stokols wyraźnie stwierdził, że ograniczenie fizyczne przestrzeni wywołuje u ludzi poczucie ograniczenia. Definiuje on stłoczenie jako subiektywne odczucie ograniczenia wymaganej przestrzeni i zauważa, że zmienne społeczne i osobowościowe są tak samo ważne, jak przestrzenne. Altman upatruje klucza do rozwiązania problemu stłoczenia w wykorzystaniu mechanizmu zdolności jednostki do uzyskiwania przez nią pożądanego poziomu prywatności. Wicker zaproponował koncepcję overmanning do wyjaśniania stłoczenia. Overmanning dotyczy sytuacji przestrzennej, w której liczba osób w kontekście danej sytuacji społecznej przekracza liczbę możliwych do rozdzielenia ról społecznych .

\section{Problem poziomu analizy zjawisk w psychologii środowiskowej}

Psychologia środowiskowa, podobnie jak szereg innych dyscyplin naukowych zajmujących się problemami społecznymi, jest multidyscyplinarnym obszarem badań. W centrum jej zainteresowania leży badanie zachowań człowieka w relacji do fizycznego środowiska ze szczególnym uwzględnieniem tych jego aspektów, które są wyspecjalizowanym wytworem ludzkiej kultury (tj. aspektów projektowych). W związku z tym w psychologii środowiskowej występuja różne i nieograniczone metodologicznie podejścia. Społeczne problemy człowieka wyrażają całą złożoność jego egzystencji w złożonym i zmieniającym się środowisku. Nie posiadają one prostych rozwiązań, ponieważ ich środowiskowe determinanty nie sa proste. Wystarczy tu wymienić choćby problemy skażeń środowiska, braku indywidualnej prywatności czy stłoczenia w wielkich aglomeracjach miejskich. Problemy te zmieniają swój charakter w zależności od wywołujących je uwarunkowań, zawsze jednak wyrażaja warunki funkcjonowania człowieka na różnych szczeblach złożoności opcji społecznej. Dlatego też interdyscyplinarność jest niezbędnym wymogiem poradzenia sobie z tymi problemami.

W określaniu związku między środowiskiem fizycznym a zachowaniem człowieka szczególnego znaczenia nabiera w psychologii środowiskowej problem decyzji, na jakim poziomie zachowań oraz organizacji społecznej należy dokonywać konceptualizacji lub realizacji badań. Najprościej rzecz ujmując, chodzi o pytanie, czy zależność między człowiekiem a fizycznym środowiskiem winna być opisywana na poziomie jednostki, czy też na poziomie większych grup społecznych. Zależność tę można zdefiniować i zanalizować na poziomie jednostki, i wtedy doświadczenie wewnętrzne jednostki wyrażające się w formach percepcji, odczuć, emocji, motywacji jest istotnym czynnikiem zarówno determinującym znaczenie (nadawanie środowisku „znaczenia” jest równoznaczne z kierunkiem zachowania się człowieka w tym środowisku). Dla zrozumienia tej zasady, tzn. dla zrozumienia zachowania się człowieka w środowisku, należy odwołać się do dwóch następujących założeń. Po pierwsze, zachowanie się człowieka zależy nie tylko od tego, co aktualnie znajduje się na zewnątrz niego i nie tylko od sposobu, w jaki zorganizowana jest sytuacja zewnętrzna, a1e 
od tego, co człowiek widzi i w jaki sposób organizuje czyli spostrzega sytuację zewnętrzną Po drugie, to, czy zachowanie się człowieka będzie adekwatne do sytuacji, czy też nie, tzn. czy osiagnie sukces, czy porażkę, zależy od tego, jak skutecznie odzwierciedla on zewnętrzną sytuację. Powyższe założenia mogą wydawać się na pierwszy rzut oka nieco paradoksalne, lecz mają one, głębokie uzasadnienie. Otóż sytuacje zewnętrzne można podzielić na takie, których stopień skomplikowania jest niewielki, co w konsekwencji powoduje jednakowy stopień ich odzwierciedlenia przez wszystkich, oraz na takie, które stanowią zestaw bodźców rzadko wywołujących u ludzi zuniformizowane reakcje. Te drugie występują częściej. Proces nadawania sensu (znaczenia) sytuacji zależy od procesów percepcji i poznania, a te z kolei zdeterminowane są fizjologiczną strukturą danej jednostki, jej potrzebami i dotychczasowym doświadczeniem. Wszystkie te procesy działają jednocześnie i to już na prostym poziomie percepcji. Na przykład mało jest prawdopodobne, aby ktoś powiedział, że widzi sześć kropek:

w układzie trzy po lewej stronie oraz trzy po prawej. Jak z tego prostego przykładu wynika, ludzie maja tendencję do spostrzegania parami elementy swojego środowiska.

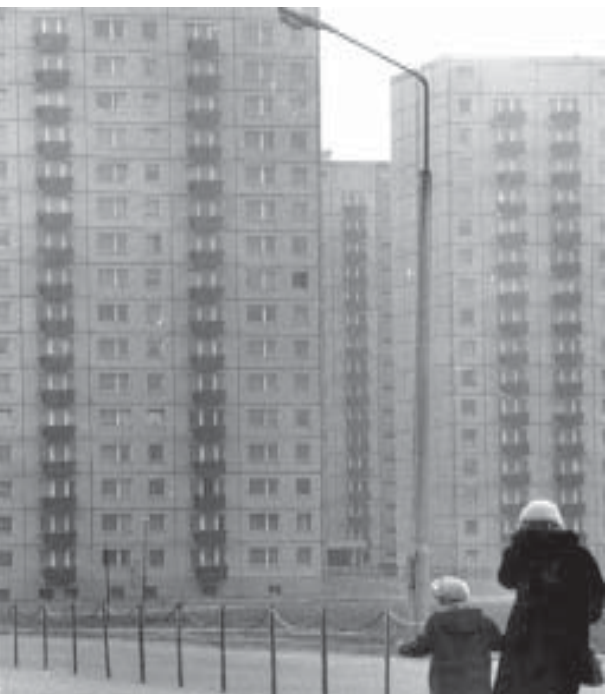

Dystans przemierzany przez dorosłych i przez dzieci obiektywnie i w percepcji wzrokowej jest taki sam, ale z punktu widzenia przestrzeni kinestetycznej zasadniczo się różni.
Ale to, jak się zachowają w tym środowisku zależy jeszcze od innych doznań, odczuć i wrażeń.

W tym miejscu należy wziąć pod uwagę jedną kwestię. Mianowicie mogłoby się wydawać, że głównym zadaniem psychologii środowiskowej jest analiza zależności między człowiekiem a fizycznym środowiskiem na poziomie zachowań jednostki - sugeruje to zreszta sama nazwa „psychologia środowiskowa”. Psychologia bowiem jako taka jest nauką zajmującą się analizą mechanizmów regulacyjnych zachowania się człowieka w jego środowisku. Chociaż mechanizmy zachowania na poziomie jednostki sa najważniejszym elementem w psychologii środowiskowej, to jednak wyznaczają one tylko część zakresu jej teoretycznej orientacji. Drugim ważnym poziomem analizy w psychologii środowiskowej jest analiza z punktu widzenia kontekstu społecznego indywidualnych mechanizmów regulujących zachowanie się jednostki w środowisku.

Fakt, że jednostka nigdy nie rozwija swojego zachowania w społecznej izolacji, lecz jest stymulowana kontaktami małych i dużych grup społecznych, narzuca konieczność analizy wpływu fizycznego środowiska również w tym aspekcie. Chodzi w tym przypadku to odpowiedź na pytanie, jak fizyczne środowisko wpływa na wzory zachowań, wartości i standardy, które charakteryzuja zorganizowaną naturę grupowego życia ludzi.

\section{Praktyczne cele psychologii środowiskowej i architektury}

Generalnie rzecz biorac, psychologia środowiskowa i architektura mają wspólny, praktyczny cel, który wyraża się w optymalizacji środowiska człowieka przez integrowanie wszystkich odnoszących się do niego czynników. Zasadnicza różnica między psychologią środowiskową a architekturą polega na tym, że pierwsza realizuje ten cel za pomocą badań (sprzężenie zwrotne), a druga przez projektowanie (sprzężenie postępowe - feedforward). Między tymi dwoma nurtami działania winny zachodzić idealne powiąania na bazie elementów, które są przedmiotem badania i projektowania. Równowaga między elementami wyszczególnionymi na rysunku powinna pozytywnie wpływać na kształt otoczenia ludzkiego. Cel ten można uzyskać przez sprzężenie trzech wymiarów tworzących model idealny.

Pierwszy wymiar wiąże się z architektonicznym kształtem przestrzeni. Powinna ona zapewniać człowiekowi odpowiednie warunki pod względem fizjologicznym, to znaczy stwarzać warunki dla zaspokojenia potrzeb fizjologicznych, takich, jak potrzeba snu, pożywienia, odpoczynku, pobudzenia, higieny, bezpieczeństwa. Natomiast przestrzeń architektoniczna w ujęciu psychologicznym powinna zaspokajać społeczne 
i egocentryczne potrzeby. „Potrzeba” jest podstawowym pojęciem w psychologii, gdyż całość zachowań ludzi kierowana jest dążeniem do zaspokojenia różnego rodzaju napięć, jakie powstają w organizmie człowieka w procesie regulacji stosunków z otoczeniem. Przez potrzebę w psychologii rozumie się brak czegoś, wprowadzający organizm w stan napięcia i stanowiący motyw (zwany też czasem popędem lub instynktem) działania w kierunku zmiany tego stanu, czyli do zaspokojenia potrzeby. Proces zaspokojenia potrzeb jest procesem właściwie nigdy nie kończącym się, ponieważ zbudowani jesteśmy w taki sposób, że gdy tylko zaspokoimy jedne potrzeby, natychmiast poddawani jesteśmy presji innych. Klasyfikacja potrzeb, czyli dyspozycji motywacyjnych jest wysoce arbitralna. Niektórzy, jak Freud usiłują wyjaśnić zachowanie w terminach jednej lub dwóch potrzeb (instynkt życia i śmierci). Inni jak Thomas rozszerzył je do czterech pragnień: bezpieczeństwa, uznania, przyjaźni, nowych doświadczeń. Z kolei Maslow (1954) wymienił następujące potrzeby: fizjologiczne, bezpieczeństwa, przynależności i miłości, szacunku oraz potrzebę samourzeczywistnienia. Inni wolą znacznie dłuższe listy, np. Murray, który opracował listę 12 potrzeb „wiscerogennych” (tj. fizjologicznych) i 28 potrzeb psychogennych.

Ukształtowanie przestrzeni architektonicznej powinno podkreślać prestiż i rangę społeczną otoczenia, akcentować uznanie dla rozwijanej aktywności (np. pracy, hobby), umożliwiać kontakty między ludźmi i w ten sposób zapewniać ich współdziałanie. Przestrzeń w tym ujęciu powinna wpływać na postawy. Z punktu widzenia psychologicznego zachowanie jednostki jest wytłumaczalne w kategoriach motywacyjnych (tj. potrzeb), emocjonalnych, percepcji, uczenia się, a więc w kategoriach podstawowych procesów psychologicznych. Jednakże nie jest wygodne i precyzyjne analizowanie i przewidywanie zachowań człowieka przez odwoływanie się do tych podstawowych procesów działających przecież jednocześnie, co więcej, zachowanie jest nie tylko funkcją teraźniejszych bodźców i ich chwilowych percepcji, ale także bardziej trwałych i bardziej ustrukturalizowanych dyspozycji. Tymi wyższymi i bardziej ustrukturalizowanymi dyspozycjami są trwałe organizacje percepcyjnych i motywacyjnych procesów zwane przekonaniami i postawami. W postawie wyróżnia się trzy istotne komponenty.

Drugi wymiar zależności psychologii i projektowania architektonicznego wiąże się z postawami, które sa wyrażane przez spostrzeganie, odczuwanie i działanie w przestrzeni. Pierwsza wymiar postawy tworzy tzw. komponenta poznawcza składająca się z przekonań o obiekcie postawy. „Przekonanie” jest trwała organizacja percepcji i poznań o pewnych aspektach świata jednostki. Na przykład, jednostka jest przekonana, że ziemia jest okragła, a jedne formy architektoniczne są doskonalsze niż inne. Drugim składnikiem postawy jest komponenta uczuciowa. Odnosi się ona do emocji, dzięki której obiekt postawy odczuwany jest jako przyjemny lub nieprzyjemny, sympatyczny albo niesympatyczny, pobudzający albo nudzacy. Ten ładunek emocjonalny nadaje postawie uporczywy, pobudzający, motywacyjny charakter. Emocjonalny element postawy uwidacznia się nie tylko $\mathrm{w}$ odczuwaniu przestrzeni, ale również w spostrzeganiu i w oddziaływaniu na przestrzeń. Trzecim składnikiem postawy jest komponenta tendencji do działania. Włacza ona wszystkie behawioralne gotowości związane $\mathrm{z}$ postawa. Jeśli jednostka ma pozytywną postawę wobec danego obiektu, wtedy jest skłonna pomagać, popierać lub chronić obiekt, natomiast jeśli ma postawę negatywna, skłonna jest go niszczyć, szkodzić mu. Obiektem postawy mogą być zarówno ludzie, jak i rzeczy. „Zespół dążeniowy" jako trzeci składnik postawy jest efektem działania potrzeb ludzi, a te z kolei wyznaczone są przez poszczególne zmysły, indywidualność jednostek (osobowość) i grup społecznych, a wreszcie całokształt kultury tworzą infrastrukturę ludzkich dążeń.

Architektura jest obiektem ujawniania się postaw, a jako składnik otoczenia ('środowiska) jest jednocześnie

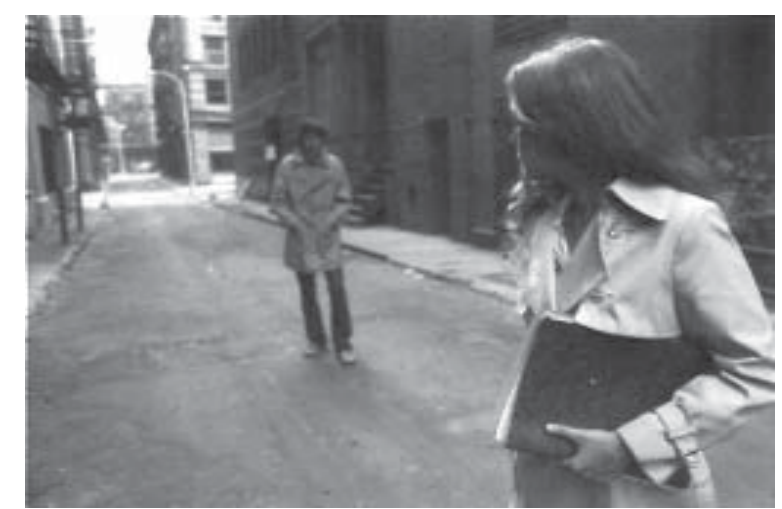

Architektura jako czynnik wyzwalający lęk i umożliwiający rozwijanie zachowań agresywnych Architektura może prowokować zachowania i pogłębiać lęk, mimo iż nie jest jego pierwszą przyczyną. 


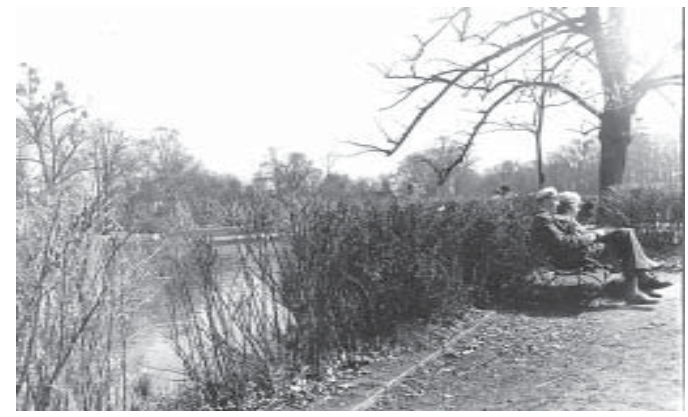

Przestrzenioterapia: Problem starości wiąże się z zapotrzebowaniem na umiarkowana stymulacje środowiska. Do 2010 roku proporcja ludzi powyżej 65 roku życia będzie stanowić ponad $22 \%$ populacji. Projektowanie środowiska nabiera coraz większego znaczenia zarówno z punktu widzenia potrzeb rezydencjalnych, rekreacji i kontaktu inetrpersonalnego.

czynnikiem moderujaccym powstawanie i funkcjonowanie postaw w jej wszystkich trzech wymiarach. Otoczenie architektoniczne winno kształtować postawy pozytywne emocje, pozytywne skojarzenia i pozytywne zachowania, aby mogło być źródłem relaksu, poczucia jakości życia, dumy i przywiązania do sytuacji. Poszczególne fizyczne cechy architektury, jak kształt, skala, faktura czy światło powinny być czynnikami ujawniania się wartościowych postaw, które powstaja przy innej okazji jak np. w procesie wychowania. Jednocześnie jednak architektura jako element sytuacji powinna być czynnikiem wyzwalajacym pozytywne postawy i współuczestniczacym w takich procesach, jak socjalizacja i wychowanie, leczenie, uzdrawianie i terapia.

Architektura kształtując pozytywne postawy dopiero wtedy wypełnia dostatecznie definicje „dobrej” architektury. „Dobra architektura” to architektura, która poprzez swoje elementy rozwija procesy poznawcze, moderuje procesy emocjonalne i wyzwala procesy zachowaniowe charakterystyczne chociażby dla syndromu lojalności: wobec siebie, bliźnich i miejsca zamieszkania, pracy, wypoczynku, nauki czy modlitwy (zachowania agoralne). Architektura powinna wzmacniać pozytywne postawy i pozytywne procesy zachodzace w umyśle człowieka. Powinna nie pozwalać na rozprzestrzeniać się emocjom destrukcyjnym, a więc lękowi z jednej strony i agresji - z drugiej. Otoczenie architektoniczne winno stwarzać poczucie wolności przez akcentowanie swobody intelektualnej i swobody wyboru ekspresji zachowań. Wreszcie ostatnim czynnikiem jest sprawa rozumienia. W swojej przestrzeni życiowej człowiek winien rozumieć jej logikę, cel swojego działania i istnienia. 


\section{ANTROPOLOGIA I AKSJOLOGIA PRZESTRZENI}

W części pierwszej zwrócono uwagę na fakt, że fizyczna przestrzeń architektoniczna jest aksjologicznie nieobojętna z dwóch powodów. Po pierwsze, jest specyficznym wytworem ludzkiej kultury oraz, po drugie, stanowi przestrzeń życiową człowieka, innymi słowy, jest przestrzenią antropologiczna. Oznacza to, że w każdym momencie kreowania przestrzeni architektonicznej niejako automatycznie „wdrukowuja się” w nią wartości wyznaczające stanowisko (pozycję) człowieka w przestrzeni oraz sposoby jej wykorzystania. Chodzi jedynie o to, by proces wyprowadzania (projektowania) fizycznej przestrzeni był procesem świadomym (maksymalne ograniczanie wspomnianego automatyzmu), tzn. aby manipulowanie fizycznymi składnikami przestrzeni uwzględniało wartości człowieka z punktu widzenia jego potrzeb indywidualnych, społecznych i kulturowych.

Zachowanie się człowieka w przestrzeni może być zrozumiałe jedynie wtedy, gdy uwzględni się je w aspekcie wielopoziomowej analizy uwarunkowań. E.T. Hall wyróżnia w związku z tym nową dziedzinę psychologii, która nazywa proksemiką (proximity bliskość, sąsiedztwo), dziedzinę związana z obserwacją i teorią użycia ludzkiej przestrzeni „wyspecjalizowanego wytworu ludzkiej kultury". Proksemika określa u człowieka odbiór wrażenia wielkości przestrzeni. Odbiór ten posiada zarówno pewne cechy zobiektywizowane, jak subiektywne.

W rozdziale tym przedstawiona zostanie problematyka przestrzeni z punktu widzenia jej

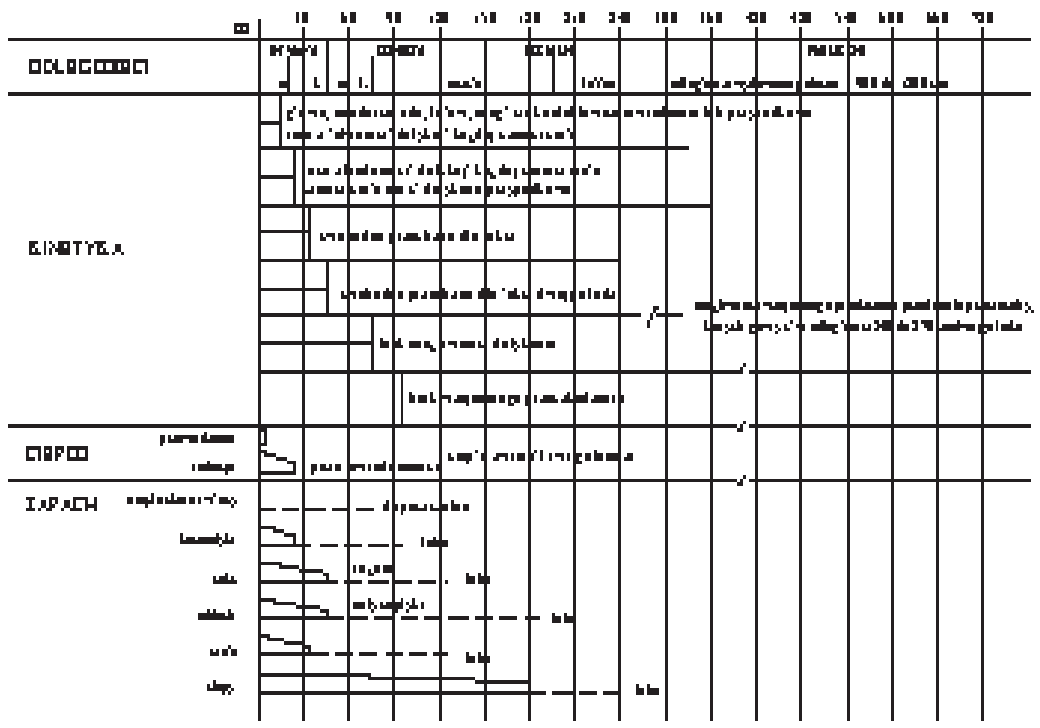

Proksemika E.T. Halla - odbiór przestrzeni przez człowieka, wersja skrócona antropologicznych determinant systemu wartości i znaczeń. Całą różnorodność uwarunkowań fizycznej przestrzeni E.T. Hall sprowadził do trzech głównych kategorii. Pierwszą tworzą determinanty infrakulturowe, druga - prekulturowe i trzecią - determinanty mikrokulturowe. Dwie pierwsze związane są z biologicznymi podstawami i mechanizmami zachowania się ludzi, a determinanty mikrokulturowe związane są przede wszystkim z prawidłowościami kulturowymi.

\section{Biologiczny wymiar zachowań przestrzennych}

Determinanty infrakulturowe percepcji przestrzeni odnoszą się do zachowań tworzących kulturę, a jednocześnie noszących na sobie piętno biologicznej przeszłości człowieka. Innymi słowy jest to instynktowa baza zachowań człowiek. Każdy człowiek ma zakodowane pewne formy reagowania na bodźce płynące z otoczenia, które są niezależne od oddziaływań otoczenia i nie podlegają procesowi uczenia się. Dziecko przychodzi na świat z instynktem ssania i jego wykształcenie się w okresie życia płodowego jest warunkiem przeżycia po urodzeniu. Podobnie jest z percepcją przestrzeni. Zarówno dziecko jak i zwierzę ma wrodzony lęk wysokości i jest to ten regulator działania, który jest biologicznie zaprogramowany. Odczuwanie bólu i faktury jest wdrukowaniem biologicznym percepcji przestrzeni, który jest w pewnych okolicznościach jest czynnikiem ważniejszym niż głód.

Determinanty prekulturowe z kolei odnoszą się do fizjologicznych mechanizmów zachowania się, kontrolujących zachowanie się jednostki ludzkiej w danym momencie życia, a dla której kultura dostarcza 


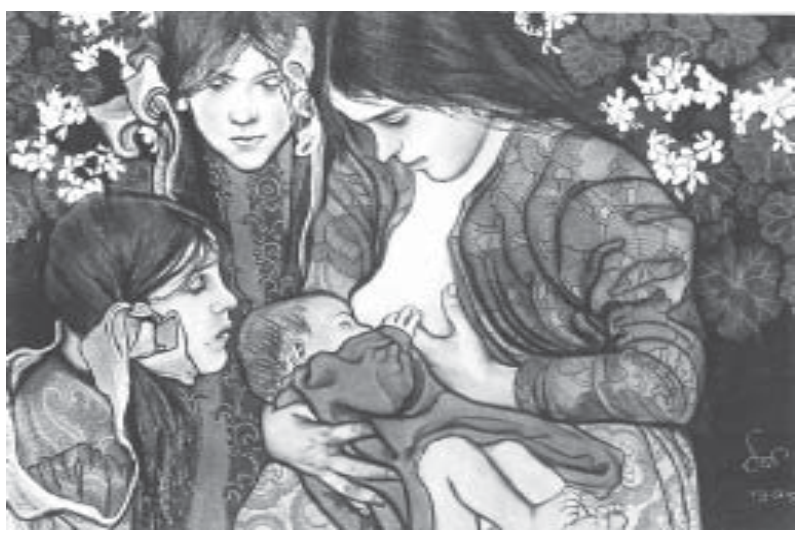

Obraz Wyspiańskiego: Odruch ssania jest reakcja, której dziecko nie musi się uczyć. Pewna liczba tego rodzaju wdrukowanych mechanizmów zachowania się jest warunkiem przetrwania człowieka jako gatunku.

struktury i znaczenia, oraz do których m.in. odwołuje się nauka chcąc dokonać porównania między kulturą A i kulturą B. Człowiek więc doznając wrażeń dotykowych czy węchowych reaguje na stymulację docierająca z otoczenia bezpośrednio, tj. na fizyczną naturę bodźca, oraz pośrednio tj. na jego znaczenie ukryte w określonej kulturze. Dotyk w kulturach arabskich i śródziemnomorskich ma inne znaczenie choć tę samą fizyczną stymulację. W Polsce rozpowszechniony zwyczaj całowania w rękę uchodzi za stymulację nieprzyjemną w kulturze północnoamerykańskiej. W kulturach południowych zapach jest elementem kultury $\mathrm{i}$ to aprobowanym, natomiast w kulturach północnych nie. Tylko wąski zakres wrażeń węchowych jest akceptowany.

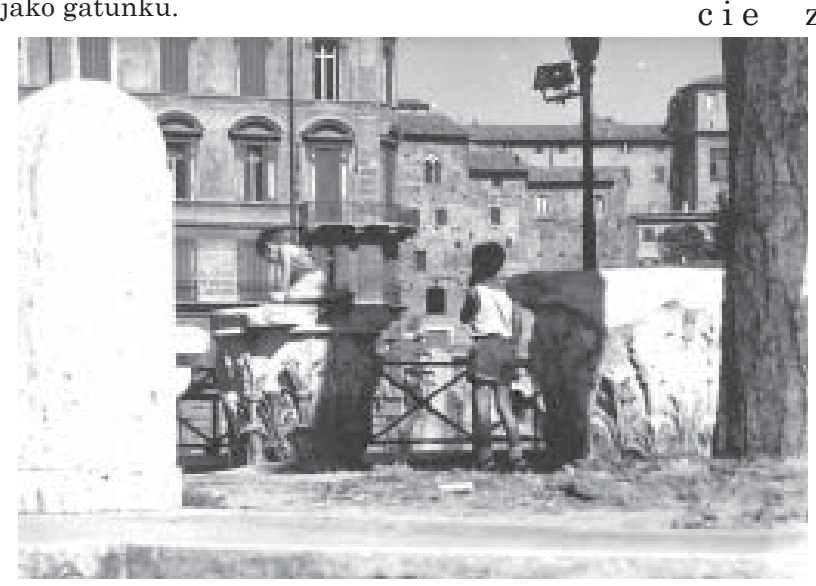
W świe-
c i e $\mathrm{z} \mathrm{e}$ -

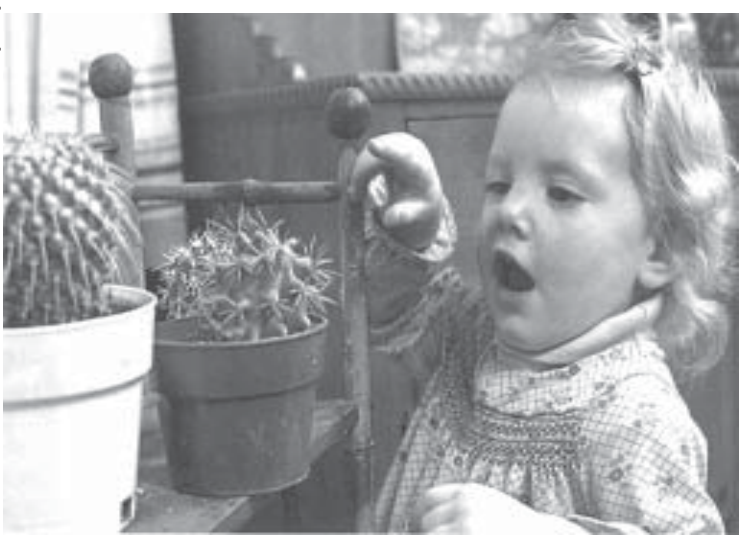

Rekcje odruchowe bólu i przyjemnego dotyku są reakcjami na podłożu fizjologicznym, które równocześnie posiadaja charakter wyuczalny.

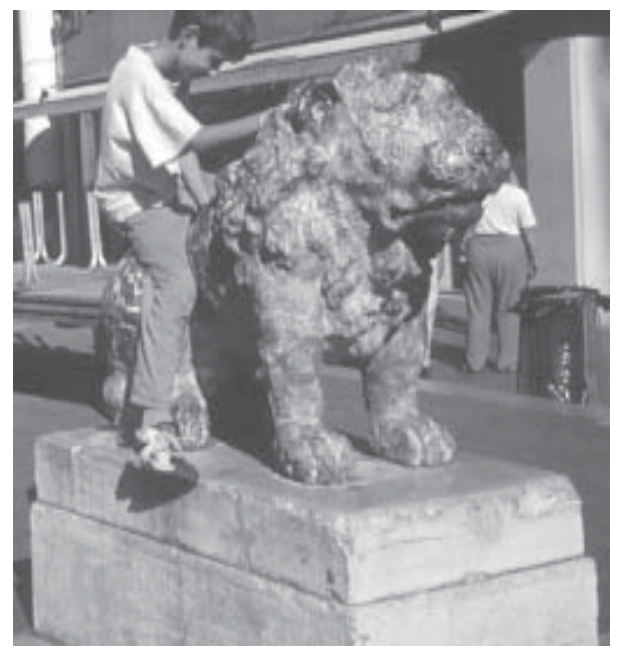

Ludzie a szczególnie dzieci uwielbiaja kontakt z formami rzeźbiarskimi, które sa elementem przestrzeni odbieranym wszystkimi zmysłami. A więc można się na nie wspinać, przytulać się do nich, głaskać i w konsekwencji czuć ich temperaturę, fakturę. Kontakt z tego typu formami pozwala jednostce koordynować trzy sfery percepcyjne: infrakulturowa, prekulturową i mikrokulturowa.

wnętrznym, niezależnie od naszych wrażeń, istnieje jedynie materia fizyczna w różnych formach i przejawach. Pod wpływem jej działania na wyspecjalizowane organy zmysłowej człowiek doznaje określonych wrażeń. Te fizyczne i chemiczne czynniki, które oddziaływują na receptor i wywołują wrażenie, nazywamy bodźcami. Wielu z wrażeń, jakie zachodzą w środowisku tylko niektóre potrafi człowiek odebrać, tj. zareagować

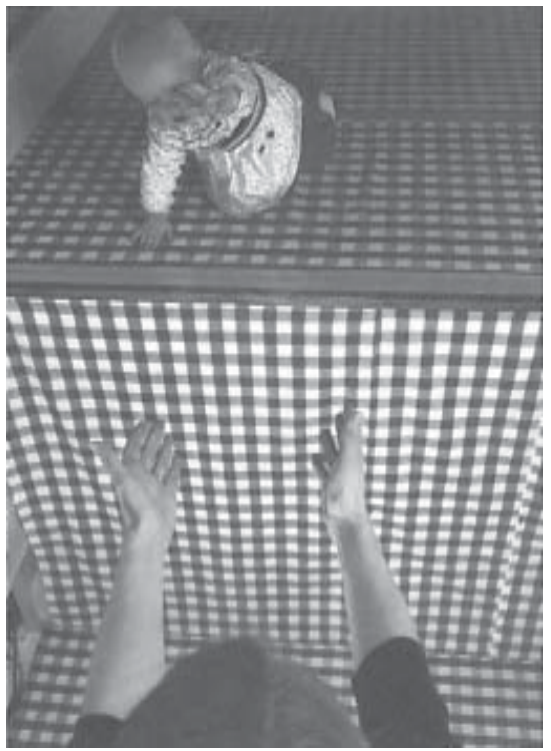

Postrzeganie urwiska u dzieci jest reakcją wrodzona, której nie musi się uczyć. Mimo nalegań matki dziecko reaguje według programu zakodowanego w mózgu i jest on silniejszy od emocjonalnego związku, na którym opiera się zaufanie do matki. na nie w sposób specyficzny. Te właśnie zdarzenia nazywamy bodźcami. Bodziec jest zawsze związany z energią fizyczną i najczęściej przy działaniu bodźca następuje dopływ energii do receptora. Zarówno w odniesieniu do analizatorów jak i organizmu, bodźcem może być 
nie tylko dopływ energii, lecz także przerwanie jej dopływu. Bodźcem są więc również zmiany zachodzące $\mathrm{w}$ działającym już bodźcu. Bodźce różnią się modalnościa, jakością i intensywnościa. Modalność to cecha, która różnią się od siebie bodźce działające na różne receptory: optyczne, akustyczne, dotykowe, węchowe, priprioreceptywne. Jakość bodźca to cecha, którą różnią się od siebie bodźce działające na ten sam receptor. Różne bodźce wizualne wywołują wrażenia różnych barw. Intensywność czyli siła bodźca to cecha, która różnią się od siebie bodźce tej samej jakości, ale o różnej mocy fizycznej. Np. intensywność cechuje bodźce dotykowe o tym samym kształcie i powierzchni, ale o odmiennej sile nacisku.

Dla każdego ze zmysłów człowiek dysponuje wyspecjalizowanymi komórkami wrażliwych na określony rodzaj energii fizycznej, czyli na określony rodzaj bodźców. Te wyspecjalizowane organy nazywamy receptorami. Ich zadaniem jest odbieranie bodźców, przekształcanie ich w impulsy nerwowe i wysyłanie do wyższych partii układu nerwowego. Na podstawie kryterium lokalizacji wyróżnia się: introreceptory, eksteroreceptory, telereceptory, kontaktoreceptory, prioprioreceptory, wisceroreceptory. Pierwsze znajdują się wewnattrz organizmu i pełnią funkcję sygnalizacji i regulacji działania narządów i układów. Informacje te włączają się do świadomości dopiero wtedy, gdy posiadają wartość informacyjna, tzn. w przypadkach zakłóceń lub uszkodzenia organizmu. Drugie znajduja się na powierzchni ciała i odbierają bodźce $\mathrm{z}$ otoczenia organizmu. Telereceptory odbierają bodźce oddalone od

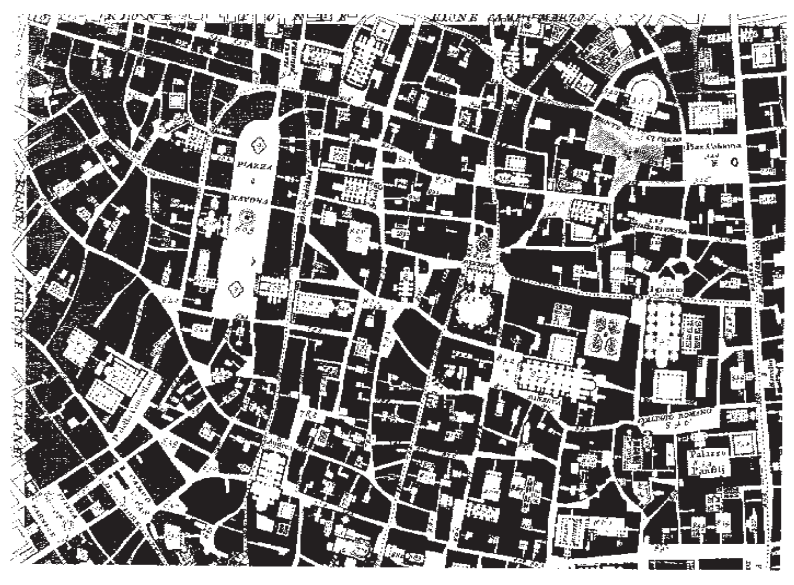

Mapa Rzymu wg Nolliego. Rozwój cywilizacji, a szczególnie wynalazek samochodu zdawał się przeczyć potrzebie percepcji przestrzeni via prioprioreceptory. Tak nie jest o czym świadczy rozwój na całym świecie systemów komunikacji pieszej. Miasta rozwijają się dwutorowo: poprzez rozwijanie komunikacji samochodowej, gdzie ruch w przestrzeni oparty jest na telereceptorach i komunikacji pieszej, w której ruch sterowany jest poprzez stymulacje prioprioreceptywną.

Człowiek zawsze odczuwał i odczuwać będzie przestrzeń nie tylko za pomocą telereceptorów. Jednym z najbardziej zasadniczych zmysłów, który bierze udział w percepcji przestrzeni jest zmysł ruchu związany z funkcjonowaniem prioprioreceptorów. Od najdawniejszych czasów ludzie odmierzali przestrzeń krokami. Od najdawniejszych czasów skali przestrzeni była dostosowana do stymulacji prioprioreceptywnej piechura. „Rozpychanie” przestrzeni w ramach przestrzeni zamkniętej i niezdolnej do ekspansji zewnętrznej odbywała się poprzez udostępnianianie przestrzeni prywatnej na rzecz przestrzeni publicznej - potrzebnej do chodzenia. Proces ten pokazuje mapa Rzymu Nolliego.

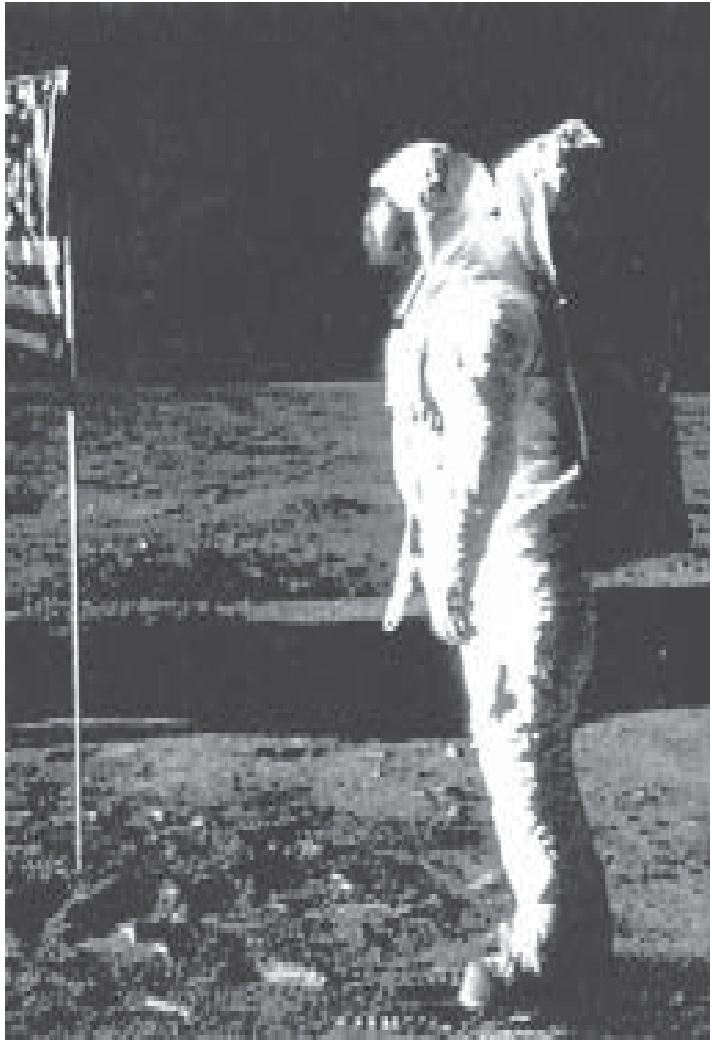

Funkcjonowanie człowieka na księżycu zmienia charakter stymulacji płynących z priorioreceptorów i wymaga od lunonauty innej, tj. świadomej kontroli ruchu. Poruszanie się w stanie nieważkości wymaga wypracowania planu ruchów i strategii ich kontroli.

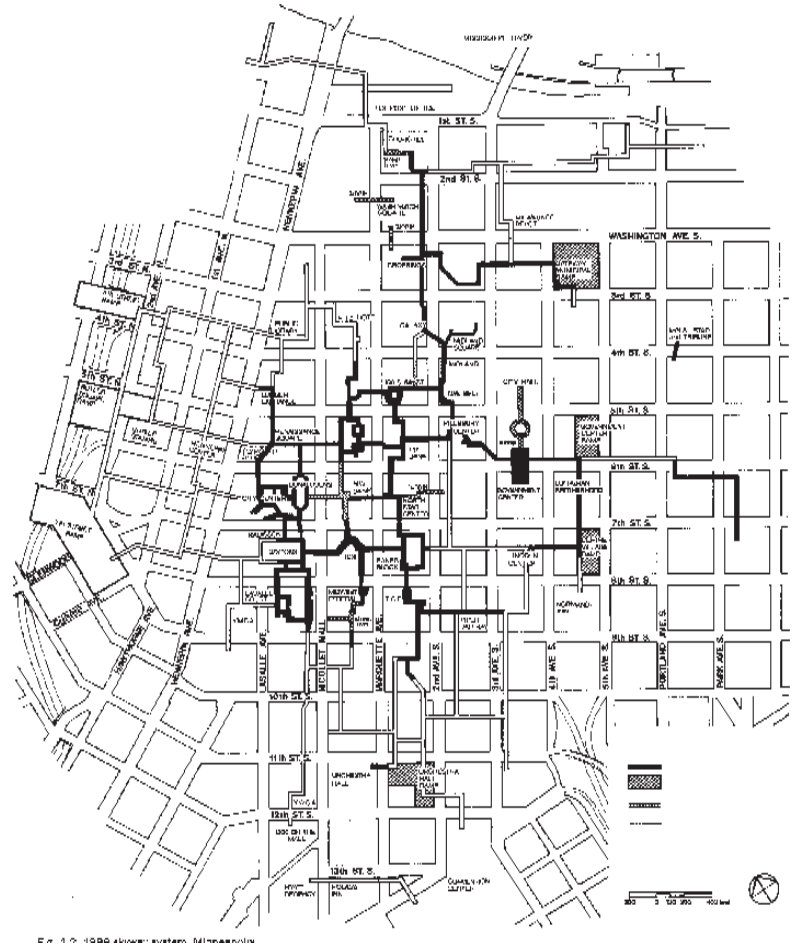


organizmu. Kontaktoreceptory odbieraja bodźce w zetknięciu z receptoryczną powierzchnią organizmu. Prioprioreceptory znajduja się w narządach ruchu i odbierają bodźce związane z ruchem i położeniem poszczególnych części ciała oraz organizmu jako całości. Wisceroreceptory znajdują się w narządach wewnętrznych i odbierają bodźce związane ze stanem tych narządów.

Wrażenia są to odzwierciedlenia poszczególnych cech zmysłowych przedmiotów działających na nasze narządy zmysłowe np. smaku, barwy. Do wrażeń należą też obrazy i zjawiska naoczne. Infrakulturowe postrzeganie przestrzeni i oparte na nich wzory zachowań powstają właśnie na bazie obrazów i zjawisk naocznych, które są wdrukowane w biologiczny program działania. Wrażenia stanowią najprostszy jednorodny proces psychiczny i poznawczy, powstały pod wpływem prostego bodźca działającego na receptory
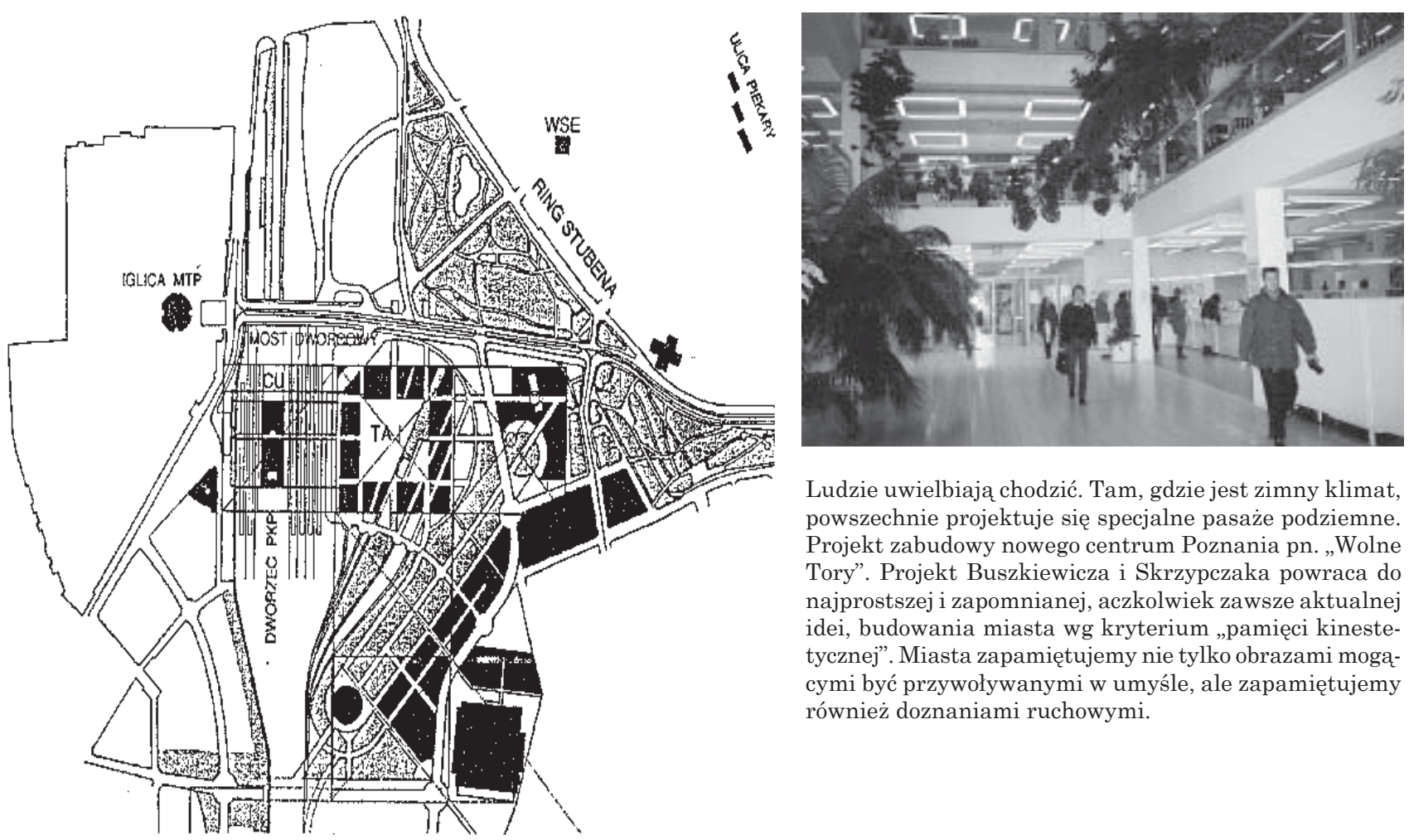

Ludzie uwielbiają chodzić. Tam, gdzie jest zimny klimat, powszechnie projektuje się specjalne pasaże podziemne. Projekt zabudowy nowego centrum Poznania pn. „Wolne Tory”. Projekt Buszkiewicza i Skrzypczaka powraca do najprostszej i zapomnianej, aczkolwiek zawsze aktualnej idei, budowania miasta wg kryterium „pamięci kinestetycznej”. Miasta zapamiętujemy nie tylko obrazami mogacymi być przywoływanymi w umyśle, ale zapamiętujemy również doznaniami ruchowymi.

poszczególnych jakości zmysłowych. Wrażenie jest niezróżnicowanym i bezprzedmiotowym odzwierciedleniem otoczenia. Poszczególne jakości zmysłowe różnią się pomiędzy sobą siłą czyli intensywnościa.

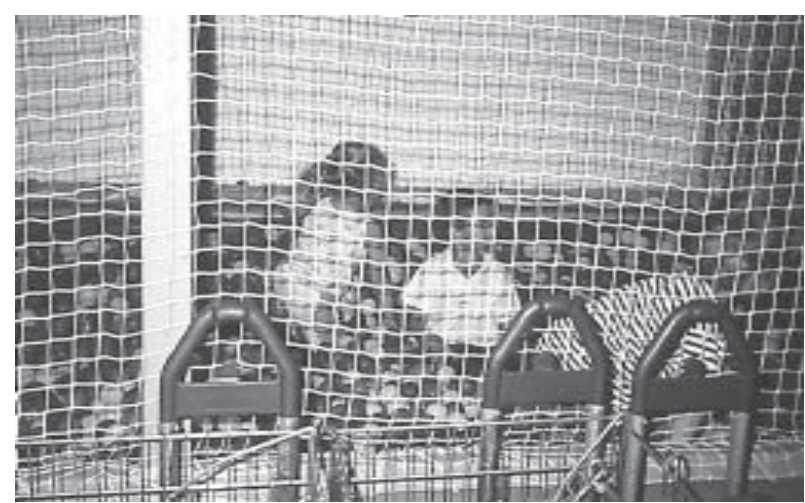

Dorosły i dziecko mają tyle samo satysfakcji ze stymulacji prioprioreceptywnej, tyle tylko, że swoje potrzeby zaspokajaja w innych sposób, a więc pod inną kontrola kodów kultury. We wszystkich niemal supermarketach ulubioną zabawą dzieci jest balansowanie ciała w kojcach z kulkami plastykowymi. Dorośli wybierają bardziej kulturowo „bezpieczne” formy stymulacji prioprioreceptywnej, jakich dostarcza karuzela czy śródmiejski spacer.
Intensywność wrażenia z jednej strony zależy od siły wywołujaccego go bodźca, a z drugiej od warunków działania i stanu receptora. Czułość i wrażliwość receptorów określają absolutne progi wrażeń, czyli najdrobniejsze bodźce, jakie dają się wyróżnić za pomoca zmysłów. Progi dzielą się na: a) próg dolny, czyli najmniejszą ilość energii bodźca zdolną do wywołania reakcji receptora $\mathrm{w}$ postaci impulsu nerwowego; b) próg górny czyli największą ilość energii bodźca, przy której receptor jeszcze reaguje specyficznie do ilości bodźca; c) próg różnicy czyli wrażliwość receptora określoną najmniejszą zmianą bodźca fizycznego, która można zarejestrować nieuzbrojonym receptorem (np. okularami czy wzmacniaczami dźwięku). Im niższy próg różnicy, tym wyższa wrażliwość receptora.

Wśród architektów przyjęło się uważać, że spostrzeganie przestrzeni i zachowania przestrzenne znajduje się w bezpośredniej relacji jedynie do zmysłów telepatycznych, głównie wzroku i słuchu. Tymczasem przestrzeń odbierana jest przez niemal każdy moduł 
sensoryczny i zachowania przestrzenne są determinowane przez każdy rodzaj wrażeń. Architekt i architektura nie moga ignorować danych dotyczacych sposobu funkcjonowania psychologicznej przestrzeni życia człowieka realizującej się na jakimkolwiek poziomie systemu percepcyjnego. Najogólniej systemy percepcyjne przestrzeni można podzielić na systemy oparte na telereceptorach i kontaktoreceptorach. Poszczególne systemy percepcyjne jak wzroku, słuchu i powonienia (telereceptory) uzupełniają się z systemami percepcyjnym dotyku, smaku czy ruchu (kontaktoreceptory).

Zmysł smaku tworzą kubki smakowe znajdujące się przede wszystkim w języku oraz z rzadka sa rozsiane w strukturach tylnej ścianki jamy ustnej. Człowiek rozróżnia cztery podstawowe rodzaje smaku: słony, słodki, kwaśny i gorzki. Biologiczne znaczenie smaku polega na ocenie przydatności pokarmu do spożycia a także na wywołaniu odruchowego pobudzania gruczo-
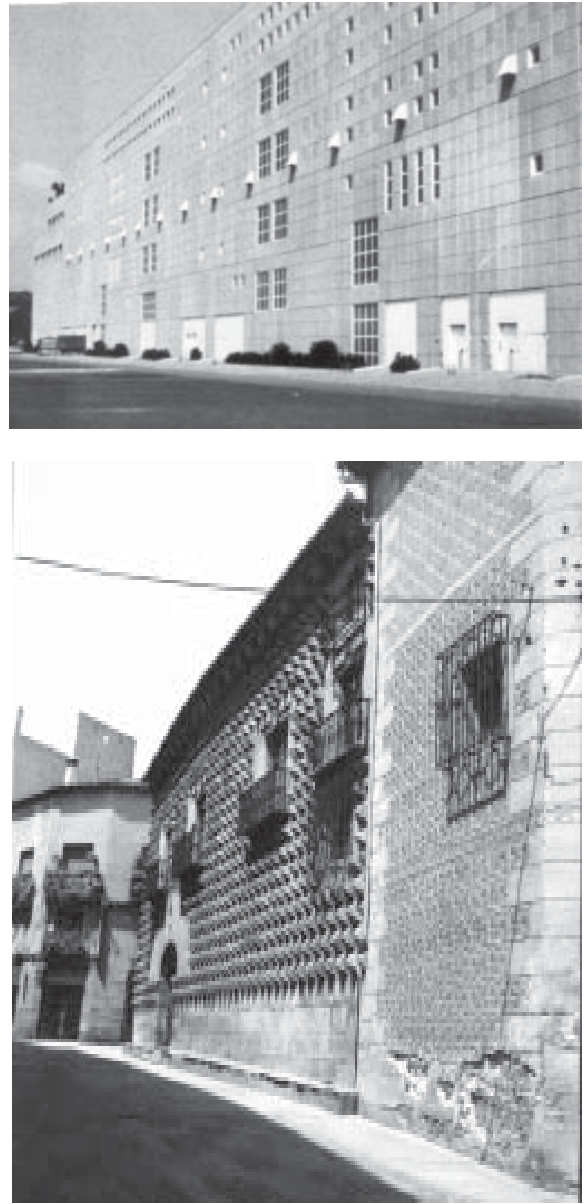

Różne sposoby operowania fakturą w architekturze.
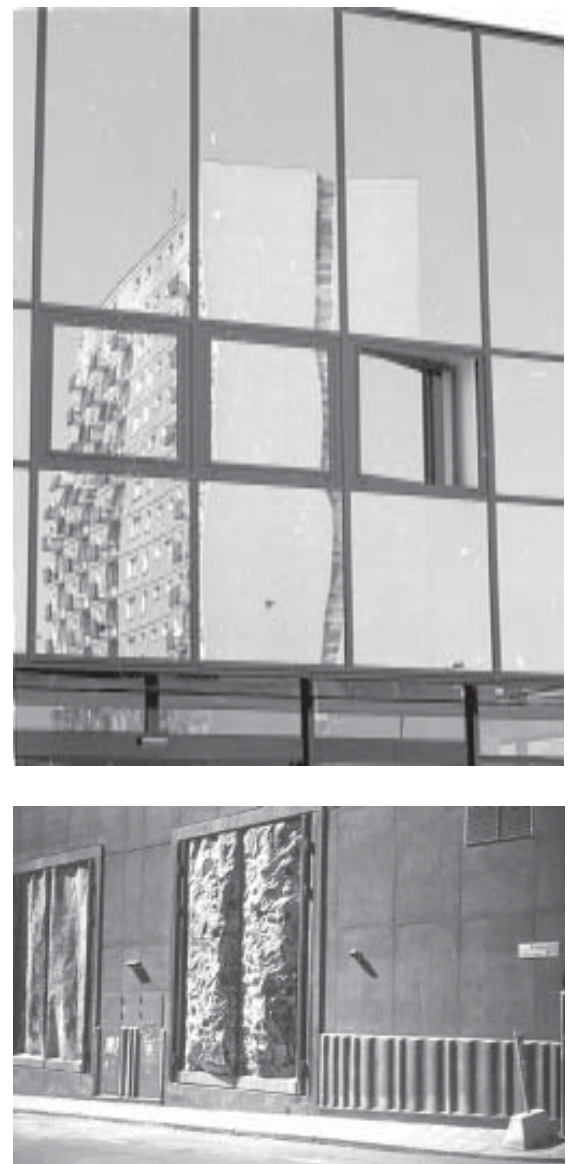

łów trawiennych do wydzielania soków trawiennych o odpowiednim składzie. Wrażenia smakowe nie pozostają w bezpośrednim związku z przestrzenią behawioralną tj. zachowaniami przestrzennymi. Architekt w niewielkim stopniu może wykorzystywać ten rodzaj wrażeń w projektowaniu przestrzennym. Mimo to musi mieć świadomość tego, że inne cechy przestrzenne jak oświetlenie czy barwa mogą moderować wrażenia smakowe. Synestezja wrażeń, czyli wzajemne nakładanie się, jest szczególnie istotna w miejscach, w których spożywane są posiłki, nabywane są produkty spożywcze.

Czuciowym narządem jest skóra. W skórze zlokalizowane sa obok receptorów dotyku (mechanoreceptorów) receptory temperatury (termoreceptory) i receptory bólowe (nocireceptory). Nie sa one skupione w wyodrębnionym narządzie zmysłu jak oko, lecz są rozsiane. Mechanoreceptory odbieraja czucie ucisku, dotyku i łaskotania. Receptory ucisku informują o sile mechanicznego pobudzenia skóry i głębokości wywieranego ucisku. Receptory styku działają za pośrednictwem włosów; umiejscowione w opuszce włosa dają wrażenie dotyku tylko przy ruchu nadanym tym włosom. Receptory wibracji informuja o przyspieszeniu przemieszczeń skóry w głąb przy pobudzaniu impulsami przerywanymi o amplitudzie 30-200 Hz. Bodźce mechaniczne zwykle pobudzaja kilka typów mechanoreceptorów jednocześnie. Przestrzeń odbierana bezpośrednio przez mechanoreceptory jest ważna

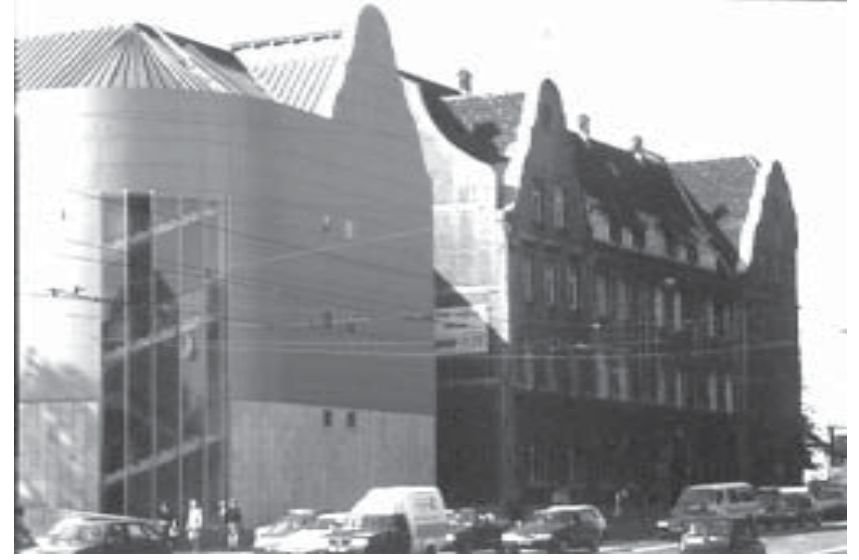

Stary i nowy gmach akademii muzycznej w Poznaniu rozróżnialny jest głównie poprzez wizualne odczucie faktury. Jednak ze względu na pamięć dotykową istnieje łatwość przełożenia doznań wzrokowych na wyobrażenia doznań dotykowych. W tym przypadku faktura wykorzystana została do skontrastowania formy historycznej i nowoczesnej. 

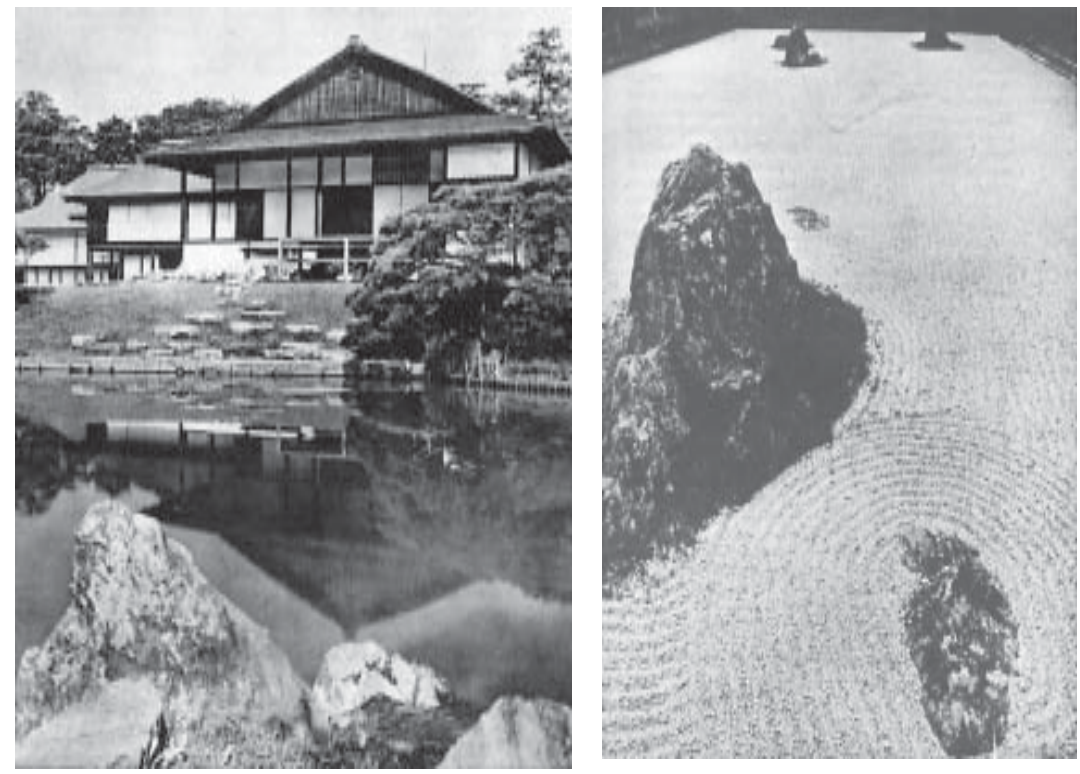

dla architekta. Wrażenie faktury materiału jest kojarzone $\mathrm{z}$ innymi wrażeniami dając $\mathrm{w}$ rezultacie zintegrowane odczucie przestrzeni architektonicznej. Ludzie zachowuja się inaczej w gładkich, przeszklonych przestrzeniach niż w chropowatych. Gdy na te wrażenia dotykowe nałożymy wrażenia świetlne, barwne, akustyczne i zapachowe, uzyskujemy niezliczoną liczbę możliwych kombinacji doznań przestrzennych i odpowiadajacym im wzorów zachowań przestrzennych. Przestrzeń dotykowa istotne znaczenie z punktu widzenia poczucia bezpieczeństwa Przestrzeń odbierana zmysłem dotyku uważa za przestrzeń o wiele bardziej przyjazna człowiekowi niż przestrzeń wizualna. Poczucie bezpieczeństwa wzmacnia w szczególności dotyk

Mistrzami w wykorzystywaniu różnych sposobów doświadczania przestrzeni przez człowieka byli i sąjapońscy projektanci ogrodów. Ogród japoński wykorzystuje przede wszystkim związek między kinestetycznymi doznaniami przestrzeni a doznaniami wizualnymi. Japończycy potrafili wykorzystać zasadę synestezji wrażeń do rozwiązywania problemów zwiazanych z brakiem przestrzeni. Ogród japoński dostarcza poza tym wrażeń, które są podstawą iluzji otwartości w przestrzeni zamkniętej.

aktywny. Architektura przestrzeni życia powinna umożliwiać człowiekowi eksplorację dotykowa, dzięki której chroni swoja psychikę przed niedoborem informacji o świecie w którym się znajduje. Faktura
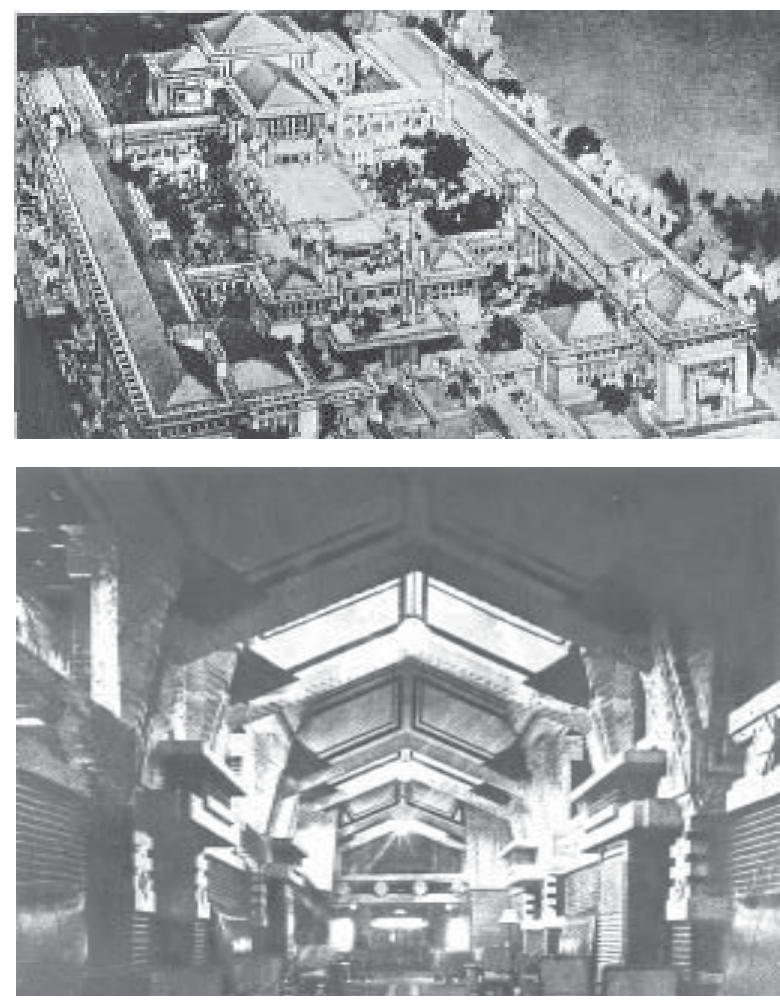

Jak zauważa E.T. Hall sukces F.L. Wrighta jako projektanta związany był z jego podejściem do architektury uwzględniajacym fakt różnych sposobów doświadczania przestrzeni przez ludzi. Imperial Hotel w Tokio był przykładem architektury zdolnej uzmysłowić przybyszowi z Zachodu to, że znajduje się w zupełnie innym świecie, w którym na równocześnie pobudzana jest sferę kinestetyczna, zapachowa i wizualna. Umiejętność operowania zmieniającymi się poziomami, zmiennymi fakturami, zmiennymi skalami, zmiennymi zapachami prowadzi przybysza w świat wyobrażeń, które świadomie wiążą jego doznania zmysłowe ze strukturą budynku. jest jednym z najważniejszych elementów architektury, ponieważ pamięć dotykowa opiera się na najbardziej osobiście doświadczanych wrażeniach zmysłowych.

Architekci w niewielkim stopniu rozumieją istotę zmysłu dotyku w całościowej percepcji przestrzeni architektonicznej. Świadome wykorzystywanie zmysłu dotyku w tworzeniu przestrzeni życiowej człowieka powinno wykorzystywać w większym stopniu zmienne faktury, ponieważ człowiek żyje pełnią jedynie wtedy, gdy ma możliwości aktywnego doświadczania swojego ciała i otaczającej go przestrzeni. Niestety rozwój cywilizacji jak np. samochodów sprawia, że coraz częściej człowiek jest w sytuacji pasywnego odbiorcy informacji pośrednich, przetworzonych, a nie bezpośrednich tj. płynących z podrażnienia zmysłów. Fakt przechodzenia z pierwszego układu sygnalizacyjnego tj. bezpośrednich doznań receptorowych, na drugi układ sygnalizacyjny czyli informacje przetworzone, zmediatyzowane, powoduje, iż człowiek coraz bardziej alienuje się ze swojego naturalnego środowiska.

Termocepcja przejawia się jako uczucie zimna lub ciepła. W skórze znajdują się punkty chłodu punkty cieplne. Sa one rozsiane równomiernie. Termocepcja jest w równym stopniu zmysłem kontaktowym jak i telereceptorycznym. Człowiek jest w stanie odbierać promieniowanie cieplne z odległości i lokalizować jego położenie. W przeciwieństwie do zmysłu słuchu czy powonienia nie jest jednakże w stanie za jego pośrednictwem określić precyzyjnie odległości. Przestrzeń termalna jest ważnym składnikiem przestrzeni architektonicznej, bowiem tolerancja organizmu ludzkiego na zmiany wewnętrznej temperatury ciała jest wyjątkowo ograniczona. Przestrzeń termiczna ma poza tym ważne znaczenie $\mathrm{z}$ punktu widzenia komunikacji 
międzyludzkiej. Człowiek odbiera ciepło i emituje. Ciepło i temperatura organizmu jest ważną informacją o stanie emocjonalnym. Detekcja temperatury ciała następuje w wyniku działania jednego z trzech mechanizmów: a) pobudzenia termoreceptorów na skórze, b) intensyfikacji interakcji zapachowych i c) wizualnie obserwowalnych zmian w zabarwieniu skóry. Temperatura jest ważnym czynnikiem odczuć związanych ze stłoczeniem i tłumem. W pomieszczeniach, gdzie gromadzi się większa liczba osób zaplanowana musi być jego większa obszerność. Wymagana wielkość fizycznej przestrzeni wzrastają w przypadku, gdy prze-
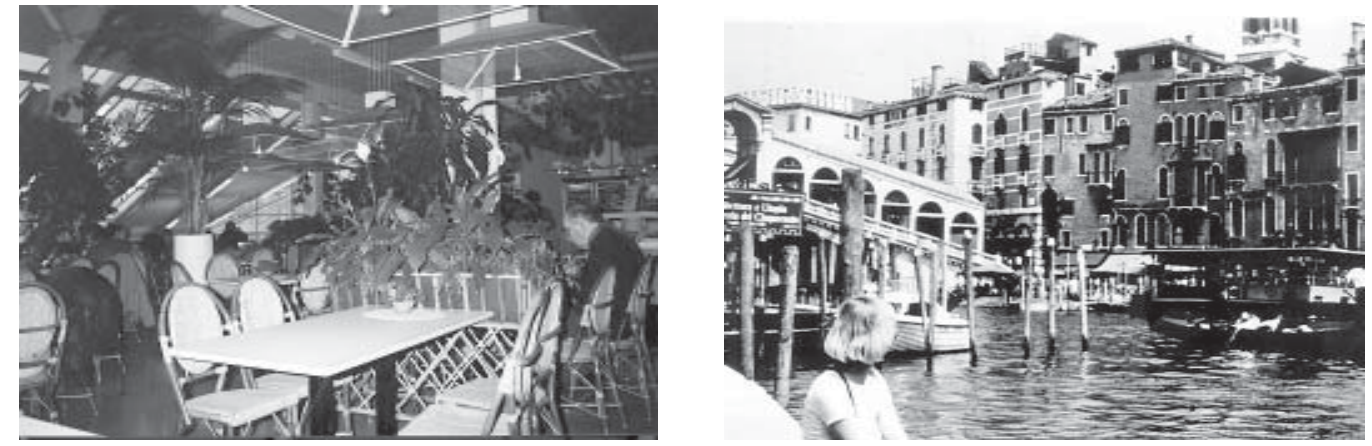

Potrzeba doświadczania przestrzeni wieloma zmysłami równocześnie powoduje, że coraz częściej kawiarnie zakłada się w marketach sprzedajacych produkty ogrodnicze. Synestezja wrażeń kinestetycznych, wizualnych i zapachowych czyni z nich ulubione miejsca spędzania wolnego czasu . Na tej samej bazie wrażeniowej opiera się fenomen Wenecji jako miejsca niezwykłego.

strzeń termalna odbiega od normalnie doświadczanych wzorów i jest dodatkowo powiązana z nieznanymi zapachami. W przypadku ludzi głuchoniewidomych i niewidomych wrażenia termiczne sa najważniejszym źródłem orientacji przestrzennej. Głuchoniewidomi mają bardziej wyostrzoną wrażliwość na zmiany gradientu temperatur w przestrzeni wokół okien i drzwi. Specyficzne wyczucie przestrzeni termalnej u głuchoniewidomych pozwala im na w miarę bezpieczną nawigację, przynajmniej tam, gdzie są drzwi i okna.

Ważnym rodzajem przestrzeni telereceptorycznej jest przestrzeń węchowa. Bodźce zapachowe moga wywołać reakcje emocjonalne dające uczucie przyjemności lub wstrętu. Zapach jest ważnym źródłem informacji, które uważamy za sygnały zagrożenia. Zmysł powonienia pełni mniej istotną rolę u ludzi niż u zwierząt. U zwierząt zapach jest wyznacznikiem terytorium przynależności gatunkowej itd. Zapach pełni ważną rolę w życiu dziecka. Wśród ludzi dorosłych zapach jest czynnikiem osobistym. Uważa się, że zmysł powonienia należy do zmysłów prymitywnych i cywilizowany człowiek tę sferę doznań stara się maksymalnie ograniczyć, poddać kontroli i zawężyć jedynie do zakresu doznań przyjemnych. Przestrzeń zapachowa ciała uznawana jest za przestrzeń intymna, choć pewne przestrzenie publiczne są identyfikowalne głównie po zapachu jak np. francuskie kawiarnie. Ludzie staraja się zabezpieczyć się przed nieprzyjemnymi zapachami i uciekaja lub odsuwają się w miarę możliwości od źródeł nieprzyjemnych zapachów. Te ostatni mogą być przyczyną poważnych napięć stresowych.

Zmysł słuchu jest drugim po zmyśle wzroku źródłem informacji o otoczeniu. Narząd słuchu składa się z trzech części: ucha zewnętrznego, środkowego i wewnętrznego, które jest właściwym narządem czuciowym. Ucho człowieka słyszy dźwięki o częstotliwości od 16 do 20000 Hz. Dźwięk słyszymy także wówczas, gdy drgający przedmiot przytkniemy bezpośrednio do czaszki. Energia dźwiękowa jest w tym przypadku przekazywana przez kości. Zmysł słuchu i przestrzeń słuchowa pełnią istotną rolę $\mathrm{w}$ nawigacji. Przestrzeń akustyczna ma w dużym stopniu charakter przymusowy; nie można zamknąć uszu tak, jak zamyka się oczy. Stąd też hałas jako świat dźwięków niepożądanych silniej zakłóca psychikę niż inne bodźce. Poza tym, promieniowanie akustyczne stale działające na organizm „odkłada się” w psychice człowieka i efekt tego oddziaływania ma charakter kumulacyjny. Kontrola przestrzeni akustycznej ma zasadnicze znaczenie dla poczucia jakości życia. Współcześnie cywilizacja tworzy zbyt wiele niepożądanych

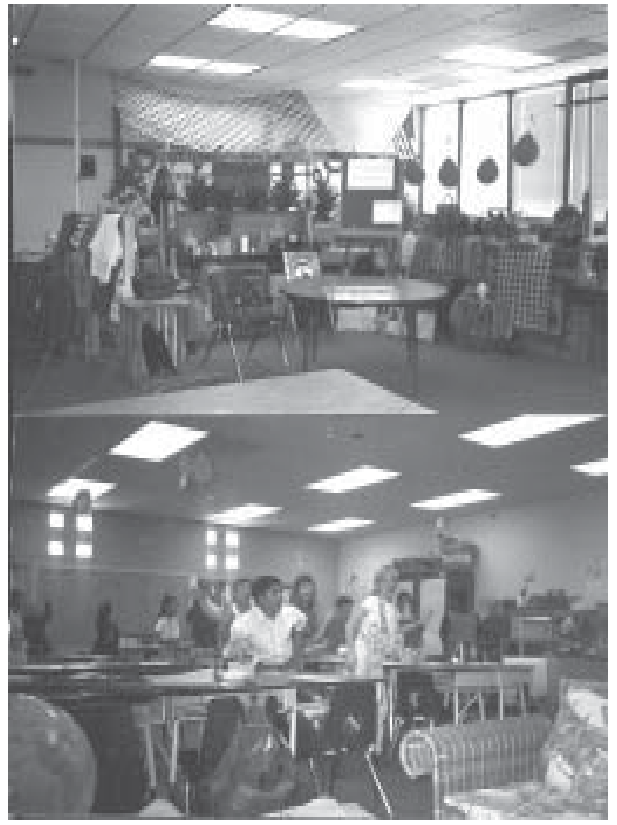

Las Vegas. Ze względu na olbrzymie upały panujące na pustyni wiele instytucji przenosi się pod ziemię, gdzie łatwiej i taniej jest kontrolować warunki mikroklimatyczne. Jednak całkowite wyeliminowanie naturalnych emitorów światła i ciepła uniemożliwia naturalną nawigację głuchoniewidomym. Prawdziwe okna zastępuje się namiastkami, mającymi dać wrażenie naturalnego światła. 


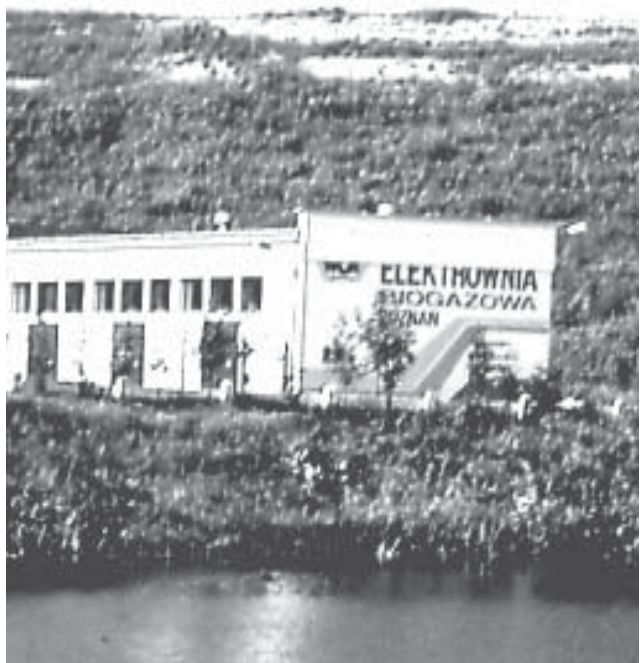

ferencji wobec określonych miejsc jest zdeterminowany również czynnikami zapachowymi. $\mathrm{Z}$ tych też powodów domki letniskowe w pobliżu toalety nie ciesza popularnościa.

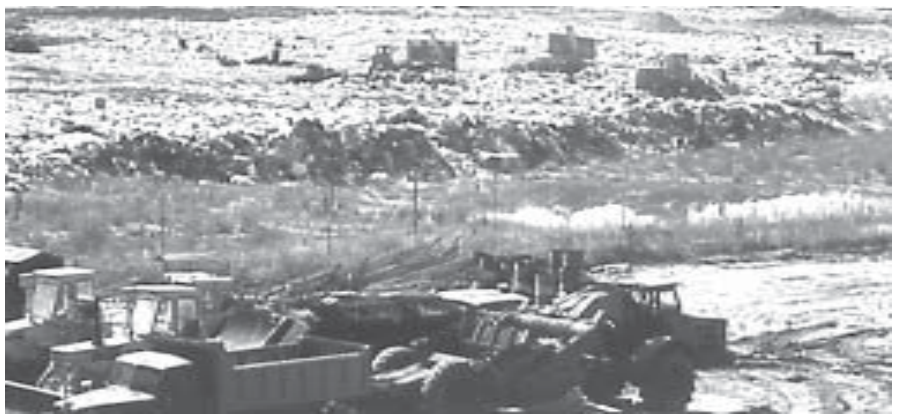

Wypoczywanie czy zamieszkiwanie $\mathrm{w}$ pobliżu oczyszczalni ścieków lub składowiska odpadów komunalnych niezależnie od uciążliwości rzeczywistej może mieć również znaczenie symboliczne. Dlatego też rozkład pre-

dźwięków i architektura jest ważnym czynnikiem kontrolowania pożądanego poziomu dźwięków. O ile w kulturze japońskiej ściana z papieru swobodnie przepuszczająca dźwięk jest zjawiskiem tolerowalnym dzięki kulturowego treningowi sprawowania kontroli nad przestrzenia akustyczna, o tyle w kulturze Zachodu ludzie nie są dostatecznie uczeni aktywnego kontrolowania przestrzeni akustycznej. W kulturze zachodniej w kontrolowaniu przestrzeni akustycznej bardziej ufaja technicznym i materialnym środkom, takim jak ściana. Ma ona za zadanie stanowić ekran możliwie najlepiej tłumiący dźwięki. Jeżeli to nie jest możliwe, dla zapewnienia odpowiedniego komfortu akustycznego stosuje się odpowiedni dystans.

Ruch w jakimkolwiek momencie jest niezbędnym elementem uruchomienia innych zmysłów a nie tylko zmysłu ruchu i równowagi. Stąd też tak duże jest znaczenie prawidłowego zaprojektowania przestrzeni kinestetycznej niezależnie od tego, że źródłem stymulacji dla wrażenia ruchu i równowagi są pobudzenia płynące z wnętrza organizmu, tj. z prioprioreceptorów. Wyróżnia się dwa ich rodzaje. Jeden rodzaj to receptory kinestetyczne. i umiejscowiony jest w mięśniach i stawach. Drugi rodzaj receptorów, zwanych kinestetycznymi, rejestruje przemieszczenia ciała względem otoczenia. Receptory kinestetyczne związane sa z narządem przedsionkowym Jest on odpowiedzialny za poczucie równowagi. Badania empiryczne wskazuja na to, że człowiek lepiej jest przystosowany do odczuwania ruchów dużych niż małych. Większość ludzi

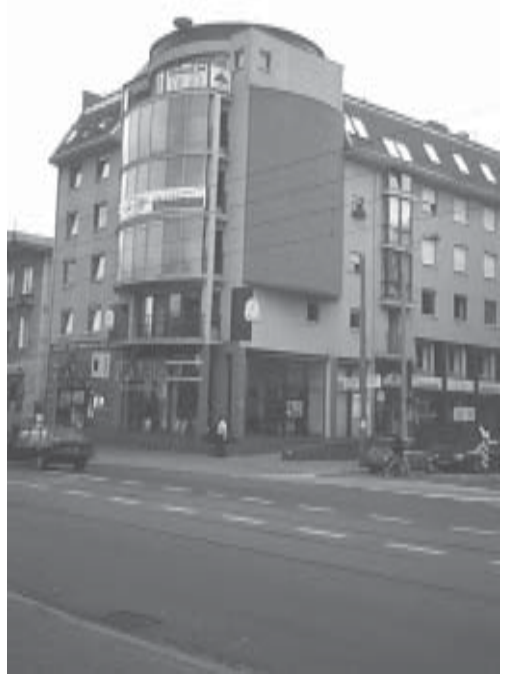

Ekrany wygłuszające hałasy komunikacyjne w zabudowie mieszkaniowej staja się koniecznościa.

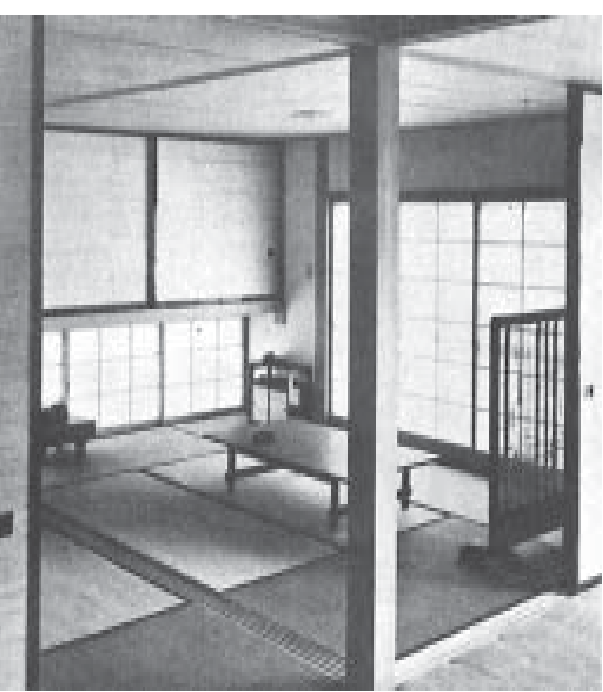

Ściana w architekturze japońskiej nie pełni funkcji przegrody akustycznej. lepiej odczuwa zmiany w ruchach bioder, nóg i ramion niż palców. Uruchomienie stawów palcowych nie jest tak dokuczliwe jak uruchomienie stawów dużych. Zasada ta ma bezpośrednie przełożenie na zasady projektowania architektonicznego. Chodzi o to, że człowiek posiada ukryte wymiary percepcji przestrzeni via zmysł kinestetyczny. Dla każdej funkcji życiowej jak praca, zabawa, relaks przestrzeń kinestetyczna zmienia się. Np. Hall odkrył istnienie trzech ukrytych wymiarów przestrzeni kinestetycznej w pracy biurowej. Sa one „ukryte” na tej zasadzie, że sa niewidoczne gołym okiem, ale dajac się zaobserwować pośrednio poprzez analizę zachowań przestrzennych ludzi pracujących za biurkiem. Pierwszy 


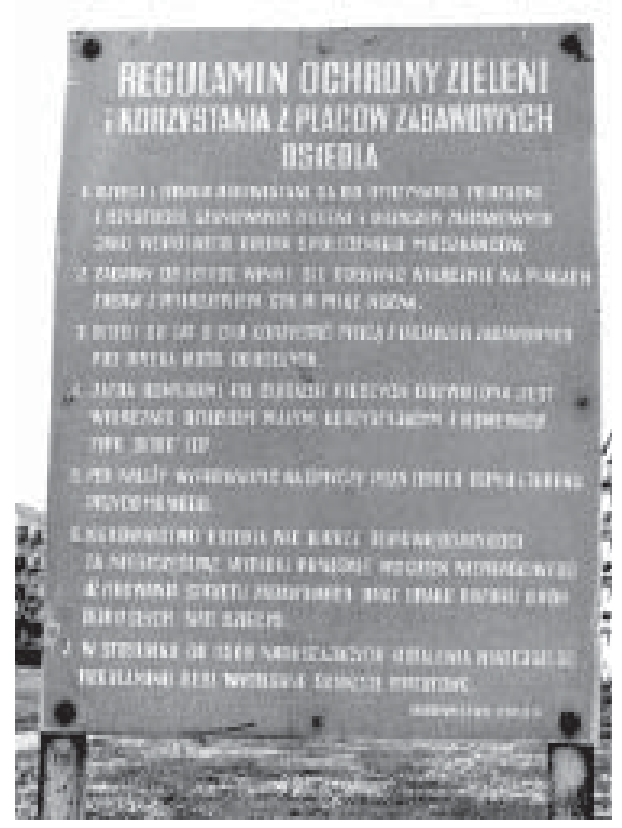

Przepisy, jakie opracowują dorośli, którzy dawno zapomnieli kim sami byli, nie honoruja podstawowych praw psychofizjologicznych $\mathrm{z}$ zakresu percepcji przestrzeni i zachowań przestrzennych.

kinestetyczne postrzega skale architekt

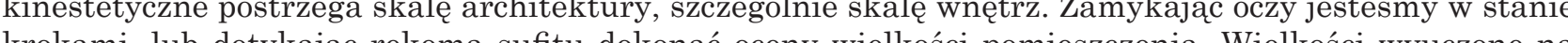
krokami, lub dotykając rękoma sufitu dokonać oceny wielkości pomieszczenia. Wielkości wyuczone na bazie doznań kinestetycznych nabierają w umyśle człowieka cech symbolicznych. Plac Św. Marka w Wenecji fascynuje nie tylko dlatego, że jest piękny sam w sobie, ale dlatego, że oferuje możliwość ruchu i pieszej eksploracji w każdym kierunku. Wielkość gabinetów jest również czynnikiem wyzwalającym symboliczne

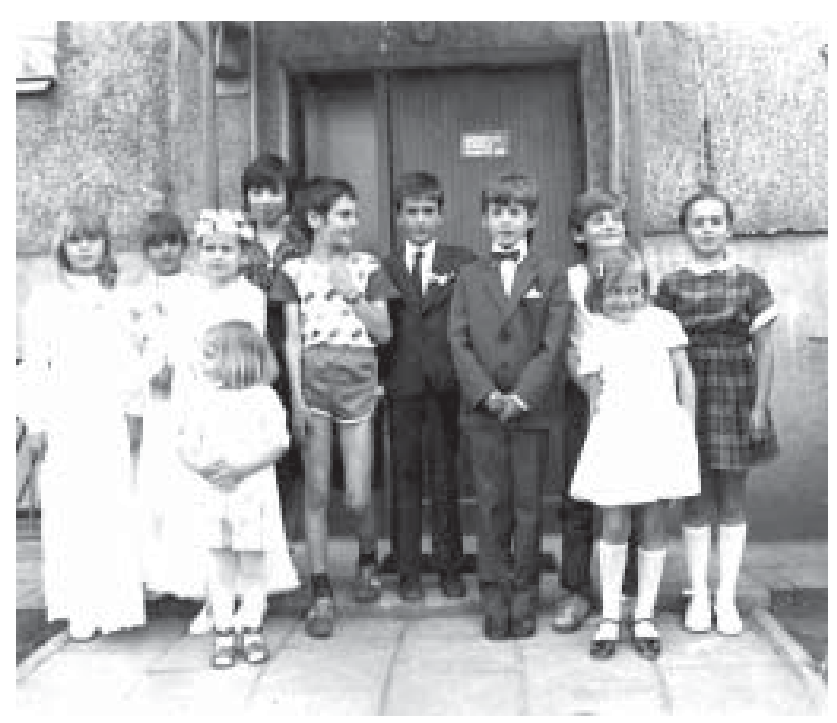

Potrzeba ruchu jest niezbywalną potrzeba szczególnie u dzieci: niemożność zapanowania nad ruchem i potrzeba stałych doznań kinestetycznych jest cechą młodości.
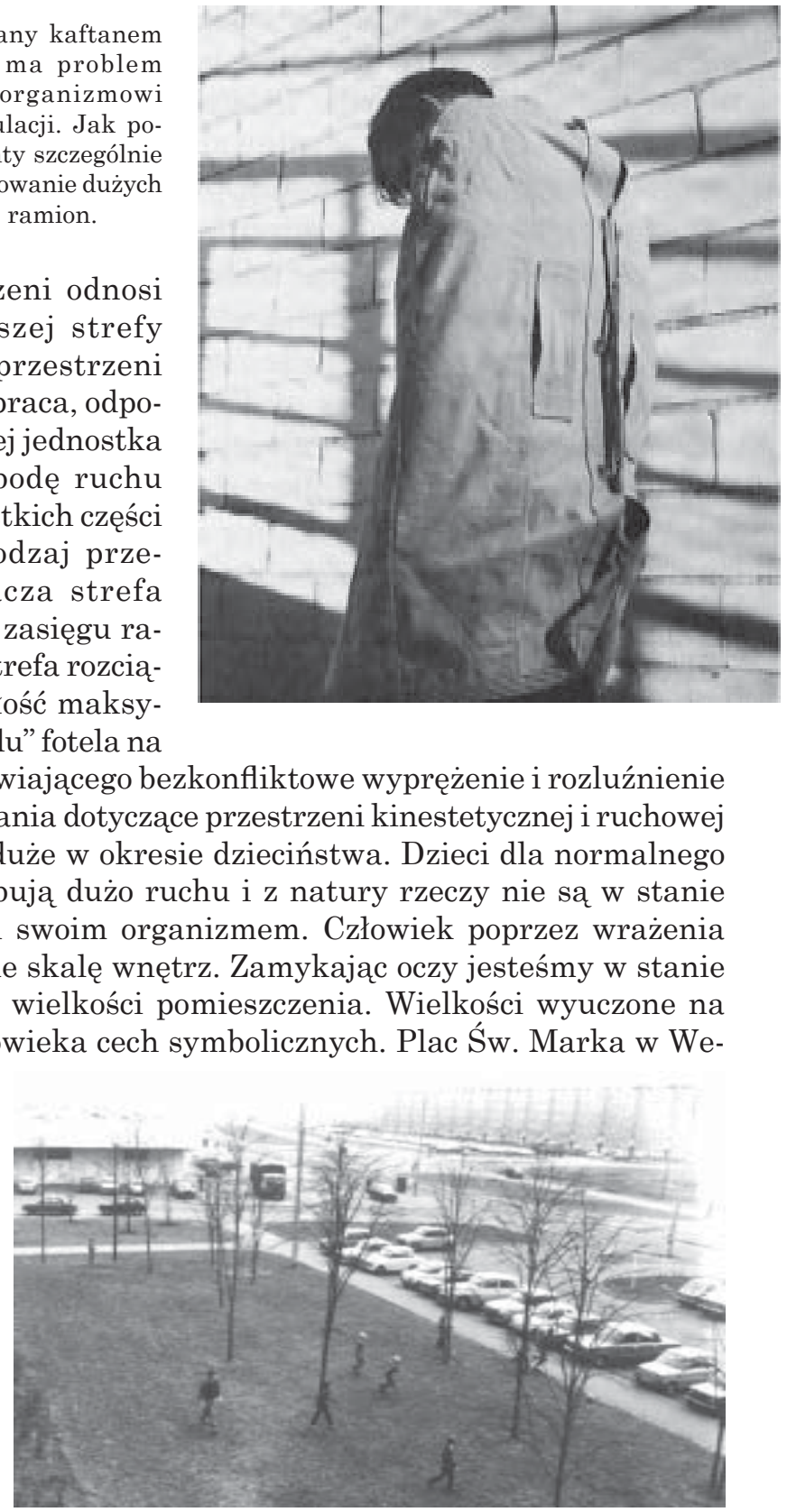

Normalne prawa natury sprawiaja, że dzieci podobnie, jak zwierzęta, niewiele robią sobie z przepisów ustanawianych przez bezmyślnych biurokratów.

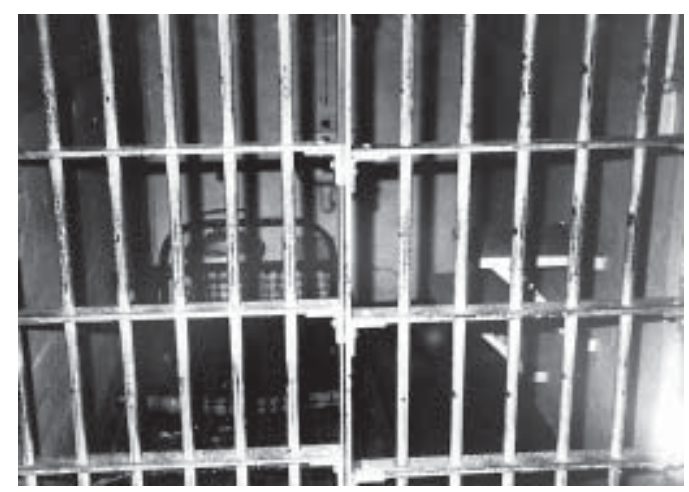

Cela Al Capone w dawnym więzieniu Alcatraz. 


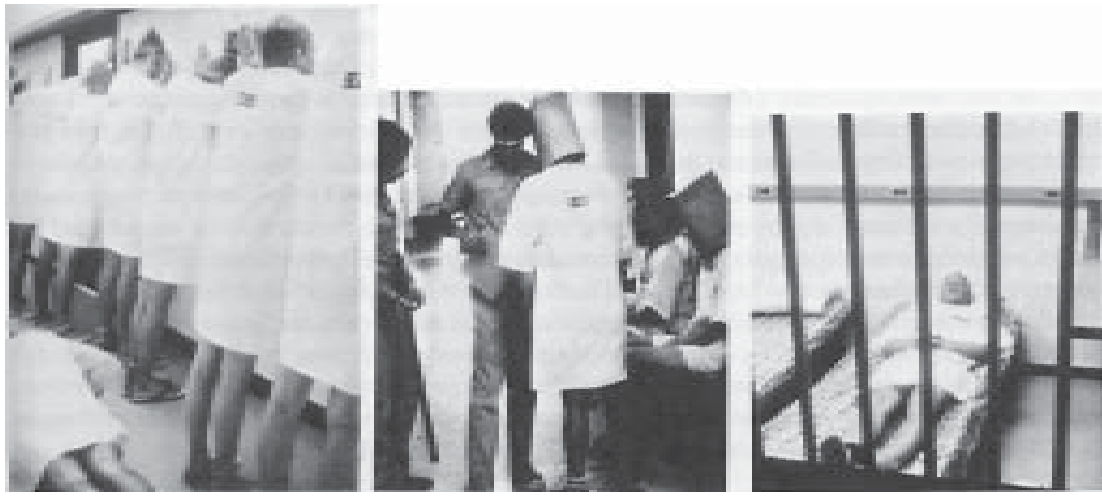

Istotą więzienia jest z jednej strony skrępowanie ruchu, z drugiej - specyficzne naznaczenie (ubiór więzienny) oraz z trzeciej - ograniczenie dopływu informacji.

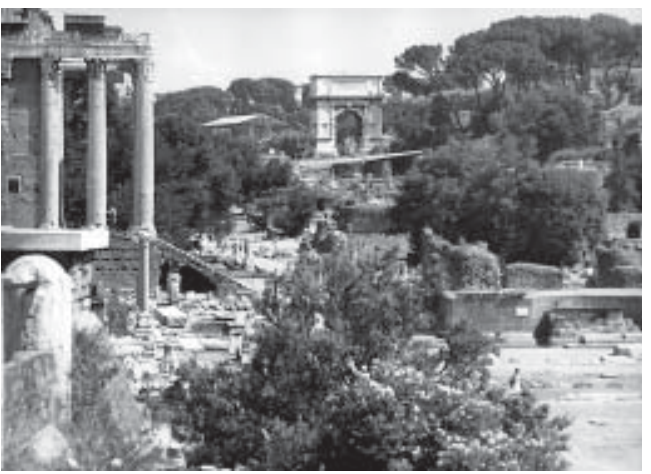

Via Sacra w Rzymie jest najstarszą drogą świadomie zaprojektowaną zmyślą o odczuciach kinestetycznych piechura.

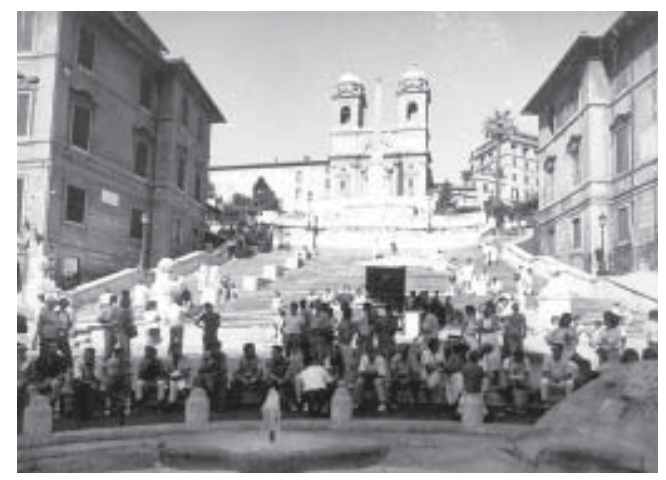

Schody Hiszpańskie w Rzymie pozwalają odbierać przestrzeń kilkoma zmysłami.

wyobrażenie ważności czy nie-

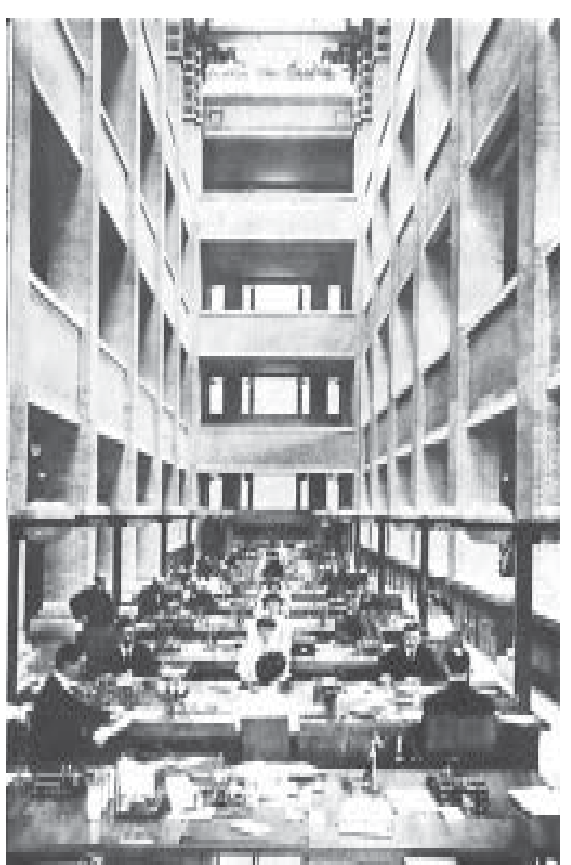

Ludzie potrzebuja wokół siebie nieco więcej przestrzeni, niż wynikałoby to tylko i wyłącznie z analizy ruchów celowych. Biuro Larkin Co. zaprojektowane przez F.L. Wrighta jest klasycznym przykładem pogwałcenia zasad organizacji przestrzeni z punktu widzenia potrzeb kinestetycznych organizmu człowieka.
Gabinet Hitlera jest przykładem zapro jektowania przestrzeni, której wielkość była doświadczana zarówno na podstawie wrażeń wzrokowych, jak i wrażeń priorioreceptywnych. 


\section{Przestrzeń o stałych cechach}

Determinanty mikrokulturowe percepcji przestrzeni odgrywają najistotniejszą rolę w sposobie użytkowania jej przez człowieka i posiadają trzy, w pewnym sensie niezależne aspekty: aspekt związany z przestrzenią o stałych cechach, aspekt związany z przestrzenią o semistałych cechach oraz aspekt związany z przestrzenią nieformalną

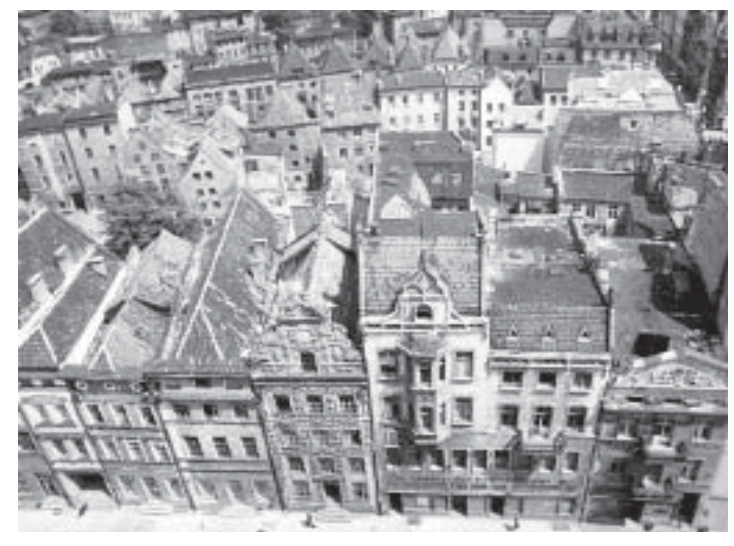

Toruń. Zinternalizowanym wzorcem przestrzeni w naszej tradycji jest kształt i forma miasta średniowiecznego.

„Wzorzec kulturowy” przestrzeni o stałych cechach jest jednym z podstawowych sposobów wyznaczających aktywność jednostek i grup ludzkich. Przestrzeń o stałych cechach obejmuje z jednej strony zarówno manifestowane, jak i ukryte własności materii składającej się na przestrzeń oraz $-\mathrm{z}$ drugiej strony - zinternalizowane wzorce - projekty sterujące zachowaniem się ludzi w kontakcie z przestrzenia. Internalizacja jest to proces psychologiczny polegajacy na przyjmowaniu jako własnych wartości, poglądów, postaw, norm narzucanych z zewnątrz, np. przez grupę społeczna. Wyrazicielami kulturowo zdeterminowanych wzorów-projektów przestrzeni sa zarówno pojedyncze budynki czy obiekty architektoniczne, jak i ich rozmaite zbiory, jak osiedla, miasta.

Kulturowe uwarunkowanie przestrzeni według stałych cech polega m.in. na tym, że w naszej (euroamerykańskiej) kulturze każdy budynek mieszkalny ma określone przestrzenie - pomieszczenia dla poszczególnych funkcji, takich jak odpoczynek (sypialnia, bedroom), sporządzanie i spożywanie posiłków (kuchnia, jadalnia), funkcje sanitarne (łazienka, WC). W tym aspekcie również w kulturze euroamerykańskiej występuja mniej lub bardziej istotne zróżnicowania. Tak np. dining room (jadalnia) oraz living room (pokój dzienny) są stałymi elementami w domu angielskim, niezależnie od stopnia statusu ekonomicznego. W Polsce te dwie kategorie przestrzeni mają tendencję do łączenia się w jedną kategorię. Jeżeli pewne aktywności czy nawet czynności zostają przeniesione z jednej przestrzeni na inna, to fakt ten rzadko uchodzi uwagi. Ludzie żyjący w tzw. ustawicznym nieładzie lub w ciagłym roztargnieniu, to właśnie osoby, które nie potrafią uporządkować swojej aktywności według jednorodnego, spójnego i przewidywalnego przestrzennie planu. Przeciwieństwem tych ludzi są osoby precyzyjnie organizujące obiekty w czasie i przestrzeni.

Współcześnie wewnętrzna struktura budynku mieszkalnego, tzn. rozmieszczenie wewnętrzne w planie funkcjonalnym, zarówno w Europie, jak i w Ameryce, jest całkowicie świeżej daty. Według Phlippa. Ariesa pomieszczenia w budynkach mieszkalnych w Europie nie miały stałych funkcji do końca 18 stulecia. Członkom rodziny w owym czasie nie przysługiwało prawo prywatności w dzisiejszym tego słowa znaczeniu. Nie było też przestrzeni wyspecjalizowanej lub o szczególnym przeznaczeniu, tzn. szczególnie czemuś poświęconej. W miarę rozwoju i zmiany koncepcji np. dzieciństwa czy rodziny zaczęła ulegać zmianie forma domu, przejawiając się w separacji jednych pomieszczeń od innych i w różnicowaniu się ich funkcji w sensie specjalizacji.
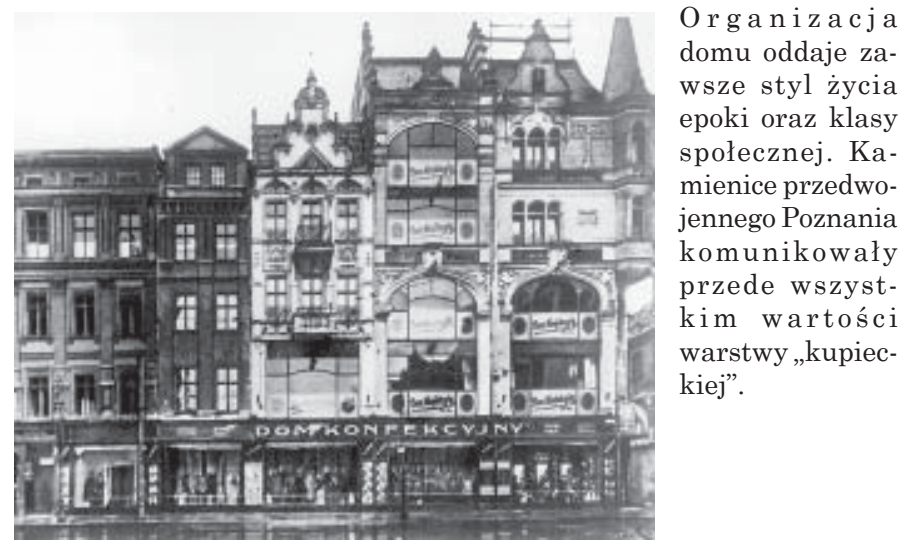

Velasques: Portret infantki jest dowodem na to, że dziecko było traktowane jak osoba dorosła, tylko że w miniaturze.

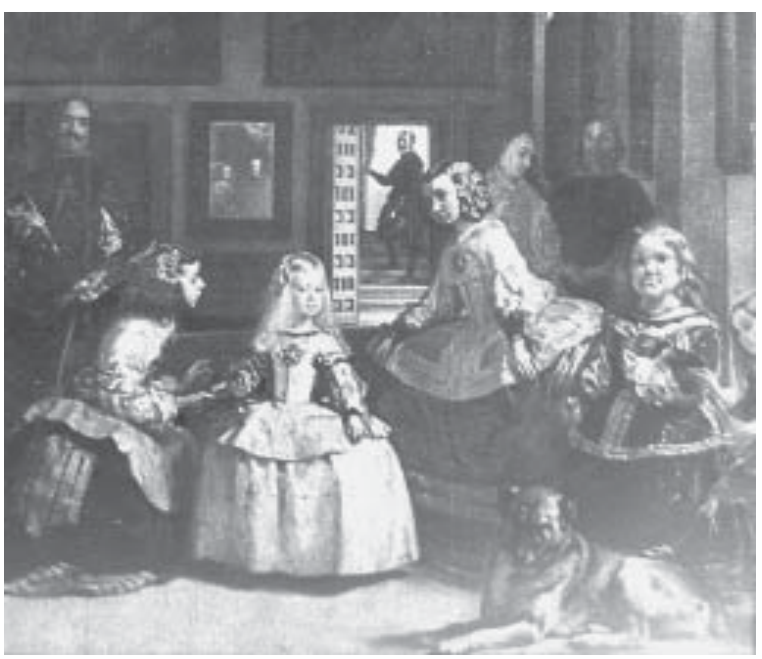




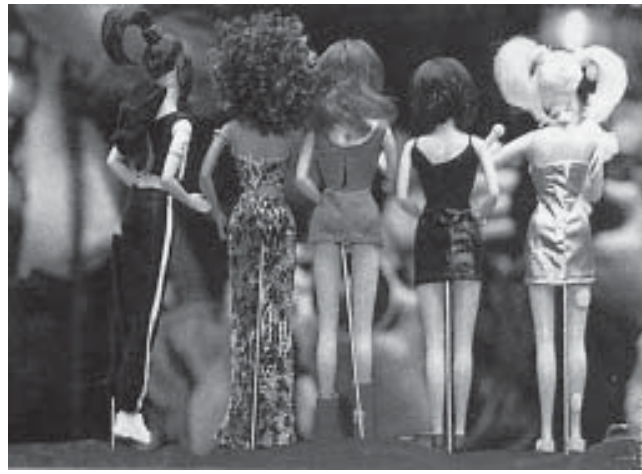

Spice Girls w obecności lalki Barbie są przykładem tego, jak współczesna cywilizacja ma tendencję i cofania się do „dzieciństwa”.
Architektura bardzo często wykorzystywana jest przez ludzi jako środek różnicowania atmosfery zależności między człowiekiem a przestrzenia. Szczegółową i ciekawą analizą zależności między façade, która ludzie stosują na pokaz, a ich własnym ja. Termin, ,ja” (self), inaczej jaźń lub ego, jest to pojęcie o niezbyt dokładnie określonym znaczeniu. Wprowadzone przez amerykańskiego filozofia i psychologa (1890) W. Jamesa jeszcze do niedawna pojęcie to było unikane ze względu na pewne filozoficzne problemy. Aczkolwiek terminologia dyskusji nie została jeszcze w pełni uzgodniona, przyjmuje się rozróżnienie pomiędzy dwoma aspektami jaźni: jaźni wydedukowanej przez zewnętrznego obserwatora oraz jaźni, której jest świadomy sam podmiot. Jaźń wydedukowana, tj. strukturę osobowości reprezentuja „ośrodek" podejmowania decyzji, planowania i-obrony, może zrozumieć i poznać zewnętrzny obserwator, może on nawet wykryć cechy nieświadome, z których dana jednostka nie zdaje sobie sprawy. Ten aspekt jaźni zwykle bywa nazywany „ego”. Termin ten zapożyczony od Zygmunta Freuda, chociaż nie pasuje ściśle do freudowskiej definicji, jest konstrukcja utworzoną na podstawie objawów zachowania, dedukcja, która może być dokonana przez poinformowanych obserwatorów. Słowo „ja” zarezerwowane jest z kolei dla jaźni, której jest świadomy podmiot (zwanej czasami jaźnią „,fenomenologiczną), jaźni postrzeganej przez samą siebie. „Ja” stanowi to wszystko, co: a) przy całej zmienności człowieka (np. wraz z wiekiem) jest w nim trwałe, dzięki czemu każdy czuje się ciagle tym samym człowiekiem, choć z biegiem lat zmienionym; b) jest niepowtarzalne, dzięki czemu nikt nie może pomylić siebie z kimś innym; c) niepodzielne, dzięki czemu każdy czuje się jednością jedną osoba.

Zastosowanie przez Goffmana terminu façade jest odkrywcze i zasługuje na uwagę. Wskazuje on na fakt, że własności architektury moga być wykorzystywane jako parawan, za którym od czasu do czasu ujawniają się najbardziej intymne potrzeby ludzkie. Fakt, że stosunkowo niewielu biznesmenów posiada swoje biura w domu, zdaniem Halla jest wytłumaczalne dążeniem do realizacji różnych aspektów swojej osobowości lub nawet rozwoju różnych osobowości, będacych udziałem tego samego człowieka.

U niektórych ludzi struktura osobowości może odznaczać się większa jednolitością i spoistościa, niż u innych, lecz większość ludzi może przybierać różne role i zachowywać się w nich w bardzo odmienny sposób. Pewne przejawy osobowości moga być fragmentaryczne i calkiem niezależne od jakiegoś głównego nur-

Przykładem architektury fasadowej jest budownictwo rezydencjalne tzw. „nowobogackich”. Nie służy ono wyłącznie do zamieszkiwania, ale też do pokazywania informacji o sobie innym.

tu. Przypadki „rozszczepionej osobowości” stanowia obrazowy przykład istnienia odrębnych struktur w ramach jednej osobowości. Do klasycznych przypadków należy opisany przez Hilgarda (1967) przypadek Ewy Białej z jej alternatywnymi osobowościami określanymi jako Ewa Czarna i Janina. Ewa Biała była poważnie myślącą i sumienną młodą matka, która przyszła do terapeuty w celu wyleczenia się z silnych bólów głowy. W trakcie jednego z posiedzeń, w czasie którego ze znacznym wzburzeniem opowiedziała, że czasami słyszy

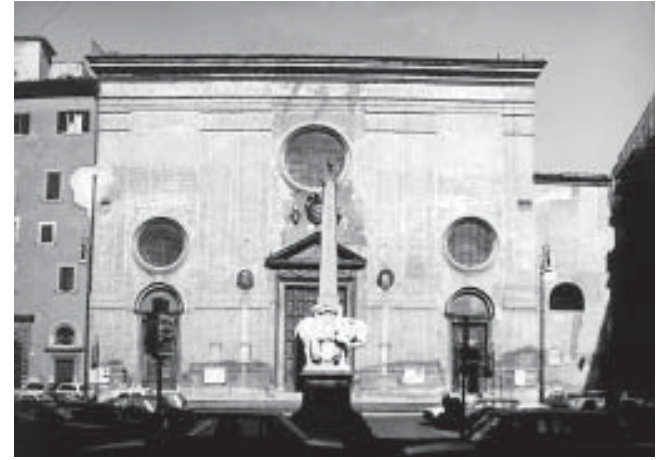

Rzym nigdy nie zaakceptował gotyku, jako własnej formacji architektonicznej i mentalnej. Najbardziej gotycki kościół w Rzymie wykorzystuje własna façade do ukrycia we wnętrzu tego, co „konieczne”, czyli gotyckie. 
„halucynacyjne głosy”, nagle wystapiła w niej uderzająca zmiana osobowości, stała się młodzieńcza, pogodna, flirtująca osóbka, która nazywała siebie Czarna Ewa. Osobowość Ewy Czarnej była całkiem świadoma myśli i czynności Ewy Białej, lecz Ewa Biała nawet nie podejrzewała istnienia Ewy Czarnej, dopóki nie „poznały się" w gabinecie terapeuty. Później wyłoniła się trzecia osobowość, bardziej dojrzała, która nazwała się Janina. To, co w opisywanym przypadku występuje w skrajnej postaci, w mniejszym stopniu jest także prawdą w odniesieniu do osoby normalnej, tzn., że typowa osobowość scala szereg wątków, które w różnym czasie i przy różnych okazjach moga wywoływać takie sposoby zachowania, które wydają się bardzo różne, a jednak odzwierciedlają pewne podstawowe potrzeby osobowości.

Utrzymywanie przez biznesmenów czy artystów pracowni i biur poza domem stwarza im możliwość zachowania dwóch niezależnych od siebie obliczy osobowości bez ryzyka konfliktu i dodatkowo za pośrednictwem różnych form architektonicznych otaczającego środowiska umożliwia zachowanie wyidealizowanego obrazu każdej z wersji.

Odczucie człowieka związane z jego miejscem i rolą w przestrzeni ma kapitalne znaczenie z punktu widzenia jego przetrwania oraz zdrowia psychicznego. Lewis Mumford zaobserwował, że zuniformizowany wzór miasta na planie regularnej siatki, charakterystyczny dla miast w USA, powoduje u starszego pokolenia mieszkańców charakterystyczne wyobcowanie. Starsi mieszkańcy przyzwyczajeni są do planów miast opartych na wzorach europejskich, które nie są tak proste. Młodzi Amerykanie i ci, którzy do takiego prostego wzorca miasta sa przyzwyczajeni, wykazuja z kolei trudności adaptacyjne $\mathrm{w}$ planach miast europejskich. Różnice te są często powodem stanów frustracji. Podobnie, jak źle się czuje Amerykanin w starym mieście europejskim, tak samo źle się czuje Europejczyk przyzwyczajony do zabudowy na planie rzymskim lub francuskim, gdy nagle znajdzie się w Japonii, gdzie wewnętrzny (zinternalizowany) plan przestrzeni oparty jest na całkowicie odmiennych stałych cechach. Podczas gdy system europejski oznacza linie, przyporządkowujac im nazwy (ulic, alei, tras), w systemie japońskim stałymi cechami porządkujacymi przestrzeń miejską są skrzyżowania (inter-sections) i tylko im przynależa

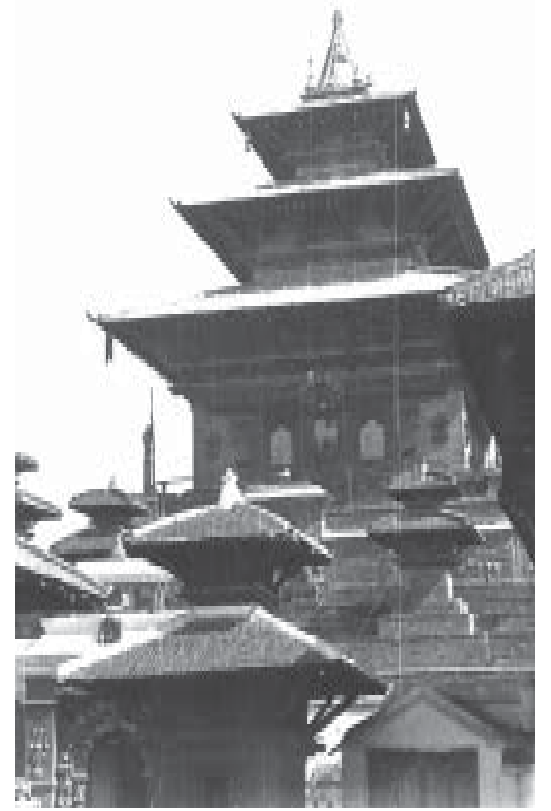

Typowy wzór architektury azjatyckiej. nazwy, a nie układom linearnym, czyli ulicom, alejom, autostradom.

Jedna z podstawowych różnic między poszczególnymi kulturami wynika

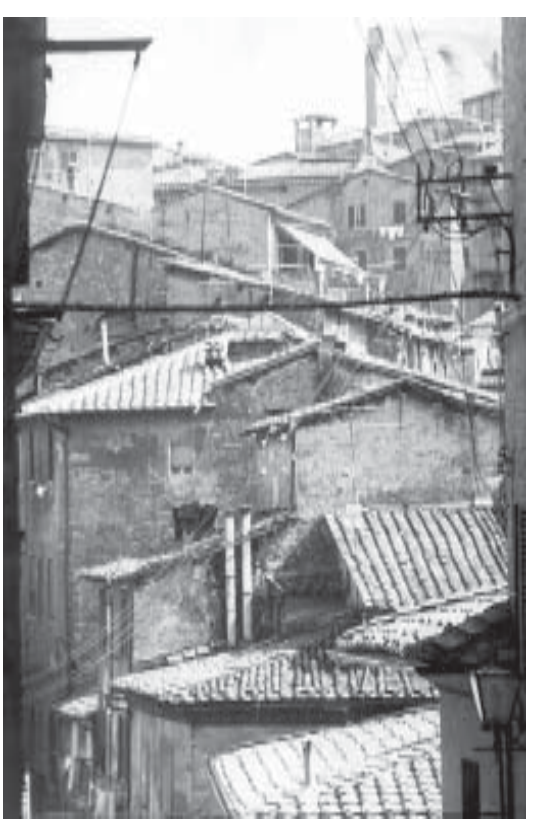

Siena. Typowy wzór miasta włoskiego. $\mathrm{z}$ anatomicznych lub behawioralnych cech ludzkiego organizmu. Nawet wtedy, gdy dochodzi do zrównywania się (akulturacji) kultur poprzez wzajemne zapożyczenia, to i tak podlegają one daleko idacej adaptacji.Co więcej, stare i nowe wzory kulturowe niekoniecznie muszą ulegać stopieniu, lecz moga współegzystować i to nawet w sprzeczności. Przykładem tego jest Japonia, gdzie występują trudności w integracji ruchu samochodowego w ramach „wzorca kulturowego stałych cech przestrzeni zurbanizowanej”, preferującego punkty przecięcia zamiast linii między poszczególnymi punktami. Tym też tłumaczy się przyczynę słynnych na cały świat korków ulicznych w Tokio. Trudności adaptacyjne samochodu do wzorca kulturowego zurbanizowanego środowiska występują również w Indiach. Samochód stosunkowo trudno „adaptuje” się tam z powodu dużego fizycznego stłoczenia oraz funkcjonowania hierarchicznej struktury społeczeństwa. $\mathrm{O}$ ile inżynierom nie uda się definitywnie oddzielić ruchu pieszego od szybko poruszających się pojazdów to zawsze problemem w Indiach będzie tendencja u kastowo świadomych kierowców do wywoływania kolizji z niższymi kastowo użytkownikami dróg. 


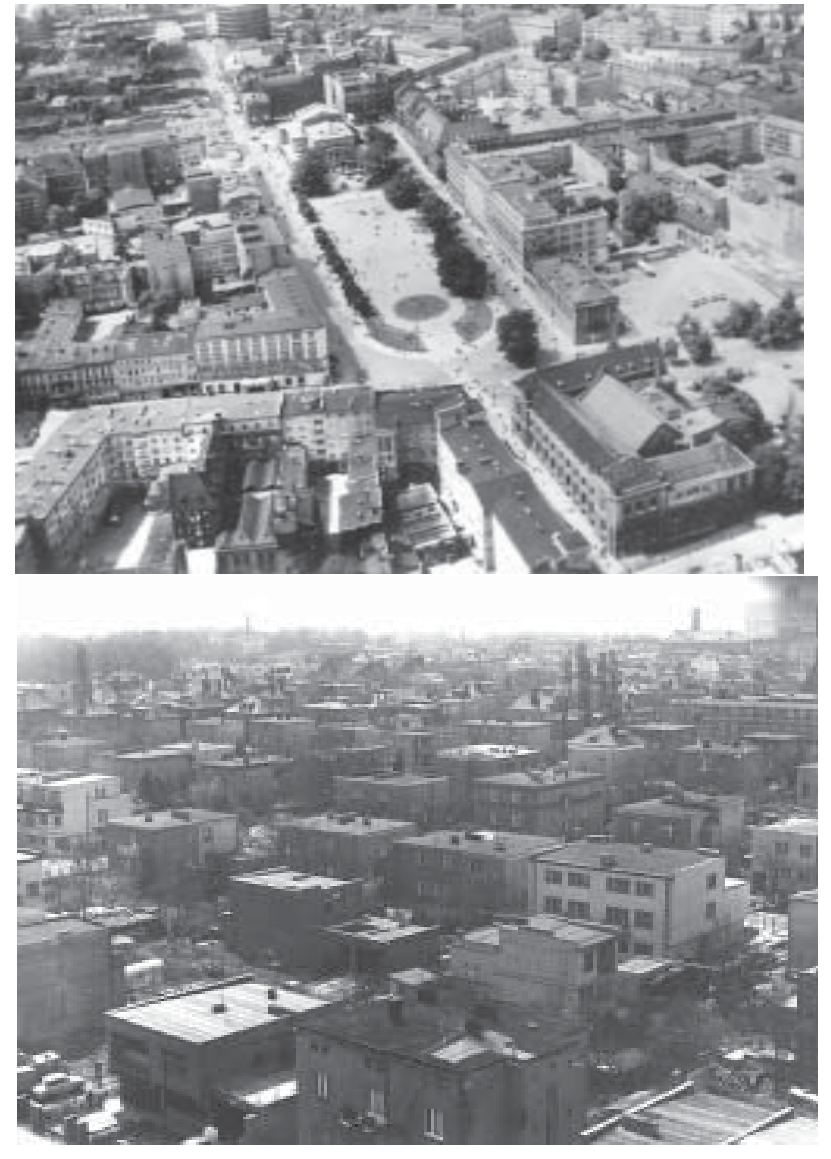

Poznań: Typowe zinternalizowane wzory architektury z dwóch epok: z epoki dziewiętnastego wieku oraz z lat sześćdziesiątych bez stylu, smaku i indywidualności.

Występowanie różnic międzykulturowych we wzorach percepcji stałych cech przestrzeni architektonicznej jest faktem, którego nie można ignorować. Nawet wielkie projekty Le Corbusiera zrealizowane w Chandigarh, w stolicy stanu Punjab, zostały z tego powodu zmodyfkowane przez samych użytkowników, którzy uznali konieczność nadania tym budowlom cech,zamieszkiwalności”. Zamurowano więc zaprojektowane przez Le Corbusiera balkony, zamieniając je na kuchnie. Podobnie Arabowie przyjeżdżając do Europy konstatuja, że ich oczekiwania ujęte $\mathrm{w}$ formie zinternalizowanych wzorów stałych cech przestrzeni nie znajduja zadośćuczynienia. Najogólniej rzecz ujmujacc, mieszkanie - w „naszym stylu” odczuwaja jako nieadekwatne do ich potrzeb. Sufity sa zbyt niskie, pokoje za ciasne, prywatność z powodu łatwości wglądu do wewnątrz jest niedostatecznie zapewniona.

Nie należy z tego wszystkiego wyciagać wniosku, że niespójność między zinternalizowanymi a zeksternalizowanymi (uzewnętrznionymi) wzorami przestrzeni może występować tylko i wyłącznie w aspekcie interkulturowym. W miarę rozwoju techniki i technologii, a więc ze wzrostem umiejętności kontrolowania środowiska powietrznego (klimatyzacja) i opanowywaniem coraz to nowych źródeł oświetlenia coraz bardziej staje się możliwe projektowanie w skali masowej form architektonicznych (budynków mieszkalnych, biur, sklepów) pomijających tradycyjne wzory.

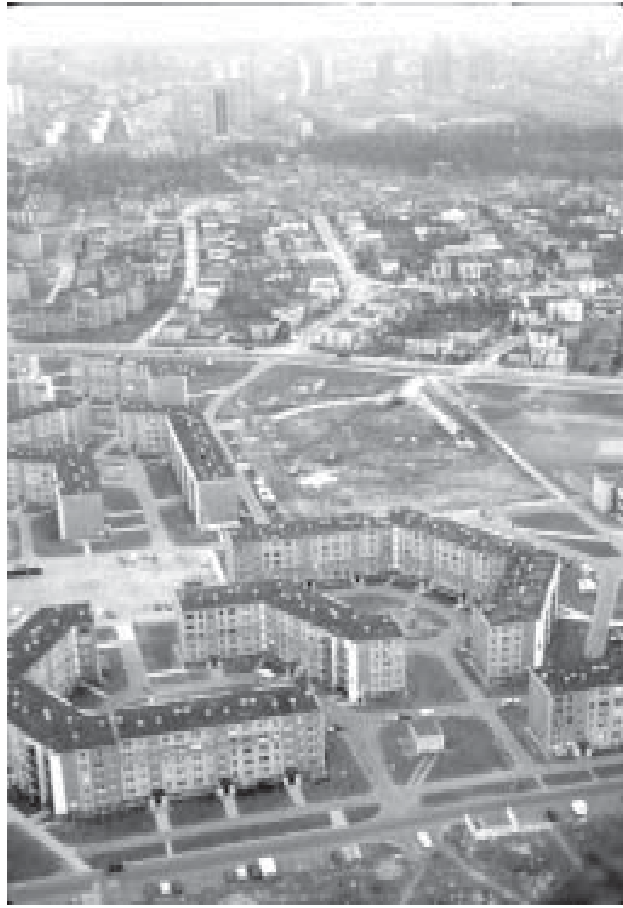

Współczesna urbanistyka i przyzwyczajenia projektantów do widzenia przestrzeni urbanistycznej z góry sprawia, że przestrzeń miejska traci kontakt z kulturowymi wzorami przestrzeni. Przestrzeń taka jest atrakcyjna tylko z lotu ptaka, natomiast jest mniej atrakcyjna i komunikatywna z perspektywy piechura, który oprócz doznan wzrokowych odbiera doznania kinestetyczne.
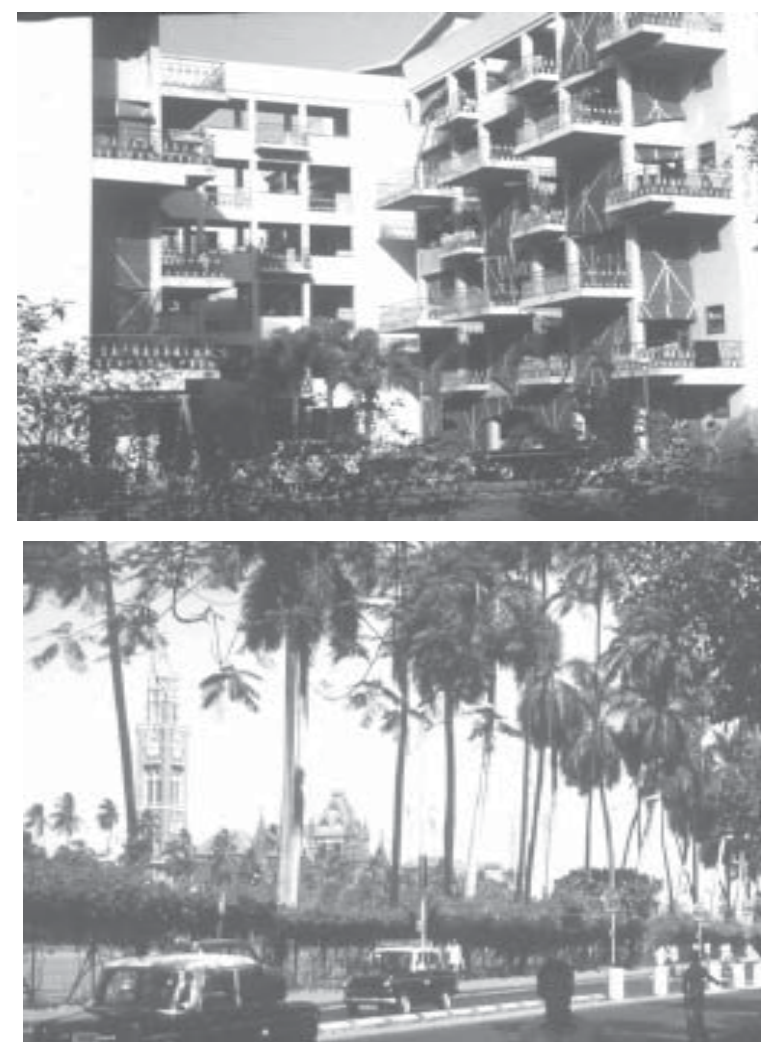

Indie: Indie są przykładem cywilizacji, w której akulturacja napotyka na wewnętrzne opory. Szczególne problemy w zakresie korzystania z przestrzeni stwarzają bariery kastowe. 


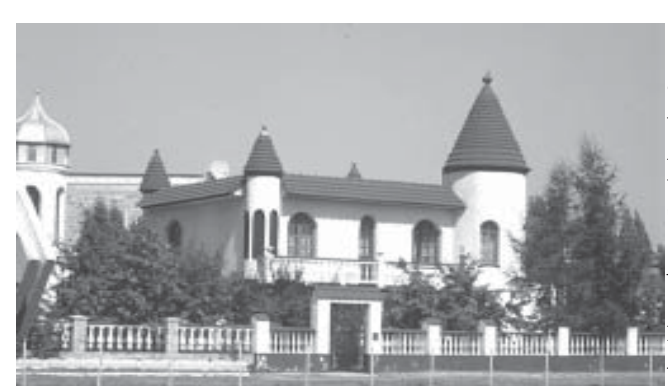

Dom w Poznaniu. Mniejszości etniczne często posia dają swój własny model przestrzeni i estetyki przestrzennej, niezrozumiały dla reszty społeczeństwa.
Tak np. we współczesnej architekturze przemysłowej sa tendencje do zastapienia światła dziennego światłem sztucznym.

Szmidt twierdzi, że w budynkach zblokowanych nie należy stosować oświetlenia dziennego. Wychodzi on $\mathrm{z}$ założenia, że udział promieni słonecznych i promieni rozproszonych jest zmienny, wskutek czego natężenie oświetlenia ulega wahaniom, które wyma-

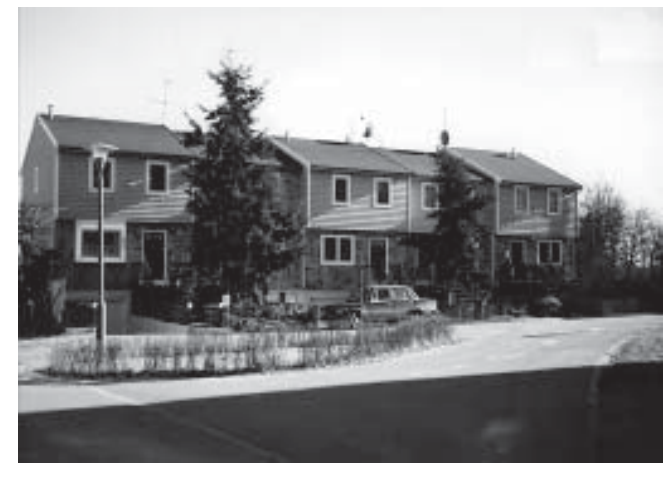

Domki kanadyjskie nie sa zgodne z polskimi kodami kulturowymi, a szczególnie jeśli chodzi o definicję ściany.

gają stałego przystosowywania się wzroku, wywołując przedwczesne zmęczenie, bóle głowy i wzrost wypadków. Jednak w miejscu pracy światło dzienne ma więcej plusów niż minusów. Oddziałuje ono dodatnio na psychikę człowieka, pozwalając mu na odczuwanie zmienności pór dnia i roku. Aktywność psychofizyczna waha się w zależności od pory dnia. W związku z tym obserwacja zmienności natężenia światła utrzymuje właściwy rytm biologiczny człowieka.

\section{Przestrzeń o zmiennych cechach}
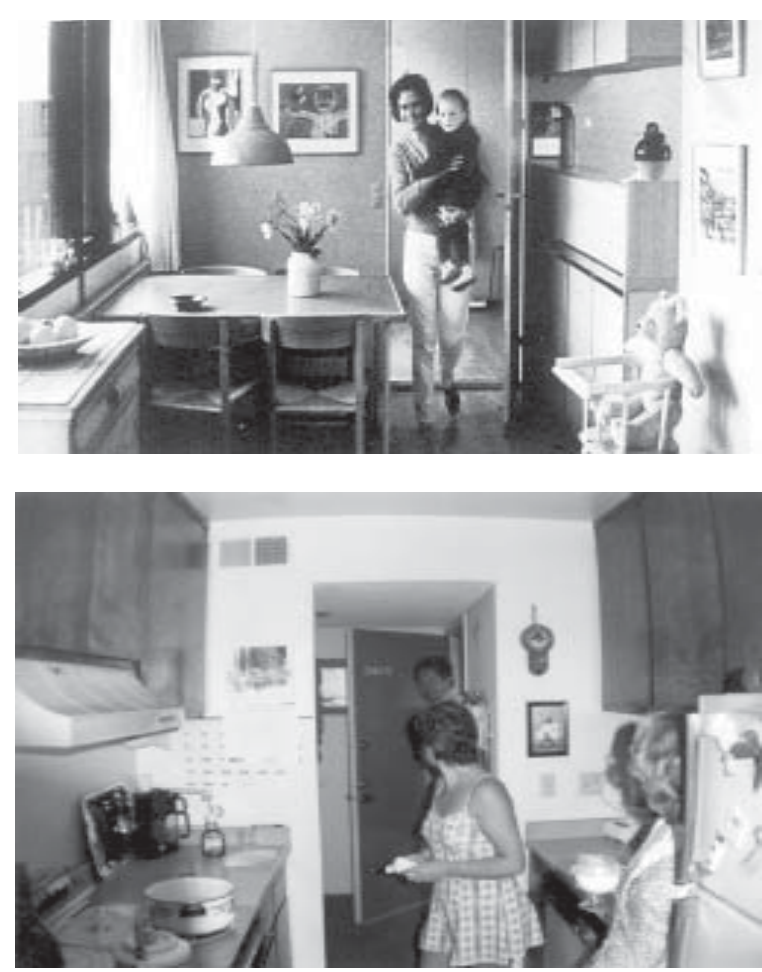

Aranżacja kuchni jest odzwierciedleniem kulturowo zmiennych wzorów przestrzeni. Kuchnia duńska kładzie nacisk na wspólnotę, której elementem integrujacym jest stół. Kuchnie często sa projektowane jako przestrzeń „gorsza”, toteż w takich przypadkach występuję brak zależności między wzorami zachowań a elementami materialnymi; przestrzeń staje się przestrzenią społecznie ucieczkową.
Pojęcie przestrzeni o zmiennych cechach wiąże się z cytowanymi już wcześniej wynikami obserwacji $\mathrm{H}$. Osmonda. Kiedy Osmondowi powierzono kierowanie szpitalem w Saskatchewen, jedna z pierwszych zaobserwowanych przez niego prawidłowości była zależność między pewnymi cechami fizycznej przestrzeni a zachowaniem pacjentów i personelu szpitalnego. Generalnie stwierdził on, że niektóre rodzaje przestrzeni, takie jak poczekalnie dworcowe, toalety, mają tendencję do podtrzymywania dystansu między ludźmi. Z drugiej strony są formy przestrzenne, jak np. liczne kawiarnie typu

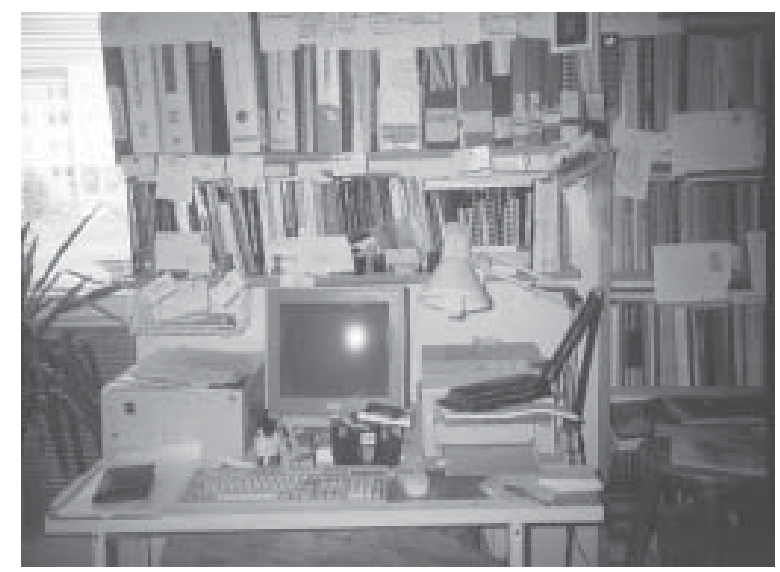

Organizacja przestrzeni na i wokół biurka jest odzwierciedleniem półstałego wzoru kulturowego, gdyż obok obiektywnych elementów ładu występują zmienne przestrzenno-czasowe, będące korelatami indywidualnego ładu panującego w umyśle jednostki. 


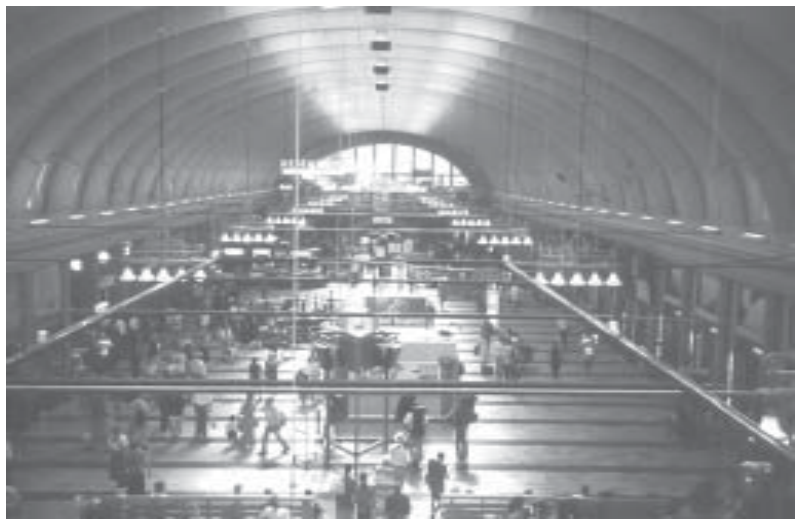

Dworzec centralny w Sztokholmie, jak wiekszość przestrzeni publicznych charakteryzuje się odspołecznieniem, tj. cecha, w efekcie której ludzie niechętnie nawiązują między sobą bliższe kontakty.

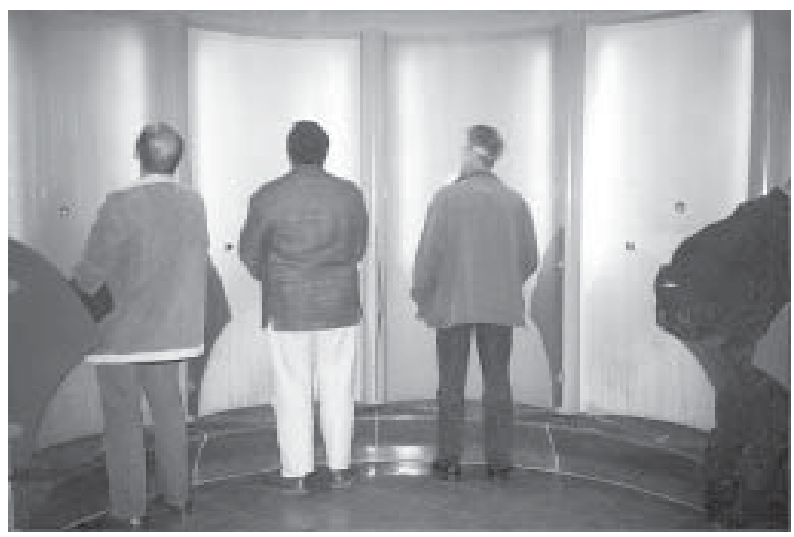

Ucieczkowość przestrzeni jest do pewnego stopnia sterowalna, a więc może być bądź osłabiana starannym zaprojektowaniem wnętrza, bądź wzmacnia. Przykładem pierwszego efektu jest toaleta zaprojektowana w Kassel Przykładem efektu drugiego rodzaju jest stosowanie rozwiązań konstrukcyjnych świadomie zmniejszających komfort, jak np. niewygodnych krzeseł.

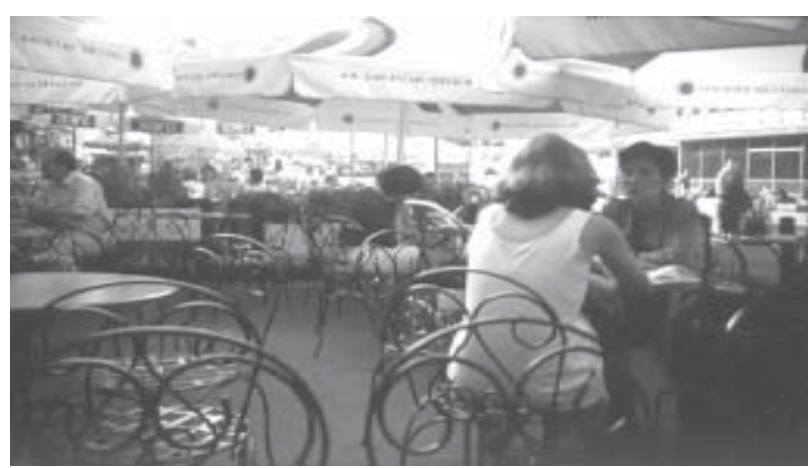

Atrakcyjność przestrzeni jest czasem czynnikiem niepożądany. W związku z tym poprzez odpowiednie zaprojektowanie przestrzeni i np. krzeseł można regulować czas okupowania danego terytorium w atrakcyjnym miejscu . francuskiego, które ułatwiają wzajemne zbliżenie między ludźmi. Pierwszy rodzaj przestrzeni nazwał przestrzenią „społecznie ucieczkową" (sociofugal), a drugi-,społecznie przyciagajaca" (sociopetal). Szpital, którym Osmond kierował, ocenił jako mieszaninę przestrzeni społecznie ucieczkowych oraz społecznie przyciagających. Stosunek różnych użytkowników do każdej z tych dwóch form przestrzeni nie jest jednakowy. Personel szpitalny preferuje pierwsza formę przestrzeni jako ułatwiającą funkcję zarządzania i kierowania. Krzesła, które do wizyty ustawiane były na planie półokręgu, po wizycie personel szpitala skrzętnie ustawiał pod ścianami w równych szeregach, przypominających szyk wojskowy.

Okazję do przeprowadzenia pogłębionej obserwacji problemu właściwości przestrzeni o aksjologicznie zmiennych cechach dał Osmondowi nowo wybudowany „modelowy” dom starców. Wszystko było w nim porządnie wykonane, „pogodne”, kolorowe, przestrzenne, jedynym mankamentem było to, że im dłużej przebywali w tym środowisku pensjonariusze, tym bardziej stawali się zamknięci w sobie i odizolowani jeden od drugiego. Stopniowo upodabniali się do mebli i odnosiło się wrażenie, jakby wyrastały między nimi ściany milczenia.

Spostrzeżenie, że przestrzeń może być bardziej społecznie ucieczkowa niż społecznie przyciagająca zainspirowało cytowanego już R. Somera do badań nad wpływem niestałych elementów przestrzeni na zachowania konwersacyjne. Badania te pomimo wielu ograniczeń udowodniły, że zmienne cechy przestrzeni (klasycznym przykładem jest miejsce przy stole - maja głęboki wpływ na zachowania ludzi. Tym też należy tłumaczyć dążenie wielu ludzi do uporządkowania przestrzeni mieszkalnej w taki sposób, który w efekcie daje akceptowaną przez domowników i gości równowagę między stałymi (ściany, sufit, okna, drzwi) i zmiennymi jej cechami. Praktycznie polega to na odpowiednim rozmieszczeniu we wnętrzach (tj. w przestrzeni o stałych cechach) elementów o niestałych cechach, jak meble, źródła oświetlenia etc. O tym, że nie jest to sprawa prosta, mogło przekonać się wielu z nas, przebywajac we wnętrzach czy mieszkaniach, gdzie wszystko było niby na „swoim” miejscu, każdy element z osobna bez zarzutu, a mimo to, dawało się odczuć wyraźna trudność w nawiązaniu kontaktu z innymi ludźmi.

Cechy „przestrzeni przyciagającej” nie są w każdym przypadku wartościa nadrzędna, jak również „ucieczkowość przestrzeni”nie jest z góry rzeczą złą. Niewątpliwie pożądana jest między nimi równowaga, tzn. takie dostosowanie zaprojektowanej przestrzeni do funkcji życiowych człowieka, aby poprzez jej różnorodność umożliwi człowiekowi swobodny wybór uczestnictwa bądź w przestrzeni ucieczkowej, bądź w przestrzeni przyciagającej.

Wzory percepcji przestrzeni o zmiennych cechach wykazuja podobną podatność na wpływy międzykulturowe, co wzory percepcji przestrzeni o stałych cechach. Dodatkowo przestrzeń będąca przestrzenią o stałych cechach w jednej kulturze może być uważana w innej kulturze za przestrzeń o półstałych cechach i odwrotnie. W Japonii np. ściany sa elementami ruchomymi, zmieniającymi swe własności w miarę rozwoju dziennej aktywności użytkowników, a więc są elementami 
o półstałych cechach. Tymczasem w naszej kulturze ściany sa elementami stałymi. Zmiana funkcji i znaczenia przestrzeni w Japonii dokonywana jest poprzez zamykanie, otwieranie lub przesuwanie ścian. W naszej kulturze efekt ten uzyskiwany jest poprzez swobodne przemieszczanie się z jednego pomieszczenia do drugiego lub z jednej części pomieszczenia do innej w zależności od formy aktywności, a więc w zależności od tego, czy jest, to spożywanie posiłków, sen, procesy socjalizacyjne etc.

Kultura chińska dostarcza dodatkowych informacji o różnicach w znaczeniu czynnika przestrzennego. To, co dla Chińczyka jest stałym elementem w przestrzeni, Europejczycy skłonni są traktować jako cechę zmienną. Wybór krzesła przez gościa w domu chińskim uważany jest przez gospodarza za afront, a przemieszczenie $\mathrm{w}$ przestrzeni tego elementu wyposażenia mieszkania (uważanego za stały element przestrzeni) może nastapić co najwyżej za, jego wyraźnym przyzwoleniem Europejczycy są w tym względzie bardziej liberalni i potwierdzają to codzienne obserwacje, dostarczając informacji, że np. krzesło w naszej kulturze jest elementem zmiennym przestrzeni w różnym stopniu nasilenia oraz zdeterminowanym kontekstowo. Wiele osób ma trudności z wyborem miejsca, na którym można usiąść w obcym domu, w urzędzie, czy też w innym miejscu Wszystko to świadczy o tym, że wzory przestrzeni są determinowane zarówno wzorami kulturowymi większych społeczności, jak i zmiennymi w czasie wariacjami mikrokulturowych wzorów, umożliwiających jednostce zachowanie swojej odrębności.

\section{Przestrzeń nieformalna}

Najważniejszą kategorią w antropologii przestrzeni jest tzw. przestrzeń nieformalna. Oznacza ona dystans między ludźmi, jaki wytwarza się na gruncie kulturowo zdeterminowanych wewnętrznych wzorów przestrzeni. Trzeba stwierdzić, że wobec doniosłości elementu przestrzennego w tworzeniu się ugrupowań ludzkich zarówno psychologia, socjologia, jak antropologia poświęciły temu czynnikowi wiele uwagi.

Przechodząc do zarysowania pewnych form udziału przestrzeni w procesach i wytworach społecznych, odróżnić musimy od razu dwa punkty widzenia. Pierwszy - to ujmowanie wielości ludzkiej w pewne całości przez obserwatora, który może się znajdować wewnątrz niej lub na zewnątrz. Takie czy inne rozmieszczenie ludzi w przestrzeni bywa dla osoby obserwującej podstawa widzenia ich jako pewnego zbioru, pewnej grupy. Temu subiektywnemu punktowi widzenia przeciwstawić można punkt widzenia obiektywny. Mianowicie fakt takiego czy innego rozmieszczenia ludzi w pewnym obszarze może stać się punktem wyjścia dla powstania między nimi kontaktu psychicznego, pewnej więzi, i to niezależnie od tego, czy jakiśs obserwator widzi ich jako jedną grupę, czy też nie.
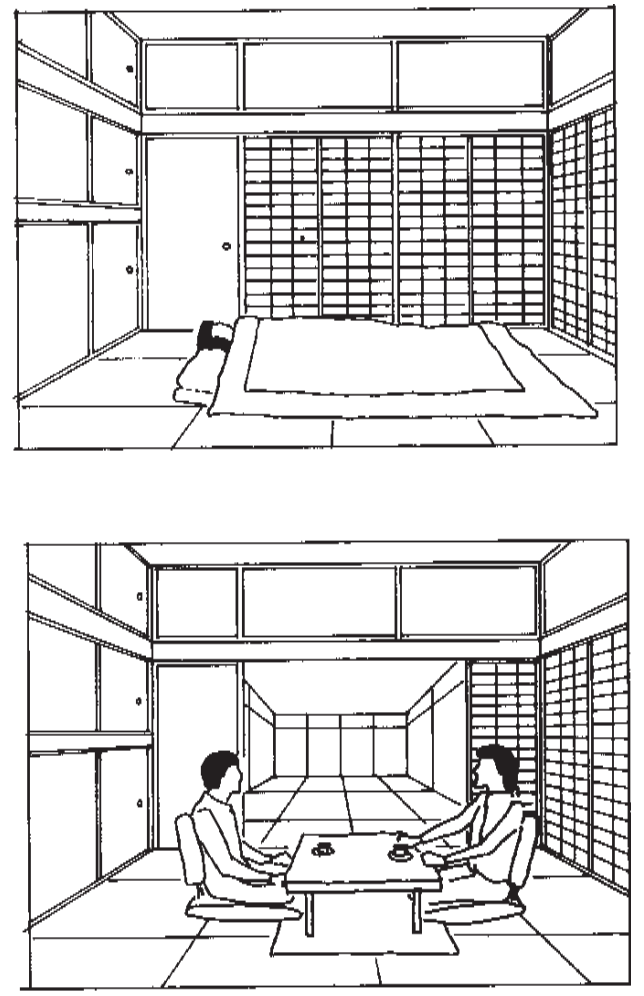

Przykład domu japońskiego zmieniającego funkcję w trakcie dnia.

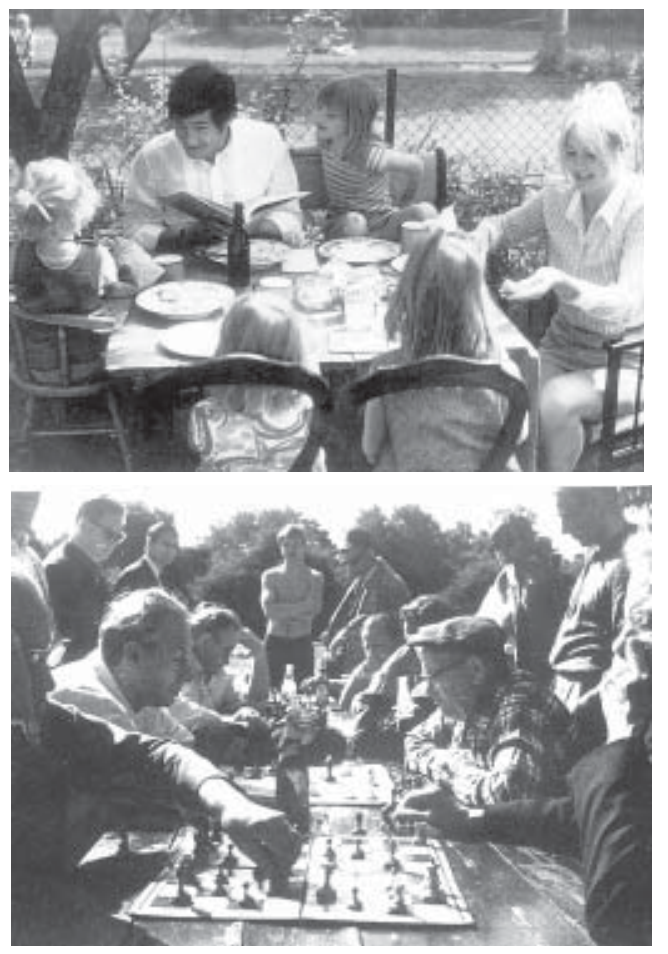

W świecie ludzkim najważniejsze sa kontakty twarzą - w twarz. Stąd też stół jest najstarszym i najbardziej niezbywalnym terytorium wspólnym dla najmniejszych zbiorowości ludzkich, jakimi są grupy rodzinne, nieformalne, spotkaniowe. 


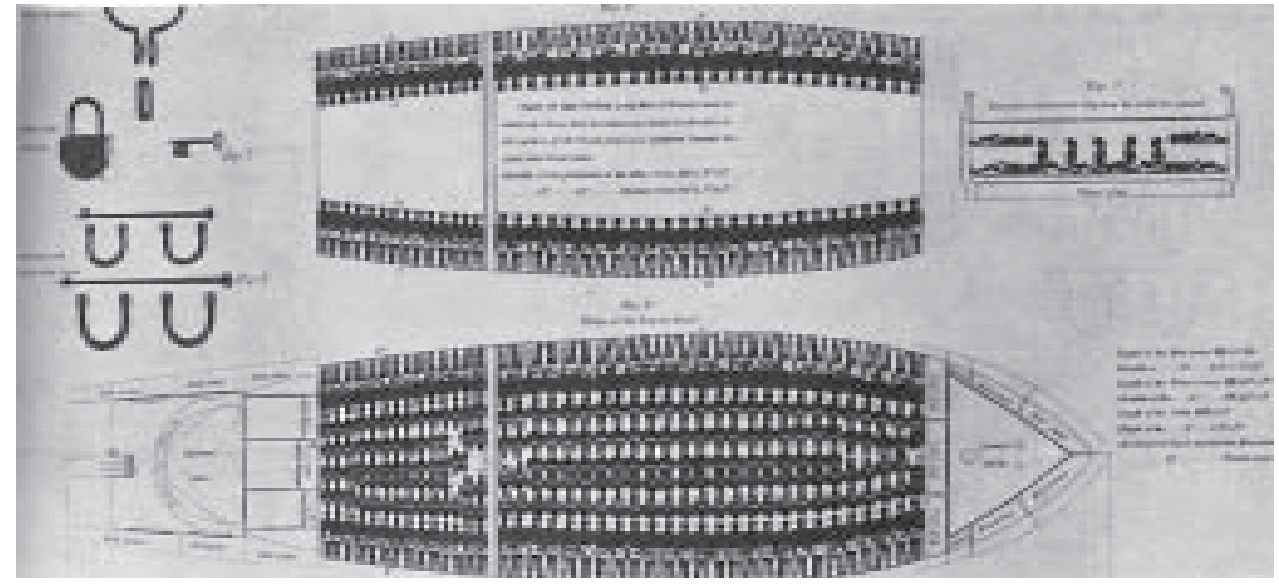

Projekt łodzi do transportu niewolników z Afryki jest skrajnym przykładem przestrzennego rozmieszczenia ludzi wg kryterium obiektywnego, jakim jest maksymalizacja wykorzystania powierzchni. Ludzie w tym przypadku traktowani byli wyjątkowo przedmiotowo.

downictwie mieszkaniowym zabiegiem, u podstaw którego legło powyższe założenie. Ale analogia miedzy ujmowaniem przestrzennym ludzi i dowolnych przedmiotów fizycznych ma swoje granice. Owa geometryzacja zbioru ludzkiego nie jest prawie nigdy pozbawiona odcienia czegoś sztucznego i nie może być nadużywana. Zresztą geometryzacja zbiorów ludzkich, np. w architekturze, poprzez wprowadzenie normatywów M natrafiła na wyraźny opór społeczeństwa, który właściwie przekreślił praktyczne wykorzystanie zalet, jakie przyświecały projektodawcom koncepcji, tj. przyspieszenie procesu zaspokojenia potrzeb mieszkaniowych, demokratyzacja warunków życia oraz potanienie kosztów. Ludzie wszystkimi możliwymi sposobami dążą tylko do formalnego zadośćuczynienia pewnym wymogom objęcia w posiadanie mieszkania, w którym zgodnie z normatywem „przymusowo” powinny zamieszkiwać dwie, trzy, cztery lub pięć osób.

Nawet tam, gdzie geometryzacja zbioru ludzkiego jest bardziej naturalna, jak np. w trakcie wspólnego zamieszkiwania w trakcie klęsk żywiołowych, w marszach lub pochodach, musi się liczyć z człowiekiem jako z przedmiotem swoistym. Zachowane muszą być minimalne dystanse i warunki prywatności. Idacy w pochodzie ludzie muszą znajdować się we wzajemnych odstępach, które nie są dyktowane względami formalno-przestrzennymi, lecz ponadto faktem, że elementem związanym w pewną formę przestrzenną są właśnie ludzie. Zmasowanie osób, które się tu dokonuje, musi w pewnych przynajmniej granicach liczyć się z zasadami naturalnego grupowania się ludzi kontaktujących ze sobą w przestrzeni.

Fakty, o które tutaj chodzi, zaznaczają się wyraźniej wtedy, gdy rozpatrzy się je na tle psychologii rozwojowej. Psychologia rozwojowa mówi, że dzieci do dwóch lat nie wyróżniaja jeszcze należycie człowieka spośród przedmiotów martwych. Dziecko dwuletnie bez żenady posłuży się towarzyszem jako podpora, jakby było przedmiotem fizycznym (,dezanimizacja” w przeciwieństwie do „animizacji”). Z czasem pod wpływem wychowania wytwarza się u dziecka zdolność właściwego ustosunkowania się do człowieka jako istoty swoistej, wymagającej respektu, w

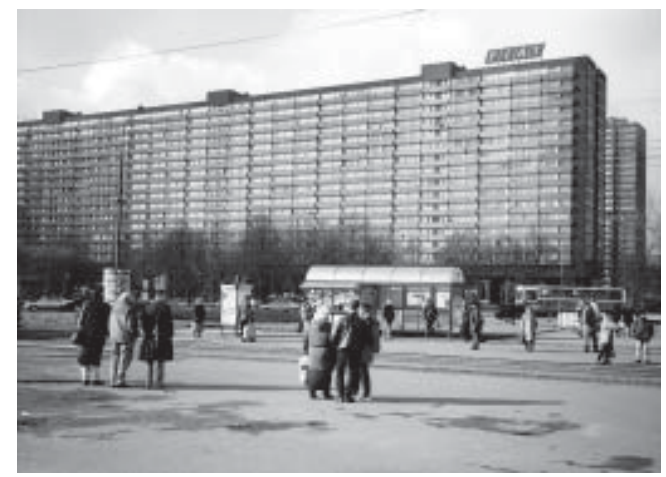

Spółdzielczy normatyw mieszkaniowy polegał głównie na geometryzacji przestrzeni życiowej człowieka. Absurdalność wyliczeń minimalnego normatywu mieszkalnego polegała na tym, że za życia człowiekowi przysługiwało mniej powierzchni niż na cmentarzu. 


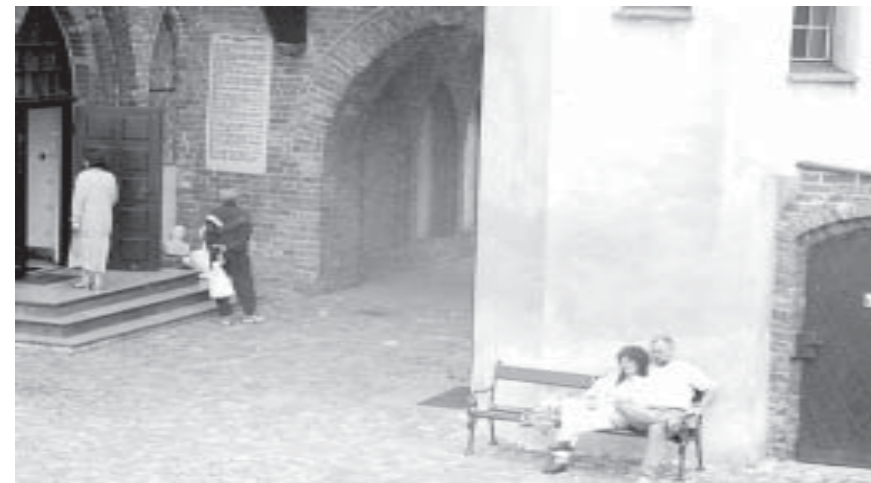

W świecie dorosłych inwazja prywatności jest czasami zachowaniem pożądanym.

skład którego wchodzi zasada, zachowania minimalnego dystansu przestrzennego. Głównym dystansem utrzymywanym przez dziecko z dorosłymi jest tzw. dystans intymny. Obowiąuje on najczęściej w stosunku do matki lub opiekuna. Jest to dystans, dzięki któremu inne osoby oceniane sa niedwuznacznie jako bliskie, a utrzymywany jest za pośrednictwem zapachu, temperatury ciała - ogólnie organów zmysłowych. Przestrzeń ta według Halla ma około $40 \mathrm{~cm}$ (Hall, 1969). Oprócz dystansu intymnego Hall wyróżnia jeszcze dystans socjalny, wynoszący około $300 \mathrm{~cm}$ oraz publiczny - ponad $300 \mathrm{~cm}$.

Kontaktujaccy się ze sobą w przestrzeni ludzie, jeżeli kontakt ten ma być naturalny i stanowić należyta podstawę kontaktu psychicznego w zwykłych sytuacjach społecznych, ustawiaja się w pewnej odległości, tak aby nie było ani zbyt blisko, ani zbyt daleko. Obowiazuje przy tym reguła stawania twarza w twarz, tak by stojący naprzeciw siebie mogli widzieć się nawzajem (patrzeć sobie w oczy). Reguła ta stosuje się z pewną modyfikacją również do grup wieloosobowych. Powyższe względy tłumaczą uprzywilejowanie, którym przy grupowaniu się przestrzennym ludzi cieszy się koło. Kołowe usytuowanie grupy pozwala wszystkim uczestnikom zachować względem siebie pozycję zbliżona do twarzą w twarz. Tak więc geometryzacja zbiorów ludzkich musi liczyć się $\mathrm{z}$ zasadami naturalnego przestrzennego grupowania się ludzi i z tym że grozi jej ciagle naruszanie tych zasad.

Bardziej szczegółowa analiza wykazuje, iż na zasadę zachowania właściwego dystansu przy obcowaniu ludzi składa się więcej warstw. Jedną z nich można by określić jako fizjologiczno-biologiczna. Ta warstwa była badana najdokładniej, gdyż w badaniach tych posługiwano się zwierzętami. Wyniki badań były przenoszone na populację ludzka. Przykładem takich badań są m.in. badania Hedigera na ptakach i ssakach. Wyróżnił on między innymi dystans lotu, dystans krytycz-

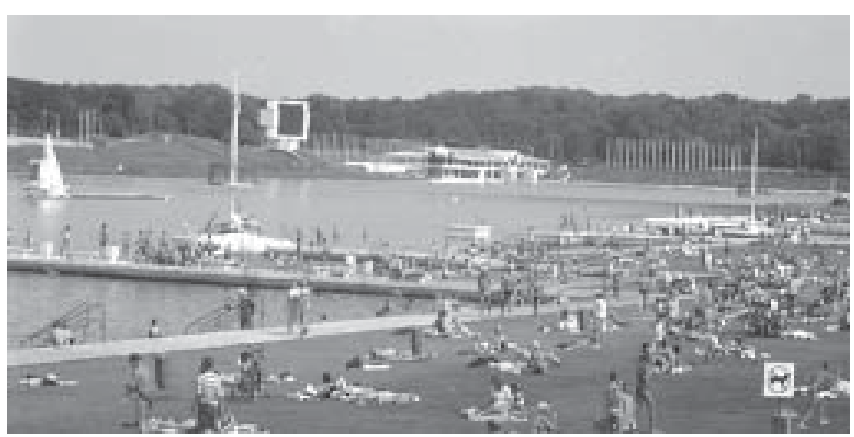

Ludzie we wzajemnych kontaktach starają się zachować w stosunku do siebie dystans odpowiedni do sytuacji i wymaganego szacunku. Zasady tutaj obowiązujące są takie same jak w świecie zwierzęcym. ny, dystans osobniczy oraz dystans społeczny. W przypadku człowieka wchodzi w gre przy kontakcie przestrzennym druga warstwa, już specyficznie ludzka, związana z zasadą szacunku człowieka dla człowieka. Właśnie ów szacunek wymaga zachowania odpowiedniego dystansu, który w pewnych granicach zwiększa się równolegle ze wzrostem szacunku. Zasada zachowania należnego szacunku ulega zniesieniu w sytuacjach skrajnych, jak np. zmęczenia, paniki czy w środkach komunikacji. 

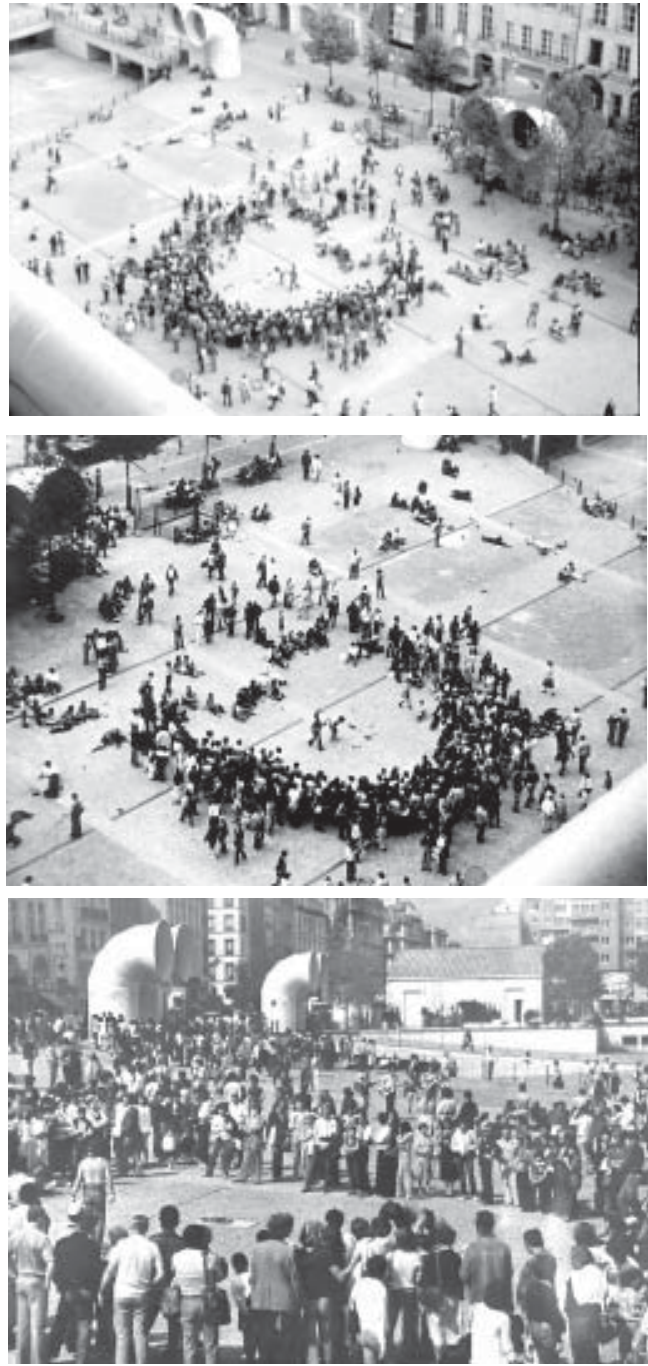

Paryż -- plac przed Centrum Kulturalnym Pompidou. Reguła kołowego usytuowania grupy jest nie tylko regułą demokratyczna, ale reguła podtrzymująca spontaniczne zachowania. Jakość miejsca i rozwiązania architektonicznego można mierzyć zdolnościa do spontanicznego wyzwalania w przypadkowych społecznościach ludzkich kołowej organizacji grupy.

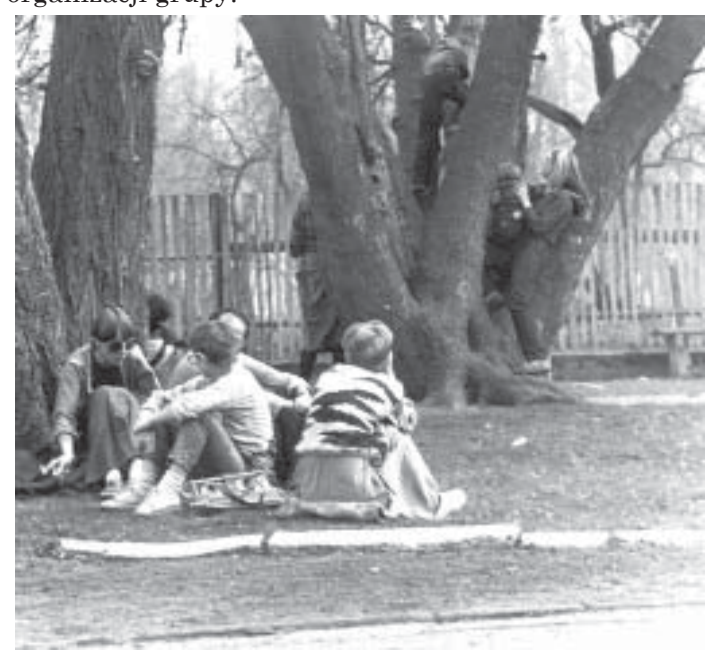

Jak już wspomniano, „naturalne” przestrzenne grupowanie się ludzi zakłóca geometryzacja, która bywa zazwyczaj czymś sztucznym, poniekąd z zewnątrz narzuconym ograniczeniem (komenda wojskowa). Niejednokrotnie jednak zjawisko takie dokonuje się samorodnie i ma wtedy swoiste społeczne znaczenie. Istotę tłumu w oczach obserwatora stanowi nie tylko sam fakt wielości, ale ponadto rodzaj przestrzennego rozmieszczenia uczestników zbioru. Charakterystyczne dla tłumu czy zbiegowiska jest swoiste przestrzenne zagęszczenie. Ludzie stanowiący tłum nie mogą znajdować się od siebie zbyt daleko. Co więcej, zwłaszcza w przypadku tłoku, zaczynaja w pewnym momencie traktować siebie jak rzeczy (niesamowitość tłumu).

Z subiektywnym spojrzeniem na przestrzeń wiąże się ściśle obiektywne spojrzenie. Otóż zanalizowane uprzednio ustawienie ludzi twarza w twarz ma duże socjogenne znaczenie. Znajduje to wyraz w fakcie, iż szereg psychologów dzieli grupy ludzkie na dwa zasadnicze rodzaje: grupy, których osnowa jest bezpośredni kontakt ich członków i które nazywane sa grupami twarzą w twarz oraz grupy oparte o kontakty pośrednie. Grupy, których członkowie maja możność częstego bezpośredniego spotykania się ze sobą odgrywaja w strukturze społecznej swoista, ważną rolę. Należą tu grupy rodzinne, sasiedzkie itp. Grupy o takiej strukturze zajmuja genetycznie pierwsze miejsce w rozwoju społeczeństwa. Grupy oparte o kontakty pośrednie to m.in. tzw. stowarzyszenia.

Każda przestrzeń, która użytkuje człowiek, nigdy nie jest przestrzenia czysto geometryczna, lecz posiada swoiste społeczne nacechowanie. W przestrzeni geometrycznej wszystkie kierunki i wymiary nie są z reguły sobie równorzędne. Jest rzeczą nieobojętna, co uzna się za górę, a co za dół, co jest z przodu, a co znajduje się w tyle. Tej obojętnej, jednorodnej przestrzeni przeciwstawia się przestrzeń osobowa, inaczej przestrzeń personalna (der personale Raum-Stern, personal space). Przestrzeń personalna jest swoista strefa buforową między jednostką a poszczególnymi ożywionymi i nieożywionymi obiektami przestrzeni. Strefa ta jest większa w stosunku do ludzi niż w stosunku do obiektów nieożywionych.

Przestrzeń personalna kształtuje się w miarę jak konstytuuje się nasza osobowość. Poszczególne osie i kierunki ulegają tu zróżnicowaniu i w związku z tym otrzymują różne wartości. Przód i tył zmieniaja swoja pozycję przy obrocie osoby, a są niejednakowo ważne (dostojne). To co jest ważne, ludzie chcą mieć przed soba, a to co jest za nimi staje

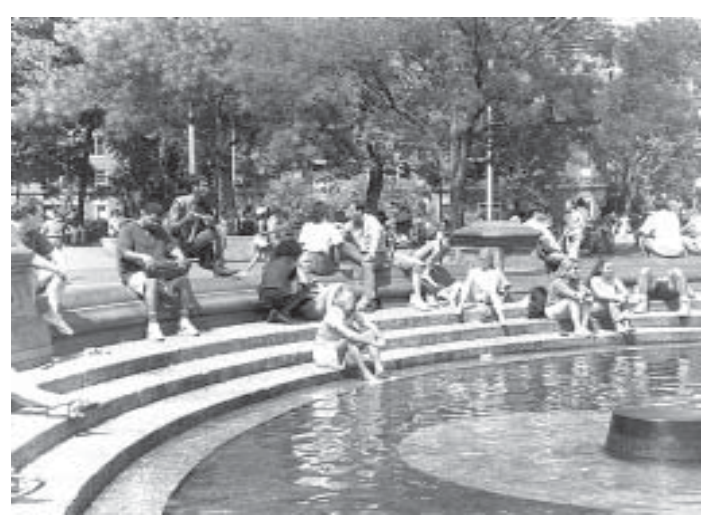
się niepewne, obce. Podobnie dół jest gorszy od kierunku ku górze. Analogicznie dzieje się z prawą i lewą ręka, i strona. Zgodnie z powyższą zasada mańkut wydaje się osobą upośledzona, a z kolei honorujemy pewne rzeczy i osoby przez to, że

W przestrzeni odgeometryzowanej, jaka tworzy środowisko naturalne, grupy nieformalne i spotkaniowe w naturalny sposób przyjmują organizację kołowa, w której komunikacja ma charakter twarzą w twarz. Kołowa organizacja grup ludzkich może być „wymuszona” odpowiednim ukształtowaniem architektonicznym. Ale w takim przypadku, nie jest to warunek wystarczający do nawiązywani kontaktów twarzą w twarz. 


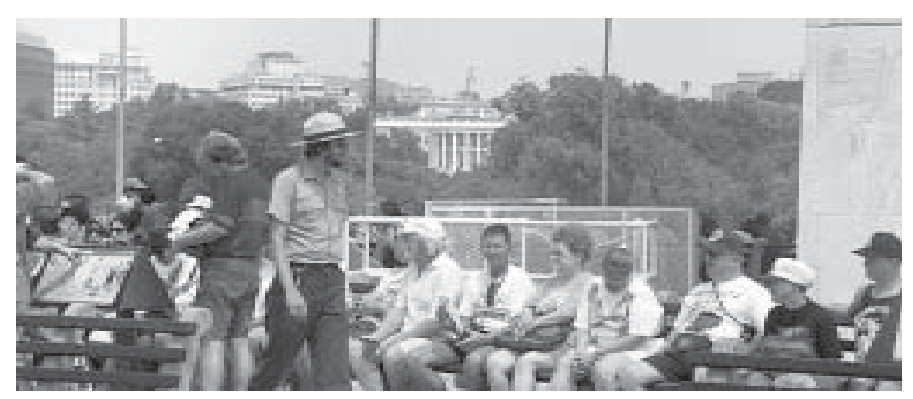

Zasada zachowania należnego szacunku w sytuacjach skrajnych jak np. $\mathrm{w}$ zmęczeniu ulega zniesieniu nawet $\mathrm{w}$ tak restrykcyjnych kulturach jak amerykańska.
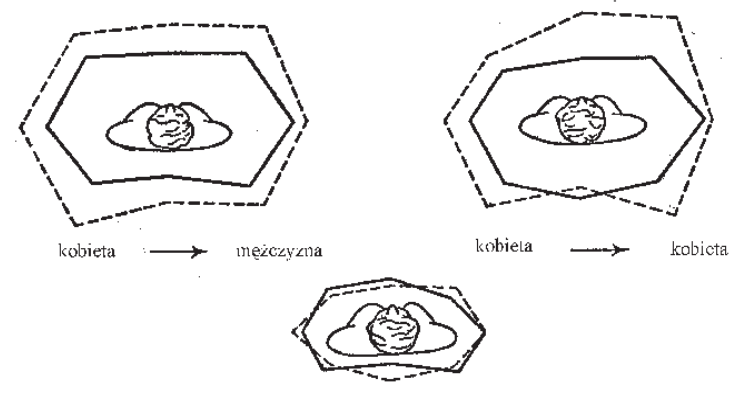

kobiet:a

obiekt fizyerny

$$
\begin{array}{ll}
--- & \text { schizofrenicy } \\
- \text { - nie sclizelremicy }
\end{array}
$$$$
\text { l stopa }
$$

Przestrzeń personalna jako dystans zbliżenia. W odniesieniu do obiektów fizycznych jest on mniejszy, niż w stosunku do obiektów ożywionych. Schizofrenicy zachowują większy dystans aniżeli nie schizofrenicy

umieszczamy je po naszej prawej stronie. Społeczeństwo nie tylko przyjmuje to personalne zróżnicowanie do wiadomości, ale czyni je zasadą społecznego obcowania jednostek. Ustosunkowanie przestrzenne nabiera przy tym symbolicznego znaczenia. Po prawej, lepszej stronie ustawia się tego kogoś, kogo się bardziej szanuje, jako pierwszego przepuszcza się również kogoś dostojniejszego od nas. Ta przestrzenna symbolika obejmuje też oprócz żywych osób przedmioty, którym przypisuje się większe znaczenie społeczne. Świątynie i pomniki ustawia się na miejscach podwyższonych, w górę też podnosi się flagi. Symboliką tłumaczy się obowiązujący w wielu metropoliach świata przepis ograniczający wysokość zabudowy. Na przykład w Waszyngtonie obowiąuje zakaz wznoszenia budynków przewyższających Kapitol, a w Sztokholmie wyższych od pałacu królewskiego.

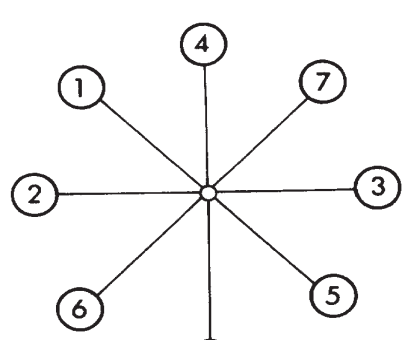

(8)
Diagram przedstawiający domniemane okragłe pomieszczenie, gdzie każdemu promieniowi odpowiada jedno wejście. Załóż, iż znajdujesz się w pozycji oznaczonej 8. Załóż, że na każdym z ośmiu promieni znajduje się jakaś osoba podchodząca do Ciebie. Zareaguj poprzez wskazanie miejsca, w którym chciałbyś tę osobę zatrzymać. Wskazany punkt na osi jest miejscem, w którym myślisz, że tracisz poczucie komfortu. Po oznaczeniu dystansów komfortu na wszystkich ośmiu promieniach, połącz linią poszczególne punkty. Królewski. Wyjątek przysługiwał jedynie kościołom.

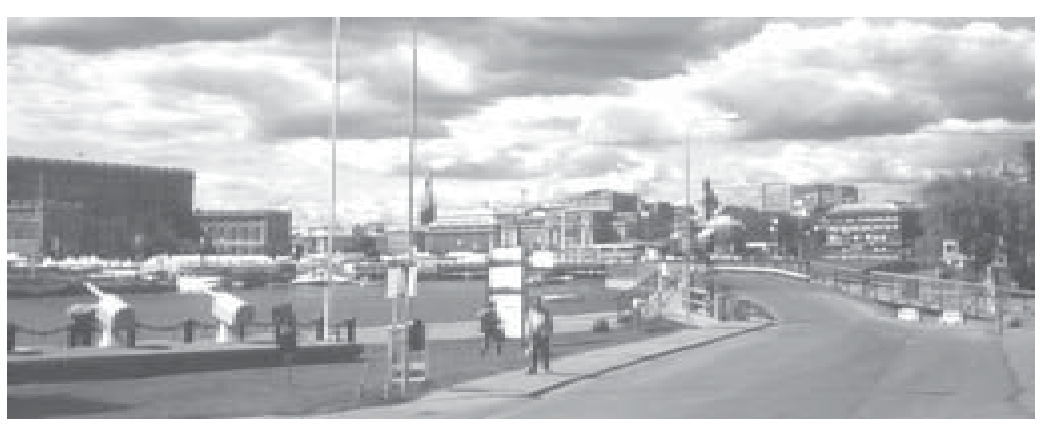

Sztokholm: Specyfikę a zarazem urodę miasta ukształtowały przepisy prawa budowlanego z 1874 roku zakazujące stawiania budynków przewyższających Pałac

Sekta Moona jest przykładem rozmycia kryterium podziału na grupę formalną i grupę nieformalną. Sytuacja ukazująca ślub kilku tysięcy par ukazuje przemieszanie kryteriów charakteryzujących rodzinę, zgeometryzowany tłum, oraz stowarzyszenie. Ludzie, którzy na zdjęciu zawierają związek „małżeński” widzą się po raz pierwszy w życiu.

Milionowy tłum ludzi wyczekujących na koncert muzyki pop w Waszyngtonie: Istotę tłumu w oczach obserwatora stanowi
nie tylko sam fakt wielości, ale ponadto rodzaj przestrzennego rozmieszczenia uczestników zbioru.
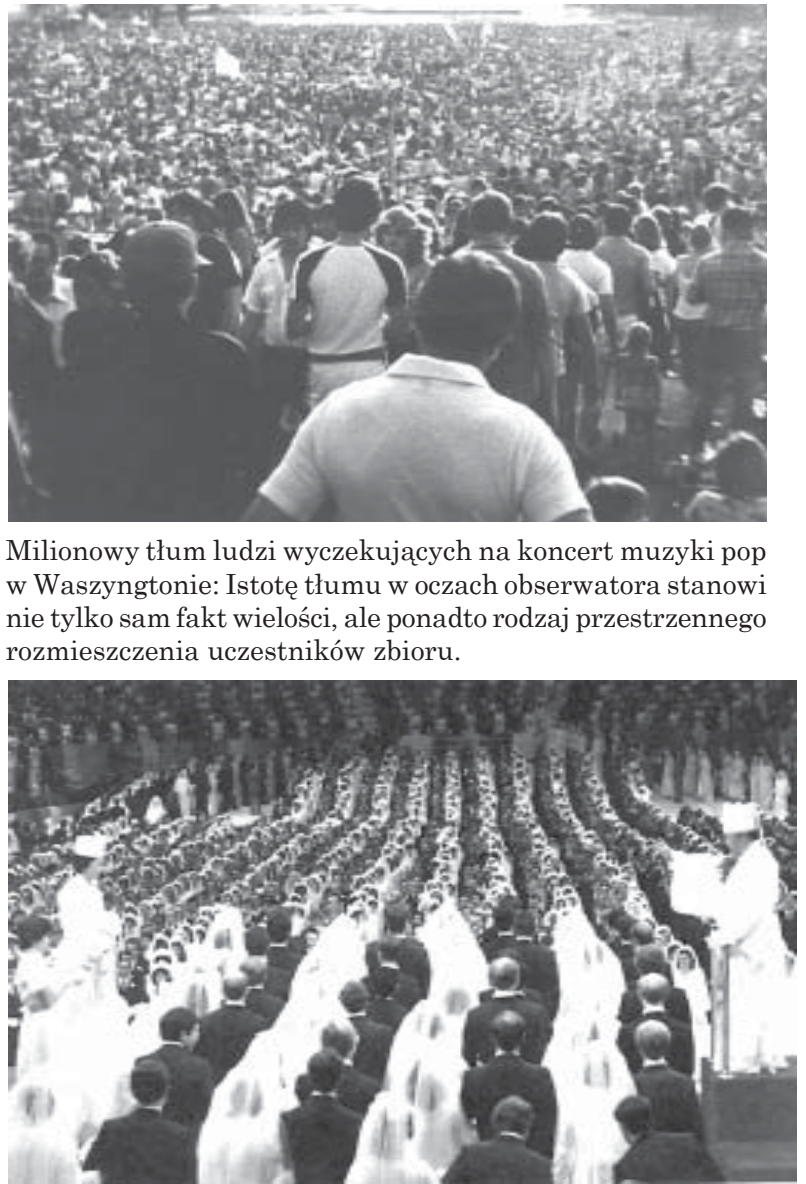


\section{PRZESTRZEŃ, TERYTORIALNOŚĆ A ZMIENNOŚĆ ZACHOWAŃ}

\section{Obszar i jego granice}

Symbolika przestrzenna obejmuje jeszcze inne niż omówione i wzmiankowane poprzednio stosunki. S. Ossowski zwraca uwagę na osobowe znaczenie przymiotnika bliski, który wiążé i identyfikuje poniekąd styczność przestrzenną ze stycznością psychiczną. Odnosi się to m.in. do omawianego wcześniej dystansu przestrzenno-społecznego.

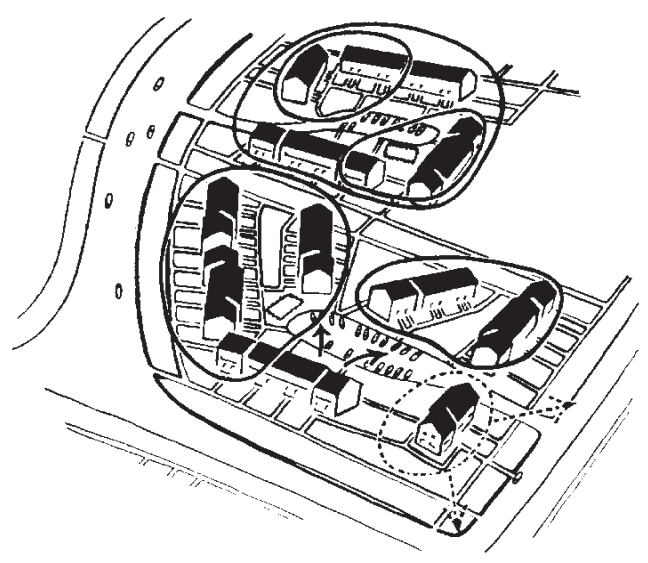

Zasada bliskości przestrzennej i styczności psychicznej grupuje przestrzennie mieszkańców. W badaniu Whyte'a (1956) budynki zwrócone w stosunku do siebie twarzą w twarz tworzyły specyficzne podwórka, którym odpowiadały specyficzne wzory zachowań mieszkańców, niezależnie od tego, kto w danym momencie był członkiem danej społeczności.

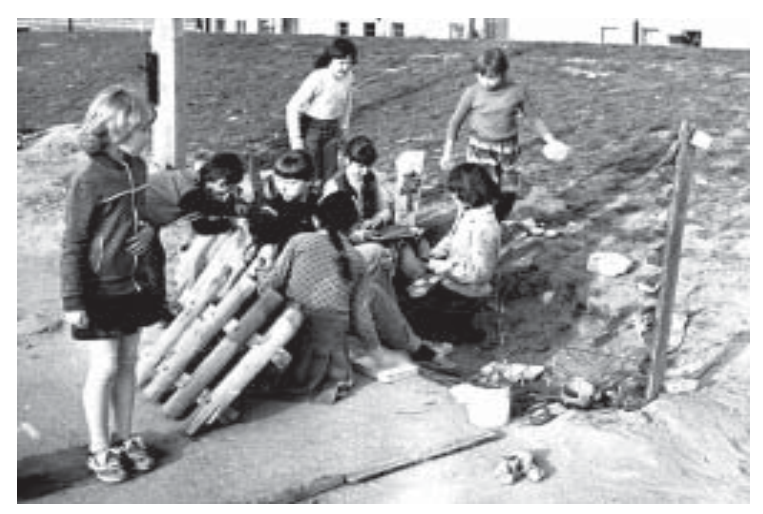

W ramach rozważań dotyczących roli przestrzeni omówione teraz zostanie zagadnienie zamkniętego obszaru, jego granic i wpływu na zachowania ludzi. Zagadnienie to nie jest nowe i spotykamy się ż nim na każdym kroku zwłaszcza w przypadku środowiska przestrzennego, które celowo jest kształtowane przez człowieka. W takim przypadku mamy zawsze tendencję do ujmowania przestrzeni jako zdefiniowanej fizycznymi barierami poddającymi restrykcji sferę motoryczna, poznawczą i słuchową człowieka.

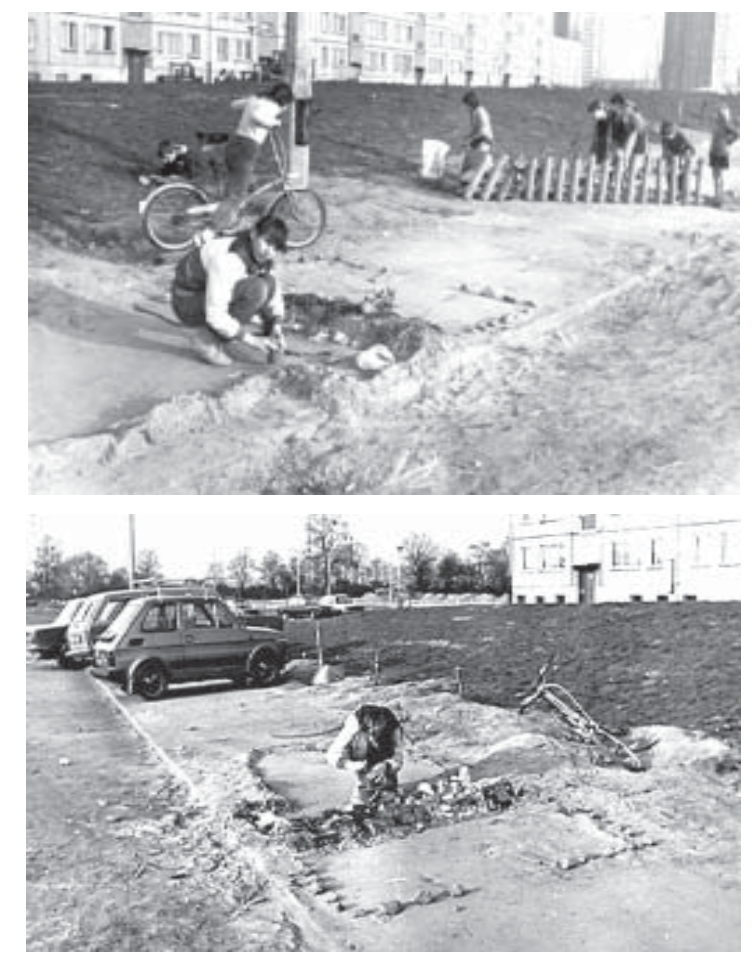

Jak silnie i wcześnie idea granicy jest wbudowana w umysł człowieka, świadczy o tym najlepiej zabawa dzieci. Z różnych odpadów budują przede wszystkim „swoje” terytoria odgradzając się od reszty symboliczną granicą.

W rzeczywistości jednak przestrzeń zaprojektowana przez człowieka jest również zdefiniowana zachowaniami ludzi ją użytkujacych (okupujących). Wiele jest cech charakteryzujacych zachowanie przestrzenne, ale najbardziej charakterystyczne noszą ogólną nazwę terytorialności (od Davida Stea - theory of territoriality) lub zachowań terytorialnych.

Tu zaś zarówno zoologia, etnologia, socjologia i psychologia ujawniaja ciekawe zjawiska, których wyjaśnienie sprawia badaczom niemały kłopot. W opisie zachowań organizmów niższych od człowieka znane są indywidualne i zbiorowe terytoria, w których zwierzęta mają inklinacje do zachowań agresywnych w stosunku do intruzów przekraczających ich granice. 


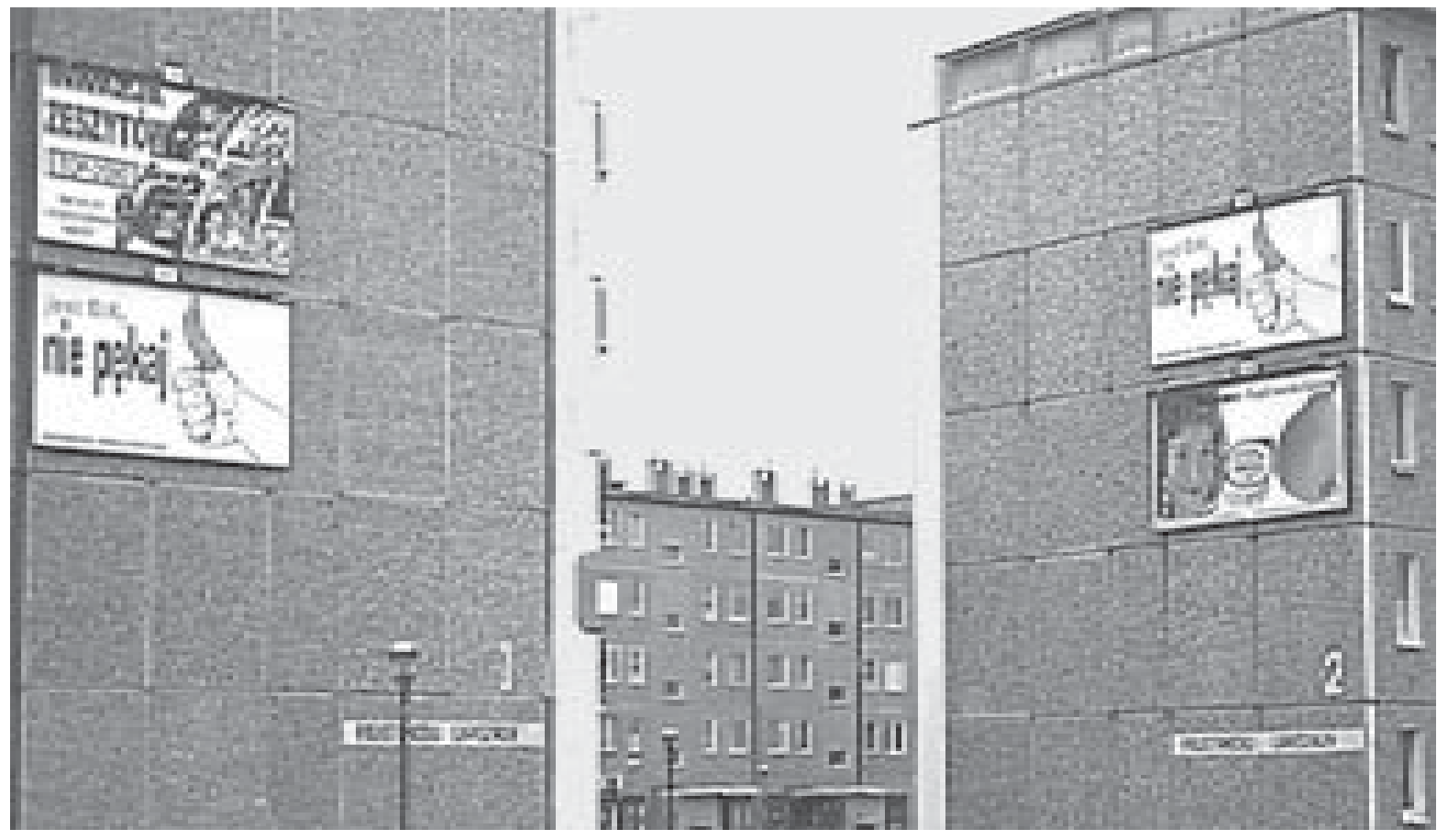

Zawłaszczanie przestrzeni może przybierać formę grabieży, jak i formę pozytywnej działalności prospołecznej. Tworzenie w nadmiernie zdemokratyzowanej przestrzeni blokowiskowej enklaw terytoriów prywatnych należy uznać za przejaw pozytywnych tendencji. Z kolei zawłaszczanie przestrzeni przez niektóre instytucje reklamowe jest antyspołecznym działaniem agresywnym, nie pozostawiającym najmniejszych złudzeń „kto tutaj rządzi”.

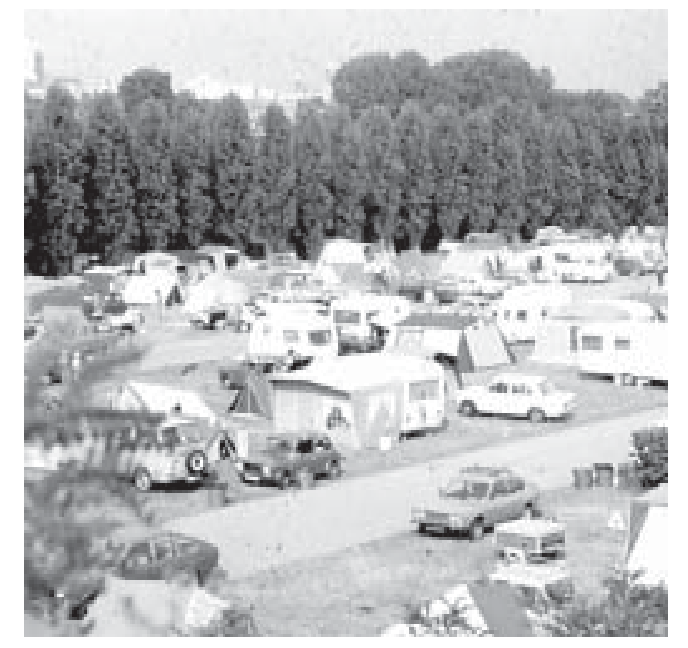

Dystanse wyznaczające indywidualne terytoria nakazują zachować odpowiednią tj. akceptowalna odległość.

tak samo jak inni, użycie podę i myślącym form zachowania nie jest możliwe. Niemniej jednak zachowania terytorialne, tzn. dążenia do posiadana i okupowania jakiegoś kawałka przestrzeni, są u ludzi tak samo rozpowszechnione, jak u zwierząt. Przykładem tego są zachowania gangów ulicznych, spory sąsiedzkie o miedzę, dążenia mieszkańców współczesnych osiedli mieszkaniowych do zapewnienia sobie prywatności i izolacji akustycznej mieszkań. Zarówno u zwierząt, jak i wśród ludzi terytorialność pełni funkcję zbliżoną do tzw. posiadania seksualnego. Dążenia terytorialne przybierają formę zawłaszczania przestrzeni. 
Najbardziej prymarną formacją sakrum jest „święty krag”, który jest niczym innym jak zamkniętym obszarem, pojawił się w przestrzennej symbolice sakrum na długo wcześniej, zanim człowiek nauczył się zamykać sakrum w świątyniach.

W różnych wierzeniach i przesądach granica, zamykająca pewien teren albo oddzielająca go od innych terenów, uzyskuje często znaczenie jakiegoś magicznego tworu posiadającego swoiste walory i przywileje. Przesunięcie jakiejś osoby czy rzeczy poza taka granicę ma charakter jak gdyby nadania jej innej formy bytu czy też sprowadzenie jej do niebytu. Polski psycholog S. Szuman zauważył, że dzieci w pewnym wieku systematycznie rzucają różne przedmioty poza siebie. Ma to dla nich prawdopodobnie to znaczenie, że w ten sposób powodują zniknięcie przedmiotów, sprowadzając je do niebytu.

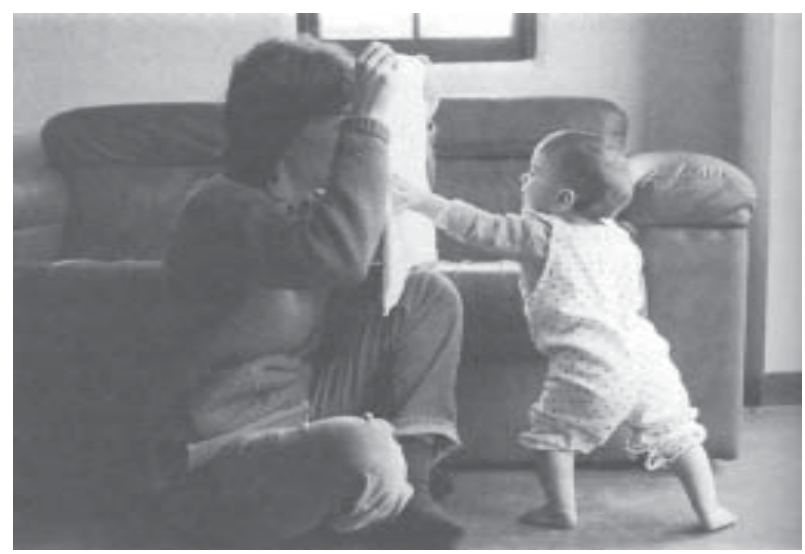

Popularną grą uprawianą przez matki na całym świecie jest gra w „akuku”. Pozwala ona rozwinąć u dzieci pojęcie obecności obiektu, mimo zniknięcia go z pola widzenia. Według J. Piageta nabycie umiejętności dostrzegania przedmiotu nawet wtedy, gdy znika on z pola widzenia jest najważniejszym osiągnięciem w okresie wczesnodziecięcym.
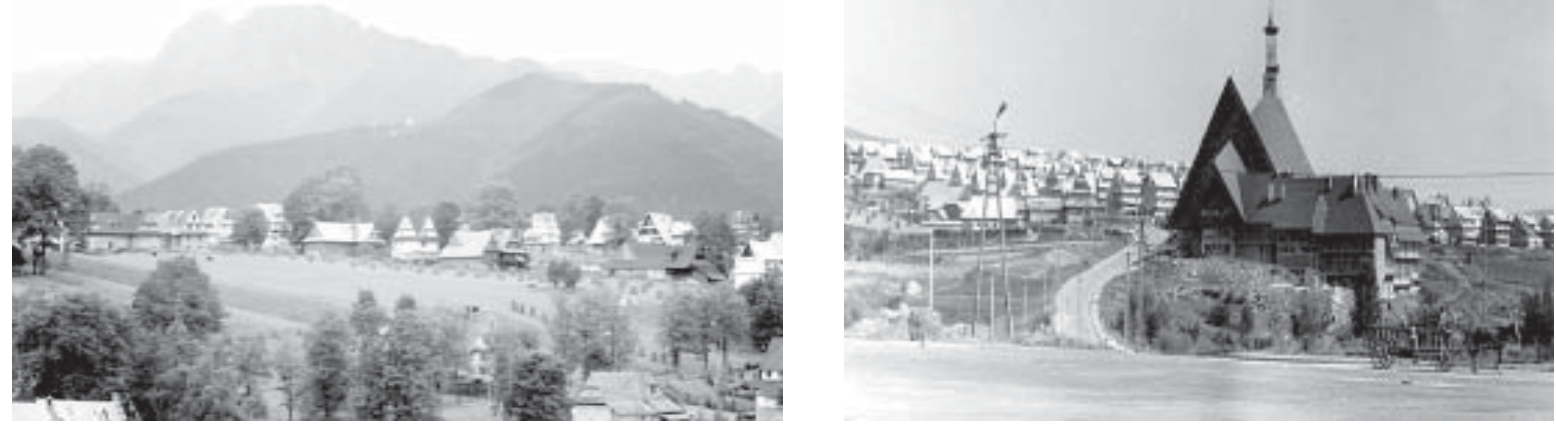

Kulturowy wzór przestrzeni architektonicznej na podhalu jest najlepiej wykształcony w Polsce, ale ulega stopniowej erozji. Nowe Maniowy zachowując wiele elementów tradycji przestrzennej zmodernizowały jednak znacznie stosunki przestrzenno-psychiczne, przez co styl życia upodobnił się do miejskiego.

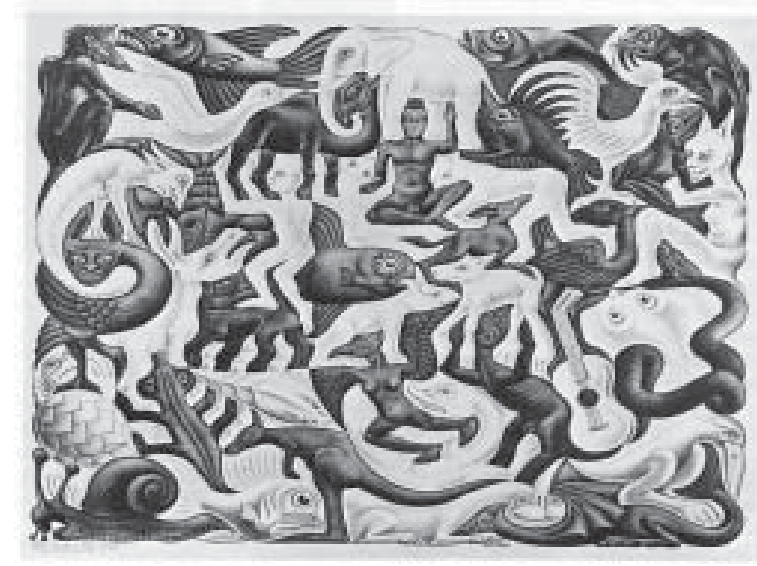

Na obrazie M.C. Eschera można zobaczyć raz białe a raz czarne stwory.
Granica staje się czymś świętym, czego nie można bezkarnie przekroczyć w jedną czy w drugą stronę. Szerpowie w Himalajach zobowiązani są do przestrzegania tej zasady na drodze zakazu budowania swoich domostw w zbyt małej odległości od sąsiada. Niepodporządkowanie się tej zasadzie byłoby równoznaczne z wyłączeniem ze społeczności. Podobne tendencje obserwujemy na wielu obszarach Polski. Przykładem może być problem przekwaterowywania mieszkańców wsi Maniowy położonej na terenie budowanej zapory wodnej w Czorsztynie Mieszkańcy tej wioski mieli przenieść się na wyżej położone tereny, na których wybudowano od podstaw nowa wioskę, spełniającą wszystkie współczesne wymagania prócz jednego, a mianowicie przyzwoitego dystansu między poszczególnymi zabudowaniami. W tym przypadku okazało się, że to, co zadowoliłoby mieszkańca zurbanizowanego regionu kraju, nie jest do zaakceptowania przez mieszkańca Podhala. 
Otóż psychologa interesuje tu pytanie, czy ostateczna przyczyna magicznego niemal znaczenia granicy nie tkwi czasem w zanalizowanym przez E. Rubina psychologicznym prawie dzielenia się naszego pola spostrzeżeniowego - zwłaszcza wzrokowego na figurę i tło. E. Rubin wyjaśnia to prawo za pomocą figury odwracalnej, tj. rysunku który w trakcie oglądania zmienia subiektywnie (tj. w odczuciu oglądającego, a bez jakichkolwiek zmian faktycznych, obiektywnych) swój wygląd: np. narysowane schematycznie pole złożone z dwu czarnych płaszczyzn ograniczających w środku leżącą białą płaszczyznę o pewnym kształcie, raz wydaje się białym kielichem na czarnym tle, to znów dwoma czarnymi konturami twarzy widzianych z profilu na białym tle. Prawo to studiowane było późnej specjalnie przez tzw. psychologów postaci, którzy identyfikują zasadniczo Rubinowskie pojęcie figury z pojęciem postaci.

Rubin zwrócił uwagę na fakt, iż między tłem a figurą (postacia) otoczoną owym

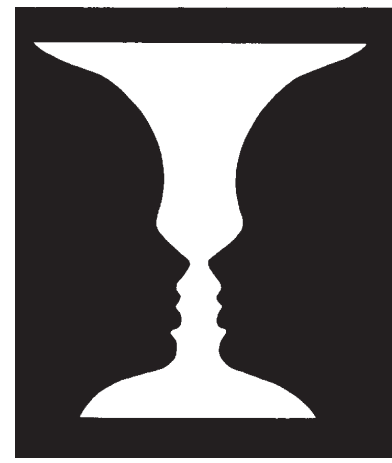

Zjawisko odwracalnego przekształcania się figury w tło. tłem zachodzi szereg psychologicznych antagonizmów. Figura zdaje się być bliżej obserwatora aniżeli tło i posiadać bardziej zwartą niż ono konsystencję. Tło ma budowę jak gdyby bardziej mgławicowa, ucieka poniekąd w nieokreśloną dal i odpycha od siebie uwagę, która przyciaga natomiast figura. Wszelkie zmiany w polu widzenia stają się łatwiej dostrzegalne wtedy, gdy dokonują się wewnątrz figury, aniżeli gdy miejscem ich zjawiania się jest tło. Rzecz jasna, że w związku z tym kontur figury, będący granicą między nią i tłem, nabiera specjalnego znaczenia. Oddziela on bowiem od siebie jak gdyby dwa oddzielne światy, dwa odmienne rodzaje bytu.

Można więc przypuszczać, że fenomen „magicznego koła” jest podniesieniem do poziomu magii właśnie owej zasadniczej strukturalnej właściwości spostrzeżeń ludzkich. A zjawisko „magicznego koła” i zjawisko granicy szerzej pojętej jako „miedzy”, jako linii demarkacyjnej terytorium zajętego przez człowieka to sa rzeczy psychologicznie pokrewne. Przekonanie, że to, co się dzieje poza granica jest antagonistyczne i wrogie, że życie człowieka poza tę granicę czyni go jak gdyby w danej społeczności obcym, że to, co się tam dzieje, już się jakoś nie liczy, zdaje się stanowić rozciagnięcie powyższego psychologicznego prawa na szerszy, społeczny grunt.

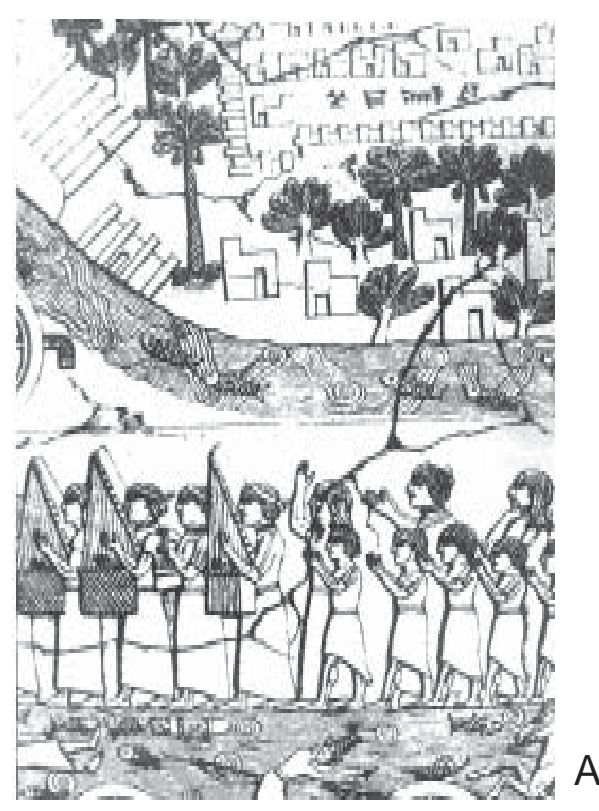

Koło jako pierwowzór zamkniętego obszaru oddzielającego przestrzeń niebezpieczną od bezpiecznej jest prototypem a nawet archetypem bezpiecznej architektury, miasta i urbanistyki. A) Miasto z Gilgamesza. B) Projekt O. Sosnockiego „Okolnica” dla 50 udziałowców. C) W USA w miejscach, w których zagrożenie włamaniami i napadami jest szczególnie duże domy ustawiane sa w formie barykady wokół centralnego placu, dodatkowo ogrodzonej płotem jak palisada. Podobnie jak w innych projektach przed poszczególnymi domkami przewidziano parking, na którym każdy właściciel ma baczenie na swój samochód.

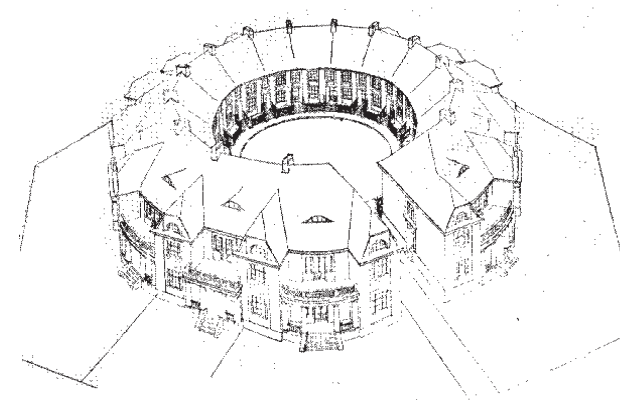

B

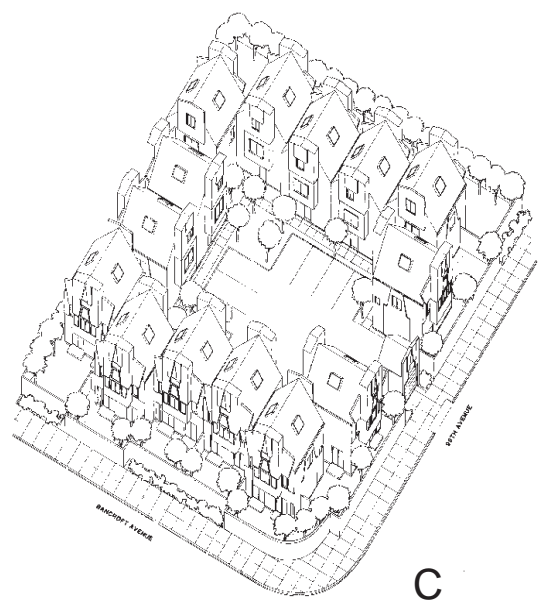




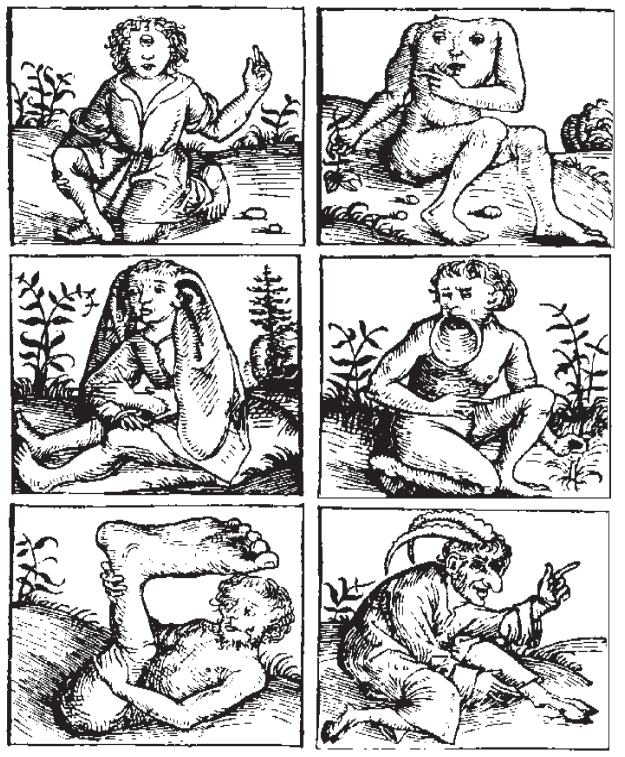

Średniowieczne wyobrażenie ludzi żyjących po drugiej stronie (płaskiej) ziemi. Zainteresowanie społeczno-kulturowymi aspektami środowiska rośnie w miarę rozwoju cywilizacji. Dawniej cywilizacje odseparowane od siebie nie miały wzajemnie o sobie dobrego pojęcia. Dzisiejsze osiagnięcia telekomunikacji nie eliminuja od razu uprzedzeń i stereotypów, ale powoduja, że populacje i regiony geograficzne nie są już sobie tak drastycznie obce.
Trzeba jeszcze uwzględnić, że chociaż w wypadku najbardziej charakterystycznym, który jest poniekąd wypadkiem krańcowym, tło jest materia całkowicie nieuformowana, bezkształtna, może ono w pewnych wypadkach - nie przekreślajacc dominacji figury - być samo w pewien sposób uformowane albo składać się z innych figur, które w danej konstelacji ulegaja jak gdyby pewnemu zamgleniu. Mogą one równocześnie pozostawać z owym przedmiotem (figura) w swoistym związku, mogą dźwigać go, uwypuklać nadawać mu pewien sens. Tło przechodzi w pewien kontekst. Dla nauczyciela klasa szkolna może stanowić tło, a równocześnie kontekst, który sprawia, że jego zachowanie staje się zrozumiałe.

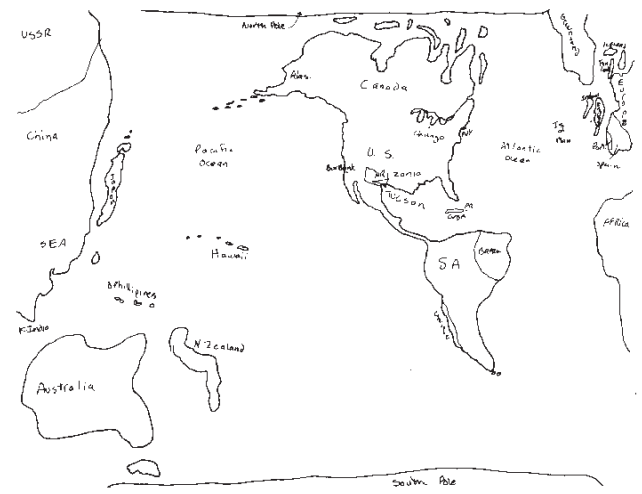

Mapy rysowane przez reprezentantów różnych kultur są dokładne, gdy chodzi o ich własna przestrzeń, ale silenie zniekształcone i rozmyte, gdy w grę wchodza obszary peryferyjne w stosunku do ich własnych zainteresowań.

Zjawisko powyższe jest szczególnie istotne w sytuacjach, w których terytorium jest „własnościa” zbiorową. Dla ukształtowania się wzorca tzw. „zachowań patriotycznych” członkowie zbiorowości nie są bezkształtnym tłem, lecz stanowią kontekst, który sprawia, że zachowania takie stają się zrozumiałe. W szerszym kontekście, którym mogą być inne zbiorowości, takie same zachowania mogą być niezrozumiałe i oceniane negatywnie jako przejaw nacjonalizmu i szowinizmu.
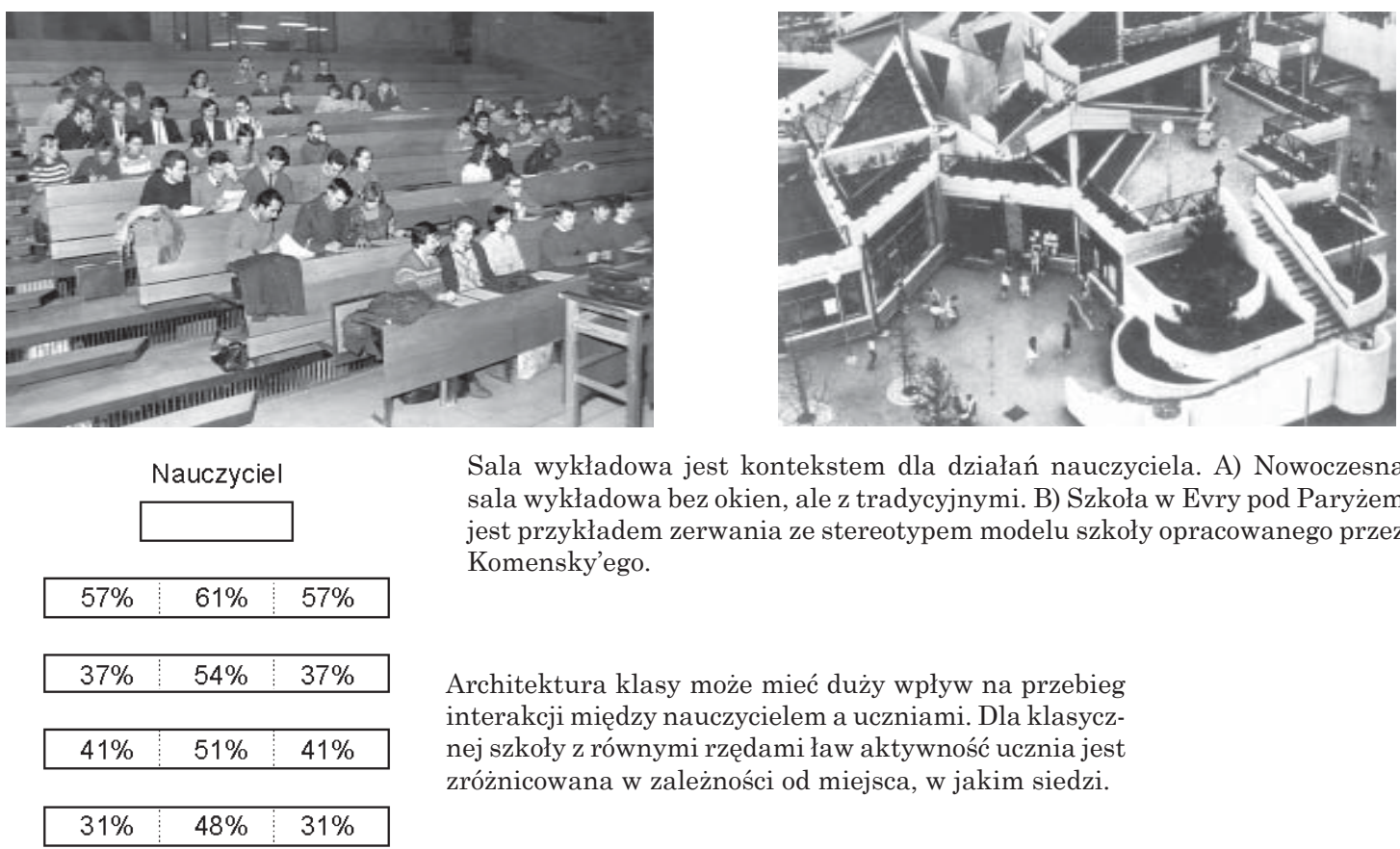

Sala wykładowa jest kontekstem dla działań nauczyciela. A) Nowoczesna sala wykładowa bez okien, ale z tradycyjnymi. B) Szkoła w Evry pod Paryżem jest przykładem zerwania ze stereotypem modelu szkoły opracowanego przez Komensky'ego.

Architektura klasy może mieć duży wpływ na przebieg interakcji między nauczycielem a uczniami. Dla klasycznej szkoły z równymi rzędami ław aktywność ucznia jest zróżnicowana w zależności od miejsca, w jakim siedzi. 
Zachowania terytorialne na niższym poziomie, tj. na poziomie terytorium jednostki najczęściej związane są z małymi terytoriami kształtowanymi przez zaprojektowane środowiska. W tym przypadku występuje wyraźna zależność między zmianą w projektowanym środowisku a zmianą terytorium i związanych z tym terytorium zachowań terytorialnych. Przykładem tego rodzaju małych terytoriów są terytoria związane z miejscami pracy w biurach, urzędach, fabrykach. Najogólniej rzecz ujmując, terytoria te wiążą się ze środowiskiem ukształtowanym przez różnego rodzaju rozwiązania architektoniczne.

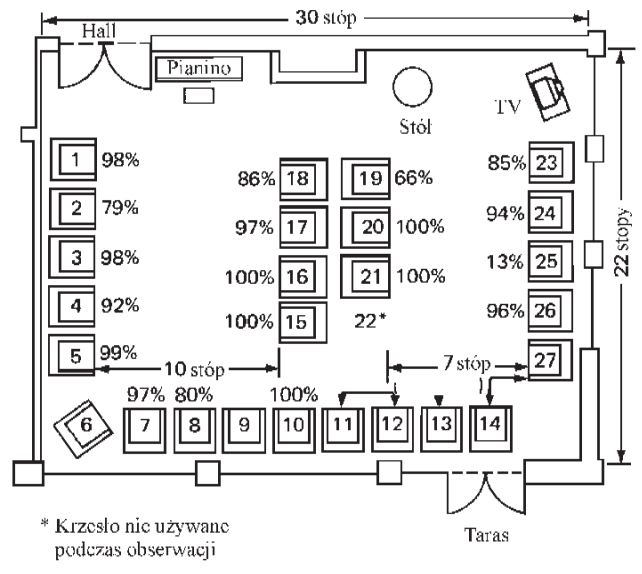

Jak się okazuje najprostszym terytorium jest krzesło. Rysunek obrazuje procent czasu, jaki przypada na poszczególne krzesło w zależności od umieszczenia w przestrzeni (Lipman, 1967).

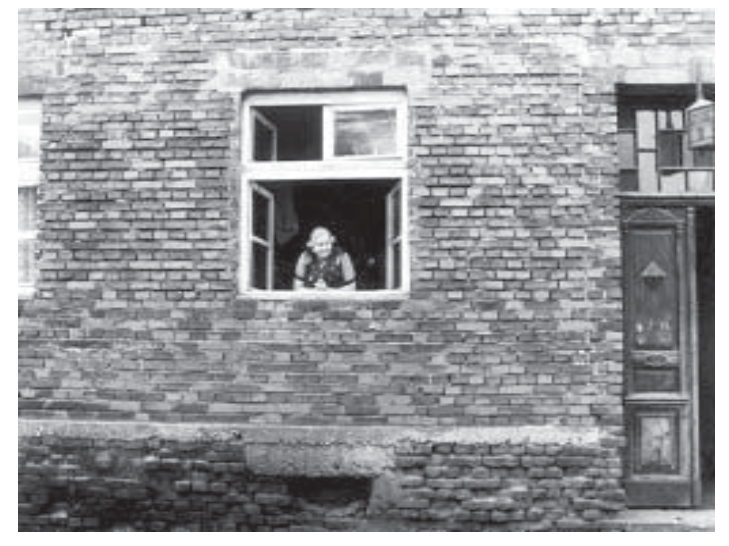

Niektórzy ludzie mogą kontrolować przestrzeń tylko przez swoje okno. To jest ich twierdza i ich terytorium.

Cały system zachowań i interakcji w przestrzeni znaczonej przez architekturę, tworzy swoistą subkulturę egzystencji danej zbiorowości ludzi, przy czym jedni mają większy wpływ na nadanie piętna swoistości terytorialnej (np. wyższy personel urzędniczy w biurach lub wyższe kierownictwo w fabrykach), a inni relatywnie mniejszy (np. robotnicy). Niemniej jednak każdy człowiek, żyjąc w środowisku architektonicznym, okupuje w nim stałe elementy, stałe terytoria, których nie może znacząco zmieniać. W czasie użytkowania tej określonej porcji przestrzeni człowiek zmuszony jest do identyfikowania się z nia, niezależnie od tego, kto w sensie prawnym jest jej właścicielami. W odczuciu użytkownika danej przestrzeni jest to ,jego” terytorium. Użytkownik przestrzeni, symbolizuje swoje terytorium poprzez różnego rodzaju oddziaływania personalne, jak swoiste rozmieszczenie drobnych elementów. fizycznych, poprzez szczegółowe „wyobra-żenie" sobie przestrzeni, poprzez swoją postawę wobec tej przestrzeni, wreszcie poprzez postawę wobec osób przekraczających granicę terytorium.

\section{Model organizacyjny zachowań terytorialnych}

Z tego. co wcześniej powiedziano na temat zachowań terytorialnych, wynika, że mogą one manifestować się zarówno w przestrzeni kolektywnie użytkowanej, jak i indywidualnie. Terytorium indywidualne jest najczęściej elementem przestrzeni zbiorowej i między nimi występują wzajemne sprzężenia zwrotne.

Załóżmy, że mamy do czynienia z dużym zakładem przemysłowym, który ma szereg filii, wydziałów, oddziałów, budynków, biur etc. Instytucja te zatrudnia cały szereg ludzi w różnych zawodach, z różnym wykształceniem. Zaspokaja szereg potrzeb swoich pracowników, a więc prowadzi bufety, stołówki, biblioteki, miejsca aktywnego i pasywnego odpoczynku. System zachowań i interakcji w przestrzeni wyznaczonej przez poszczególne obiekty owej instytucji tworzą specyficzną subkulturę w antropologicznym tego słowa znaczeniu. Subkultura ta może być i najczęściej jest wewnętrznie zróżnicowana, to znaczy nie musi być wcale tak, iż podobne zachowania przestrzenne wykazują np. członkowie kierownictwa i szeregowi pracownicy. Każda z grup pracowniczych wykazuje nieco odmienne zachowania w ramach wspólnej subkultury m.in. z powodu innego przestrzennego usytuowania. W ten sposób subkultura zakładu przemysłowego, rozpatrując ją z punktu widzenia przestrzenno-terytorialnego rozbija się na poszczególne subkultury. Dalej idąc, poszczególne osoby najczęściej realizują swoją pracę w jednym określonym miejscu, z którym 
się identyfikuja. W ten sposób doszliśmy do trójstopniowej organizacji przestrzeni w aspekcie zachowań terytorialnych człowieka, której autorem jest David Stea.

Pierwszym podstawowym elementem przestrzeni życiowej człowieka jest jednostka terytorialna (territorial unit), to jest niewielki wycinek kulturowo zdeterminowanej przestrzeni otaczajaccej człowieka. Tak rozumiana jednostka terytorialna jest równo, znaczna z pojęciem przestrzeni personalnej zdefiniowanej przez Sommera. Człowiek najczęściej posiada więcej niż jedną jednostkę terytorialną, np. jedną w samochodzie, jedną w biurze, w domu etc.

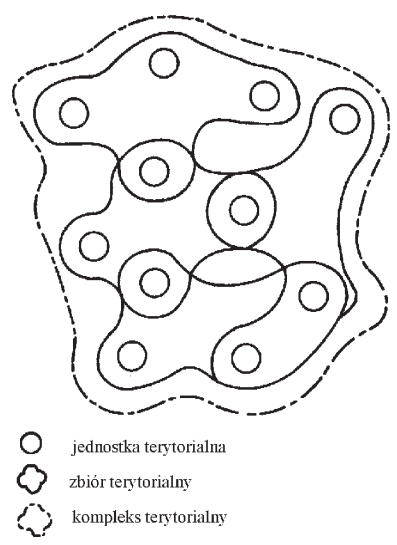

Przestrzeń personalna jako ogół jednostek terytorialnych, zbiorów terytorialnych oraz kompleksów terytorialnych .

Mimo, że poszczególne jednostki terytorialne fizycznie są od siebie niezależne, konceptualnie tworzą jednak zamkniętą całość, którą Stea nazywa terytorialnym zbiorem (territorial cluster). Zbiór terytorialny obejmuje prócz różnorodnych jednostek terytorialnych danej osoby również inne osoby z ich własnymi jednostkami terytorialnymi. Każda z osób wchodzacych w skład takiego zbioru terytorialnego posiada zarazem własny zbiór terytorialny, a cały zestaw wzajemnie powiązanych ze sobą zbiorów terytorialnych tworzy coś w rodzaju kompleksu terytorialnego. Trzy takie „stacjonarne” kompleksy terytorialne przedstawia schematycznie rysunek.

Wyróżnione terytoria nie zawsze muszą mieć charakter stacjonarny, lecz mogą ulegać zmianom lub być w ciagłym ruchu. Poza tym mogą one mieć charakter bądź indywidualny (jednostka terytorialna lub przestrzeń personalna), bądź zbiorowy czy też kolektywny (niektóre grupy terytorialne oraz kompleksy terytorialne). Przestrzeń terytorialna posiada szereg szczegółowych cech, takich jak kształt, rozmiar, liczbę jednostek, ekstensywność, typ granic.

Opisany trójdymensjonalny schemat przestrzeni życiowej człowieka, wyodrębniający trzy rodzaje terytoriów, wykazuje pewne podobieństwa do psychologicznej teorii pola związanej z nazwiskiem Kurta Lewina. Słowo „pole” stosuje się w fizyce np. do oznaczenia pola magnetycz-

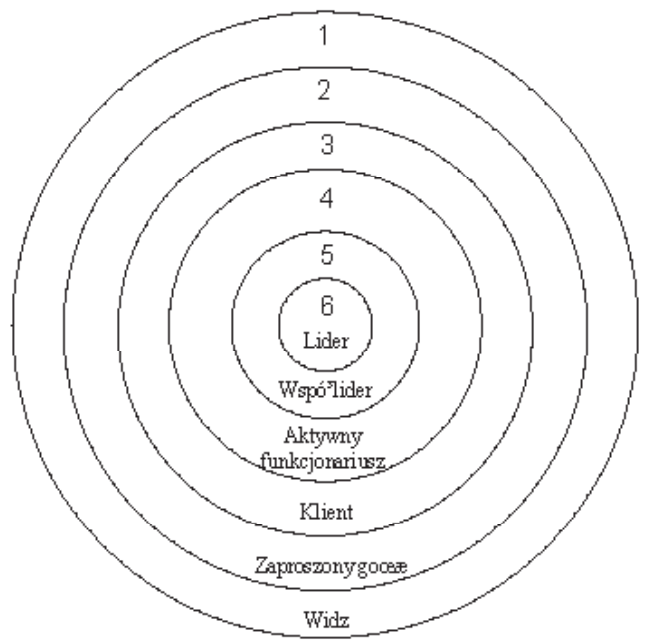

Strefy penetracji wg Barkera. nego, które określa układ linii przyciagania i odpychania. Ustrukturalizowany układ pól fizycznych dostarczył użytecznej analogii do struktur organizacji faktów psychologicznych.

Jakaś sytuacja, w której znajduje się dana osoba, stanowi według Lewina jej przestrzeń życiowa, która jest psychologiczną reprezentacja środowiska tej jednostki oraz istniejacych d1a niej w danej chwili możliwości. Osobę tę przedstawia się czasami jako punkt, który krąży wewnątrz przestrzeni życiowej i na który działają występujące tam siły. Tak więc osoba ta jest odpychana przez zadania nie lubiane, pociagana przez lubiane, jest przyciagana przez przestrzeń architektoniczna lub jej unika etc. Wszystkie te określenia odnoszą się do „ruchów" w przestrzeni życiowej niezależnie od tego, czy osoba ta rozwiązuje swe problemy w myśli czy w działaniu.

$\mathrm{Z}$ drugiej strony, osoba ta posiada również swoją strukturę, a zatem to, co z jednego punktu widzenia przedstawiono jako punkt poruszający się w przestrzeni życiowej, może otrzymać również reprezentację geometryczną.

Na tym schemacie obszary ruchowe i spostrzeżeniowe, które kontaktują się ze środowiskiem, przedstawione są na powierzchni, zaś „wewnętrzny obszar osobowości” leży w środku podzielony na części peryferyjne i ośrodkowe, które są głęboko ukryte. Rozwój osobowości w czasie wiąże się z różnicowaniem lub zacieraniem się różnic między tymi cząstkowymi obszarami w ramach pewnej całości. Obszary przedstawione na schemacie osobowości Lewina łączą się ze sobą poprzez granice, które różnią się pod względem stopnia sztywności czy przenikalności. Przy większym zróżnicowaniu granice są mniej przenikalne, co powoduje odizolowanie jednej części od drugiej.

Osobowość dziecka jest mało zróżnicowana, tj. dziecko nie spostrzega różnicy między sobą a otoczeniem, a oprócz tego różne obszary wewnątrz jego własnej osobowości nie są tak złożone, jak będą wówczas, gdy dorośnie. Proces różnicowania wytwarza bardziej złożoną organizację osobowości, którą zwykle nazywamy strukturą osobowości. 


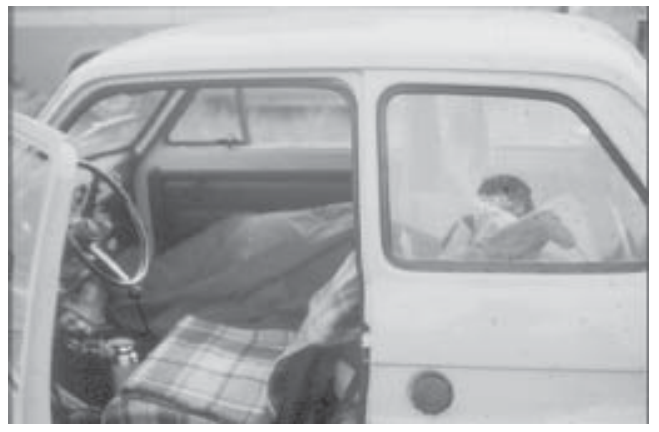

Samochód jest najbardziej charakterystycznym terytorium współczesnego człowieka obok domu. Staje się on w niektórych przypadkach elementem przestrzeni życiowej ważniejszym nawet od domu.

Teoria Lewina stanowi wariant psychologii postaci, która kładzie nacisk na jedność i całość oraz na teraźniejszość. Z teorii tej wynika, że aby zrozumieć jednostkę należy zrozumieć różne środowiska (ekologie) oraz społeczne interakcje, w których jednostka uczestniczy. Z drugiej strony, aby stworzyć odpowiadające jednostce środowisko, którego elementem jest przestrzeń architektoniczna, należy w trakcie projektowania zdefiniować strukturę osobowości, której fizyczna forma przestrzeni nada bodźce do różnicowania, się (rozwoju) tej osobowości. Innymi słowy, tak jak zrozumienie osobowości człowieka uwarunkowane jest zrozumieniem otaczajacego go, środowiska, tak samo zrozumienie środowiska, tj. fizycznej przestrzeni życiowej, zdeterminowane jest zrozumieniem jego osobowości. Tak jak przestrzeń architektoniczna wyznacza zachowania człowieka, tak samo osobowość człowieka wyciska swoje piętno poprzez swoiste personalne nacechowanie tej przestrzeni.

Personalne nacechowanie przestrzeni zależy od stopnia zaangażowania w przestrzeń. Roger Barker wyróżnia dwa wskaźniki zaangażowania. Jeden jest mierzony wielkościa jednostek przestrzennych i ilością spędzanego w nich czasu. Drugi mierzony wielkością jednostek przestrzennych i zakresem odpowiedzialności, jaki jednostka ponosi za swoje w nich uczestnictwo. Na tej podstawie wyróżnił Barker sześć stopni albo stref penetracji: od zwykłego, niezaangażowanego widza i kibica (strefa 1), aż do maksymalnego zaangażowania i maksymalnej odpowiedzialności lidera,

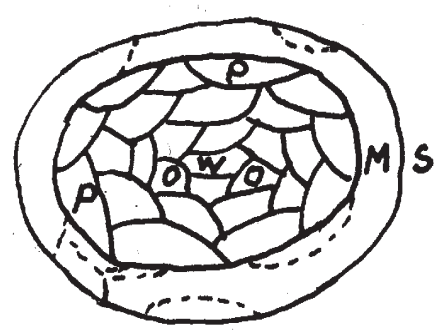

Obraz osobowości według Lewina. Obszary motoryczne (M) i spostrzeżeniowe pozostaja w kontakcie ze środowiskiem (S), lecz są one regulowane przez głębiej leżącą strukturę osobowości przedstawionąjako różne obszary otoczone granicami. Części peryferyjne (P) pokrywaja warstwy bardziej ośrodkowe $(\mathrm{O})$, w samym środku leży wewnętrzny obszar osobowości. bez którego dany przestrzenny układ zachowania nie jest w stanie samodzielnie funkcjonować.

Reasumując, zależność między osobowością a przestrzenią życiową człowieka jest zależnością dynamiczną. Przejawia się to w tym, że rozwojowi (różnicowaniu się) osobowości człowieka towarzyszy proces różnicowania się przestrzeni życiowej poprzez wyodrębnianie się terytoriów z zaznaczonymi granicami. Im bogatsza, bardziej zróżnicowana jest osobowość człowieka, tym bardziej zróżnicowana jest jego przestrzeń życiowa, tzn. tym więcej człowiek posiada terytoriów oraz tym bardziej są ustabilizowane jego wewnętrzne wyobrażenia przestrzeni. A zatem, z im bardziej zróżnicowaną osobowością człowieka mamy do czynienia, w tym większym stopniu musimy liczyć się, że dla zaspokojenia swoich potrzeb wymagać on będzie bardziej zróżnicowanej przestrzeni.

\section{Zmiany przestrzenne a zmiany zachowań}

Uwzględnienie dynamicznej zależności między osobowością a przestrzenią życiową człowieka prowadzi do konkluzji (hipotezy), że zmiany w elementach lub cechach terytorium prowadzą do zmian we wzorach zachowań terytorialnych oraz odwrotnie, zmiany w zachowaniach terytorialnych stymuluja zmiany $\mathrm{w}$ ramach terytoriów. Zależność ta ma istotne znaczenie w „myśleniu architektonicznym”, gdyż sugeruje to, że każde architektoniczne działanie projektowe w przestrzeni życiowej człowieka prowadzi do zmian terytorialnych, a w konsekwencji do zmian zachowań terytorialnych.

Powyższą zależność prześledzić można na przykładzie z dziedziny projektowania biur. Najbardziej rozpowszechniony sposób projektowania biur polega na rozmieszczeniu pomieszczeń wokół różnego rodzaju przestrzeni korytarzowych. Pomieszczenia takie zapewniają pracownikom dobrą izolację wizualna, akustyczna, społeczna oraz poczucie terytorialności. Wydawać by się mogło, że rozwiązanie takie jest rozwiązaniem idealnym, i nie będzie stymulowało nikogo do szukania nowych rozwiązań. 


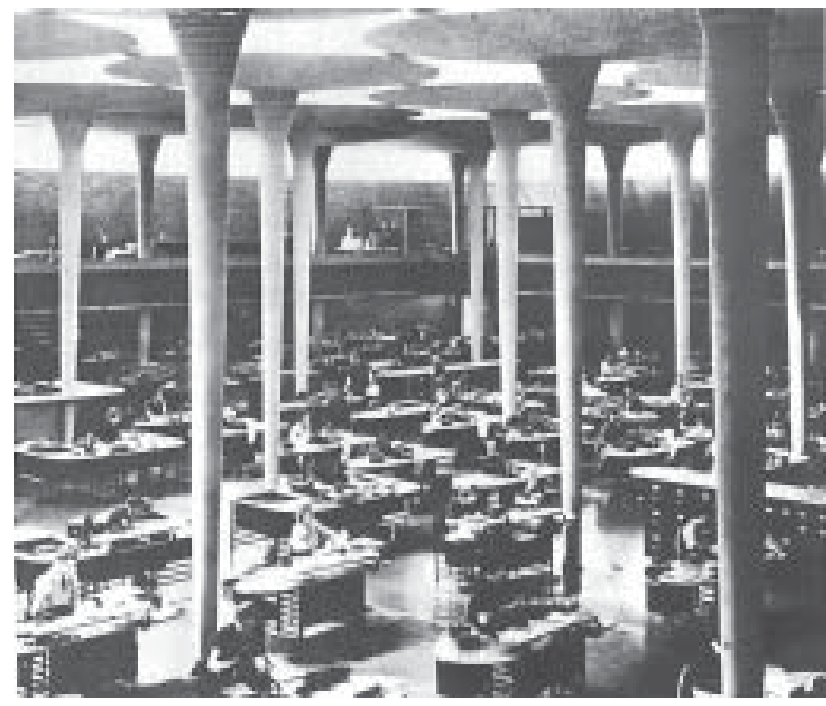

Jednym z pionierów projektowania biur z otwartą przestrzenia jest F.L. Wright. S.C. Johnson Administration Building obrazuje organizację wnętrza i pracy wykazującą znaczny postęp w stosunku do Larkin Co. Poszczególne stanowiska pracy stanowia już niezależne jednostki terytorialne.
W latach sześćdziesiątych architekci niemieccy zapoczatkowali jednak nowe podejście do projektowania przestrzeni biurowej. Nowy typ przestrzeni biurowej nazwali „pejzażem biurowym” (bürolandschaft) lub biurem z otwarta przestrzenia (Grossraum-büros). Scheucher definiuje biuro o otwartej przestrzeni jako pojedyncze pomieszczenie zajmowane przez więcej niż 40 osób. Biura liczace średnio 20-50 osób zaliczane sa do średnich, natomiast te, które obejmują mniej niż 20 osób zaliczane są do biur typu konwencjonalnego (biuro-zbiór cel). Oczywiście, głównym czynnikiem dyskryminującym biuro nowego i starego typu nie jest liczba osób je użytkujących ani też wielkość, lecz organizacyjna i wewnętrzna dekoracja przestrzeni biurowej. Stąd też właśnie nazwa pejzażu biurowego. System ten charakteryzuje się brakiem ścian działowych i innych (stałych) przegród oraz celowo amorficznym rozlokowaniem sprzętów.

Koncepcja biura o otwartej przestrzeni nie jest koncepcja stara. Szacuje się, że w 1960 roku w Republice Federalnej Niemiec zatrudniano w nich zaledwie 700 pracowników, ale już w 1965 roku było ich około 20000. Specjaliści przytaczają następujące zalety tego typu biur.

Zalety organizacyjne. Wymienia się tu najczęściej giętkość organizacyjną i reorganizacyjna systemu, szybszą komunikację oraz łatwiejszą wymianę informacji. Coraz częściej nie można realizować jakościowo dobrej obsługi klienta w biurach tradycyjnych. Do takich nowych zadań kompleksowej obsługi musiały się dostosować w Polsce większe urzędy pracy obsługujące bezrobotnych. Klient musi być w jednym dniu załatwiony przez szereg wyspecjalizowanych urzędników i specjalistów. Wymaga to szybkiej i transparentnej ścieżki przejścia. Załatwianie sprawy przy „otwartej kurtynie” dostarcza poczucia pewności i jawności.
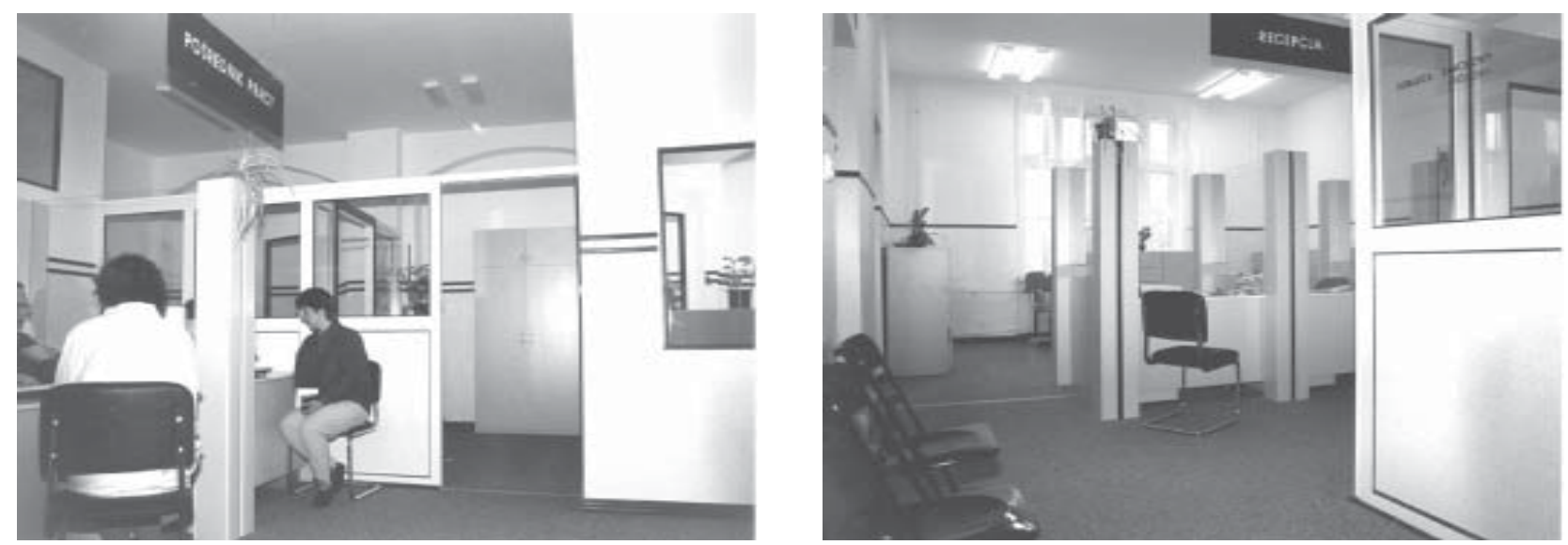

Otwarta przestrzeń pracy w rejonowym urzędzie pracy w Gdańsku.

Zalety przestrzenne. Zwraca się w tym przypadku uwagę na fakt, że duża część powierzchni korytarzowej i innej w biurach tradycyjnych jest powierzchnią mało wykorzystaną lub martwa. Schmidt dokonał obliczeń na modelach przestrzeni biurowej i stwierdził, że w rozwiązaniu konwencjonalnym przestrzeni biurowej powierzchnia wykorzystywana jest zaledwie w 57\%, natomiast w „pejzażu biurowym” w $83 \%$.

Zalety psychosocjologiczne. Według Kyburza możliwość bezpośredniego kon-taktu zwierzchnika ze wszystkimi podwładnymi stwarza sprzyjające warunki do rozwoju tzw. kooperatywnego stylu zarządzania. Dyscyplina i obustronne odniesienia umożliwiają rozwój nowych, niepisanych ról i wzorów zachowań. Gubler z kolei wskazuje na możliwość pojawienia się w otwartej przestrzeni mechanizmów samokontroli i zaniku rywalizacji między pracownikami. Lappat sądzi natomiast, że zwiększony dopływ informacji do 
pracowników w związku z otwartością przestrzeni prowadzi do wzrostu zainteresowania praca.

Zalety ergonomiczne. Einbrodt i Beckman przeprowadzili badania porównawcze w zakresie oświetlenia i warunków akustycznych między małymi biurami a nowoczesnymi o otwartych przestrzeniach. Z tych nie nazbyt reprezentacyjnych badań wynikało, że bardziej zadowalające warunki środowiskowe występują w biurach o otwartych przestrzeniach.

Wielu autorów argumentuje, że biura o otwartych przestrzeniach stwarzają większe możliwości montowania w nich bardziej technologicznie zaawansowanych instalacji, jak np. klimatyzatorów. Wszystkie jednak wymienione tu argumenty wydają się mieć wartość jedynie opinii, a nie empirycznie potwierdzonych prawd naukowych. Szczególnie dużo jest zastrzeżeń co do warunków akustycznych panujaccych w takich biurach. Dlatego téz

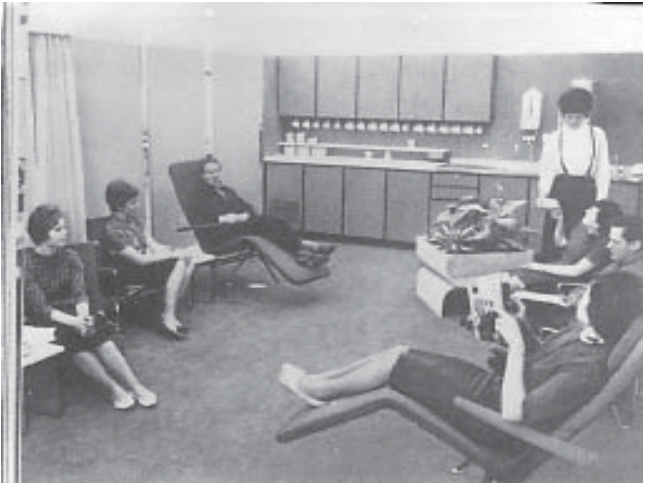

Dzięki otwartej i łatwej komunikacji interpersonalnej pracownicy nie muszą udawać się do specjalnych pomieszczeń na przerwy w pracy. projektanci „pejzaży biurowych” musieli uznać, że codzienna praca, w dużej przestrzeni użytkowanej przez dużą liczbę osób musi wiązać się ze znacznym dyskomfortem. W związku z tym próbowali rozwiązać ten problem poprzez nadanie przestrzeń „domowego klimatu”, rozmieszczając biurka w różnych kierunkach (odgeo-metryzowując przestrzeń), zapewniając niewielka choćby dawkę prywatności i obniżając stymulację słuchową do minimum. Amerykańscy projektanci w tym przypadku więcej uwagi poświęcają ograniczeniu stymulacji wizualnej, uznając stymulację słuchową za mniej ważną. Ograniczenie stymulacji wizualnej uzyskują poprzez parcelację przestrzeni na mniejsze elementy, tj. terytoria, za pomocą nieprzenikliwych dla wzroku przegród (jak kwiaty, rośliny), jednakże nie w postaci substancjonalnej (szkło, drewno etc.).

Biura typu „otwartego” mają dwojaki wpływ na zachowania ludzi. Z jednej strony, tak jak to zakładaja ich zwolennicy, przeciwdziałają rozluźnieniu się dyscypliny pracy. Pracownicy np. nie mają dostatecznej swobody na urządzenie sobie „kawek” i „herbatek”. Z drugiej jednak strony, wzmacniając system kontroli i nadzoru, biura tego typu zwiększają potrzebę większej fizycznej terytorialności, która nie mogąc być zaspokojona, powoduje wzrost niepewności.

Poddanie działalności pracowników surowej, zewnętrznej dyscyplinie prowadzi najczęściej do zaniku symboli statusu, obniża morale zmniejszając w istotny sposób efektywność pracy. Morale jest to zespół ocenianych pozytywnie cech odnoszących się do stosunków panujących w obrębie jednostki organizacyjnej między pracownikami, przełożonymi i podwładnymi, do stosunku jednych i drugich do pracy (obowiązkowość, dyscyplina i zadowolenie z pracy), do integracji pracownika z zespołem, do zaangażowania społecznego etc. Ten kompleks cech ocenianych pozytywnie jest globalną oceną utylitarną i moralną. Utylitaryzm oceny polega na zależności między sprawnością organizacji a jej morale. Im wyższe jest morale, tym większa sprawność i wobec tego podnoszenie morale służy bezpośrednio usprawnianiu funkcjonowania organizacji. A zatem, gdy zewnętrzne granice terytorium úlegają zniesieniu lub są łatwo przekraczalne, następuje zanik autonomii miniaturowego systemu społecznego. Jego zanik wzmacnia stres psychologiczny, wynikający ze zmniejszenia się liczby możliwych wyborów zachowań. Z kolei zmniejszenie swobody poruszania

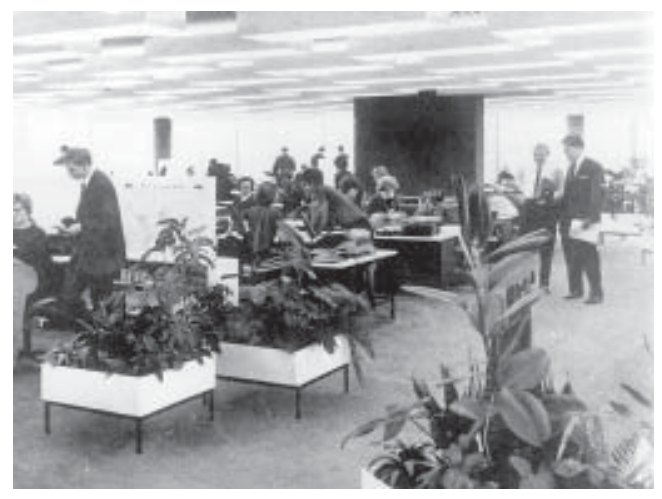

Ludzie próbuja w różny sposób zapewnić sobie minimum prywatności w otwartej przestrzeni. Najbardziej wypróbowanym środkiem prowadzącym do tego celu jest stosowanie przegród z kwiatów. się powoduje zanik odczuwanej różnorodności środowiskowej. Reasumujac, zaburzenia w kształcie, zakresie, granicach czy w zróżnicowaniu, terytorialnych jednostek, grup i obszarów prowadzi do znaczących zaburzeń w zachowaniu się jednostek.

A.F. Parr podkreśla wagę zmienności (variability) w środowisku w aspekcie potrzeby zmian i różnorodności stymulacji z pola psychologicznego przestrzeni życiowej. Ogólna sugestia jest taka, że ludzie potrzebuja, a zarazem poszukują zmienności oraz różnorodności, zwłaszcza wtedy, gdy nie znajdują jej w uwarunkowaniach wewnętrznych organizmu. Oczywiście źródłem pobudzenia niekoniecznie muszą być tzw. środowiska projektowane, tzn. zakłady przemysłowe, ulice, sklepy, domy. Źródłem wystarczającej często stymulacji, jak różnorodności i zmienności może być dla człowieka jego aktywność, np. praca. Praca, jeżeli jest dostatecznie ciekawa i zróżnicowana, może adekwatnie kompensować niezróżnicowana, nudna, monotonna przestrzeń pracy. 
Mówiąc o pracy, jako źródle tak potrzebnej człowiekowi do życia różnorodności i zmienności, należy jednak mieć na uwadze, że dla większości ludzi praca jest formą aktywności odczuwaną jako przymus. Stanowi ona wtedy tzw. heteroteliczną formę działań związaną z gratyfikacjami, nagrodami i celami zewnętrznymi, jak pieniądze, co oznacza, że różnorodność psychologiczna nie jest związana z pracą. Rozróżnia się umownie działania autoteliczne i heteroteliczne. Działanie autoteliczne to takie które człowiek wykonuje dla niego samego ze względu na jakieś rezultaty, a nie ze względu na przyjemność wykonywaniá pewnych czynności, jak np. zabawa, „,sztuka dla sztuki”. Ponieważ niemal zawsze cel nie bywa jednoelementowy, lecz jest wiązką celów, można odnaleźć jakieś inne cele poza samą działalnością jako taka, autoteliczność polega na tym, że działanie dla samego działania zajmuje pierwsze miejsce w hierarchii wyróżnionych celów. Działanie heteroteliczne, w przeciwstawieniu do działania autotelicznego, ma cel poza działaniem jako takim. Przykładem jest praca, która nie jest wykonywana dla niej samej, której cel leży poza działaniem. Tak np. pracownicy biurowi na całym świecie rzadko mogą swoje czynności uważać za wystarczająco stymulujące i zapewniające psychologiczną potrzebę różnorodności. W związu z tym sensowne jest pytanie, w jakim stopniu środowisko przestrzenne pracy może kompensować „nudę” samej pracy. Można postawić hipotezę, że jednym z najważniejszych sposobów przełamywania nudy związanej z praca jest aktywność zachowaniowa pracownika nazywana w psychologii poszukiwaniem zmian. Realizuje się ona poprzez wzbogacanie granic grup terytorialnych bez równoczesnego zwiększania liczby jednostek terytorialnych składających się na grupę terytorialna. Zasada ta tłumaczy m.in. dlaczego znudzony pracownik ma tendencję do organizowania sobie różnego rodzaju przerw w pracy, jak wycieczek do innych działów i komórek organizacyjnych.

Projektanci zakładu montażowego samochodów osobowych Volvo w Konarze w Szwecji, uznając. naturalność dążeń ludzkich do zmian i różnorodności, zaprojektowali przestrzenie relaksowe typu kawiarnianego w bezpośrednim sąsiedztwie stanowisk roboczych.

W efekcie okazało się, że ma to podwójne znaczenie. Po pierwsze, sprzyja naturalnym dążeniom do przekraczania granic terytorialnych związanych ze stanowiskiem roboczym, które to granice, wyznaczając przestrzeń psychologiczną o jednostronnie działających bodźcach, nie są w stanie zaspokoić wszystkich podstawowych psychologicznych potrzeb pracownika. Po drugie, w zwiazku z naturalna tendencją do poszukiwania zmian, tego rodzaju przestrzeń socjalna przeciwdziała nadmiernemu rozszerzaniu przez pracowników terytorialnego kompleksu działania, a tym samym sprzyja przestrzennemu ograniczeniu terytorium, poddając go akceptowanej kontroli.

W skład kompozycji, będącej elementem funkcji rozszerzającej granice terytorialne, wchodzi kilka kategorii przestrzeni. Jedną z nich jest przestrzeń typu korytarzowego. Przestrzeń zdeterminowana technologia wymaga osobnych pomieszczeń dla rozczłonkowanych procesów o zmiennych wymaganiach środowiskowych. Pomimo wydłużenia komunikacji, stwarzają one człowiekowi korzystne warunki na skutek naturalnego oświetlenia korytarza, możliwości wprowadzenia kontaktu bez-pośredniego lub wzrokowego z otaczającym terenem, zielenią etc. Przykłady rozwiązań przestrzeni przemysłowych zaprojektowanych z myśla o wprowadzeniu w środowisko pożądanej różnorodności za pośrednictwem przestrzeni korytarzowych przedstawiono na rysunku.

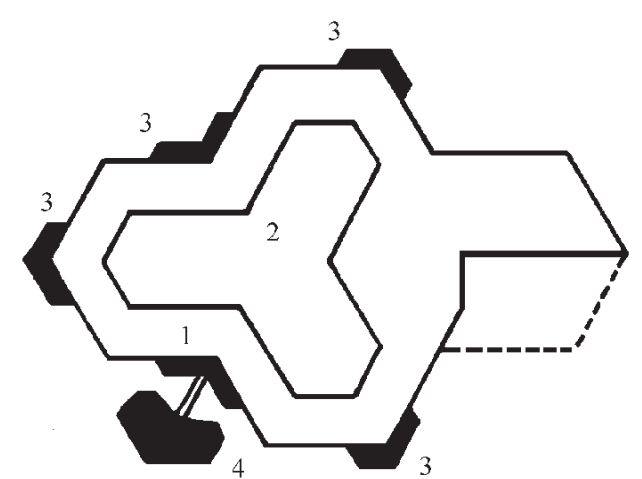

Fabryka samochodów Volvo w Kolmarze (Szwecja).1- przestrzeń produkcyjna, 2 - przestrzeń magazynowa, 3 - przestrzeń socjalna, 4 - przestrzeń administracyjna.

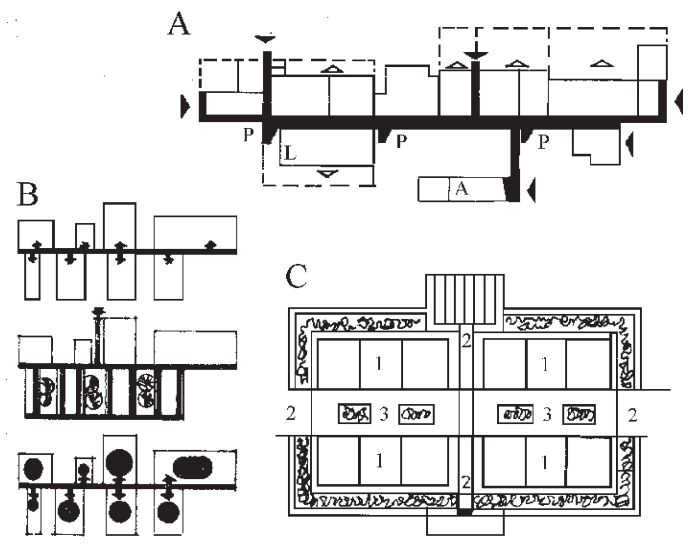

Przykłady rozwiązania przestrzeni zakładu przemysłowego. A - Przestrzeń korytarzowa. Zakład przemysłu elektronicznego (USA): P - przestrzenie wypoczynkowe, L - laboratoria, A - administracja;

B - Przestrzeń korytarzowa zintegrowana. Laboratorium elektroniczne (USA), poziom głównego korytarza komunikacyjnego, atria wypoczynkowe i górny transport technologiczny; C - Przestrzeń zintegrowana. Laboratorium fabryki telefonów w Holmndel (USA): 1 - przestrzeń produkcyjna, 2 - korytarze komunikacyjne, 3 - ogrody zimowe, kropka - kuluary wypoczynkowe. 
Jak dotąd nie udało się ani naukowcom, ani architektom stworzyć prototypu idealnej fabryki. Aby zrozumieć dlaczego trudniej jest wskazać idealną fabrykę niż idealny dom mieszkalny, przede wszystkim trzeba się cofnąc do pierwszej części niniejszej pracy. Zwrócono w niej uwagę, że projekt przestrzeni jest funkcja subiektywnej mapy, subiektywnej przestrzeni umysłowej, która do pewnego stopnia jest odbiciem obiektywnego świata. Obiektywny świat osoby ludzkiej składa się z trzech elementów: socjosfery, ekosfery i technosfery. Obiektywny świat przekształcony na mapę subiektywna tworzy w umyśle socjoprzestrzeń, ekoprzestrzeń i technoprzestrzeń. Problem hipotetycznej czy prototypowej „fabryki” jest więc tylko projekcją obiektywnego świata w subiektywnej przestrzeni umysłu. Szybkiej zmianie podlega nie tylko subiektywna mapa, ale również obiektywny świat, w tym obiektywny świat zawodów.

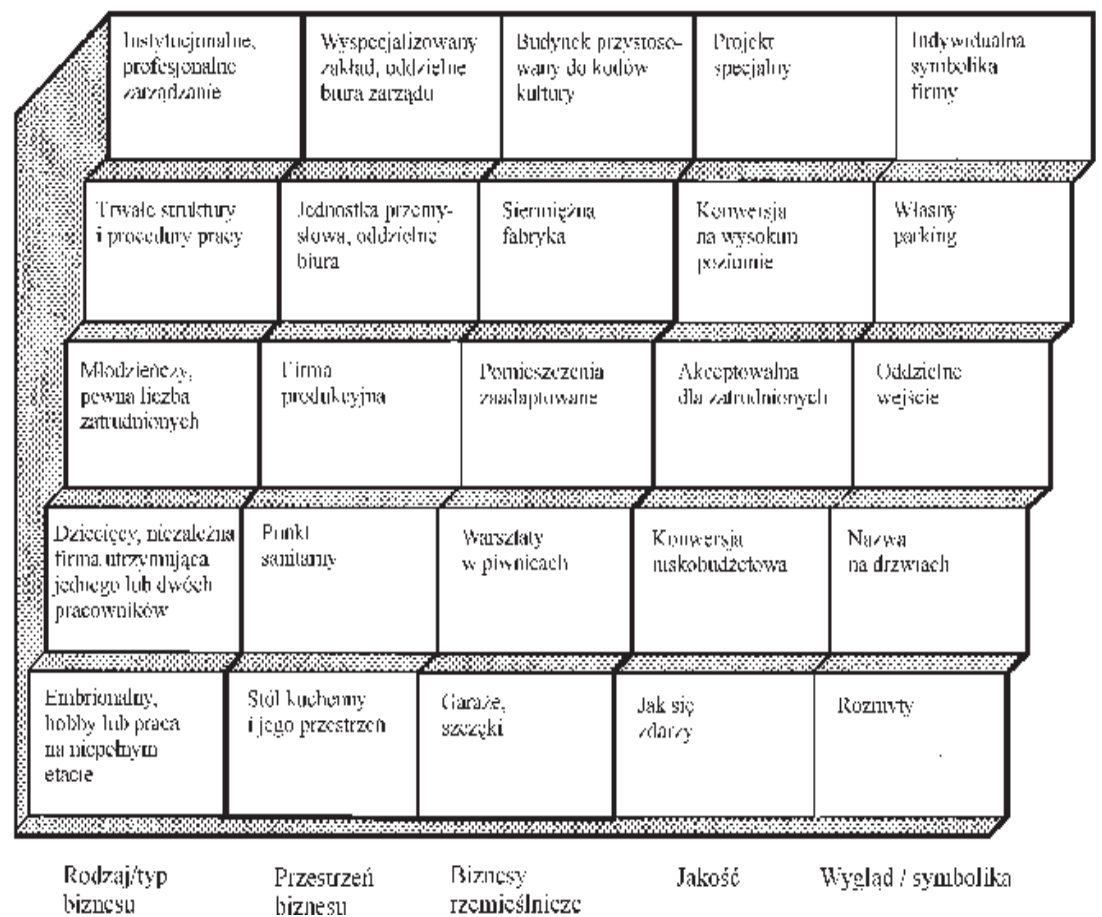

Wygląd, struktura i wymagania przedsiębiorstwa prowadzącego działalności gospodarczą zmienia się w zależności od miejsca w cyklu rozwojowym.

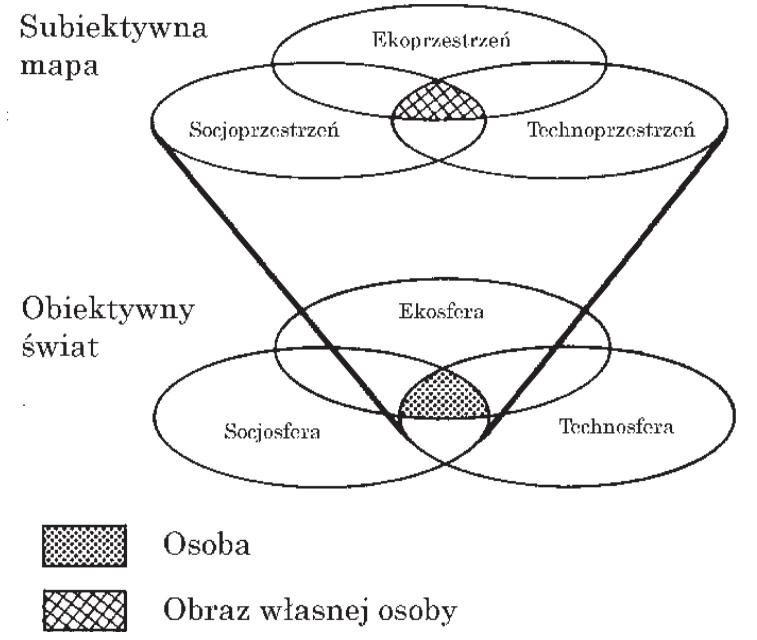

Subiektywna mapa obiektywnego świata.

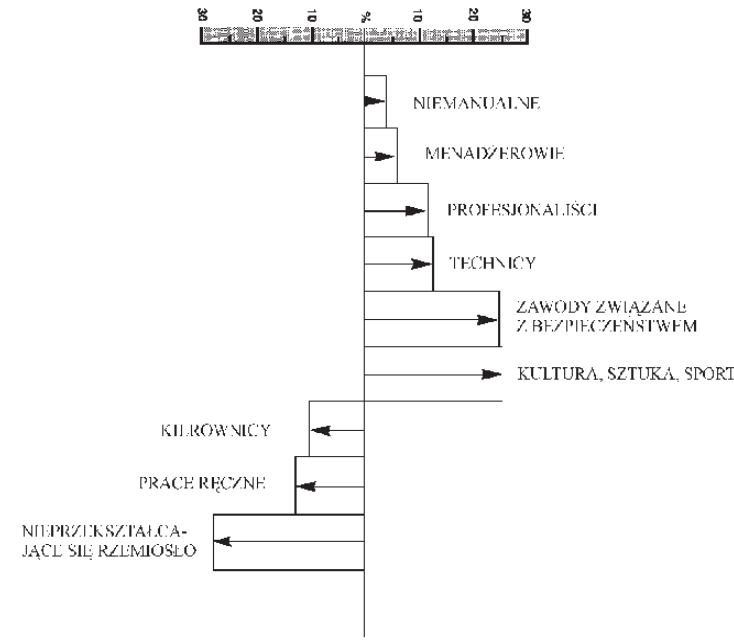

Zmiany obecne i prognozowane na przyszłość w świecie zawodów. Po lewej stronie znajdują się zawody zanikające, a po prawej stronie zawody „wschodzące”.

Zmianom obiektywnym podlegają też: rodzaj i typ prowadzonej działalności gospodarczej, zmienia przestrzeń dla prowadzenia działalności gospodarczej, zmieniają się przedsięwzięcia gospodarcze wyrastające z działalności rzemieślniczej, zmienia się jakość przestrzeni przeznaczonej na działalność gospodarczą i dopiero wreszcie zmienia się dostrzegalny wizualnie wygląd i symbolika biznesu. 


\section{Różnorodność psychologiczna a architektoniczna}

Dążenia do terytorialnej i przestrzennej różnorodności ujawniają się we wszystkich przestrzeniach funkcjonowania człowieka, a nie tylko w środowisku pracy. Ludzie poszukują takiej różnorodności w swoich indywidualnych i zbiorowych siedzibach zamieszkania, tj. w domu, w osiedlu, na ulicy, w mieście itd. Należy jednak w tym miejscu mieć na uwadze pewną różnicę między dążeniem do zmian w architekturze a psychologicznym dążeniem do różnorodności. Tak np. ludzie oczekują od projektantów, że projektowane przez nich siedziby mieszkalne nie tyle spełniać będą wymóg odmienności w sferze technologicznej czy nawet stylowej (tzn. z punktu widzenia kryteriów formalnych), lecz z punktu widzenia ich psychologicznych potrzeb stymulacji. Oznacza to, że nie każda zmiana w architekturze jest oceniana przez użytkowników jako zmiana pożądana lub wprowadzająca pożądaną różnorodność.

Systemowe, tj. włączone w program polityki społecznej upowszechnienie uprzemysłowionego budownictwa wielkopłytowego jest tego jaskrawym przykładem. Jego negatywna ocena dokonywana przez mieszkańców współczesnych osiedli wynika między innymi stąd, że monotonność zabudowy, elewacji, układu przestrzennego czy materiałów narzuca percepcję przestrzeni

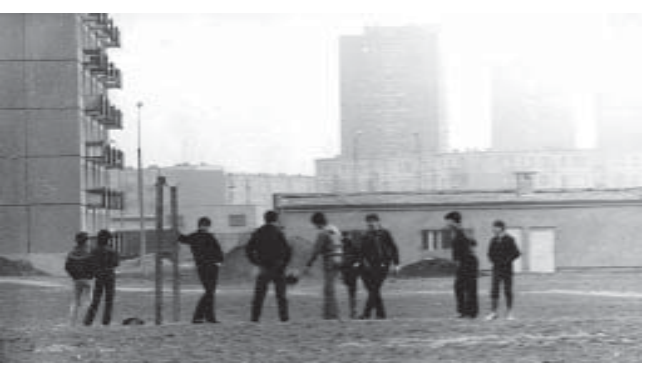

Uprzemysłowienie budownictwa od samego początku było zauważone przez dużą część obserwatorów za zagrożenie dla elementarnych wymagań różnorodności. Przestrzenne rozmieszczenie budynków tworzące pustkę środowiskową powoduje nudę, monotonię i poczucie „dodania” do środowiska. jako niedostatecznie bogatą w bodźce. W rezultacie mieszkańcy współczesnych osiedli nie w pełni identyfikują swój kompleks terytorialny z przestrzenią wydzieloną - granicami osiedla i dla normalnego funkcjonowania przekraczająjego granice. Znaczna większość mieszkańców współcześnie budowanych osiedli nie identyfikuje swojego psychologicznego pola działania (układu jednostek terytorialnych, grup i kompleksu terytorialnego) z granicami osiedla, czego przejawem jest m.in. rzadkość zjawiska „patriotyzmu osiedlowego”. Pole w sensie psychologicznym jest to kompleks społecznych, osobowościowych i fizycznych czynników, w ramach którego realizują się różnego rodzaju zjawiska psychologiczne. Dlatego też u ludzi o dużym zapotrzebowaniu na stymulację przestrzeń osiedlowa traktowana jest wyłącznie jako „sypialnia”, natomiast inne przestrzenie miejskie, w szczególności centrum - jako właściwe miejsce dla realizacji dziennej aktywności.

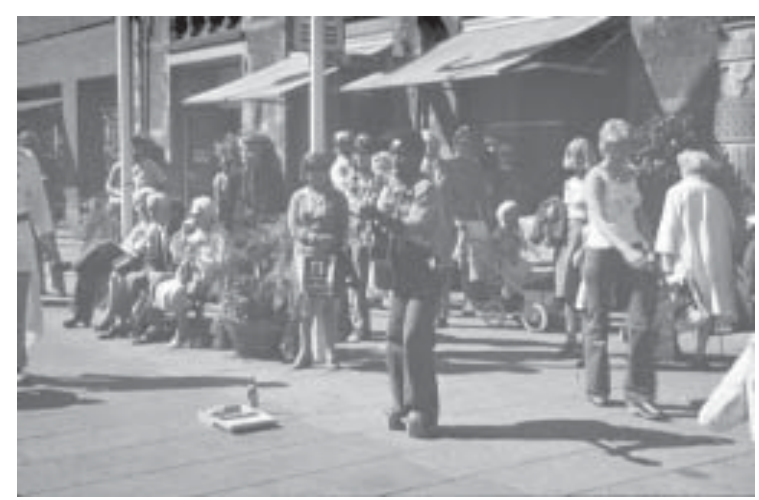

Sprawdzianem wielkomiejskości jest przestrzenna różnorodność, która umożliwia powstawanie aktywności twórczej, nie koniecznie bardzo dochodowej.
Im bardziej sypialnie miast pozbawiają człowieka różnorodności przestrzennej, tym bardziej podobaja mu się dziewiętnastowieczne miasta.

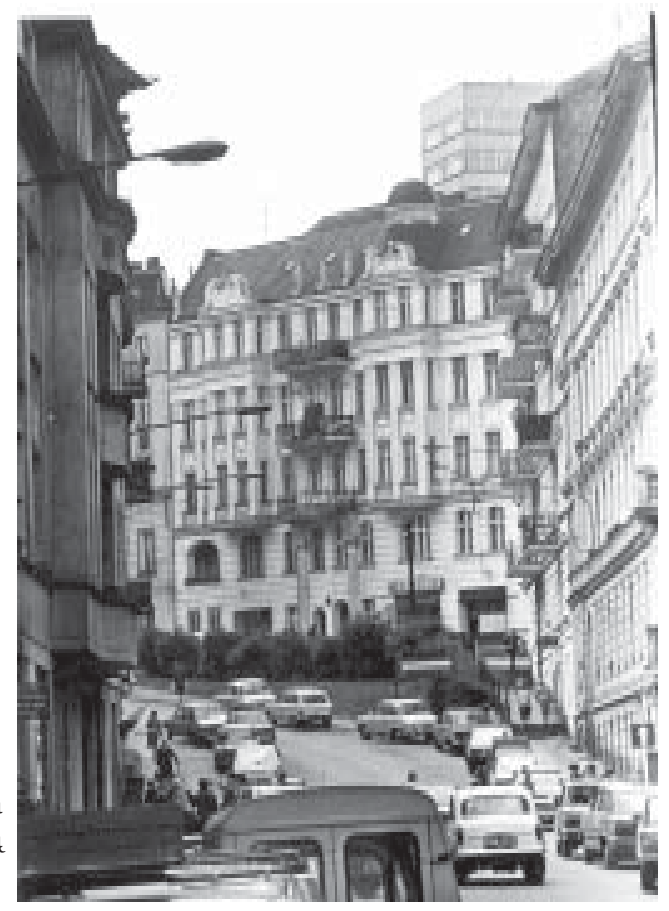


Ciekawe więc staje się porównanie tradycyjnej zabudowy miejskiej, mającej w Europie wielowiekowa tradycję, ze współczesną koncepcją architektury miast, polegającą na stereotypowym rozumieniu miasta jako odpowiednio uporządkowanych, przestrzennie rozmieszczonych obiektów architektonicznych. W tych pierwszych mieszkańcy, mając zaspokojona potrzebę różnorodności środowiskowej, wykazywali dużą stabilność w zamieszkiwaniu, natomiast w tych drugich występuje tendencja do traktowania swoich siedzib bardziej tymczasowo i bardziej ucieczkowo.

Pomijając na razie determinanty cywilizacyjne (np. zwiększone tempo zmian w rozwoju społeczeństw), można stwierdzić, że opisane wyżej zjawisko ma wymiar indywidualny (psychologiczny) oraz społeczny (socjologiczny). Wymiar indywidualny ma w tym sensie, że architektura tradycyjna w większym stopniu odpowiada psychologicznym oczekiwaniom na różnorodność w odniesieniu zarówno do pojedynczego mieszkania, jak i jego przestrzennego kontekstu. Tak na ten temat pisze w swoim eseju Przemiany obyczaju Marcin Czerwiński: „Racjonalizm nowych kompozycji przestrzennych, podobieństwo architektury typowej, brak elementów przypadkowych, narosłych obcych, charakterystycznych, kompozycja linearna - wszystko to sprawia, że wspomnienie bezpośrednie, fizyczne, automatyczne nie ma się o co zaczepić. Najwięcej spostrzegamy nie uważając, spoglądając na rzeczy mijane z roztargnieniem Zachodzi to jednak pod warunkiem, że są wśród nich indywidualności, tzn. przedmioty mniej więcej niepowtarzalne. Najmniejszym indywiduum w nowym osiedlu bywa samo osiedle. Pamiętam damę z lampą w dłoni, zdobiąca pierwszy podest klatki schodowej w domu, w bardzo brzydkim domu, w którym mieszkałem przed wielu laty, Pamiętam ją, bo mi się wydawała najbrzydszą „ozdobą” jaką wymyślił człowiek. Lubię ją w moich wspomnieniach, gdyż uruchamia ona łańcuch obrazów: widzę witraż w oknie następnego podestu, rzeźbione drzwi i krój liter na tabliczce z nazwiskiem". Poza tym mieszkaniec tzw. kamienicy czynszowej wbrew pozorom ma większą swobodę w kształtowaniu przestrzeni mieszkalnej, niż mieszkaniec współczesnego osiedla. W miarę jak ulegają zmianie jego predylekcje przestrzenne, jest w stanie zmieniać jej strukturę, dzięki czemu nie musi poszukiwać innego mieszkania. Jego status w odniesieniu do fizycznej przestrzeni jest bardziej naturalny i zbliżony do tego jaki ma mieszkaniec jednorodzinnego domu. Takiej swobody ingerencji w przestrzeń materialna pozbawiony jest mieszkaniec współczesnego osiedla, gdzie wynikające z technologii ograniczenia techniczne ograniczaja do minimum swobodę kształtowania przestrzeni.

Przestrzeń, jaką dysponuje mieszkaniec tzw. bloku, jest przeważnie przestrzenią fizycznie odmiennie ograniczoną. Stłoczenie terytorialne współczesnego mieszkania jest szczególnie uciążliwe dla ludzi o zróżnicowanej osobowości i bardzo niebezpieczne dla rozwijających się osobowości, tj. dzieci. Ludzie o zróżnicowanej osobowości mają tendencję do większego różnicowania granic terytorium, a więc również mie-szkania. Dobre mieszkanie z psychologicznego punktu widzenia to takie, które zaspokaja psychologiczne potrzeby mieszkańca. Musi się ono charakteryzować taką przestrzenia, która umożliwia rozwijanie różnych aktywności i przestrzenną lokalizację różnych jednostek terytorialnych (przestrzeni personalnych). Zbyt

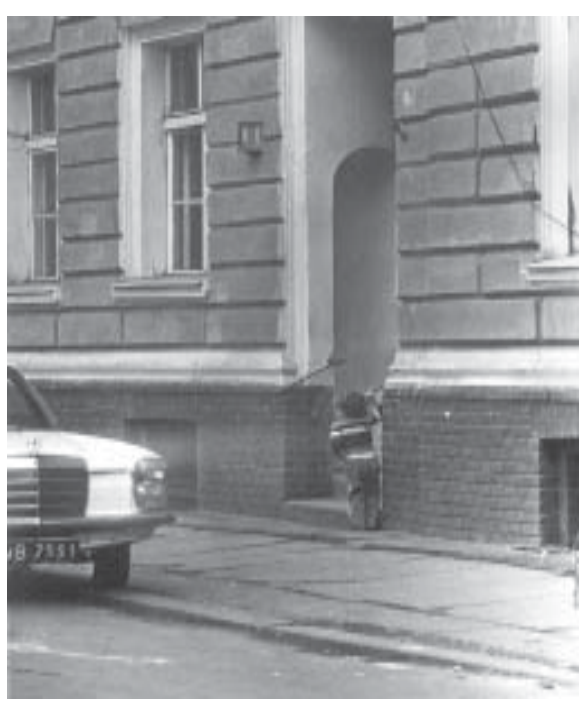

Brama w kamienicy czynszowej jawi się w wyobraźni dziecka jako jego terytorium i wejście do „bezpiecznej jaskini”. ciasna przestrzeń uniemożliwia swobodną allokację jednostek terytorialnych, co w konsekwencji może powodować dalsze nieprawidłowości w rozwoju osobowości. Na przykład użytkowanie przez rodzinę mieszkania, w którym wskaźnik zagęszczenia jest większy niż l:l, prowadzi do uniwersalizmu przestrzeni mieszkalnej. Te same pomieszczenia służą do odpoczynku nocnego, dziennej relaksacji, całodziennej zróżnicowanej aktywności poszczególnych człon-ków rodziny. Mamy tu niejako powrót do średniowiecznej koncepcji uniwersalnego mie-szkania. Uniwersalizm przestrzeni mieszkalnej zmniejsza osobowościowe nacechowanie poszczególnych elementów przestrzeni, które byłoby zgodne z zasada „moje terytorium - moja osobowość”. Utrudnieniu lub nawet całkowitemu uniemożliwieniu poddane zostają szczególnie te rodzaje aktywności, które z natury rzeczy wymagają przestrzeni.

Niedostateczna przestrzeń i związany z tym uniwersalizm funkcjonalny hamuje rozwój tych zachowań przestrzennych, które kolidują z zachowaniami przestrzennymi innych współmieszkańców. Prowadzi to w konsekwencji do zmian w układzie psychospołecznym rodziny. Siedmiometrowa kuchnia dla pięcio- lub sześcioosobowej rodziny z psychologicznego punktu widzenia jest przestrzennie niewystarczająca i niesie za sobą szereg konsekwencji. Jedną z nich jest to, że praktycznie w tak małej przestrzeni nie jest możliwe umieszczenie stołu, przy którym w jednym czasie cała rodzina mogłaby się zmieścić i spożywać posiłek przy 
spełnieniu podstawowych wymagań dotyczących minimum dopuszczalnego dystansu. Z badan R. Sommera dodatkowo wiadomo, jaką integracyjną rolę pełni stół. Będąc miejscem spotkań, wyznacza równocześnie pozycje i role poszczególnych członków rodziny. Nie każde miejsce jest jednakowo „wartościowe” przy stole, a jego brak co najmniej utrudnia „naturalizowanie” stratyfikacji wewnatrz rodzinnej w przestrzeni.

Wielu z opisanych wyżej ułomności, cechujących uprzemysłowione budownictwo „masowe”, pozbawione jest budownictwo jednorodzinne. Budownictwo rodzinne jest cenne z tych powodów, że pozwala na swobodniejszą manipulację fizyczną formą przestrzeni, wyrabia poczucie terytorialności i umożliwia więk-szą swobodę wyboru zachowań terytorialnych.. Chodzi tu o poczucie terytorialności w sensie psychologicznym, a nie socjologicznym. Sens socjologiczny terytorialności wiedzie ku koncepcji „osiedla” (neighbourhood unit - jednostka sasiedzka), której autorem był amerykański urbanista C.A. Perry (Perryry, H. 1929). twórca planu regionalnego Nowego Jorku. Według tej koncepcji, której najmniejszą jednostką terytorialną jest „jednostka sąsiedzka”, poczucie terytorialności definiowane jest na gruncie więzi międzyludzkich. Koncepcja ta nie zdała do końca egzaminu, ponieważ okazało się, że można prawidłowo zaprojektować osiedla, w których występuje silna więź sąsiedzka, lecz mimo to mieszkańcy nie mają poczucia terytorialności w sensie osobowościowego panowania nad terytorium (poczucie niedostosowania). Stąd też w ostatnich latach nastapił zwrot w kierunku teorii psychologicznych lepiej precyzujących warunki, które muszą być spełnione, aby wywołać u mieszkańców poczucie terytorialności w takim sensie, w jakim zostało ono opisane w tej części. Reasumując, koncepcje socjologiczne opierają się. na relacji „miasto-ludzie”, natomiast koncepcje psychologiczne terytorialności oparte są na relacji „miasto-ludzie-osobowość-rzeczy”. Ogólnie rzecz ujmując, budownictwo jednorodzinne umożliwia w najwyższym niemal stopniu osobowościowe nacechowanie poszczególnych elementów przestrzeni składających się na terytorium wyznaczane granicami posesji. Poza tym, co jest bardzo istotne, budownictwo rodzinne stwarza duże możliwości zmiany fizycznych cech przestrzeni w miarę zmiany trybu życia lub tempa życia mieszkańców. Dom jednorodzinny stanowi niejako oazę różnorodności przestrzennej, która znakomicie może kompensować brak zmian lub brak różnorodności (nowych bodźców) w innych dziedzinach aktywności życiowej człowieka (np. w pracy).
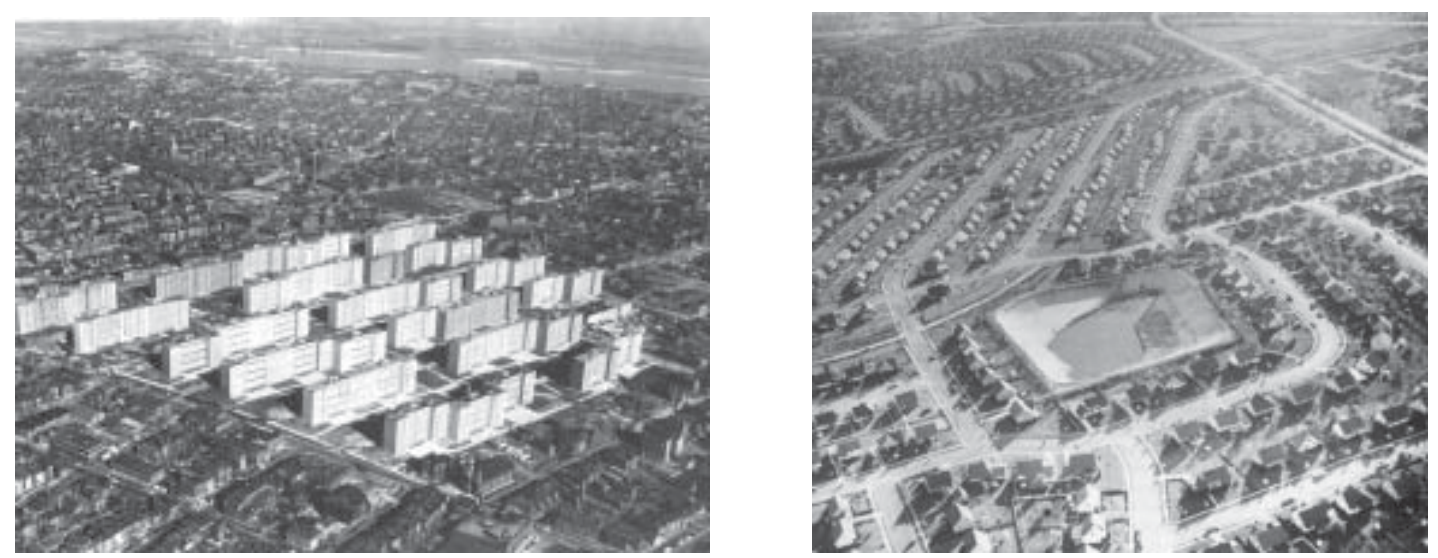

Widok z lotu ptaka (po prawej) osiedla Levittown na Long Island (USA) jednego z pierwszych projektów developerskich, zrealizowane między rokiem 1947 a 1960. Mimo wyraźnych braków w zakresie koncepcji sąsiedztwa, różnorodności środowiskowej i innego tego typu pojęć, ten rodzaj demokratycznej architektury wypada zdecydowanie na korzyść w porównaniu z nieistniejącym już dzisiaj osiedlem Pruitt-Igoe z Saint Louis (1957).

Budownictwo jednorodzinne ma jeszcze tę szczególną rolę do spełnienia, że powinno być dla społeczeństwa, znajdującego się w wirze burzliwych przemian, czymś w rodzaju „enklaw przeszłości”, w których tempo zmian jest świadomie regulowane. Ludzie pragnący wolniejszego rytmu życia, wymagajacy mniej pobudzających (denerwujących) warunków egzystencji, mają szansę znaleźć je w domku jednorodzinnym.

Uogólniając można powiedzieć, że architektura może kompensować zarówno wolne tempo i małą różnorodność zmian w życiu człowieka, jak i nadmierne tempo życiowe i nadmierną stymulację bodźcowa. Architektura ma również do spełnienia dużą rolę w dziele tworzenia, jak to nazywa A. Toffler, „enklaw przyszłości”. Sporą część populacji cechuje duże zapotrzebowanie na zmianę, nowość, duże tempo zmian, ekscentryczność czy odmienność Innymi słowy wielu (przeważnie młodych) ludzi satysfakcjonuje wszystko to, czego jeszcze nie było i co jeszcze lub dopiero może być. Architektura „nowa”, „niezwykła”, „drapieżna”, „ekstrawagancka”, od której uciekają ludzie o małym zapotrzebowaniu na stymulację, jest akceptowana i poszukiwana, przez ludzi o dużym zapotrzebowaniu na stymulację. W następnej części pracy omówione zostaną szczegółowo mechanizmy emocjonalne i poznawcze wyznaczające sposób zachowania się ludzi w różnych sytuacjach. 


\title{
CZĘŚĆ III
}

\section{ARCHITEKTURA EMOCJONALNEJ PRZESTRZENI ŻYCIA}

\author{
PSYCHOLOGICZNE POJĘCIE ŚRODOWISKA \\ ARCHITEKTONICZNEGO
}

\author{
Forma, środowisko i sytuacja architektoniczna
}

Każdy człowiek realizuje swoje czynności życiowe zawsze w jakimś środowisku, które w za-leżności od ukształtowania może: a) sprzyjać lub przeszkadzać w ich realizacji, b) wpływać dodatnio lub ujemnie na funkcje życiowe i zachowania. Przez środowisko rozumie się „,względnie trwały układ elementów otoczenia człowieka, ważnych dla jego życia i zachowania się". Jak już w poprzedniej części wspomniano, fakt, że człowiek żyje i działa w takim środowisku, jakim jest środowisko architektoniczne, ma również podstawowe znaczenie dla psychologii i musi być uwzględniany przy stawianiu i rozwiązywaniu jej problemów.

Elementami jakiegokolwiek środowiska są rzeczy i ludzie pozostający ze sobą w różnych stosunkach. Na przykład w przypadku środowiska pracy jego elementami są m.in. architektura hal fabrycznych lub biur, maszyny, warunki świetlne, akustyczne, współpracownicy, zwierzchnicy. Z kolei w przypadku środowiska domowego tymi elementami sa architektura domu, me-ble, sąsiedzi itd. Jak z tego wynika, fizyczna forma architektoniczna jest tylko jednym z elementów różnych środowisk życiowych człowieka oraz sam człowiek jest elementem swojego środowiska i jego obecność w środowisku nie pozostaje bez wpływu na związi zachodzace między innymi jego elementami.

Choć fizyczna forma architektoniczna jest tylko jednym z elementów środowiska życiowego człowieka, stanowi ona jednak element wyróżniający się. Znajduje to odbicie między innymi w tym, że środowisko, którego składnikiem jest architektura, nazywa się środowiskiem architektonicznym. Fizyczna forma architektoniczna wyznacza niejako trzecia, pośrednią (mezo) formę środowiska, oddzielająca środowisko

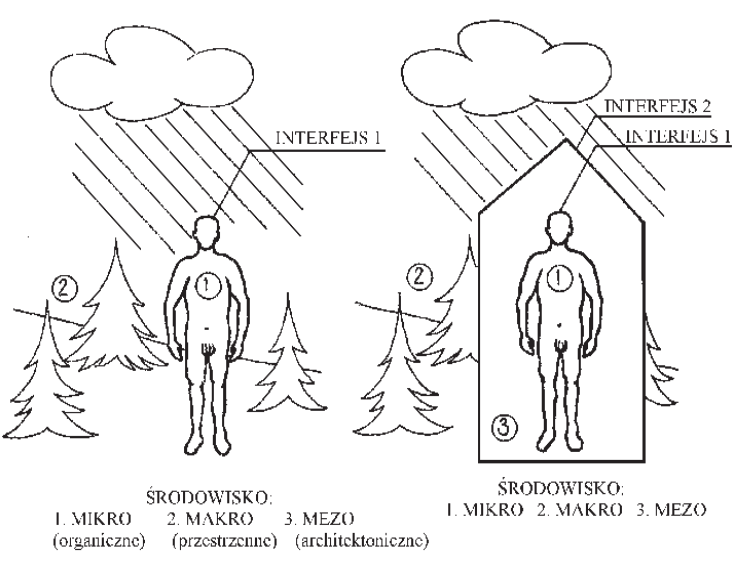

Zależność między człowiekiem i środowiskiem obejmuje dwa podstawowe interfejsy. Pierwszym jest kontakt poprzez skórę za pośrednictwem ubioru, a drugim jest kontakt za pośrednictwem architektury. wewnętrzne organizmu człowieka od zewnętrznego środo-

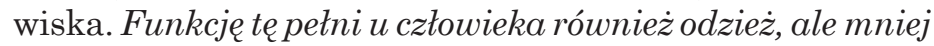
skutecznie. Dla kosmonauty i nurka, a więc ludzi działajacych w środowisku skrajnie nieprzyjaznym człowiekowi, skafander jest podstawowym systemem podtrzymania życia. Dla człowieka cywilizowanego owo mezo-środowisko tworzone przez architekturę stanowi najbardziej podstawowe środowisko jego bytowania.

Każdy człowiek jest również elementem swojego środowiska. Jeżeli mówimy o zakładzie pracy, domu czy o jakimkolwiek innym środowisku architektonicznym, to musimy pamiętać, że człowiek sam jest integralnym elementem tego środowiska, włączonym w skomplikowaną sieć wzajemnych stosunków z innymi jego elementami. Zmiana w jakimkolwiek elemencie wywołuje natychmiastową reakcję u człowieka. W związku z tym, jak mówi James Fitch „w architekturze nie ma widzów: są tylko uczestnicy". 
Zależność między środowiskiem zewnętrznym a wewnętrznym człowieka odbywa się na dwóch różnych, a równocześnie ściśle skorelowanych ze soba poziomach: metabolicznym i percepcyjnym. Procesy metaboliczne stanowią podstawę życia, biologiczne podłoże świadomości, a tym samym biologiczne podłoże percepcji zmian zachodzących w środowisku. Między procesami metabolicznymi a czynnikami środowiska architektonicznego zachodzi zależność podobna do tej, jaka występuje między embrionem a macica. Środowisko architektoniczne stanowi specjalny rodzaj kontenera, w którym przebywa człowiek, realizując swoje procesy życiowe na obydwu wyróżnionych poziomach, tj. metabolicznym i percepcyjnym. Zadaniem architektury jest zatem faworyzowanie organizmu ludzkiego i funkcję tę spełnia między innymi taki element fizycznej formy architektonicznej, jakim jest ściana. Na ścianę nie należy patrzeć jak na nieprzenikliwy interfejs oddzielający mezo- i makrośrodowisko, lecz raczej jak na selektywnie przenikliwą membranę oddzielająca czynniki środowiska wewnętrznego i zewnętrz-nego. Zadanie tej membrany sprowadza się do modulowania sił, oddziaływujacych z dwóch stron w interesie mieszkańców, tzn. tworzenie trzeciego, tzw. mezośrodowiska.

Zależność „maciczna” między człowiekiem a środowiskiem architektonicznym sprawia, że zastosowanie diametralnie nowej fizycznej formy architektonicznej (tak, jak w opisanym przypadku pejzaży biurowych) może zmienić charakter sytuacji człowieka wskutek zmiany jego relacji do innych elementów otoczenia. I tak pamiętamy, że wprowadzenie do praktyki biur typu otwartego zmieniło charakter ogólnego środo-

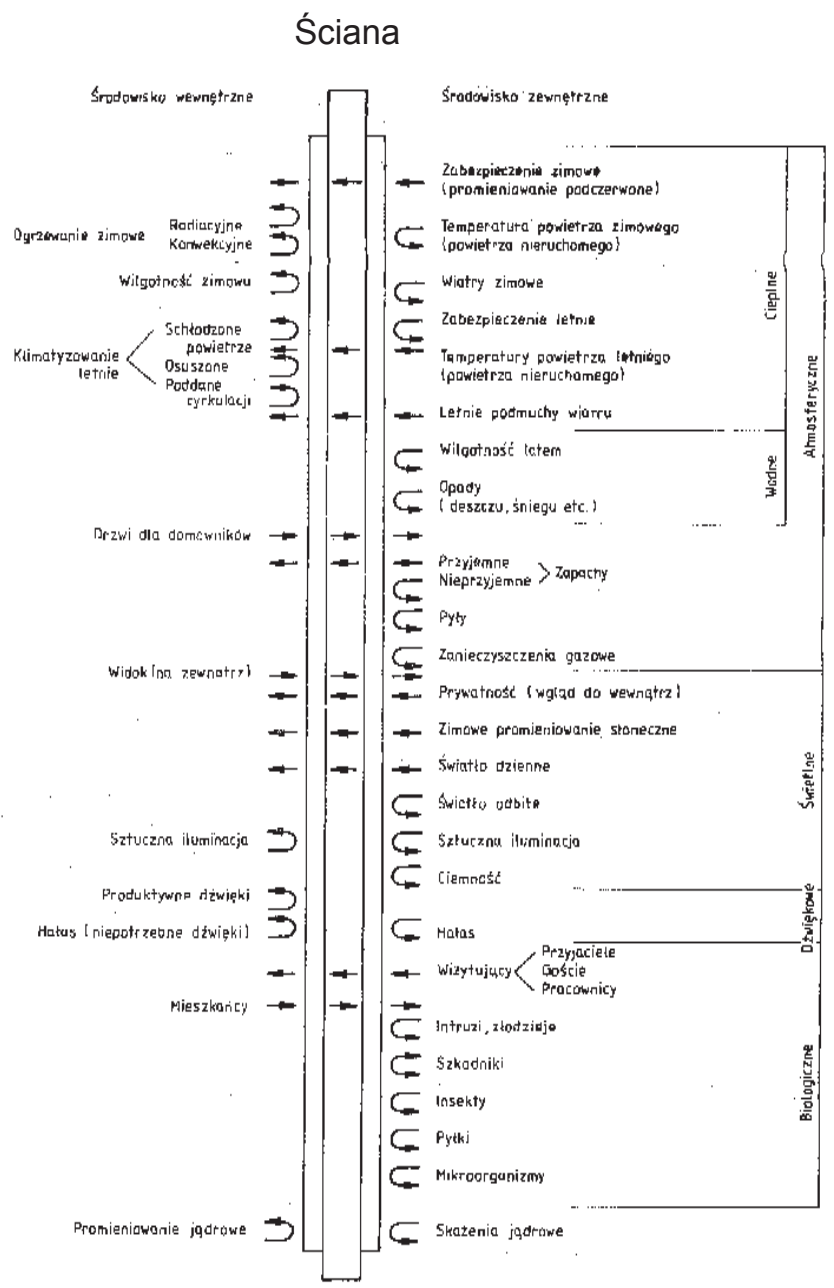

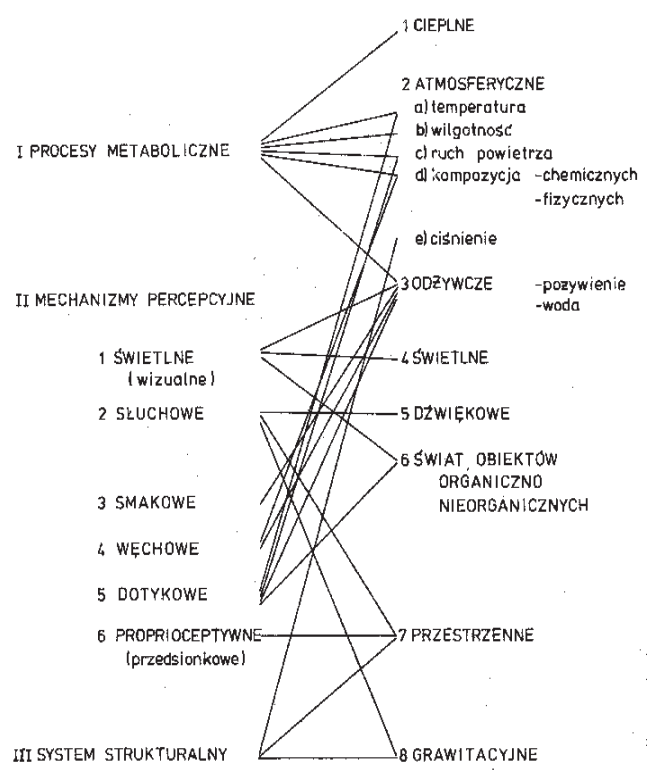

Zależność między procesami organizmu ludzkiego a środowiskiem. wiska pracy, wprowadzając głębokie zmiany w stosunkach między pracownikami, wynikajace m.in. z konieczności zmiany funkcji poszczególnych członków załogi. W związku z tym określone środowisko architektoniczne ma znaczenie biologiczne i psychologiczne nie tylko dla pojedynczego człowieka, ale także dla większych całości, takich jak rodzina, grupa sąsiedzka, przedsiębiorstwo.

Poszczególne elementy środowiska człowieka, podobnie jak i on sam, podlegają różnorodnym zmianom. Dlatego też obok pojęcia środowiska, które podkreśla względną stabilizację wzajemnych stosunków człowieka z otoczeniem, w psychologii często używane jest pojęcie sytuacji dla podkreślania zmienności tego układu. T.Tomaszewski przez sytuację człowieka rozumie „układ jego wzajemnych stosunków z innymi elementami jego środowiska w określonym momencie czasu". Jak z tego wynika, pojęcie sytuacji jest bardzo złożone. Zgodnie z jej najogólniejszą definicją sytuacja architektoniczna określona jest przez jej elementy składowe (takie, jak elementy formy fizycznej, przestrzeń, czynniki środowiskowe), przez ich cechy (np. cechy ściany, przestrzeni), przez stan poszczególnych elementów w określonym momencie oraz przez wzajemne stosunki, jakie w tym mo mencie zachodzą między tymi elementami.

Rola ściany jako selektywnie przenikliwej membrany oddzielającej czynniki środowiska wewnętrznego i zewnętrznego. 


\section{Stymulacyjny i zadaniowy aspekt środowiska}

Mówiąc o człowieku i fizycznej formie architektonicznej, czyli o środowisku architektonicznym, pamiętamy jednak o tym, że należy rozpatrywać tego rodzaju układ ze względu na człowieka będącego jednym z jego elementów, ale z wielu względów elementem wyróżnionym. Człowiek, ze względu na którego rozpatrujemy cały układ warunków architektonicznych, jest podmiotem sytuacji. Inaczej mówiąc, z psychologicznego punktu widzenia istotne jest to, że tak jak każda sytuacja jest „czyjaś” i nie da się określić bez podania jej podmiotu, tak samo sytuacja architektoniczna (czyli fizyczna forma architektoniczna plus człowiek) jest również zawsze „czyjaś” i nie da się w pełni określié bez podania jej podmiotu, czyli konkretnego człowieka. Ponieważ w układzie sytuacji tworzonej przez architekturę uczestniczy przeważnie więcej niż jeden człowiek, układ ten musi być rozpatrywany ze względu na poszczególnych ludzi, gdyż dla każdej osoby sytuacja może być inna. Zagadnienie to uwzględnione jest we współczesnych koncepcjach projektowania architektonicznego, m.in. przez Rittla (cz. I) i Alexandra (cz. I), według których fizyczna forma architektoniczna powstaje w wyniku procesu negocjacji różnych architektonicznych „Weltanschauungen”, czy też Bazjanca, według którego w procesie wyprowadzania najbardziej optymalnej fizycznej formy architektonicznej projektant uczy się różnych architektonicznych „weltanschauungen” (cz. I).

Każdą sytuację, a więc również tę, którą determinuje fizyczna forma architektoniczna, należy rozpatrywać ze względu na określoną aktywność podmiotu. W zachowaniu się można wyróżnić dwa różne poziomy jego organizacji. Na poziomie elementarnym zachowanie się ma charakter reaktywny, na poziomie zaś wyższej organizacji - charakter ukierunkowany i celowy. Dlatego też, określając fizyczną formę architektoniczną z psychologicznego punktu widzenia, należy uwzględniać zarówno jej aspekt bodźcowy (stymu-lacyjny), oznaczający, że fizyczna forma architektoniczna, tworząc człowiekowi mezośrodowisko, jest źródłem bodźców, które oddziałuja na człowieka wywołując określone reakcje, jak i jej aspekt zadaniowy wynikający stąd, że sytuacja architektoniczna jest polem, w którym człowiek rozwija swoją działalność podstawowa, realizując określone zadania, jak np. pracę, zabawę, wychowywanie dzieci. Opisując więc różne przejawy zachowania się ludzi w przestrzeni architektonicznej, należy uwzględniać nie tylko to, że są one reakcją na tę sytuację, lecz i to, że niektóre przejawy tego zachowania są również rozwiązaniem tej sytuacji. Na przykład zwiększone rozmiary absencji lub zmniejszoną wydajność pracy w opisanym w poprzedniej części problemie pejzażu biurowego można traktować równocześnie jako reakcje na brak różnorodności i jako sposób rozwiązania przez pracowników sytuacji trudnej (obciążającej).

Dla właściwego rozumienia bodźcowego i zadaniowego aspektu sytuacji związanej z przestrzenią architektoniczna istotne znaczenie ma fakt, że człowiek jako podmiot sytuacji sam jest również jednym z elementów swojej sytuacji, a więc, że jego „sytuacja architektoniczna” jest określona zarówno przez cechy i stany elementów jego otoczenia (np. obszar, kształt, usytuowanie, warunki akustyczne), jak i przez cechy i stany samego człowieka (np. wrażliwość, pobudzenie emocjonalnej).

Wrażliwościa nazywamy zdolność organizmów żywych do odbioru określonych bodźców (np. wrażliwość wzrokowa, dotykowa, słuchowa). Tak więc w otoczeniu hałaśliwym sytuacja człowieka z podwyższonym progiem słyszalności lub całkowicie głuchego jest inna niż sytuacja człowieka dobrze słyszącego (sensytywnego). Analogicznie inaczej odbiera przestrzeń architektoniczna człowiek ślepy niż człowiek ze sprawnym analizatorem wzrokowym, dobrze oceniającym kształt, wielkość, kolor, głębię.

Reaktywnościa nazywamy charakterystyczny dla różnych ludzi stosunek siły reakcji do siły wywołujących ją bodźców. Pod względem tej cechy zachodzą między ludźmi znaczne różnice indywidualne, co sprawia, że sytuacja różnych ludzi znajdujących się w tym samym oddziaływaniu bodźcowym jest różna. Jedne
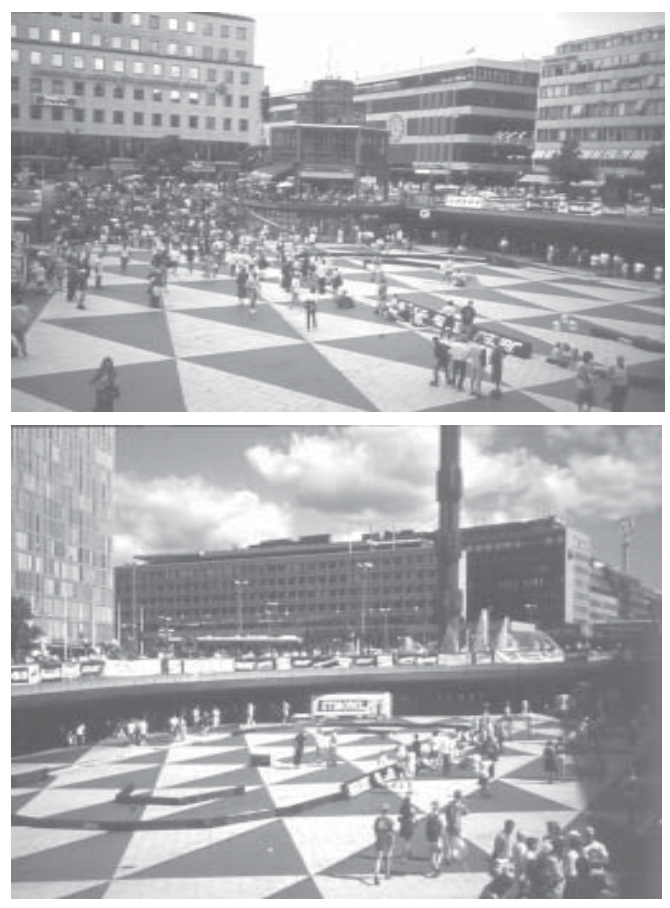

Forma architektoniczna jest źródłem bodźców, które wywołuja reakcje zachowania zależne od stałych i zmiennych elementów sytuacji. Stymulacyjny aspekt sytuacji określony jest z jednej strony przez fizyczne cechy elementów otoczenia (kształt, wielkość, proporcje) oraz cechy zdarzeń zachodzących w otoczeniu (dźwięki, zapachy, interakcje społeczne - z jednej strony, a z drugiej strony przez odpowiednie właściwości samego człowieka, a mianowicie przez „wrażliwość” i „reaktywność”. 
osoby reagują na bodźce o określonej sile słabiej, inne silniej. Inaczej mówiąc, to samo otoczenie oddziałuje na ludzi z różną siła, wskutek czego zachowanie się różnych ludzi w tym samym otoczeniu może być różne.

Poważny udział w kształtowaniu się sytuacji psychologicznej człowieka ma również jego świadomość, ponieważ pojęcie sytuacji obejmuje zarówno jego samego jak i takie elementy otoczenia człowieka, jakie sa obiektywnie i w obiektywnych stosunkach wzajemnych, oraz takie, jakimi spostrzegaja je ludzie uczestniczący w tej sytuacji. A zatem obiektywne cechy sytuacji architektonicznej kształtują zachowanie się podmiotu zależnie od tego, jak on sam spostrzega swoją sytuację (czynniki cieplne, świetlne, dźwiękowe, przestrzenne itd.), przy czym samo spostrzeganie tej sytuacji jest zależne od tego, jakie są obiektywne cechy otoczenia, jaki człowiek jest sam i co on w tej sytuacji robi. W związku z tym w ocenie wpływu architektury na sytuację psychologiczną jednostki należy uwzględniać, oprócz różnych fizycznych cech przestrzeni architektonicznej, subiektywną ocenę (percepcję) różnych związanych z nią aspektów.

\section{Specyficzne i niespecyficzne oddziaływanie architektury}

Oddziaływanie środowiska architektonicznego jako układu stymulacyjnego jest dwojakie, a mianowicie specyficzne i niespecyficzne. Przez oddziaływanie specyficzne rozumie się bezpośredni wpływ bodźców środowiska na organy zmysłowe i procesy metaboliczne organizmu ludzkiego. Efektem specyficznego oddziaływania
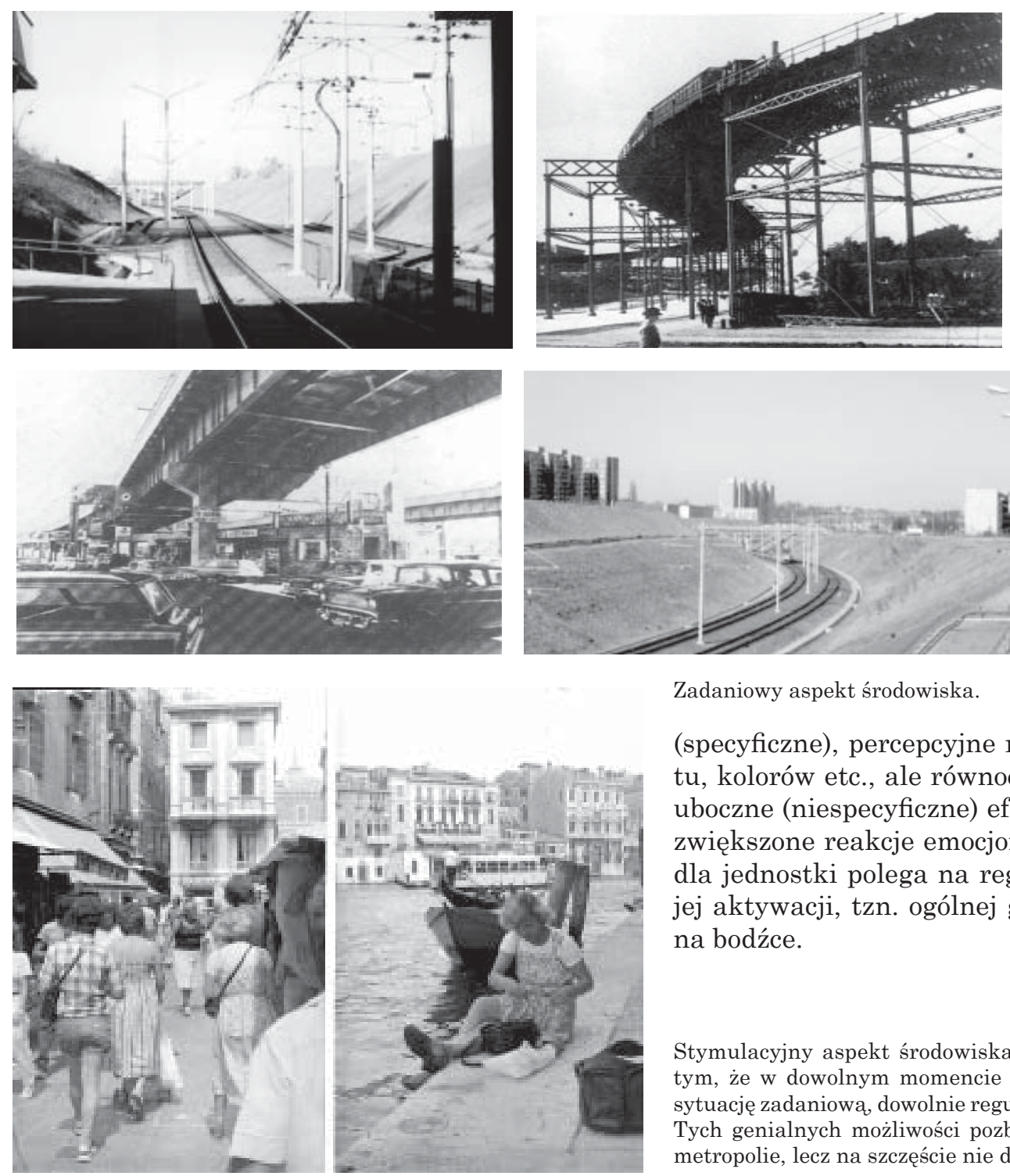
na bodźce. metropolie, lecz na szczęście nie do końca. czynników środowiska architektonicznego na organizm ludzki są bezpośrednie reakcje organizmu przejawiajace się w procesach metabolicznych i percepcyjnych, jak wrażenia wizualne, słuchowe, węchowe. Natomiast przez oddziały-wanie niespecyficzne czynników środowiska architektonicznego należy rozumieć ich pośredni wpływ na różne narządy i układy ustroju człowieka oraz strukture psychiczna. Tak np. fizyczna forma architektoniczna, jaka jest budynek, wywołuje u człowieka bezpośrednie Zadaniowy aspekt środowiska. (specyficzne), percepcyjne reakcje wielkości, kształtu, kolorów etc., ale równocześnie może wywoływać uboczne (niespecyficzne) efekty zachowania, jak np. zwiększone reakcje emocjonalne, których znaczenie dla jednostki polega na regulacji ogólnego poziomu jej aktywacji, tzn. ogólnej gotowości do reagowania

Stymulacyjny aspekt środowiska. Fenomen Wenecji polega na tym, że w dowolnym momencie można świadomie zobrazować sytuację zadaniowa, dowolnie regulować sobie dopływ stymulacji. Tych genialnych możliwości pozbawiają człowieka współczesne 
Zachowanie się człowieka w środowisku architektonicznym stanowi zatem globalną sumę specyficznych i niespecyficznych reakcji organizmu. W projektowaniu architektonicznym po-winno się równoprawnie uwzględniać potencjalne oddziaływanie projektowanej formy architektonicznej na obydwie sfery reakcji. Tak np. projektując szpital, nie można uwzględniać jedynie tego faktu, że jest to przestrzeń, która musi zawierać optymalne warunki atmosferyczne, świetlne, dźwiękowe czy biologiczne, ale również to, że wpływa ona na emocje i postawy pacjentów, których wpływ na przebieg rekonwalescencji trudno przecenić.

\section{Architektura a struktura sytuacji zadaniowej}

Ponieważ środowisko architektoniczne jest ważnym elementem środowiska życiowego czło-wieka, w związku z tym w sposób istotny kształtuje ono strukturę sytuacji zadaniowej ludzi. Strukturę zadaniową sytuacji T. Tomaszewski charakteryzuje jako układ wartości i możliwości, przy czym wartością nazywa stan rzeczy, który określa kierunek aktywności człowieka, możliwością zaś - stan rzeczy od którego zależy, czy wartość zostanie osiagnięta. Tak np. w sytuacji produkcyjnej wartościa jest powstanie produktu, na możliwość zaś składa się istnienie odpowiednich materiałów, narzędzi, odpowiednich umiejętności i warunków fizycznych. Natomiast w sytuacji szpitalnej podstawową wartościa jest fizyczna i psychiczna rehabilitacja pacjentów, natomiast możliwością są odpowiednie warunki medyczne i przestrzenno-architektoniczne.

Ponieważ przestrzeń architektoniczna w różnych sytuacjach życiowych stanowi określoną możliwość realizacji różnego rodzaju wartości, wydaje się więc uzasadnione określenie jej ważności, jako czynnika sprzyjającego lub uciążliwego, na odpowiednim kontinuum dystansu w stosunku do szeregu innych możliwości. Jak jednak wiadomo wartości i możliwości mogą być obiektywne i subiektywne, takie jakie są niezależnie od czyjejś oceny, i takie, jak je oceniają ludzie uczestniczący w danej sytuacji. Ocenę obiektywną architek-

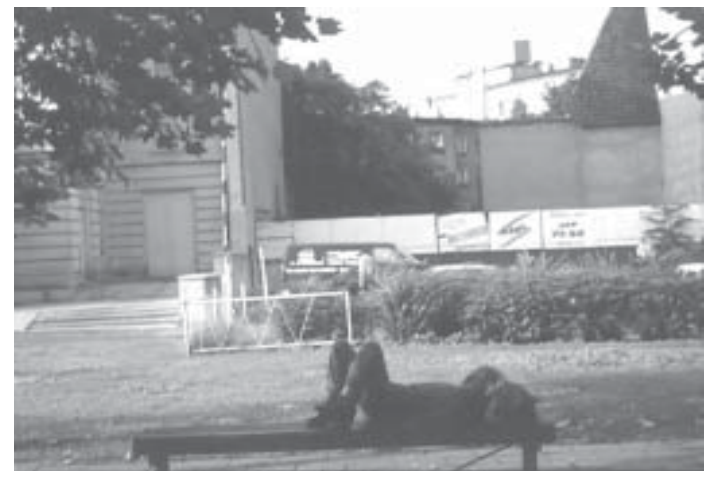

Dla bezdomnego ławka jest jego domem. To co dla jednych jest oddziaływaniem niespecyficznym, dla innych jest działaniem specyficznym. tury jako możliwości, choć jest z punktu psychologicznego przydatna, należy zostawić samym architektom. Domeną psychologii jest subiektywna ocena możliwości, jaką stanowi fizyczna forma architektoniczna, i jej w głównej mierze poświęca się rozważania w tej części pracy.

Sytuacja związana z przestrzenią architektoniczna jako układ wartości i możliwości, może mieć różne wymiary i różny obszar (pole). Wymiary sytuacji odpowiadają kierunkom aktywności podmiotu, a więc wartościom, jakie podmiot stara się w danej sytuacji realizować. Na przykład podstawową wartością realizowaną w sytuacji drink baru jest wypicie alkoholu, ale nie jest to wartość jedyna. Sytuacja ta przedstawia, jak tego dowodzą badania Sherri Cavana, skomplikowany układ wartości możliwych do realizacji, począwszy od nawiązania kontaktu z innymi ludźmi, a skończywszy na „samotności w tłumie”. W związku z tym architektura powinna odpowiadać różnym wartościom, jakie ludzie chcieliby realizować w danej sytuacji.

Sytuacje człowieka, a więc również te, które wyznacza architektura, stanowią z psycholo-gicznego punktu widzenia sytuacje wielowymiarowe w jeszcze innym sensie. Ludzie bowiem najczęściej znajduja się w sytuacji, w której wartości pozytywne mogą osiagnąć tylko kosztem akceptacji pewnych wartości negatywnych. Tak np. względy higieniczne przemawiają za stosowaniem w budownictwie szpitalnym czy domowym łatwiejszych do utrzymania w czystości materiałów, natomiast względy związane z samopoczuciem przemawiają za szerszym stosowaniem materiałów o zróżnicowanej strukturze.

Sytuację związaną z poszczególnymi środowiskami człowieka można ują́ w kategoriach cybernetycznych jako układ względnie zamknięty, ograniczony do obszaru związanego z danym środowiskiem. Oznacza to, że np. na przebieg podstawowej aktywności pracownika wywierają decydujący wpływ bodźce, wartości i możliwości występujące w obszarze zakładu pracy. Z kolei zaś na aktywność tego samego człowieka w życiu prywatnym wywierają wpływ bodźce, wartości i możliwości występujace w jego środowisku prywatnym, natomiast nie mają wpływu albo wpływają tylko pośrednio elementy z obszaru zakładu pracy. Kurt Lewin wprowadził na określenie tego obszaru pojęcie „pola” i pojęcie „bariery”, która otacza takie pole. 


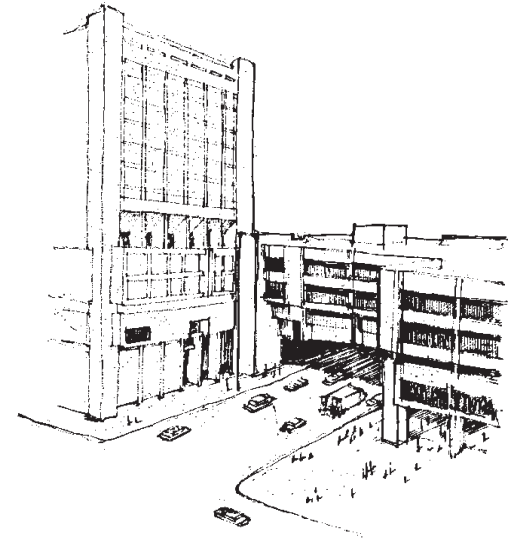

Projekt centrum medycznego H. Fielda (1970) zakłada, że miejsce rehabilitacji medycznej nie tylko nie musi być odseparowane od miasta i jego uciążliwości, ale powinno być bramą wjazdową do miasta.

Jednak obserwacje i badania z ostatnich lat wskazują na to, że podstawowe pola sytuacyjne człowieka przecinają się. Obserwuje się np. ścisłe powiązanie wpływów kształtujących sytuację osobnika w miejscu pracy z jego funkcjonowaniem w życiu prywatnym, oraz odwrotnie, powiazanie wpływów kształtujących sytuację osobnika w życiu prywatnym z jego dyspozycja do wykonywania pracy. Szczególnie silnie uwidacznia się ta zależność na przykładzie oddziaływania różnego rodzaju hałasów.

Niezależnie od tego, czy silne bodźce akustyczne (hałasy) występuja w środowisku pracy, czy w środowisku domowym, pobudzaja ujemnie sferę emocjonalną człowieka, powodując często powstanie sytuacji trudnej, która w przypadku niezbyt dużego natężenia bodźców może mieć charakter sytuacji utrudnienia, lecz w przypadku silnego natężenia hałasu może przybrać charakter sytuacji przeciążenia. W tego rodzaju sytuacjach, oprócz obniżenia się poziomu wykonania zadań (mniejsza wydajność i jakość pracy), często obserwuje się zaburzenia nerwowe, przejściowe stany napięcia nerwowego albo mniej lub bardziej trwałe nerwice. Reakcje te są bardzo złożone i określane najczęściej terminem stres. Stres jest to stan organizmu wywołany przez tzw. stresor, tj. każdy bodziec nieobojętny dla organizmu, przejawiający się swoistym zespołem objawów. Stan stresu, wywołany w organizmie człowieka przez określona trudność, utrzymuje się zwykle dłużej, niż trwa trudna sytuacja, która go wywołała, a jego następstwem może być szereg tzw. „posytuacyjnych” obciążeń. Subiektywne reakcje człowieka na sytuacje trudne objawiają się przedłużającym się stanem napięcia emocjonalnego oraz oceną własnego zachowania się w sytuacji, która minęła, analizą przyczyn takiego a nie innego zachowania się, oceną trud-

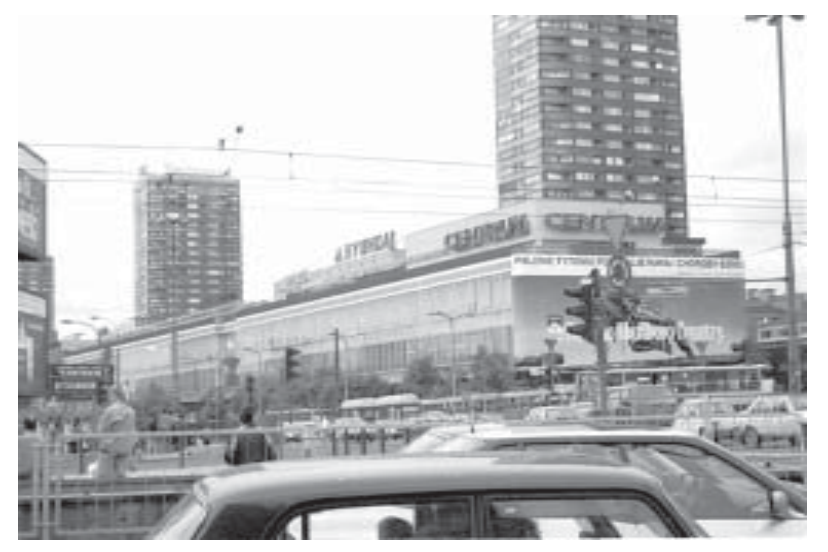

Pola sytuacyjne człowieka przecinają się. W środowisku urbanistycznym człowiek przemierza dystans z domu do pracy i z powrotem. W natłoku informacji do świadomości docierają tylko niektóre z nich, inne nieuświadomione działają na psychikę jako podprogowe stresory.

ności i sensowności zadania. Tego rodzaju psychologiczne następstwa sytuacji trudnej wywierają wpływ na kształtowanie się następnej sytuacji, ponieważ podmiot wchodzi w nią mniej lub bardziej obciążony psychologicznymi następstwami sytuacji poprzedzającej.

Na podstawie powyższych przesłanek można uznać, że w ocenie wpływu danego środowiska na człowieka należy uwzględnić zarówno jego doraźne skutki, jak i dalsze następstwa psychologiczne ujawniające się w późniejszym zachowaniu. 


\title{
WEWNĘTRZNE REAKCJE EMOCJONALNE NA CZYNNIKI ŚRODOWISKA ARCHITEKTONICZNEGO
}

\author{
Psychologiczny model zależności między czlowiekiem a środowiskiem
}

W rozdziale poprzednim omówiono teoretyczne aspekty wpływu środowiska architektonicznego na psychologiczną sytuację jednostki. Istotnym teoretycznym problemem, który w dotychczasowych rozważaniach nie został jeszcze wystarczająco uwzględniony, jest zagadnienie zmiennych (niezależnych, zależnych i pośredniczących) związanych z reakcjami człowieka na sytuację. W rozwiązaniu tego problemu bardzo pomocne okazują się osiagnięcia nowego działu psychologii, a mianowicie psychologii środowiskowej. Psychologia środowiskowa koncentruje się na dwu problemach: na wpływie fizycznych bodźców środowiska architektonicznego na sferę emocjonalną człowieka oraz na wpływie fizycznych bodźców środowiska na różnorodne zachowania.

Chociaż psychologia środowiskowa wniosła bardzo wiele do usystematyzowania zmiennych w badaniach nad wpływem bodźców fizycznego środowiska architektonicznego na zachowania się ludzi, to należy jednak

\begin{tabular}{|c|c|c|c|}
\hline \multicolumn{2}{|c|}{ 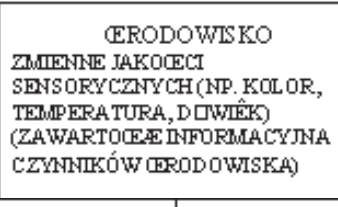 } & \multicolumn{2}{|c|}{ 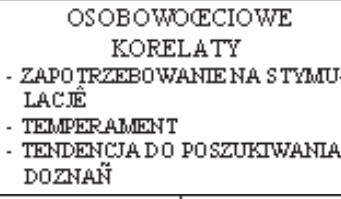 } \\
\hline$\downarrow$ & & & $\sqrt{1}$ \\
\hline \multirow{2}{*}{\multicolumn{2}{|c|}{$\begin{array}{l}\text { PIERWOTNE } \\
\text { - PRZYJEMNOW:I }\end{array}$}} & IE & $\begin{array}{l}\text { EMOCJONALL } \\
\text { - DOMINACII }\end{array}$ \\
\hline & & \\
\hline \multicolumn{4}{|c|}{ 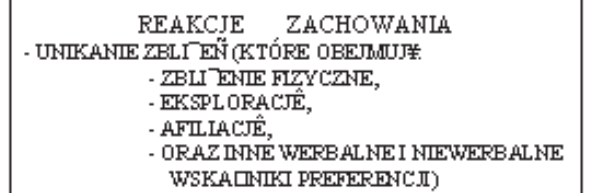 } \\
\hline
\end{tabular}

Podstawowe zmienne wyznaczające ocenę wpływu środowiska fizycznego na człowieka. zaznaczyć, że problem ten nie został jeszcze rozstrzygnięty do końca. Ciekawą propozycją w tym względzie jest koncepcja Mehrabiana i Russella. Koncepcja ich wskazuje i porzad kuje podstawowe zmienne, jakie powinno się kontrolować w ocenie i kształtowaniu wpływu bodźców środowiska fizycznego na człowieka. Ogólny zarys teoretyczny tej koncepcji przedstawia rysunek.

$\mathrm{W}$ przedstawionym na rysunku modelu występuja trzy rodzaje zmiennych. Zmiennymi niezależnymi sa bodźce środowiska (atmosferyczne, słuchowe, wizualne, przestrzenne etc.), które odbierane przez poszczególne zmysły wywołują określone stany emocjonalne. Stany te mogą być opisane za pomocą trzech ogólnych reakcji emocjonalnych, jakimi sa przyjemność - nieprzyjemność, pobudzenie - niepobudzenie oraz dominacja submisja. W powyższym modelu te trzy reakcje emocjonalne stanowią zmienne pośredniczące w powstawaniu różnych reakcji zachowania zarówno werbalnego, jak i niewerbalnego w stosunku do środowiska. Ogół reakcji zachowania na fizyczne bodźce środowiska określa się terminem unikanie - zbliżenie.

Przedstawiony na rysunku wykres zależności między zmiennymi jest wynikiem pewnego ogólnego podejścia do badania i rozumienia interakcji człowieka ze środowiskiem. Podstawową cechą owej orientacji teoretycznej jest dążenie do wykrycia takich reakcji, które byłyby bezpośrednim rezultatem stymulacji i które występowałyby w różnym stopniu w każdym środowisku. Jak więc z tego wynika zamierzeniem psychologii środowiskowej jest dokonanie „oszczędnego” opisu reakcji człowieka na bodźce środowiska. Reakcje percepcyjne nie spełniają tego warunku, ponieważ w ramach każdej modalności sensorycznej konieczne byłoby rozważenie co najmniej kilku dymensji reakcji. Dlatego też usiłowania badaczy poszły w kierunku intermodalności, tzn. wykrycia reakcji wspólnych dla wszystkich bodźców niezależnie od rodzaju stymulowanego organu sensorycznego. W dalszej części omówione zostaną najważniejsze badania, które świadczą o tym, że przedstawione na rysunku reakcje emocjonalne stanowią „jądro” wszystkich reakcji człowieka na najróżnorodniejsze bodźce środowiska.

Badania nad synestezją wrażeń, nad dyferencjacją semantyczną oraz reakcjami fizjologicznymi wskazują na istnienie trzech podstawowych demensji reakcji, które krzyżują się z poszczególnymi wrażeniami sensorycznymi. Mówiąc inaczej, badania te świadczą o tym, że emocjonalne reakcje stanowią wspólny „rdzeń” reakcji człowieka na różnego rodzaju bodźce środowiska. Intermodalne skojarzenia stwierdzano wielokrotnie w badaniach eksperymentalnych, podczas których stymulacja jednej jakości sensorycznej wywoływała wrażenia w innej. Między innymi Hazard prosił osoby badane o scharakteryzowanie 14 różnych zapachów 
i stwierdził, że duży procent użytych przymiotników charakteryzował stymulację innych jakości sensorycznych. (np. lekki, szorstki, jasny). W innych badaniach stwierdzono, że niektóre osoby odzwierciedlaja podniecająca muzykę $\mathrm{w}$ jasnych kolorach lub w kanciastych kształtach, a muzykę wolną kojarzą z formami okragłymi. Zietz stwierdził, że tony o różnych częstotliwościach wywołują różne wrażenia. Tony o niskiej częstotliwości (około $200 \mathrm{~Hz}$ ) wywoływały najczęściej wrażenia tonów ciemniejszych, cieplejszych, bardziej miękkich, dawały wrażenia stłumionych kolorów i nieokreślonych kształtów. Tony średniej częstotliwości $(550 \mathrm{~Hz})$ odzwierciedlano w ostrych kształtach, jako jaśniejsze, zimniejsze, czystsze i jako „twardsze” w kolorach. Tony wysokiej częstotliwości były odbierane w „krępych” formach. Zietz stwierdził poza tym, że w jasnym pomieszczeniu osoby badane oceniały te same tony jako dźwięki o wyższej częstotliwości niż w pomieszczeniu mrocznym.

Wyniki powyższych badań wykorzystała w praktyce amerykańska firma nagrań muzycznych MUZAK. Firma ta opracowuje muzykę, której zadaniem jest wywołanie komplementarnych w stosunku do sytuacji architektonicznej nastrojów emocjonalnych pobudzenia, przyjemności lub odprężenia.

Niezależnym źródłem dowodów na istnienie niezależnych, wspólnych wszystkim bodźcom reakcji (tj. niezależnie, od tego, jaki organ sensoryczny jest stymulowany) są badania nad dyferencjacją semantyczną. Dyferencjał semantyczny jest to metoda opracowana przez amerykańskiego psychologa Osgooda, stosujaca skale ocen i analizę czynnikową do badania znaczenia konotacyjnego słów, „semantyczny” - ponieważ dotyczy znaczenia, a „dyferencjał” - ponieważ metoda ta wprowadza kilka różnych wymiarów (dymensji) znaczenia. Znaczenie konotacyjne jest to znaczenie emocjonalne związane z jakimś słowem lub symbolem, wykraczającym poza jego znaczenie denotacyjne, tzn. podstawowe znaczenie danego symbolu lub znaku słownego). Tak więc obydwa słowa: „nagi” i „goły” oznaczają kogoś nieubranego (znaczenie denotacyjne), lecz mają one odmienną konotację. Badania techniką dyferen-

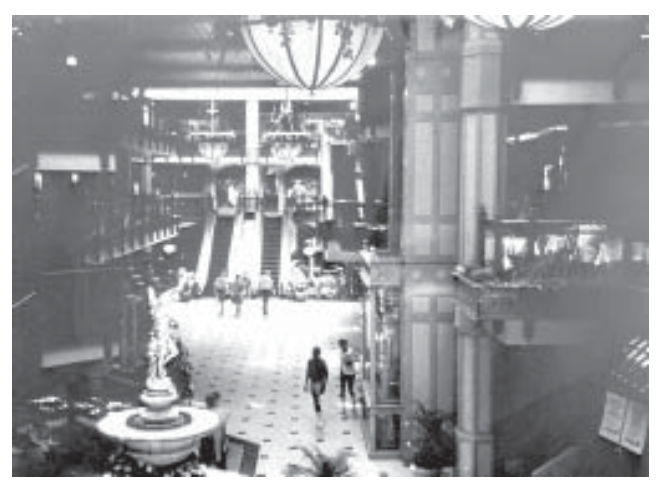

Nowy Jork: Supermarket jest w zasadzie przestrzenią multimedialna, której walory podnosi pomysłowe wnętrze, przyjemny nastrój. Jego elementem składowym jest starannie dobrana muzyka. Ilość zakupów jest funkcją czasu spędzonego w danej przestrzeni, okres przebywania w przestrzeni zależy od rodzaju emocjonalnych podniet. interakcji odgrywają bardzo istotną rolę, mogą być opisane w kategoriach trzech podstawowych wymiarów, które są podobne do tych, jakich użyli we wcześniejszych badaniach Osgood, Suci i Tannenbaum.

Jak z tego wynika, badania nad synestezja, deferencjacją semantyczna oraz reakcjami fizjologicznymi potwierdzają istnienie ograniczonego zestawu podstawowych reakcji emocjonalnych na wszystkie sytuacje bodźcowe, niezależnie od tego, jaki moduł sensoryczny (organ zmysłowy) poddany jest stymulacji. Wysnuwa się hipotezy, że reakcjom oceniającym typu oceny i aktywności z dyferencjału semantycznego można odpowiednio przyporządkować emocjonalne reakcje przyjemności i emocjonalne reakcje pobudzenia. Natomiast oceniającej reakcji siły można przyporządkować emocjonalną reakcję, którą charakteryzuje dychotomia: dominacja - submisja (uległość).

W ramach tej dychotomii bodziec o małej sile wywołuje uczucie dominacji, a bodziec o dużej sile wywołuje uczucie submisji (uległości). Zmiany w przyjemności, pobudzeniu i dominacji tworzą podstawowy układ emocjonalnych reakcji człowieka na wszystkie bodźce. Wszystkie inne reakcje, którym odpowiadają inne terminy reakcji emocjonalnych (tzw. reakcje złożone), mogą być ujęte w kategoriach tych trzech podstawowych dymensji. Tak np. uczucie nudy lub zmęczenia można określić jako uczucie cechujące się niską przyjemnością na skali „przyjemność-nieprzyjemność”, niskim pobudzeniem na skali „pobudzony-niepo- 
budzony” oraz uczuciem zbliżonym do submisji na skali „dominacja-submisja”. Odwrotnie, podniecenie można scharakteryzować jako stan o dużej przyjemności, pobudzeniu i dużej dominacji. Zrelaksowanie i komfort plasują się wysoko na skali przyjemności i dominacji, ale nisko na skali pobudzenia.

\section{Emocjonalne reakcje przyjemności a zachowania typu „unikanie-zbliżenie”}

Zgodnie z przedstawionymi wyżej założeniami uczucia jednostki w jakimkolwiek czasie określić można za pomoca trzech podstawowych reakcji emocjonalnych: przyjemności, pobudzenia i dominacji. Reakcje te sa wynikiem oddziaływania bodźców środowiska z jednej strony oraz funkcją cech osobowości i chwilowych stanów organizmu z drugiej. Emocjonalne reakcje przyjemności, pobudzenia i dominacji stanowią zmien-ne pośredniczące między fizycznymi i społecznymi bodźcami środowiska a różnymi reakcjami zachowania w danym środowisku.

Podobnie, jak możliwy jest oszczędny opis pierwotnych (podstawowych) reakcji na bodźce środowiska za pomocą trzech reakcji emocjonalnych, tak samo możliwy jest oszczędny opis reakcji zachowania wywołanych bodźcami tego środowiska. Celowi temu służy ogólna koncepcja reakcji zachowania typu unikanie-zbliżenie. Koncepcja ta sprowadza całość zachowań do jednego kontinuum, którego jeden koniec reprezentują zachowania ucieczkowe, a drugi - zachowania zbliżeniowe. Zachowania ucieczkowe (unikania) oraz zbliżeniowe obejmuja bardzo szeroki zakres reakcji, takich jak: zbliżenie lub oddalenie się fizyczne od środowiska lub bodźca, zachowania eksploracyjne, postawy w postaci werbalnie i niewerbalnie wyrażanych preferencji, zbliżenie do innych osób, podejście do wykonania zadań. Jak z tego wynika, termin „unikanie-zbliżenie” jest syntetycznym określeniem całego spektrum zachowań się człowieka w jakiejkolwiek sytuacji. W rozdziale tym omówione zostaną te aspekty literatury przedmiotu, które w największym stopniu wyjaśniaja wpływ emocjonalnych reakcji podmiotu, jako skutek fizycznej stymulacji środowiska architektonicznego, na zachowania „unikania-zbliżenia”. Drugim omawianym zagadnieniem jest problem pośredniczącej roli architektury w kształtowaniu ucieczkowo-zbliżeniowych zachowań międzyludzkich.

Zasadnicza hipoteza dotycząca związku między emocjonalną reakcją przyjemności, a zachowaniami typu „unikanie-zbliżenie”, zakłada wzrost tendencji do zachowań typu zbliżeniowego w miarę zwiększania się uczucia przyjemności na kontinuum „przyjemność-nieprzyjemność”. Istotną implikacją tej tezy jest to, że reakcja przyjemności może wywodzić się z wielu źródeł, tzn. podejście do jakiegoś jednego aspektu sytuacji (np. zadania lub innej osoby) może być wzmocnione innym aspektem tej samej sytuacji. W oparciu o powyższą hipotezę przeprowadzono wiele badań, w których analizowany był wpływ uczucia przyjemności na zachowania zbliżeniowe do różnych aspektów sytuacji, które nie są źródłem tego uczucia. Badania te wykazały, że np. interpersonalne zachowania zbliżeniowe, takie jak zwiększone tendencje afiliacyjne, pozytywne oceny w stosunkach między osobami całkowicie sobie obcymi, sa skorelowane $\mathrm{z}$ odczuciami przyjemności. Afiliacja jest to jedna z dyspozycji motywacyjnych, które pociagają za sobą stosunki z innymi osobnikami należącymi do danego gatunku. Tak więc, motywy afiliacyjne, tj. szukanie towarzystwa innych ludzi, tworzą ważna grupę w ramach obszerniejszej grupy motywów społecznych. Afiliacyjne zachowanie przyjmuje różne formy - od skrajnej zależności niemowlęcia, poprzez zwykłe koleżeństwo i przyjaźń, do wzajemnej lojalności, jak w przypadku szczęśliwego małżeństwa. Uczucia te we wszystkich badaniach zdeterminowane były wyłącznie fizycznymi właściwościami sytuacji.

Reasumując można powiedzieć, że doznania przyjemności, wypływajace $\mathrm{z}$ sytuacji, sa ważnym wy-

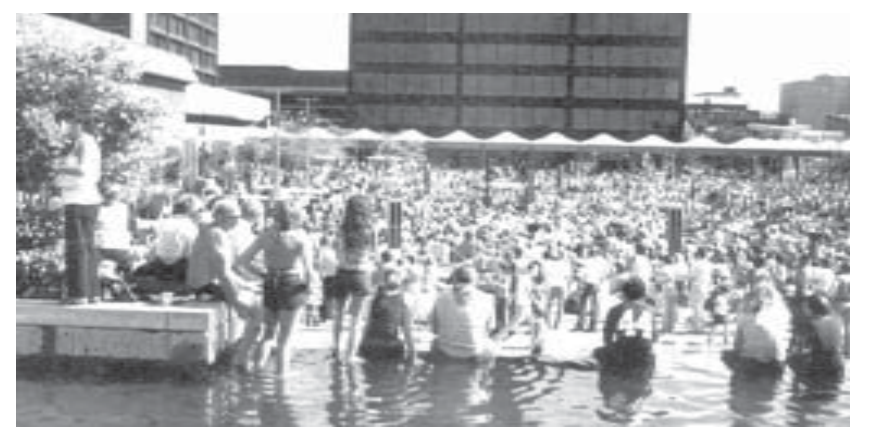

Przyjemna atmosfera miejsca powoduje wzrost tendencji zbliżeniowych. znacznikiem zachowań ucieczkowo-zbliżeniowych w sytuacji. Dodatkowo empiryczne obserwacje wyraźnie sugeruja, że zachowania zbliżeniowe można w znacznym stopniu wywoływać i kontrolować, manipulując czasowymi i przestrzennymi aspektami sytuacji, które stanowią z kolei główne wyznaczniki odczuć przyjemności w sytuacji. Działanie powyższych uwarunkowań prześledzić można na przykładzie środowisk, które z natury rzeczy projektowane są z myślą o ich przyjemnościowym oddziaływaniu na ludzi. Środowiska te, 
to kawiarnie, bary, hotele, dworce lotnicze. W projektowaniú tego rodzaju miejsc przez dłuższy okres czasu obowiązywała zasada zapewniania w maksymalnym stopniu poczucia relaksacji, braku lęku, możliwości lub łatwości nawiązywania kontaktów. Okazało się jednak, że projektowanie miejsc publicznych według tej zasady przynosi ich właścicielom lub gospodarzom wiele nieoczekiwanych a zarazem ujemnych skutków. Na przykład w przypadku kawiarń okazało się, że nazbyt przyjemna atmosfera wydłuża w stopniu niepożądanym czas ich okupowania. W związku z tym jeden z kopenhaskich właścicieli kawiarń, mając na uwadze przeciwdziałanie tym niekorzystnym tendencjom, zaproponował architektowi wnętrz Henningowi Larsenowi odpowiednią współpracę. Larsen rozwiązał problem zbyt długiego przebywania w kawiarni projektując odpowiednio niewygodne krzesła, które uciskały różne partie ciała i już po kilku minutach stwarzały, poczucie niewygody, co stanowiło wystarczający motyw do opuszczenia lokalu. Krzesła Larsena natychmiast zostały zastosowane na całym świecie.

Podobne problemy napotykają w codziennej praktyce właściciele lub zarządcy instytucji publicznych, do których lgna amatorzy komfortu tanim kosztem. Conrad Hilton poddał szczegółowej obserwacji jeden ze swoich hoteli, Walferd Hotel. Zauważył on, że komfortowe hole okupowane są dzień po dniu przez tych samych bywalców, którym z formalnego punktu widzenia trudno cokolwiek zarzucić. W tej sytuacji Hilton postanowił zmniejszyć drastycznie przestrzenie ogólnie funkcjonalne, przyłączając dużą część hollu do przyległych barów, kawiarni i restauracji. W ten sposób sformułowana przez Hiltona zasada „mały holl - duże kawiarnie" stała się obowiązująca w projektowaniu nowych hoteli prawie na całym świecie. Przykładem hiltonowskiego rozwiązania na gruncie polskim sa hotele w sieci NOVOTEL.

Taka sama zasada obowiąuje w projektowaniu terminali lotniczych. W większości krajów świata terminale lotnicze projektuje się w taki sposób, który w konsekwencji daje przestrzeń społecznie ucieczkową. Społecznie-ucieczkowe uporządkowanie przestrzeni przejawia się w występowaniu tendencji do gromadzenia się w peryferyjnych obszarach przestrzeni. W przeciwieństwie do przestrzeni społecznie-ucieczkowej przestrzeń społecznie przyciagająca przyciaga ludzi w obszar centralny, co automatycznie sprzyja nawiązywaniu kontaktów. W większości terminali lotniczych niemożliwe jest kontynuowanie przez dłuższy czas rozmowy między dwiema siedzącymi osobami. Dzieje się tak za sprawą tego, że krzesła najczęściej złączone są razem, uszeregowane w rzędach jeden za drugim naprzeciw kas biletowych albo zwrócone ku sobie tyłem, lub jeśli nawet uporządkowane są w układzie face-to-face, to dystans między nimi uniemożliwia komfort rozmowy. Motyw projektowania społecznie-ucieczkowych form przestrzeni ma jeden główny cel, a mianowicie zmusić ludzi do opuszczenia obszarów oczekiwania, a zachęcić do przebywania w barach, kawiarniach czy restauracjach.

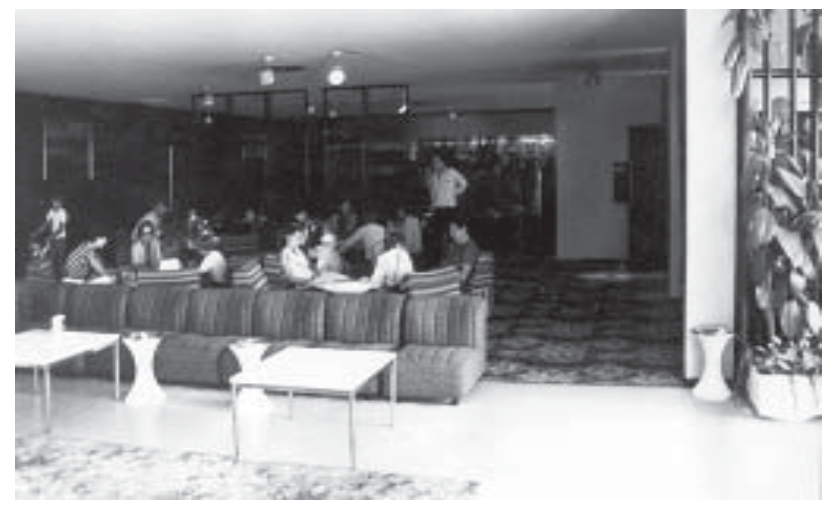

Novotel. Hall i kawiarnia posiadają wspólną strefę „miękkiego” przechodzenia jednej funkcji w druga.

Uczucia przyjemności związane z sytuacja, choć stanowią warunek konieczny rozwoju zachowań zbliżeniowych (afiliacyjnych), to jednak nie sa warunkiem wystarczającym. Problem ten badał m.in. Sheri Cavan, zajmując się wpływem różnych form rozmieszczenia ludzi. przy stole na rozwój kontaktów interpersonalnych między nimi. Przedmiotem zainteresowania Cavana były bary, kawiarnie, i restauracje, a więc miejsca, które z natury rzeczy projektowane sa z myślą o ich przyjemnościowym oddziaływaniu. $\mathrm{Z}$ jego badań wynika, że granice między osobami siedzacymi w rzędach (np. przy barze) są niejasne i łatwe do przekroczenia w porównaniu z tymi, jakie zachodzą między osobami siedzącymi dookoła stołu. W układzie lateralnym osoby nawiazujące konwersację zawsze zachowują dystans, który uniemożliwia przekroczenie granicy intymności. Podobnie dwóch obcych sobie mężczyzn nawiązujących konwersację przy barze (uszeregowanie w rzędzie) ma tendencję do pozostawiania pośrodku jednego pustego stołka celem zachowania dystansu. Sytuacja ta zmienia się jednak, gdy w grę wchodzi kontakt między mężczyzną a kobietą. W tym przypadku mężczyźni mają tendencję do zajmowania, miejsc najbliżej usytuowanych w stosunku do kobiety - interlokutora i maksymalnego zmniejszania dystansu.

Jak z tego wynika, wpływ przestrzennego rozmieszczenia na odczucia przyjemności, a w konsekwencji na zachowania afiliacyjne, można określić jako dwukierunkową zależność między bliskością a przyjem- 
nością. Bliskość oznacza stopień wzajemnej stymulacji sensorycznej między dwiema osobami mierzonej w terminach przestrzennoczasowego sąsiedztwa lub liczby możliwych „kanałów informacyjnych». Kanał informacyjny jest to środek, przy pomocy którego jednostka przekazuje swoje myśli i uczucia drugiej osobie, np. słowa gest, mimika twarzy. Sympatia i przyjemność prowadzą do większej bliskości i odwrotnie, bliskość wzbudza sympatię i przyjemność.

Badania dowodza, że osoby darzące się wzajemną sympatią wykazują silne tendencje afiliacyjne oraz częściej wybierają sytuacje charakteryzujące się bliskością. Podobnie osoby, które w różnych sytuacjach rozmieszczone są w bezpośredniej bliskości mają tendencję do nawiązywania więzi sympatii lub przyjaźni. W wyjaśnianiu tzw. więzi sąsiedzkich dużą wartość mają badania Festingera nad mechanizmem przestrzennych uwarunkowań rozwoju kontaktów międzysąsiedzkich w nowych osiedlach mieszkaniowych. Osobami badanymi byli mieszkańcy nowo budowanego osiedla, którzy jeszcze w fazie projektowej mieli możliwość wzajemnego poznania się. W rezultacie przeprowadzonych badań Festinger doszedł do wniosku, że dwoma podstawowymi wyznacznikami więzi sąsiedzkiej sa: dystans między budynkami i kierunkowa orientacja budynków. Przyjaźń nawiązywała się o wiele częściej między przyszłymi bezpośrednimi sąsiadami, natomiast rzadziej między mieszkańcami, których domy rozdzielone były innymi budynkami. Drugie odkrycie Festingera dotyczy wpływu zorientowania głównej fasady budynku, na kształtowanie się więzi sąsiedzkiej. W odkryciu tej zależności dopomógł Festingerowi przypadek, kiedy dla części mieszkańców, którzy chcieli mieć główny widok z okien na ulicę, zmieniono stosownie orientację budynków tak, że okna ich domów nie były zwrócone w kierunku podwórek sassiadów. W rezultacie okazało się, że mieszkańcy ci mieli o połowę mniej przyjacielskich kontaktów ze swoimi sąsiadami, niż ci, którym zachowano tradycyjna orientację domów. Uogólniając powyższą zależność można powiedzieć, że zwrócenie budynku w kierunku ulicy powoduje społeczną izolację mieszkańców.

\section{Reakcje emocjonalne pobudzenia a zachowania „unikanie-zbliżenie”}

W kształtowaniu zachowań „unikania-zbliżenia” w środowisku architektonicz-nym ważną rolę odgrywa poziom pobudzenia. Jak wcześniej wskazywano, ma to ścisły związek z dążeniem organizmu do zachowania optimum stymulacji. Ponieważ środowisko może je znacznie zakłócać, dlatego też reakcje typu „unikanie-zbliżenie" są wyrazem dążenia organizmu do utrzymania tanu optymalnego pobudzenia. Szereg wyników badań pochodzących z różnych źródeł wskazuje na to, że reakcje unikania i zbliżenia są funkcją pobudzenia o kształcie odwróconego U.

Innymi słowy, zbliżenie fizyczne, preferencje, pozytywne postawy, wydajność, sprawność itd. są optymalne na średnim poziomie pobudzenia. Ekstremalnie wysoki lub niski poziom pobudzenia powoduje reakcje unikania sytuacji lub bodźca, które są źródłem tego pobudzenia. Pamiętać należy jednak o tym, że poziom pobudzeniá może być wynikiem zarówno stymulacji środowiska (np. złożoność, zawartość informacyjna), jak i stymulacji wewnętrznej (lęk, zmiany fizjologiczne wywołane zażyciem alkoholu lub leków etc.).

Cele więzienne, długie podróże morskie, eksploracja regionów polarnych stanowią przykłady sytuacji o niskiej zawartości informacyjnej. Badania tych środowisk mają najczęściej charakter anegdotyczny lub autobiograficzny, lecz mimo to dają spójny obraz skutków ubogiej stymulacji na psychikę człowieka. Skutki te obejmują zaburzenia w sferze myślenia, uczuć oraz procesów postrzegania (np. iluzje). Niezależnie od zaburzeń psychicznych deprywacja sensoryczna, zwłaszcza

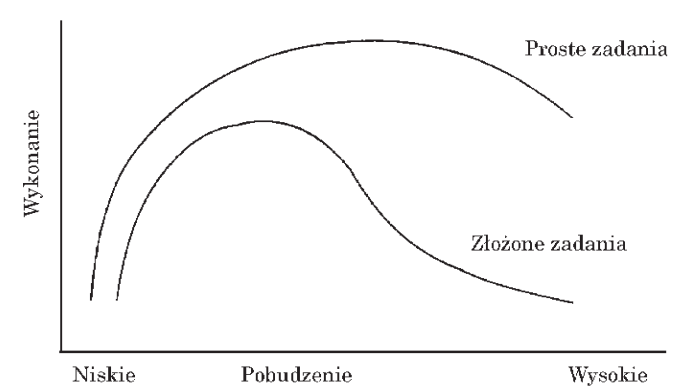

Reakcje zachowania „unikanie-zbliżenie” jako funkcja pobudzenia o kształcie odwróconego U. długotrwała, wywołuje tendencję do unikania lub wycofywania się z sytuacji deprywacyjnej.

Bexton, Heron i Scott przeprowadzili eksperyment nad całkowita deprywacją sensoryczną (pozbawienie dopływu wszelkich bodźców zewnętrznych) z udziałem ochotników, którym płacono 20 dolarów za dzień uczestnictwa w eksperymencie (suma ta znacznie przewyższała przeciętny zarobek). Po dwóch dniach okazało się, że część badanych nie wytrzymuje trudu eksperymentu, polegającego na nierobieniu niczego, niesłyszeniu, nieodczuwaniu i zdecydowanie wycofywała się z badań. Unikanie sytuacji deprywacyjnych można 
wyjaśnić subiektywnym odczuciem niskiego pobudzenia wywołanego przez te sytuacje. Potwierdzają to liczne badania eksperymentalne, wskazujące na zależność między zmniejszeniem się aktywności EEG, a przedłużaniem się deprywacji. Charakterystyczne jest to, jak zauważa Kubzansky, że przystępujący do badań nad deprywacja sensoryczną nastawiaja się na przedsięwzięcie w całej rozciagłości przyjemne, co potwierdza tylko pierwsza faza uczestnictwa w sytuacji deprywacyjnej. Dopiero w następnej fazie okazuje się, ku zdziwieniu zresztą samych zainteresowanych, że brak pobudzenia jest trudny do zniesienia. Podobne nastawienie, przyjmuje wielu ludzi zmęczonych nadmiernie pobudzającym oddziaływaniem zurbanizowanego środowiska, od którego uciekają i poprzez zmniejszenie dopływu informacji starają się uzyskać równowagę psychiczna. Jednakże przebywanie dłuższy czas gdzieś w dziurze, o której sam diabeł zapomniał powoduje spadek poziomu pobudzenia, który nie jest już tolerowany przez psychikę i stanowi silny motyw do wycofywania się $\mathrm{z}$ sytuacji. W zwiazku z tym Toffler proponuje, aby w przyszłości w projektowaniu urbanistycznym świadomie kształtować coś na kształt „oaz przyszłości” (środowisk bogatych w stymulację) oraz „oaz przeszłości” (środowisk o mniejszym tempie zmian, ubogich w stymulację). Miejsca te zdaniem Tofflera, byłyby przedmiotem swobodnego wyboru $\mathrm{w}$ zależności od zapotrzebownia jednostki na stymulację.

Biologicznej podbudowy wyjaśniającej mechanizm kształtowania się reakcji unikania silnie pobudzających sytuacji i środowisk dostarczył H. Selye. Odkrył on ogólną reakcję stresową wywoływaną przez negatywne czynniki fizyczne, infekcyjne, metaboliczne, toksyczne, chorobowe, psychologiczne, zwane stresorami. Reakcja stresowa, zwana też przez Selyego Ogólnym Syndromem Przystosowawczym, stanowi ogół nieswoistych zmian w układzie biologicznym przebiegajacych w trzech fazach: faza alarmowa, stadium odporności, stadium

Kabina użyta w eksperymencie Bextona.

wyczerpania. Przy działaniu stresów ważnym, choć nie jedynym czynnikiem jest napięcie emocjonalne. Powstaje ono i wzrasta w wyniku współdziałania kilku mechanizmów fizjologicznych, a mianowicie:

- układu podkorowego, który aktywizuje korę mózgowa,

- układu autonomicznego,

- podkorowych ośrodków motorycznych zarządzających wrodzonymi schematami ruchowymi, mimicznymi, pantomimicznymi i instynktowymi,

- mechanizmu wydzielania wewnętrznego (tarczyca i nadnercze),

- mechanizmu aferentacji zwrotnej, który poprzez intero- i prioprioreceptory doprowadza pobudzenia od mięśni i narządów wewnętrznych z powrotem do kory, dodatkowo podnosząc jej aktywizację.

Wszystkie te mechanizmy pozostają we wzajemnym związku, wskutek czego pobudzenie emocjonalne ma tendencję do samoczynnego wzrastania Stresory podnoszą w ten sposób poziom aktywizacji nie tylko mózgu, ale i całego organizmu, co przejawia się: a) w zmianach czynności narządów wewnętrznych; b) w zwiększonym napięciu mięśni oraz pojawieniu się ruchów mimowolnych; c) w przeżyciach uczuciowych osobnika, z których najczęstszymi są różne odmiany strachu i gniewu. Stresory mogą również powodować dezorganizację zachowania, którą w stanach stresowych wyjaśnia się tym, że silne pobudzenie kory mózgowej zaburza orientację w otoczeniu i samoorientację, a tym samym też samokontrolę, panowanie nad soba. Pojawiają się wtedy formy zachowania nieprzemyślane, impulsywne, mniej lub bardziej przymusowe. Przykładem tego jest zachowanie się ludzi w sytuacji zagrożenia pożarowego, które może być dodatkowo potęgowane nieznajomością układu przestrzennego obiektu. Dezorganizacja zachowania może przybierać różne formy, z których najważniejsze to:

1. Lękowe zahamowanie działania, przejawiające się m.in. w trudności wykonywania ruchów przy równoczesnych objawach fizjologicznych, takich jak drżenie rąk, załamywanie się głosu, pocenie się.

2. Gniew wyrażający się w działaniu agresywnym. Nieraz gniew przechodzi we wrogość, a agresja w atak werbalny lub fizyczny Do tej samej kategorii można zaliczyć również autoagresję.

3. Regresja, tj. zastosowanie prymitywnej techniki rozwiązywania problemu, typowej dla wcześniejszych stadiów rozwoju człowieka.

4. Fiksacja, czyli uparte powtarzanie pewnej operacji, mimo że jest ona niecelowa i nie przyczynia się do rozwiązania problemu.

5. Szczególną formą dezorganizacji zachowania jest pojawianie się objawów przebytej choroby nerwowej $\mathrm{w}$ czasie trwania ostrego stresu. 
Spośród wszystkich rodzajów stresorów środowiskowych najsilniej działa nowość bodźca. Organizm człowieka nie ma nieograniczonych możliwości przystosowania się do sytuacji na stale i wysoce pobudzajaccym charakterze. Reakcje stresowe organizm sa tylko czasowym środkiem przystosowawczym, który przestaje pełnić tę funkcję, gdy stresor jest zbyt intensywny lub długotrwały. Stąd zrozumiałe jest, że silnie pobudzające sytuacje wywołują tendencję do wycofywania się z nich. Zasadę tę wykorzystują często właściciele barów, tawern itp. Istnieje bowiem ścisły związek między poziomem oświetlenia i hałasu czy formą architektoniczna, a pozostawaniem w sytuacji. Zauważono, że wzrost intensywności oświetlenia zwiększa odczucie intensywności hałasu, a obydwa czynniki razem zmniejszają w istotny sposób czas przebywania w pomieszczeniu. W związku z tym restauratorzy, którym zależy na dużej fluktuacji ludzi, stosują wysokie natężenie oświetlenia i nie przywiąują żadnej wagi do zabezpieczeń akustycznych.

Na podstawie wcześniej sformułowanej prawidłowości, wedle której reakcje zachowania unikania-zbliżenia są funkcją wartości pobudzającej sytuacji, można założyć, że siła dążeń eksploracyjnych w środowisku jest funkcja jego pobudzającego oddziaływania o kształcie odwróconego U.

Wyniki badań wskazują na to, że reakcją organizmu na sytuacje monotonne jest wzrost preferencji do bardziej pobudzających działań, m.in. eksploracji. Poza tym zaobserwowano, że gdy zwiększa się czynnik nowości w sytuacji, to zmniejszeniu ulegaja tendencje eksploracyjne.Najbardziej preferowanymi przez człowieka są sytuacje średnio pobudzające.

Dodatkowe informacje wyjaśniające zależność między pobudzeniem a zachowaniami ucieczkowo-zbliżeniowymi dostarcza hipoteza rozbieżności, której autorami są McClelland, Atkinson, Clark i Lowell. Zakłada ona, że ludzie wykazują umiarkowaną preferencję wobec stymulacji bodźcowej, do której są zaadaptowani. Maksymalna preferencja zachodzi w sytuacji nieznacznie różniacej się od poziomu adaptacji natomiast preferencja minimalna dotyczy stymulacji znacznie odbiegającej od poziomu adaptacji.

Zgodnie z powyższą hipotezą należy przewidywać, że wzrost rozbieżności poziomu stymulacji od poziomu adaptacji zwiększa charakterystykę nowość stymulacji, zwiększając też poziom pobudzenia, a w konsekwencji powodujac wzrost preferencji do pewnego poziomu. Później rozbieżność, zwiększając nadmiernie pobudzenie, zmniejsza preferencję do takich sytuacji. Przy pomocy hipotezy rozbieżności można wytłumaczyć dość powszechne u ludzi upodobania do form architektonicznych, do których są najbardziej przyzwyczajeni, oraz zmniejszanie. się upodobania do form architektonicznych $\mathrm{w}$ miarę zwiększania się ich cech nowości, lub odmienności.

Wyniki licznych badań nad reakcjami zachowania na różne bodźce, o różnym stopniu złożoności można podsumować w następujący sposób: ludzie wykazują niska preferencję do bodźców o niskim i wysokim stopniu złożoności, a najwyższa preferencję do bodźców o umiarkowanej złożoności. W eksperymencie Mintona osoby badane, obserwujące przeźrocza, o wiele dłużej oglądały te, które cechowała większa złożoność (zawartość informacyjna). Podobnie Leckert i Bakan zanotowali istotną korelację między długością czasu oglądania a złożonością przeźroczy, przedstawiających różne krajobrazy i obiekty sztuki (m.in. nowoczesnej). Vitz, badając reakcje na nieregularne figury, odkrył, że preferencja do kształtów jest funkcja ich złożoności o kształcie odwróconego U. Wyniki tych badań tłumaczyć można tym, że złożoność jest równoznaczna z większą ilością informacji, a tym samym jest czynnikiem indukującym większy poziom pobudzenia.
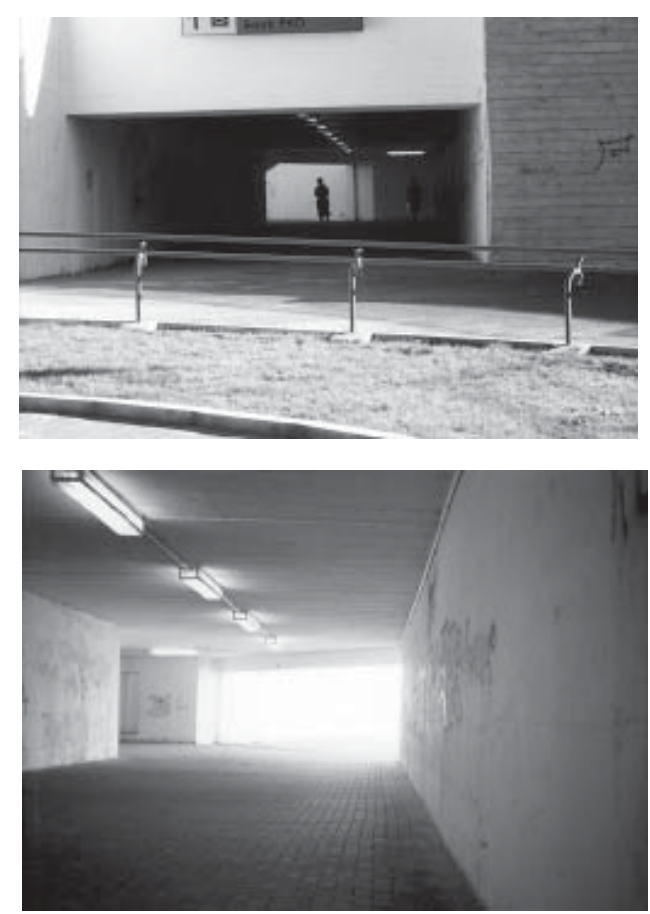

Problem przejść podziemnych, to głównie problem bezpieczeństwa spowodowany małą ilością bodźców i skapym oświetleniem. Normy oświetlenia nie biora pod uwage potrzeb psychologicznych.

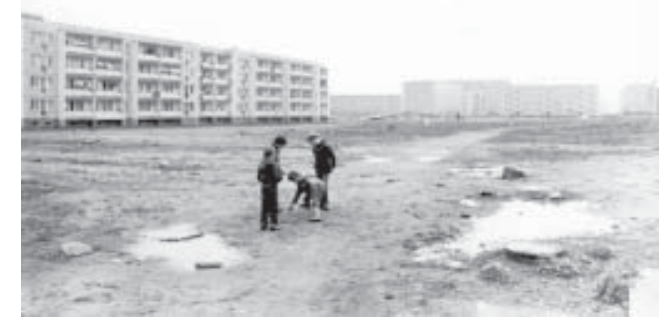

Brak możliwości działania i nuda otoczenia tworzą sytuacje deprywacji sensorycznej, czyli głodu stymulacji. W takiej sytuacji brak jest warunków dla rozwoju, a do głosu dochodzą niskie pobudki działania. 


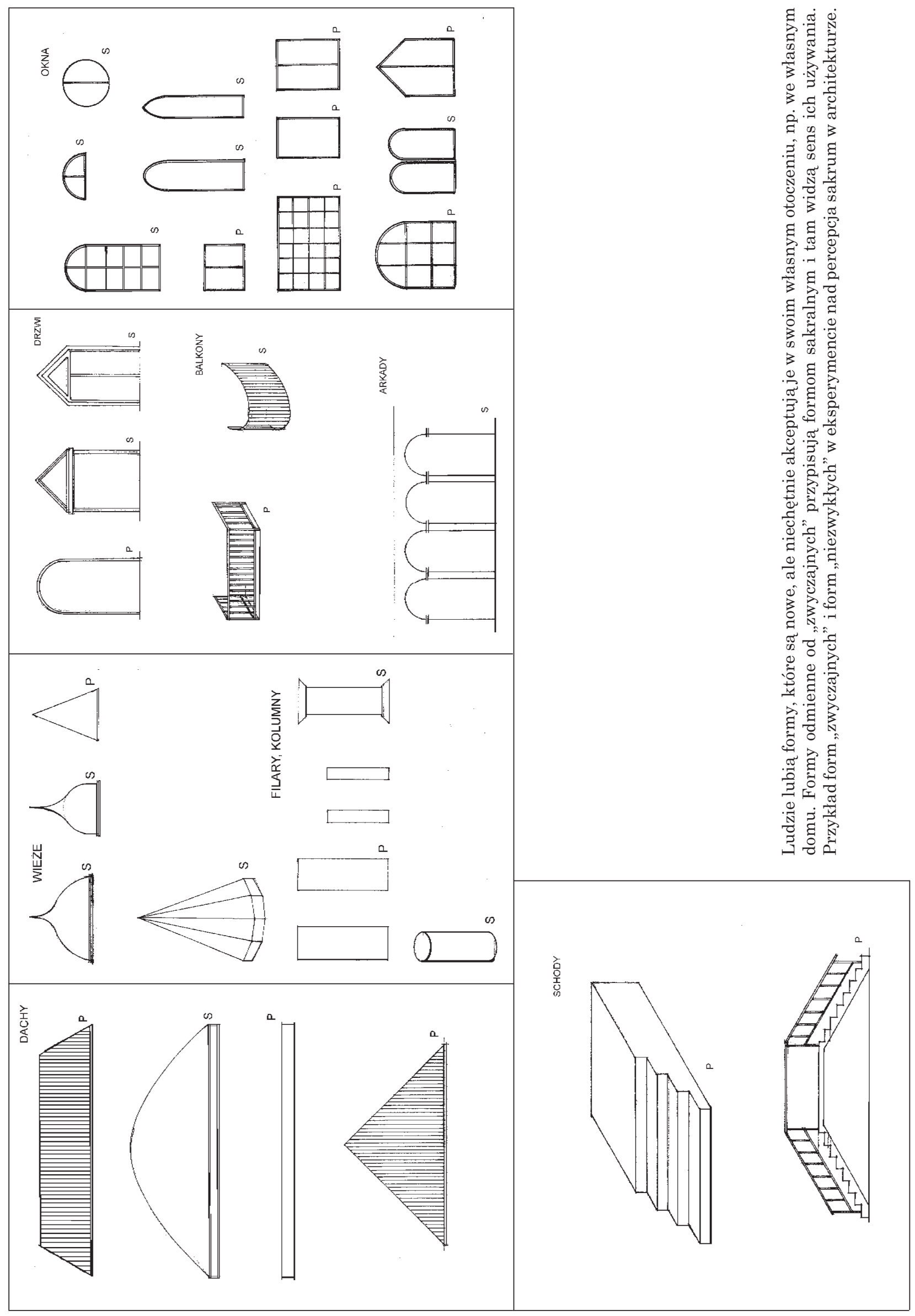




\section{Emocjonalne reakcje dominacji}

Reakcja dominacji-submisji jest stanem uczuciowym, któremu odpowiada stopień, w jakim jednostka odczuwa ograniczenie swobody wyboru działania pod wpływem fizycznych i społecznych bodźców środowiska. Proshansky, Uttelson i Rivlin zaproponowali termin swoboda wyboru (freedom of choice) na określenie dymensji, która sprowadza koncepcje „prywatności”, „terytorialności” i „stłoczenia” do wspólnego mia-nownika. Prywatność daje możliwość swobodnego wyboru, gdy stłoczenie ogranicza swobodę. Podstawowa różnica między dominacją a swobodą wyboru polegałaby na tym, że dominacja jest pierwotną (podstawowa) reakcją emocjonalną związaną z cecha emocjonalności osobowości, natomiast swoboda wyboru jest reakcją zachowania unikania-zbliżenia determinowaną wspólnie przez osobowościową cechę dominacji i środowisko.

Dominacja równoznaczna jest z dużą swobodą wyboru zachowań w sytuacji, submisja zaś oznacza brak swobody. Na przykład jednostka má większą swobodę wyboru zachowań, a tym samym większą dominację na swym własnym terytorium, a mniejszą na terytorium, które jest udziałem również innych osób. Tak więc o wiele większą swobodę wyboru sposobu słuchania muzyki posiadamy w domu niż w sali koncertowej, o wiele większą swobodę czytania książki w domu niż w bibliotece.

Swoboda wyboru zachowań jest jednym z bardziej krytycznych aspektów zachowania się ludzi w odniesieniu do fizycznego środowiska. W każdej sytuacji jednostka usiłuje rozpoznać środowisko fizyczne, w takim stopniu, aby zmaksymalizować sobie swobodę wyborów. Zwiększając swobodę wyborów, jednostka przechodzi w stosunku do środowiska z pozycji emocjonalnych doznań submisji w kierunku emocjonalnych doznań dominacji oraz większa możliwość zaspokajania swoich indywidualnych potrzeb, m.in. w zakresie potrzeby doznań przyjemności i optymalnego pobudzenia.

Dążenie jednostki do maksymalizacji swobody wyborów zachowań w środowisku fizycznym, w oparciu o dążenie do satysfakcji ze środowiska, implikuje jej aktywność poznawczą w środowisku, jak i aktywność, polegająca na wprowadzaniu zmian do środowiska, w sensie zmiany swojej pozycji w strukturze organizacyjnej środowiska. Innymi słowy, chodzi o to, że każdy człowiek wchodząc w określona sytuację zdeterminowany jest w kierunkach swojego działania (w swobodzie wyborów) nie tylko obiektywnymi, relacjami zachodzącymi między elementami środowiska, lecz również od jego indywidualnej interpretacji (oceny) otoczenia. Skoro więc relacje między elementami otoczenia są wyznacznikami swobody wyborów pośrednio poprzez ocenę, zatem swoboda wyboru zachowań nie jest czymś stałym, lecz jest uwarunkowana aktywnościa poznawcza podmiotu. W miarę coraz to bardziej dokładnego rozpoznania relacji między elementami środowiska jednostka zmienia swoją pozycję $\mathrm{w}$ strukturze organizacyjnej środowiska, stając się coraz swobodniejsza w operowaniu elementami środowiska, jak i w zaspokajaniu własnych potrzeb. Swoboda wyboru zachowań, a tym samym dominacja nad środowiskiem, jest funkcją aktywności poznawczej, która zmniejsza entropię informacyjna środowiska. W związku z tym, swoboda wyboru zachowań zwiększa się w miarę wzrostu adaptacji do środowiska oraz $\mathrm{w}$ miarę zmniejszania się jego

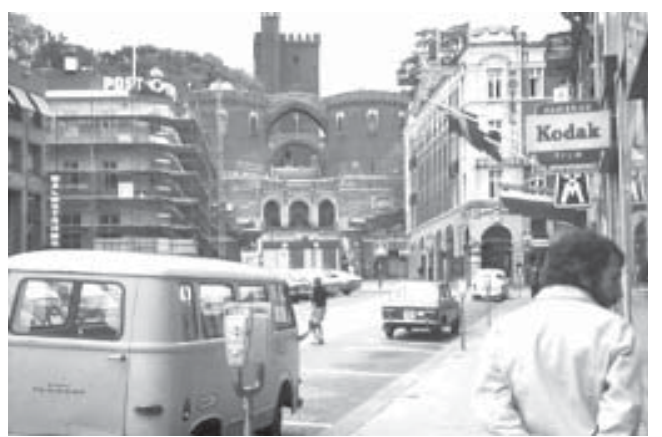

Fenomen miasta polega na tym, że jednostka ma poczucie wystarczającej różnorodności wrażeń, które daje jej swobodę działania. nowości. Ponieważ nowość środowiska skorelowana jest zwykle z jego złożonością zatem swoboda wyborów jest mniejsza w środowisku złożonym, a większa w środowisku o małej złożoności, czyli małej zawartości informacyjnej.

Stopień osobistej swobody wyboru zachowań zależy nie tylko od stałej struktury organizacyjnej środowiska, a więc nie tylko ód tego, jak ono zostało zaprojektowane i jak je jednostka postrzega, lecz również od tego, co zachodzi między poszczególnymi elementami czasu. Tak np. zmiany w natężeniu oświetlenia, natężeniu dźwięków, czy w temperaturze mogą zarówno zwiększać, jak i zmniejszać swobodę wyboru zachowań.

Generalnie swoboda wyboru zachowań posiada swoje uwarunkowania środowiskowe, jak i zwiąane z funkcjonowaniem ludzkich potrzeb. Związana jest ona również z takimi koncepcjami, jak prywatność, stłoczenie czy terytorialność. Na przykład. swoboda wyboru zachowań w pokoju szpitalnym uzależniona jest zarówno od elementów przestrzennych, jak i społecznych, tzn. obecności i ilości ludzi.

Formalna definicja Westina ujmuje prywatność jako ,żądanie jednostek, grup lub instytucji do określenia im kiedy, jak i do jakiego stopnia informacje bezpośrednio ich dotyczące są komunikowane innym”. Warunki 
prywatności zawarte w powyższej definicji mają charakter obiektywny. Oznacza to, że ich spełnienie jest warunkiem wystarczającym zaistnienia poczucia prywatności.

Zasadnicza rola pojęcia „prywatność” w wyjaśnianiu zachowań ludzkich w środowisku projektowanym i

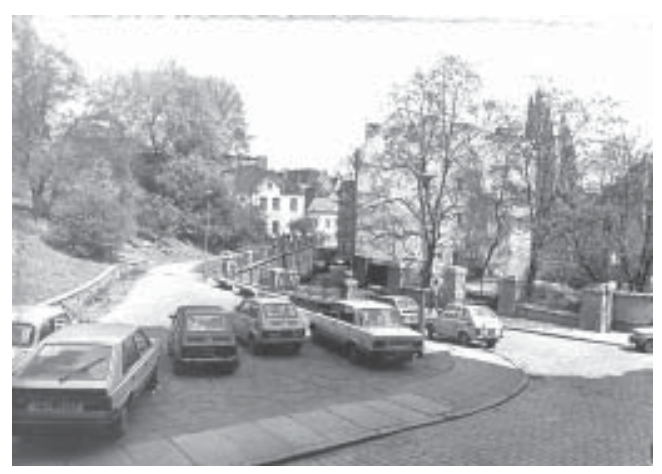
kształtowanym przez ludzi nie jest ostatecznie rozstrzygnięta. Z punktu widzenia psychologii środowiskowej najistotniejsze jest pytanie: Jaką funkcję dla jednostki pełni prywatność? Pytanie to obejmuje szereg aspektów prywatności teoretycznych, jak i praktycznych. Najważniejsze z nich można ując w następujących pytaniach: 1) Jakie sa potrzeby jednostki w zakresie prywatności? 2) W jakim stopniu środowisko fizyczne może zaspokoić te potrzeby? 3) Jakie czynniki warunkują wzbudzenie potrzeby prywatności? 4) Jakie sa konsekwencje frustracji niezaspokojenia potrzeby prywatności? 5) W jakich sytuacjach prywatność jest szczególnie istotna dla człowieka?

Westin analizuje prywatność w oparciu o koncepcję czterech podstawowych stanów prywatności i wynikających z nich czte-

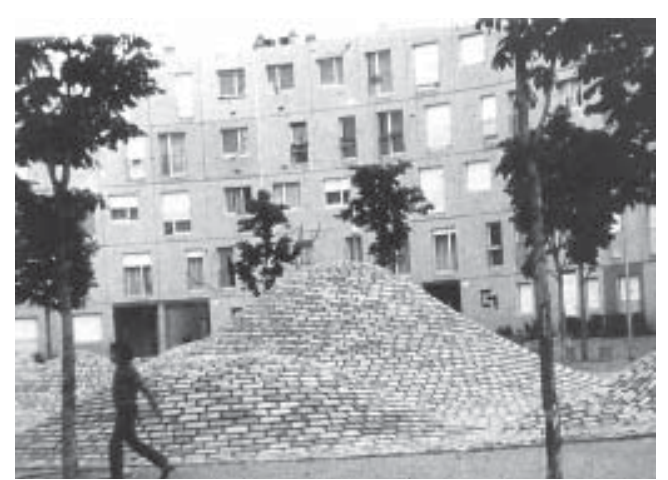

Swoboda wyboru zachowań zależy od zawartości informacyjnej sytuacji. Atrakcyjnośc miejsca zależy od zróżnicowania rzeźby terenu. Efektu tego nie można jednak łatwo osiagnacc środkami formalnymi. rech podstawowych funkcji. Czterema podstawowymi stanami prywatności sugerowanymi przez Westina sa: samotność, intymność, anonimowość, rezerwa. Samotność jest stanem prywatności, w którym jednostka jest wolna od możliwości obserwowania jej przez inne osoby. Przez „wolność od obserwacji przez inne osoby" Westin rozumie izolację jednostki pod każdym względem, a więc izolację wzrokowa, słuchową itd. Intymność oznacza ten rodzaj prywatności, który odnosi się do pary lub większej liczby ludzi, dążących do maksymalizacji interpersonalnych zależności z równoczesnym wymaganiem wolności od zewnętrznej obserwacji. Anonimowość jest stanem, w którym jednostka wykazuje dążenie i równocześnie osiąga stan uwolnienia się od identyfikacji w miejscu publicznym. Rezerwa jest tym stanem prywatności, który w odróżnieniu od trzech poprzednich bardziej leży w naturze zależności interpersonalnych, aniżeli w naturze i organizacji środowiska fizycznego. Rezerwa jest zatem stanem prywatności umożliwiającym każdej osobie nieujawnianie, nawet w najbardziej intymnych sytuacjach, szeregu cech osobowych, które są albo zbyt osobiste, albo skandaliczne i niegodziwe, albo profanacyjne.

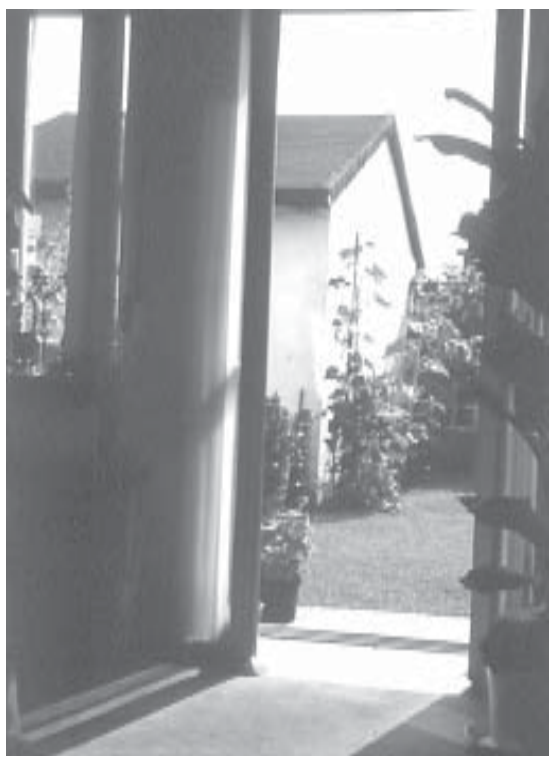

W porównaniu z blokami domek z małym choćby ogródkiem daje poczucie intymności, anonimowości i rezerwy, przy jednoczesnym dostępie do otoczenia zewnętrznego.

Analogicznie do czterech stanów prywatności Westin wyróżnia cztery podstawowe funkcje prywatności. Pierwsza z nich polega na zabezpieczaniu jednostce osobowej autonomii. Osobowa autonomia oznacza zachowanie indywidualności i świadomego wyboru celem zachowania kontroli nad środowiskiem (włączając w to zdolność do zachowania prywatności w momentach, w których jednostka najbardziej jej potrzebuje). Prywatność niezależnie od tego, czy jest związana z intymnościa,

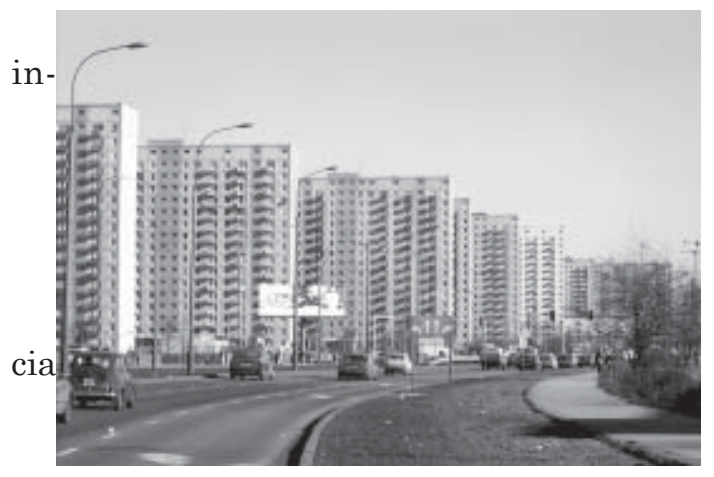

Wielkie bloki zaburzają równocześnie prywatność, poczucie terytorialności i swobody działania. samotnością czy autonomia, zawsze pełni strumentalną funkcję emocjonalnego rozładowania. Emocjonalne rozładowanie jest psychologicznym stanem optymalnego napięcia emocjonalnego. Trzefunkcja prywatności wiąże się z możliwościa samooceny. Znaczenie samooceny w życiu 
codziennym polega na integracji i asymilowaniu informacji docierających do człowieka o nim samym i otaczającym go świecie. Ostatnia funkcja prywatności polega na ograniczaniu układów komunikacji $\mathrm{z}$ otoczeniem. Mechanizm ten ustanawia swoisty dystans psychologiczny jednostki w stosunku do innych ludzi bądź w momentach, w których jednostka tego potrzebuje, bądź gdy wynika to z jej roli społecznej (stąd tabliczki z napisami „tylko dla pracowników”, „tylko dla nauczycieli”).

Cztery wymienione wyżej funkcje prywatności można sprowadzić do jednej ogólnej, polegającej na stwarzaniu jednostce takich możliwości zachowań, które w konsekwencji dają jednostce autonomię, samoocenę, emocjonalne rozładowanie i ustabilizowanie układów komunikacji. Owa ogólna funkcja prywatności dotyczy zwiększenia zakresu opcji, dzięki którym jednostka jest w stanie podejmować działania odpowiadające jej celom i potrzebom. W tym sensie potrzeba prywatności może być rozumiana jak potrzeba maksymalizacji swobody wyboru zachowań lub jako potrzeba przymusu i ograniczeń zachowania się.

Jeden ze sposobów osiagania pożądanej swobody wyboru zachowań polega na wykorzystywaniu przez jednostkę zdolności do kontroli zdarzeń zachodzących w życiowo ważnej dla niej przestrzeni. Zdolność ta to nic innego, jak opisywana wcześniej zdolność człowieka do zachowań terytorialnych. W związku z tym można postawić pytanie, w jakich warunkach dochodzi do ujawniania się zachowań terytorialnych? Człowiek jest zarówno żywym organizmem, jak i fizycznym obiektem w przestrzeni. Do życia i przetrwania w jakiejkolwiek przestrzeni potrzebuje minimum przestrzeni, która umożliwia uniknięcie bólu i fizycznego dyskomfortu. W warunkach zagrożenia tego minimum dochodzi do wzbudzenia i ujawnienia się potrzeby terytorialności, tzn. tendencji do eliminowania z przestrzeni innych ludzi.

Minimum przestrzeni nie jest jedynym wymaganiem jednostki spełniającym jej fizjologiczne i psychologiczne potrzeby. Oprócz tego jednostka musi mieć możliwość poruszania się w przestrzeni między poszczególnymi jej fizycznymi elementami w celu zaspokojenia potrzeb społecznych i egocentrycznych. Swoboda poruszania się w przestrzeni daje jednostce możliwość określenia wielkości „swojej” przestrzeni, a tym samym nadania przestrzeni charakteru społecznego.

Społeczno-przestrzenna natura potrzeby terytorialności była przedmiotem badań Altmana i Haythorna. Badacze ci obserwowali rozwój zachowań przestrzennych u marynarzy. Przebadali oni 9 par, z których każda mieszkała w małym pomieszczeniu bez jakichkolwiek zewnętrznych kontaktów. Badani wykazywali wzrost zachowań terytorialnych i tendencji do wzajemnego unikania się w miarę, jak badania były kontynuowane. W początkowym okresie zachowania terytorialne ograniczały się do wyznaczania stałych „geograficznych” obszarów uznawanych za własne, w postaci części pokoju, łóżka czy też miejsca przy stole. Później zachowania terytorialne obejmować zaczęły bardziej ruchome, i mniej osobowościowo nacechowane, rzeczy takie, jak krzesła. Tego rodzaju terytorialność broniona była tym bardziej nieustępliwie, im poszczególne pary badanych były bardziej dominujące osobowościowo. W parach, gdzie jedna osoba wykazywała cechy dominacji, a druga uległości, podział terytorialny nie przebiegał tak ostro (pary zgodne). W rzeczywistości jednak terytorialność niezależnie od tego, czy osiagana jest przez dominację, agresję czy autorytet zawsze decyduje, która z jednostek ma prawo do jakiegoś obszaru fizycznego otoczenia lub do jakiego stopnia potrzeby poszczególnych jednostek będą mogły być zaspokojone.

Terytorialność nie ogranicza się wyłącznie o sytuacji społecznej izolacji. Wręcz odwrotnie, terytorialność jest zjawiskiem powszechnym i pełni instrumentalną funkcję w określaniu i organizowaniu zależności między różnymi rolami społecznymi, jak np. między lekarzem i pacjentem. W wielu przypadkach rola określa wyłączność w korzystaniu i kontroli danej przestrzeni oraz otoczenia. Na przykład tylko lekarze mają dostęp do pomieszczeń w szpitalach gdzie przechowuje się leki. Podobnie

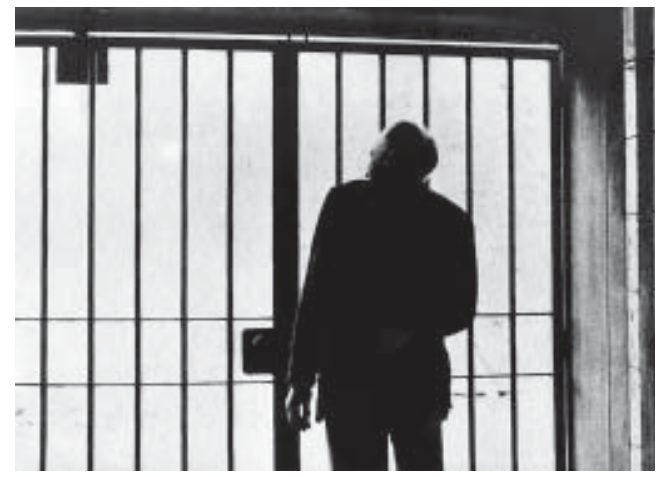

Sytuacja uwięzienia to problem radzenia sobie $\mathrm{z}$ niedoborem informacji oraz swobodą ruchu i ograniczeniem kontaktów interpersonalnych. 
gabinety dyrektorskie z reguły stanowią przestrzenie o ograniczonym dostępie dla większości z wyjątkiem sekretarek i najbliższych współpracowników. W wyższych uczelniach bardzo często kawiarnie, dostępne dla profesorów, nie są dostępne dla studentów itp.

Rozwój i tożsamość jednostki w środowisku zależy od dwóch rzeczy. Po pierwsze, od tego, jak inni reagują na jej zachowania, zdolności i osiagnięcia. Po drugie, od skali wartości odnoszącej się do poszczególnych obiektów i miejsc w fizycznej przestrzeni. Brak przez dłuższy czas sprecyzowanej skali wartości, hierarchizującej poszczególne elementy przestrzeni, może prowadzić nawet do zatracenia przez jednostkę poczucia tożsamości. Terytorialność jest zatem środkiem ustanawiania przez jednostkę poczucia osobowej tożsamości. Fakt ten tłumaczy m.in. to, dlaczego w warunkach społecznej izolacji pojawiają się zachowania terytorialne, tak jak w opisanych wcześniej badaniach Altmana i Haythorna.

Reasumując, z przeprowadzonych rozważań wynika, że terytorialność, określona jako osiaganie kontroli nad poszczególnymi elementami przestrzeni, jest zawsze instrumentem w osiaganiu podstawowych celów jednostki. Wewnętrzną determinantą zachowań terytorialnych jednostki jest jej dążenie do osiagnięcia prywatności. Terytorialność w związku z tym jest jednym z mechanizmów, za pomocą którego jednostka zwiększa zakres swoich otwartych wyborów i maksymalizuje swobodę wyboru zachowań w danej sytuacji.

Termin stłoczenie odnosi się do warunków, w których kontrola terytorium poddana została znacznemu ograniczeniu. Stłoczenie jest zjawiskiem charakterystycznym dla współczesnego zurbanizowanego życia, chociaż niektórzy, jak np. Rivlin i Proshansky nie przypisują mu w każdym przypadku negatywnego znaczenia

Kiedy stłoczenie staje się istotnym problemem społecznym? Najogólniej jest to wtedy gdy wzrost populacji przekracza możliwości środowiska urbanistycznego (stłoczenie w miastach, domach, szkołach, szpitalach itd.). Dopóki jednak możliwe jest zachowanie optymalnej liczby ludzi w środowisku, poprzez rozwój umiejętności projektowania przestrzeni, dopóty ujemne skutki stłoczenia można kontrolować. W tym kontekście nasuwa się jednak pytanie, jak określić optymalna wielkość populacji przypadającą na jednostkę przestrzeni, np. w osiedlu, w mieszkaniu, w szkole. W przypadku projektowania, tzw. instytucjonalnych przestrzeni, jak szkoły, szpitale, sanatoria, rutynowo przyjmuje się normy, które najczęściej ujmują jedynie liczbę osiagalnych możliwości. Na przykład w przypadku szkoły będzie to liczba miejsc w klasie, w przypadku szpitali liczba łóżek. Posługiwanie się norma, choć jest niewątpliwie wygodne, nasuwa szereg wątpliwości. Pierwsza jest pytanie, czy np. zaprojektowanie klasy szkolnej dla 35 uczniów daje takie same efekty dydaktyczne i wychowawcze, jak dla 50 uczniów? Następnie, czy przyjęcie normatywu powierzchni dla jednego mieszkańca, jak np. we współczesnym polskim budownictwie mieszkaniowym, jest krokiem naprzód w kierunku rozładowania stłoczenia (rozwiązaniem problemu mieszkaniowego), czy też jest może jedną z genetycznych przyczyn wtórnego stłoczenia?

Te i inne watpliwości wskazują na to, że problemu stłoczenia

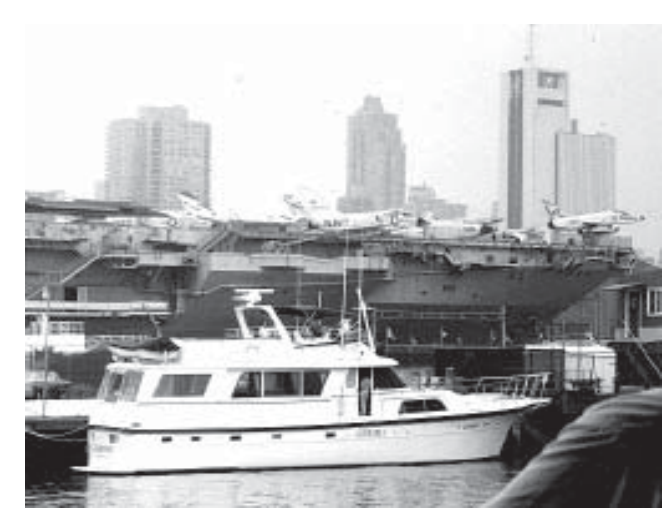

W warunkach społecznej izolacji oraz ograniczenia przestrzennego, jak na statkach i okrętach wojennych zawsze pojawiają się silne zachowania terytorialne. nie da się rozwiązać uproszczonymi, obiektywnymi podejścia-

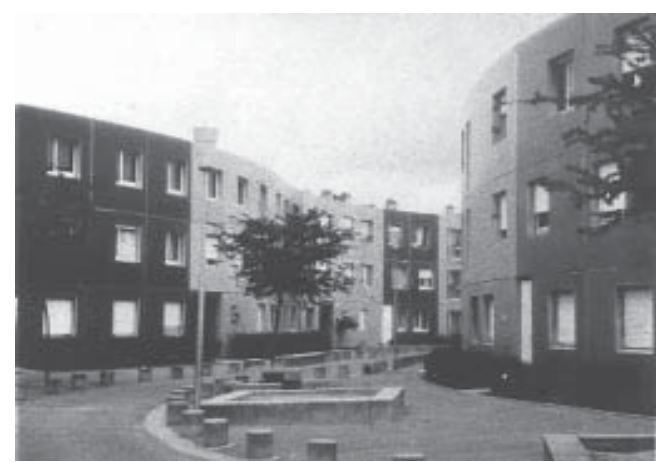

Niekiedy stłoczenie jest wrażeniem subiektywnym gdy towarzyszy mu poczucie kontroli osobowej. mi. Niejednokrotnie

bowiem zdarza się tak, że zaprojektowana przestrzeń spełnia obiektywne kryteria wymagań, gdy w rzeczywistości wywołuje subiektywnie odczucie stłoczenia. Z tego należy wnioskować, że na stłoczenie należy patrzeć jak na zjawisko społeczne zarówno z obiektywnego jak i psychologicznego punktu widzenia. Innymi słowy, należy mieć na uwadze, że dla określenia czy to przyczyn, czy konsekwencji stłoczenia należy wykraczać poza standardową odpowiedź na pytanie: „Jaka jest dopuszczalna i optymalna liczba osób przypadajacca na jednostkę przestrzeni?” Badania porównawcze wykazuja, że wzory percepcji przestrzeni nie sa skorelowane z obiektywnymi ich kryteriami (np. liczba $\mathrm{m}^{2}$ przypadajaca na jednego mieszkańca). W związku z tym często się zdarza, że mieszkańcy starych, zatłoczonych dzielnic miejskich wykazują mniejsze poczucie stłoczenia, niż mieszkań- 
cy nowych osiedli. Reasumując, czynniki warunkujące stłoczenia zależą od tego, w jaki sposób przestrzeń została zorganizowana, dla jakich celów została zaprojektowana oraz jakie rodzaje ludzkiej aktywności zostały „wpisane” w przestrzeń.

Stłoczenie, jak już wspomniano na wstępie, może być źródłem pobudzenia zarówno o charakterze przykrym, jak i przyjemnym. Osoby, które mają wysoki poziom zapotrzebowania na stymulację dużo częściej tolerują sytuacje stłoczenia. Bywa i tak, jak w przypadku ludzi młodych, których z natury rzeczy cechuje duże zapotrzebowanie na wszelakie pobudzenie, że stłoczenie może być wartością pożądana, przyciagająca zamiast odpychająca. Przykładem takich środowisk, których immanentną cechą jest stłoczenie, a które równocześnie mają dużą siłę przyciagająca ludzi młodych, są dyskoteki, centra dużych miast, stadiony piłkarskie, duże magazyny sklepowe. Oczywiście przy opisywaniu tych środowisk i sytuacji najczęściej unika się terminu stłoczenie. Z drugiej strony ogromna większość tych sytuacji oceniana jest negatywnie, a przez wielu uważana nawet za czynnik rozwoju chorób psychicznych i innych nieprawidłowości funkcjonowania psychicznego.

R. Bastide sugeruje, że koncentracja jest najważniejszym czynnikiem ekologicznym w występowaniu zaburzeń psychicznych. Tak np. Gruenberg ustalił, że najwyższy procent otępienia starczego spotyka się w mieszkaniach przeludnionych (dzielnice Onondago w mieście Syracuse, Stany Zjednoczone), więcej niż 2,25 osób na 1 izbę - 395,3 na 100 tys. mieszkańców, mniej niż 1,25 osoby na 1 izbę - 213,2 na 100 tys. mieszkańców. Chombart de Lauwe odkryła - na drugim krańcu grup - u dzieci mieszkających w dużych osiedlach nowoczesnego budownictwa (HBM, HLM - habitations á loyer modéré), że niebezpieczny próg przeludnienia wynosi 2-2,5 osób na jedną izbę (w przeliczeniu na powierzchnię mieszkalną 8-10 m2 na osobę).

Jest rzeczą zrozumiała, że dziecko, które w mieszkaniu ma ograniczone pole działania, ma równocześnie ograniczoną swobodę wyboru zachowań, napotyka liczne zakazy, częściej dostaje w skórę, bo denerwuje albo męczy rodziców, że takie dziecko jest bardziej podatne na zaburzenia psychiczne. Poza „progiem niebezpieczeństwa" jest jeszcze próg równowagi (14-16 m2 na osobę). Pomiędzy tymi dwiema granicami mamy strefę przejściowa, w której proporcja zaburzeń jest bliska wartościom przypadkowym. Pojęcie „progu niebezpieczeństwa" może odnosić się także do osób dorosłych.

Pierwszymi, którzy postawili hipotezę, że istnieją strefy miejskie niszczące zdrowie psychiczne, byli dwaj badacze amerykańscy - Faris i Dunham. Pionierskie studium Farisa i Dunhama, które uznano za klasyczne, stało się punktem wyjścia dla szeregu prac w Stanach Zjednoczonych i we Francji. Badania te potwierdziły założenie o koncentracji chorych psychicznie w centrum (w rejonach o większym stłoczeniu) i spadku ich ku peryferiom. Budowa jednakże „wielkich zespołów” mieszkaniowych na peryferiach również zaostrza problem przestrzennego „progu bezpieczeństwa”. We Francji rozpoczęto badania, które świadcza o pojawianiu się koncentracji chorób psychicznych na peryferiach miast wraz z pojawieniem się tzw. „dużych zespołów” mieszkaniowych.

Powracając jednakże do całościowej analizy stłoczenia, należy stwierdzić, że jest to kategoria psychologiczno-przestrzenna posiadająca dwa oblicza: normatywne i psychologiczne. Oznacza to, że do wywołania doznania stłoczenia niezbędne jest zaistnienie odpowiednich warunków przestrzennych, które najlepiej charakteryzuje proporcja przestrzeni do liczby ludzi, oraz psychologiczne nastawienia. W tym drugim przypadku chodzi o to, że to, czy jednostka doświadczy poczucia stłoczenia w normatywnej przestrzeni, czy też nie, zależy od tego, jakie jest jej uprzednie doświadczenie i jakie w związku z tym żywi oczekiwania wobec sytuacji. Niezależnie bowiem od odczuwanego dyskomfortu i frustracji, wywołanych nadmierna ilością osób okupujących przestrzeń, jednostka niekoniecznie musi odczuwać stłoczenie, jako coś, czego nie da się zaakceptować. Przykłady sytuacji, które podlegają często daleko idącej akceptacji, zostały wcześniej wymienione. Akceptacja w tych przypadkach jest forma adaptacji do negatywnych sytuacji, w których gotowość do aktywnej ich zmiany ulega daleko idącej neutralizacji.

\begin{tabular}{lcc}
\hline & mniej niż 2 osoby na pokój & 2 osoby i więcej na pokój \\
\hline Agresywność & $3,25 \%$ & $64,8 \%$ \\
\hline Kradzieże, ucieczki & $33,3 \%$ & $66,7 \%$ \\
\hline Zaburzenia psychosomatyczne & $43,0 \%$ & $57,0 \%$ \\
\hline Nerwowość & $49,0 \%$ & $51,0 \%$ \\
\hline
\end{tabular}




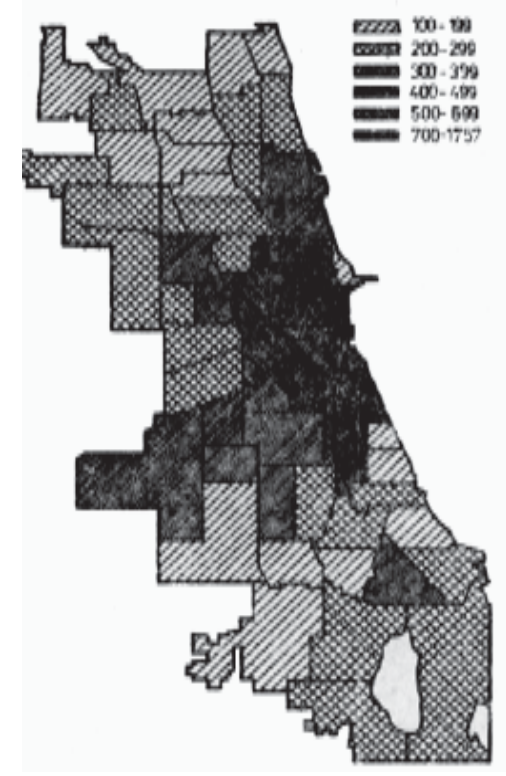

Wskaźniki chorobowości psychicznej w Chicago w latach 1930-1931 w przeliczeniu na 100 tys. dorosłych mieszkańców miasta według stanu ludności z 1930 r.
Stłoczenie jako zjawisko psychologiczne jest ściśle i bezpośrednio związane z liczbą lub gęstością ludzi w danej przestrzeni. W związku z tym można odczuwać stłoczenie w obecności kilku osób, ale nie można wywołać tego zjawiska w izolacji. Stłoczenie jest związane ściśle z prywatnością i terytorialnością. Pojawia się ono wtenczas, kiedy kontakt jednostki z określoną liczbą osób uniemożliwia jej rozwijanie pewnych zachowań, tzn. ogranicza swobodę wyborów.

Podsumowując, można powiedzieć, że swoboda wyboru zachowań stanowi klucz do zrozumienia prywatności, terytorialności i stłoczenia. Istotność omawianych zagadnień dla każdego, kto na co dzień zajmuje się kształtowaniem zależności między formą fizycznej przestrzeni a ludzkimi zachowaniami, najogólniej podsumował Dexiadis: „Musimy nauczyć się planowania i budowania miast w sposób umożliwiający maksymalną swobodę wyborów. Ponieważ miasta, ze względu na swoją strukturę, ograniczają ogólną ilość naszych wyborów..., należy coraz więcej uwagi poświęcać różnego rodzaju badaniom, które w efekcie umożliwiałyby eliminację struktur o najmniejszej możliwości wyborów. Dla osiagnięcia tego celu należy wpierw sformułować najlepszy model życia, a następnie budować struktury, które w swych funkcjach dają maksimum swobody wyborów".

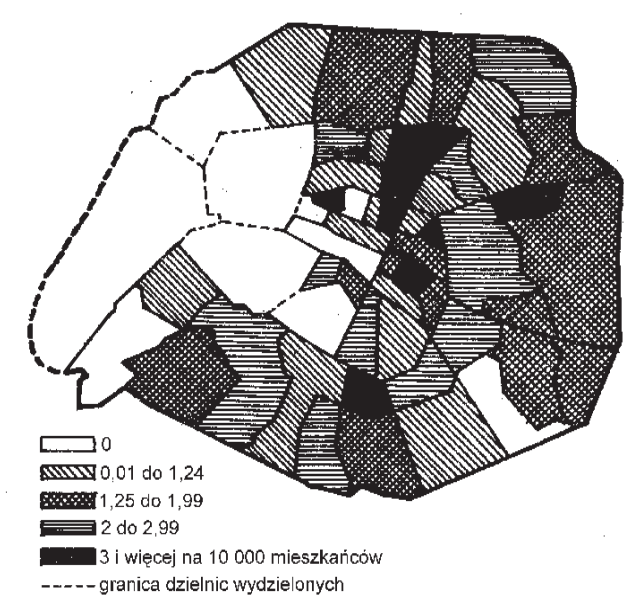

Rozmieszczenie trzech grup chorób psychicznych w niektórych dzielnicach Paryża i niektórych gminach departamentu Sekwany (oprac. G. Mayer-Massé). Przewlekłe psychozy urojeniowe (mężczyźni i kobiety).

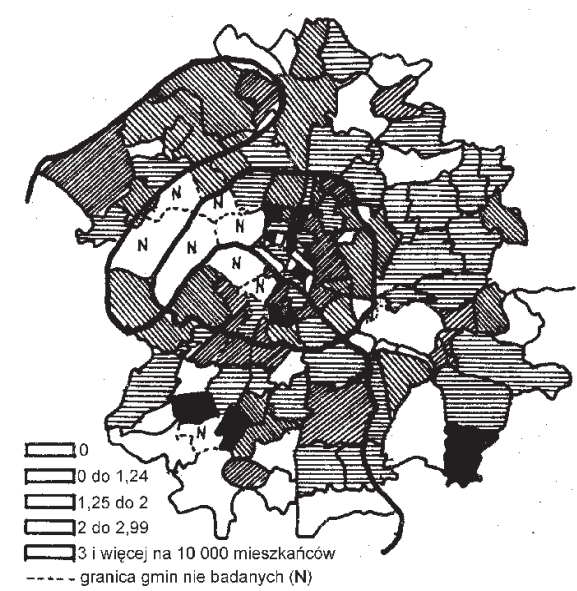

Rozmieszczenie grup chorób psychicznych w niektórych dzielnicach Paryża i niektórych gminach departamentu Sekwany (oprac. G. Mayer-Massé). Przewlekłe psychozy urojeniowe 1948-1950 (mężczyźni i kobiety). 


\section{OSOBOWOŚCIOWE A SYTUACYJNE KORELATY REAKCJI EMOCJONALNYCH NA CZYNNIKI ŚRODOWISKA ARCHITEKTONICZNEGO}

Każda jednostka ludzka zawsze wchodzi w sytuację z określonymi już wcześniej stanami emocjonalnymi. W związku z tym emocjonalne reakcje jednostki na bodźce sytuacji architektonicznej determinowane sa przez dwa czynniki: przez bodźce samej sytuacji (przestrzeń, zjawiska akustyczne, zjawiska świetlne itd.) oraz przez specyficzny stan emocjonalny, w jakim jednostki wchodzi w sytuację. Stan emocjonalny, o którym tutaj mowa, związany jest z jednej strony z oddziaływaniem pewnych chwilowych wewnętrznych stanów organizmu, które powstają pod wpływem działania takich czynników, jak głód, używki, narkotyki. Z drugiej strony stan ten związany jest z oddziaływaniem specyficznych dla każdej jednostki cech osobowości, które decydują o jej emocjonalności. Zatem, aby przewidzieć wpływ różnego rodzaju bodźców środowiska, które są przedmiotem projektowania architektonicznego, należy wpierw rozpoznać, jaki jest możliwy wpływ bodźców środowiska na stany emocjonalne jednostek, a następnie należy zidentyfikować specyficzne cechy osobowości, które decydują o charakterystycznym dla każdej jednostki sposobie emocjonalnego reagowania na bodźce. Osobowość jest ogólną sumą aktualnych bądź potencjalnych wzorów zachowania organizmu, określoną przez dziedziczność i środowisko.

Mehrabian i Russell jako podstawowe osobowościowe korelaty reakcji emocjonalnych przyjmują temperament oraz tendencję do poszukiwania doznań. Temperament jest to cecha osobowości, przejawiająca się w tendencji do przeżywania w charakterystyczny sposób nastrojów lub zmian nastrojów. Specyficzne rozumienie temperamentu przez wyżej wymienionych autorów opiera się na rozróżnieniu między stanem emocjonalnym, a cechqemocji. Charakterystyczny dla każdego człowieka poziom emocjonalności związany z jego osobowością (będący korelatem osobowości), to znaczy temperament może być określony w terminach „cechy przyjemności”, „cechy pobudzenia” oraz „,echy dominacji”. Z drugiej strony chwilowe odczucia jednostki można opisać w terminach „stanu przyjemności”, „stanu pobudzenia” oraz „stanu dominacji”. Powyższe rozróżnienie między „stanem” a „cechą” analogiczne jest do ujęcia lęku u Spielbergera, Gorsehua i Lushena. Badacze ci pierwsi rozróżnili stan lęku, odnoszący się do chwilowego stanu, w jakim znajduje się jednostka w danym momencie, od cechy lęku odnoszącej się do trwałej predyspozycji.

W ostatnich latach wielu psychologów szczególną rolę w determinowaniu preferencji jednostki do określonego środowiska przypisuje cesze pobudliwości. Dzięki tej cesze osobowości niektóre osoby wykazuja preferencję do „spokojnych” sytuacji, inne zaś preferują sytuacje nowe, skomplikowane, zaskakujące. Preferencję tę określa się najczęściej terminem tendencji do poszukiwania doznań. W dalszej części niniejszego rozdziału przedstawione zostaną zależności powyższej tendencji od reaktywności (temperamentu) oraz od dwu innych wymiarów osobowości, tj. introwersji, ekstrawersji oraz neurotyzmu. Badania empiryczne przeprowadzone w ostatnich latach nad tendencją do poszukiwania doznań stawiają w nowym świetle zagadnienie percepcji środowiska architektonicznego i urbanistycznego.

\section{Reaktywność}

Przez reaktywność rozumie się typowy dla jednostki stosunek wielkości reakcji do wywołującego ją bodźca. Reaktywność przedstawić można jako wymiar, który przejawia się we wrażliwości (np. zmysłowej, emocjonalnej) oraz w wydolności (odporności) jednostki. Zgodnie z powyższym reaktywność jest tym większa, im słabszy jest bodziec wywołujący ledwo dostrzegalną reakcję. Odwrotnością wrażliwości jest wydolność, to jest odporność adekwatnego reagowania na bodźce silne, długotrwałe, bądź często powtarzające się. W tym sensie pojęcie reaktywności jest równoznaczne z pojęciem siły układu nerwowego wprowadzonym przez Pawłowa.

Pawłow przyjmował, że u podstawy zdolności układu nerwowego do pracy, jego odporności na działanie bodźców silnych, długotrwałych czy powtarzających się, leży pewna ogólna cecha układu nerwowego, która nazwał sita procesów nerwowych. Na podstawie szeregu eksperymentów stwierdzono, że występuje odwrotna 
zależność między odpornością układu nerwowego na działanie bodźców silnych bądź powtarzających się, tj. jego wydolnościa, a reaktywnościa, czyli wrażliwością tegoż układu. Przyjęto również, że u podstaw obu tych zjawisk - wydolności i reaktywności - leży wspólna cecha ośrodkowego układu nerwowego, mianowicie siła procesów nerwowych. Obecnie zależność między wrażliwością a wydolnością można uznać za sprawdzoną.

Reaktywność przejawia się w dwojakiego rodzaju reakcjach wywoływanych przez bodźce. Chodzi tutaj o ten typ zachowań, które amerykański psycholog Skinner nazwał zachowaniem reaktywnym i zachowaniem sprawczym. Zachowanie reaktywne jest wywoływane bezpośrednio przez bodziec, jak np. w odruchach bezwarunkowych: wydzielanie śliny jako reakcja na pokarm, zwężenie źrenicy na błysk światła czy też odruch kolanowy na uderzenie w ścięgno rzepkowe. Stosunek zachowania sprawczego do bodźców jest nieco inny. To zachowanie jest emitowane, tzn., że jest ono spontaniczne, a nie stanowi reakcji na bodziec. Ruch tancerza można w tym właśnie sensie sklasyfikować jako zachowanie emitowane. Większość tak zwanego zachowania dowolnego zalicza się raczej do zachowania emitowanego, niż reaktywnego. Gdy zachowanie sprawcze staje się związane z bodźcem (jak wówczas, gdy ktoś zgłasza się do dzwoniącego telefonu), dzwoniący telefon jest bodźcem dyskryminacyjnym, który mówi, że można zgłosić się, lecz nie zmusza nikogo do podniesienia słuchawki. Nawet jeśli dzwonek telefonu jest naglący, reakcją nań jest zachowaniem sprawczym, a nie reaktywnym.

Słowa „sprawczy” użyto dlatego, że zachowanie sprawcze oddziaływa na otoczenie, aby wywołać pewien skutek. Z tego samego powodu takie zachowanie bywa czasami nazywane zachowaniem instrumentalnym, ponieważ jest ono środkiem do osiagnięcia jakiegoś skutku, podobnie jak narzędzia lub inne instrumenty. Tak więc podejście do telefonu i podniesienie słuchawki są to czynności sprawcze, które prowadzą do rozmowy telefonicznej. Na tej samej zasadzie cała klasa zachowań ludzkich związanych z użytkowaniem przestrzeni architektonicznej należy do grupy zachowań określonych tutaj terminem zachowań sprawczych, tzn. takich, które zawsze prowadzą do realizacji określonego celu.

Mówiąc o jednostkach silnie i słabo reaktywnych należy mieć na uwadze te osoby, które pod względem nasilenia reaktywności zajmują pozycje skrajne. Fizjologiczną podstawę reaktywności stanowią mechanizmy tłumienia i wzmacniania stymulacji. Jednostki wysoko reaktywne posiadają mechanizm wzmacniania stymulacji. Znaczy to, że określone bodźce (np. wizualne) dochodzace z zewnątrz organizmu wywołuja u tych osób reakcje silniejsze w porównaniu z jednostkami słabo reaktywnymi. Z kolei jednostki mało reaktywne posiadają mechanizm tłumiący stymulację, co oznacza, że bodźce o określonej sile wywołują u nich mniejszą reakcję niż u jednostek bardziej reaktywnych.

Z reaktywnością związana jest ściśle inna właściwość temperamentu - aktywność. Właściwość ta związana jest z kolei z koncepcją optimum pobudzenia wprowadzoną do psychologii przez Hebba oraz Leubę. Według koncepcji optymalnego pobudzenia jednostka dostarcza sobie bodźców dopóty, dopóki nie osiaga optymalnego pobudzenia. Z kolei jednostka, u której występuje nadmierne pobudzenie, podejmuje działania mające na celu zredukowanie go do poziomu optymalnego. Utrzymanie optimum pobudzenia jest pewnego rodzaju potrzeba, w związku z czym zakłócenie równowagi w tym zakresie wywołuje u jednostki motywację do działania mającego na celu zapewnienie (dostarczenie bądź utrzymanie) optymalnego poziomu pobudzenia. Jednostki reaktywne, wyposażone w mechanizm wzmacniający stymulację, posiadają znacznie mniejsze zapotrzebowanie na stymulację $\mathrm{w}$ celu osiagnięcia optimum pobudzenia aniżeli jednostki mało reaktywne. Te ostatnie ze względu na charakterystyczny dla nich mechanizm tłumiący stymulację dostarczają sobie większej liczby bodźców po to, by utrzymać optymalny poziom pobudzenia.Jednostki wyposażone $\mathrm{w}$ mechanizm tłumiący stymulację, a więc mało reaktywne, charakteryzują się dużą aktywnością. Niezależnie od treści samej aktywności czy obiektu, na który jest ona skierowana, aktywność ta ma na celu dostarczenie odpowiedniej stymulacji w celu utrzymania bądź też doprowadzenia do optymalnego pobudzenia.

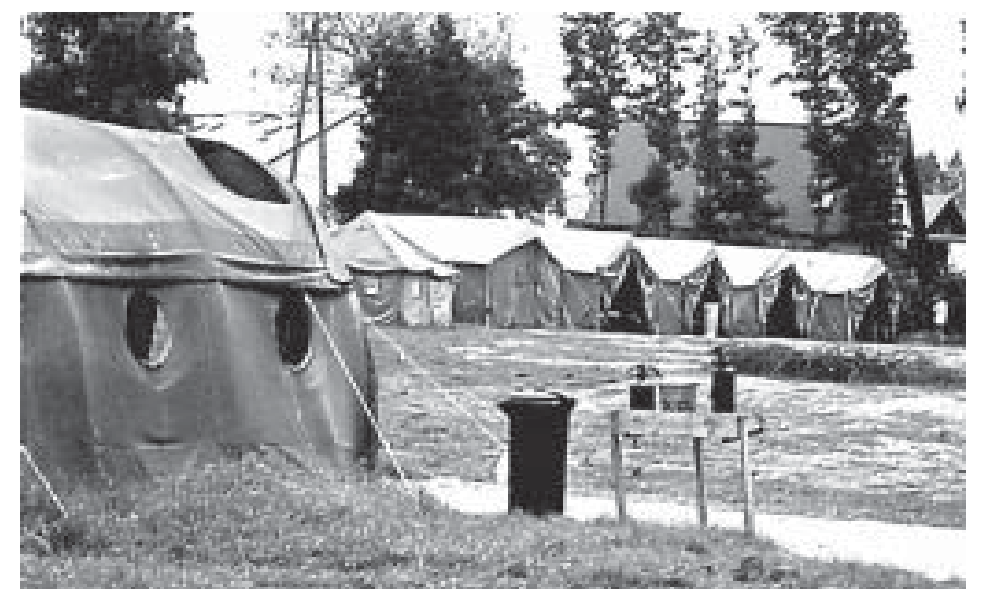

Przy dużej aktywności i poczuciu czasowości, ograniczenie prywatności, jak i wszelkie różnice osobowościowe nie ujawniają jeszcze utajonej siły oddziaływania. 
Odwrotnością aktywności jest bierność zachowania, której jednym z wyznaczników jest mechanizm wzmacniania stymulacji, charakterystyczny dla jednostek silnie reaktywnych. Utrzymanie optimum pobudzenia wymaga w tym przypadku ograniczenia aktywności, tzn. zmniejszenia preferencji do sytuacji i otoczenia bogatych w bodźce.

Koncepcja optimum pobudzenia zwróciła uwagę badaczy na zachowania świadczące o „poszukiwaniu” doznań, a zatem na zachowania prowadzące do zwiększenia liczby oraz siły bodźców, na przykład ze względu na ich nowość, złożoność, „,nieoczekiwaność”. Dotychczasowe klasyczne teorie motywacji działania opierały się na założeniu, że organizm cechuje pierwotna skłonność do redukcji stymulacji. Zgodnie z tym poglądem bodźce zewnętrzne i wewnętrzne skłaniają jednostkę do działania dopóty, dopóki nie znajdzie ona sposobu umożliwiającego zaspokojenie popędu wywołanego destabilizacyjnym działaniem bodźców. Celem najwyższym jest osiagnięcie stanu nirwany, jako stanu, który cechuje brak jakiejkolwiek stymulacji.

Jest rzeczą niewątpliwa, że ludzie dążą. do unikania nadmiernej stymulacji płynącej z otoczenia, jak również stanów wewnętrznego napięcia. W czasie letnich miesięcy większość mieszkańców miast pragnie zmienić życie w wielkomiejskim ruchu, obowiązki pracy zawodowej i gwar zebrań towarzyskich na ciszę i spokój wsi. Jednakże prędzej czy później przeciętny wczasowicz zaczyna odczuwać pewien rodzaj nudy i myśleć o swym normalnym, pełnym podniet i napięcia życiu, snują mu się po głowie nowe plany i pomysły, nowe tematy rozmów. Wydaje się, że dla człowieka niepożądany jest zarówno brak wszelkiej stymulacji, jak jej nadmiar, zaś stanem optymalnym jest jakieś rozsądne wypośrodkowanie stanu pobudzenia oraz pewna w tym zakresie periodyczna odmiana.

Ludzie poszukują nieprzypadkowej i niedowolnej stymulacji. Jednym z ważnych aspektów wrażeń budzących w ludziach zainteresowanie jest ich nowość. Można ją określić na podstawie zakresu i stopnia, w jakim jednostka poprzednio zetknęła się z danym bodźcem. Czasem jest dość trudno ustalić stopień nowości bodźca, nie znając w pełni przeżyć danej osoby. Niemniej jednak bodziec w dostatecznym stopniú nowy budzi zainteresowanie zarówno dziecka, jak i osoby dorosłej. Jeśli bodziec jest zbyt nowy lub zadziała nagle, może wywołać lęk lub tendencję do unikania go. Salvatore Meddi ogłosił wyniki badań przeprowadzonych nad motywacją wywołaną przez bodziec o umiarkowanym stopniu nowości. Dzieciom w wieku przedszkolnym dał on do zabawy zestaw ośmiu małych zabawek. Następnie pozwolił dzieciom dodatkowo wybrać drugi zestaw zabawek spośród pięciu zestawów przygotowanych w taki sposób, że: pierwszy składał się z ośmiu identycznych zabawek ( $0 \%$ nowości); w drugim było 6 takich samych i 2 nowe (25\% nowości); w trzecim - 3 takie same i 3 nowe (50\% nowości); w czwartym - 2 takie same i 6 nowych (75\% nowości); w piątym wreszcie wszystkie zabawki były nowe (100\% nowości). Według wyników obliczonych łącznie dla całej grupy - dzieci wybierały na ogół zestawy zawierające od $25 \%$ do $75 \%$ nowości, unikały zaś ekstremów: zestawu całkowicie im znanego i kompletnie nowego.

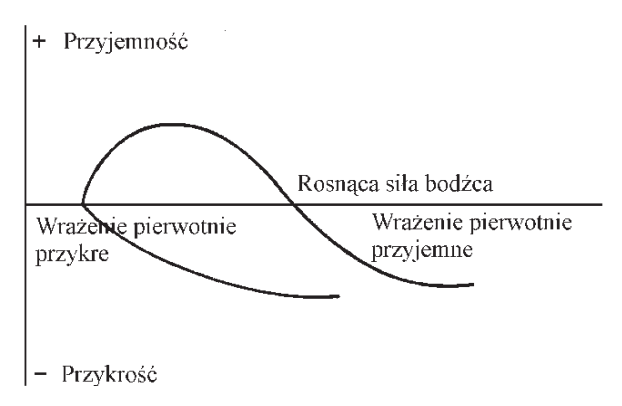

Zależność znaku emocji od siły lub długotrwałości bodźca.

Reasumując zawarte $\mathrm{w}$ tym rozdziale rozważania, można powiedzieć, że istotnym czynnikiem wyznaczajacym siłę i kierunek zachowań ludzkich w każdej sytuacji, a tym samym w sytuacji architektonicznej, jest temperament. Będąc cechą osobowości, temperament (reaktywność) sprawia, że ta sama sytuacja architektoniczna powoduje wśród ludzi różne nastawienia do tej sytuacji, a w konsekwencji odmienną aktywność zachowaniową przejawiająca się $\mathrm{w}$ formie poszukiwania bądź unikania doznań (pobudzenia). W świetle przytoczonych mechanizmów regulujących zachowanie się człowieka w jego otoczeniu, staje się bardziej zrozumiałe, dlaczego część ludzi wybiera sytuacje, środowiska i formy bogate w stymulację (z pierwiastkiem nowości, niezwykłości, „nieoczekiwaności”, dużej siły), a część wybiera sytuacje, środowiska czy też formy spokojne, dobrze znane, z niewielkim natężeniem czynników siły. 


\section{Introwersja i neurotyzm a preferencje estetyczne dotyczqce architektury}

Reaktywność, jak w ogóle temperament, jest tylko jedną z indywidualnych cech osobowości, decydująca o specyficznych sposobach przystosowania się danej jednostki do jej środowiska. Osobowość zdefiniować można jako zorganizowaną strukturę indywidualnych cech i sposobów zachowania, decydującą o specyficznych sposobach przystosowania danej jednostki do jej środowiska (Hilgard, 1967). Układ trwałych, niepowtarzalnych cech tworzy tzw. strukturę osobowości. Reaktywność nie jest jedynym osobowościowym wyznacznikiem i korelatem reakcji emocjonalnych człowieka na bodźce otoczenia. Innymi cechami osobowości związanymi z emocjonalnymi reakcjami jednostki na stymulację otoczenia są wymiary intro-ekstrawersji oraz neurotyzmu. W psychologii pojęcie wymiar jest rodzajową właściwością psychiczną przysługująca (w formie cechy) w różnym stopniu różnym osobom. W przeciwieństwie do tego cecha jest indywidualną właściwością psychiczną osoby, polegającą na tym, iż w pewnych kategoriach sytuacji powtarza ona pewien rodzaj postępowania. W tym sensie temperament jest zarówno cechą jak i wymiarem. Będąc cechą osobowości wyznacza on indywidualność danej osoby. Indywidualność jest to ogół cech konkretnej osoby. Będąc z kolei wymiarem osobowości temperament, ekstrawersja, czy neurotyzm jest wyznacznikiem osobowości. Termin „osobowość” odnosi się do pojęcia o wyższym stopniu abstrakcji niż „indywidualność”, ponieważ obejmuje on cechy wspólne wszystkich indywidualności. Osobowość jest to ogół wymiarów psychicznych (Hilgard, E. 1967). W praktyce jednak obydwa terminy - cecha i wymiar - są używane zamiennie bez większych konsekwencji.

Pojęcie użyte zostały przez szwajcarskiego psychologa Carla J. Junga (współpracownika Zygmunta Freuda) do opisania typów osobowości opartych na cechach behawioralnych. Problematyka typów osobowości wywodzi się że starożytności. Teorie typów osobowości przetrwały do dziś, chociaż psychologowie wielokrotnie odrzucali ich klasyfikacje. Przyczyny rozpowszechniania się tych teorii są bardzo proste. Reprezentują one próbę znalezienia jakiegoś porządku w ludzkiej różnorodności. Teorie typów opierają się na powszechnie obserwowanym fakcie, że przynajmniej u niektórych ludzi osobowość koncentruje się wokół jakiejś głównej czy dominującej cechy - ambicji, dumy, ryzykanctwa czy dbałości o przyjemności ciała.

I tak według Junga introwertyk, zwłaszcza w czasie emocjonalnego stresu czy konfliktu, skłonny jest zamykać się w sobie. Do charakterystycznych cech introwersji należy nieśmiałość oraz skłonność do pracy w samotności, np. raczej w bibliotekach i laboratoriach niż wśród ludzi. Ekstrawertyk przeciwnie, gdy znajduje się w sytuacji stresowej, pragnie zagubić się wśród ludzi. Na ogół bardzo towarzyski, jest za pan brat ze wszystkimi. Skłonny jest do wyboru takiego zawodu, w którym ma do czynienia raczej z ludźmi niż z rzeczami. Zwykle stosuje się do konwenansów, jest ortodoksyjny, dbały o ubiór, ambitny. Nietrudno będzie znaleźć każdemu z nas wśród swych znajomych typowego introwertyka i typowego ekstrawertyka, Fakt ten powoduje, że klasyfikacja Junga budzi zaufanie i tłumaczy jej popularność.

Przyjmując założenia typologiczne osobowości człowieka, angielski psycholog Hans Eysenck na drodze eksperymentów naukowych poddał weryfikacji koncepcję Junga w zakresie intro-ekstrawersji oraz dodatkowo wyodrębnił wymiar neurotyzmu. Autor ten dokonał analizy czynnikowej różnego rodzaju zachowań patologicznych, a także zachowań ludzi normalnych w sytuacjach życia codziennego i w sytuacjach eksperymentalnych, i wydzielił na tej podstawie trzy kwantyfikowane wymiary osobowości, określając je jako „,introwersja” (1), „neurotyzm” (N) i „psychotyzm” (P). Psychotyzm jest pojmowany jako predyspozycja do zaburzeń procesów psychicznych (poznawczych), w przeciwieństwie do neurotyzmu, który tych objawów nie wykazuje. Wymiary te utożsamił on z pewnymi wrodzonymi cechami organizmu, które decyduja o predyspozycji do zaburzeń nerwicowych bądź psychofizycznych. Pomijając w tym miejscu wymiar P, jako nie związany z interesującym nas tutaj zagadnieniem reakcji emocjonalnych na bodźce środowiska, zajmiemy się tylko czynnikami I oraz N.

Wymiar introwersji Eysenck identyfikuje z łatwością albo trudnością warunkowania odruchów ze strony układu autonomicznego, które łączy się z emocjonalnością. Warunkowanie jest to wytwarzanie odruchów warunkowych, tj. nadawanie bodźcom obojętnym znaczenia sygnału. Zagadnienie to wiąże się z kolei ze sprawą fizjologicznego podłoża introwersji - ekstrawersji, które upatruje w różnym poziomie równowagi procesów pobudzania-hamowania, stanowiących przeciwległe bieguny jednego kontinuum. Pobudzanie w najogólniejszym tego słowa rozumieniu oznacza wewnętrzny proces przebiegający w centralnym układzie nerwowym, który ułatwia spostrzeżeniowa, poznawczą i motoryczną aktywność organizmu.

W podobny sposób wymiar neurotyzmu został powiązany z pobudliwością układu autonomicznego, czyli z pobudliwością emocjonalna. innymi słowy, przez neurotyczność Eysenck rozumie pewną wrodzoną właściwość autonomicznego układu nerwowego, mianowicie szczególną właściwość tego układu u pew- 
nych ludzi, przy której wywoływane za jego pośrednictwem emocje występują łatwo, są silne i trwałe - w przeciwieństwie do innej grupy ludzi, u których emocje pojawiają się wolniej, pod wpływem silniejszych bodźców, są słabe i nietrwałe, a także do pozostałej, zdecydowanie większej części populacji, która znajduje się pomiędzy tymi dwoma krańcami. Neurotyczność przypisywana jest oczywiście tylko tej pierwszej grupie. Innymi słowy, neurotyczność stanowi brak tolerancji na działanie stresú (tak fizycznego, jak i psychicznego), jak np. nadmierne zagęszczenie bodźców wzrokowych i słuchowych, zbyt duża nowość, nagłość etc. Oba te wymiary tworzą kontinua, które można przedstawić graficznie jako dwie przecinające się osie współrzędnych, lokując w powstałej w ten sposób dwuwymiarowej przestrzeni każdego osobnika z punktu widzenia I oraz $\mathrm{N}$.

Wyniki szeregu badań nad poszukiwaniem doznań, w których jako zmienną zależna przyjmowano wymiar ekstra-introwersji, dowodzą pewnego związku między tym wymiarem a reaktywnością oraz emocjonalnymi reakcjami na bodźce środowiska. Wskazuje się przy tym na znaczne podobieństwo między mechanizmem fizjologicznym, określonym jako siła procesu pobudzenia

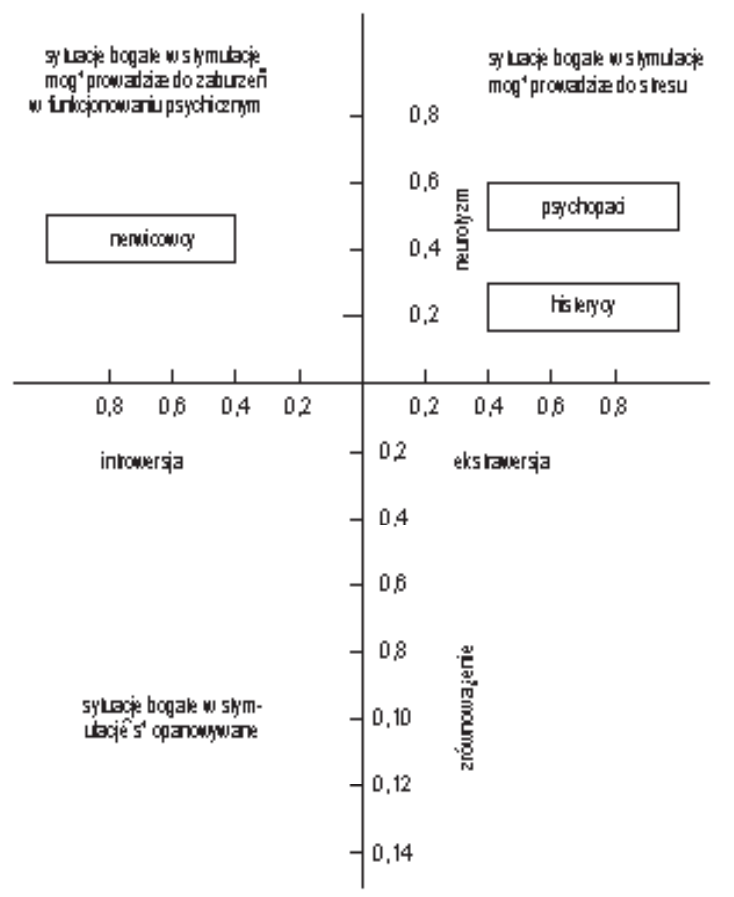

Dwa wymiary osobowości według Eysencka. układu nerwowego (fizjologiczna „baza” reaktywności), a fizjologiczna podstawą ekstrawersji. Bliski próg pobudzenia wstępującego układu siatkowego (ARAS) jest charakterystyczny dla słabego układu nerwowego, jak i dla introwersji. Z kolei u jednostek o silnym układzie nerwowym, jak i dla esktrawertyków, próg pobudzenia tego układu jest wysoki.

Cooper i Payne, badając różne aspekty przystosowania do pracy monotonnej, czego miernikiem było wycofywanie się z pracy, stwierdzili, że jednym z czynników determinujacych przystosowanie do pracy jest ekstrawersja. Między innymi dopatrują się przyczyny tego w tym, że ekstrawertycy sa mało pobudzeni, podczas gdy introwertycy pobudzeni sa chronicznie. Ekstrawertycy wobec tego wykazuja większe zapotrzebowanie na podniety płynące ze środowiska. Na podstawie tego samego założenia, próbowano wyjaśnić korzystny wpływ muzyki, a nawet niewielkiego hałasu na ekstrawertyków przy wykonywaniu prostych i powtarzalnych zadań (introwertycy są bardziej odporni na monotonię). Tak np. Davies i Hockey zaobserwowali, że przy wykonywaniu prostych zadań wzrokowych oddziaływanie hałasu o poziomie $95 \mathrm{~dB}$ okazuje się pomocne dla ekstrawertyków, lecz niekorzystne dla introwertyków. Weisen stwierdził, że ekstrawertycy w porównaniu z introwertykami o wiele mocniej naciskali przycisk, aby zwiększyć stymulację w postaci kolorowych świateł, dźwięków wydobywających się z radia itp. Odwrotnie introwertycy, bardziej naciskali przycisk wyłączający stymulację, gdy miała ona charakter ciagły.

Podobny związek zaobserwowano między reaktywnością a neurotyzmem. Dougier stwierdził, że neurotycy przejawiają nadwrażliwość na bodźce słuchowe i świetlne. Podobnie Broadbent wykrył, że bardziej neurotyczne jednostki odczuwają hałas w środowisku pracy i zamieszkania jako bardziej dokuczliwy. Wyniki tych badań tłumaczy się tym, że osoby neurotyczne w porównaniu z nieneurotycznymi mają wyższy poziom pobudzenia, a zatem wykazują niższą tolerancję na bodźce silnie pobudzające.

Z przytoczonych wyników badań wynika, że zarówno introwersja, jak i neurotyzm są istotnymi czynnikami wpływającymi na przystosowanie się ludzi do fizycznego środowiska. Podstawowe kombinacje wymiarów introwersji i neurotyzmu w aspekcie ustosunkowania się jednostki do płynącej z sytuacji stymulacji pokazane są na rysunku.

Różnice w percepcji architektury w zależności od typu psychologicznego wynikają z ambiwalencji samego aktu percepcji, która może być skierowana na zewnątrz percypującego organizmu, albo na podmiot, czyli wyobrażenie lub wrażenie. Na podstawie percypowania bodźców estetycznych i sposobów ekspresji artystycznej można wyróżnić typ wizualny i haptyczny. Pierwszy opiera się na spostrzeganiu świata bezpośrednio przez przeżycia związane z wrażeniami wywoływanymi działaniem bodźców, natomiast drugi opiera się na własnych przeżyciach (wyobrażeniach) wywołanych działaniem bodźców zewnętrznych. Typ 
przeżyciowy odpowiada w terminologii Eysenck'a osobowości introwertywnej, a typ wizualny - ekstrawertywnej. Introwertycy są w porównaniu z ekstrawertykami bardziej sensomotoryczni. Oznacza to, że w ekspresji twórczej preferują barwne plam, kolor, a ekstrawertycy bardziej preferują kształt. Introwertycy preferuja kształty niesymetryczne, bardziej skomplikowane oraz mniejsze figury, natomiast ekstrawertycy kształty symetryczne, mniej komplikowane.

Stosunkowo mało sprawdzonych informacji posiadamy na temat zależności między typem osobowości a preferencjami w stosunku do określonych form architektonicznych. Dwa badania takie przeprowadzone w Uniwersytecie Poznańskim. Rzucają one pewne światło na związek jaki istnieje między typem osobowości a preferencjami estetycznymi architektury jednorodzinnych budynków mieszkalnych oraz architektury wnętrz.

Przedmiotem pierwszego badania (Maria Alvarado, Typ osobowości a preferencje estetyczne środowiska architektonicznego, Poznań, 1995) były projekty domów jednorodzinnych wybrane z „Krajowego Zestawu Domów Jednorodzinnych 83”. Wybór oparty był na założeniu, że domy różnią się pod względem formy ogólnej, elementów, a także pod względem stylu i typowości. Wybrane domy typowe podzielono na grupy pod względem cech wspólnych. W ten sposób uzyskano charakterystyczne grupy domów przedstawiające charakterystyczne, czarno-białe elewacje dobrane parami z uwzględnieniem ogólnego kształtu danego obiektu: A. Płaski, niski, jedopoziomowy; B. Płaski, niski, dwupoziomowy; C. Płaski, wysoki, wielopoziomowy; D. Płaski, wysoki, symetryczny; etc. Zarówno osoby introwertywne, jak ekstrawertywne poddawane były indywidualnie tym samym badaniom, które składały się z dwu części. W części pierwszej badani porządkowali tablice w kolejności największych i najmniejszych upodobań. W części drugiej badani charakteryzowali projekty, które podobały im się najbardziej i wskazywali też elementy geometryczne, które zwróciły ich uwagę najbardziej. W ten sposób uzyskano kryteria wyboru jednych i odrzucenia innych projektów.

$\mathrm{Na}$ podstawie wyników badań stwierdzono, że introwertycy w większym stopniu preferują budynki o niesymetrycznym ogólnym kształcie i spadzisty dachu opartym na zarysie trójkąta nierównoramiennego. Ekstrawertycy z kolei preferują spadziste dachy w budynkach symetrycznych, o masywnej budowie, opartej na planie figury regularnej, o nadbudowanych dachach. Kobiety w większym stopniu niż mężczyźni preferuja obiekty architektoniczne zróżnicowane w formie. Opisy budynków dokonywane przez kobiety nacechowane są emocjonalnością. Mężczyźni zwracają uwagę w większym stopniu na formę niż na funkcję obiektu, co wynika z ogólnych, technicznych zainteresowań, z jednej strony, i innymi warunkami socjalizacji tożsamości płciowej (identyfikacji z rolą męska) - z drugiej strony.

Przedmiotem drugiego badania (W. Monikowska, Typ osobowości a preferencje estetyczne architektury wnętrz mieszkalnych, Poznań, 1993) były typowe wnętrza mieszkalne odpowiadające pięciu wymiarom: 1- jasne - ciemne; 2 - przestrzenne - zatłoczone; 3 - nowoczesne - tradycyjne; 4 - typowe - nietypowe; 5 - „otwarte” dla innych - „zamknięte” dla innych. Do badań wybrane zostały fotografie spełniające następujące kryteria: typowości (fotografia nr 1); przestrzenności (fotografia 2); mroczności (3); „zamkniętości” dla innych (4); staroświeckości (5); „otwartości” dla innych (6), nietypowości (7); jasności (8); stłoczenia (9); nowoczesności (10). Tytuły fotografii barwnych nie były znane badanym.

Introwertycy preferują wnętrza o ciemniejszej kolorystyce, zharmonizowane, ze sprzętami wtopionymi w tło, ze słabiej zaznaczonymi granicami, których zbiory tworza „zamknięte obszary” dające poczucie bezpieczeństwa i możliwość odcięcia się od otoczenia. Ekstrawertycy preferują wnętrza o kolorach jasnych, o wyraźnie zaznaczonej symetrii, widocznych kątach, pochyłych ścianach. Sprzęty w preferowanych wnętrzach wyraźnie odcinają się od tła, mają wyraźniej zaznaczone granice (drewniane poręcze foteli, wyróżniająca je kolorystyka). Introwertycy jako typy refleksyjne z większą skłonnością do rozmyślania wola wnętrza zakomponowane harmonijnie, wygodnie, uspokajające. Ekstrawertycy obdarzeni większym zapotrzebowaniem na stymulację wolą pomieszczenia o większej złożoności z wyodrębniającymi się sprzętami, żyw szą kolorystyką i ogólnie panującym „chaosem”. W opisie wnętrz introwertycy preferują wyrażenia abstrakcyjne, a ekstrawertycy preferują wyrażenia dotyczące konkretnych elementów komponujących całość. U ekstrawertyków przeważa myślenie obrazowo-konkretne. Kobiety wola pomieszczenia jasne, ciekawie zaplanowane, przestrzenne, z dużą ilością kwiatów, światłem dziennym. Mężczyźni preferują pomieszczenia mniejsze, o ciemniejszej kolorystyce, światło sztuczne, punktowe, meble zapewniające wypoczynek. 


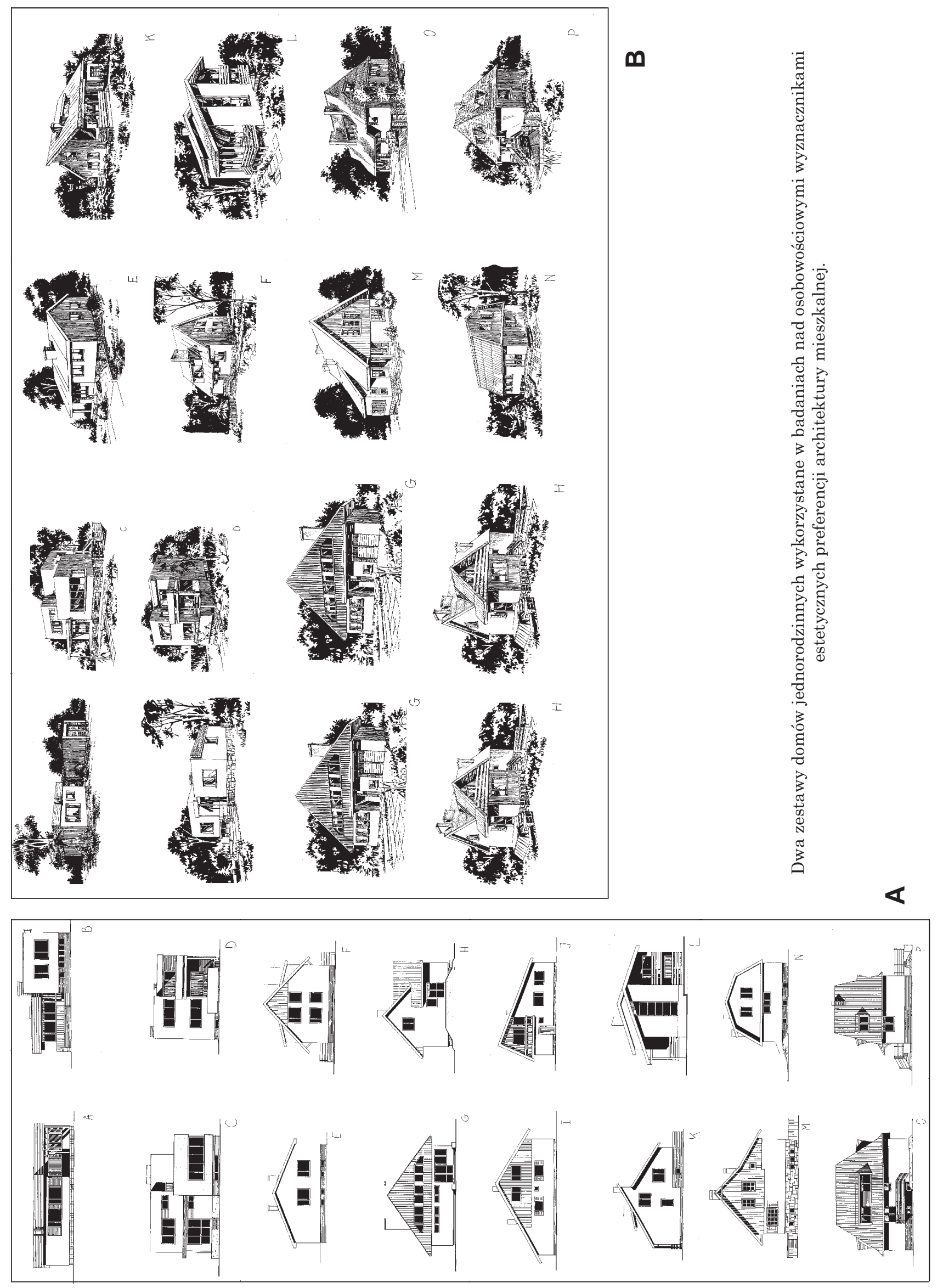



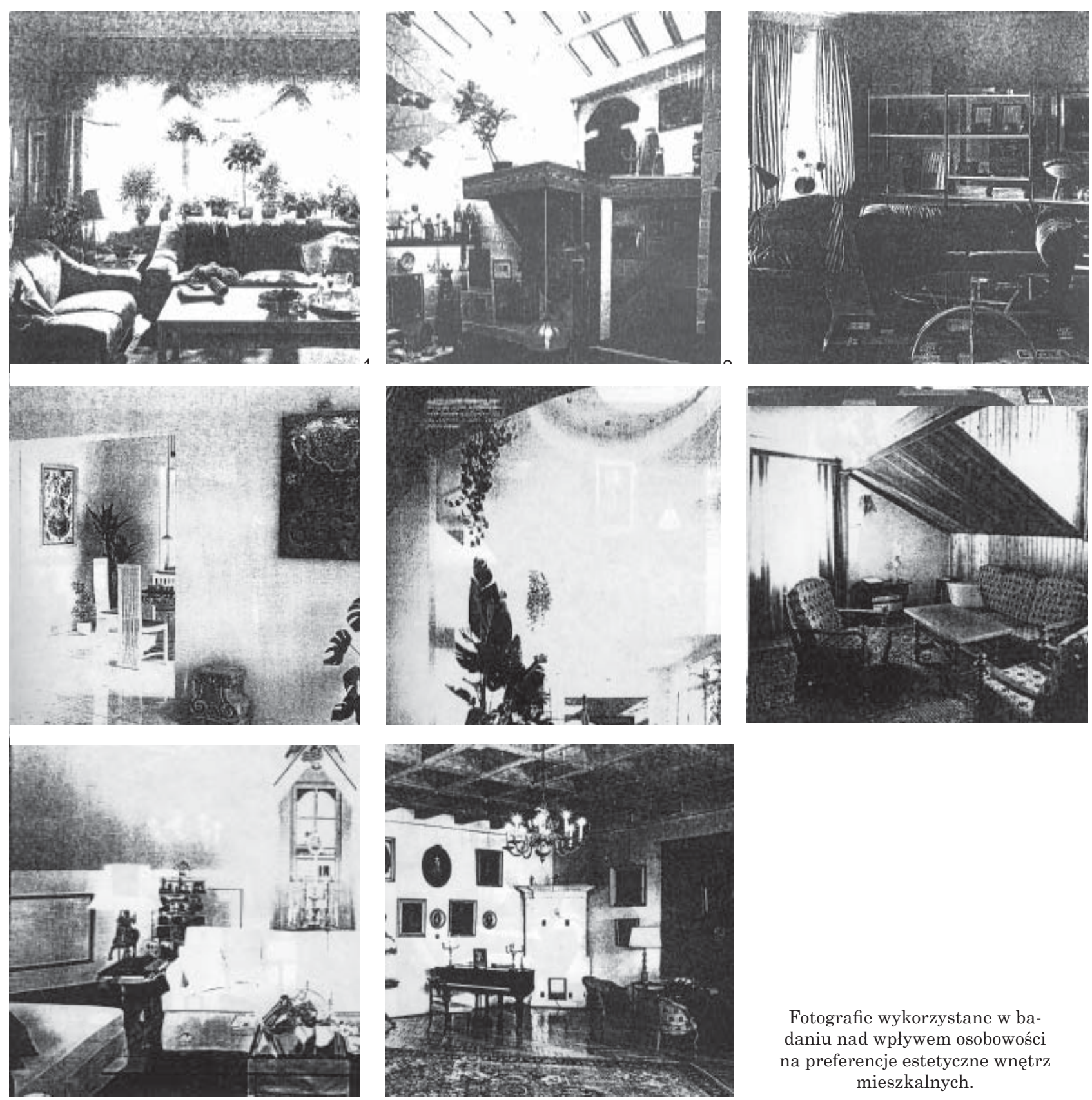

Fotografie wykorzystane w badaniu nad wpływem osobowości na preferencje estetyczne wnętrz mieszkalnych.

\section{Zawartość informacyjna środowiska architektonicznego}

Opisane w poprzednim rozdziale psychologiczne mechanizmy kształtujące zachowania jednostki w środowisku nie wyczerpuja jeszcze zagadnienia, które streścić można w dwóch następujących pytaniach. Po pierwsze, jak poszczególne fizyczne bodźce przestrzeni architektonicznej wpływają na takie, a nie inne zachowania się ludzi? Po drugie, jak w związku z tym należy kształtować przestrzeń architektoniczną? W ocenie potencjalnego wpływu fizycznych aspektów środowiska architektonicznego na charakter i kierunek zachowań ludzkich istotna jest znajomość oprócz mechanizmów emocjonalnych, również zawartości informacyjnej zarówno izolowanych jak i złożonych bodźców. Szczególnym problemem z metodologicznego punktu widzenia jest dokonywanie oceny zawartości informacyjnej bodźców tworzących złożone zespoły stymulacyjne, takie jak kombinacja dźwięków, kształtów, ruchu. Wynika to m.in. z tego, że o ile stosunkowo 
łatwo jest określić zależności między prostymi bodźcami (dźwięk, światło) a reakcjami na nie organizmu ludzkiego, to trudniej jest określić takie same zależności między zewnętrznymi i wewnętrznymi reakcjami na różnorodne kombinacje tych prostych bodźców np. dźwięk, kolor oraz kształt.

Pewne możliwości rozwiązania tego zagadnienia wyłoniły się w związku z próbami zastosowania pojęć i schematów teorii informacji do analizy, interpretacji i przewidywania w zakresie zachowania się, człowieka w określonych warunkach. Najważniejszym pojęciem jest tu pojęcie ilości informacji. Przeciętną ilość informacji nazwano taką wielkość $\mathrm{H}$, która mierzy przeciętny stopień niepewności ukazania się sygnałów. Innymi słowy H jest miarą usuwanej przez sygnał niepewności.

Wartość H jest zależna od prawdopodobieństwa ukazania się sygnałów. Za jednostkę ilości informacji $\mathrm{H}$ przyjmuje się najczęściej taka jej ilość, która redukuje niepewność o połowę. Jednostkę tę nazwano bitem. Tak np. niepewność w losowaniu moneta określona jest przez $\log _{2} 2=1$ bit, tzn. zawartość informacyjna wyniku losowania (redukcja niepewności) wynosi 1 bit. Uogólniając można powiedzieć, że niepewność rezultatu, która jest jedna $\mathrm{z}$ k jednakowo możliwych alternatyw, wynosi $\log _{2} \mathrm{k}$. Zatem określony wynik (wystapienie jednej z k alternatyw) wynosi $\log _{2} \mathrm{k}$ bitów informacji. Ilość informacji dla $\mathrm{n}$ niezależnych zdarzeń, gdzie każde jest jednym z k jednakowo możliwych alternatyw, określona jest wzorem:

$$
\mathrm{H}=\mathrm{n} \log _{2} \mathrm{k}
$$

Powyższe rozważania maja zastosowanie do charakterystyki informacyjnej konfiguracji przestrzennych. Na przykład spośród dwóch obrazów, z których jeden zawiera dwa, a drugi osiem jednakowo rozmieszczonych kolorów, obraz drugi ma trzy razy większą $\left(\log _{2} 8=3\right)$ ilość informacji vii porównaniu z pierwszym $\left(\log _{2} 2=1\right)$.

W przypadku, gdy różne alternatywy zdarzeń nie są dokładnie takie same, lub kiedy poszczególne elementy w konfiguracji przestrzennej nie są jednakowo rozmieszczone, ilość informacji określa się wzorem:

$$
\mathrm{H}=\Sigma \mathrm{p}_{\mathrm{i}} \log _{2} 1 / \mathrm{p}_{\mathrm{i}}=-\Sigma \mathrm{p}_{\mathrm{i}} \log _{2} \mathrm{p}_{\mathrm{i}}
$$

gdzie: $p_{i}$ - prawdopodobieństwo i-tego sygnału (alternatywy)

Pierwszą implikacją powyższej miary ilości informacji jest to, że kiedy alternatywy zdarzeń nie sa jednakowo prawdopodobne, ilość informacji jest mniejsza. Nawiązując do przytoczonego wcześniej przykładu
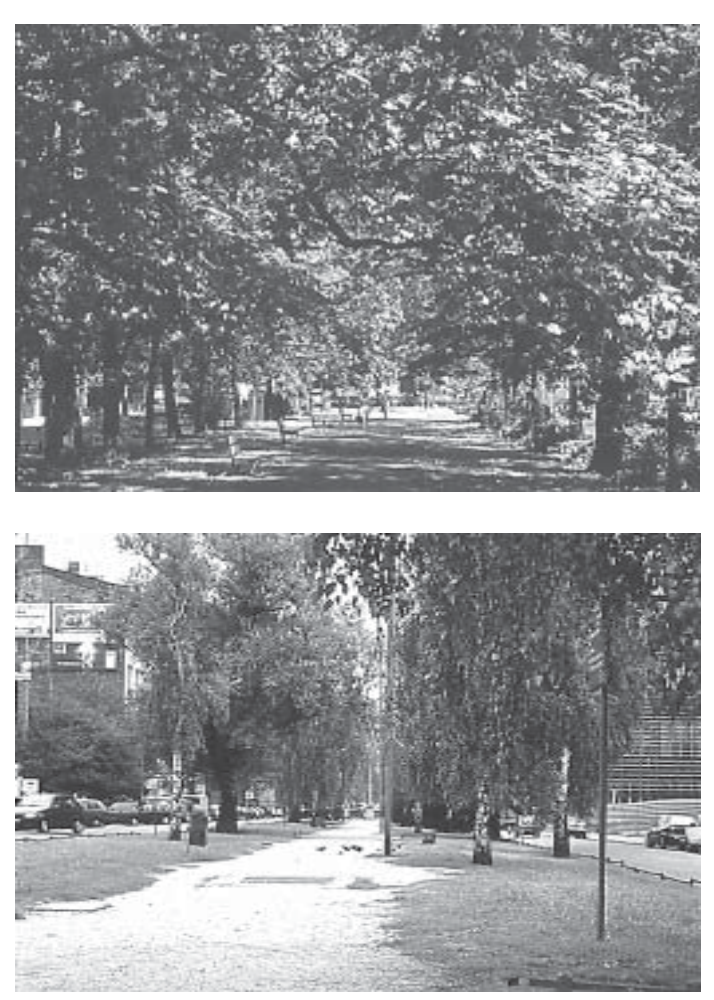

Dwie aleje o różnej zawartości informacyjnej. Aleja obsadzona nieregularnie ma mniejszą zawartość informacji i mniejszą atrakcyjność. konfiguracji przestrzennej, obraz, który posiada osiem równo rozłożonych kolorów na swojej powierzchni, zawiera większa ilość informacji w porównaniu z obrazem, w którym jeden z ośmiu kolorów pokrywa 90\% powierzchni. Drugą ważna implikacją tej miary ilości informacji jest to, że zdarzenia rzadkie i nowe zawierają większą ilość informacji, ponieważ informacja dotycząca zdarzenia wynosi $\log 21 / p$, gdzie p stanowi prawdopodobieństwo zdarzenia.

W odniesieniu do zdarzeń przestrzennych i czasowych ogólna ilość informacji stanowi prostą sumę informacji poszczególnych zdarzeń przy założeniu, że poszczególne zdarzenia są niezależne (np. zakładając, że poszczególne składniki w konfiguracji przestrzennej sa równomiernie rozmieszczone). Jeżeli dana informacja dotycząca konfiguracji bodźców jest określona dla danego czasu, to każdą zmianę w konfiguracji można uznać za zmianę wprowadzająca dodatkową informację. I tak, nie zmieniająca się konfigurację bodźców należy uważać za konfigurację o mniejszej ilości informacji w ramach określonego przedziału czasowego w porównaniu z konfiguracja, której składniki gwałtownie ulegają zmianie.

Z psychologicznego punktu widzenia całość sytuacji życiowych człowieka uporządkować można na kontinuum konfiguracji bodźcowych, którego jeden kraniec charakteryzować będzie idealna regularność, redundancja oraz entropia. Drugi natomiast kraniec tego kontinuum charakteryzować będa takie zjawiska, jak ekstremalne zaburzenia, nieprzewidywalność oraz nieograniczony chaos. Przykładem pierwszego 
rodzaju konfiguracji krańcowych jest deprywacja sensoryczna, tzn. pozbawienie człowieka dopływu zewnętrznych podniet zmysłowych. Drugi rodzaj skrajnych konfiguracji bodźcowych właściwy jest sytuacjom szybko zmieniającym się, jak np. na skrzyżowaniach ulic w centrach dużych miast.

Zdefiniowanie kontinuum konfiguracji bodźcowych nie rozstrzyga jednak jeszcze problem w wskaźnika ilości informacji zawartych w konfiguracjach bodźcowych zmieniających się w nieprzewidzianych kierunkach. Wydaje się wątpliwe, czy uda się kiedykolwiek znaleźć taki precyzyjny wskaźnik ilości informacji. W sposób uproszczony za wskaźnik informacji zawartych w konfiguracjach bodźcowych można przyjąc ogólną ilość informacji zawartych w danym czasie w danej konfiguracji. Biorąc za punkt wyjścia tak zdefiniowany wskaźnik zawartości informacyjnej przeprowadzono szereg badań mających na celu określenie zawartości informacyjnej różnego rodzaju bodźców. Niestety, badania, o których mowa za chwilę, najczęściej dotyczyły prostych figur geometrycznych oraz kombinacji różnych tonów prostych. Jak dotychczas nie podjęto na szerszą skalę badań (z wykorzystaniem założeń teorii informacji) nad zawartością informacyjną całościowych, a zatem z natury rzeczy złożonych sytuacji bodźcowych spotykanych w życiu codziennym.

W charakterystyce zawartości informacyjnej codziennych sytuacji lub środowisk, w jakich funkcjonujemy w życiu codziennym, dominują koncepcje wykorzystujące proste kontinua opisane parami przymiotników, takich jak: prosty - złożony, uporządkowany - chaotyczny, harmonijny - drażniący, homogeniczny - heterogeniczny, stały - zmienny, ciagły - przerywany, konsonansowy - dysonansowy. Tym sposobem można porównać np. muzykę elektroniczną z muzyką klasyczna, wnętrza funkcjonalne z wnętrzami barokowymi, kubizm z surrealizmem. Przymiotniki takie, jak „nowy”, „rzadki”, „nieoczekiwany”, „zaskakujący” odnoszą się do małego prawdopodobieństwa zdarzeń. Jak już wspomniano, zdarzenia takie wiążą się z małą zawartością informacyjna.

Jednoznaczne obiekty lub sytuacje sa łatwo rozpoznawalne, znajome, prawdopodobne, a zatem cechuje je mniejsza zawartość informacyjna. „Zmiana” lub „ruch” pociaga za sobą zwiększanie się zawartości informacyjnej sytuacji w jednostce czasu, w porównaniu z taka samą sytuacją statyczną. Na przykład ,symetria" zakłada uporządkowanie, a zatem redukuje w pewnym stopniu. zawartość informacyjną. Również omawiane wcześniej zagadnienie „dystansu” można wyjaśnić w kategoriach ilości informacji. Mianowicie w miarę, jak dystans w stosunku do jakiegoś obiektu zmniejsza się, zwiększa się dopływ bodźców, a tym samym zwiększa się ilość informacji. Uogólniając można powiedzieć, że zawartość informacyjna jest minimalna w „otwartych”, „eksponowanych” przestrzeniach, gdzie średni dystans w przestrzeni jest duży.

Zbliżenie do innych osób zwiększa ilość informacji ze względu na to, że ludzie z natury rzeczy są źródłem najróżnorodniejszej stymulacji. Poza tym zmniejszenie dystansu (odległości) między ludźmi powoduje wzrost bezpośredniej stymulacji, tzn. oddziaływania bodźców za pośrednictwem kilku kanałów sensorycznych, a więc wzroku, słuchu, dotyku, powonienia, smaku. Taka bezpośrednia stymulacja niesie z sobą większą ilość informacji aniżeli stymulacja pośrednia. Tak np. fotografia przedstawiająca dom jest źródłem stymulacji pośredniej związanej z danym domem, a dom realny jest źródłem stymulacji bezpośredniej. Podobnie osoba, z którą mamy kontakt dotykowy, wzrokowy i węchowy, jest źródłem bardziej bezpośredniej stymulacji, niż gdy kontakt ten istnieje na odległość.

Omawiane wcześniej pojęcie stłoczenia, które wykorzystywane jest do opisu środowisk architektonicznych i urbanistycznych, wytłumaczalne jest w terminach informacyjnej zawartości sytuacji. Ogólnie rzecz biorąc, stłoczenie związane jest z małym dystansem między człowiekiem a innymi obiektami w przestrzeni oraz jest źródłem dużej, zmiennej i różnorodnej stymulacji. Sytuacja zagęszczenia, spowodowana zapełnieniem przestrzeni przez ludzi, jest sytuacją o większej zawartości informacyjnej niż sytuacja, w której podmiot przebywa w przestrzeni nie zagęszczonej lub zagęszczonej (zapełnionej) „nieożywionymi” w swej naturze obiektami.

Również pojęcie skali wiąże się z zawartością informacyjną sytuacji. Zachowując stały dystans w stosunku do obiektu, a zwiększając jego skalę, cechy i szczegóły obiektu stają się coraz bardziej rozpoznawalne i wzrasta jego zawartość informacyjna. Zdjęcie lub nawet wierna, ale mała replika Wieży Eiffla mają mniejsze znaczenie emocjonalne dla obserwatora, aniżeli oddziaływanie realnego monumentu. Podobnie zwiększenie skali dobrze znanego obiektu może być czymś nieoczekiwanym i w konsekwencji zwiększać ilość informacji związanych z tym obiektem. Tak też uczynił Campbell z puszką zupy, nobilitując ją do rangi dzieła sztuki. Generalnie zabieg polegający na swobodnym operowaniu skalą wykorzystywany jest w pop-arcie, głównie przez reprodukcję prostych i dobrze znanych obiektów w nieoczekiwanej skali, z nieoczekiwanymi zmianami w ich emocjonalnym oddziaływaniu. Różnice indywidualne w reakcjach na dużą skalę są w dużym stopniu uzależnione od stopnia nowości lub niezmienności obiektu. Sytuacje bodźcowe określane takimi terminami, jak: „zewnętrzny”, „za progiem” „wiejski”, które są generalnie przeciwstawne do sytuacji określanych terminami „wewnętrzny”, „przed progiem”, „zurbanizowany”, charakteryzują środowiska o dużym dystansie, niewielkim skupieniu, a w konsekwencji środowiska o niedużej zawartości informacyjnej. 
Poziom pobudzenia wywołany bodźcami środowiska skorelowany jest z jego zawartością informacyjna. Zależność tę można rozbić na dwie bardziej szczegółowe. Pierwsza zakłada, że pobudzenie jest wprost proporcjonalne do stopnia złożoności statycznych konfiguracji bodźców. Druga natomiast mówi, że pobudzenie jest proporcjonalne do zmian w konfiguracjach bodźców. Badania Bakera i Frankena nad zależnościa między pobudzeniem (mierzonym desynchronizacją EEG) a złożonościa informacyjną bodźców wykazały znaczącą w tym względzie zależność. Okazało się, że u ludzi występuje wyraźny wzrost pobudzenia pod wpływem oddziaływania złożonych figur. Berlyne i Borsa wykorzystali w podobnych badaniach obrazy białe i białobłękitne. Ponieważ błękitnobiałe obrazy maja mniejszą jednoznaczność w porównaniu z czysto białymi obrazami, dlatego też powodowały one większe pobudzenie, tzn. dłuższą desynchronizację EEG.

Znacznie więcej badań przeprowadzono nad zależnością reakcji pobudzenia od zmieniających się bodźców. Szczególnym przypadkiem tej zależności jest nowość bodźca. Zwiększą nowością bodźca związana jest większa ilość informacji. Baker i Franken, wyświetlając badanym przez dłuższy czas te same obrazy, zaobserwowali u tych osób spadek pobudzenia. Wyraźną zależność między jakościa pobudzenia a nowościa bodźców stwierdzili również inni badacze.

Reasumując, badania empiryczne potwierdzają hipotetyczną zależność między zawartościa informacyjną sytuacji a pobudzeniem emocjonalnym. Zależność ta, niezależnie od swojej prostoty, posiada liczne implikacje, m.in. w postaci licznych hipotez, które, co prawda nie doczekały się jeszcze empirycznej weryfikacji, ale mimo to mają istotny udział w wyjaśnianiu wpływu codziennych sytuacji życiowych człowieka na jego zachowanie. Z zależności tej wynika m.in., że im większa jest różnorodność barw w oświetleniu, bardziej niezwykłe sytuacje, większa liczba ludzi, tym większe pobudzenie emocjonalne podmiotu. Uogólniając można założyć, że jednostka będzie pod wpływem większego pobudzenia, gdy funkcjonować będzie w gęsto ustrukturalizowanym obszarze, a mniej pobudzona w obszarze rzadko ustrukturalizowanym. Na przykład obszarami gęsto ustrukturalizowanymi, a więc pobudzajacymi, będa środowiska zurbanizowane i stłoczone, natomiast obszarami rzadko ustrukturalizowanymi będą środowiska wiejskie i niestłoczone.

Zależność między zawartością informacyjną sytuacji a zachowaniem się jednostki w tej sytuacji przedstawia się nieco inaczej $\mathrm{z}$ punktu widzenia tzw. rytmów zachowania. Na zjawisko rytmów zachowania zwrócił uwagę m.in. Kendon, który zaobserwował, że jednostka reaguje ruchliwością na ruchliwość innej osoby. Zauważoną przez Kendona prawidłowość uogólnić można jako synchronizację aktywności jednostki z rytmicznymi zmianami w środowisku. Podniecająca, szybka i głośna muzyka, która oddziałuje na wzrost fizycznej aktywności słuchacza, stanowi dobry tego rodzaju przykład. Problem synchronii oddziaływań otoczenia i rytmów zachowania wiazze się ściśle z projektowaniem środowiskowym. Projektowanie środowiskowe rozmyślnie lub mimowolnie poddaje kontroli różne rytmy zachowania się lub różne stany emocjonalne. Na przykład załóżmy, że zbudowaliśmy autostradę składająca się z naprzemiennych betonowych segmentów różniących się odcieniami szarości. Efektem tego stanu rzeczy jest to, że kierowca w czasie prowadzeniá pojazdu podlega rytmicznym zmianom w wizualnym obrazie drogi. Długość danego segmentu, korespondująca z optymalnym zakresem pobudzenia, przez kogoś, kto prowadzi samochód z określona prędkościa, przyjmowana jest często za bezpośredni wskaźnik prędkości. $\mathrm{W}$ tym przypadku różnice indywidualne $\mathrm{w}$ pożądanym poziomie pobudzenia prowadziłyby do charakterystycznych różnic w prędkości

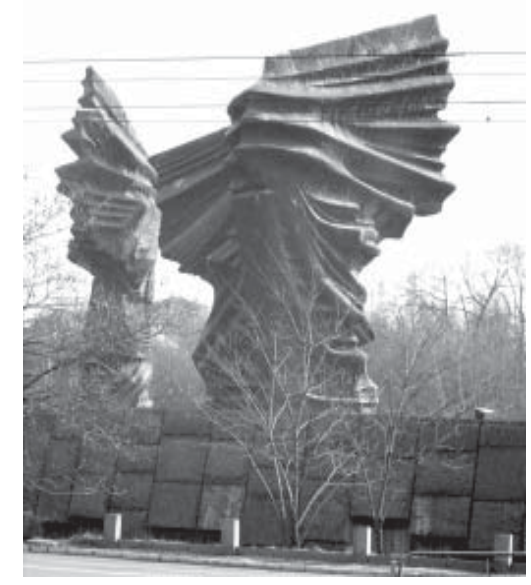

Zemła: Pomnik Powstańców Śląskich w Katowicach jest udanym przykładem uzyskiwania efektu monumentalizmu przez skrajne powiększenie detalu. Daje to nieoczekiwane efekty emocjonalne.

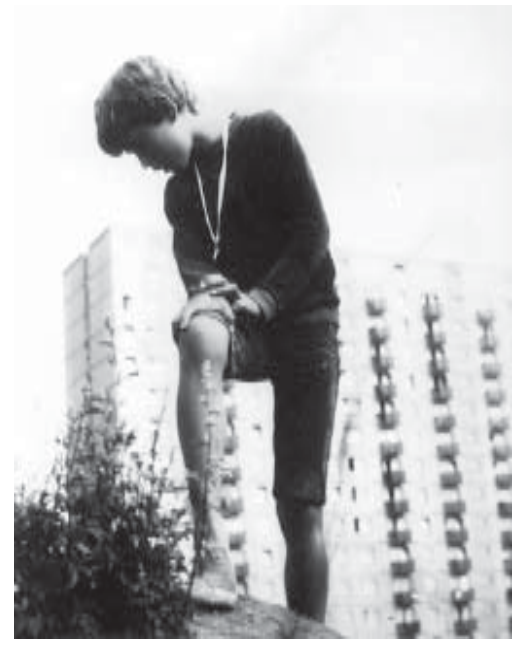

Problem optymalnej skali architektury musi być ujmowany przez pryzmat wybranego „metrum”. Jednym z nich jest skala dziecka.

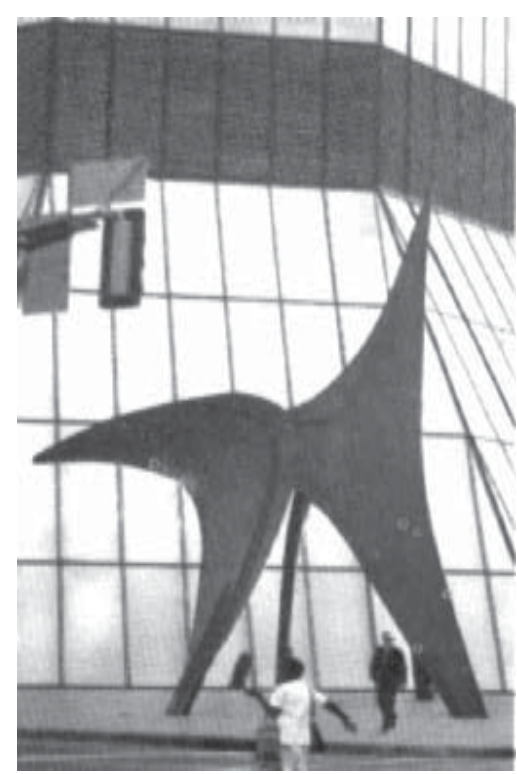

Colder: Stabile i Mobile. Z psychologicznego punktu widzenia różnią sięzawartością informacyjną konfiguracji bodźców dynamicznych. 

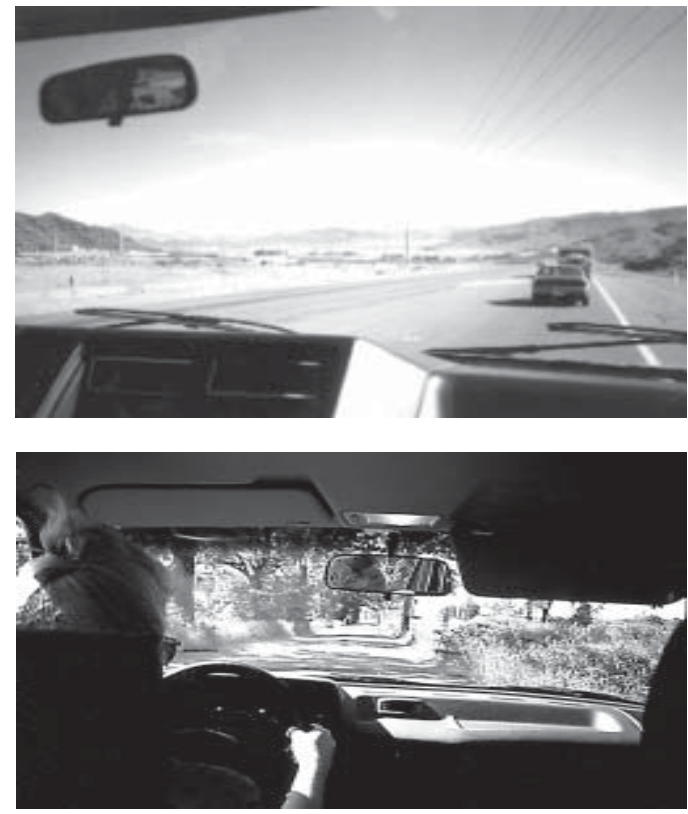

Wjechanie w aleję porośniętą drzewami drastycznie zwiększa zawartość informacyjną nawet do stopnia przeciażenia informacyjnego, co może być przyczyną wypadków drogowych. prowadzenia pojazdów, czemu towarzyszyłyby niepożądane konsekwencje, jak zwiększona wypadkowość.

R.G. Alen dokonał oceny różnych form architektonicznych w aspekcie synchronii ich oddziaływań na różne stany psychiczne człowieka. I tak według Alena napięcia psychiczne (nadmierne pobudzenie emocjonalne powiązane $\mathrm{z}$ silnym odczuciem nieprzyjemności - przypis własny) moga być spowodowane:

- kompozycją niestatyczną lub niewyważona,

- zastosowaniem dużych skal i krańcowych kontrastów

- wprowadzeniem kontrastowych kolorów i silne podkreślonych form narożnikowych,

- eksponowaniem nieznanych elementów w nieznanym otoczeniu.

Wrażenie relaksacji, tj. niewielkie pobudzenie połączone ze znaczna przyjemnościa, może być wywołane przez:

- wprowadzenie znanych i lubianych elementów (kwiaty, zieleń, akwaria),

- zachowanie porządku otoczenia i swobody poruszania się $\mathrm{w}$ przestrzeni,

- zastosowanie elementów w drobnej lub zrozumiałej skali

- niestosowanie silnych kontrastów, natomiast wprowadzenie miękkich, płynnych form przestrzeni, łagodnego światła i pokrewnych kolorów,

- stosowanie muzyki (miłych i łagodnych dźwięków),

- utrzymanie komfortowego mikroklimatu dla człowieka.

Odczucie zadowolenia z przebywania w danej przestrzeni można uzyskać przez:

- zastosowanie płynnych form,

- zestawienie dużych i małych form w skali zrozumiałej dla człowieka,

- wprowadzenie do wnętrza przestrzeni elementów ruchomych i zdynamizowanych,

- szerokie zastosowanie rytmów,

- projektowanie niektórych obiektów wyrażające pewne powszechnie zrozumiałe idee (np. ekspresjonizm, funkcjonalizm, symbolizm).

Stany lękowe (wysokie pobudzenie, niska przyjemność oraz wysokie odczucie submisji) mogą wywoływać:

- przestrzenie utworzone z elementów o niezrozumiałych wymiarach, sprawiających wrażenie niestabilnych, a latem niebezpiecznych,

- formy skomplikowane i przestrzenie typu labiryntu,

- zastosowanie niezrozumiałe wielkich skal i skrajnych kontrastów,

- projektowanie przestrzeni niedostatecznie oświetlonych lub oświetlonych światłem zimnym,

- skontrastowanie pomieszczeń słabo oświetlonych z olśniewająco jasnymi i podkreślonymi przestrzeniami,

- wprowadzenie gry rytmicznie przesuwających się cieni,

- nieprzyjemny zapach. 


\title{
CZĘŚĆ IV
}

\section{ARCHITEKTURA POZNAWCZEJ PRZESTRZENI ŻYCIA}

\section{ROZWÓJ PERCEPCJI PRZESTRZENI U CZŁOWIEKA}

\author{
Rola aktywności $w$ rozwoju percepcji przestrzennej
}

Rozwój percepcji przestrzeni wymaga od jednostki aktywności. Aktywność ta przejawia się już od chwili urodzenia i ma bardzo silny wpływ na percepcję przestrzeni w ciagu całego życia jednostki. Z badań wynika, że druga połowa pierwszego roku życia jest okresem gdy zaczyna się niezależność lokomocyjna. Dziecko ma już spore doświadczenia w koordynacji bodźców płynących z głowy, ręki i ruchów ciała. Do końca pierwszego roku życia dziecko jest zwykle bardzo czujne dotykowo. Ciagle porusza kończynami, zwłaszcza rękami i palcami, wykonując ruchy chwytające w przestrzeni dookoła swojego ciała.

Dzieci aktywne, bez względu na wiek, rozwijają lepszą wiedzę o przestrzeni tak znanej im, jak i nieznanej. Dzieci sześcioletnie, kierujące samodzielnie swoimi działaniami w przestrzeni, potrafiły lepiej szacować odległości, niż dzieci które były kierowane przez dorosłych trzymających je za rękę (Spencer et al., 1989). To jak dzieci spostrzegają zależności przestrzenne zależy też od celu, a więc od własnej aktywności. Informacja zależna od celu działania jest spostrzegana i zapamiętywana o wiele efektywniej niż w przypadku działań nie zorientowanych na cel. Niezależna lokomocja zachęca dzieci do rozwoju skuteczniejszych strategii poznawania przestrzeni i dostarcza im stałego strumienia bodźców i doświadczeń, z którego później można wyprowadzić zasady wnioskowania dotyczące przestrzeni. Zakłada się przy tym, że kluczową rolę mają tu doświadczenia wzrokowe.

Aktywne uczenie się przestrzeni daje bardziej adekwatną wiedzę niż pasywna obserwacja. W eksperymencie, w którym jedna grupa dzieci obserwowała model miasteczka z jego peryferiów, a druga mogła swobodnie przechodzić przez ten model, grupa aktywnie badająca miasteczko opisywała je o wiele lepiej, niż grupa obserwująca. Stwierdzono też, że poruszanie się w sposób aktywny zwiększa liczbę ciagle zmieniających się serii obrazów perspektywicznych.

Choć jednostki mogą uzyskiwać informacje o środowisku pośrednio - dzięki mapom, opisom, - to jednak źródłem najwartościowszych informacji o otaczajacej przestrzeni jest własne bezpośrednie doświadczenie. Osiaga się je w ruchu i aktywności. Uzyskuje się wtedy najpewniejszą wiedzę o świecie, o cechach przestrzeni i miejsc. Wiedza ta może być bardzo subiektywna, zależnie od predyspozycji osobistych i własnej aktywności. Poruszając się aktywnie w przestrzeni o wiele lepiej poznajemy tę przestrzeń i stabilizujemy nasz świat wizualny. Efektywne poruszanie się i aktywność w przestrzeni jest niezbędna dla zrozumienia środowiska i rozwoju wiedzy o przestrzeni. Dla dzieci widzaccych rozwój tej umiejętności gra główną rolę jako wskaźnik stopnia rozwoju. Nieruchome dziecko staje się nieruchomym dorosłym. Dzieci niewidzące mają skłonność do bycia mniej aktywnymi. Brak stymulacji wzrokowej blokuje motywację do poruszania się, szukania czegoś w przestrzeni, do spostrzegania świata dookoła. Przy poruszaniu się dzieci niewidome często zderzają się z różnymi przedmiotami i często się ranią. Dla większości dzieci są to bardzo frustrujące konsekwencje bycia aktywnym. Dzieci niewidzące zniechęcone do aktywności ruchowej, są opóźnione w uczeniu się sięgania po przedmioty wydające dźwięki. Niektóre z nich nigdy nie zdobywają tej umiejętności. Tak więc aktywne, samodzielne poruszanie się i badanie otoczenia jest dla nich jeszcze trudniejsze. 


\section{Percepcja własnego ciała jako poczqtek rozwoju percepcji przestrzeni}

Rozwój percepcji przestrzeni i orientacji w niej, jest procesem polegającym na swego rodzaju budowaniu przestrzeni począwszy od najbliższych obszarów ciała, przez przestrzeń dookoła ciała, a skończywszy na przestrzeniach szerszych, geograficznych. Percepcja przestrzeni własnego ciała jest więc najbardziej podstawowym stadium percepcji przestrzeni. Obraz własnego ciała powstaje zaraz po urodzeniu. Zaczątki wiedzy o sobie, jako o czymś odrębnym od otaczającej rzeczywistości, dziecko zdobywa przez odczuwanie własnego ciała. Obraz własnego ciała jest wytworem autopercepcji własnego organizmu, począwszy od okresu życia płodowego. Przed narodzinami dziecko doznaje różnego rodzaju wrażeń i ucisku i już w tym okresie uczy się odróżniać wrażenia przyjemne - przykre.

Doświadczanie własnego ciała ma początkowo charakter globalny. Dziecko odczuwa własne ciało jako strumień czy też ośrodek względnie przyjemnego lub przykrego podniecenia i aktywności Doświadcza siebie jako niezróżnicowanej mieszaniny dźwięków, obrazów czy dotyków. Stopniowo uczy się odróżniać bodźce, które płyną z własnego ciała od tych, które płyną z zewnątrz. Najwcześniejsze operacje różnicowania siebie samego od nie-siebie dokonują się za pomocą wrażeń dotykowych i kinestetycznych. Dziecko najpierw spostrzega siebie jako usta, czuje się ustami ponieważ są one najwrażliwsze w pierwszych miesiącach życia. Później stopniowo wzrasta wrażliwość rąk i nóg. Spostrzeganie własnego ciała w sposób systematyczny zaczyna się w czwartym lub piątym miesiącu życia dziecka. Dzieci obserwują swoje ręce, stopy, ciaggną się za włosy, nos, palce. Małe dziecko dobrze spostrzega własny brzuch i dolną cześć klatki piersiowej, przy czym dzieci chore bardziej interesują się swoim ciałem.

Pełne chodzenie
Pierwsze kroki
Wstawanie
Podnoszenie się
na klęczkach
Siadanie
Raczkowanie
Czołganie
Przewracanie się
z pleców na brzuch
Przewracanie się
z brzucha na plecy
Przewracanie się
z brzucha na bok

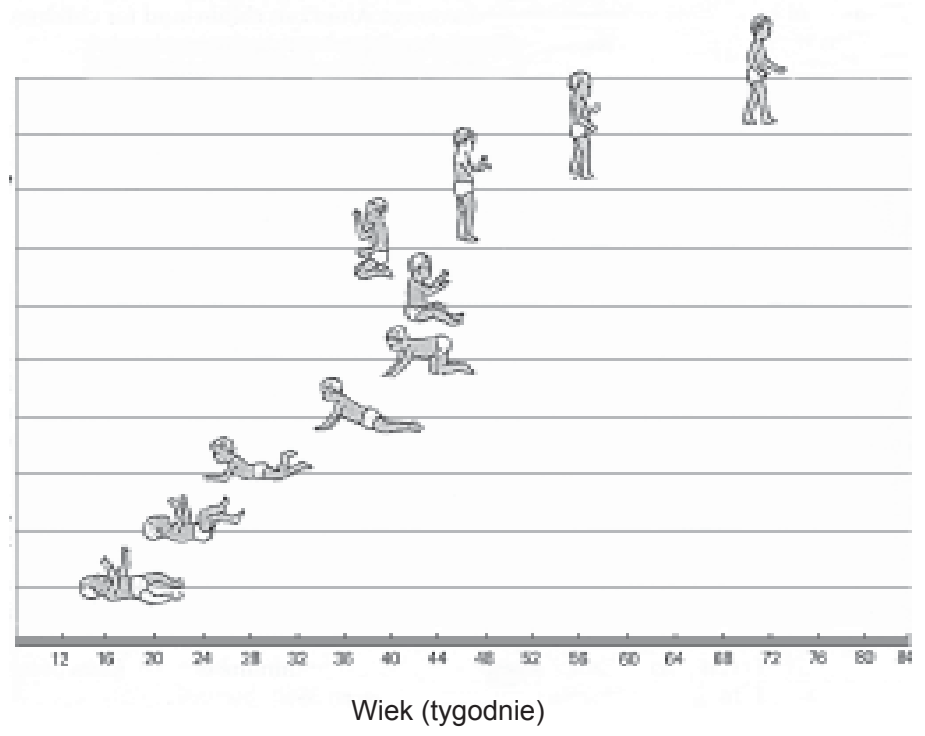

Rozwój zdolności motorycznej u dziecka

Gdy dziecko leży w absolutnym spokoju bez poruszania się, wtedy rozwija się u niego przestrzeń jedynie przestrzeń ciała (body space), ograniczona do jego wymiarów fizycznych. W najczystszej formie dotyczy to małych dzieci w sierocińcach, pozbawionych stałych relacji z opiekunem, jak też niewidomych od urodzenia. Przestrzeń ciała jest funkcjonalnie najbliższą przestrzenią. Obrazy przestrzenne sa tu ograniczone głównie do obrazów proprioceptywnych. Jedynymi wrażeniami dotykowymi są te, którymi odczuwany jest ciężar ciała stykającego się z podłożem. Pod wszystkimi innymi względami nie istnieje nic prócz „pustej przestrzeni bez wymiarów".

Na obraz własnego ciała wpływa też fakt, że ciało jest spostrzegane w zależności od jego reprezentacji w korze mózgowej, a dokładniej w ośrodkach motorycznych. Obraz własnego ciała jako czegoś przestrzennego tworzy się już w momencie, gdy dziecko skieruje swoją aktywność na siebie i zacznie tym samym uzyskiwać podstawy koordynacji pomiędzy ramionami oraz między okiem i ręką. Piaget (1956) stwierdził, że zmysł dotykowo-kinestetyczny jest bardzo ważny w percepcji przestrzeni ciała oraz w zrozumieniu przestrzeni pomiędzy jego ramionami. Spostrzeganie przestrzeni własnego ciała to złożony wzór sensoryczny, w dużej mierze zależny od wrażeń płynących ze skóry, mięśni i receptorów wewnętrznych. Obraz własnego ciała 
pełni następujące funkcje: 1 . dzieli ciało na płaszczyzny, dzięki czemu dziecko może określić przód, tył, boki, oraz położenie obiektów w stosunku do tych płaszczyzn; 2. pozwala identyfikować części ciała; 3. pozwala na koordynowanie ruchów ciała i kończyn; 4.wspomaga lateralizację tj. identyfikację strony prawej i lewej oraz umieszczanie obiektów na prawo, lewo; 5. umożliwia identyfikację elementów obiektów i innych ludzi.

Istnieje wyraźna zależność między percepcja przestrzeni własnego ciała i zaawansowaniem dziecka w poruszaniu się. Efektywność poruszania się zależy od adekwatnego obrazu własnego ciała. Niewłaściwy obraz ciała może być równie upośledzający jak brak takiego obrazu w ogóle.

\section{Percepcja przestrzeni bliskiej}

Do właściwego spostrzegania przedmiotów zdolne jest dopiero dziecko kilkumiesięczne, Dzięki sukcesywnemu ustawianiu kilku zmysłów na to samo źródło wrażeń. Przedmioty nie są spostrzegane od urodzenia, lecz tworzą się dopiero w psychice dziecka przez scalenie podniet zmysłowych, mających wspólne źródło w przedmiotach fizycznych. Scalenie to następuje na drodze aktywnej. Realizuje się ono w dążeniu do potwierdzenia i uzupełniania informacji przez inne receptory wrażeń odbieranych przez jeden receptor.

Bodźce działaja zwykle najpierw na telereceptory (wzrok i słuch) a dopiero wtórnie na receptory kontaktowe. Podrażnienie jednego z narządów zmysłów wywołuje ogólny niepokój oraz nastawienie innych narządów zmysłowych w kierunku pierwotnego źródła bodźców. Istnieje współzależność wzroku i dotyku funkcje chwytne dzieci w wieku ok. 5 miesięcy za pomocą wyświetlanych cieni. Koordynacja gałek ocznych pod wpływem bodźców świetlnych zaczyna się już u kilkudniowego noworodka. Wykazuje on wrażliwość na bodźce wzrokowe, początkowo tylko na duże i jasne poruszające się przedmioty, za którymi wodzi oczami. Reakcje na bodźce wzrokowe w przypadku kształtów, w pierwszych dwóch miesiącach życia wydają się być niezależne od jakości kształtu. Dopiero konwergencja gałek ocznych, umożliwia odbieranie bardziej wyraźnego obrazu kształtów na siatkówce.

Przestrzeń wizualna niemowlęcia nie ma jednak struktury ani trwałości. Przedmioty są w niej impresjami - Istnieją tak długo, jak długo pozostają w polu widzenia. To samo dotyczy kształtów i rozmiarów przedmiotów - przedmiot oddalony to zupełnie inny przedmiot niż gdy się go przybliży. Niemowlę ma wrodzona zdolność do dość ogólnego rozpoznawania trójwymiarowości przedmiotów i kształtów. Może też czasami odróżnić przedmioty dalsze od bliższych lecz tylko w swoim najbliższym otoczeniu. Pierwszym otoczeniem rozpoznawalnym przez dziecko są rodzice. Według Piageta (1954) dorośli są konieczni po to, aby dziecko mogło rozwinać poczucie obiektywnego świata. Zaczynają zdobywać poczucie odległości dzięki potrzebie rozpoznania gdzie znajduje się dorosły. To samo dotyczy zdobywania poczucia kierunku. Dzieci trzymiesięczne są w stanie rozpoznawać twarz matki a nieco starsze odróżniają twarze matki od obcych. Dziecku wystarczy obejrzeć dany obiekt by stwierdzić czy jest mu znany. Nowe obiekty trzeba ponadto sprawdzić dotykiem. Mimo to telereceptory odgrywają coraz większą rolę.

Raczkujące niemowlę potrafi już rozpoznawać przestrzeń. Potwierdzają to eksperymenty Gibsona (1960) z tzw. „urwiskiem wizualnym” (visual cliff). Raczkującemu dziecku przestrzeń horyzontalna wydaje się bezpieczna. Ma świadomość tylko jednego rodzaju niebezpieczeństwa w otoczeniu fizycznym tj. pochyłości. Jego oczy reagują na oznaki gwałtownych zmian wysokości terenu. Rozwój spostrzeżeń zaczyna coraz bardziej polegać na coraz precyzyjniejszej i coraz bardziej złożonej strukturze podniet kompleksowo działających na zmysły. Rozwój spostrzeżeń a zwłaszcza percepcji kształtów dokonuje się dzięki częstszej eksploracji rozmaitych bodźców i ich układów poprzez wzrokowe przeszukiwanie pola widzenia (scanning) oraz przez manipulację. Zakres informacji poszerza się w miarę tego, jak dziecko w sposób bardziej ukierunkowany eksploruje przestrzeń dookoła. Uwaga jednak samorzutnie przechodzi z obiektu na obiekt. Dziecko interesuje się tylko czymś bardzo blisko lub bardzo dalekim, natomiast to, co jest „pośrodku” interesuje je w bardzo małym stopniu. Takie opozycje przestrzenne wyraźnie pojawiają się w wieku dwóch, trzech lat. Sa to: daleko-blisko, na-pod, przód-tył, wierzch-spód itd. Na ogół rozróżnienia te sprowadzają się do prostego „tu” i „tam” (Tuan 1977). W okresie przedszkolnym następuje wzrost ostrości wzroku. Poza tym cecha przedmiotu, która zostanie nazwana staje się cechą wyróżniającą. Następuje więc wyodrębnienie przedmiotu z tła. Dziecko zaczyna też poprawnie oceniać wielkości przedmiotów niezbyt oddalonych, pod warunkiem, że są nieruchome. Zadziwiająco dobrze potrafi też rozpoznawać zdjęcia lotnicze i pokazane na nich obszary. Jest to prawdopodobnie spowodowane tym, że takie obrazy nie wymagaja gry wyobraźni i rozpatrywania perspektywy, która wymaga z kolei odrzucenia egocentrycznego punktu widzenia (Tuan, 1977). 
Dotychczas omówione mechanizmy rozwoju percepcji przestrzeni odnoszą się do pojęcia rozwoju jako zmiany postępowej. Istnieje jednak alternatywne podejście do rozwoju, zakładające jakościową zmianę w strukturze organizmu. To, co bardziej rozwinięte jest bardziej zrównoważone, logiczne i hierarchicznie zintegrowane. Ale w tym drugim znaczeniu, rozwój percepcji przestrzeni, jako jakościowe zmiany w życiu człowieka, obejmuje, oprócz bardziej rozwiniętych i zróżnicowanych możliwości zachowania, również stadia charakterystyczne dla niższych poziomów rozwoju.

Zgodnie z twierdzeniami J. Piageta podstawową siłą napędową rozwoju człowieka, w tym również poznania przestrzennego, jest adaptacja, czyli rozwój inteligencji. Obejmuje ona rozwój od niższych do wyższych modeli funkcjonalnych. Proces adaptacji, rozwoju inteligencji, zaczyna się od funkcjonowania na poziomie biologicznym i odruchowym, poprzez orientację na podstawie informacji płynaccych z działania i operowania przedmiotami, a kończy się funkcjonowaniem pojęć (abstrakcji) i symboli. Adaptacja jest równowagą między

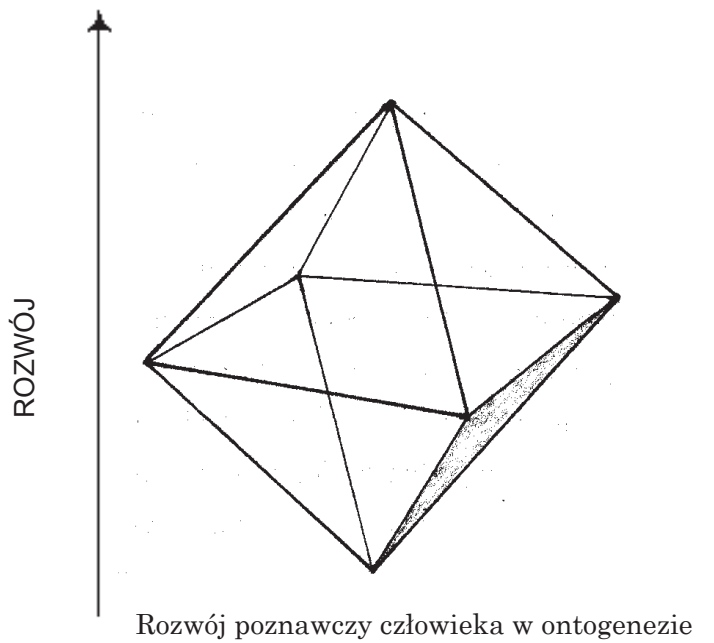
asymilacja, czyli włączaniem zewnętrznego świata do schematów poznawczych, a akomodacją czyli przystosowaniem tych schematów poznawczych do asymilacji. Tego rodzaju aktywne funkcjonowanie jest budowania wszechstronnej wiedzy o środowisku.

Inteligencja jest asymilacją w tym sensie, że jako struktura obejmuje wszystkie informacje nabywane w doświadczeniu. Inaczej mówiąc, inteligencja jest ustrukturyzowana inkorporacją zewnętrznej rzeczywistości wskutek podmiotowej aktywności. Tak, jak rzeczywistość jest asymilowana do życia umysłowego, tak to ostatnie jest akomodowane (przystosowywane) do środowiska. Inteligencja generalnie, a struktury poznawcze przestrzeni życiowej człowieka w szczególności, nie są więc strukturą wrodzona, biologicznie zaprogramowana, ani też nie powstają wskutek bombardowania pasywnej psychiki człowieka, czyli jego tabula rasy. Na podstawie intensywnych badań Piageta i jego współpracowników wiemy już, że dziecko od narodzin obdarzone jest intelektualna zdolnością do adaptacji i pewnym zakresem wrodzonych elemntarnych odruchów, ale nie gotowymi schematami widzenia złożonego świata i przestrzeni. Bardziej złożone struktury, w tym mentalne obrazy przestrzeni, powstają na bazie podstawowych, wrodzonych odruchów sensomotorycznych. Proces konstruowania w przestrzeni umysłowej (poznawczej) pojęcia przestrzeni jest procesem długim i złożonym. Przede wszystkim jest to proces konstrukcyjny, w którym oprócz sfery zmysłowej bardzo ważne znaczenie odgrywa świadomość.

W rozwoju i w konstruowaniu pojęcia przestrzeni wyróżnić można sześć podstawowych prawidłowości. Po pierwsze, mentalna reprezentacja (konstrukcja) przestrzeni jest poprzedzona reprezentacja przedmiotów w postaci tzw. „koncepcji przedmiotu” lub „stałości istnienia obiektu”. Reprezentacja mentalna oto-

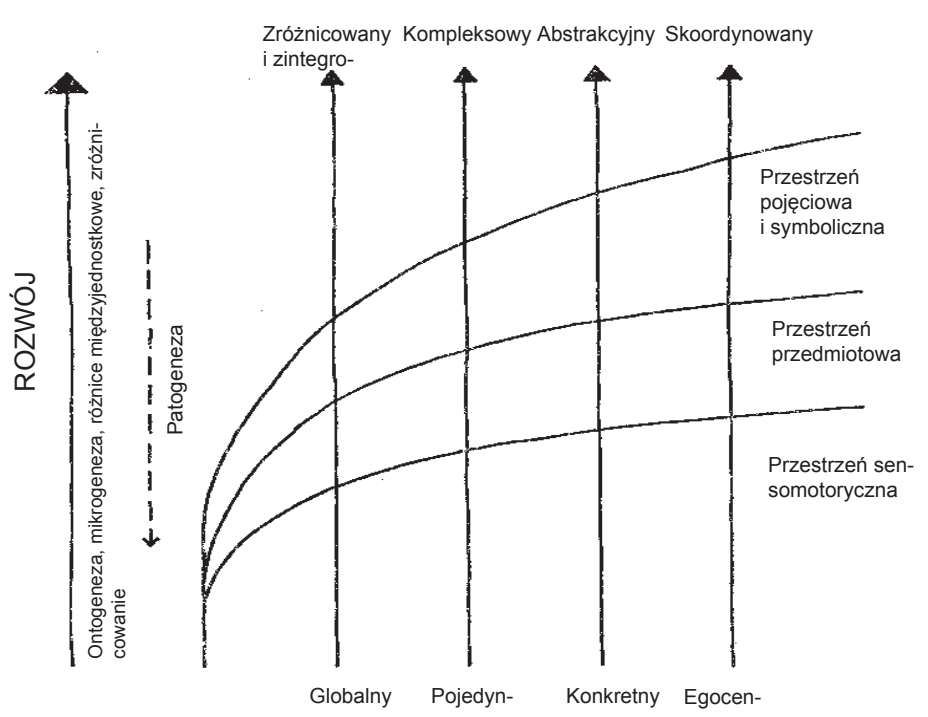
czenia dziecka przewyższa stymulację zarówno dotykowa, jak i percepcyjna. W umyśle dziecka przedmioty kontynuuja swoją egzystencję nawet wtedy, gdy są czasowo niewidoczne. Po drugie, reprezentacja przestrzeni powstaje poprzez koordynacje i internalizacje dziatań. Rozumienie przestrzeni i interpretacja przestrzeni wynikaja z zewnętrznej manipulacji przedmiotami i z poruszania się $\mathrm{w}$ przestrzeni, a także raczej z obserwacji wyników tych działań i ruchów niż z „odczytywania” lub „kopiowania” środowiska. Po trzecie, reprezentacja przestrzeni jest konstruowana w umyśle człowieka wskutek internalizacji (uwewnętrznienia, przyswojenia,

Dymensje rozwoju poznawczego pokazujace główne typy analiz rozwojowych i progresji: sensomotorycznych, przedmiotowych i pojęciowych przestrzeni. 
uznania za własne, a więc uświadomienia sobie) senseomotorycznych przeksztatceń i przemieszczeń przestrzennych. W stadium czwartym wyobrażenia przestrzenne wywodza się z intermalizacji odroczonych imitacji działań $\mathrm{w}$ przestrzeni. Jjednostka wykonuje pewną czynność po upływie czasu, natomiast nie imituje jej bezpośrednio. Na przykład gesty i czynności osób dorosłych, dziecko powtarza dopiero po pewnym czasie. $\mathrm{W}$ tej genezie pojęcia przestrzeni istnieje zatem wyobrażeniowa reprezentacja zjawiska rzeczywistego w postaci obrazu umysłowego. Po piąte, istnieją cztery podstawowe poziomy lub struktury poznania przestrzennego: a) sensomotoryczny (czyli reprezentacja umysłowa przestrzeni kształtowana poprzez działanie); b) przedoperacyjny (intuicyjne, nieskoordynowane wyobrażenia świata przestrzennego opierajace się na pamięci uprzednio spostrzeganych przedmiotów i manipulacji nimi); c) operacji konkretnych (opartych na konkretnych i symbolicznych przedmiotach, obejmujace systematyczne i odwracalne operacje poznawcze); d) operacji formalnych (abstrakcyjnych pojęć przestrzennych, niezależnych od realnych działan, realnych przedmiotów i realnych przestrzeni).

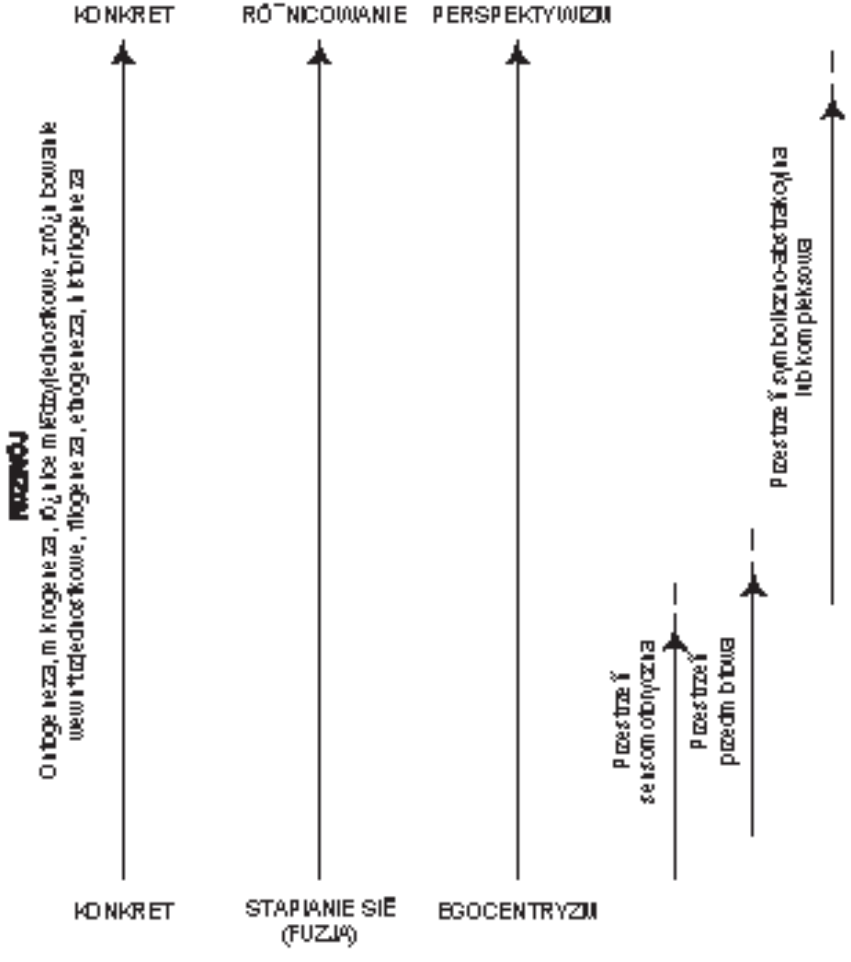

Wymiary rozwoju poznawczego i przestrzennego.

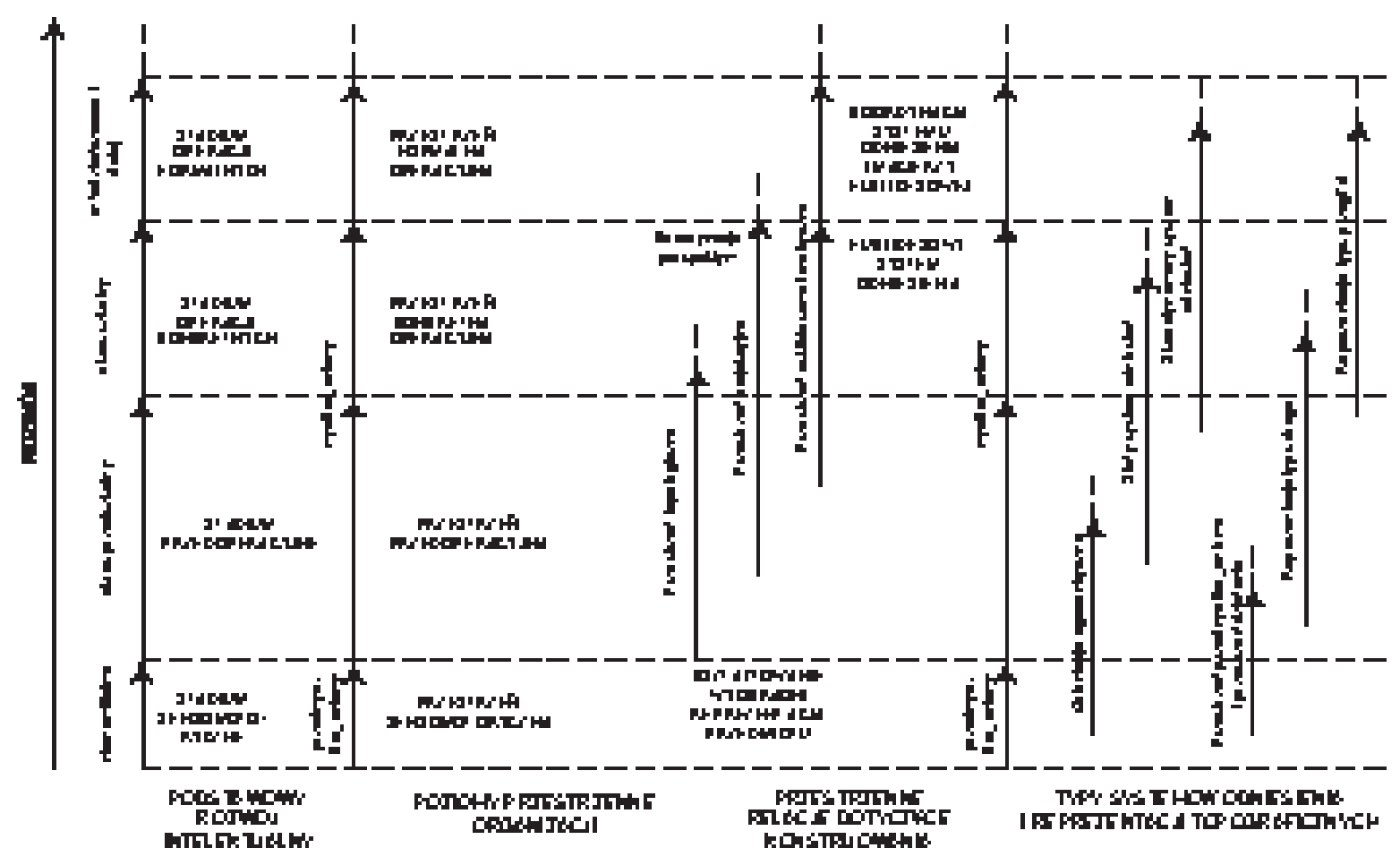

Sumaryczne przedstawienie sposobów konstruowania podstawowych pojęć przestrzennych w trakcie rozwoju psychicznego. Lewa strona wykresu pokazuje trzy główne wymiary rozwoju, według których można analizować poznanie środowiskowe. Następne trzy kolumny podsumowuja obserwacje Piageta oraz innych psychologów dotyczace rozwoju pojęcia przestrzeni w relacji do podstawowego nurtu rozwoju poznawczego. Kolumna wysunięta najbardziej na prawo pokazuje kilka hipotez dotyczących mentalnych mechanizmów orientacji przestrzennej w codziennym środowisku życia. 
Po szóste, istnieją trzy sekwencyjne klasy relacji przestrzennych: 1) Klasa relacji skonstruowanych topologicznie. Jest to stadium intuicyjne; dziecko może brać pod uwagę to, że niektóre obiekty są „bliżej lub dalej” od siebie. Te właściwości spostrzegania sa nieodłączne od konkretnego obiektu, nie ma tu jednak lokalizacji według perspektywy. W tym stadium dziecko nie pojmuje map gdyż nie odpowiadają one jego rozumieniu przestrzeni i świata. Stosunki między obiektami przestrzennymi mają charakter jakościowy, oparty na bliskości lub rozdzielności. 2) Klasa relacji konstruowanch projekcyjnie. Jest to stadium rozwojowe, w którym dziecko spostrzega część zależności przestrzennych. Widać tendencję do lokalizowania obiektów lub elementów z punktu widzenia obserwatora. Relacje między obiektami ustanowione są w terminach determinowanych przez poszczególne pesrpektywy lub punkty odniesienia (widzenia), takie jak linie proste lub trójkaty. 3) Klasa relacji euklidesowych lub metrycznych. Jest to stadium metryczne (euklidesowe) - dziecko potrafi odtworzyć model przestrzenny z właściwymi odległościami pomiędzy cechami charakterystycznymi. Obiekty są koordynowane względem siebie w odniesieniu do stabilnej struktury „koordynatów" przestrzennych (systemów odniesienia). W systemie osi lub wzajemnie skoordynowanych równych interwałów, trójkątów i metrycznych dystansów konstruowany jest model rzeczywistości przestrzennej.

\section{Rozwój reprezentacji przestrzennych jako przejaw spostrzegania środowiska dużej skali}

Podstawową funkcją reprezentacji przestrzennych jest ułatwienie procesu umiejscawiania obiektów i siebie, oraz ułatwianie nawigacji na dużym obszarze geograficznym. Drugą ważną funkcja jest działanie jako organizatora doświadczeń. Dostarczają one ram odniesienia, w których informacje nieprzestrzenne moga zostać włączone do systemu wiedzy i zinterpretowane (Lynch, 1960). Najmniejszymi elementami reprezentacji przestrzennych są punkty orientacyjne (landmarks) i drogi (routes). Punkty orientacyjne sa unikalnymi konfiguracjami zdarzeń percepcyjnych, które identyfikują specyficzne położenie przestrzenne. Są one strategicznymi punktami ogniskowymi, do których ludzie kierują się, lub z których wyruszają. Na ogół identyfikują one początki, choć służą też do utrzymywania kierunku. Drogi z kolei, można określić jako różne procedury sensomotoryczne, w związku z którymi idacy ma pewne oczekiwania co do punktów orientacyjnych. Drogi są często charakteryzowane przez ich punkty końcowe, które są punktami orientacyjnymi. Wiedza o drogach jest do pewnego stopnia wiedza sekwencyjna. Drogi kształtuja reprezentacje przestrzenne o tyle, o ile reprezentują zwyczajowe linie po których się poruszamy. Tworzą one „odtwarzalną reprezentację terenu poruszania się".

Można więc wyobrazić sobie środowisko jako przestrzeń złożoną z potencjalnych punktów orientacyjnych połączonych potencjalnymi drogami. Wiedza o konfiguracjach punktów orientacyjnych i dróg to trzeci, wyższy element reprezentacji przestrzennych. Wiedza ta daje coś więcej niż zwykłą konfigurację. Jest to element wyższego rzędu, który daje jego posiadaczowi pewną przewagę nad osobą orientującą się jedynie na podstawie punktów i dróg w znajdywaniu celu i organizowaniu doświadczenia przestrzennego. Przykładem tych reprezentacji sa: a) zarysy, jak np. reprezentacja granicy państwa; b) szkielety graficzne, jak diagramy linii autobusowych miasta czy metafory figuratywne typu „but włoski”. Takie prezentacje zostaja wyprowadzone z bardzo zagęszczonych, bogatych w połączenia, hierarchicznie zorganizowanych mentalnych struktur poznawczych. Reprezentacje przestrzenne są istniejącymi w umyśle konstrukcjami symbolicznymi i odtwarzalnymi, powstałymi z percepcji przestrzeni i aktywności.

Według Piageta i Inhelder (1956) wiedza o przestrzeni konstruowana jest na trzech poziomach: $1 . \mathrm{Na}$ poziomie działania przestrzennego i jest to etap rozwoju operacyjnie oraz hierarchicznie skoordynowanego systemu informacyjnego; 2. Na poziomie percepcji przestrzeni i jest to etap rozwoju zróżnicowanego oraz częściowo skoordynowanego systemu informacyjnego; 3. Na poziomie pojęciowego rozpracowania przestrzeni i jest to poziom skoordynowanego oraz hierarchicznie zintegrowanego systemu informacyjnego. Te trzy poziomy i etapy rozumienia przestrzeni są związane z głównymi etapami ogólnego rozwoju intelektualnego i współistnieją w dorosłości. Mówiąc prościej, przejście na wyższy poziom rozwoju intelektualnego oznacza przejście na wyższy poziom percepcji i konceptualizacji przestrzeni, ale z zachowaniem funkcjonalności schematów widzenia i rozumowania przestrzennego, które są charakterystyczne dla wcześniejszych etapów rozwoju.

Poziom pierwszy, czyli egocentryczny system informacyjny, polega na tym, że elementy zawarte w wyobrażeniach dzieci i dorosłych ograniczone sa jedynie do tych aspektów przestrzeni, które mają największe znaczenie osobiste. Mając do czynienia z droga, dzieci najpierw ustalają plan działania (ruchów), a dopiero 
później punkty orientacyjne w przestrzeni odnoszące się do tych działań. Dzieci na tym etapie rozwoju orientują się w sposób praktyczny i odgaduja relacje przestrzenne między punktami oraz elementami podczas podchodzenia do nich, ale nie organizująich $\mathrm{w}$ przestrzenną całość. Pozycje są lokalizowane głównie przez egocentryczne, ciagłe i topologiczne relacje bliskości, porządku, otoczenia oraz ogrodzenia bez zwracania uwagi na relacje lewo - prawo, przed i za czy odległości.

$\mathrm{Na}$ poziomie rozwoju zróżnicowanego i częściowo skoordynowanego osoba organizuje przestrzeń w formie „zlepek” nie powiązanych elementów i ich podgrup. Powiązania występuja jedynie między elementami wewnątrz grup. Wewnętrzna organizacja grup elementów jest często oparta na podobieństwach funkcjonalnych i topologicznym sasiedztwie, na użyciu relacji rzutu i czasami odległości stosunkowej. Każda grupa budowana jest w umyśle dziecka czy dorosłego ze szczególnego, dogodnego i subiektywnego punktu. Plany
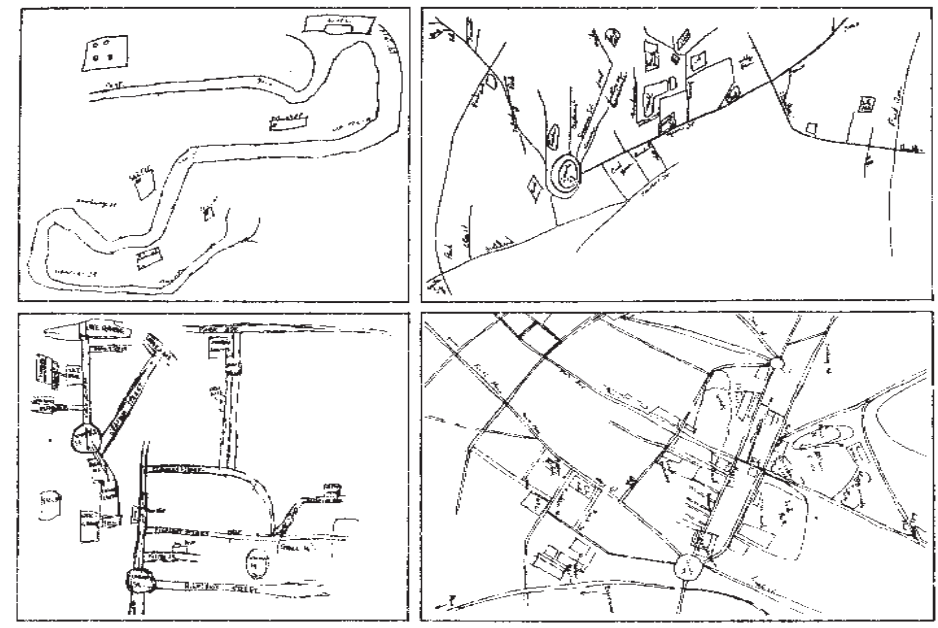

Przykłady rozwoju trzech podstawowych poziomów konstruowania poznawczego (mapowania) przestrzeni. Lewy górny przedstawia poziom I, egocentryczny niezróżnicowany. Prawy górny przedstawia poziom II, częściowo skoordynowany wg podgrup stałego liniowo-drogowego systemu odniesienia. Lewy dolny przedstawia poziom II, częściowo i punktowo-radialnie skoordynowanego systemu odniesienia. Prawy dolny przedstawia poziom III, operacyjnie skoordynowanych i hierarchiczni zintegrowanych elementów systemu odniesienia. takie częściowo nie są ze sobą powiązane, ponieważ człowiek nie jest w stanie zapełnić luki pomiędzy „zlepkami” lub skoordynować swobodnie dobrane punkty widzenia. Nie istnieje system, który mógłby połączyć te grupy. Na poziomie pośrednim różne grupy są organizowane w jeden lub więcej stałych typów odniesień: 1) Stałego odniesienia punktowo-promieniowego, jak np. lotniska, głównej ulicy, boiska, śmietnika, skrzyżowania. W tym przypadku przestrzeń rozchodzi się we wszystkich kierunkach promieniście. 2) Stałego odniesienia drogowo-liniowego, jakimi są w większości przypadków arterie komunikacyjne, rzeki, ścieżki rowerowe. W tym przypadku przestrzeń jest ograniczona dwoma punktami końcowymi. 3) Stałego odniesienia powietrzno-przestrzennego, jakim jest np. główna dzielnica biznesu czy handlu, teren mieszkalny, teren rekreacyjny. W tym przypadku przestrzeń jest mniej zróżnicowana i często składa się ze strefowych lub sąsiednich części rozmieszczonych topologicznie.

$\mathrm{Na}$ poziomie operacyjnie skoordynowanym i hierarchicznie zintegrowanym system informacyjny dotyczący przestrzeni jest konstruowany na podstawie koordynacji lewo-prawo i przed-za różnych punktów widzenia oraz stosunków odległości. Koordynacja na tym poziomie nie zależy od działań własnych podmiotu. Osoba funkcjonujacca na tym poziomie rozwoju percepcji przestrzeni opisuje działania i ruchy w kategoriach usystematyzowanego, abstrakcyjnego systemu informacyjnego, a nie w kategoriach konkretnych poczynań. Systemy uporządkowane są łączone w hierarchiczne całości. Dodawanie nowej podgrupy przestrzennej do modelu lub rysunku nie powoduje straty czasu na dopasowanie różnych części. Powstanie abstrakcyjnej struktury i pojęciowego systemu przestrzennego pozwala na systematyczne transformacje poznawcze $\mathrm{w}$ wyobrażeniu. $\mathrm{Na}$ tym poziomie rozwoju wyobraźni przestrzennej podmiot buduje poznawczo środowisko w kategoriach pojedynczego, obszernego i abstrakcyjnego systemu informacyjnego, niezależnego od personalnej skali ważności i personalnie ustalonych odniesień. Różnorodne punkty orientacyjne oraz grupy przestrzenne moga być co prawda dalej indywidualizowane wg subiektywnego punktu, ale ich integracja generalnie przebiega wg obiektywnego charakteru i obiektywnego umiejscowienia elementów przestrzennych.
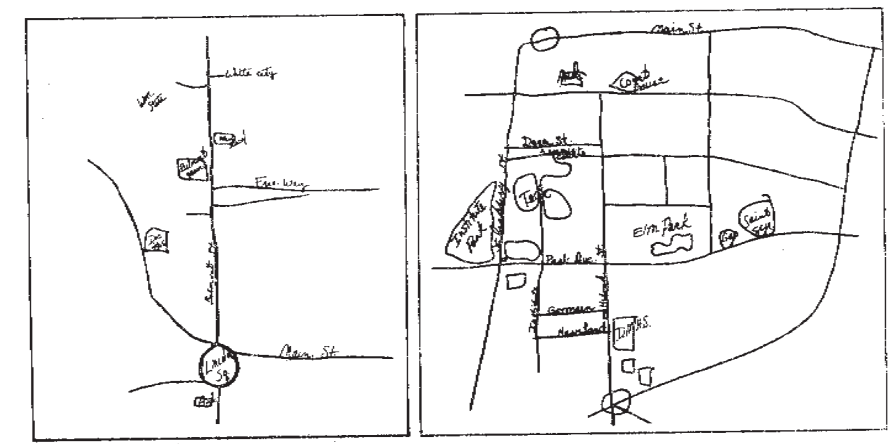

Przykłady dwóch szkiców wykonanych przez tę samą dorosłą osobę, obrazujące dwa różne osiedla mieszkaniowe. Szkic po lewej stronie odwzorowuje przestrzeń mało znana podmiotowi i oddaną w związu z tym w systemie informacyjnym częściowo skoordynowanym (poziom II). Szkic po prawej stronie odwzorowuje przestrzeń dobrze znaną w systemie informacyjnym operacyjnie skoordynowanym (poziom III). 


\title{
WZROKOWE SPOSTRZEGANIE PRZESTRZENI
}

\author{
Rola zmystu wzroku w spostrzeganiu przestrzeni
}

Nasze życie przebiega w świecie rzeczy i ludzi. Kanałami informacji o świecie są zmysły, z których czucie wzrokowe, słuchowe i skórne odgrywają największą rolę w orientacji przestrzennej. Obdarzone są one, co prawda w niejednakowym stopniu, elementarną cechą rozciagłości, czy rozległości, która jest tylko rozległa, bez określonego kształtu, bez rozpoznanej wielkości, bez stosunków do jakichkolwiek innych rozciagłości, nie będąca ani blisko ani daleko. Najlepiej ją sobie przedstawić zamknąwszy oczy i obserwując ciemne pole widzenia: mamy tu jaką́s czarna, czy też ciemno czerwoną rozciagłość, która nie ma ani wielkości określonej, ani kształtu, ani nie leży na zewnątrz w przestrzeni. Ta elementarna cecha rozciagłości jest podstawa, na której opierają się wszelkie postacie świadomości przestrzeni bez względu na ich subtelność i wyra-finowanie.

Wszelkie doznania związane z przedmiotami lub zdarzeniami występują w czasie i przestrzeni. Wzrok jest naszym głównym zmysłem przestrzennym, który daje nam urozmaicone układy kształtów i barw w trzech wymiarach, lecz jest on także zmysłem czasu, ponieważ widzimy następstwo, ruch i zmianę. Spośród trzech wymienionych na wstępie zmysłów decydujących o percepcji przestrzeni zmysł wzroku obdarzony jest w największym stopniu cechą rozciagłości pierwotnej. Słuch jest zmysłem przestrzennym, ale w stopniu o wiele bardziej ograniczonym niż wzrok. Jest to przede wszystkim zmysł czasu, ponieważ podstawowymi układami w jego przypadku są układy następstwa, zmiany i rytmu. Ze względu na pierwszoplanową rolę wzroku, jako zmysłu przestrzennego, rozważania nad spostrzeganiem przestrzennym przebiegać będą w kategoriach spostrzegania wzrokowego.

Wzrok jest zmysłem, który rozwiną się na końcu i jest najbardziej złożony. Przez oczy napływa danych znacznie więcej i szybciej niż przez jakikolwiek inny moduł sensoryczny. Percepcja wzrokowa pozwala wg Gibsona (1966) na trzy ważne rzeczy: wykrywanie układu otoczenia, wykrywanie zmian i sekwencji, wykrywanie i kontroli ruchu. Wzrok dostarcza najbardziej oczywistych i najbogatszych informacji percepcyjnych. System wzrokowy jako typowy system przestrzenny jest lepiej przystosowany do percepcji przestrzeni niż jakikolwiek inny system sensoryczny, toteż widzenie jest istotne dla każdego rodzaju pojmowania przestrzeni. Wzrok dominuje przy normalnej widzialności a w przypadku widzialności ograniczonej lub jej braku, pozwala tworzyć wyobrażenia pozycji ciała i jego położenia w stosunku do środowiska. Gdy osoba o normalnym wzroku odbiera jakiekolwiek bodźce, ale rozproszone bądź nieokreślone, to zaczyna szukać źródła tych bodźców. Nawet ci, którzy stracili wzrok robia to jeszcze nawykowo przez długi czas.

Podstawową zaletą wzroku jest zdolność do odbierania świata trójwymiarowo. Wskaźnik głębi jest układem pobudzenia proksymalnego, który może przenosić informację co do przestrzennej lokalizacji odległych przedmiotów. Dzięki takim wskaźnikom przedmioty sprawiją wrażenie ustawionych przestrzennie. Zgodnie z definicją każdy wskaźnik jest dwuwymiarowy obrazem przedmiotu trójwymiarowego. Obecnie narasta tendencja do traktowania głębi nie jako konstrukcji wrażeń, ale jako jeden z wymiarów doświadczenia wzrokowego.

Według Gibsona (1952) istnieje trzynaście „perspektywicznych” wrażeń wizualnych, którym towarzyszy spostrzeganie głębi ponad ciagła płaszczyzna.. I. Perspektywa stacjonarna: 1) faktury, 2) rozmiaru, 3) linearna; II. Perspektywa paralaksy: 4) lornetkowa, 5) ruchu, III. Perspektywa niezależna od pozycji i ruchów osoby patrzaccej: 6) powietrzna, 7) zamazana, 8), relatywna górna lokacja w polu widzenia, 9) faktury, 10) zmiany w rozdwojeniu obrazów, 11) zmiany szybkości ruchów, 12) ciąłości zarysu, 13) związku między światłem a kształtem.

\section{Stałość spostrzegania}

Spostrzeganie otaczającej człowieka przestrzeni nastawione jest na przedmioty, a nie na jakości zmysłowe, które określają te przedmioty. Poszczególne jakości zmysłowe („niebieskość”, „czerwoność”) mogą być spostrzegane, lecz zwykle spostrzega się je jako cechy przedmiotów. Widzimy zatem żółte kwiaty, miękki fotel, goraccy grzejnik, a nie „żółtość”, „miękkość” lub „gorącość”. 
Gdy pewien przedmiot został poznany jako rzecz trwała i stała, spostrzegamy go takim niezależnie od oświetlenia i położenia, w jakim go widzimy, i w odległości, w jakiej się pojawia. Postrzeganie przedmiotu w jego normalnej barwie, niezależnie od światła czy mroku, nosi nazwę stałość jasności barwy. Postrzeganie go w jego normalnym kształcie, niezależnie od kąta widzenia, nazywa się stałościa ksztattu. Tendencja, aby widzieć go w jego zwykłych rozmiarach, bez względu na odległość, nazywa się stałościq wielkości. Wreszcie zachowywanie przez przedmioty „tego samego” położenia, nawet gdy jesteśmy w ruchu, znane jest jako stałość położenia.

Stałość jasności barwy określa fakt, że czarna elewacja budynku wydaje się równie czarna w jasnym świetle słońca, jak i w cieniu. Postrzeganie stałości jasność i barwy nie jest doskonałe. Przedmioty moga nieco ciemnieć, gdy oświetlenie się zmniejsza. Podobnie można spostrzegać kolorowe przedmioty, które zachowuja swe oryginalne barwy nie tylko przy zmianach jasności oświetlenia, lecz nawet wtedy, gdy oświetlamy je kolorowym światłem, pod warunkiem, że występują odpowiednie kontrasty i cienie. Istnieją jednakże poważne ograniczenia stałości barwy przy kolorowym oświetleniu ponieważ różne barwniki w różny sposób pochłaniają kolorowe światło. Na przykład w białym świetle, złożonym jedynie z czerwonego i niebieskozielonego, żółty przedmiot może wydawać się czerwony, a zielony - szary. Odchylenia od stałości barwy związane są również ze zjawiskiem obrazu następczego: kontrastu barwy. Gdy będziemy się wpatrywali w czerwone koło, a następnie spojrzymy na jasnoszary prostokąt, to prawdopodobnie zobaczymy na nim zielone koło, doznanie to nosi nazwę negatywnego obrazu następczego, ponieważ zieleń jest barwa dopełniająca. Pary barw dopełniających się występują także w kontraście wspótczesnym. Cień rzucany przez chromatyczne światło ma powierzchnię słabo oświetloną światłem achromatycznym, ma żywe zabarwienie w kolorze dopełniającym do barwy światła chromatycznego. Kontrast uwydatnia granice między barwami dopełniającymi, jest to jedna z przyczyn, że flagi sygnalizacyjne wykonuje się z takich par barw dopełniających, jak czerwony i zielony, żółty i niebieski. Na koniec, w pewnych warunkach występuje zjawisko zwane dyfuzja barw. W tym przypadku powierzchnie ciemne powoduja, że sąsiadujące z nimi części wydaja się ciemniejsze, natomiast jasne powierzchnie rozjaśniają sąsiadujące obszary.

Stałość kształtu oznacza zjawisko spostrzegania takiego samego kształtu przedmiotu niezależnie od tego, czy patrzymy na niego z boku, czy z góry. Zniekształcenia, które występuja, kiedy znany przedmiot obraca się, służą raczej jako sygnały jego obrotu, a nie zmian zachodzących w samym przedmiocie. Ilustrację tej zasady stanowią obroty okna w kształcie trapezu przedstawionego na rysunku. Powodem złudzenia jest fakt, że widzimy to okno jako znany nam prostokąt.

Ocena wielkości przedmiotu z pewnej odległości może przebiegać trzema sposobami:

1. Wielkość perspektywiczna. Gdybyśmy oceniali przedmioty zgodnie z geometrycznymi zasadami perspektywy jako tym mniejsze, im dalej się znajduja, wielkość ich byłaby odwrotnie proporcjonalna do odległości i odpowiadałaby wielkości obrazu na siatkówce.

\section{Wielkość rzeczywista}
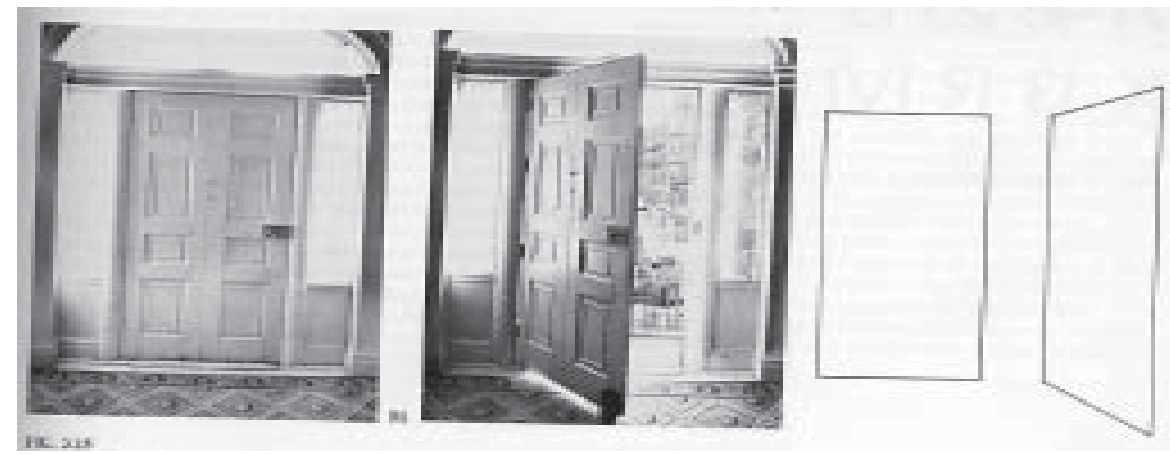

Zamknięte drzwi są prostokątne. Gdy są otwarte na siatkówce oka powstaje trapezoid ale mimo to obserwator widzi drzwi wciąż jako prostokątne. przedmiotu. Gdyby stałość wielkości była doskonała, moglibyśmy ocenić wielkość przedmiotu zgodnie z jego znanymi (dającymi się zmierzyć) rozmiarami, a zatem z odległości nie wydawałby się wcale mniejszy.

3. Kompromis między wielkościa perspektywiczna a rzeczywista. Możemy przyjąć kompromis i widzieć odległy przedmiot jako nieco mniejszy, lecz nie tak mały, jakby wynikało to z geometrii perspektywy.

Z przytoczonych trzech możliwości zachodzi zwykle ta ostatnia. Nasze spostrzeganie wielkości jest kompromisem między wielkością perspektywiczną a wielkością rzeczywista. Charakter występującego w naszym spostrzeganiu kompromisu polega na tym, że im większą ilością informacji rozporządzamy, tym bardziej wielkość spostrzegana zbliża się do rzeczywistej wielkości przedmiotu, im bardziej informacja jest niewystarczająca lub niepewna, tym bardziej wielkość spostrzegana zbliża się do wielkości perspektywicznej. 

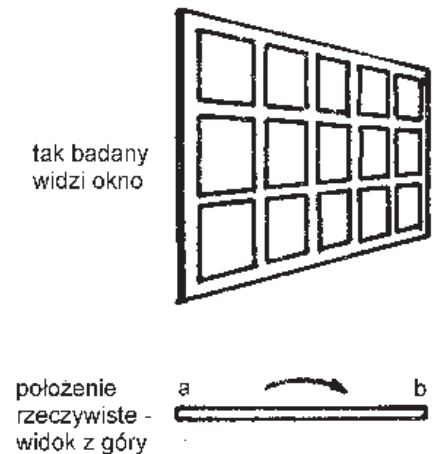
widok z góry

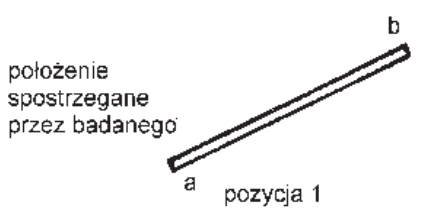

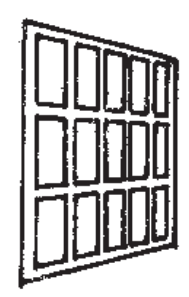
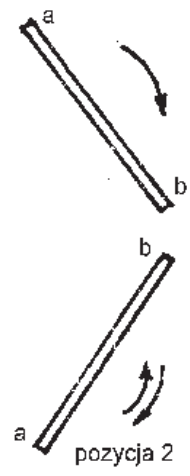
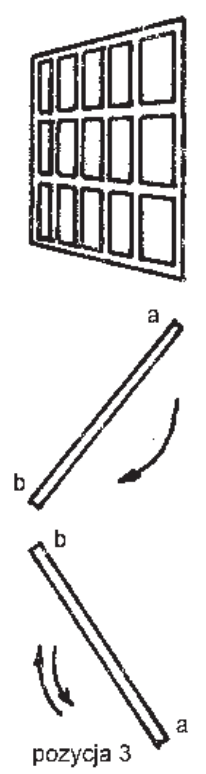

Złudzenie stwarzane przez obracające się okno. Okno jest skonstruowane w ten sposób, że w pozycji 1 wygląda jak okno prostokątne, którego lewa krawędź znajduje się bliżej osoby badanej. W rzeczywistości lewa krawędź (a) i prawa krawędź (b) są w równej odległości od obserwatora. Gdy okno obraca się zgodnie z ruchem wskazówek zegara (patrząc z góry), badany widzi lewą krawędź nadal jako większą niż prawa, dlatego też wydaje się ona nadal bliższa, nawet jeśli się oddala (pozycja 2). Kiedy okno wykonuje całkowity obrót krawędź „a” przechodzi przez punkt najbardziej oddalony od obserwatora i ponownie zaczyna się zbliżać (pozycja 3), przy czym ciagle wydaje się bliższa niż „,b”. Obserwator zatem skłonny jest widzieć okno raczej jako wahające się w przód i w tył, niż jako obracające się wokół osi.
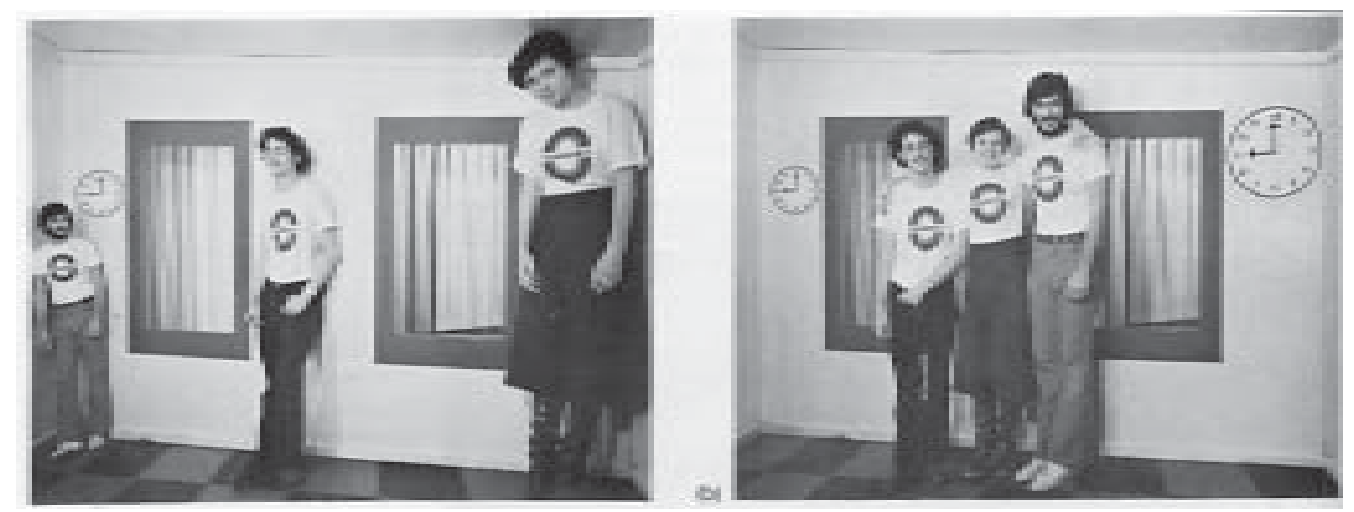

B

Pokój Amesa. Pokój po lewej drastycznie zaburza wysokości trzech osób pokazanych na zdjeciu obok.

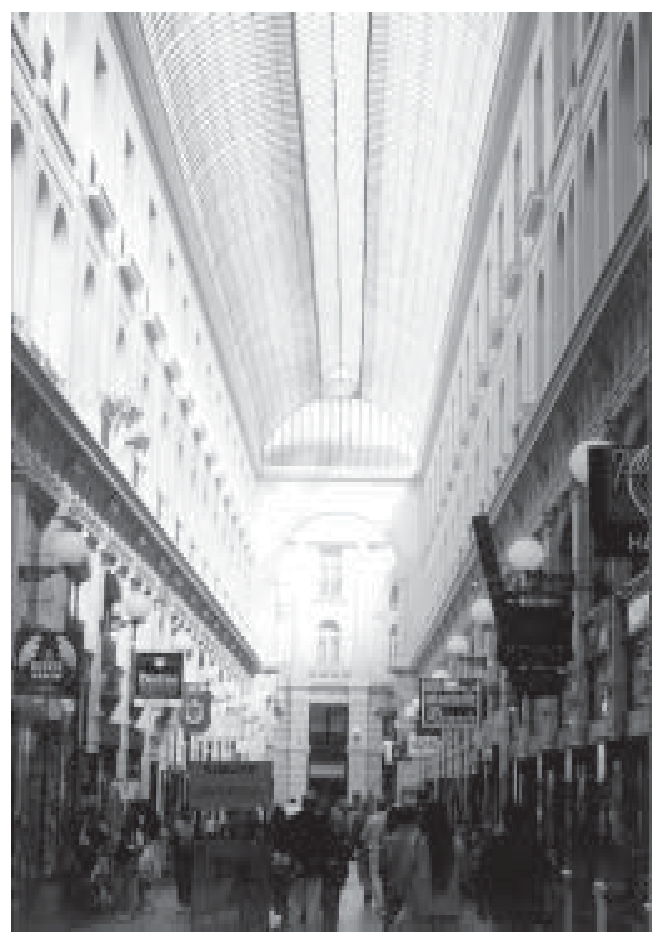

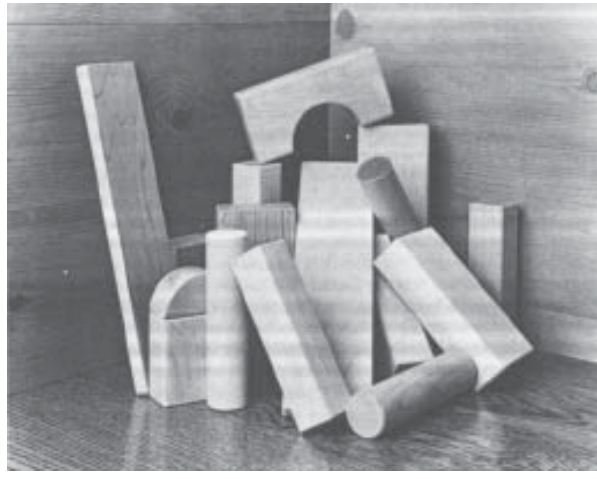

A

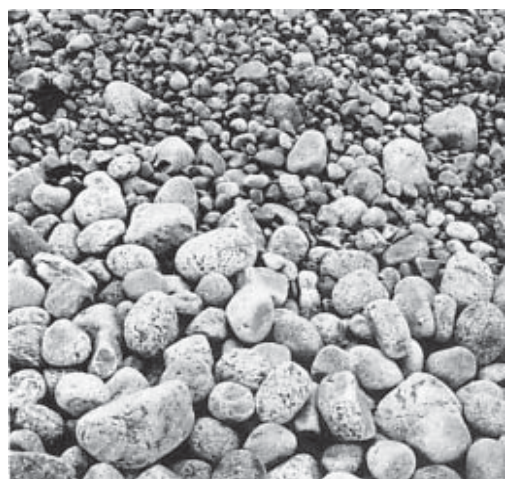

D
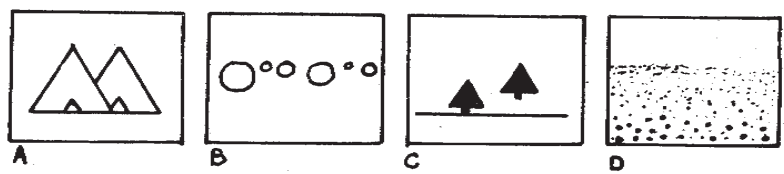

C Wzrokowe spostrzeganie odległości. Pokazano tu kilka rodzajów wskaźników wykorzystywanych przy spostrzeganiu odległości. A - nakładanie się, B - względna wielkość, C - wysokość położenia w płaszczyźnie, D - gradient struktury powierzchniowej. 
Chociaż nie stosujemy się ściśle do praw perspektywy, jednak widzimy rzeczy bardziej oddalone jako mniejsze. Gdy patrzymy przez rząd sklepień łukowych, każde z ruch mieści się we wnętrzu poprzedniego. Najdalszy łuk może wydawać się dwa razy mniejszy niż bliższy, chociaż jest dziesięć razy dalej i powinien wydawać się dziesięć razy mniejszy. Gdy mówimy o stałości wielkości, mamy na myśli zdolność widzenia odległego przedmiotu jako równego pod względem wielkości bliskiemu przedmiotowi o tych samych rozmiarach. Stałość wielkości spostrzegania wiąże się ściśle ze zdolnością spostrzegania trzeciego wymiaru, to jest odległości i głębi. W ocenie odległości i głębi decydującą rolę odgrywają liczne jednooczne wskaźniki odległości. Najważniejsze z nich to: nakładanie się przedmiotów, perspektywa, światła i cienie, ruch.

Świat naszych spostrzeżeń odznacza się nie-

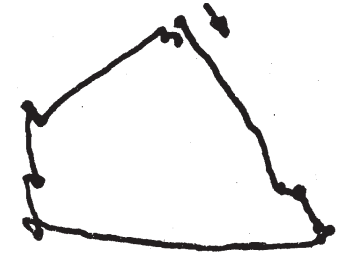

Ruchy oka przy poruszaniu się po okręgu. Linie oznaczają ruchy skokowe, a punkty patrzenie. Tego rodzaju zapisy, które otrzymał Stratton, wykazały niemożność wyjaśnienia estetycznej przyjemności przyglądania się linii krzywej, rzekomym gładkim ruchom oczu wzdłuz krzywej.

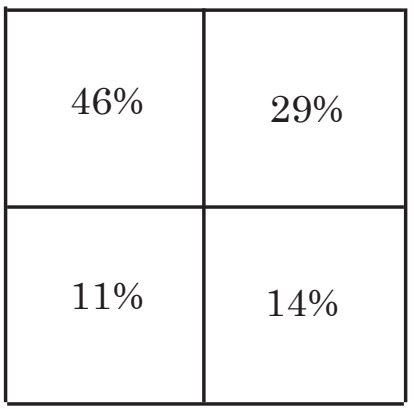

Częstotliwość zatrzymywania się wzroku podczas obserwacji grupy 16 przyrządów usytuowanych symetrycznie w czterech rejonach tablicy z przyrządami strzegamy przedmioty jako stałe. Również położenie przedmiotów postrzegamy jako wzolednie stałe, na przekór faktowi, że widzimy świat niczym kalejdoskop, który, gdy się poruszamy, przesyła nam miliardy zmieniających się pobudzeń. Jedną z podstawowych przyczyn stałości położenia jest skokowy ruch oczu. Jest on jedna z przyczyn tego, że świat nie przesuwa się w odwrotnym kierunku, gdy poruszamy głową. Oczy nasze przeskakują z jednego miejsca na drugie, tak że nie spostrzegamy tego wszystkiego, co przesuwa się przed oczami. Jak wykazują eksperymenty przeprowadzone przez psychologów inżynieryjnych, w czasie wykonywania ruchów skokowych oczy nie zatrzymują się jednakowo na wszystkich rejonach pola spostrzeżeniowego.

Dzieląc pole spostrzeżeniowe na cztery części White, Warick i Grether zauważyli, że wzrok znacznie częściej spoczywa na górnej lewej ćwiartce pola spostrzeżeniowego, a najrzadziej na dolnej lewej . Prawidłowość ta znalazła zastosowanie w konstrukcji, a konkretnie w rozplanowaniu wszelkiego rodzaju konsoli i pulpitów sterowniczych, zmniejszając ryzyko niezauważenia najbardziej ważnych wskaźników.

\section{Organizacja w spostrzeganiu}

Stałość spostrzegania implikuje istnienie organizacji w spostrzeganiu. Przy codziennej obserwacji wydaje się nam, że cechy przedmiotu sa widziane równie bezpośrednio jak jego kolor i jasność. A jednak ich związek z całym zespołem różnorodnych bodźców odbieranych przez siatkówkę nie jest tak bezpośredni. Musi zajść coś więcej niż zwykła recepcja bodźców, zanim pewne partie tego zespołu zostaną wydzielone z reszty i przedstawią się nam na przykład jako określony kształt, taki jak linia prosta, kąt, kwadrat lub koło. Z tego też względu przyjęło się mówić o spostrzeżeniu kształtu, a nie o wrażeniach kształtu. Pojęcie spostrzeżenie nie ma opisywać jakiegoś znanego nam procesu, określa ono rezultat osiągany przez organizm, wytwór procesu spostrzegania, a nie proces doprowadzający do tego rezultatu.

Gdy patrzymy na układy geometryczne, zawsze odróżniają się one od tła i dlatego, mając granice czy kontury, wydają się podobne do przedmiotów. Takie zorganizowane figury na tle możemy uważać za podstawę strukturalizacji bodźców. Układy bodźców nie muszę tworzyć znanych przedmiotów, aby zróżnicować się na figurę i tło. Hebb wyraża pogląd, że najprostszy aspekt figury stanowi jej ,jedność pierwotna”. Wyraża on myśl, że ograniczone pole, figurę, widzimy jako odbijająca od tła jedność, jeszcze zanim ją rozpoznamy. Dowodem na to są pacjenci, którym usunięto kataraktę, a więc tacy, którzy jako dorośli po raz pierwszy patrzyli na swe otoczenie, od razu widzieli figury, a dopiero znacznie później potrafili odróżnić jedną figurę od drugiej, np. trójkąt od kwadratu.

Figura odwracalna, w której albo jasne, albo ciemne pola mogą być spostrzegane jako figury na tle.

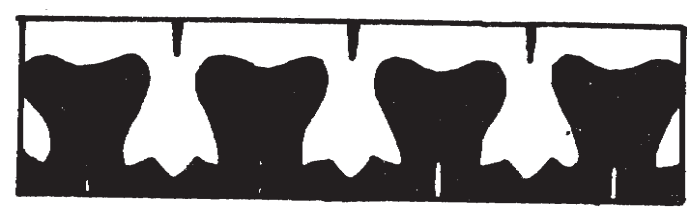


Układy bieli i czerni oraz wiele wzorów tapetowych spostrzegamy jako figury na tle, często też figura i tło mogą się zamieniać ze sobą rolami. Zwróćmy uwagę, że gdy część czarna albo biała jest całkowicie otoczona przez druga, wtedy jako figurę łatwiej widzimy część otoczona, ale przy pewnej wprawie można jako figurę zobaczyć też części otaczające. O ile kontur dzielący obie części pola jest w przybliżeniu pionowy i nie otacza żadnej części pola figura i tło łatwo ulegają zamianie.

Fenomenologiczne różnice, jakie zachodzą między figurą a tłem, są następujące:

1. Figura posiada pewien kształt, natomiast tło jest stosunkowo bezkształtne. Jeżeli tło posiada kształt, to zawdzięcza go jakiejś innej figurze znajdującej się na nim, a nie konturowi oddzielającemu je od tamtej figury 2. Tło wygląda tak, jak gdyby rozprzestrzeniało się poza figurę w sposób ciagły, a nie jak gdyby było przerwane przez figurę 3. Figura ma charakter rzeczy, tło zaś przedstawia się jako nieukształtowany materiał. 4. Figura wygląda zwykle tak, jakby była wysunięta ku przodowi, a tło - jakby znajdowało się w tyle. 5. Figura silniej się nam narzuca, jest lepiej zapamiętywana i bardziej wygląda na coś, co ma jakieś znaczenie.

A

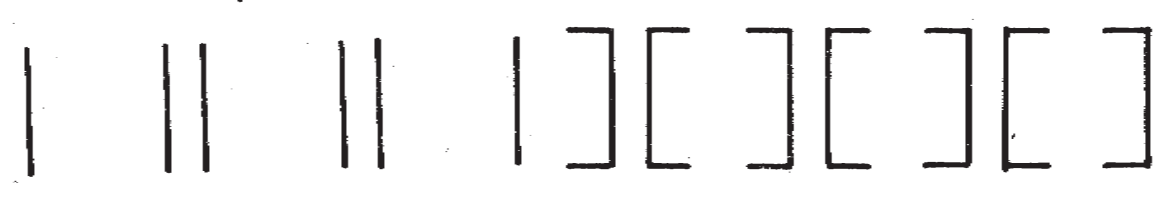

Układ elementów a strukturalizacja spostrzeżeniowa. Bliskość kresek, które zdają się tworzyć pary powoduje, że widzimy trzy pary i dodatkową kreskę po prawej stronie. Dodane do nich zakończenia skłaniają do odmiennego grupowania: trzy rozerwane kwadraty i dodatkowa kreska po lewej stronie.

Prawa, które do pewnego stopnia wyjaśniaja, dlaczego pewne elementy pola widzenia układają się w figurę, a inne stają się składnikami tła, to prawa grupowania i strukturalizacji. Związane są one z naturalną tendencją do nadawania struktury temu, co widzimy. Nawet proste zbiory kresek i kropek układaja się, gdy na nie patrzymy w uporządkowane struktury. Jak widać to na rysunku, układy bodźców narzucaja nam sposób widzenia figur. Spośród zasad istotnych dla wyjaśnienia takich zjawisk, jak te, które występuja przy patrzeniu na kolejny rysunek, najważniejsze sa: bliskość, „wspólna droga”, podobieństwo, ciagłość lub tak zwana dobra figura, zamykanie.

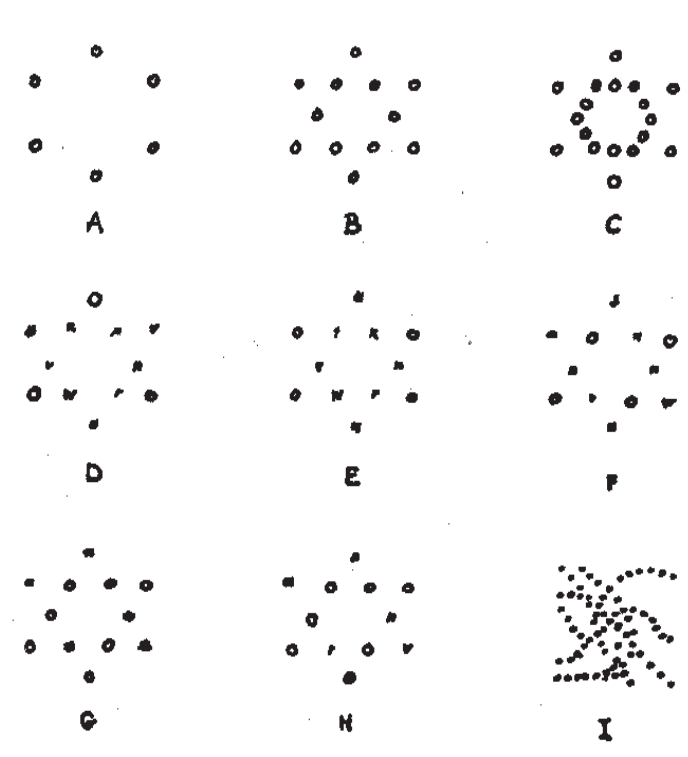

Figury złożone z kropek, ilustrujące działania czynników bliskości, jednakowości, kontynuacji i „dobrej figury”. Sześciokąt, tak wyraźnie widoczny w A, jest w B zamazany przez dodatkowe kropki, ale pojawia się ponownie w $\mathrm{C}$ po dodaniu jeszcze kilku położonych blisko siebie kropek, które uwypuklają wewnętrzny sześciobok. W D, E oraz F pewne szczegóły sa jednakowe i to sprzyja połaczeniu ich w jedna grupę, pozostałe zaś łatwo wiążą się w grupę uzupełniająca, gdy tworza regularną figurę lub też gdy - jak w G - są do siebie podobne. Przeciwnie w H: pozostałe szczegóły są tu niepodobne i ułożone nieregularnie, toteż niełatwo wiążą się w całość. I - pokazuje czynnik jednostajnej kontynuacji, mianowicie kropki sprawiają wrażenie, jakby były ułożone wzdłuż linii prostych lub wzdłuż wyraźnych krzywych

Bliskość przestrzenna lub sąsiedztwo występuje wtedy, gdy np. kropki położone stosunkowo blisko siebie łatwo widzi się jako jednolitą grupę.

Jednakowy wyglad lub podobieństwo ma miejsce, gdy np. kropki jednakowego koloru widzi się jako grupę odróżniającą się od kropek innego koloru, które mogą tworzyć inna grupę. Podobieństwo może też dotyczyć kształtu.

Wspólna droga występuje wtedy, gdy jako jednolita grupę widzi się kropki, które poruszają się jednocześnie w tym samym kierunku.

Ciagtość lub tzw. dobrq figurę tworzą grupy, które pod pewnym względem zbudowane są według jednolitej zasady. Grupa tworząca linię zamkniętą ma przewagę nad grupą ułożoną w linię otwartą. Innym ważnym czynnikiem jest symetria czyli zrównoważenie całej figury. Symetryczność i zwartość są czynnikami wyznaczającymi tendencję do widzenia figur dwuwymiarowych w układzie trójwymiarowym. Rysunek 
przedstawia kilka rzutów sześcianu, rzuty niesymetryczne widzi się jako sześciany, ale regularny sześciokąt łatwo przybiera wygląd figury dwuwymiarowej, choć i tu po dłuższym wpatrywaniu się występuje obraz trójwymiarowy.

Jeśli spojrzymy znów na rysunek, przypomnimy sobie, że byliśmy skłonni wypełniać luki, aby uzyskać kwadraty. Ta tendencja, aby w spostrzeganiu uzupełniać niekompletne figury, nosi nazwę zamykania.

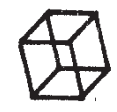

a
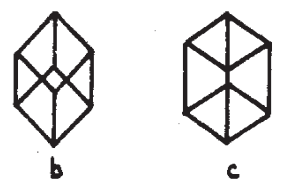

c
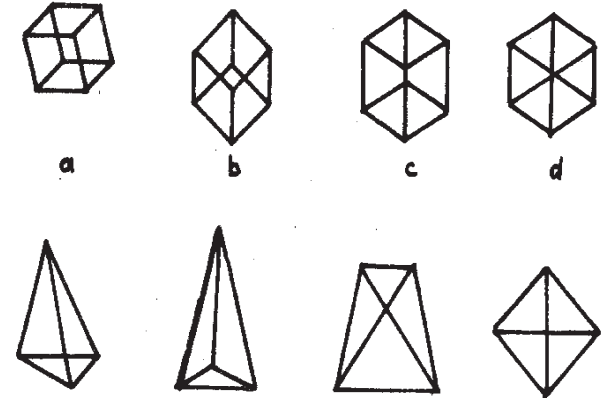

6

b

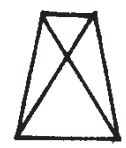

c

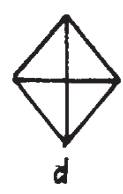

Rzuty na płaszczyznę sześcianu i ostrosłupa.
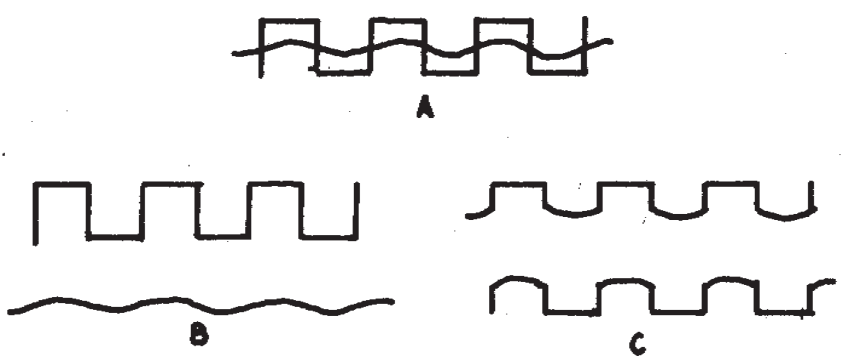

Ciagłość a strukturalizacja. Linie faliste, podobnie jak motyw prostokątny, są percepcyjnie ciagłe tak, że łatwiej jest widzieć figurę A złożoną z dwóch elementów, takich jak w B, niż z równoważnych części przedstawionych w C.

W wielu okolicznościach tendencja do trwałego zorganizowania może spowodować percepcyjne zniweczenie jednej figury na rzecz innej, bardziej trwałej. Z zasady tej korzysta się przy maskowaniu, gdzie staramy się ukryć jakąś rzecz, włączając ją w bardziej dominujący wzór.

Jednym z najbardziej skutecznych sposobów wydzielania z tła pewnej części pola widzenia jest otoczenie jej linia, czyli obrysowanie. Taki zarys stanowi szczególny rodzaj konturu. Kontur jest czynnikiem ,produkującym kształt”. Kształt nie jest jednak identyczny z konturem. Dwie czesści pola podzielone wspólnym konturem mogą się różnić kształtem, mimo, że mają jeden i ten sam kształt.

Gdy zwracamy uwagę na kształt figury, raczej jesteśmy skłonni wpatrywać się w jakaśs jej część, ale gdy skupimy się na konturze, traktujemy go jako ścieżkę, której przebieg śledzimy. Śledzimy kontur mniej lub więcej szczegółowo ale nie łatwo określić, na czy to „śledzenie” polega. Jakie zatem czynniki wytwarzaja kontur? Mach wykazał jeszcze w 1865 r., że kontur nie jest po prostu zmiana barwy lub jasności pola w pewnej jego części, gdyż stały gradient jasności w żadnym punkcie pola nie wytwarza konturu. Kontur - to

A

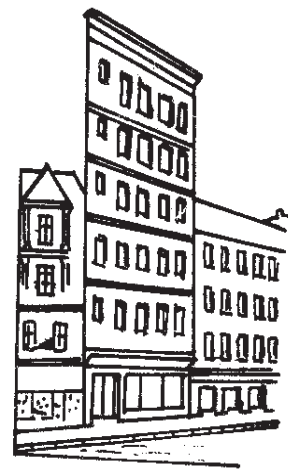

$\mathrm{B}$

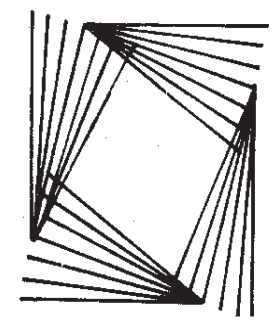

A. Interpolacja w spostrzeganiu. Spośród 67 badanych przez Behara i Bewana dzieci jedynie troje spostrzegło, że z głównego domu istnieje tylko przednia ściana. B. Ukryty kwafdrat. zmiana zmiany, tzn. druga a nie pierwsza różniczka jasności.

$$
\frac{\mathrm{d}^{2} \mathrm{i}}{\mathrm{ds}^{2}}, \frac{\text { nie } \mathrm{di}}{\mathrm{ds}}
$$

Kontur jest stosunkowo gwałtowną zmianą gradientu bądź co do jasności, bądź też co do barwy. 


\section{Ztudzenie wzrokowe}

W większości przypadków nasze spostrzeganie wzrokowe jest na tyle zadowalające (por. omawiane tendencje stałości spostrzegania), że przyjmujemy dokładność spostrzegania jako coś oczywistego. Dlatego też wielu ludzi przyznaje ze zdziwieniem, że po prostu wzrok ich myli. Inaczej rzecz się ma w psychologii. Psycholo-

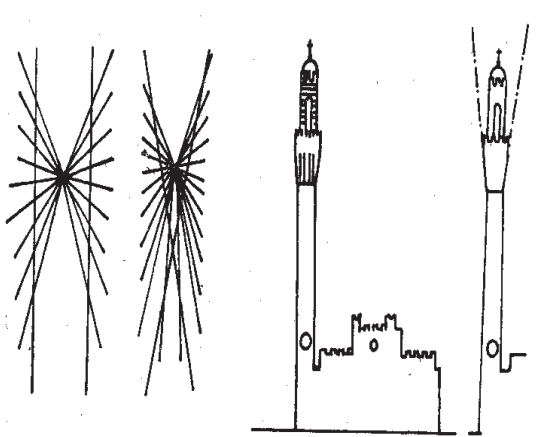

Złudzenie Heringa. gowie prowadząc badania nad spostrzeganiem, zajęli się złudzeniami, kiedy spostrzeżenia są wyraźnie mylące, gdyż sądzili, że tą drogą uda się odkryć, w jaki sposób spostrzegamy. Złudzenia dzieli się zwykle na: złudzenia kontrastu oraz złudzenia zbieżności czyli asymilacji. Gdy osoba niska stojąca pomiędzy dwiema osobami wysokimi wydaje się jeszcze niższa niż jest w rzeczywistości - jest to złudzenie kontrastu, gdyby jednak wydawała się komuś wyższa, niż jest naprawdę, to byłby to przykład na zbieżność, czyli asymilację.

Złudzenia te, podobnie jak i inne błędy, są czymś więcej niż zwykłymi ciekawostkami nie tylko w psychologii, ale i w architekturze, gdzie jak mówi prof. L. Niemojewski „rzecz widziana musi się wydawać nie taka, jaka jest, lecz taka, jaka była pomyślana”. Do najbardziej znanych złudzeń geometrycznych należą złudzenia: Heringa, Zolnera, Loeba, Muller-Leyera, Poggendorfa i Lipsa. Jest także wiele złudzeń nie nazwanych, z którymi często się spotykamy.

Złudzenie Heringa polega na tym, że linie proste przecięte pękiem promieni wydają się być wygięte w kierunku na zewnątrz ogniska, z którego wychodzą. Złudzeniu temu ulegamy patrząc na wieżę Palazzo Publico w Sienie.

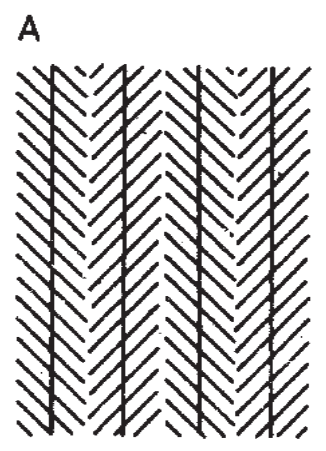

Złudzenie Loeba.

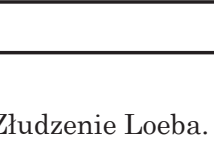

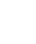
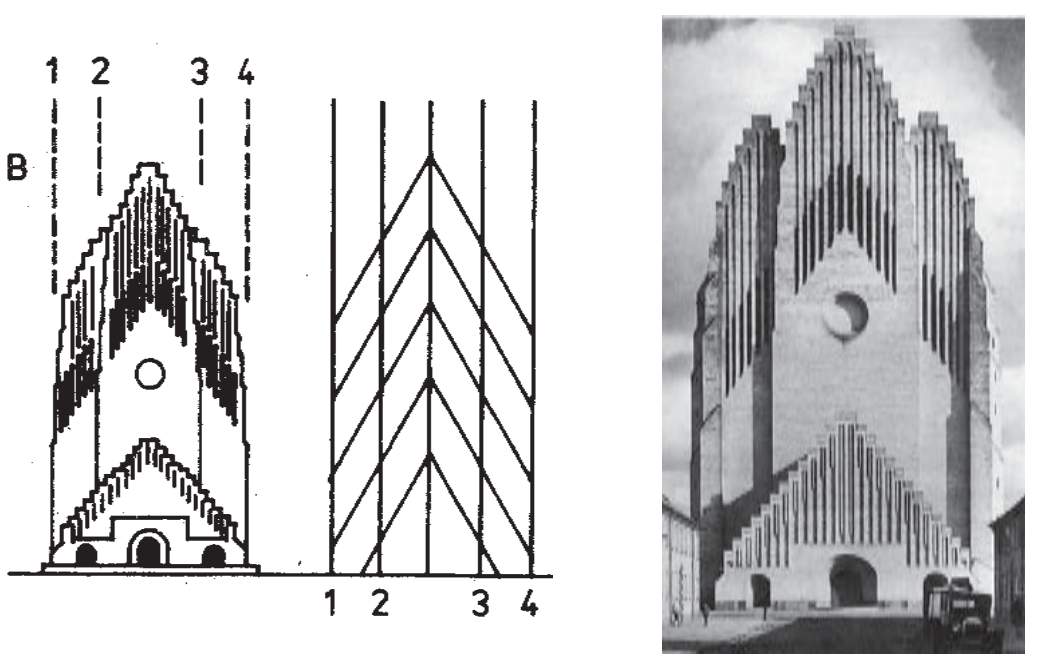

Złudzenie Zolnera.

Złudzenie Zolnera polega na tym, że linie równoległe przecięte skośnymi wydają się nierównoległe. Złudzenie tego rodzaju występuje np. w kościele Gruntwigaw Kopenhadze. Piony zewnętrzne 1 i 4 wydają się zbiegać ku górze, zaś wewnętrzne 3 i 2 - ku dołowi. Złudzenie wywołane jest tu skosami ząbkowanych linii oraz skośnie ustawionymi oknami szczelinowymi. Skarpowane obrzeża korygują odchylenia pionów 1 i 4.

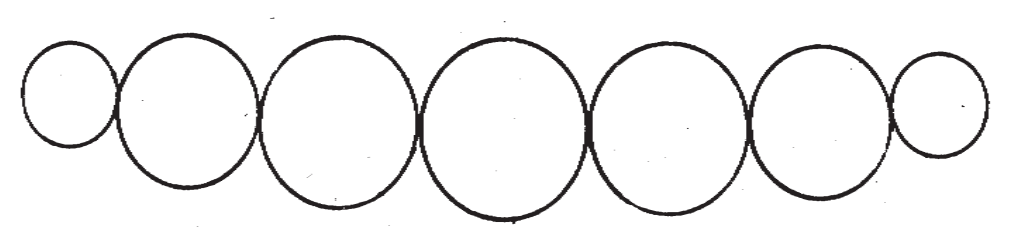



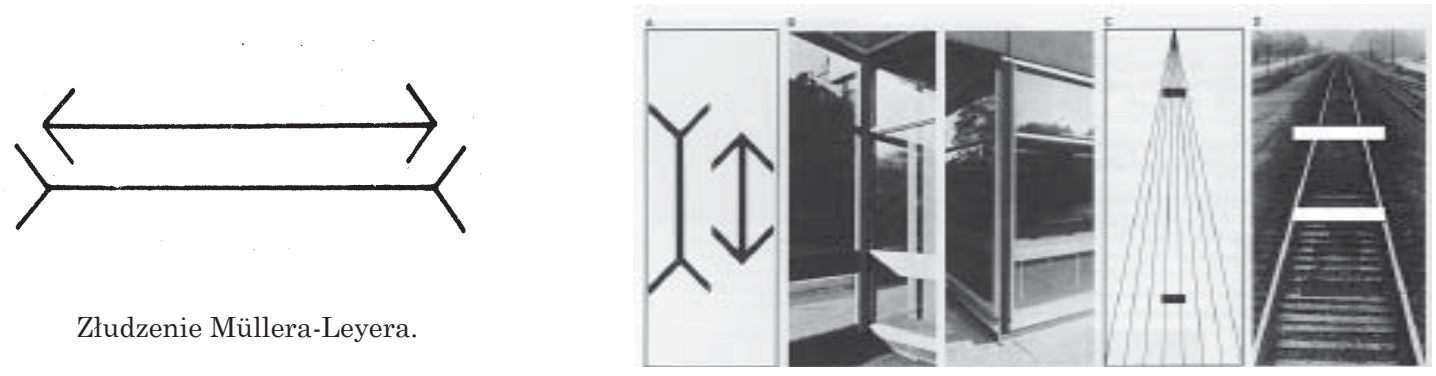

Złudzenie Loeba polega na tym, że dwie proste równoległe o różnej długości wydają się być zbieżne. Takie złudzenia występują m.in. w surowej architekturze średniowiecza przy niejednakowych długościach (pionowych lub poziomych) rzędów okien.

Złudzenie Müllera-Leyera polega na tym, że z dwóch jednakowych długości odcinków dłuższy będzie się wydawał ten, który zakończony strzałkami otwartymi na zewnątrz.

W złudzeniu Lippsa szereg kół stycznych do prostej sprawia wrażenie stycznych do łuku, gdy średnica kół stopniowo się zmniejsza. Z tym złudzeniem związane jest zjawisko „zwisu” elementów poziomych. Na przykład, gdy stoimy na osi sali i patrzymy na sufit, odbieramy wrażenie, że środkowa część sufitu znajduje się niżej od jej części przyściennych.

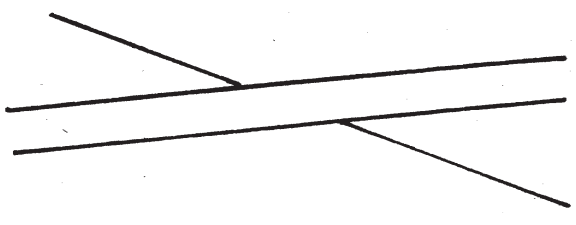

Złudzenie Poggendorffa.

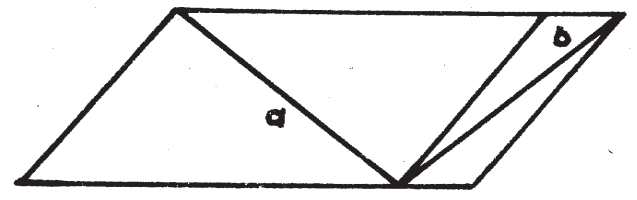

Złudzenie oparte na fałszywie założonej perspektywie. Równoległobok Sendera. Gdyby spojrzeć na tę figurę jak na perspektywiczny rysunek dwóch prostokątów, wówczas prostokątna „a” musiałaby być dłuższa niż „b” (a = b).

Złudzenie Poggendorffa występuje wtedy, gdy dwie linie równoległe są przecięte trzecią - skośną w ten sposób, że część skośnej wydaje się nie należeć do jednej i tej samej prostej.

Złudzenie oparte na fałszywie założonej perspektywie polega na tym, że gdyby spojrzeć na figurę przedstawioną na rysunku, jako na perspektywiczny rysunek dwóch prostokątów, wówczas przekątna „a” musiałaby być dłuższa niż „b”. W rzeczywistości jednak mają one jednakowa długość.

Z głównych teorii, jakie wysuwano dla wytłumaczenia tych złudzeń, na uwagę zasługuja: teoria ruchów oczu, teoria widzenia perspektywicznego, teoria wczuwania (empatii), teoria przesunięcia oraz teoria wyrazistości.

W swej najprostszej postaci teoria ruchów oczu przyjmuje, że doznanie długości linii powstaje wskutek poruszania oczami wzdłuż linii, od jednego jej końca do drugiego. Ponieważ ruchy oczu w kierunku pionowym trudniej jest wykonać niż w kierunku poziomym, dlatego ujęcie długości odcinka pionowego wymaga więcej wysiłku niż przy takim samym odcinku poziomym i odcinek pionowy wydaje się dłuższy. Teoria widzenia perspektywicznego wychodzi od niewątpliwego faktu, że w schematycznym rysunku łatwo dostrzegamy trójwymiarowe przedmioty, i wnosi stąd, iż widziana długość linii zależy od perspektywy, która człowiek jakby „wczytuje” w figurę. Teoria empatii przedstawiona przez Teodora Lippsa (1897) służyła swemu twórcy do wyjaśnienia przeżyć estetycznych wywołanych przez architekturę. Lipps utrzymywał, że przygladanie się nawet prostym figurom wywołuje u obserwatora pewne reakcje emocjonalne i mięśniowe.

Według teorii przesunięcia ocena linii kątów figury wymaga analizy, co jest trudną sprawa, ponieważ obserwator jest skoncentrowany na wyglądzie figury jako całości. Jeżeli obserwujący nie może oderwać się od tego całościowego ujęcia i zacieśnić uwagi skupiając się na poszczególnym odcinku, wówczas przesuwa wrażenie odniesione przy oglądaniu całości na ten odcinek, wyobrażając sobie, że ocenia właśnie jego długość.

Teoria wyrazistości, zwana też teorią pregnacji, sugeruje, że obserwator, widząc figurę posiadająca określona cechę, skłonny jest widzieć tę cechę jako wyrażoną w stopniu tak pełnym, jak tylko pozwalaja na to okoliczności, na przykład figurę zbliżoną tylko do koła widzi się jako regularne koło, to znaczy jako 
lepsze koło niż w rzeczywistości. Jeśli więc obserwator widzi, że jeden z dwóch członów figury Muller-Leyera składa się z części rozbiegających się w przeciwnych kierunkach, ujmuje tę rozbieżność w sposób przesadny, a skoro drugi człon będzie widzieć jako pojedynczy, zwarty przedmiot, to znów ta zwartość zostanie podkreślona w sposób przesadny.

\section{Czynniki wptywajace na spostrzeganie}

Spostrzeżenia nasze są selektywne. Nie reagujemy w równym stopniu na wszystkie bodźce, które na nas oddziaływaja, lecz koncentrujemy się na nielicznych. Tę percepcyjną koncentrację nazywamy uwagą. Dzięki procesom uwagi możemy skupić się na wybranych bodźcach i nie dopuścić do bodźców zakłócających. Uwaga jest zatem, wewnętrznym schematem organizującym proces spostrzegania. Tak na przykład, gdy jesteśmy zmuszeni zapamiętać drogę powrotną w nieznanym sobie mieście, to z zadania tego wywiązujemy się tym lepiej, im w większym stopniu zwracamy na nią uwagę. Jeżeli porównamy nieznane sobie miejsce do „źródła” rywalizujących bodźców, to skierowanie uwagi na ten, a nie inny szczegół lub układ jest wynikiem rozwiąania tego konfliktu. Kierunek rozwiazania tego konfliktu zależy od czynników wyróżniających, decydujących o wyższości jednej organizacji bodźców nad innymi. Wśród rywalizujących układów bodźców przewagę ma układ o największych rozmiarach, największej intensywności, najczęściej się powtarzający oraz najbardziej żywy, ze względu na swój kształt, kontrastowość lub barwę. W miastach o zunifikowanej zabudowie orientacja w otoczeniu jest znacznie utrudniona, nawet przy dużej koncentracji uwagi, ze względu właśnie na brak czynników wyróżniających.

Pewna selektywność spostrzegania występuje już przed pojawieniem się bodźca. Możemy przygotować się do spostrzegania bodźców, których pojawienia się oczekujemy oraz do zareagowania na nie. Takie przygotowanie nazywamy nastawieniem przygotowawczym, a słowo to ma tutaj to samo znaczenie, co w przypadku kierowcy, który nastawia się że na zielone światło ruszy z miejsca. Tak więc, nastawienie poznawcze jest przejawem funkcjonowania wewnętrznych wzorów percepcyjnych i ma wpływ na powstawanie spostrzeżeń przedmiotowych. Umożliwia ono antycypację zmian zachodzących w przedmiocie spostrzegania, czyli oczekiwanie, że pojawi się to a to, że będzie miało takie a takie cechy. Tego rodzaju oczekiwania umożliwiają u człowieka w określonych sytuacjach percepcyjnych stan gotowości do wykonywania określonych operacji poznawczych.

Podsumowując, to co spostrzegamy, zależy po części od tego, na co jesteśmy przygotowani. Gdy przedmiot spostrzegania jest wieloznaczny, jak rzeczy widziane w ciemności, przez mgłę, osoba spostrzegająca skłonna jest nadawać mu większe znaczenie, niżby wynikało to z samych warunków pobudzenia. O tym, co spostrzega, mogą decydować w pewnej mierze potrzeby i przyjęty przez nią system wartości, kontekst, posiadana wiedza, cechy osobowości.

Wpływ potrzeb na spostrzeganie jako pierwsi eksperymentalnie udowodnili McClelland i Atkinson. Wykazali om między innymi, że głodni oceniają przedmioty nadające się do jedzenia jako większe. Na tej samej zasadzie ludzie, którzy nie posiadają własnego mieszkania, którego by bardzo pragnęli, skłonni są oceniać małe mieszkania jako wystarczająco duże. Wartości społeczne „zrastają się” z przedmiotami jako część ich pełnego obrazu. Po takim zrośnięciu się mogą wpływać na tak proste odczucia, jak właśnie ocena wielkości. Na przykład ludziom biednym monety o większej wartości wydają się większe. Podobne analogie zaobserwować w odniesieniu do manifestowanych przez ludzi preferencji wobec zjawisk architektonicznych. Przykładem tego niech chociażby będzie tendencja do przesadnej oceny wielkości różnych obiektów znajdujących się w dużych miastach przez mieszkańców pochodzących ze środowiska wiejskiego.

$\mathrm{Na}$ kształtowanie się spostrzeżeń niewątpliwy jest również wpływ cech osobowości. Badacze stwierdzili, że ludzie różnią się pod względem sposobu zachowywania orientacji w przestrzeni, co obrazuje następujący eksperyment Witkina. Badanego przywiąuje się do krzesła w ten sposób, że po przechyleniu krzesła ciało badanego będzie nadal prostopadłe w stosunku do siedzenia krzesła. Badany, znajdujący się w zaciemnionym pomieszczeniu, patrzy na świecąca ramę na ciemnym tle. Ma on za zadanie ustawić w pionowej pozycji pręt, znajdujący się w środku ramy. Jeżeli rama jest w normalnym położeniu, a badany siedzi normalnie, udaje mu się ustawić pręt pionowo z minimalnym błędem. Gdy przechylona jest tylko rama lub kierunek osi ciała osoby badanej jest bardziej zgodny z kierunkiem osi ramy, wówczas badani ustawiają pręt w położeniu odbiegającym od pionowego.

Witkin i jego współpracownicy klasyfikowali badanych jako zależnych od pola widzenia, jeśli sądy ich opierały się przede wszystkim na wskaźnikach wzrokowych odbieranych z otoczenia, i jako niezależnych 
od pola widzenia, jeśli polegali na wskaźnikach dostarczanych przez własne ciało, skutkiem czego przechylenie pola widzenia nie wprowadzało ich w błąd. Zależność i niezależność od pola związana jest z cechami osobowości (introwersją i ekstrawersją oraz wychowaniem. Ludzie zależni od pola widzenia, sa na ogół bardziej niespokojni, natomiast niezależni odeń - opanowani i bardziej pewni siebie. Zależni od pola są przeważnie ekstrawertykami, a niezależni - introwertykami.

Zależności te wyjaśniają nam m.in. fakt, dlaczego ekstrawertycy są bardziej podatni na modę w porównaniu z introwertykami. Tak na przykład w latach dwudziestych pod wpływem m.in. projektu pawilonu radzieckiego Mielnikowa na Wystawie Sztuki Dekoracyjnej w 1925 r. ukształtował się w Paryżu określony maison-type, dom-studio, głównymi orędownikami owej nowoczesnej architektury byli artyści, ich protektorzy i marszandzi. Klientela ta, była zdolna zaakceptować formy architektoniczne, które bez względu na swa funkcjonalność i racjonalizm były równie niefunkcjonalne, jak formy sztuki kubistycznej i futurystycznej. Skutek był taki, prawie wszyscy ekscentrycy (ekstrawertycy) domagali się jednego dużego pomieszczenia z licznymi oknami od północy, które chcieli wykorzystywać jako studio lub galerię. Ich życie prywatne było tak ekscentryczne, że nietypowe żądania wysuwały się przed planowane racjonalne.

Kończąc, na przykładzie tego rozdziału znów widzimy sztuczność ostrych rozgraniczeń między różnymi, prezentowanymi dotychczas dziedzinami wiedzy, ujawniającymi sens, znaczenie i spostrzeganie środowiska architektonicznego.

\section{Kulturowe aspekty spostrzegania przestrzeni}

Według Tuana (1977) przestrzeń to abstrakcyjny termin, który określa złożony zespół pojęć. Ludzie żyja w różnych kulturach, różnią się więc między sobą sposobem w jaki spostrzegają przestrzeń, jak ją dziela, jakie wartości jej nadają i jak ją mierza, a także sposobem w jaki jej używają. Oczywiście istnieją też podobieństwa przekraczające granice poszczególnych kultur. Człowiek zawsze żyje w obiektywnym świecie, którego składnikiem niezbywalnym jest kultura. Kultura dzieli się na część stałą i dynamiczną. Część dynamiczna oddziałuje za pomoca „,potencjalnych możliwości” (wg Gibsona affordances czyli kulturowych wyzwalaczy), wbudowanych w środowisko naturalne i kulturowe. Część statyczna oddziałuje poprzez tradycję. W pierwszym przypadku oznacza to, że ludzie mają wszelkie dane, aby widzieć świat na wszystkich trzech poziomach pojęciowego konstruowania przestrzeni, ale z powodu wbudowanych w dana kulturę specyficznych „potencjalnych możliwości” widzenie zatrzymuje się na prostszym sposobie tworzenia reprezentacji poznawczej. W drugim przypadku kulturowa matryca petryfikuje dany styl poznawczy, przy czym jego ustalenie się nie oznacza, że jest to stała cecha etniczna czy biologiczna. Człowiek zmieniając kulturę zmienia swoje widzenie świata, bowiem zmieniają się „kulturowe wyzwalacze” (wymagania).

Kulturowo uwarunkowane spostrzeganie przestrzeni i różnice z tym związane nie polegają tylko na zmyśle wzroku, na którym bazuja głównie kultury zachodnie. Większość badań dotyczących różnic w percepcji przestrzeni dotyczy eksperymentów i obserwacji tzw. kultur obrazkowych i bezobrazkowych. Większość badaczy z zakresu psychologii międzykulturowej zakłada identyczność aparatu percepcyjnego u wszystkich ludzi. Ludzie z epoki faraona mają takie same warunki percepcyjne jak człowiek współczesny. Jak odkrył badacz niemiecki starożytni Egipcjanie znali, wbrew rozpowszechnionym opiniom, perspektywę linearna, jedynie nie stosowali jej na co dzień.

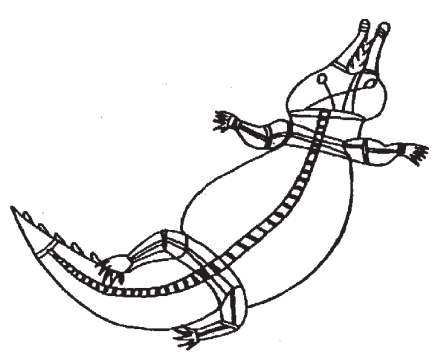

W niektórych kulturach systemy wzrokowe rozwinęły się, by mogły podołać jedynie tym kształtom, które są istotne $\mathrm{z}$ punktu widzenia przetrwania w środowisku. Krokodyl kakadu przedstawia każdą część zwierzęcia z zarysowanymi konturami tak, jakby ich typowe kontury tworzyły wspólną płaszczyznę z papierem. Starożytni egipscy rysownicy „zniekształcali” postacie ludzi w podobny sposób.

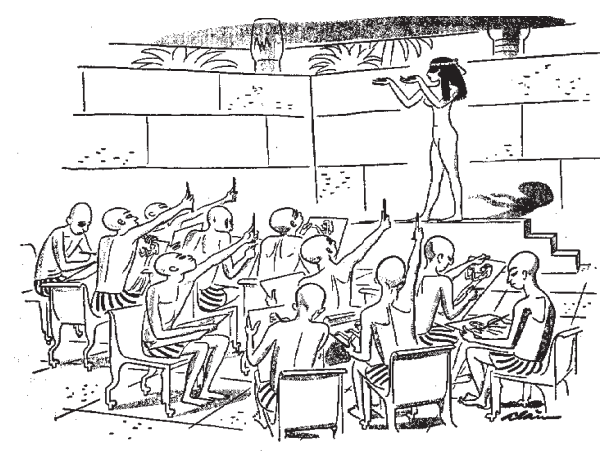

Rysowanie widzianego przedmiotu nie jest czymś więcej niż zwykłym odwzorowywaniem obrazu na siatkówce oka. 
Kultura jest uwikłana z szerszymi, ekologicznymi aspektami środowiska. Przykładem może tu być badanie Turnbulla w Afryce. Analizował on zachowanie Pigmejów z lasów Konga. Żyją oni w bardzo gęstym lesie równikowym. Ich przestrzeń ogranicza się do najwyżej kilkuset metrów. Wyprowadzeni na otwarta przestrzeń Pigmeje nie są w stanie ocenić właściwych rozmiarów czy odległości obiektów na horyzoncie, które są dla nich np. insektami rosnącymi w miarę przybliżania się. Widać wyraźnie że środowisko uniemożliwiło im wyuczenie i poprawne interpretowanie wskaźników odległości występujących w otwartej przestrzeni.

Wrażenie głębi i przestrzenności można wywołać sztucznie za pomoca obrazów. Istnieją tu dwa zasadnicze sposoby. Można wykorzystać tzw. obrazy epitomiczne. Prezentują one pewne charakterystyczne, łatwo rozpoznawalne cechy przedmiotu, różne od tych które pokazują trójwymiarowość; jest to sposób pośredni - patrzacy rozpoznaje przedmiot na rysunku. Inny sposób to tzw. obrazy eidoliczne. Wywołuja one wrażenie głębi nie mówiąc nic o samym przedmiocie (Deręgowski, 1990). Istnieją dowody na to, że umiejętność rozpoznawania takich rysunków występuje głównie w kulturach bogatych w obrazy, poprzez uczenie się w miarę upływu lat. Dzieci potrafią nazwać wiele przedmiotów, ale nie mogą opisać czynności z nimi związanych ani ich interpretować na obrazkach. Sugeruje to, że w kulturach, gdzie kontakty z obrazkami są sporadyczne lub nawet żadne, rzeczywiście występują trudności w interpretowaniu obrazów. Jednak badania w plemieniu Mekan w Etiopii, które bardzo rzadko kontaktuje się z przedstawicielami kultur obrazkowych, wykazały, że takie trudności w dostrzeganiu i interpretowaniu obrazów są wyraźne,

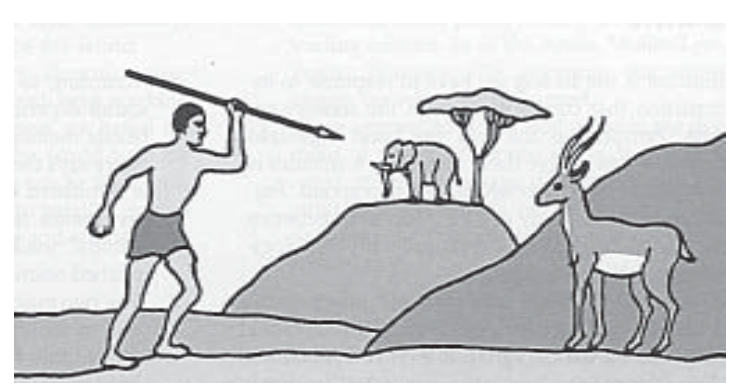

Przedstawiciele niektórych kultur nie są na podstawie rysunku ocenić prawidłowo odległości i wskazują słonia jako obiekt polowania. zwłaszcza gdy dotyczy to przedmiotów codziennego użytku i gdy rysunek wykonany jest wyraźnie na znanym materiale (Deręgowski, 1990).

Twierdzenie, że dwie osoby nigdy nie widzą dokładnie tej samej rzeczy w zwyczajnej sytuacji oznacza, że nie wszyscy odnoszą się do otaczającego ich świata w ten sam sposób. Jednakże bez uznania tego założenia nie da się wyjaśnić wszystkich różnic i niezgodności. Dowodem na to, że ludzie z różnych kultur żyją w różnych światach percepcyjnych jest ich orientowanie się w przestrzeni, sposób docierania i przenoszenia się z jednego miejsca na drugie. Świat percepcyjny Eskimosów jest zupełnie odmienny od świata Europejczyka. W Arktyce nie ma czasami horyzontu oddzielającego ziemią od nieba. Eskimosi mają naturalne punkty odniesienia. Nie są to najczęściej punkty w dosłownym znaczeniu, ale raczej cechy: wiatr, kontur śniegu, pęknięcia lodu itd. połączone razem różnymi zależnościami. integrują oni w jedną całość czas i przestrzeń, żyją raczej w przestrzeni akustyczno-węchowej niż wizualnej (Hall 1969).

Na ogół zakłada się, że bez względu na kulturę, osoby pracujące na co dzień np. z bryłami prostokątnymi, powinny łatwiej ulegać złudzeniu Müllera-Lyera. Trzeba jednak pamiętać, że różne kultury oferują różne warunki ('́rodowiskowe wyzwalacze) zdobywania takich doświadczeń. W kulturze zachodniej większość przedmiotów produkuje się maszynowo, stąd kąty proste są zjawiskiem powszednim. Z drugiej strony istnieją kultury w których przedmioty o kształtach prostokątnych w ogóle nie są znane np. plemię u Zulusów. Zdaniem Deręgowskiego (1990) należy tu brać pod uwagę stopień „urzemieślniczenia” danej kultury. Badania wykazały, że różne kultury są w różnym stopniu podatne na złudzenia, które z kolei mają związek z percepcją przestrzeni. Podatność ta zależy od stopnia obycia ze środowiskiem przemysłowym lub rzemieślniczym. Osoby z kultur tradycyjnych są w bardzo małym stopniu wrażliwe na złudzenia.

Przykładem wpływu środowiska na percepcję przestrzeni jest efekt wynikający z wieloznaczności obrazów rzutowanych na siatkówkę. Jeżeli na siatkówce powstanie prosty wzór, może on stanowić odbicie nieskończenie wielu rzeczy. Jeśli ten wzór jest w stanie wywołać efekt przestrzenny to musi zawierać element eidoliczny, a więc sposób jego powstawania zależy silnie od doświadczenia obserwatora. Tak więc traktowanie obrazów zależy w znacznej mierze od indywidualnych cech widza. Obserwatorzy „niedoświadczeni wzrokowo”, tzn. niedoświadczeni kulturowo, błędnie spostrzegają obrazy, które dla bardziej doświadczonych są wyraźnie niedwuznaczne (Deręowski, 1991 ). Podatność na rozwój percepcji przestrzeni w kategoriach środowiskowych jest związane z tym, co Gibson nazwał afordancjami. Są to „wyzwalacze” działań ludzkich wbudowane w środowisko. Przedstawiciele danej kultury podlegają więc specyficznym wpływom kulturowym, które pozwalają na spostrzeganie w pewien specyficzny i narzucony sposób. Zmiana tego sposobu wymagałaby przyjęcia nowego zestawu „wyzwalaczy”, czyli nowych warunków środowiskowych nabywania doświadczenia percepcyjnego. Potwierdza to fakt, że stopień podatności w kulturach tradycyjnych na złudzenia Mullera-Lyera, zjawiska typowego dla kultury zachodu, wzrasta proporcjonalnie do stopnia „zarażenia” się kulturą zachodnią. 


\title{
SPOSTRZEGANIE PRZESTRZENI ARCHITEKTONICZNEJ I URBANISTYCZNEJ
}

\author{
Mapy poznawcze a percepcja środowiska
}

Mapy są szczególnym sposobem przedstawiania świata przy użyciu charakterystycznych konwencji i symboli. W ten sposób odzwierciedlają one zależności przestrzenne w środowisku. Zależności te mogą być przedstawione w skali bezpośredniej w stosunku do środowiska. W rozumieniu bardziej psychologicznym mapa jest umysłową reprezentacją otoczenia zakodowaną w umyśle jednostki. W tym wypadku bliższe i pełniejsze jest określenie reprezentacja przestrzeni. Według Tolmana pojęcie „mapa poznawcza” (cognitive map) oznacza percepcyjną reprezentację przestrzeni którą człowiek wyrabia sobie opierając się na wskaźnikach środowiska i własnych oczekiwaniach, będących podstawą uczenia się dróg i osiąania celów w przestrzeni. Człowiek poruszający się po danym obszarze, np. w mieście, uczy się czegoś w rodzaju mapy tej przestrzeni, opierając się na spostrzeganiu i próbach zrozumienia stosunków przestrzennych. Uczenie się dotyczy tu głównie punktów orientacyjnych.

Zdaniem von Fieandta i Moustgaarda (1977) informacja percepcyjna, którą uzyskujemy od świata tworzy poznawczą reprezentację przestrzeni, tj. mapę poznawczą-symboliczna. Jest to struktura mentalna zawarta w pamięci długoterminowej, w której symbole reprezentujące punkty orientacyjne, miejsca i zależności między nimi występują w formie dwuwymiarowej.Mapy można używać na wiele sposobów. Sposoby te można ujać w trzy główne grupy: 1. Czytanie map - wykorzystywanie bezpośredniej informacji dostarczanej przez mapy; 2. Interpretacja map - wychodzenie poza informacje dostarczane bezpośrednio; 3. Używanie map do nawigacji.

Te trzy główne grupy nie są niezależne. Najczęściej posługujemy się różnymi sposobami jednocześnie. Mapy obszaru moga zawierać koordynacyjny system odniesienia. Stwierdzono, że starsze dzieci są w stanie uwzględniać te koordynaty przy lokalizowaniu i zapamiętywaniu przynajmniej tych najważniejszych punktów orientacyjnych.

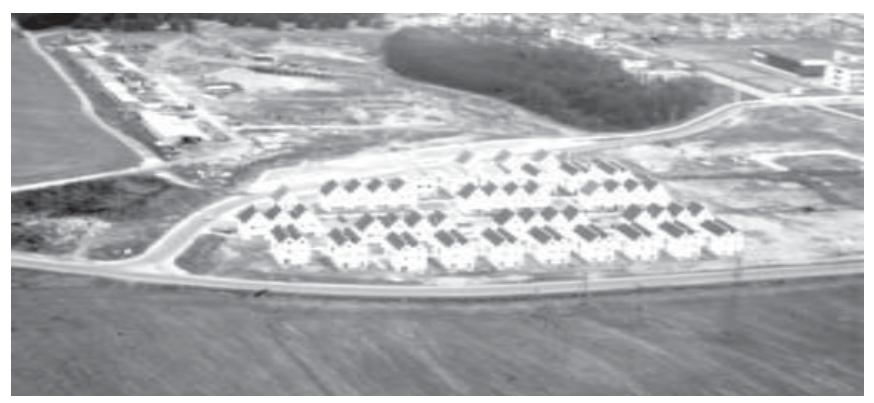

Już trzylatki są w stanie rozpoznać cechy charakterystyczne swojego obszaru, który został sfotografowany z lotu ptaka.

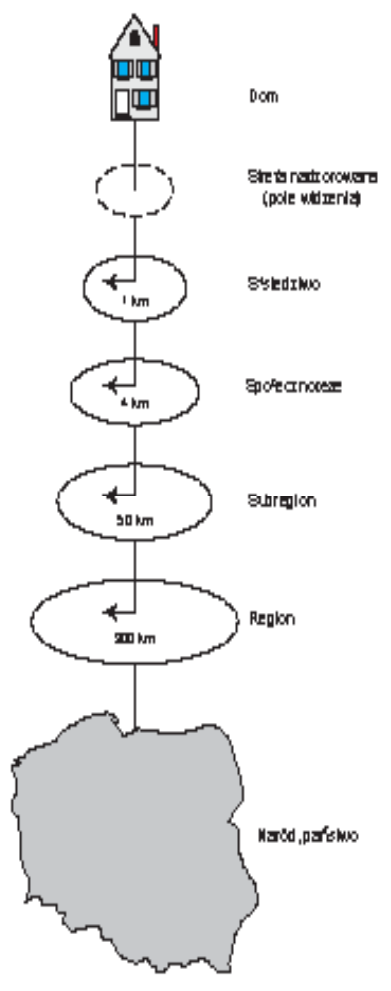

Hierarchia obszarów środowiska. Dokładność poznania przestrzeni i dokładność tworzonych map poznawczych zmienia się w zależności od strefy penetracji przestrzeni. Im bliższa strefa penetracji, tym większa dokładność poznania i dokładniejsza mapa.

Badania nad wiedzą ludzi o ich środowisku przestrzennym sugerują że u człowieka mapy nie musza być całkowicie wizualne, nie muszą być mapami opisowymi, a nawet nie muszą być podobne do zwykłych map. Sa one raczej fragmentaryczne i zniekształcone tak w znaczeniu projektowym, jak i euklidesowym (Lynch, 1960). Umysłowe modele przestrzenne pozwalają jednostce na wyrysowanie mapy, choć model taki sam w sobie mapy nie przypomina. W badaniach dziecięcych reprezentacji otoczenia często stosuje się 
oprócz map obszaru także zdjęcia lotnicze. Badania wykazały, że nawet 3-letnie dzieci potrafią rozpoznać cechy charakterystyczne obszaru oglądając zdjęcia lotnicze. W badaniach tak małych dzieci nie stosowano dotąd map lecz przypuszcza się, że zdolność rozpoznawania jest w obu przypadkach identyczna lub bardzo podobna (Spencer, Blades, Morsley, 1989)

\section{Mapy poznawcze miasta i przestrzeni zurbanizowanej}

Jak już wspomniano pionierem badań nad mapami poznawczymi był Tolman. Jednak większość badań nad percepcją miast wywodzi się od pionierskich propozycji K.Lyncha (1960). W rozważaniach nad poznawczymi wyobrażeniami przestrzeni miejskiej Lynch zasugerował, że środowisko zurbanizowane (i jakiekolwiek inne) jest mentalnie percypowane jako struktura:

- obiektów środowiskowych (architektonicznych) o spektakularnym wyglądzie (landmarks),

- obszarów węzłowych (nodes),

- ścieżek (paths),

- obszarów granicznych (edges),

- dzielnić (districts).

Znaczenie obiektów o spektakularnym znaczeniu spotkało się od samego początku ze szczególnym zainteresowaniem badaczy, którzy podjęli liczne badania potwierdzające hipotezy Lyncha. Równolegle podjęte zostały badania nad modelami organizacji informacji przestrzennych szczególnie w naukach o poznaniu (cognitive science), ze szczególnym uwzględnieniem ogólnej koncepcji lokacji, znaczenia granic i barier w różnego rodzaju kontekstach, takich jak np. zbiory rozmyte.

Większość badań nad poznaniem przestrzeni skoncentrowała się na pojęciu tzw. „wyobrażalności”
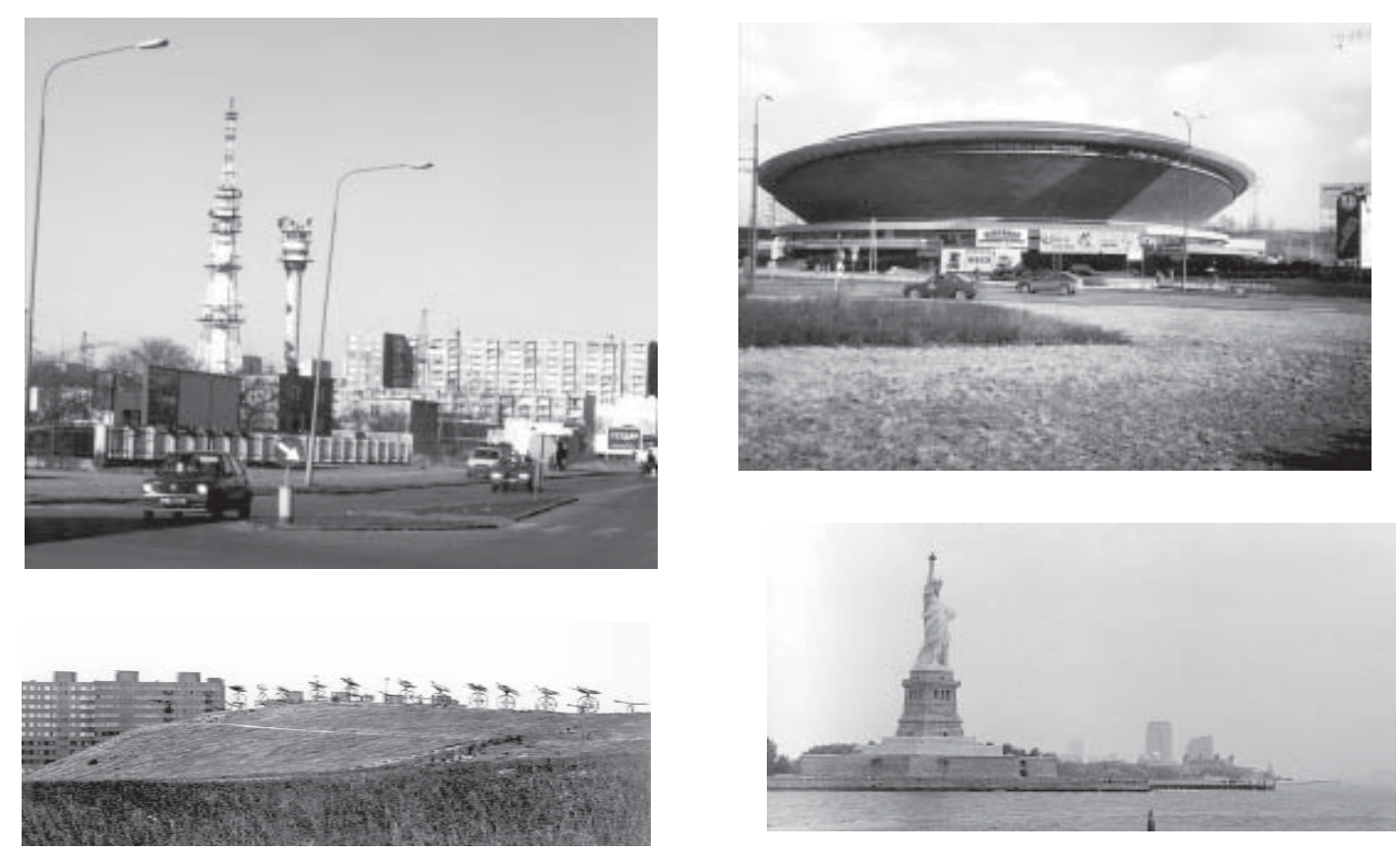

Cztery przykłady obiektów architektonicznych, które są punktami charakterystycznymi (landmarkami) miasta bądź dzielnicy. „Landmarkiem” może być również charakterystyczne ukształtowanie terenu z dodatkowym akcentem rzeźbiarskim.

(imageability). Pojęcie to zakłada, że w każdym środowisku (naturalnym i zbudowanym przez człowieka) istnieją elementy, które dzięki posiadanym cechom wyróżniającym się (np. takim, jak kolor, kształt, rozmiar, niezwykłość), lub też dzięki wtopionym albo wbudowanym symbolom (miejsca o wyjątkowym znaczeniu historyczny, religijnej lub społeczno-kulturowej ważności) wyróżniają się spośród innych. Ponieważ elementy taki są szczególnie wyróżniające się, są dzięki temu łatwo rozpoznawalne, zapamiętywal- 
ne, oraz nadające się do wykorzystania jako punktu odniesienia dla większej liczby ludzi w środowisku. Obiekty o spektakularnym wyglądzie (landmarks) są zarazem kategorią doświadczaną indywidualnie, jak i społecznie. Sa one podstawowym wyznacznikiem wiedzy środowiskowej, na której opiera się orientacja i nawigacja przestrzenna. „Landmarki” są niezwykle pomocne w ocenie dystansów i kierunku dla ludzi niezbyt obeznanych ze środowiskiem, natomiast dla stałych bywalców lub mieszkańców sa one „punktami zakotwiczenia" (anchor-point) w indywidualnej mapie poznawczej, która pozwala na zachowanie poczucia tożsamości, identyfikacji z miejscem i zachowania poczucia sensu życia w skali własnego życia i otoczenia.
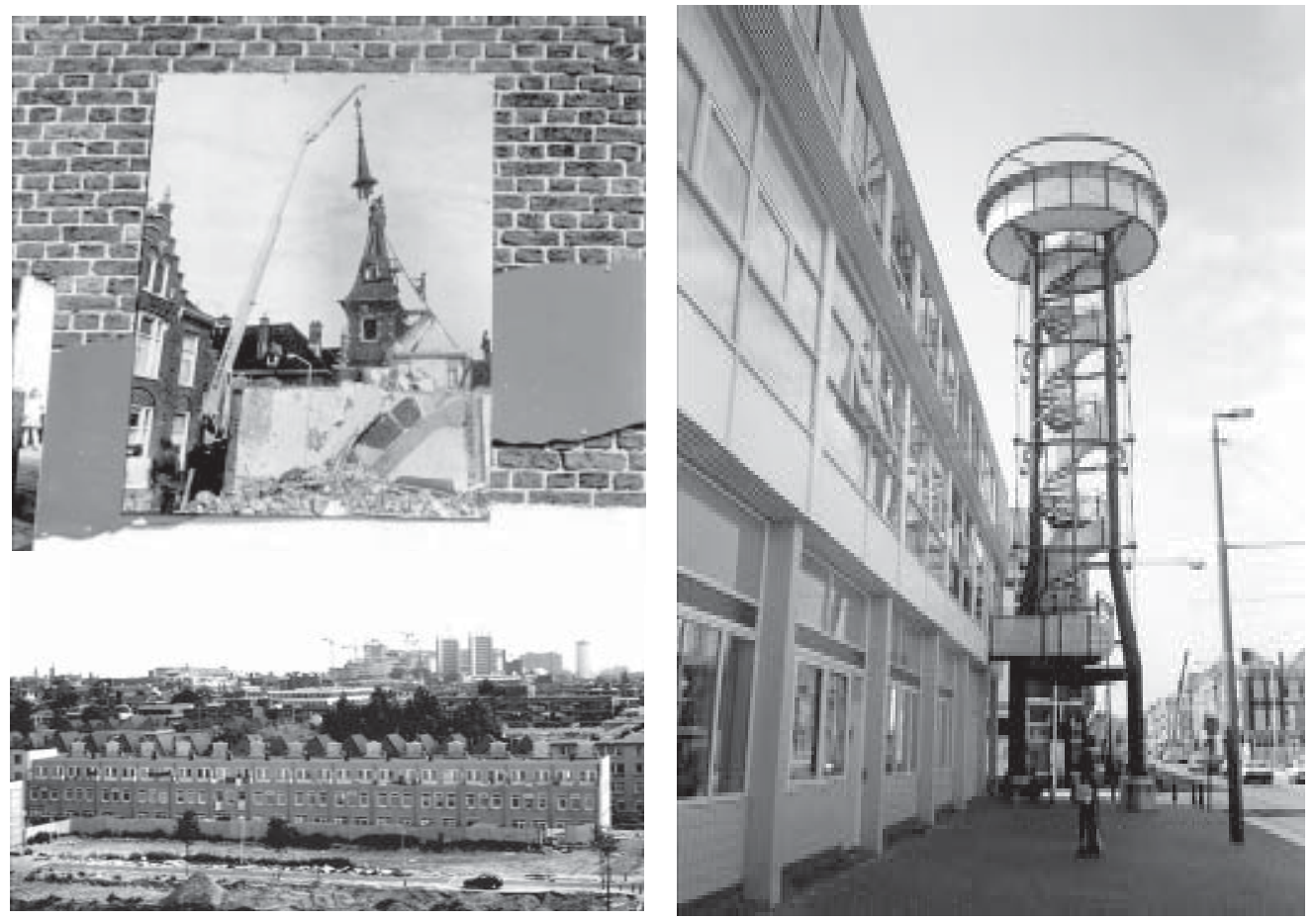

Sekularyzacja i laicyzacja życia po drugiej wojnie światowej w Holandii uruchomiła falę burzenia kościołów. Ruch ten przybrał olbrzymie rozmiary, że w wielu miastach, takich jak Haga wyburzono niemal wszystkie kościoły. W efekcie powstał bardzo zunifikowany krajobraz, pozbawiony punktów orientacyjnych, a dominującym elementem w krajobrazie stał się górujący nad Harlemem zespól budynków Międzynarodowego Trybunału Sprawiedliwości. Ludzie, którzy wyjechali ze swojej dzielnicy i dziś wracają do niej, po latach nie odnajdują żadnych punktów charakterystycznych (landmarks), które byłyby punktami zakotwiczenia (anchor points) dla mapy poznawczej konstruowane w biegu życia (life span). Dawnych mieszkańców już nie ma, a obecni mieszkańcy pochodzą często z najbardziej egzotycznych krajów. W miejscu zburzenia w latach sześćdziesiątych Harlemie ostatniej wieży kościelnej postanowiono dużym nakładem kosztów zbudować „muzeum pamięci miasta” z „landmarkiem” w postaci wieży widokowej. Z pewnością udało się wybudować „landamark”. Watpić jednak należy w to, czy jest on punktem zakotwiczenia (anchor point) dla indywidualnych map poznawczych dawnych mieszkańców pragnących przejrzeć się w „lustrze życia”.

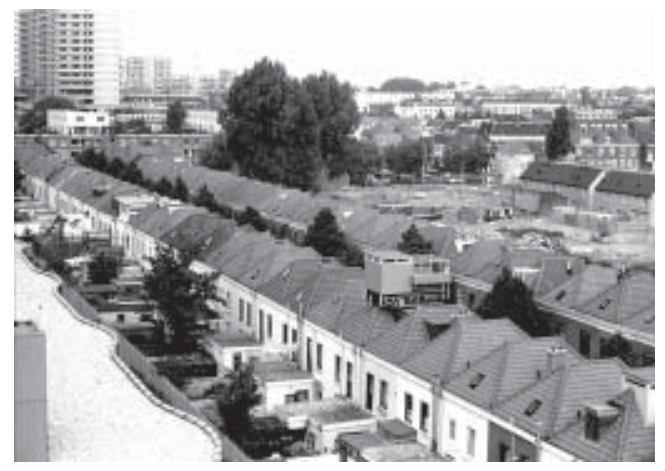

O ile „landmarki” są konkretnymi, najczęściej wizualnymi wskazówkami przestrzennymi, o tyle „punkty zakotwiczenia" są elementami abstrakcyjnymi, które nie muszą mieć swojej jednoznacznej lokacji. Przykładem tego jest dom, praca, miasto, a nawet region. Sa to kategorie przestrzenne, fizykalne czy geograficzne, ale jednocześnie abstrakcyjne, zpersonalizowane, zorganizowane procesualnie i nie koniecznie muszą być kolektywnie doświadczanymi „landmarkami”. Bezdomny też ma swój dom, bowiem w najgorszym przypadku jest nim jego miasto. Współczesna architektura i urbanistyka zakłóciła naturalny rytm powstawania i utrawalania się punktów zakotwiczenia (anchor-points). 
A

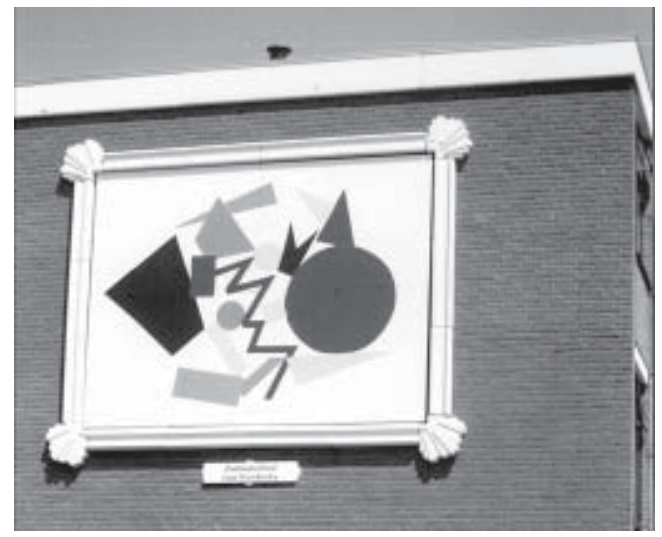

B
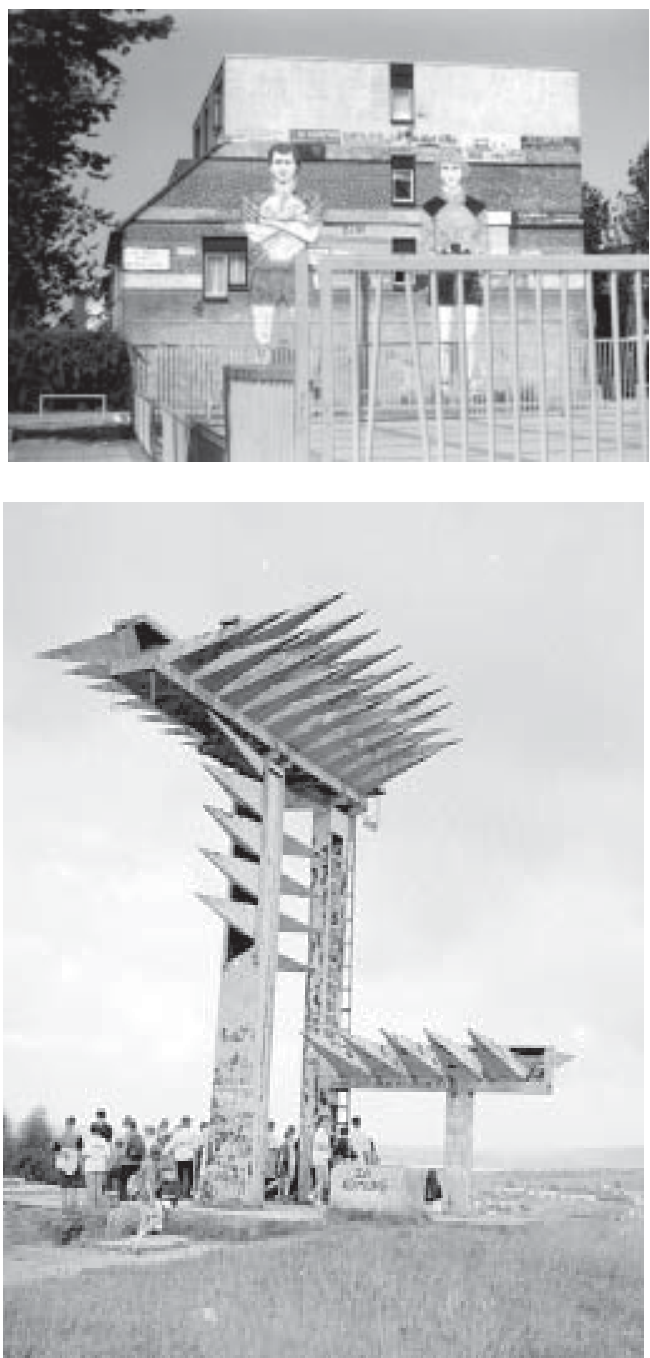

W Hadze, jak w wielu innych miastach próbuje się metoda urzędnicza ustanawiać w przestrzeni miejskiej punkty zakotwiczenia, które byłyby podstawą do utożsamiania przez mieszkańców „ich” przestrzeni miejskiej z ich przestrzenią mentalną (zdjęcie A, 20). Innym usiłowaniem jest namawianie ludzi do „prac ręcznych” (zdjęcie B 21), Jak udowadnia jednak życie, punkty zakotwiczenia dla indywidualnych map poznawczych muszą być konstruowane podmiotowo, ponieważ na mocy definicji są konstrukcjami personalnymi. (zdjęcie C). Niektóre „landmarki” mimo niezwykłości, wysokich walorów artystycznych, właściwości multimodalnych (zdolności jednoczesnego działania na różne zmysły) nigdy nie stały się punktami zakotwiczenia indywidualnych map poznawczych ludzi zamieszkujących dane terytorium (zdjęcie D).

Prawidłowa percepcja miasta, obszaru czy regionu podlega psychologicznemu prawu przestrzennej hierarchizacji. Poszczególne punkty zakotwiczenia w danym środowisku oraz w indywidualnej mapie poznawczej układają się w strukturę hierarchiczną, która ma jednak wymiar ukryty (np. pod względem ważności). Oznacza to, że dla jednej osoby wymiar najwyższy (najważniejszy) w skali przestrzennej będzie odpowiadał punktowi zakotwiczenia na poziomie międzynarodowym, a dla kogo innego na poziomie miasta, regiony, sasiedztwa czy własnego podwórka. A zatem przestrzenna hierarchia punktów zakotwiczenia zależy od stref (zasięgu) penetracji w przestrzennej mapie poznawczej. W dobrze zintegrowanym mentalnie środowisku ludzie posiadają wielostopniową hierarchię przestrzenną punktów zakotwiczenia. W społeczeństwach i w środowiskach zdegradowanych ludzie ograniczają strefy penetracji i punkty zakotwiczenia do własnego domu lub sasiedztwa, by z tego niskiego szczebla przejść od razu na inny abstrakcyjny poziom, jak. zakładu pracy, regionu czy państwa. 
Obszary węzłowe (nodes) sa reprezentowane przez miejsca połączone relacjami przestrzennymi, w przestrzeni fizycznej i w przestrzeni semantycznej. Różne obszary węzłowe mogą tworzyć hierarchiczne związki wskutek transformacji empirycznych punktów odniesienia i linii w mapie poznawczej przestrzeni euklidesowej, jak i wskutek rozbudowywania abstrakcyjnych pojęć w sieci semantycznej. Obszary węzłowe moga mieć zarówno cechy metryczne, gdy odpowiadają im rzeczywiste cechy przestrzeni, jak mogą cechy topologiczne, gdy ich podstawa organizacji w mapie poznawczej jest przestrzeń semantyczna. Sieć semantyczna obszaru węzłowego jest tylko i wyłącznie wiedzą i to w dodatku wiedzą deklaratywna. Obszar węzłowy jako punkt zakotwiczenia może być raz wiedzą deklaratywna, innym razem wiedzą funkcjonalną a jeszcze innym razem relacyjnym aspektem wiedzy przestrzennej. Nowoczesna architektura i urbanistyka powinna starać w stopniu, w jakim jest to jest tylko możliwe starać się wykorzystać w praktyce projektowania wiedzę o sposobie funkcjonowania obszarów węzłowych sieci relacji przestrzennych i sieci semantycznej.

\begin{abstract}
W rozumieniu nauki o budowie dróg, skrzyżowanie, na którym drogi zbiegają się nie pod kątem prostym, jest na mocy definicji, rozwiązaniem wadliwym. Takie rozwiązania są jednak zalążkiem obszarów węzłowych, punktów zakotwiczenia indywidualnych map poznawczych (we wszystkich niemal kulturach z wysoko rozwiniętą percepcją wzrokowa) i często zwyczajnie dobrej architektury.
\end{abstract}

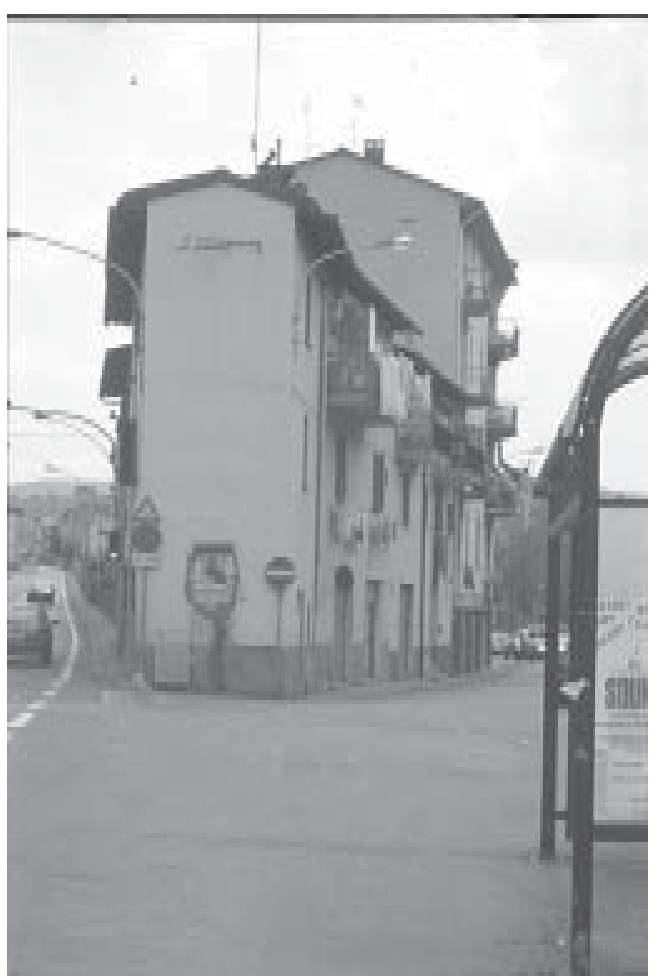

Prawidłowa konstrukcja mapy poznawczej miasta i środowiska powinna spełniać cztery podstawowe warunki: a) wiedzieć co; b) wiedzieć jak; wiedzieć gdzie i kiedy w sensie absolutnym; d) wiedzieć gdzie $\mathrm{w}$ sensie relacyjnym. W pierwszym przypadku jest to zdolność rozpoznawania, przypominania oraz opisywania elementów przestrzennych. W drugim przypadku jest wiedza niezbędna do realizacji rzeczywistych zadań nawigacyjnych na określonych obszarze i wzdłuż określonych dróg. W trzecim przypadku jest to wiedza o tym „gdzie i kiedy” oraz co robić w odniesieniu do niestałych elementów środowiska. Jest to wiedza asocjacyjna niezbędna w identyfikacji poznanych elementów środowiska w raz z ich punktami odniesienia w rzeczywistym czasie i w rzeczywistej przestrzeni, oraz identyfikacji konfiguracji takich elementów $\mathrm{z}$ odpowiadajacymi im konfiguracjami w przestrzeni euklidesowej. W czwartym przypadku jest to wiedza o związkach między względnymi dystansami, kierunkami, uporządkowaniami sekwencyjnymi itd. O ile wiedza relacyjna jest rzetelna w ramach danej przestrzeni (np. obiektywnej-geograficznej lub subiektywnej), o tyle wiedza asoscjacyjna mapuje dwie różne przestrzenie jedną na druga, poprzez ustanawianie skojarzeń między specyficznymi punktami w jednej przestrzeni i charakterystycznymi punktami w drugiej. 


\section{LITERATURA}

Alexander, C. (1964). Notes on the Synthesis of Form. Cambridge: Harvard University Press.

Alexander, C. (1971). The State of the Art in Design Methodology, [wywiad w:] Design Methods Group Newsletter, Vol $5, n r 3,3-1$.

Alexander, C., Sarah, I., Murray, S., Jacobson, M., Soli, A., King, J. (1974). Pattern Language. Oxford Press.

Altman, J., Haythorn, W.W. (1967). The Ecology of isolated Groups. Behavioral Science, 12, 169-182.

Altman, J. (1975). Environmental and Social Behavior: Privacy, Personal Space, Teritority and Crowding. Monterey, California: Brooks/Cole.

Archer, L.B. (1965). Systematic Method for Designers, Council of Industrial Design. London.

Ariés, P.(1962). Centuries of Childhood. New York: Knopf.

Asimow, M. (1961). Wprowadzenie do techniki projektowania. Warszawa: WNT.

Attenave, F. (1959). Stochastic Composition Processes. Journal of Aesthetics and Art. Criticism, 17, 503-510.

Baker, G., Franken, R. (1967). Effects of Stimulus Size, Brightness and Complexity Upon EEG Desynchronization. Psychonomic Science, 7, 289-290.

Baley, S. (1963). Wprowadzenie do psychologii spotecznej. Warszawa: PWN.

Baley, S. (1964). Wprowadzenie do psychologii społecznej. Warszawa: PWN.

Bańka, J. (1973). Technika a środowisko psychiczne człowieka. Warszawa: WNT.

Bańka, A. (1975). Psychological Aspects of Man-Technology Integration and Some Theoretical Problems of Ergonomics. Polish Psychological Bulletin, 191-197.

Bańka, A. (1978). Struktura myślenia w technice a problemy humanizacji techniki. Prace Naukowe INES, Seria Filozoficzna nr 10, WPP, 24-33.

Bańka, A., Dmochowski, J. (1979). The Method of Determining the Influence on Ergonomic Factors Design-Failures at Successive Stages of the Plant Investment. IEA, September 1979, Ergonomics, 6. Warszawa,

Bańka, A., Bagieńska, M. (1979). Psychologia pracy i kierowania. Poznań: WPP.

Bańka, A. (1980). Psychologiczne wyznaczniki projektowania ergonomicznego w technice. Zeszyty Naukowe PP. Seria: Ekonomika i Organizacja Przemystu, 9, 101-112.

Bańka, J. (1980). Filozofia techniki. Katowice: Wydawnictwo Śląsk”.

Baron, R.M., Mandel, D.R., Adams, C.A., Griffen, L.M. (1976). Effects of Social Density in University Residential Environments. Journal of Personality and Social Psychology, 34, 434-466.

Bastide, R. (1972). Socjologia chorób psychicznych. Warszawa: PWN.

Bazjanac, V. (1974). Architectural Design Theory: Models of the Design Process, [w:] Spillers, W.R. (Ed.), Basic Questions of Design Theory. North-Holland Amsterdam.

Benedict, R. (1966). Wzory kultury. Warszawa: PIW.

Berlyne, D.E., Borsa, D.M. (1968). Uncertainty and the Orientation Reaction. Perception and Psychophysics, 3, 77-79.

Bexton, W.H., Heron, W., Scott, T.H. (1954). Effects of Decreased variation Sensory Environment. Canadian Journal of Psychology, 8, 70-71.

Bickman, L., Teger, A., Gabriele, T., McLaughlin, C., Sunday, E. (1973). Dormitory Density and Helping Behavior. Environment and Behavior, 5, 465-490.

Blackman, A. (1966). Scientism and Planning. The American Behavioral Scientist,10, 24-28.

Broadbent, D.F. (1954). Some Effect of Noise on Visual Performance. Quarterly Journal of Experimental Psychology, $6,1-5$.

Bruner, J. S. (1911). O poznaniu. Warszawa: PIW.

Bruner, J.S., Goodman, C.C. (1947). Value and Need as Organizing factors in Perception. Journal of Abnormal Social Psychology, 17.

Calhoun, J.B. (1962). Population Density and Social Pathology. Scientific American, 206, 139-146.

Calhoun, J.B. (1962). The Ecology and Sociology of the Norway Rat. Maryland: Bethesda.

Cavan, S. (1966). Liquor License. Chicago: Aldine.

Coper, R, Payne, E. (1969). Ekstrawersja a niektóre aspekty zachowania przy pracy. Przeglad Psychologiczny, 17.

Czechowicz, B., Sławińska, J. (1977). Historyzm, awangarda, neohistoryzm. Projekt, 4, 46-52.

Czerwiński, M. (1972). Przemiany obyczaju. Warszawa: PIW.

Czerwiński M. (1977). Okiem przechodnia. Warszawa: PIW.

Day, H.I. (1967). The Effects of Increased Arousal on Attention in High and Low - anxiouss Subjects. Ontario Journal of Educational Research, 9, 185-191.

DeJonge, D. (1962). Images of Urban Areas, their Structures and Psychological Foundations. Journal of the American Institute of Planners, 28, 266-216.

Dember, W.N., Earl, R.W. (1957). Analysis of Explanatory, Manipulatory and Curiosity Behaviors. Psychological Reviews, 64, 91-96.

Deutsche Gesellschaft für Arbeitsschutz. Voraussetzunngen für Grossraumbüros. Merkblatt der Deutschen Gesellschaft für Arbeitsschutz, D-6 Frankfuft/Main 1.

Dougier, S. (1967). Reactivité en bruit et personalité. Revue de Médecine psychosomatique et de Psychologie Médicale, 9.

Doxiadis, C.A. (1968). A Man and the Space around Him. Saturday Review, 14. 
Einbrodt, H.J., Beckniann, H. (1969). Luft-Licht-und Lärmpmblem in Klein-und Grossraumbüross. Arbeitsmedizin Socialmedizin Arbeitshygiene, 2, 49-52.

Faris R.E.L., Dunham H.W. (1934). Mental Disorders in Urban Areas. Chicago.

Festinger, L. (1951). Architecture and Group Membership. Journal of Social Issues, 1, 152-163.

Firey W. (1947). Land Use in Central Boston. Cambridge: Harvard University Press.

Fitch J.M. (1965). Experimental Bases for Aesthetic Decision. Anrtals of the New York Academy of Sciences, $128,706-714$.

Francescato, D., Mebane, W. (1973). How Citizens View Two Great Cities: Milan and Rome, [w:] Downs, R.M., Stea, D. (Eds.), Image and Environment. Chicago: Aldine.

Freud, Z. (1967). Człowiek, religia, kultura. Warszawa: PWN.

Gasparski, W. (1977). Projektowanie. Koncepcyjne przygotowanie działań. Warszawa: PAN-PWN.

Goffman, E. (1959). The Presentation of Self in Everyday Life. Garden City: Doubleday.

Goode H.H., Machol, R.E. (1968). System Engineering. Warszawa: WNT.

Goodman, P. (1964). Utopian Assays and Practical Proposals. New York: Random House.

Griffitt, W. (1970). Environmental Effects on Interpersonal Affective Behavior: Ambient Effective Temperature and Altraction. Journal of Personality and Social Psychology, 15, 240-244.

Gubler, F. (1967). Erfarhrungen mit der Bürogrossraum. Industrielle Oroganisation, 36, 359-363.

Gunderson E.K.E. (1968). Mental Health Problems in Antarctica. Archives of Environmental Health, 17, 558-564.

Hall, A.D. (1968). Podstawy techniki systemów. Warszawa: WNT.

Hall, E.T. (1969). The Hidden Dimension. New York: Doubleday.

Hall, E.T. (1970). The Anthropology of Space, [w:] Proshansky, Ittelson, Rivlin Yedst, (Eds.), Environmental Psychology. New York: Holt.

Hall, E.T. (1978). Ukryty wymiar. Warszawa: PIW.

Hazard, F.W. (1930). A Descriptive Account of Odors. Journal of Experimental Psychology, 13, 279-331.

Heath, R.G. (1964). The Role of Pleasure in Behavior. New York: Harpers.

Hebb, D.O. (1955). Drives and the C.N.S. Psychological Review, 62, 243-254.

Hediger, H. (1955). Studies of the Psychology and Behavior of Captive Animals in Zoos and Circuses. London: Butterworh.

Hempel, C.G. (1968). Podstawy nauk przyrodniczych. Warszawa: WNT.

Heron, W. (1961). Cognitive and Physiological Effects of Perceptual Isolation, [w:] Sensory Deprivation. Cambridge: Harvard Press.

Heusser, M. (1968). Psychologische Aspecte des Grossraumbüros. Büro und Verkauf, 37, 452-457.

Hilgard, E.R. (1967). Wprowadzenie do psychologii. Warszawa: PWN.

Holohan, C.J. (1978). Environment and Behavior. A Dynamic Perspective. New York: Plenum Press.

Horney, K.(1976). Neurotyczna osobowość naszych czasów. Warszawa: PWN.

Horowitz ,M.J., Duff, D.F., Stratton, L.O., Personal Space and the Body-Buffer Zone, [w:] Proshansky, Ittelson, Rivlin. (Eds.), Environmental Psychology. New York: Holt.

Horton, F.E., Reynolds, D.R. (1964). Action Space Formation: A Behavioral Approach to Predicting Urban Travel Behavior. University of Iowa: Institute of Urban and Regional Research, September.

Hull, C.L.(1951). Essentials of Behavior. New Haven: Yale.

Hunt, J.McV. (1960). Experience and the Development of Motivation. Child Development, 31, 489-504.

Ittelson, W.H., Rivlin, L.G. (1970). The Influence of the Physical Environment on Behavior: Some Basic Assumptions, [w:] Proshansky, Ittelson, Rivlin, (Eds.), Environmental Psychology. New York: Holt.

Ittelson, W.H., Proshansky H.M., Rivlin L.G. (1970). Bedroom Size and Social Interaction of the Psychiatric Ward. Environment and Behavior, 2, 255-270.

Izumi, K.(1955). Psychosocial Phenomena and Building Design. Building Research, 2, ss. 9-12.

Jones, J.C. (1977). Metody projektowania. Warszawa: WNT.

Karwoski, T.F., Odbert, H.S., Osgood, C.E. (1942). Studies on Synesthetic Thinking. Journal of General Psychology, $26,199-222$.

Kaufmann, E. (1955). Architecture in the Age of Reason. Cambridge: Harvard University Press.

Krech, D., Crutchfield R.S., Ballachey E.L. (1962). Individual in Society. New York: McGraw-Hill.

Krick, E.V. (1971). Wprowadzenie do techniki i projektowania technicznego. Warszawa: WNT.

Kuhn, T.S. (1968). Struktura i kierunek rewolucji naukowych. Warszawa: PWN.

Kunkel, J.H. (1967). Some Behavioral Aspects of Ecological Approach to Social Organization. American Journal of Sociology, 1, ss.13-18.

Kuper, L. (1970). Neighbor on the Hearth, [w:] Proshansky, Ittelson, Rivlin (Eds.), Environmental Psychology. New York: Holt.

Kyburz, W.(1968). Der Grossraum als Organisatorische Idea. Büro und Verkauf, 433-435.

Lacey, J.I. (1950). Individual Differences in Somatic Response Patterns. Journal of Comparative and Physiological Psychology, 43, 338-350.

Land, I., Moleski, W. (1973). A Behavioral Theory of Design. Design and Environment, 16.

Lappat, A. (1969). Umwelt und Einrichtung im Grossraumbüro. Büro und Wohnen, 24, 1-8.

Laugier Marc-Antoine. (1775). Observations sur L'architecture. The Hague 1765; Essai sur L'architecture. Paris.

Leckart B.T., Bakan, P. (1965). Complexity Judgments of Photographs and Looking Time. Perceptual and Motor Skills, 21, 16-18. 
Lewicki, A. (969). Psychologia kliniczna. Warszawa: PWN.

Lewin K.(1935). A Dynamic Theory of Personality. New York: McGraw-Hill.

Lewin K (1936). Principles of Topological Psychology. New York: McGraw-Hill.

Lindsey, D.B. (1951). Emotion, [w:] Stevens, S.S. (Ed.), Handbook of Experimental Psychology. New York: Wiley.

Luckman, J. (1969). An Approach to the Management of Design. [w:] Design Methods in Architecture, Broadbent, G., Ward, A. (Eds.), Architectura Association Paper, vol. 4, London.

Lynch K. (1960). The Image of the City. Cambridge: MIT Press.

Malmo, R.B. (1959). Activation: A Neuro-Psychological Dimension. Psychological Review, 66, 367-386.

March, J., Simon, H. (1958). Organizations. New York: Wiley.

Mardi, J. Horowitz,. Duff, D.F., Stratton, L.O. (1964). Body-Buffer Zone. Archives of General Psychiatry, 11, $651-56$.

Maslow, A.A. (1954). Motivation and Personality. New York: Howper. 1954.

McBridge, G., King, M.G., James, J.W. (1965). Social Proximity Effects on GSR in Adult Humans. Journal of Psychology, 61, 153-157.

McCleland, D.C., Atkinson, J.W., Clark, R.A., Lowell, E.L. (1953). The Achievement Motive. New York: Appleton.

Michelson, W. (1968). A Personian Scheme for the Study of Man and Environment or What Human Ecology Left Behind in the Dust. Sociological Inquiry, 1, 200-206.

Mehrabian, A. (1972). Verbal and Nonverbal Interaction of Strangers in Waiting Situation. Journal in Experimental Research in Personality, 5, 121-138.

Mehrabian, A., Russell, J.A. (1974). An Approach to Environmental Psychology. Cambridge: MIT.

Minton, H.L. (1963). A Replication of Perceptual Curiosity as a Function of Stimulus Complexity. Journal of Experimental Psychology, 55, 522-24.

Mumford, L. (1961). The City in History. New York: Harcourt/Brace.

Mumford, L. (1966). Technika a cywilizacja. Warszawa: PWN.

Murray, J.E. (1968). Motywacja i uczucia. Warszawa: PWN.

Nemecek, J., Grandjean, E. (1973). Results of an Ergonomic Investigation of Large-Space Offices. Human Factors, 111-124.

Niemojewski, L. (1929). Architektura i złudzenia optyczne. Warszawa.

Nowak, L. (1974). Zasady marksistowskiej filozofii nauki. Warszawa: PWN.

Oken, D. (1967). Psychophysiology and Psychoendocrinology of Stress and Emotion, [w:] Appley, Appleton, Trumbull. (Eds), Psychological Stress. New York.

Osgood, C.E., Suci, G.J., Tannenbaum, P.H. (1957). The Measurement of Meaning. Urbana: University of Illinois Press.

Osmond, H. (1957). Function as the Basis of Psychiatric Ward Design. Mental Hospitals, 8, 23-30.

Osmond, H. (1959). The Relationship between Architect and Psychiatrist, [w:] Goshen, C. (Ed.), Psychometric Architecture. Washington: American Psychiatric Association.

Parr, A.E. (1964). Environmental Design and Psychology. Landscape, 2.

Perin, C. (1970). With Man in Mind. Cambridge: MIT Press.

Perry, H. (1929). Neighborhood and Community Planning. New York.

Pevsner, N. (1967). Historia architektury europejskiej. Warszawa: WAF.

Podgórecki, A. (1962). Charakterystyka nauk praktycznych. Warszawa: PWN.

Proshansky, H.M., Ittelson, W., Rivlin, L. (1970). Freedom of Choice in a Physical Setting, [w:] Proshansky, Ittelson, Rivlin, (Eds.), Environmental Psychology. New York: Holt-Reinhart.

Richards, C.B., Dobyns, H.F. (1957). Topography and Culture. The Case of the Changing Cage. Human Organization, $16,16-20$

Rittel, H.W.J. (1971). Some Principles for the Design of an Educational System for Design. Journal of Architectural Education, vol. XXVI, 1-2, 16-26.

Rittel, H.W.J. (1972). Son of Rittelthink, [w:] Design Methods Group 5-th Anniversary Report, DMG Occasional Paper 1, January, 5-10.

Rittel, H.W.J. (1972). On the Planning Crisis: Systems Analysis of the First and Second Generations. Bedriftskonomen, 8, 390-396.

Rubin, E.(1921). Visuell wahrgenommene Figuren. Kobenhavn: Gyldendalske.

Saarinen, T.F. (1971). The Use of Projective Techniques in Geographic Research. City University of New York: Graduate Center.

Sanoff, H., Cohn, S. (1970). Proceedings of the First Annual Environmental Design Research Association Conference, North Carolina State University, Releigh.

Scheuchezer, R. (1967). Der Bürogrossraum im schweizerischer Sicht. Industrielle Organisation, 37, 264-266.

Schmid, R. (1966). Der mittelgross Büroraum. Frankfurt/Main: Europeische Verlagsanstalt.

Selye, H. (1963). Stres życia. Warszawa: PZWL.

Skinner, B.F. (1953). Science and Human Behavior. New York: Mac Milan.

Skolimowski, H. (1974). Structure of Thinking in Technology, [w:] Rapp, F. (Ed.), Contributions to a Philosophy of Technology. Boston: Reidel.

Sommer, R. (1961). Leadership and Group Geography. Sociometry, 24, 99-110.

Sommer, R. (1961). Small Group Ecology. Psychological Bulletin, 67, 145-152. 
Sommer, R. (1965). Further Studies of Small Group Ecology. Sociometry, 28, 337-348.

Sommer, R. (1966). The Ecology of Privacy. The Library Quarterly, 36, 234-238.

Sommer, R. (1969). Personal Space: The Behavioral Basis of Design. Englewood Cliffs/N.Jersey, Pfentice-Hall.

Społeczne przesłanki kształtowania miasta przyszłości. Zbiór artykułów. Warszawa: PWN.

Stea, D. (1965). Space, Territory and Human Movements. Landscape, 15, 1, 13-16.

Stern, W. (1937). General Psychology from the Personalistic Standpoint.

Stokols, D. (1976). The Experience of Crowding in Primary and Secondary Environments. Environment and Behavior, 8, 49-86.

Studer, R.G., Stea, D. (1966). Environmental Programming and Human Behavior. Journal of Social Issues, 22, ss. 127-136.

Studer, R.G. (1970). The Dynamics of Behavior Contingent Physical System, [w:] Proshansky, H.M., Ittelson, W.H., Rivlin, L.G. (Eds.), Environmental Psychology: Man and his Physical Setting. New York: Holt-Reinhart.

Szparkowski, Z. (1977). Humanizacja architektury. Warszawa: Arkady.

Strelau, J. (1969). Temperament i typ uktadu nerwowego. Warszawa: PWN.

Suzin, L.M. (1974). Perspektywa wykresowa dla architektów. Warszawa: Arkady.

Szparkowski, Z. (1977). Humanizacja architektury zakładu przemysłowego. Warszawa: Arkady.

Tague, L.C. Jr. (1968). Research in Computer Applications to Architecture, [w:] Harper, G.N. (Ed.), Computer Applications to Architecture and Engineering. New York: McGraw Hill.

Thomas, W.I. (1923). The Unadjusted Girl. Boston: Little Brown.

Toffler, A. (1974). Szok przyszłości. Warszawa: PIW.

Tolman, E.C. (1948). Cognitive Maps in Rats and Men. Psychological Review, 55, 189-208.

Tomaszewski, T. (1976) (Red.) Psychologia. Warszawa: PWN.

Tomaszewski, T. (1976). Człowiek i otoczenie, [w:] Tomaszewski, T. (Red.), Psychologia. Warszawa: PWN.

Tomaszewski, T. (1976). Orientacja w otoczeniu, [w:] Tomaszewski, T. (Red.), Psychologia. Warszawa: PWN.

Tucker, W.T. (1974). Experiments in Aesthetic Communications, [w:] Mehrabian, A., Russell, J.M. (Eds.), An Approach to Environmental Psychology. Cambridge: MIT.

Valins, S., Baum, A. (1973). A Residential Group Size, Social Interaction, and Crowding. Environment and Behavior, 5, 421-439.

Van der Ryn, S., Silverstein, M. (1967). Dorms at Berkeley. New York: Educational Facilities Laboratories.

Vitz, P.C. (1966). Preferences for Different Amounts of Visual Complexity. Behavioral Science, 1l, 105-114.

Von Uexküll, J.A. (1957). A Stroll Through the World of Animals and Men, [w:] Schiller, C.H., (Ed.), Instinctive Behavior: The development of a Modern Concept. New York: International University Press.

Weisen, A. (1974). Differential Reinforcing Effects of Onset and Offset of Stimulation on the Operant Behavior of Normal, Neurotics and Psychopaths, [w:] Mehrabian. Russell. (Eds.), An Approach....op. cit.

Westin, A.F. (1961). Privacy and freedom. New York: Atheneum.

Wicker, A. (1973). Andermanning Theory and Research: Implications for the Study of Psychological and Behavioral Effects of Excess Population. Representative Research in Social Psychology, 4, 185-206.

Witruwiusz, M.P. (1956). De architektuta. Libri decem. Tł. pol. Kumaniecki, K., O architekturze. Ksiąg dziesięć, a26. W-wa: PWN.

Wojda, A. (1977). Propozycja struktury pionowej projektowania architektonicznego, [w:] Gasparski, W. (Red.), Metodologia projektowania inżynierskiego. Warszawa: PAN.

Woodson, W.E., Conover, D. (1964). Human Engineering Guide to Equipment Design. Los Angeles: Berkeley.

Woodworth, R.S., Schlosberg, H. (1966). Psychologia eksperymentalna. Tom l, Warszawa: PWN.

Wright, L. (1954). The Natural House. New York.

Zietz, K. (1931). Gegenseitige Beeinflussung von Farb und Tonerleibnissen. Zeitschrift für Psychologie, 121, 257-356.

Ziółkowski, J. (1965). Urbanizacja, miasto, osiedla. Studia Socjologiczne. Warszawa: PWN.

Ziółkowski, J. (red.). (1967). Społeczno-przestrzenne skutki industrializacji. Warszawa: PWN. 